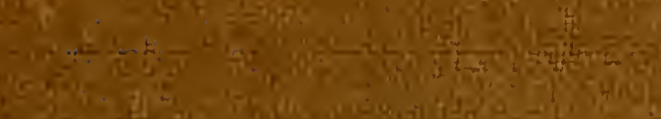
Q.

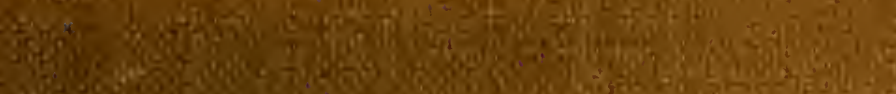

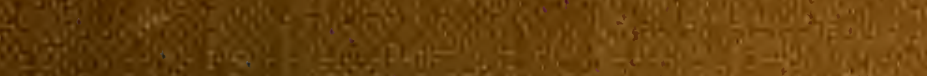
20.

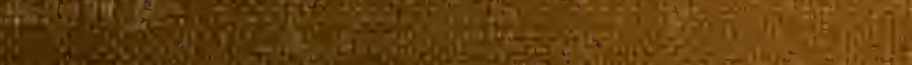

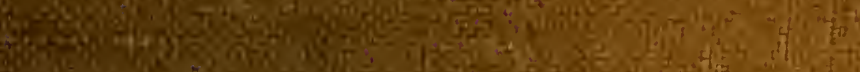

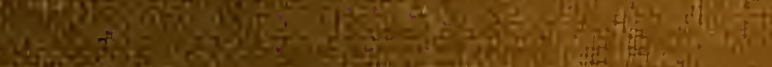

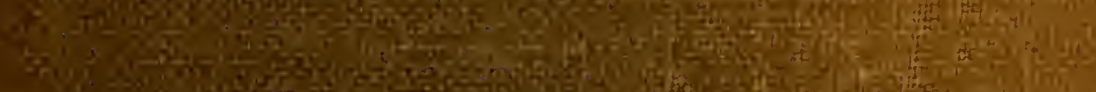

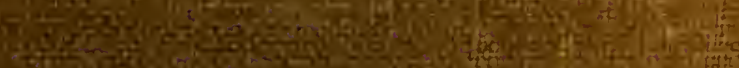

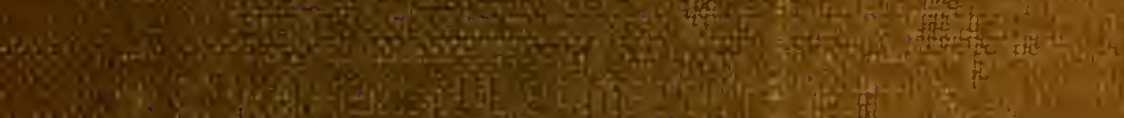

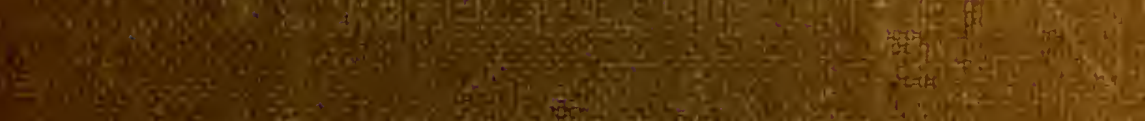

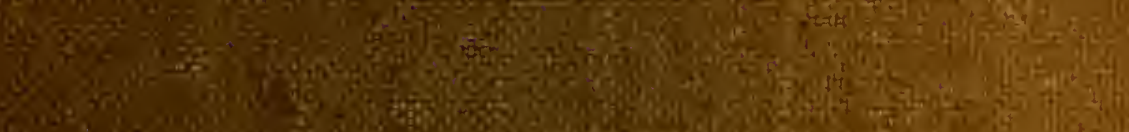

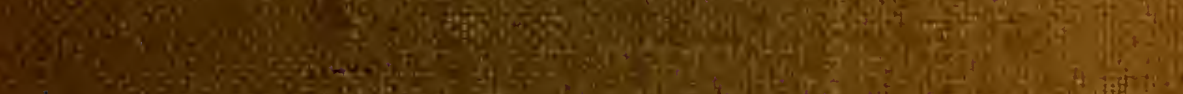
$=40$ -

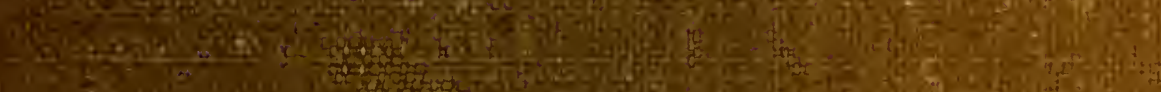

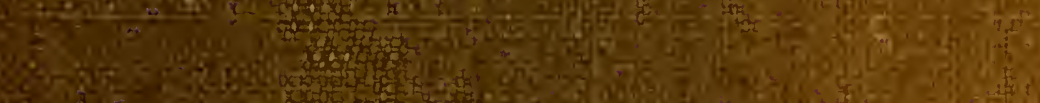

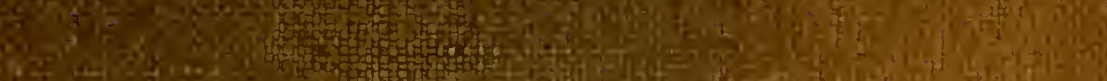
作

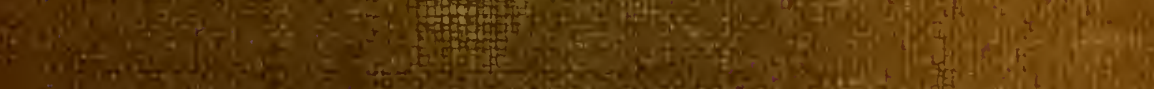

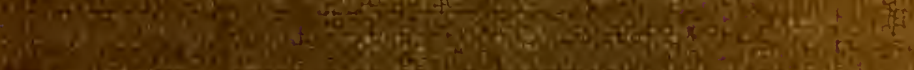

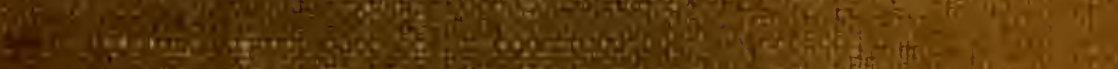
6." 3L C. Mro 20.5.

Q6n.

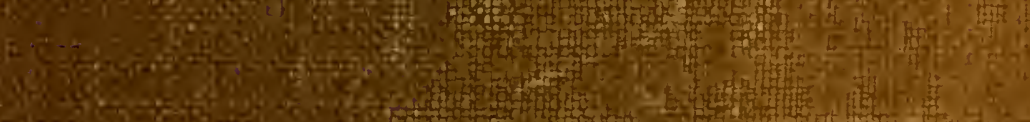

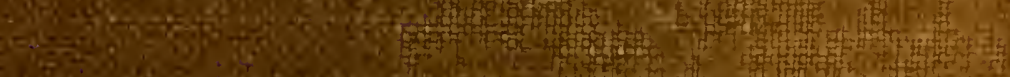

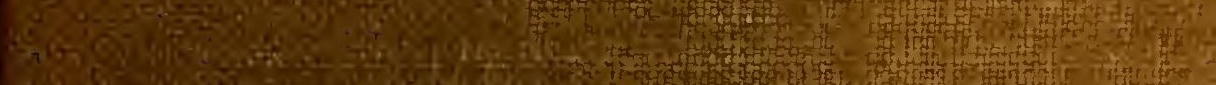

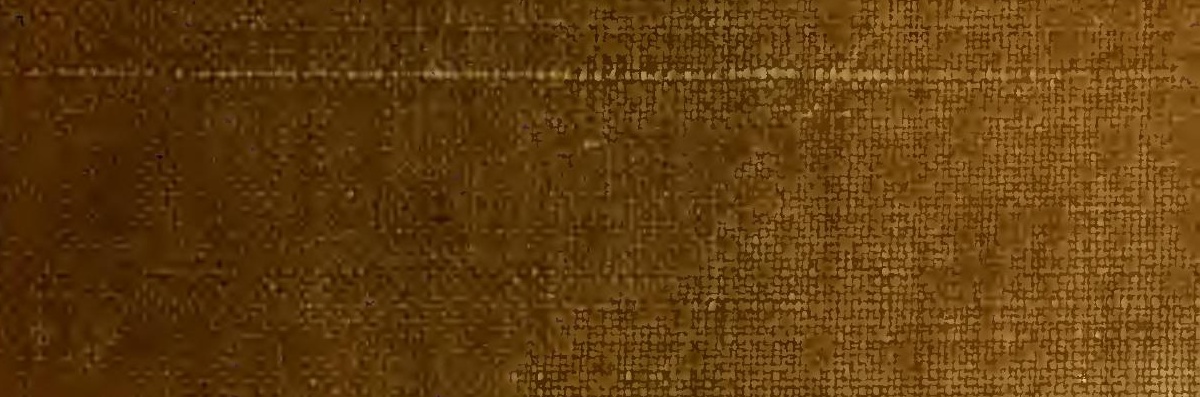




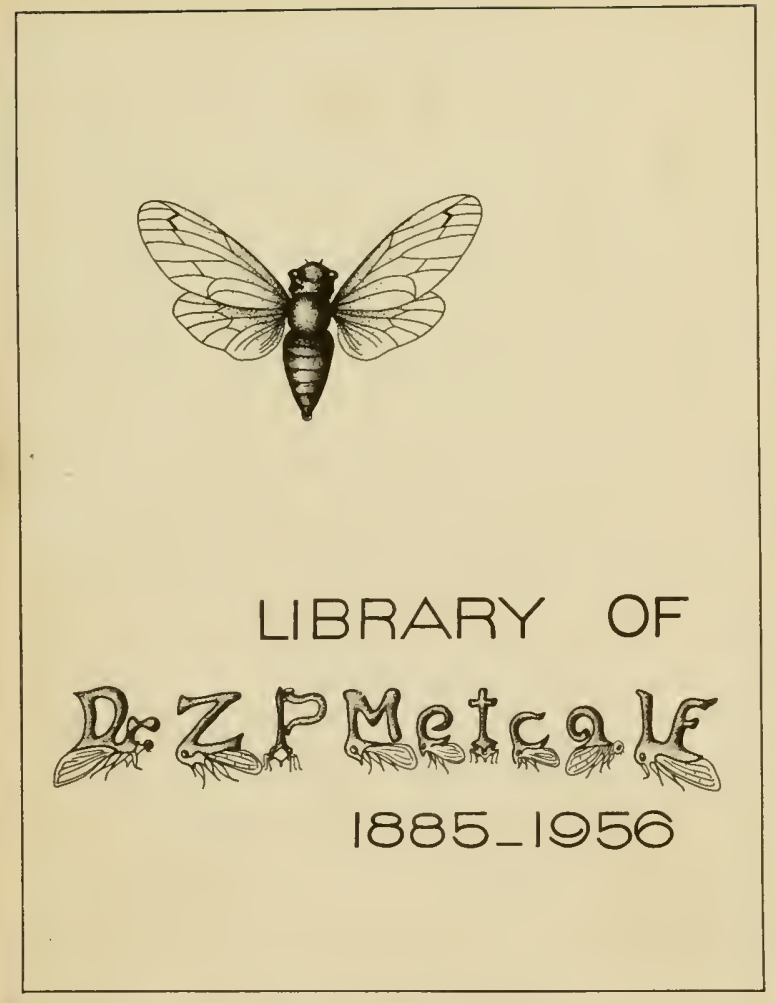


. 


\section{The Natural History}

OF

Sokotra and Abd=el=Kuri. 




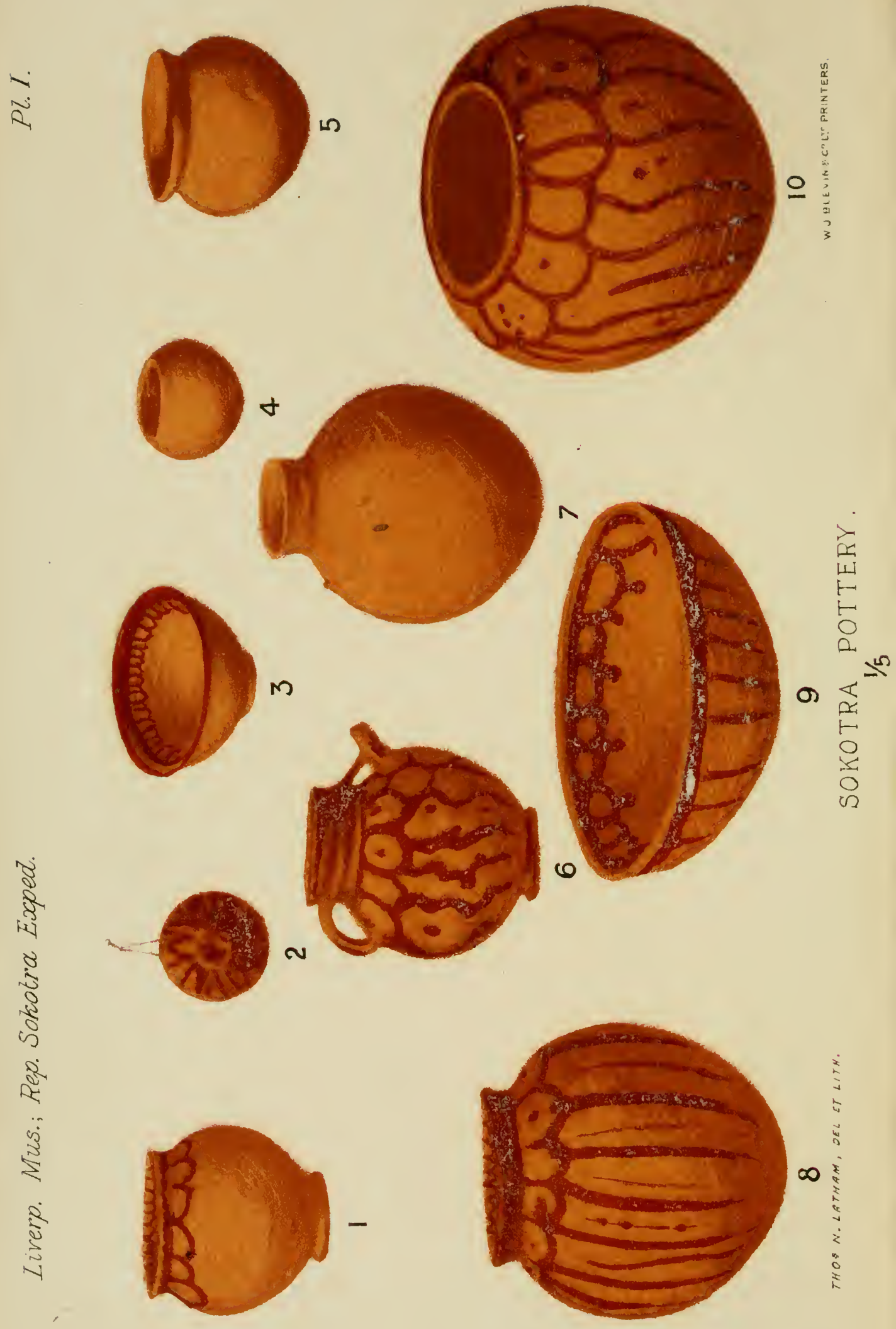




\title{
THE NATURAL HISTORY
}

()1:

\section{SOKOTRA AND ABD=EL=KURI}

Being the Report upon the Results of the Conjoint Expedition to these Islands in $1898=9$, by $M r$. W. R. OGILVIE-GRANT, of the British Museum, and Dr. H. O. FORBES, of the Liverpool Museums, together with information from other available sources

FORMING

\section{A Monograph of the Islands}

\author{
EI)ITED HI
}

HENRY O. FORBES, LL. D.

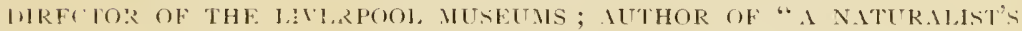
WANIERINGS IN THE EASTERN ARCHIIEIAGO," ETC:

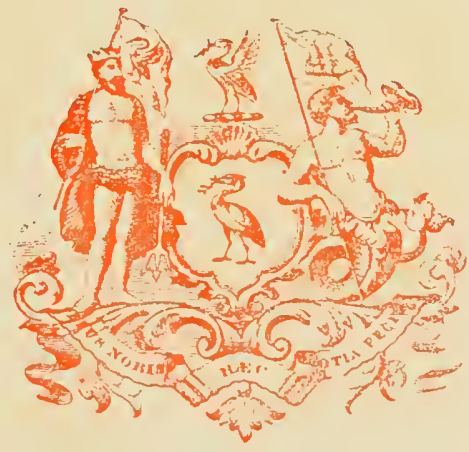

L. I IER POL

THE FREE PUELIC MUSEUMS

HENRY YOLNG \& SONS, I SOUTH CASTLE STREET

INI) 23 PAKKER STTREET

I,ONI) N : R. H, P()RER

1903 
THIS VOLUME IS ISSUED AS A S P E CI A L B ULLETIN OF THE LIVERPOOL MUSEUMS. 


\section{List of Authors.}

I. B. BALFOUR, F.R.S., liegins Profeseor of Boteny in the University of

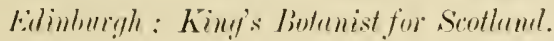

G. A. BOULENGER, F.R.S., Zoologirul Mepmitment, british Musenm.

MALCOLM BURR, F.L.S., F.E.S., Jnimms l'ml, Eitst Ginsteml.

OTTO V. DARBISHIRE, Ph.D., Orens: Colleqe, Munchester.

W. E. DE WINTON, F.Z.S., F.L.S., Aitim! lliertor of the Zoolugienl Guritens, Lamilin.

HENRY O. FORBES, LL.D. (Editor), Jirector of Mreseums to the Corperefimu of Lirenpoul: Member of the Expedition.

C. J. GAHAN, M.A., Zoologienl Inequitment, biritish IIusenm.

Lieutenant=Colonel H. H. GODWIN=AUSTEN, F.R.S., Nurf, Grorlelminu.

W. R. OGILVIE=GRANT, Zomlogicul Depurtment, Litish ILusum : Memluer of the Errpedition.

J. W. GREGORY, D.Sc., F.R.S., I'rofessor of Gcolu!y, Unirersity of Metlowine.

Sir GEORGE HAMPSON, Bart., M.A., Zoologicul Depurtment, British Wuseum.

E. M. HOLMES, F.L.S., ('urutor of the Musenm of the Phurmacentical Suciety, Lomilon.

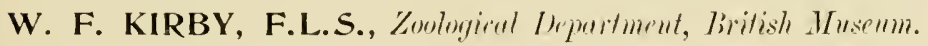

G. W. KIRKALDY, F.E.S., Wimbleiton.

R. M'LACHLAN, F.R.S., Trensurer, Entomoluricul Suriety, Londont.

R. I. POCOCK, Zoolugirel Inepartment, british Musenm.

GERTRUDE RICARDO, 12 cottesmore Gualens, Kensington, Lomlon, $I I$.

E. A. SMITH, F.Z.S., Zoolongeal Inepurtment, British Musemin.

A. SCOTT, A.L.S., liesident Fisheries Assistunt, Piel Hetehery, Lonoushire.

F. V. THEOBALD, M.A., F.E.S., Zoologist to the south-Eustern Agricultmril Collery.

A. O. WALKER, F.L.S., Ulrombe Pluce, Maidstome.

Rt. Hon. Lord WALSINGHAM, M.A., LL.D., F.R.S., Trustee of the british Musemm; Mertom Hell, Thetforrl. 



\section{PREFACE.}

This wolume contains the results of a conjoint Expertition molertaken in the winter of $1898-9$ hy representatives of the British and Liverpool Museums, for (chiefly) the Zoological exploration of Solkotris. By incorporating the results of previous or (where arailahle) eontemporaneons explorations, the work forms practically a Monograph of the islands visiterl.

The eost of the Experlition was borne ly rotes from the Government Grant of the Royal Society of luondon and the Mnseums Committee of the Liverpool City Commeil, supplemented ly sulsirlies from the Comneils of the Royal Geographical Society of London (in ardition to a loan of instrnments) and the British Association for the Arlvancement of sicience.*

This rolume is issued, in accordance with a mutual agreement under the anthority, and at the expense, of the ahove named Committee of the Corporation of Liverponl, as a special Bullotin of the Lirerpool Museums, its official publication.

The Committee desires to thank very heartily the various distinguished specialists who have contributed sections on the rlifterent groups on which they are anthorities, to whom the Editor would beg to add his acknowledgements of their forlearance orer the delay in the pullication of the work, which he deeply regrets, but which is due to circumstances quite beyond his control.

The grateful thanks of the tro Institutions interested in the Expedition are due to the Govkrisure of INDA for so generonsly granting the service of the despatch boat Elphinstoue, of the Indian Marine at Aden, for the conveyance of its members to and from their destination; for the loan of tents and for the protection, while on the islands, of a military guard consisting of a mative sub-officer and a sikh, as also for the use of camels in their excursions in Arabia : to General O'Moore Creacin, V.C., Political Resident at Aden, for the fullest offieial aid, and, together with Mrs. Creagh, for much private kindness: to Captain .J(or, First Political Assistant, from whom they received constant and valualble advice and ready assistance, hesides his own and Mrs. JAcos's hospitality in their delightfully-sitnated residence, on their return from Sokotra: to Captain MacArTHer and the ofticers of the Elphinstome, who did everything possible for their comfort and assistance while on hoard: and, finally, but not less sincerely, to I). Mackisxos, Esc., and the British India S.S. Company, for generons concessions and privileges in the matter

* The British Association Committee consisterl of Dr. J. Scott-Keltie; Dr. H. O. Forbes: Dr. Wr. T. Blanforr, F.R.S. ; and Professor Meldon, F.R.S. 
of fares and bagaage on the royages to and from Arlen, on their ships lyenore and Ghoorlikn.

I am under special obligations to my friends Johnston Watson, Escl., M.A., am S. W. Lambert, Esif., of the Mirlle Temple, for their kinduess in obtaining for the Expedition from the Eastern Telegraph Company the use, free of charge, of the cable from Arlen. This privilege was most highly appreciated hy Mr. (irant and myself, as, in possessing it, not only was telegraphie communieation with Bombay and London (necessitated during the period of anxious delay referred to in the Vurrotiow) experlited, and at at great saving to the resomres of the Expedition, lont also our fanilies wore able to be informed fresurently of our welfare.

The Nerrative of the Jomrury, by the Elitor, as originally written, dealt at consirlerable length with olservations made on the history, anthropology and ethology of the Sokotran Archipelago, hesirles treating of sulvjects the interest and importance of which only became apparent on investigation after the return of the Expedition, such as, among other's, the origin of the domestic attle found on Sokotra; the marriage customs of the ancient Sokotri; and the question of the distribution of land and water in the Indian Ocean as indicated hy a study of the famma and floma of the islands. It was found, however, that the incorporation of this material wonld have hronght the cost of publication heyond the smm provided therefor: and wonld have hesides rendered the size of the rolume inconveniently large, so that this section has had to be reduced to little more than a mere itinerary. These subjects, together with, it is hoped, the results of the topographical olservations, will form a separate pullication.

\section{HENLY O. FORBES,}

Director of Mluseums.

The Musetis, Liverpoul, April, 1903. 


\section{CONTENTS.}

Preface.

I.MI:F

vii

Narrative of the Journey, by HENRY O. F(ORBES, LL. . .. . ... Xr

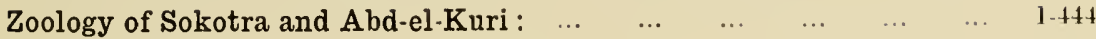

Mammalia, by W. F. DE WINTON ; HENRY O. FURBES, LL.1. ;

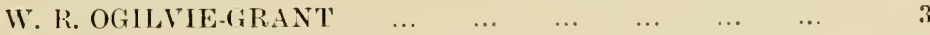

Aves, by W. R. O(iLCIE-(iRANT ; HENRY O. FORBES, LI.1). 19

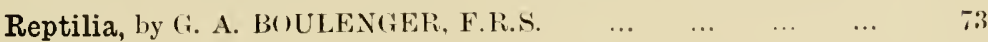

Batrachia ; Pisces, Note by HENRY O. FORBES, LL 1). .. _.. $\quad 105$

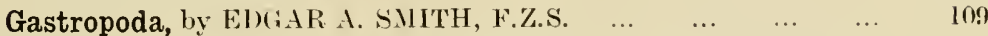

Morphological observations on genera of the Families of Cyclostomidæ and Helicidæ, by Lt.-Col. H. H. GODWIN-AUSTEN, $\begin{array}{llllllllllll}\text { F.R.S. } & \ldots & \ldots & \ldots & \ldots & \ldots & \ldots & \ldots & \ldots & \ldots & 159\end{array}$

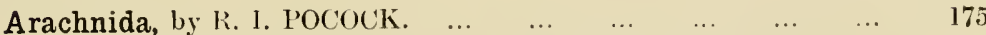

Crustacea, by R. I. POCOCK ; A. O. WALKER, F.L.S. : ANDREW

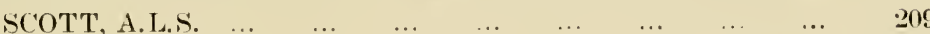

$\begin{array}{lllllllllll}\text { Insecta } & \ldots & \ldots & \ldots & \ldots & \ldots & \ldots & \ldots & \ldots & \ldots & 233-426\end{array}$

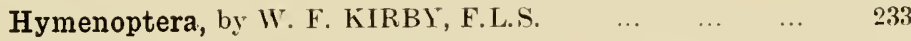

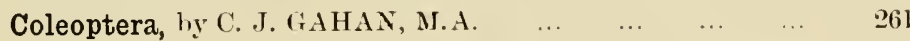

Lepidoptera I.-Rhopalocera, by W. R. OGILNIE-LRANT 293

Lepidoptera II.-Phalænæ. by Sir G. HAMISON, Bart. ... 319

Lepidoptera III.-Pterophoridæ and Tineina, by the Right Hon. Lord WALSIN(xHAM, II.A., LL.I), F.R.S. ..

Diptera, by (:ERTRUDE RICARHO ; F. V. THEOBALD, ll.A.

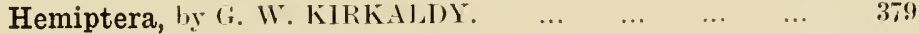

$\begin{array}{llllllll}\text { Neuroptera : } & \ldots & \ldots & \ldots & . & \text {. } & \ldots & 379-418\end{array}$

Pseudo-Neuroptera, Note by HENRY O. FORBES, LL.1.

Neuroptera Amphibiotica, by R. IfciACHLAN, F.R.S.

Neuroptera Planipennia, by W. F. KIRBS, F.L.S.

Orthoptera, by MALCOLM BURR, F.L.S. $\quad \ldots \quad \ldots \quad$.. $\quad 4 \quad 419$

$\begin{array}{llllllll}\text { Myriapoda, by R. 1. POCOCK. } & \text {.. } & \text {.. } & \ldots & \ldots & \ldots & \ldots & 427\end{array}$

Hirudinea : Chætopoda, Note by HENRY O. FORBES, LL.I). $4+1$ 
Botany of Sokotra and Abd-el-Kuri:

Angiospermæ, by Prof. I. B. BALFOUR, F.R.S.

Pteridophyta, by P'rof. I. B. BALFOUR, F.R.S. 53.5

Thallophyta : .543

Fungi, Characeæ, Algæ, Diatomaceæ, "purl BALFOUR,

"Botany of Socotri:."

Lichenes, by OT'TO V. MARBISHIRE, l'h.J).

Algæ, (ex Abd-el-Kuri) by E. M. HOLMES, F.L.S.

Geology of Sokotra and Abd-el-Kuri : $\pi 1$

Note on the Geology, by Prof. .J. W. (ARE(4ORY, F.R.S. ... .. 573

Index .5:3

\section{List of Plates.}

I. Sokotra Pottery

to face title page.

IA. Sketch Map of Sokotra, showing route .. ". page $\times$.

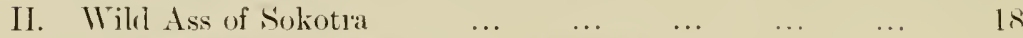

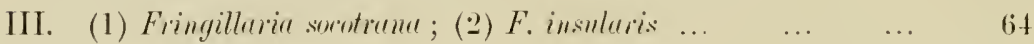

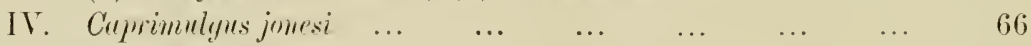

$\begin{array}{lllllllll}\text { 1. Scrops sucotruness } & \ldots & \ldots & \ldots & \ldots & \ldots & \ldots & 68\end{array}$

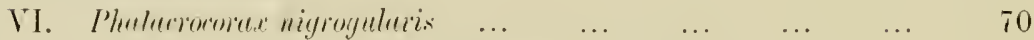

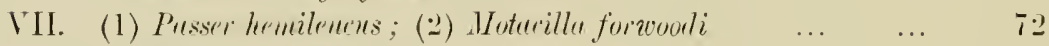

$\begin{array}{llllllll}\text { VIII. I'hyllortuctylus riebeckii } & \ldots & \ldots & \ldots & \ldots & \ldots & 98\end{array}$

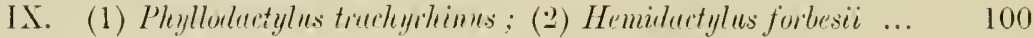

X. (1) Hemidartylus pumitio ; (2) H. oryglinuss ; (3) H. grauti ... 102

XI. (1) I'uruchulciles sorotiunus: (2) Glencoun filiformis: (3) C. $\begin{array}{llllllll}\text { metciture } \ldots & \ldots & \ldots & \ldots & \ldots & \ldots & \ldots & 104\end{array}$

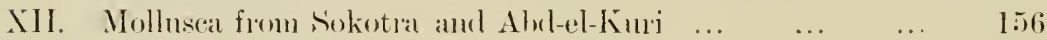

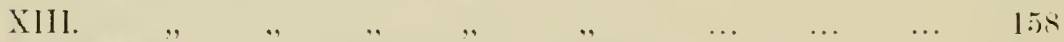

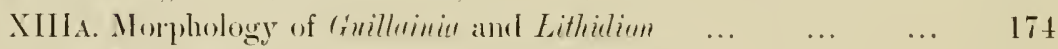

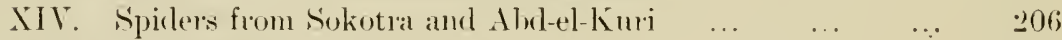

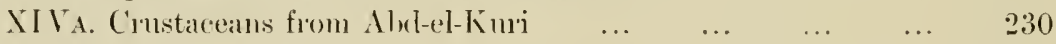

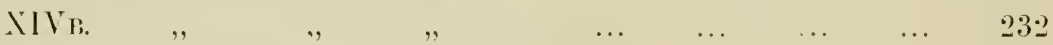

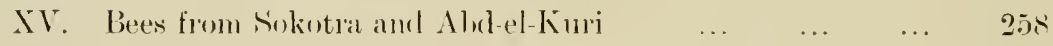

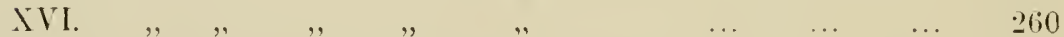

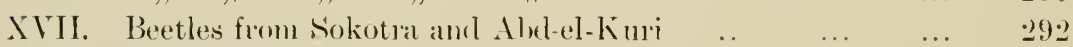

$\begin{array}{lllllllll}\text { XVIII. Cluctures velor } & \ldots & \ldots & \ldots & \ldots & \ldots & \ldots & 316\end{array}$

$\begin{array}{llllllll}\text { XIX. Butterflies from Sokotral } & \ldots & \ldots & \ldots & \ldots & \ldots & 318\end{array}$

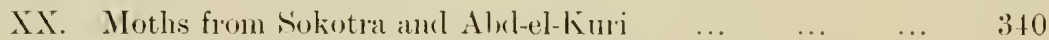

XXI. Micros from Sokotra and Abel-el-Kuri $\quad \ldots \quad \ldots . \quad \ldots \quad 356$

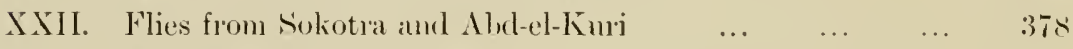

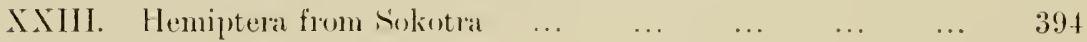


XXIS. Hagentlies from sokotra

to filce page 106 ;

XXIVA.

XXY. Orthoptera from Soliotra

108

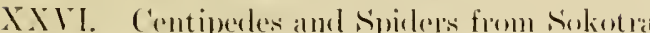

426

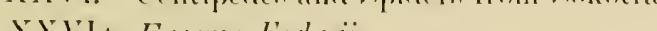

$20 \mathrm{~s}$

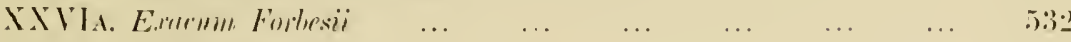

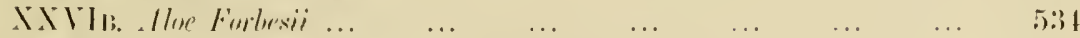

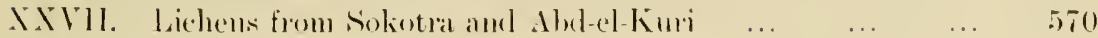

Illustrators: P. Smit, H. Gronvold, F. O. Pickard=Cambridge, J. Gireen, H. Knight, Mrs. I. B. Balfour, M. Horman=Fisher, T. Latham, and others.

\section{List of Illustrations in the Text.}

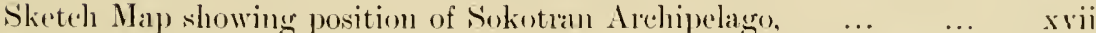

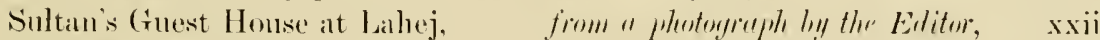

Natives of Alul-el-kini,... ... ... .

Native of Ald-el-Kmi, ... .. ... $\quad, \quad$ Xxv

Nose Pincers nsed by Ald-el-Kuri Llvers,

View of the "Strath' and Native [wellings, Abd-el-Kuri, ,

Native Dwellings, Alnd-el-Kuri, _.. $\quad$,.

View of Sonthern Face of Gelsel Saleh, Alnd-el-Kuri, ,

View of Hadibu and the Haghlier Monntains from Tamalrida Bay,

Yiew in Goahal Gorge, Sokotra, from "l plentorfreple ling the Eslitor, xxxii

Dragou's blood Tree, ... ... ...

ixix

Cucmber Tree, ... ... ... ...

Frankincense and dilrminm Trees,

('amp at Aclho I)imellus,

Sokotian Ciattle,

View of Gehel Divat from Adluo l bimellus P'ass,

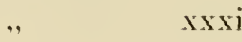

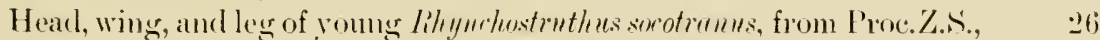

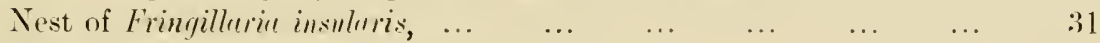

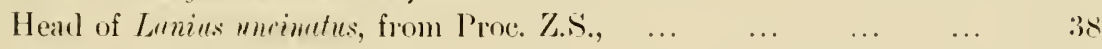

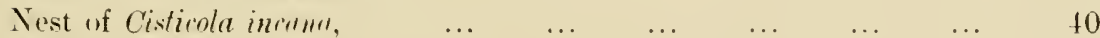

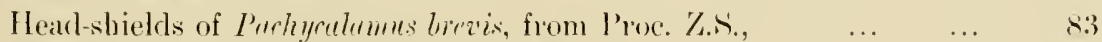

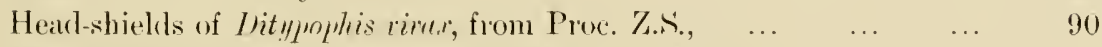

Enuen rylimtriat, from a drawing by Mr. E. A. Smith, $\quad \ldots \quad$.. 111

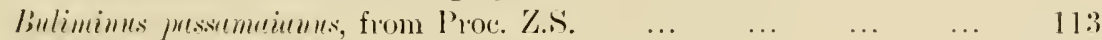

Bulimimes lentii, from a drawing ly Mr. E. A. Smith, _.. . . 11 .

$\begin{array}{lllllll}\text {, luylei, from Proc. Z.S., } & \ldots & \ldots & \ldots & \ldots & \ldots & 115\end{array}$

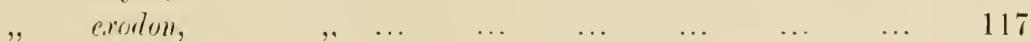

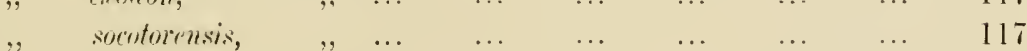

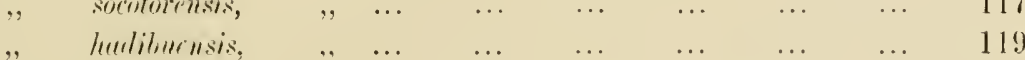




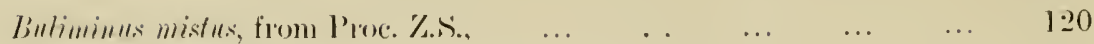

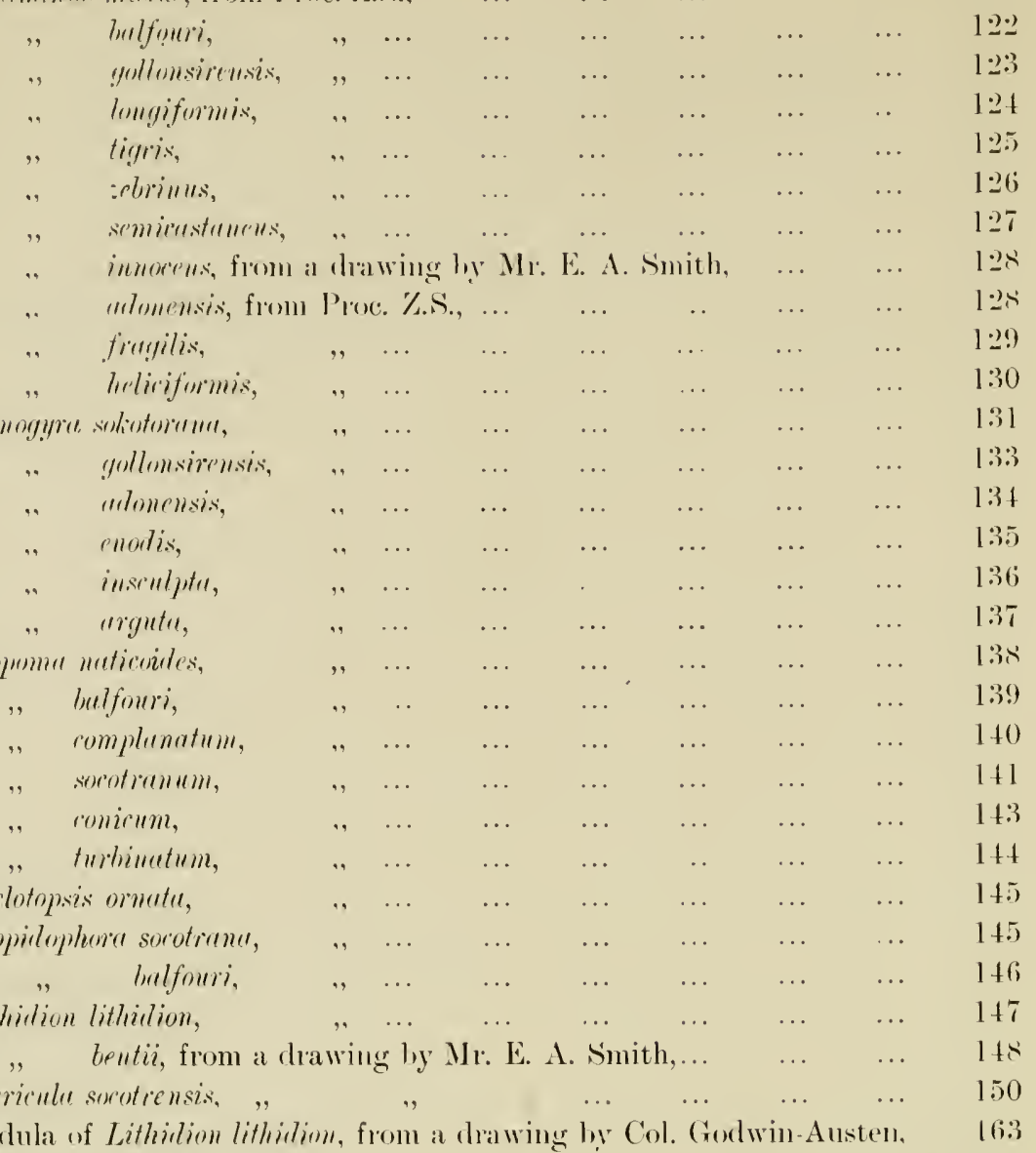

Rardula of Lithilion lithidiom, from a drawing ly Col. Godwin-Austen,

I. souleyptimum,

..164, 165

U. unticunites,

16.5

Tiopielophoru

.,

166

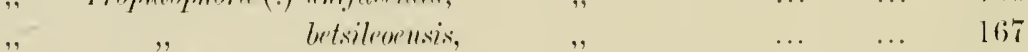

". Guillainia grotu,

bulimimus lulfouri,

Genitalia of $\quad$, somotorrusis,

Palpus of Ammene lupplophullus, from a drawing ly Ml. K. I. Pocock, 190

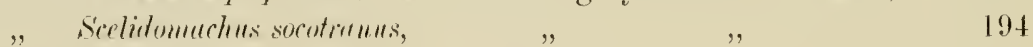

Potamoun secotiensicis,

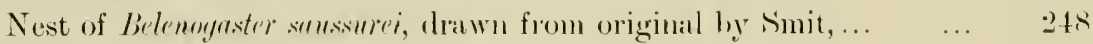

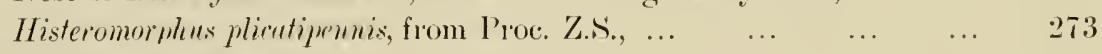

$\begin{array}{lllllllll}\text { Enseyntellia bulfouri, } \quad, & \ldots & \ldots & \ldots & \ldots & \ldots & 275\end{array}$

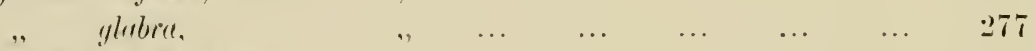

$\begin{array}{lllllllll}\text { Adelostoma biratinatum, } & , & \ldots & \ldots & \ldots & \ldots & \ldots & 278\end{array}$ 


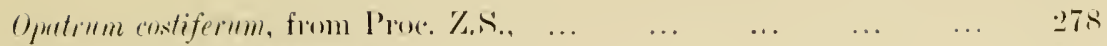

$\begin{array}{lllllllll}\text { Mouth organs of Apithesis, } & . & \ldots & \ldots & \ldots & \ldots & \ldots & \pm 79\end{array}$

Aprithesis wheset,

Meclludon arabicum,

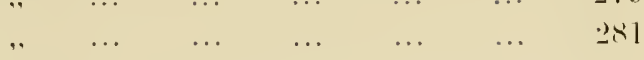

Copulatory organ of Fonturiopsis forbsit, from al drawing hy Mr. R. I.

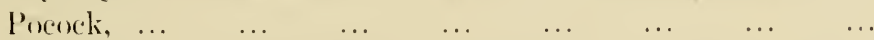

436

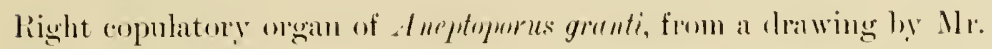

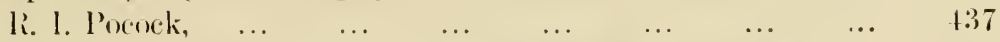

Seedling of Boswellic Amero, from a drawing ly Mrs. 1. B. Balfom, 461

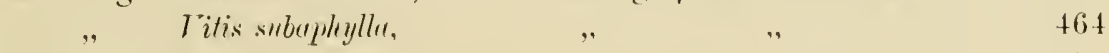

Young Cuemulier Trees, $\quad$, " $\quad 473$

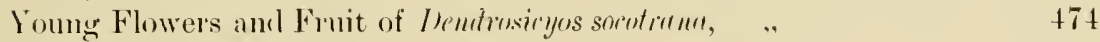

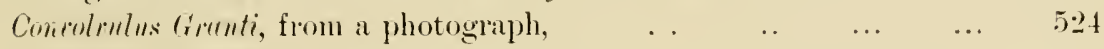

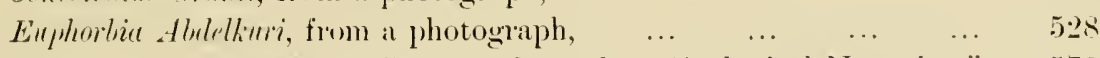

Geological sketeh Map of Sokotra, from the "Geolngical Magazine," 578 


\section{ERRATA.}

On page 50, for Gubbat Shoab, renl Ghubbet Shoab.

" 62, for OEgialitis, rml Agialitis.

,. ㄴ. 2 , for Potamon Socotrensis, reul Potamon socotrensis.

" 241, "fter Harpactopus, inseit Smith.

, $27 s$, meler "pper fiymer, insert title Adelostoma bicarinatum.

" 289, ufter Melyris, insert Fabr.

" $\quad 329$, for Chorocampa, reet Chærocampa.

". 33:, "fter Eremocossus, inse't Hamps.

. 375, "fter Anthrax, iwsert Scop.

", 385, terusfer Aspilocoryphus to line lelor. Lygxida, auctt.

, 406, for Trithernis arteriosa, rem Trithemis arteriosa.

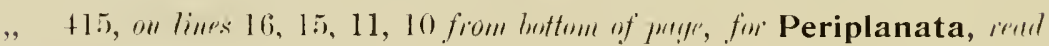
Periplaneta.

, 430, for The Centipedes of Sokotra, rmm The Centipedes and Millepedes of Sokotra.

" 441, minler Hirudinea, mell Chatopoda in setme typr "s: Himliure.

" $\quad 4.2$, ufter Momordica, insert Linn.

". 505, ufter Securinega, insert Juss.

.. 506, "fter Ricinus, inswit Linn.

.. 507 , "fter Angracum, inseit Borg.

. .31, "ffer Heterochloa, insert Desv. 



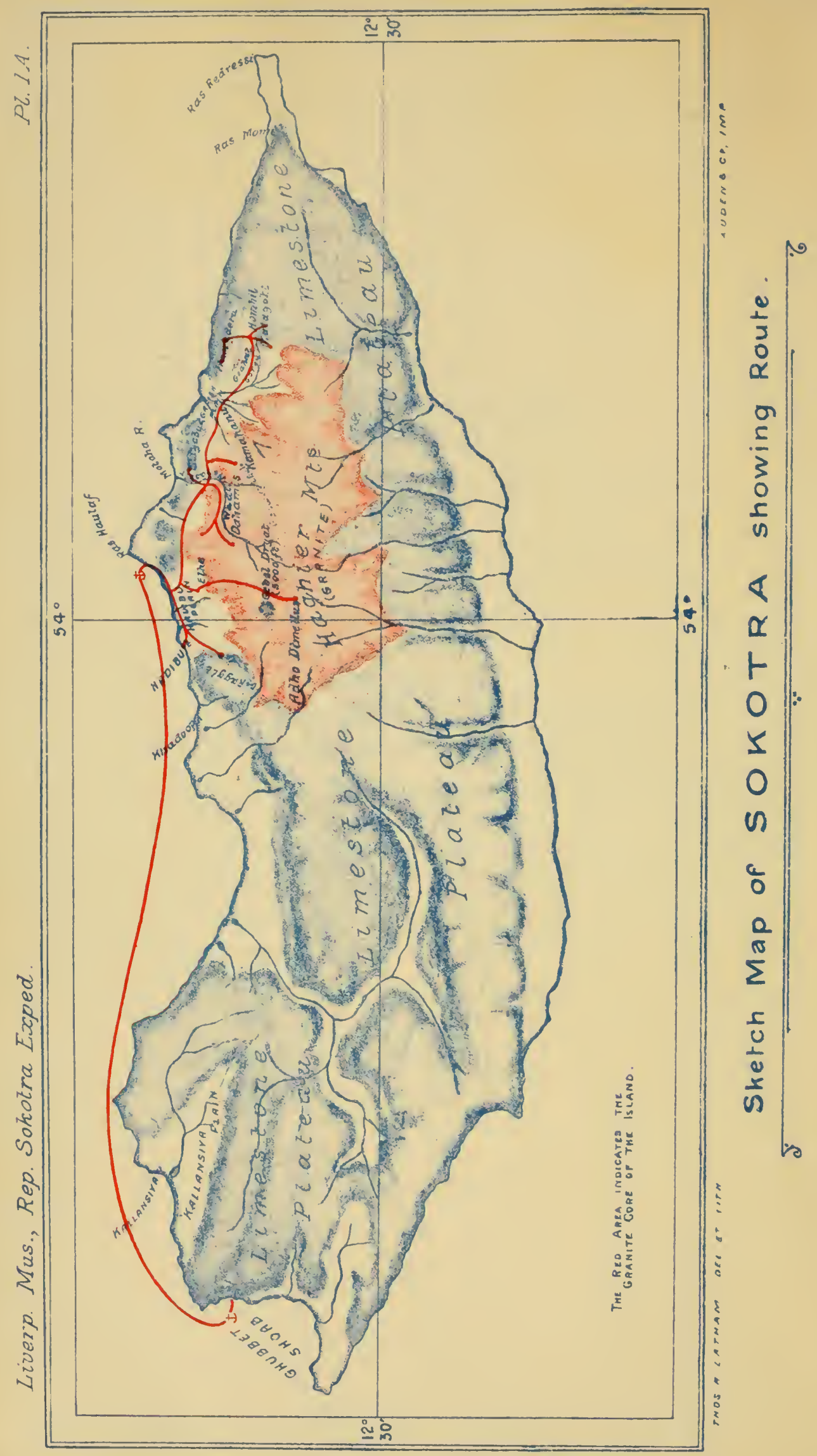




\section{Narrative}

of the

\section{Journey.}

B.y HENRY O. FORBES, LL.D.

PIATES I., IA. 



\section{Narrative of the Journey.}

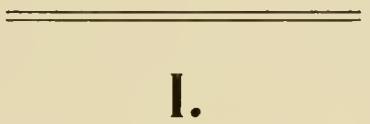

\section{Aden. Sheikh Othman. Lahej.}

Sokotra is the largest and most easterly island of a small archipelago lying some 120 miles from the const of Africa, nearly opposite its great Eastern Hor' which terminates in the Cape of Gnardafni, moler the 12th parallel of $\mathrm{N}$. latiturle. Its other members are The Brothers-frepuently called The Sister's by the older narigators -(two minute islets, Semha and l)arzi), slightly to the sonthward, and Ald-el-Kuri, the second in size and the nearest to the continent. The Brothers as well as Alol-elniri ane surromeled ly hanks covered only by 10 to 30 fathoms of water. The former bank is mited to that on which Sokotra stands: lout from Alol-el-Kuri it is separated by a valley of 100 fathoms, while Alul-el-Kmi is cut off from the extensive projecting shelf of Guardafni ly a namow but deep trongh of several hundred fathoms in deptl. The

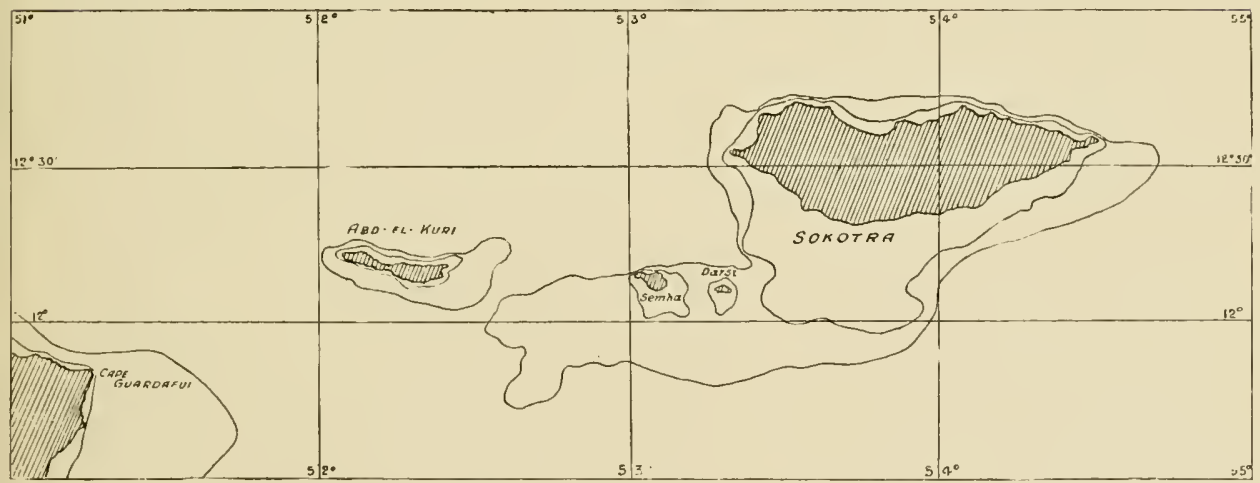

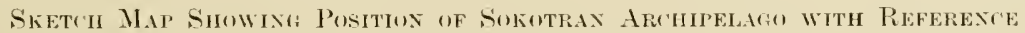
TO AFFICA.

summits, of the larger, at all events, of these islands are now known to he among the land surfaees of the glole that have longest, if not always, held their heads alove the sea, their senlptured peaks and pimacles attesting to the waste and wear they have so long endured. They have been mute wituesses probably since earliest Palieozoic times to the droming of many 
lands around them, and to the uplifting from the ocean of mighty ranges on the two continents towarls which they now look, and of which at one time or another in their wonlerful vicissiturles they have formed a part.

Few islands are better known by name to eastern travellers than Solotra. It was a very usual course for ships, in the days of the early Iurlian voyages, to make the island after rounding the Cape before "laying "before the monsoon for the coasts of Malabar, and now every funnel that eomes through the Straits of Bal-el-Mandel, wherever bound, sights its cloud-belted roeks. Nevertheless, it has been little visited by Emopeans, by reason of the great diffieulty of reaching it, for, on aecomt of its harbourless shores, it is not a port-of-call exeept for ressels specially chartered, or for native baghlahs never savoury or very safe.

Unless for surveying purposes, no seientifie investigator had visited the island, and none had devoted any attention, sare for a few desultory observations, to the biologieal problems that this insular group presents, till the year 1879-80, when, as the result of the efforts of a committee of the British Association, the exploration of Sokotra was entrusted to Professor I. B. Balfour, of Edinburgh, then in the Chair of Botany in Glasgow University, a naturalist alrealy distinguisher for similar investigations as a member of the Royal Society's Transit of Venus Expedition to the Mascarene Islands in 1\$74-5. Aecompanied by Lient. Coekhurm, Mr. Leech and Mr. Scott, Prof. Balfom deroted two months' hard labour to his task, and returned with large collections of very exceptional interest.

The following year (1881) two Germans, Dr. Schweinfurth and Dr. Riebeek (acempanied by Irs. Mantay aud Rosset), both well known as accomplished scientific men, quite maware of Professor Balfour's Expedition, had, while in Arabia, their attention directed towards this isolated speck of land, and together made their way to Sokotra in a native baghlah, and further contributed to our knowledge of the islaud by their exploration, which lasted some six weeks.

After an interval of seventeen vears Sokotra was again re-visited by the late Mr. 'Theodore Bent, an erudite traveller, well known for his archeological investigations in many countries. He was accompanied by Mrs. Bent and Mr. E. N. Bennett, of Hertford College, Oxford.

The first two expeditions-Professor Balfour's and I)r. Sehweinfurth'swere, from the eminence of their leaders in that science, specially botanieal: while of Mr: Bent's the main olject was the search for traces of the Himyaritie civilisation of Arabia. Although Dr. Balfour and the members of 1)r. Sehweinfurth's Experlition interested themselves also in the people and their language, and marle collections in several groups of zoology, as did Mr. Bennett of Mr. Bent's party, as well as a few of the naval and military ofticers who at varions times had heen officially engaged in the Arabian seas, no experlition had visited the islands with the special olject of investigating their fauna. Considering that the Report of the British Association Committee of 1880 coneluded with the statement that "the Committee feel no loubt that in every branch of science considerable results are yet to be ohtainerl by further 
investigations in Sokotra," it was thonght ly us that the region might with profit be more thoroughly investigated zoologically. It was accordingly aranged that the explonation should be undertaken during the winter of 1898-99 ly Mr. (irant and myself.

Having purchased tents and camping equipment and laid in the necessary stores, larter, and merlicines, we sailed from the Thames for Aden on the morning of the 2sith Oetober, ls9s, on hourd the British India Company's s.s. Mrenom, under the alble commandesship of Ciptain Henderson, so well known in the service for his kindness, consideration and geniality.

Among our fellow passengers we har not only the pleasure lut were fortunate in making the acquaintance of Captain . Iacol), who was on his way back to Aden to assme the duties of First Political Assistant. He was returning from furlough, after having fulfilled a period of arduons service in Somaliland. 'This Protectorate, however, hat a month hefore been trinsferred from the charge of the Indian (foresmment to the Foreign Otfice, and over it Col. Hayes Sadler, then First Political Assistant at Aden, who had been making the prelininary arrangements for our Expedition, had just heen appointed Consul-General, and to whom Captain dacol, wats then snceeding. Mrs. Iacol, we were interested to find, Wis al danghter of the late Major Hunter, formerly Assistant Political Resident at Aden, whose name had heeome well known to us, while consulting the literatme on Sokotra, as one who harl visited and witten several valnable reports on the island, and had also been a member of the Soliotra Committee appointed ly the British Association for the exploration which was carried out ly l'pofessor Balfour. To both of them we were later gleatly indeloted for much assistance and hospitality in Allen, which we reached shortly after noon on the 17 th November.

Going ashore in the liesidency hoat, in which Captain Jacol, kindly invited us to take a place, we passed the despatch hoat Elplinstome, of the Indian Manine, which was waiting to convey us to sokotra, and, lying higher. up the harlour, there was pointed ont to ns the steam yacht frotfficed, having on boarl an Expechition, for the investigation of the Himparic inseriptions of Sonthern Aralia, sent ly the Tmperial Aeardemy of Sciences of Yienna, of which Hofrath Professor David Mitller, the distinguished Arabie scholar and anthority, was a member. Landing at the Prince of Wales Quay, we fixed our quinters in the Hotel de l'Europe, where in the erening ('iptain Lloyd-lones, of the Army Medieal Fervice, called upon us to very comteonsly offer any assistance he cond, and to inform us that the honorary membership of the Chl, hat heen extended to us. From him, however, we learned, in the comse of conversation, the rather dispuieting news that difficulties of a political chander of which he was not fully acpuainted-harl arisen between the (rovermment of India and the Sultan of Sokotra which might possilly interfere with the Expedition's proceeding to its destination. It was with some anxiety, therefore, that we hove to the Residency next morning to report our arrival to General Creagh, hy whom we were received in the kindest possible mammer. He expressed the fullest sympathy with the objects of our Expedition, hut regretted he had to comvey to us the disappointing informa- 
tion that the relations between the Indian (fovernment and the Arabian Sultan of (Hishin, who is also Sultan of Sokotra, were at the moment considerahly strained, owing to His Highness having entirely ignored the various letters of complaint adclessed to him by the (iovernment of India in regard to numerous acts of piracy which he had heen permitting in Sokotra since the weck of the P. and O. steamer dden on its eastern point. The General, therefore, greatly to his regret, was mathle to give us recommendatory letters to the Sultan, or rather (forernor, of the island--who, though ouly Viceroy on his uncle of Gishin's behalf, also generally receives the style and title of Sultan. Without these letter's our reception on the island might he mifriendly, and such olsstates to moving about placen in our way as to make our visit of little profit; while if we were the bearer's of an official recommendation disregarrled by the sultan, the Gorernment of India wonld be placed in an mpleasant position. This situation had heen commmicated hy General Creagh to the Iudia Otfice liefore our departure from London, with a recommendation that we should be arlised to postpone our Expedition for a season. He was, therefore, much surprised when he heart that we had actually arrived in Aden. Strangely enough, althongh we were in communication with the India Othice, and had a few days before we sailed received a telegram throngh it from the Govermment of India glanting us the loan of tents from the Service stores at Aden for use on the Expedition, no hint of this communication had been conveyed to us. Now that we had arriverl, the liesident, sympathising with our disilppointment, most considerately rolunteerel to re-examine the question at once, in the hope of heing able to suggest some arrangement to the Indian Govermment under which the Experlition might, with as little telay as possible, he allowed to proceed. As some few dilys would necessarily have to elapse before a reply could he received, he rery amiably placed at our disposal for the interval, should we care to go there, his hungalow at Sheikh Othman, on the northern shore of the hay forming the harbour of Aden, where it was cooler, and where at least some little vegetation and more anmal life was to be fonnd than in the Settlement-an offer we corrlially accepted.

Matters connected with the landing and arrangement of our bagatge detained us for two days, during which we had the pleasure of exchanging risits with the members of the Austrian Experlition to Sonth-Arabia on the Gotffried. Count lamberg, Plenipotentiary of the Imperial Acarlemy of Sciences, we were unfortmate enough to miss on our reciprocal visits; but our intercourse then with Dr. David A. Müller, Dr. Kossmat, Professor Simony, I)r. Paulay and Mr. Bury is a pleasant recollection, while our relations at a later date, as will appear below, placed us under deep obligation for kindness of no ordinary kind during a period of grave sickness.

On the 20th, we were at last able to take adrantage of the liesickent's permission to oceupy his hungalow at Sheikh Othman, some ten miles to the north. In the eool of a relightfnl morning we set out in a couple of gharries, accompanied hy our taxilermist Cutınore and a Somali butler. Jamah. We reacherl sheikh Othman before eight o'elock, and found there a very comfort- 
ahle, airy, emropeanised oriental humgalow of stone, standing in a large walled-in shady compoumd, almulantly planted with palms, acaeias, almond trees, jasmine, hibiseus, and other flowering shrubs.

Here we spent a eouple of most pleasant clays-all we daserl arrange for, as we were in houly expectation of news from the foremment of India in regard to our joumey to Sokotra-and olstained a glimpse of the fama of the desert. life was pratically eonfined to the walled-in, well watered gimrlens sumomuling the various bungatows there, and consisterl ehiefly of insects, lizards, and birds. Considering the encompassing desert, the number of species we obtained was remarkable.

We were greatly elisappointed to learn on onr return to Arlen on the 23 rd that no reply had arrived from the Government of India to General Creagh's telegram. It was indeed possible, we now learned, that some considerable time might elapse before a reply conld he reerived. Considering, therefore, that the season and our leave were rapidly and fruitlessty passing away, and that the prohability was great that, if permission were given to proceed to Soliotra, it wonld have to he preeded ly preliminary politieal negotiations with the Sultan at Gishin, which would still further consume our time, we decided, if no reply shonld reach Aden within the next few days, to abandon altogether our Sokotra journey, and proceed into the little known mountainous Abdali conntry of South Aralia under the Sultan of Lahej, hetween whom and the English Govermment the most friendly relations have now for a long time existed.

The Resident, who, in an interview he had with the Sultan the day after our return, had taken the opportunity to warmly commend our Expedition to his assistance and protection, shonld we proceed into the interior, had received from His Highness a cordial invitation for us to visit him at Lahej, with the assulance of a safe escort and the promise that everything in his power wonld be done for the comfort and snceess of our mission among the hills.

Several days having passed withont news from India, we agreed that by accepting the Sultan's invitation to lahej we might employ on time to more adrantage there than in Arlen. For on stay in the interior General Creagh was good enough to place at om service fiom the Bombay troop at Khor Muksor, an Arab jemadar (or sulb-ofticer) and a Sikh sowar as guard, and for our transport, the necessary riding and haggage camels. Wre decided to travel as lightly equipped as possible, arranging for the bulk of om laggage and the requisite servants to be sent on to 11 , if 110 anthority for our visit to Sokotra should arrive by the date we had giren omselves as the latest we could afforil to wait. After that date we agreed, as on best comrse, to nudertake an investigation of the little known hills in the morth of the sultan's dominions. In addition to om excellent lutler .Jamah, a rehable interpreter was all we needed to complete our retinne, and him we found in Gulaid Ehmi, a Somali. This man's linguistic attaimments were really remarkable. Arabie and Somali were his mother tongues. He spoke Hindustani excellently, French by no means bally, and English with 
womlerful accumcy and with a goon accent. Moreover, he conld write each of these langmages in its own seript. His comtenance being open and pleasing, we engagerl him on trial as interpreter for om lahej excursion. I may say here that he proved most watisfactory in erery way. I learned from him subsequently that, as a hoy, he harl come moler the notice of, and been sent to a good school in Aclen by that hmmanitarian and talented officer Major Hunter. He had serverl as chrk in rarious English lusiness houses, and had been employed later as a secret service agent of the forernment in, among other places, the French possessions on the lied fiea.

Accompanied, therefore, ly our two Somali servants, we left Arlen late in the afternom of the 25th Novemler to pass the night at Sheikh Othman, whence the following morning, the efoth, on lweing joined ly our troopers and camels, we set ont across the Tehamih. In the afternoon we reacherl Lahej, and put up at the Sultan is gnest-honse. Next morning to our dismay we discorered that small-pox was rery prevalent in the town, and harl carried off on: of the Sultan's danghters the previons day. Consirlering the disastrous plight we should be in if any of us shonkl be smitten with the rlisease, which might well happen exposed as we vere to constant contact with servants from the palace, and the guards and comers and goeps generally, we decided to move withont delay away towards the momitains. The nocessary arrangements har hardly heen completed, however, when

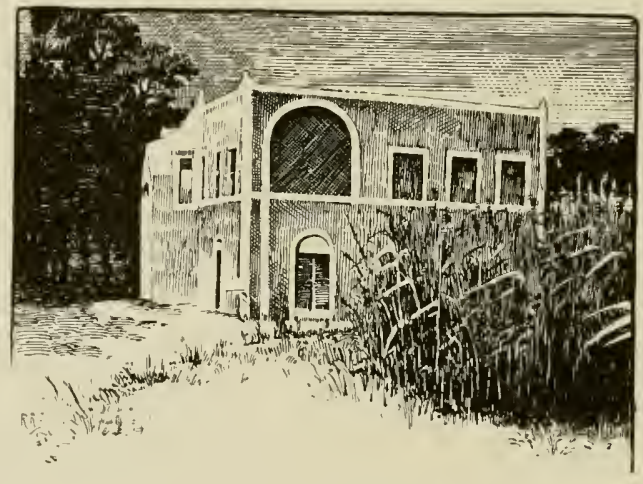

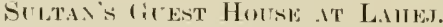

a comier anverl from delen lninging a letter from Captain dacol, with the weleome intelligence that the Resirlent hat heen anthorised to anrange for our visit to Solotra, and that the Elphinstone was under orders to sail as soon as we retmod. The 27 th was spent in making arrangements for the jommey lack, and on the evening of the 2sth we were in omr old quarters in Arlen.

The following morning on calling at the Resiclency, General ('reagh gave us the gratifying news that ly the arrangements he had made we should be able without further rlelay to proceerl to Sokotra, where also he expected we should find no difticulties placed in om way. Staying with the General we found Lord Lorat and Mr. Weld-Blumell who had just arrived thens far 
on their explonatory journey to Alyssinia and Khartoum, which they earied though with such great success.

The following two days were fully occupier in our final preparations for embarkation. In the selection and engagement of servants Gulaid Elmi, our interpeter, in whom we now conjoined the responsililities of headman, moved himself specially eftieient, business-like and trustworthy. In ardition to those aldeady employed ly us, we added a cook, all assistant cook and two gun carriers. In the discussion of terms neither the amount of the monthly wage nor the arbun or present arlvance seemer to any of them half as important a eonsideration as the promise of a liberal lukshish to be settled at the end of the engagement if their service proved satisfactory. In addition to these, ly General Creagh's kind permission, the jemadar, Saleh Abrhullal, who had attended us to Lahej, and a sikh sowal of his troop, accompanied us as personal guard. Our party, therefore, mumbered eleven, for eight of whom there had to he provided special rations mentaminated by swine's lard or Muldled flesh, uncurserl in the letting of its blood. In this matter Gulaid, who (having himself few sametified prejurlices) was reckoned hy these men a true believer, in possessing no bigotry as to the Kaftirism of his masters, could be trusted to satisfy both sides. So handing him the reduisite sovereigmi, I clespatched him to the bazar to provender the camp. He returned a few hours later with the detailed reckoning of the furniture of a kitchen-pots, kettles, and sincepans - and three months' supplies, among which ghi, chntney, onions, lieshe or cotfee bean husks and dates figured largely, hesides mussulis, or goat-skin water bottles, blankets, beads, Manchester cottons and trinkets for harter. The whole assortment was packed, paid for, and delivered ly him at the wharf before midday with perfect accuracy, and at half the price we should have had to give at any of the large Parsee stores on Steamer Point.

By the Resident we were funished with an oflicial letter to the Sultan of Sokotra, explaining the olject of our visit and intimating what would be expected of him towards the Expedition. Mohammed Jattier, the adviser in native affairs, in whose office the ofticial Arabic transeript of the Resident's native letters is registered, was also good enough to hand me, as the result of personal amenities between us, a private letter to the Sultan, an old and intimate friend of his, which would secure for us favour and assistance even if strained relations should continue with the Goremment. He was ohliging enough also to offer to select for me hukshish for the Sultan-that "unearnerl increment" which every Arab, high and low, looks for and lores more than gain-such as he knew would be appreciated ly one passing so isolated a life as the Sokotran Governor, consisting of a rial of otto of roses - the pure, unadulterated (so rare to obtain) Persian oil-and rarions richly-pattemert turbans in cloth of golk, for himself, with a large garish ormoln English-made circular mirror having a trio of carved candleholders projecting from it, intended for his harem.

Finally, to complete our arrangements came our lanker, Cowasjee, with the all-important treasury of the corlect medium of exchange on Sokotra, as 
we were assured, in the shape of abont half a hundredweight of Maria Theresil clollars, the true Alm nokut, or "Fathel of dots," shewing the orthordox seven stars on Her Majesty's tiara -all rery sticky and highly orlorous, tied up in a rough gumm has for purse.

Alont fire o'clock on the aftermoon of the 30 th Norember we embarked on board the Elphinstour, whose genial commander, Captinis Macarthur, at once put to sea.

\section{II. \\ Abd $=$ el $=$ Kuri.}

On clearing the harbour, a comrse was laid for Mbl-el-Kuri, the westemmost member of the Sokotran archipelago, where we har the Resident's permission, if we shonkl find the iskund interesting enough, to detain the Elyminstone for a week before proceeding to Sokotra.

At darlight of the 3 rol December we descried this little risited island breaking om cistern horizon as a low bar of land with two donble-peaked heights in the centre. As we approached from the west, steering for an anchorage on the sonthern and at that season the lee shore, the island resolved itwelf into a lower western and a higher eastern end. Coasting along we eagerly scamed its surface for some inclication of its promise to a matrualist ; hut its general aspect from the sea was quite disappointing, for it appeared to he composed of absolutely bare rock, devoid even of a restige of regetation and, notwithstanding the curious legends of the old navigators and historians ahout its people, to be entirely uninhalited.

The Elphinstone slowly felt her way to an anchorage in a little bay with a sandy beach about the midrle of the south coast-the Bandar Saleh of the charts-at the only place where a break in the rocks oceurs.

At first not a native showed himself, and not a sign of hahitation wis. visilble from om deck. By the time, however, that we had fimally come to anchor, at mine o'clock, a small gromp of spectators harl gathered on the shore anxionsly watching on operations. On landing we found them a rather timid, fors, and ill-nomrished company. They spoke both Aralice and Sokotri, and we learned through our interpreter that they har no oljections to offel to om going anywhere on the island we pleased : lut no one seemed to have greater anthority than another, and they referred to no superior. The men were tall, rich coppery bown in colour, while the ehildren were

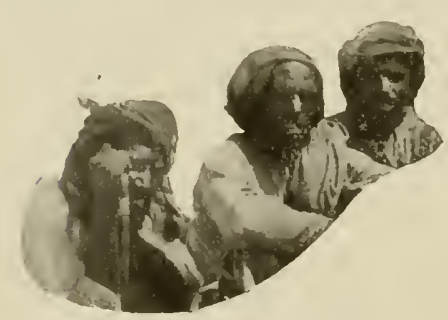

NATIE UF ABD EL-KrRI. considerably darker: but there was no admixtme of negro blood amomg those we encomintered, such as lourte Binlusa makes mention of among those he silw om the island.

A rise of a few feet from the water's extge over a clifted sand-harrier facing the shore, brought us to the level of a platean or wirle strath which stretched right alcross the islanel 
from sea to seat, and separated the higher limestome-capperl range on the east from the lower lilack archan hills on the west. This strath, which hat a low water parting ruming athwart it, was floored with the detritus from the hills on lowth Hankis. Alout a mile to the north-west, we conkl desery umbler and behind the shelter of the low hills which concealed it from the seat, a single small house-cluster, about which a few women amel children were moring.

Our collectiug party, angmented to cleven by a party

Nitive 0 H: An!- EL-Kinl. of offieres from the Eifhimstome, separated and skirmisherl over sereral miles of diy wauly and rocky rixlge. Although only the merest sheen of green was visible from our anchorage, the dry, hard foreshore was fomm to onr surprise carpeterl over (especially where the gromul showed signs of leing more or less inmolated during the wet season) with, besiles a sparse covering of low shrubs, numerous lowly and, in many instances, mere threarlike herlss, rising little above the surfice of the soil, but producing lisproportionately conspicuons flowers. Except for a single well, howerer, we saw 110 water any where.

Birds were disappointingly few, but of the species we obtained, two

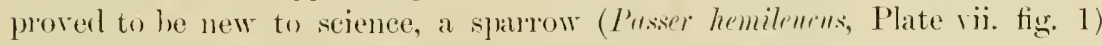
and a wagtail (.Motreillu, formonli, Plate vii. fig. -2). Two species of lizard of the genus Hemidutylus were also found to be new. Lamd shells were abmulant under stones and uyon the bushes, and of these fom are muknown elsewhere. Insect life was scantily represented, very few buttertlies-only three all told,-- beetles, or bees being ohserver ; but of the two latter groups all the species turned out to be mulescribed, while one of the beetles forms the type of a new genus. Orer many of the shrmbs a handsome spirter (Argyom flurkii, Plate xis., fig. :3) had streteher its web of sueh strong threarls that with a stearly pull one comld smap off the stoutish branches to which they were attached without hreaking the silk. Scorpions aboumlerl moler erery stone, and two representation of a new enclemic genus (IIrtemmo) were collected.

In the afternom several of the inhalitants came off in the lameh, hringing lizarls, fishes, turtle-shell, and muscorite to exchange for rice, "Intian

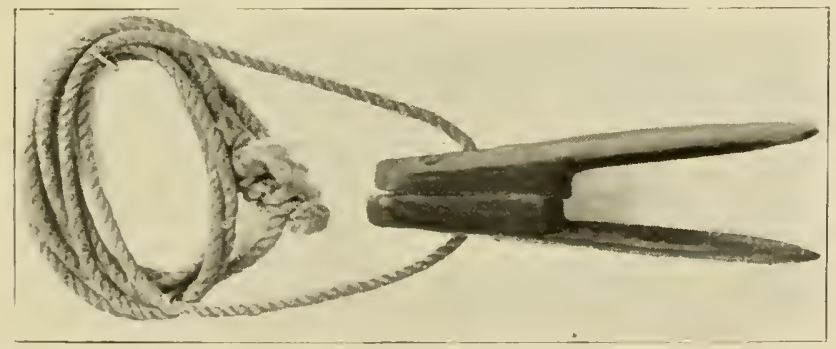

Nuse Piscers lised by Abu-el-Kilri Divers.

tolacco," and learl for sinkers for their seines. I observer that they did some line tishing also, for I saw a solitary inclividual angling astricte a pour 


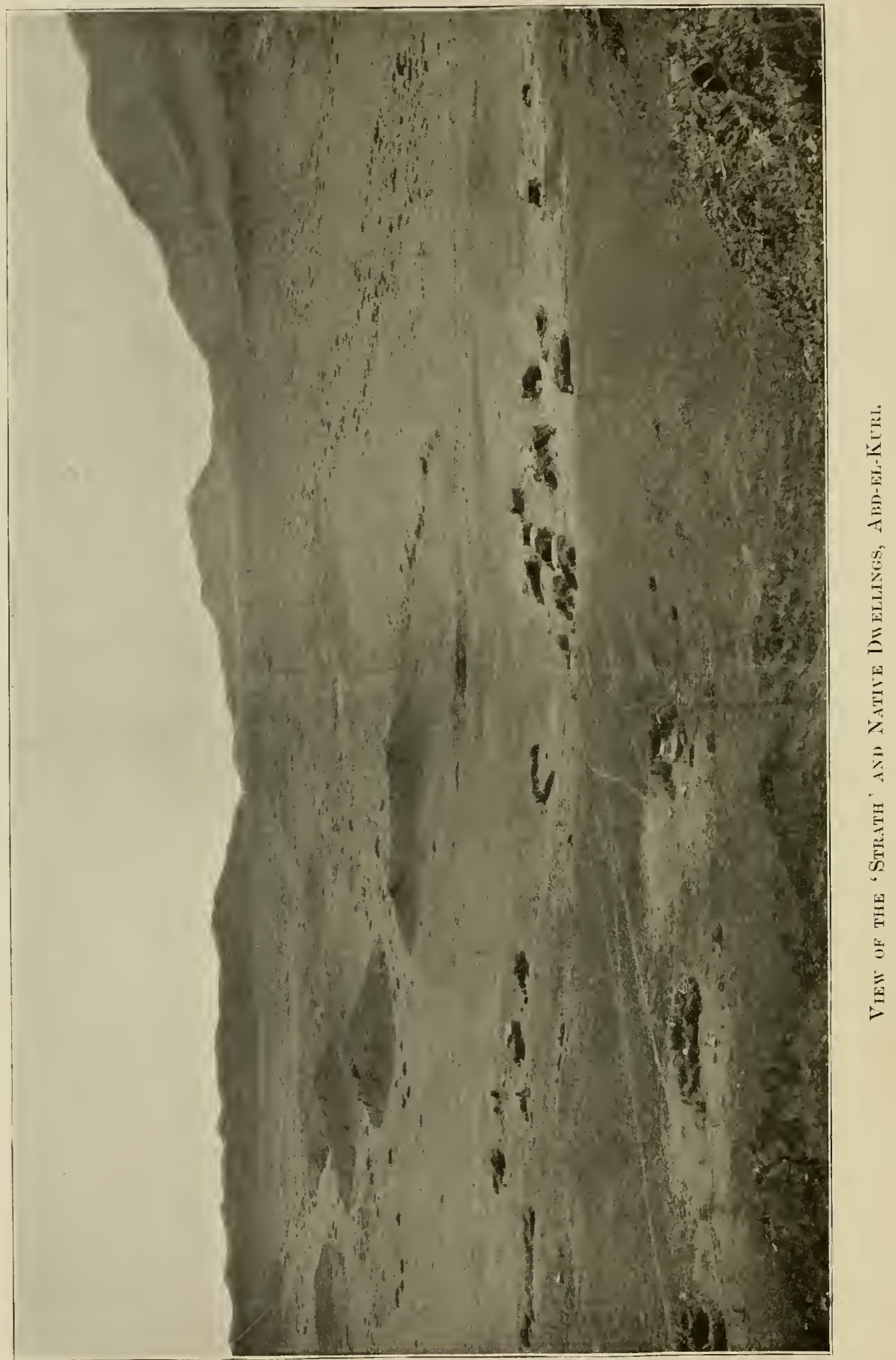


catamanan of three narrow logs of wood lashed together, with his legs dangling in the watel, by which to pardle himself about the bay. It scems that the chief employment of the people is as divers for pearl-shell on the Bacchus Bink to the north-east of the island, on the boats of shellers who come probahly from Kamzihar, Arahia, or India. The diver descends to the sea Hool holding to a line weighterl by a heary stome on which he stanels, his mostrils being closerl hy a small woorlen spring-elamp of pincers. At the end of his 'turn' he drops the stone and is pullerl to the surfice.

Next day we explored to the left of the anchorage, paying a visit to the only native hamlet, so fall as we conld learll, on tho island. 'The dwellings were extremely pool: All were more or less eireular in shape - the simplest form and the easiest to construct - three to four yarls in diameter, and eomposed of unhewn blocks of coral ant lough conglomerate stone piled one upon the other $A$ longer stone for lintel carried the superstructure orer the single small sfluared orifice which server for door, which, with the interstices in the wall, took the place also of ehimmey and windows. The roof was flat and composed of lorushwood, orer which was laid a layer of elay, or occasionally a covering of mats or skins. The apporouch to the door was protected by a double

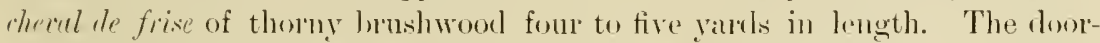
way of most of the huts faced south-east towarl the hills, which would protect them from the driving rains of the west monson. The don itself was a mere wickel-work hurlle. Some of the lwellings contanined sereral women and children, of whom, while the okler ladlies were inclifferent to the prying eyes of the Feringhee, the younger hastily and with some alarm drawing a garment orer the lower part of the face, retreated into the obsemrity of their abode as I peeped within the door. Round every hut lay mmbers of large turtle carapaces (each with an ohlong hole in the midtlle of its back, for what purpose cut I (l) not know), from which the 'shell' had been stripped. Near many of the huts also lay baskets full of dark colomerl muscovite, in large crystals, hut for what use it was collected I could not discover:

The diess of these people, who ean hardly number more than two or three score souls all tolil, comsisted, among the men, of the orelinary turban round the head from the foreheal to the nipe of the neck: a loose eotton jacket buttoned down the front, and a cotton cloth, girt alout the loins, hanging lown to the ankles from a supporting leel : over the shoulder they carried an extra cotton eloth, whose fashonalble pattern was red and white check. Of the women we got only a glimpse, lut their prineipal garment was the long thube, worn slightly open at the throat, reaching down to the ankles. Some of the men wore sandals, but the majority went about harefooted.

Scattered over the stony strath and everywhere all aroumd the base, and on the lower slopes of the anchean hills in the interior up to albout 60 or 70 feet, I observed much marine detritus, consisting of pieces of sponge, coral flagments and fiekls of dead mollusea-the most conspicuous and alumlant being a large species of limpet with perforated apex (Fiswurellu) - as if an enomous wave hat swept orel the lower part of the island at wo distant period and left this jetsim behind. A reef-limestone of Pleistocene 
age, containing Gommstren refiformis, is deposited in nearly horizontal strata ii) to about 40 feet above sea-level upon the archarm rocks west of the anchorage.

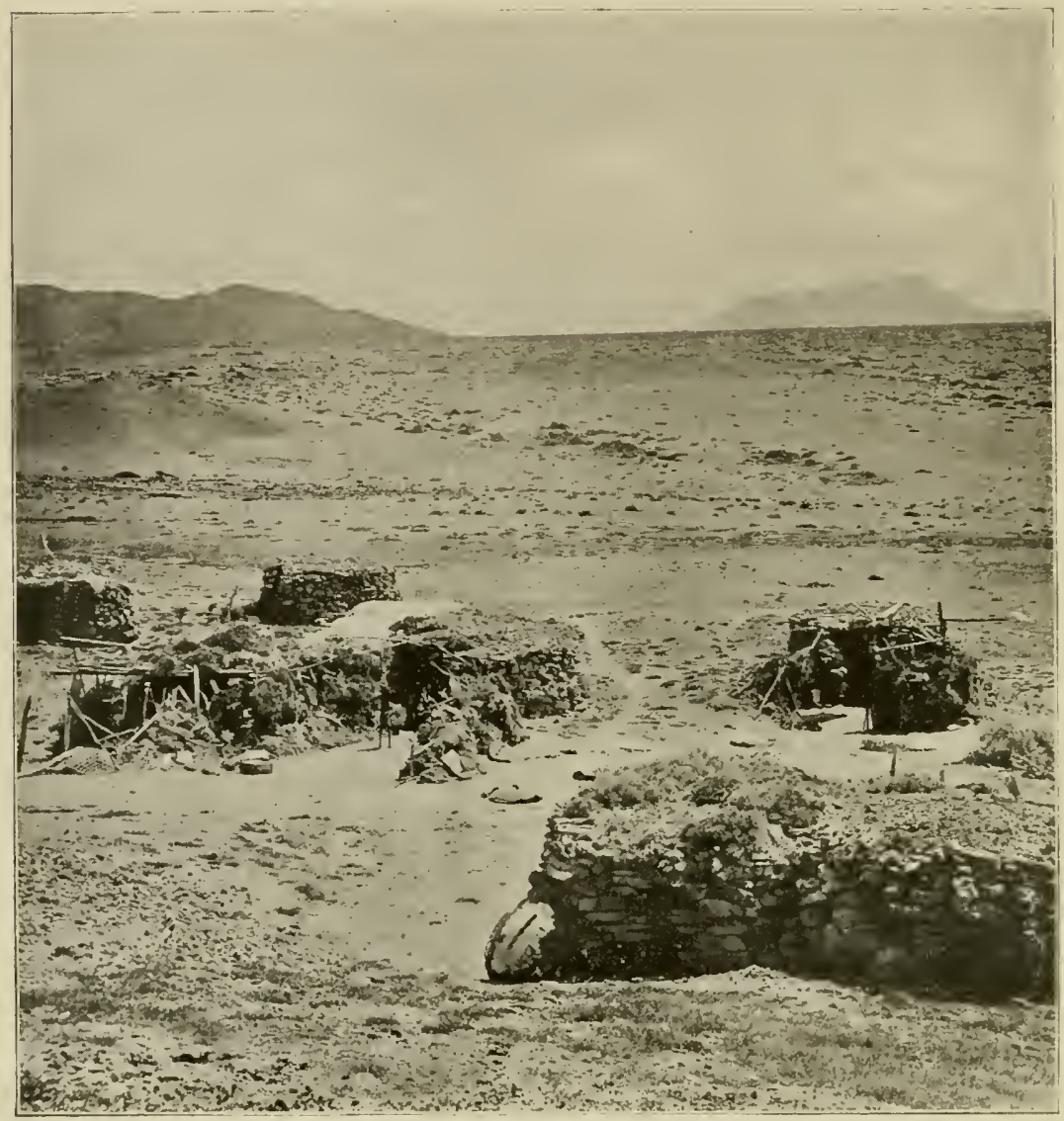

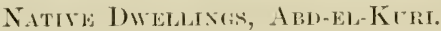

On the 5th lecember, soon after sumise, we started for a long day on (iebel Silch, the highest peak on the island. P'reeeding northwarl along the strath orer sand and shingle for alout two miles, we foumd a convenient spur on the north-west face leading more or less directly to the summit. From this aspect, which is entirely hidclen from the anchorage, the mountain appeared quite clotherl with rark green vegetation. Partly on the spur and partly in a neighbouring mullah we scrambled upward with much effort, secking out om way over the roughest of gromml. Huge blocks, themselves little hills in size, with perpendienlar escarpments 50 to 60 feet in height clislodgerl from the limestone strata above, constantly barred our way and neeessitated lengthened detours to eircminent them. Between the elevations of 500 and 600 feet, the regetation, which below that hall heen 
composed of mmerous low hushes not exceeding two to three feet, beeame more abunlant, in some places eren dense, with trees seven to eight feet high. Among them, up from abont 300 feet to nearly the summit, I gathered a small and very elegant asclepriarl, a species of Cochlanthus (C. sorotrums),

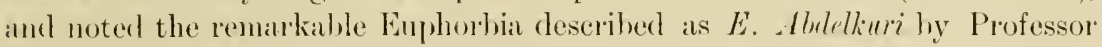
Balfonl on page 5.29, and fignred on the page opposite. The strong rellow wels of the large beantifully marked spirler referred to alove (Arygope rluilii) were met with all up the mountain sille, very aggravatingly moorerl across the open passiges betwern the trees. Several other inconspicnons arachnids were also collected, of which a full account by M1: Poecock is to le forml in a sulsequent section. Under nearly every stone, and often sereral inches deep in the soil beneath them, in the erevices of the rocks and on the twigs of the shruhs we found numerons land-shells, assignable in all to nine species belonging to the gencra Buliminus, Trophilophoru and Lithidion. On the summit the rock crannies were tenanted by crowrls of a specially charming though minnte form Lithidion yrutum, its coral-red interior conspienous against the white limestone. Of these nine species four have proved new to science. Three or four species of scorpion, one centiperte and the gigantic scolopendire bulfouri, Plate xxvi. (which was found first in Sokotra by Balfonr), together with a few beetles, inclicate the chief invertebrates taken by us on Gebel Saleh. Within a few feet of the summit 1 found two rare ferms: Schweinfurth's Asplenimu, and in faultless eondition Balfour's beantiful Maislen-hair (Adiuntum Bulfomii). A rimimutive lineal-leaved

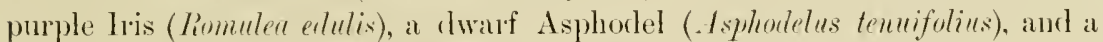
slenter sromul-orehid (Hulumuriu sorotranu), together with a long spiked Orobanche (O. abysinim) hidden away in a deep recess under a cliff, Hourished well on the seanty soil. The limestone is first seen resting on the granitoid and gneissic roeks at an devation of alout 700 to 800 feet. The uppermost linestone strata seemed to me to repose on a lower unconformable series, inclined to them at a eonsiderable angle, as seen in the accompanying view of Gelel Sileh (p. xxx.) photographed from the shore.

On the shore near our landing place 1 picked up several nodules of a water-worn, amber-like gum or resin, which certainly was not an obvions product of the island, for no gum-producing trees, save euphorbias, were anywhere seen by us. These fragments were most probably, therefore, washed out of the soil or sea-horne to Ald-el-Kuri. I hat expected them to prove to be a copal, drifted, perhaps, from the Copal Coast, but from an analysis which has been male, it seems to be neither true copal nor true amber but to possess some of the characters of loth. Its true origin and halhitat must for the present remain an open question. The "amber of good quality," which Dnarte Barlosa mentions as found in this island, refers with little doulst to the amber yris, or "grey amber" obtained from the spermwhale.

The natives complained that they suffered greatly from ferer, incluation of the liver, and, esprecially their children, from dysentery, and begged for mediene. I arministered fuinine and ipeeacnanha to sereral of those who 
were suffering most, but some of the children seemed hopelessly ill. The duration of onr visit was too short to enalole me to treat these poor people with much hope of henefit. Dysentery among the children is probably due to barl aud seanty fool. The islanders must sulosist almost exclusively on fish, molluses, and turte-on the latter so almudantly that they may truly be called chelonopheryi. The extreme aridity of the island has lreen remarked upon, ancl where the mosunitos which showed themselves in omr calins on hoard at night - with, however, little inconvenience to us - were hed, is difficult to imagine.

Nowhere dhring om excmsions dirl we see the slightest vestige of enltivit-

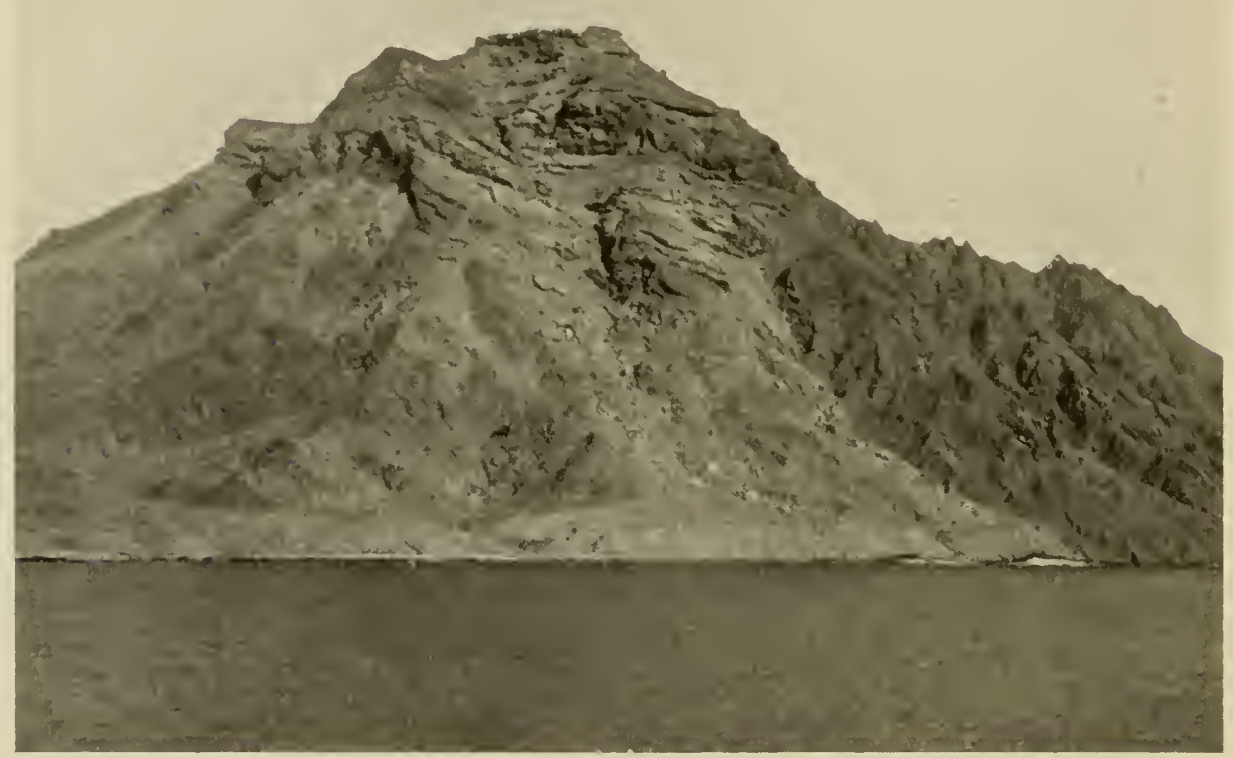

Tiew of Sorthers Facf of GeBel SALEH, Ani-ki-Kitri.

tion of any sort. With the exception of a few groats there were no domestic amimals, nor any indications of the presence of any other mammal on the island. The statement, therefore, of I 'Allumperque, who visited the island in 1507, that there were, in his day, latge flocks and herds, is rery remarkable, consiclering the vegetation that the soril now produces.

At 5:30 on the morming of the 6th Ineember, the Elphinstume weighed anchor, and stood away for Solkotra. I'roceeling eastward for some hours close under the shore as far as the sonth-east cape, her course was laid north-east ly east for Kallansiya. In several places as we passerl along, I conlel plainly observe patches of limestone abutting with a sharply defined line of demareation against the low granitoid hills facing the sea and at a 
lower plevation than anywhere else on the island, indicating very distinct lines of fault. These patehes looked as if they had leen morticed into gaps in the granitoid rocks, and lity inclined at an angle of $35^{\circ}$ to $40^{\circ}$ to the horizon. Neither on our passage along the south-western part of the eoast, "101 on our exeursions on shore, or our view of the isliurl from the top of Gebel Silch dirl we note a single deposit of limestone 1 pon the archan rocks to the westward of the depression ruming athwat the island.

\section{III.}

\section{Sokotra: Hadibu.}

In the afternoon of the 7 th December, the Elphinstome, passing muler Ras Shoal, the westermmost point of Sokotra, into the hay of the same name, cast anchor at the mooring spot indieater on the Arminalty ehart. Here our eaptain thonght it might be possible to land the Expedition in this less surf-leaten bay more safely than at the town of Kallansiya, a little to the north, where at that season the sea rolls in with great violenee on the beach, rendering a landing diftienlt and liable to accidents. The spot looked forbidling and desolate, and without sign of habitation. As ehance would have it, however, we fomd a laghlah at anchor, from which some information conld we hoped be obtained as to the locality. On landing, which harl to be accomplisherl by wading from the launch through a breast-high surf, we fomml a renerable Arab - the naghorla of the boat, which, it tmrnert ont, belonged to the sultan, and had just arrived from Bombay-sitting on the beach, who assured us that if we landed there it would be extremely difficult to olbtain food or porterage, and impossible to get eamels to the spot. On this information we deemed it mwise to risk landing there, although so near to a region of the island we speeially desired to risit. Captain MacArthur, therefore, cleeided to r'm as far east, in the morning, as Ras Haulaf, a projecting headland near to Harlibn, the eapital of the iskand, nnder which we might expect to find a sheltered anchorage and landing place.

It was only mueh later that we knew how great a risk we had rum in landing in Ghubbet shoah to make inquiries from the Sultan's baghlah. She was lying in voluntary quarantine with a large number of her erew down with small-pox: Indeer, I believer I had from our deck seen them carrying off one of their dead ; but the naghorla stontly denied they had any sickness when I asked if they had not just been burring one of their number :

Leaving (ihulbet shoab at 2 a.m. of the 7 th, we steamed slowly along the northern coast of the island with a brilliant mon orerhear. In passing through Tamarida Bay we had a splendid view, against the clear sky of the opening day, of the towering prramids and needles of the Haghier range, which here enclose a wille and deep amphitheatre in which lie embowered among palms the white houses of Hadilu. Ras Haulaf promontory under which we anchored forms the eastern arm of this Bay. Facing us a few yards from the shore stood a fair-sized square white-washed edifiee, with close by what lookerl like a mosque and other low buildings, 
while a short distance further off lay a cluster of miseralile huts. Som after we had anchored, a half-white half-red pemom appeared orer the syluare white erlifiee, which we learned later was the residence of the Gorernor; lut it had not fluttered long before it was hurrerlly replaced hy a Union Jack. Presently a canoe cime off with two men, who informenl us that they were of the household of the Sultan, who harl that morning left for a resilence he had several hours distant in the interior. To one of these men we entrusted a letter to be despatched at once informing His Highness of our arrival, and the olject of our visit, and that we had hronght for him letters from the Govermment in Aden which we desired to present as soon as he coukd honour us with an interview.

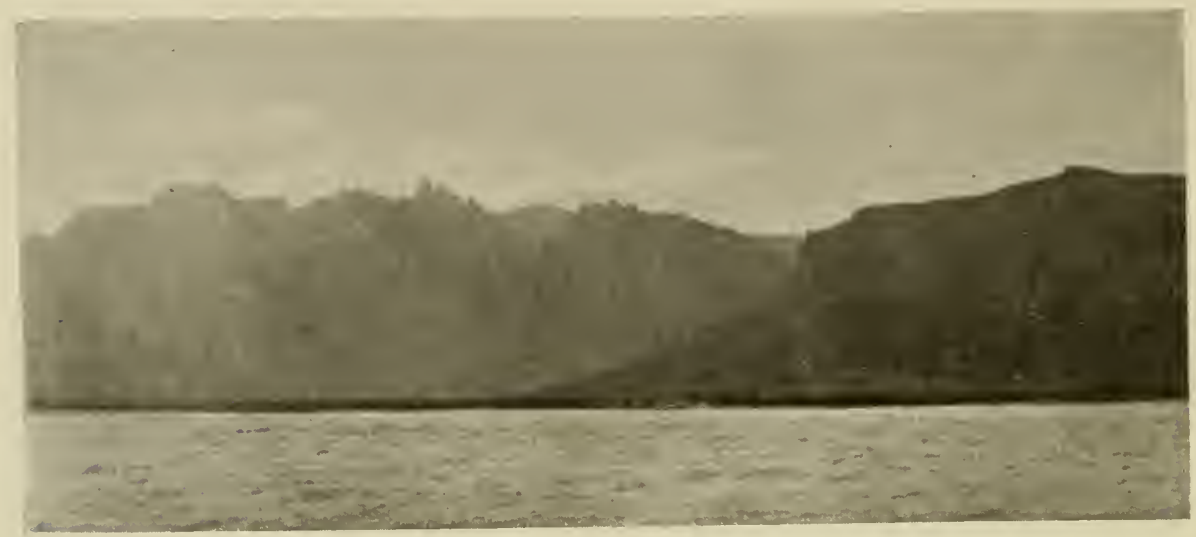

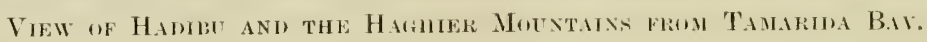

Late the same evening our messenger returned on hoad to inform us that the Sultan, who hat arranged to return orer night, woukl receive us next morning. Accordingly after breakfast the following day, Captain Malc Arthur and I with Gulaid our interpreter, proecerled om shore, where an agerl sheilih was waiting to eonduct us, hetween the lanks of a barlaric guard of homomr, to the Sultan's andience chamber in a low unfloored shed a little distance fiom his "palace." Sultan Selim received us at first very coldly and suspiciously : lut when he harl perused General Creagh's commmmication, and the letter from Nohammed lattier, and hearl we hat come on at scientific mission only and not on a retrihutory visit, he mellowed considerahly, and thromgh our interpreter returned his thanks for the letter we had hromght from the liesident of Aden. He accorled us permission to visit any part of the island we desired. On present he accepterl with little affision, and by a gesture consigned it to one of his relations near him, as if the receiving of "lukshish" was too eommon an occurrence to necessitate his even tomching or looking at it. Mrs. Theodore Bent had arlvised us to obtain as gurles two Soliotri, Amr and Ali, who had accompanied her hushand and herself and heen very useful to them during their visit to Sokntra. On making a repuest for their services from the Sultan, both men, strange to say, were standing close hy me among 
the throng that hat followed us into the reception room, and were forthwith told off to attend us and see to our reyuirements at a charge to ns of one and a quarter rupees per day. If these men had proved fathiful and helpful to the Bents, they hat been much spoiled by them, or had vastly deteriorated in character since their visit. They had bled these travellers very freely, we gathered, and we soon found ont for ourselves that unless we were prepared to pay the Bent tarifl, we should meet with opposition everywhere. Both men were entirely suliservient to the Sultan - Ali, indeed, was his slave, and half of Anr's and all Ali's pay wonld go into His Highness's pocket. A very short term of probation served to show them in their true characters, and had we not put our foot down and dismissed them after abont a fortnight's employment, we should have experienced nore trouble and greater delays than we dirl. Their suceessors, chosen by ourselves, turned out more faithful, honest and helpful.

After the conclusion of om interview, no time was lost in making arrangements with Amr for the transportation by bighlah of our baggage and servants from the Elphinstone to the mouth of the Hanefu, distant a few miles west, close to the town of Haclibu near which we proposed to camp. By erening everything was transhipped and transporterl. This was excellent 'business,' and for Orientals expedition itself. Had we landed at Ghublet Shoab or Kallansiya it would have taken at least a fortuight to have commmicated and secmed an interview with the Sultan, without whieh we could not have legum operations.

On the morning of the 9th we took leave of the Elphinstone, and landing at Hanlaf proeeeded on foot along the shore towards Hadilu or Tamarida, as it is also named. When we reached the Hanefn estuary, where the landing of our haggage through the surf was proceeding rapidly and safely, we tumed due south and lit npon a pleasant spot for onr camp abont a mile inland, close by a palm grove at a pretty bend of the river where the lank looked down from a slight elevation mpon the wimpling water. Before sunset we were established under eanvas and fairly comfortable. The crowds of insects attracted to the lights of om tents clemanding to be captmed, mate a goor begimning to our Sokotra collections.

The Plain of Hadiln, two to three miles deep and fom to five wide, in which we stayed from the 7 th to the 1 sth of the month, forms, from a geological point of view, one of the very interesting featmes of the island. It has the semblance of a vast quary with an open front to the sea, walled in elsewhere ly apparently insumomtalo pimacled and extremely picturesulue elifts, 2000 to 3000 feet in height, worked ont of the solid granite core of the island. Except for a gateway along the sea margin round the shonler of its east and west arms, the amphitheatre looked entirely land-locked. Investigation, howerer, showed that the three nearly equidistant streams which crossed the Plain were fer from as many ravines, deep cnt in the central granite mass. The undulating floor of this rast excavation was, with the exception of a few sandy swarded patches, entirely overspread with shingle and large bouklers, some of which were hundreds of tons in weight, bespeaking vist transportation power and an enormons amount of denudation, whose manner 
of action in forming the amphitheatre, howerer, seems (to me at least) not at all easy to explain.

The ronghness of the ground was concealed in the general ricw by a thick low covering of scrul, consisting chiefly of Dirichletiu, Euphorbia, Jutrophu, and conspicuous among the others from their bizzare habit, Adenium and the remarkable indigenous Cucumber-tree, Demliosicyos.

In the town of Hadihn the honses wre of the square flat-roofer form so common in Arahia (such as one sees at Ma'ala, near Ailen), set in narrow winting streets obershadowed hy bate palms. From the sea, or at some ristance off on the plain, these whitewatshed dwellings glinting from amid the palm fromls presented a heauty and pieturesplueness which were sadly discounted hy the dirt and odoms revealed by a stroll through its streets. On the plain the hamlets showed a very different style of architecture. There the huts were cireular in folm. The walls, flom 10-12 feet in cliameter, were built in the cyclopean manner of mhewn cubes of stone piled up in rough mhonded comrses to a height of seven or eight feet, the chinks between the stones serving for windows and chimney. The roof was formed of palm hanches laid upon rafters stretching from rim to rim plastered over with clay and often green with grass. In the larger huts the rafters were further supported on pillarlike piles of stone ol' on Date stems rising from the Hool: The doorway, a low square orifice, was closed by a rongh hurdle of palm leaf mid-ribs. A few skins, a rery primitive loom, a quern for milling grain, an assortment of earthenware pots and a few skin bottles for holding ghi, comprised the furniture of the best appointed of these dwellings.

The people are entirely pastoral, possessing large flocks of sheep, goats, and eattle. The latter lielong to a very small, shorthorned, deep dewlapped, unhmmped breed, differing entirely from the cattle of Arabia, India, and Africa, the lands nearest to Sokotia. The perple cultivate occasimally a few patches of millet (Sorghum rulyure), tolbaceo and cotton. The one-humped camel is their heast of burlen, a surer-footed and stronger hreer than the Arabian.

Ghi, a clarified butter made from the milk of eattle and goats, is the chief export of Sokotril. In former days the island was celebrated as a market of Aloes and Dragon's-hood-indeed, the name Sokotra is heliever to be merely a cormption of sukkatira, sul, the Arabic for "market," and liatir, "Dragon's-l,lood"; lut only a small quantity of either is now prepared or exported.

In Hadibu and the hamlets of the plain, pottery was extensively mannfactured, but in a very primitive fashion notwithstanding the long intercomse which has existed hetween Sokotra and countries producing high-class earthenware. It was entirely hand-made, the potter's wheel heing quite nnknown. The women were the fahricators, and their clay was collected from pockets in the limestone rocks, where a hright red deposit is left by the rains, and from the bases of the central cliffs and in some of the streams, where a greyish yellow, more unctuous sort resulting from the waste of the granite, accumulates in considerable quantities. The two kinds were 
levigated together, with the addition of finely powdered limestone nodules. Out of a simgle lump of this palste small pots and dishes were modelled ly the fingers and a smooth stone: larger vessels were luilt IIf from a hase, ring ly ring, to their desired size and shape, smoothed and fishioned inside and ont hy the thmuls, the palm of the hand and a smooth pebhle constantly dipped in water. A small aured disk of coeoant shellan import inte the island, whose floral does not contain this palm, singularly enongh - or the half of a livalve shell, served to scrape the vessel to a uniform thickness. After being exposed in the air till dry, the pots were baked in the open in the erentre of a fire of wood fingrots. When thoroughly fired their ware is of a bright red colour, with black patches here amb there where incompletely expersed to the action of the heat throngh contact with the atshes. Many of the sumaller pots, which they constantly userl to hold milk, were antirely of a dark manganese rolomr, as if during their firing the air had been exchuder from contact with the entire surface. 'The art of glazing was apparenty unknown. Ornamentation was generally omitted: where it existed, however, it was never scored or impressed, lont inrarially streaked npon the resseds from a motive which I have been malble to reconstruct. The pigment employed was mainly lhagons-blowd resin, but whether compounded with other ingredients and how applied I hawl no opportunity of olserving. The manufacture of pottery was evidently not contined to particular families; each household, so far as I could leam, male its own. I did not observe a trade mak upon any of the pieces I examined, and none of it was aplatently made for export. Plate i., forming the frontispiece, shows the forms most generally falmieated. Figmes 1 (designated solum), t and 5 were used for containing milk, ghi, or aloes juice, 4 and s especially for cooking or for heating milk in ; figmes 6,7 , \& and 10 represent water ressels: 6 leing specially employed to contain water for religious ahlution - of which only a few diops appeatred to be necessary at a time, $T$ (designated sirtuhu), \& and 10 served as water reeeptacles for domestic purposes, and $: 3$ ancl 9 as food holders. Figure e (named Melioreiele) was hmug on the walls for ornamental purposes

like plates on om drawingroom walls - when not in use for burning incense on. As most of the dwellings had earth floors. few of these utensils were provided with hases, it heing necessary for their upright position only to press them into the groand.

Having arranged as the general plan of our movements to risit on leaving the plain the higher regions of the Haghier momntains, then the eastern plateau. and finally the little-known south-westem valley of the island, we decided to lreak up our Hadiln eamp on the 1sth. It lookerl, however, for a time as if the region of the Haghier we were to visit was hardly to be left to our selection, for Amr, Ali and the camel men harl determined to have an say in the matter. It was impossible to name a place ont of the plains to which the paths were not, according to them, dangerous or impassable for loaded eamels; and whither camels, the only means of transport on the island, could not be taken it would be useless for us to go, as without our supplies and our apparatus we could accomplish little or nothing. long and weary were the discussions 
eondncted with them throngh om interpreter, and endless the maps traced on the ground by us and them to show the possible routes, before it hecame evident that lirs. Bent's reeommendees were simply deceiving us. As soon as this hecame apparent, we male our own selection of our next camping station and the route to it, and issued orders for the necessary camels to be lronght in. These arrived on the 17 th to the number of 2.2 , and on the lsth, after the lengthy and rather trying experience, to which we were new, of arranging associated reguirements on evenly-balanced packiges for alcommodation on the same camel, we started towarls midtalar for Dahamis on the eastern slopes of the Haghier momntains. Crossing the plain eastward we ascended by the short, narrow gorge of the Lahas river to the Ardal Pass separating the amphitheatre of Hadiln from the Plain of Kam, where we bivonacked for the night, and on tmining in were soothed to sleep by the 'song of the setting sum, from an owl of a species at that date, but we hoped not for long to be, unknown to the fauna of Sokotra-Seops wentiomes:

\section{IV.}

\section{Dahamis. Kamahanu. Jena=agahan.}

On the morning of the 19th December our kafila got away early in charge of Gulail, our headman, while Grant and I, accompanied ly C'utmole, followed behind on foot eollecting as we went. Wending our way sonthward through the Plain of Kam we emerged by a narrow gateway into the northern end of the more extensive Garieh Plain, when we reered west to enter the contracted defile by which the Nehashir, a tributary of the Motaha, drains into that plain seawarl the waters of the great Dahamis Glen. In a nook just within the gateway we fomd, on our arrival in the late afternoon, our tents ahearly pitched by Gulaid on a grassy plateau, 750 feet ahove the sea. During this march the first indications of malarial infection presented themselves in our taxilermist, in fatigne, headache and prostration, which developed within twenty-four hours into a malignant attack of astivoautumnal fever. He was followerl on the sick list in rapid suceession, within the next three days, by both of us and hy a number of om Aden servants. The fact of these men being attacked wonld tend to show that we possibly escaped infection in Arahia, and were probably first inoculated in Sokotra, notwithstanding that the perior of incubation was shorter than the 18 to 2.2 days which has generilly been my own experience. In Abd-el-Kmi mosquitos were not malignant, nor were they numerous, for the islet eontained absolutely no water exeept, so far as we could discover, in a single brackish well 15 to 20 feet leep. Still, malaria did exist there, as the imhabitants told me, and I saw some eases of it. Mosquitos were abmolut at Hadibn, and there, no douht, the disease was manly eontracted. Under the belief then, however, that the loeality, the character of the drinking water, or miasmata were the canses of fever, we decided to get without delay away from Dihamis to some more open spot orer which the wind could freely play : for though the night temperatmre was $66^{\circ} \mathrm{F}$, during the day the heat, direct and 
reflected from the hills around us, was generally over $100^{\circ} \mathrm{F}$. To Gulairl, accordingly, the only fever-free member of on company, we were compelled, On the 2:3rel, to entrust the senreh for a new camping site, which he was instructed to select as high as attimalole with camels, and open to the breeze from the sea. On his return loe reported having fomel such a spot as we desired on a height named Kimahamm, less than a tay's jommey distant.

No opportumities in the intervals of fever were lost of collecting in and investigating the Dahanis (ilen which ascended in front of us westwarl to a Pass some z000 feet high, while the peaks of its northrorn am sonthern ams overshadowed us hy another thousand. While there was little or no difference in the famm from that met with in the plains, we encomntered here for the first time many of those peeuliar plants which characterise the Hora of the llaghier $A$ ljs.

On Christmas l hily we struck our camp at bahamis, and set out for our new and, we tristed, more healthy quarters. We presented a sorry spectacle, for we were all either actually suffering from ferer, or weak and dispirited from an attack recently passed. On emergins on the (arrich Plain, Kamahanu was pointed ont to us as a hill, isolated in the centre of the plain, rising only some 600 or 700 feet above its level. On the slope of this hill had been chosen our campung slound, to our elisappointment puite away from the high range, though open to the sea breeze.

IThen the last of our followers with the hatggage arriverl at Kamahanm it was quite dark, and as most of our party harl hecome ineapacitated by fever during the march, the baggage had to lie as it was dropped from the camels' backs. Next morning things were even worse, as all but three out of om company of eleven were on the sick list, and within twenty-four hours these three also. In my own calse the paroxysms were less severe and prolonged than in the case of the others, so that I was alle to administer the necessary medicines, and, with the aid of Jamah, our hutler, who, ill though he was, liavely kept the kitchen going, to have prepared such food as they could take.

From the camp 1 could clearly make out with a glass a village situated high up on one of the north-eastern buttresses of the granite mussif of the Haghier, and ahore it a Hat grassy platean, which, as there was clearly a path to the village, ought to be easily reached from it ly camels. To this spot we determined to move as soon as the health of the camp permitter. This was not till the morning of the $30 t h$, when, after a great effort in loading the tents and haggage upon the camels, we were able to set out for Jena-agahan, or Thlutid, as our destination was varionsly destignated. The ascent was rery laborious, but the site when attained proved an excellent eloice. The altitucle was nearly 1600 feet, the air delightfully fresh, ancl the view of mountain, plain and sea commanted from it charming and exhilarating. Milk and fresh meat were ahmolant, and the health of onr party, except in the taxiflemists case, rapilly improved. The severity and intractability of the fever in his case, complicated as it was with hemoglohinuria, caused us great anxiety, so much so that we had decided on the 13th, if there were no amelionation next clay, to break up the Expedition, hire a baghlah from the 
Sultan and return to Arden. By great gorl fortume, a few hours later a messenger sent by the sultan arrived from Kallansiya - 70 niles distantwith a letter from Hr. Miiller informing us of his arrival there on the Gotffinal, along with the members of the Austrian Experlition, and of his having brought a mail for us. As there was a medieal officer in their party, we dispatcher our Arab jemarlar the same afternoon on eamel-back with a history of C'utmore's ease, and a request for advice under the eircunstances.

Many interesting arditions were made to our collections during the the seventeen days we camper at Jend-agahan-minerals, plants, insects, reptiles, and mammals. Among the latter were examples of the wild Ass (Plate ii.), which was among the most inportant of our zoological acpuisitions. These herls which roam the Garieb Plain are, in my behef, the survivols of Nubian ancestors hronght from the lied Sea coast ly, probably, the ancient Egyptian incense collectors. When closely examined they are seen to differ in colour and in many other points from the eommon donkey, with some few incliviluals of which I harl an opportmity of comparing them sirle ly side in Hadibu. The Sokotran Ass differs entirely also from the fomaliland species, which wants the shoukler and dorsal stripes.

Numerons house-elmps dotted the neighlouring spurs of the mountains, inhabiterl hy sheep-and cattle-herels whose chief ocenpation was milking the cows and goats for the preparation of ghi. This was collected from them hy traders from Zanzilar in Africa and Makulla in Arabia, who gave rice, calieoes, Afriean slares (in large transactions), amber or Marlia Theresa dollar's and two-anma pieces of the Indian mint in exchange. These coins were, however, lookerl on everywhere (except perhaps in Hadilu and hy the Sultan, who was the chiof trader of the islaull), more as barter than true currency. They would palss from the recipients lirectly to the silver workers in Harlibn or Kallansiga, to be marle into ornaments for themselves or their womankind. Among themselves coins were rarely used. In their commercial transactions, the harter was eattle, shi, hicles, rates, pottery, or cakes. Pottery was not an article of export, but appeared to be an instrument of currency in the island, two pots having the value, as I learned after much yuestioning, of one eake-probahly a luxury not always obtainable-haked of Jowari meal, pure or mixed with rates, of which 25 were equivalent $t_{1}$ ) one Maria Theresa dollar. Thus 500 pots, 250 cakes, 10 sheep, 5 goats, 1 cow, 15 fraselas (ahout 48 1ls.) of Gragon's-blood resin, and 10 Majla Theresa dollars would all be of about eyulal vilue.

\section{V. \\ Homhil.}

The taxilermist's fever having at last given way to aconite, arsenie and quinine, we were able to arrange to leave our pleasant tented field at Jena-agahan on the 16th for Homhil on the platean overlooking the eastern sicle of the Garieh Plain. With a caravan of over a seore of camels the rate of march eould be no faster than the speerl of the slowest of them, so that we 
had to bivonac for a night on the way in the led of the nearly dry Dimichiro river, which skirts the eastern sille of the plain, whence on the 17 th we continued our jommey south-eastwarl. Throughout these two days, which were of exceptional clearness, the heauty of the view presented by the Haghier slopes and summits, it would loe difficult to exiggerate. From no other part of the island can the majestic outlines of the crests, crages and

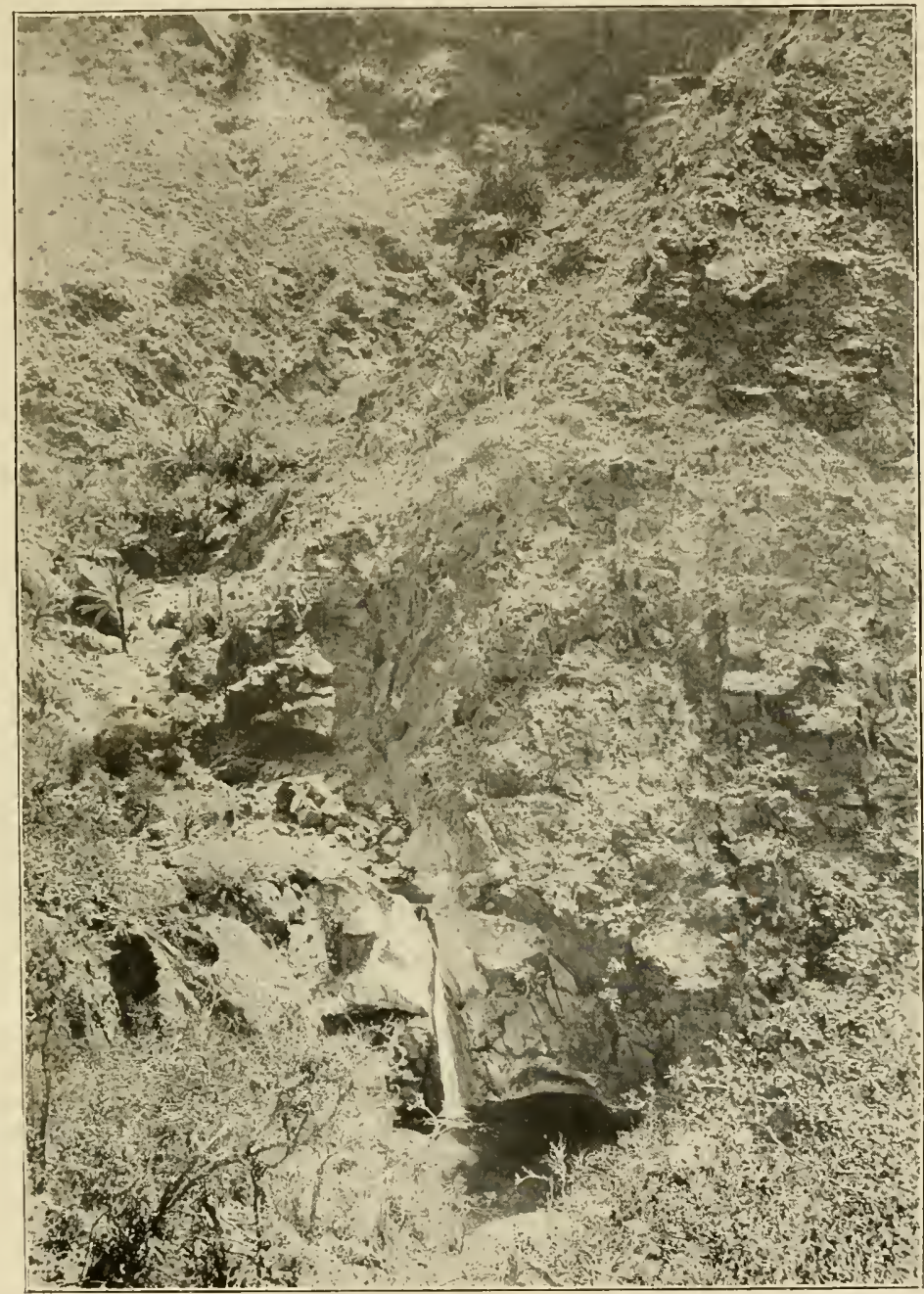

VIEW IN GU.AHAL GoRgE, SOKOTRA.

aigulles of this most picturesquely sculptured granite eore of the island he so well seen as from the Garieh Plain. Our route to the platean ascenderl steeply for 1500 feet up the gorge of the Goahal, which flowerl strong and noisily, like a scotch burn, over its shingly herl, meanlering from its upper and precipitous reaches down through palm-rlotterl gulehes and over several 
charming waterfalls. The Homhil Plain we found to be another of those remarkable geologie features of the island, similar to but somewhat smaller than the Halibu amphitheatre - a vast excavation denuded out of what was once an mbroken platean of limestone a thonsanil feet higher than its present floor, and 2000 to 3000 feet above the level of the Garich Plain.

On the 20th, the jemadar returned from Kallansiya loringing on first mail since Novemher, and kind letters from Professor Müller (who was now in charge of the Viemna Expedition), and from Dr. Stefan Paulay, with medieines and alvice as to the treatment of om siek, luckily by that time less needer. On Anstrian friends sent not alviee only, but a

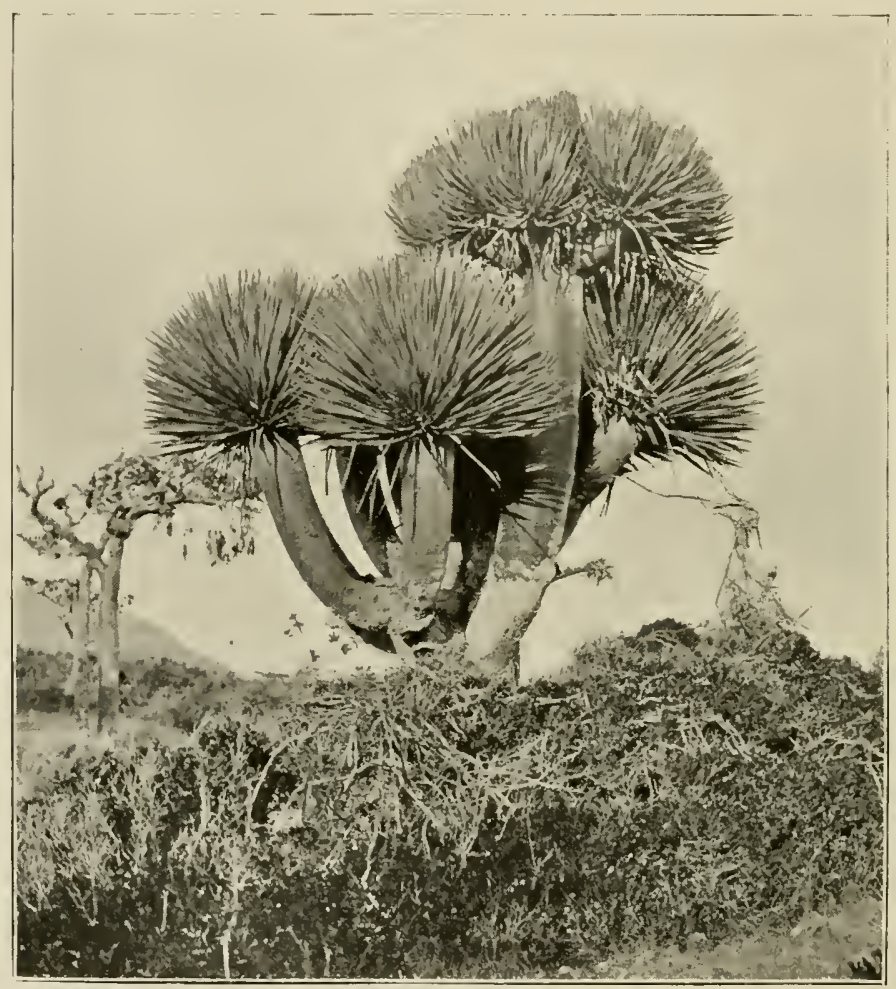

Dratiox's-BuOOD TrEk.

largesse of two camel loads of 'medical eomforts,' eousisting of a large supply of ä̈rated mineral water, a few bottles of wine, some fresh bread which was a great luxury, and a quantity of biseuits onr supply of which was rmuning low. Of all these the mineral water proved the ehief boon in acting as an alterative probahly. Certain it is that after a short use of it the improvement in onr general health was rery marked and continued. How deep our gratitude for this most generous and thoughtful kindness was and is ean only he appreeiated by those who have had to eamp for lengthened periods far 
from the "resonces of civilisition," and are lesponsible for the health and lives of other's.

The gereological structure of .Jena-agahau and the surrommling region wats entirely granite. 'The Homhil Plain, on the other hatnd, was surrounded by limestone esearpments, and although the altiturles of 010 . eamp at both places valied little, the vegetation was mankerlly in eomtrast. It the former station that elrious and ancient tree, one of the chief botanical chanaceteristies of the island, the I)ragon s-bloor (Diuremu) eould be seen only on the highest tops far above us, while at the latter it surrommled our camp as a prestominant feature of the Hora, along with Framliincense trees and with felminm, In'n. drasicyns, and lonstenin, an interesting triar whose swollen stems suggested their leeing atfected with elephantiasis.

We stayed here till the 27th of Jannary, and hat a very successful amul delightful sojourn, adding largely hoth of the flora and fannit to our collections, ats well as to our topographieal and geological observations. Here also we came more in contact with the people than at any former station, and I was suceessful in ohtaining some interesting notes on their customs, manners, games and industries. It was

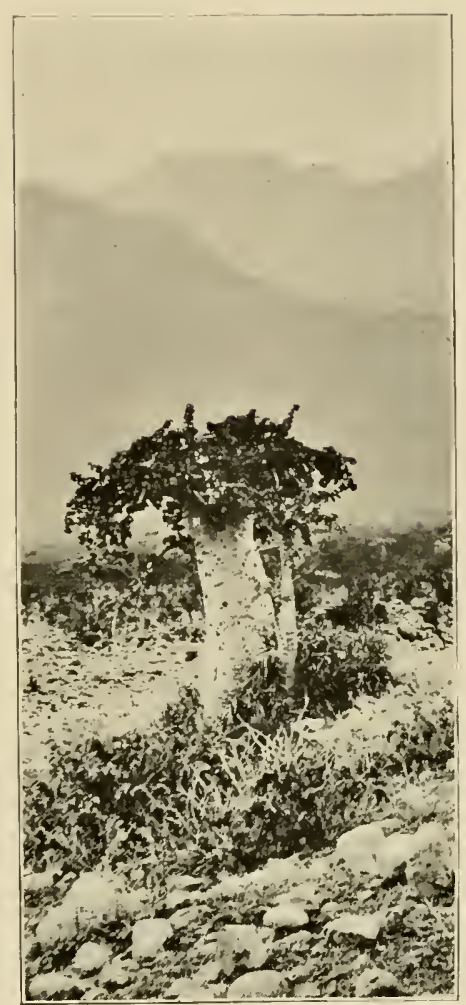

('reumber Thee (Denilrosiryos).

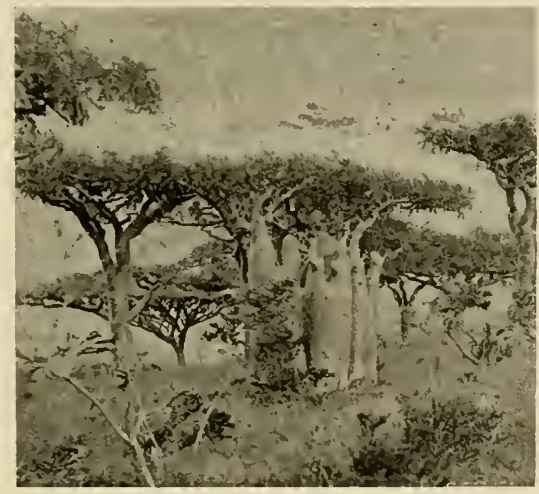

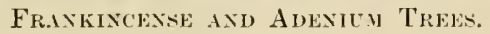

impossible, however, owing to the religious scruples of the Sokotri, to induce them to sulmit to be photographed, ol to have their physical dimensions taken. Nerertheless I obtained surreptitionsly a few likenesses. These notes, howerer, extending as they do to a considerable length, must he reserved for some other place, the space at my disposal here being limiterl. I may merely mention the fact that these observations, taken along with the tradi. tions recorded by ancient witers on Sokotra, seem to point to a rery remote antipuity for the advent of the Sokotri to their present home. 
The elimate on the Homhil Plain was delightful. The temperature during the day rarely exceeded $78^{\circ}$ to $79^{\circ} \mathrm{F}$ - - - on one oceasion only reaching $90^{\circ}$ - while during the night from $62^{\circ}$ to $65^{\circ} \mathrm{F}$. Was the usual reading of the thermometer.

From Homhil it was our intention to reach Adho I)imellus, situated amid the highest peaks of the Haghier, by one or other of the two deep central valleys that open on the Nugget Plain, which stretches along the southern coast, and thereafter, if possible, proceed to the sonth-western distriet. No persmasion, however, conld indnce our camel men to take the southern route. They resolutely refuser to retreat from the declaration they had made that camels could not ascend from that sicle, but only from the Harlibu Plain. Without more eertain knowledge of the country than we possessed we were compelled to adopt the latter route: and it was only when we reached our desired destination that we discovered how deliberately they harl misled us. The path was probably somewhat more diflicult, but the number of loaded camels that came up these rery valleys and passed our camp on their way to Khadoop prover that had we insisted on our orders leing carried ont, we should have enconntered no insmmountahle diffienlties. Unfortmately we had no time to risk in proving by actual triverse that our sumine was right and the camel men were wrong.

\section{VI. \\ Elhe. Adho=Dimellus. Hadibu. Bandar Saleh ( Abd $=$ el $=$ Kuri $)$.}

On the 27th of Jamary we broke camp at Hombil, unwillingly retracing om steps down the Goahal gorge and north-westwards across the Garieh Plain, till reaching the Wady Jubher, in which we bivonacked for the night, not far from onr former camp, of mhappy memory, at Kamahanu. Next morning we continued our jommey, and clossing the Addah Pass reached Hadiluu Plain, where, tmining sonthwards, we pitched om tents late in the aftermoon at Elhe, a hamlet not far from where the Dinchan the deep glen ly which we purposed to ascend to the heart of the Haghier-flows out through its iron gates into the plain on its way to the sea. Here we spent two days preparing for the jommey before us by selecting fresh camels in place of those that secmed mit, and redneing and re-arranging the loads for distribution among an inereased number of animals. We had also our collections to pack in hoxes and ITarlian cases for storage in Harlibu, and to replenish our stock of preservatives, ammmition and foor-supplies from the stores left in that town in December. Collecting was not neglecterl in the intervals of this work. Mr. Grant secured some excellent speeimens of the endemie Grosheak and other birds, and made many additions to his stock of the new Charares velor (Plate xviii.), as well as capturing numerous Hymenoptera, Nenroptera and other inseets.

It may lie mentioned as an example of the permaneney of the eflect of the sun's rays upon the skin that, having on the 30th Jannary omitted to put 
on one of my gaiters, a few inches of the naked skin of that leg was left exposed below the erlge of my knickerbocker and serercly burned. The exposure lasted less than two homs, hut so seorched was the part that I was quite crippled for several diyss. The skin in the orlinary course gralually turned brown, and although it was continnonsly afterwards covered by a

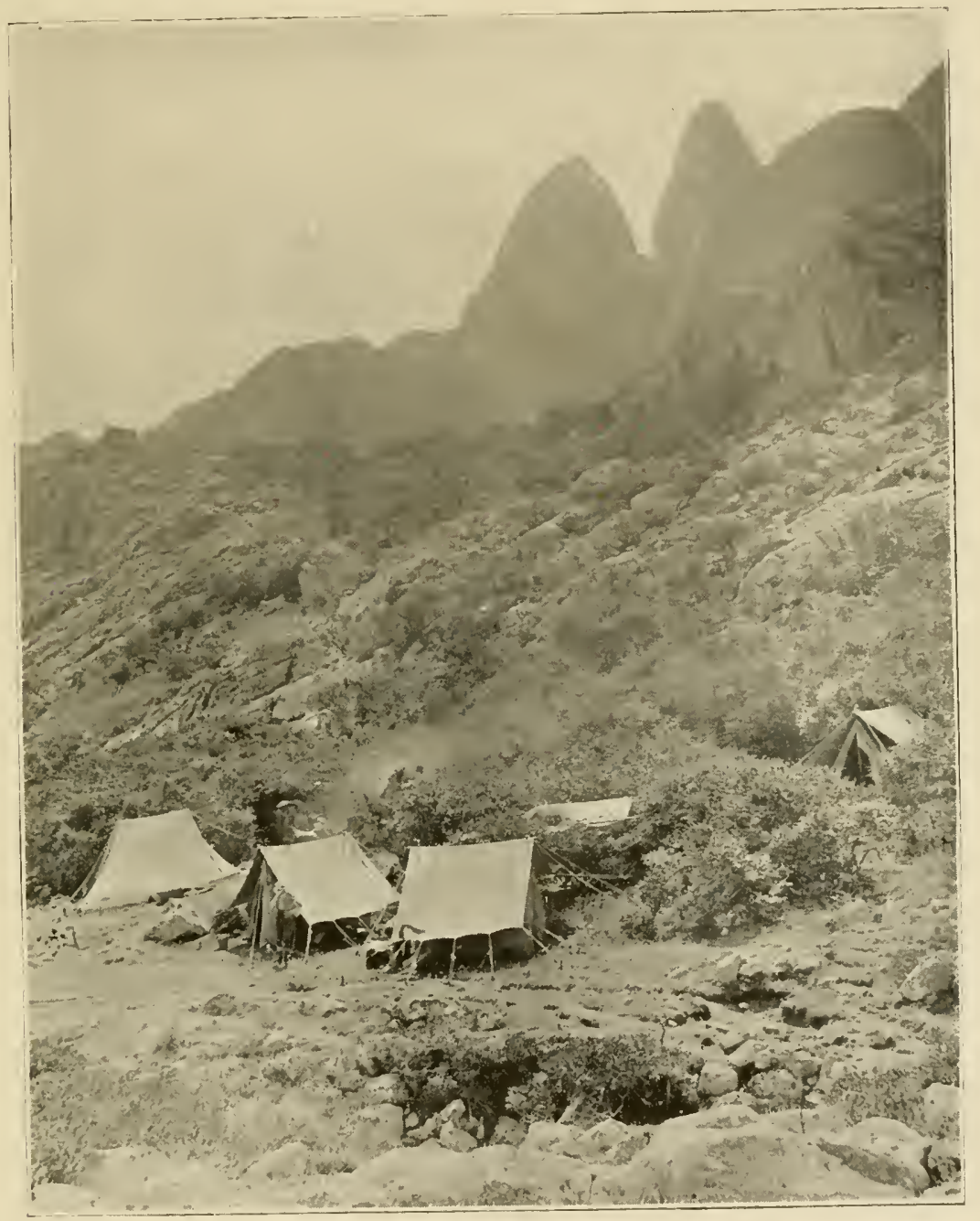

Oni: CiMP at ADIO-DIMLLLT.

bamlage, and later by my ordinary dress, the browned belt on my leg was conspicuons in the millle of 1902 , and was still traceable in Jamury, 190:3, three year's after the occurrence.

On the 31st of fantary, we resumed our manch to Arlbo Dimellus, taking our way up the Dinchan Valley. As the ascent is rery steep, and the patl in many places narrowed to a few feet, great care was recuired 
in directing the camels, and conserpuently progress was slow. The climb, however, flisplayed the splendid character of the Sokotran rlromedary, its sure-footedness, the wisdom with which jt picks its steps in dangerous places, its doeility and its enduranee. In mirl-afternoon we bivonacked on a recesserl corner in the glen, some 2000 feet alove the sea. Next morning continuing our ascent, we reacherl Atho Dimellus Pass, the highest platean on the jsland, and the water parting between the two coasts, at an altitude of 3000 feet. From this point we olstained a magnificent riew, on the one hand, to the nonth, down the stere valley up which we hard climbed and ont to the sca horizon leyond; on the other hand, southwards, over wilder and even more picturestue glens to the gate-like clefts which their rivers have cut through the limestone eliffs that harred their way to the sumly Nugget Plain and the sea. Out of this platean rises a forest of majestic peaks, of which Geled Iryat, the loftiest summit in Sokotra, rears its twin spires nearly 5000 feet into the clouds. Descending a little way on the sunthern side of this Pass, we pitched our camp under the sharlow of two lofty pillats

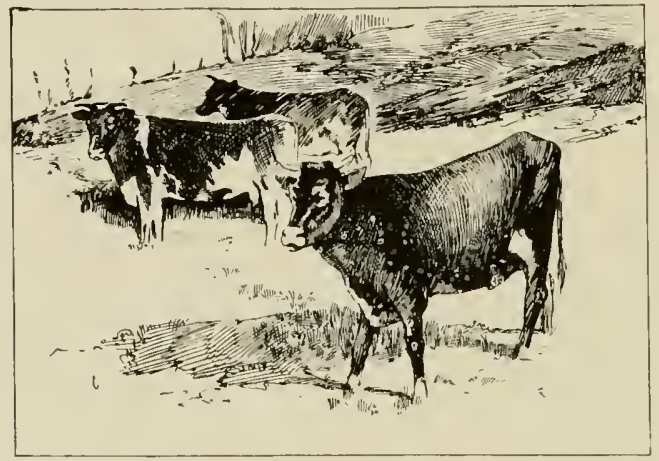

Sokothax CatThe.

of granite, in a corner in the midst of a wilderness of lwolders half huried

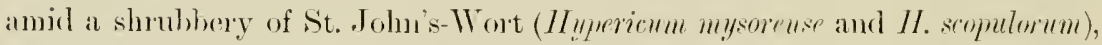
and herlged romul by an impenetrable thickst of the remarkable Corculus lialfourii - a site which for picturespueness could with rifticulty be edualled.

Here we remained till the 17th of Folnuary, for we had decided to abanrlon om visit to the south-westem valley, as after spending a week ol. ten days at Adho Inmellus it was evident it would lave taken all the available time we had hefore the -20th (when the Eilyhinstome was rlue to return for us), even to reach that district. This elevaterl camp, at all events, stood in the mirlst of the peculiar Hora of the island, and in a locality where we fouml much to add to our zoological collections as well. The roof of siolotra, as we may call this distriet, was fomed of a series of hay-like mearlows, cut off from each other hy buttresses of the peaks. They were elarl with a luxuriant ankle-rleep swarl of snceulent herbage on which grazerl flocks of sheep and goats and large herds of the extremelybeantiful dwarf eattle of which I have alrearly spolien. It is one of our chicf rogrets that we brought back 
with us no specimen of their skins or skeletons for home examination. It never struck me till our return that they were not an introduction by the Portuguese, since they were so kuropean in form, and differed altogether from the races fomd in India, Ambia or Africa, the comntries nearest to Sokotra. That attle oeenpied the island for many centuries prior to the advent of that nation, I have discovered evidence since my return which I have not the space here to discuss. Nor can I enter into a description of the remarkable remains that eover the gromd on the more westerly of these water-parting plateans.

The elimate at this altitule was simply superb, and if a goorl path were eonstructed from the Hadihn Plain - an engineering molertaking of absolutely no diffienlty - a delightful sanatorium for our Aden troops might witi very little cost be elected a short day's march only distant from the east, where fresh meat (beef, mutton, and kid) and milk could be abundantly obtained, while fruit and regetables of every sort could be grown, and fish procurerl with the greatest ease.

On the 1:3th we hat the great pleasure of welcoming in our camp and entertaining for a night Mr. Miiller and the member's of the Austrian Expedition, whose yacht, the Crottfrienl, harl come romul to Hanlaf. We had thus the opportunity of personally expressing to them our thanks for their kindness to us iu our sickness. 1)r. Kossmat and Professor Simony had hoped to make the ascent of Gebe] 1)ryat, but the extremely wet weather that came on-almost the only truly heary rains we experienced while on the islandand lasted incessantly for three days, frustrated their plans for that oceasion.

On the listh we packerl up our eamp and helongings and set ont for Hadihn to await the retum of the Elphinstone. We arrived the same evening, and pitched our tents a little nearer the shore than the site of our first encampment. We comld not hut le struck with the difference of the plain in the interval. Every sign of grass had disappeared, and a brown stony desert lay before us. The few eattle and sheep which han not heen drafted to the uplands wantered disconsolately and thin orer it searching for food, and finding it almost entirely on the leaves and twigs of the shrubs. The next two days were occupied in packing n], our collections and baggage for embar kation, and in paying off on camel drivers and lonkshish-ing those who harl assisted us.

On the morning of the 2lst the Elphinstone anchored off the town. The transfer of our belongings on board began at once, and was completer in the afternoon. After paying a farewell visit to the Sultan, who was then residing in Hadibu, to thank him for the mfettered way we had heen permitted to rove about the island, for the use of his eamels (for which we had paid him well), and to receive from him his reply to the communication brought ly us from General Creagh, Mr. Grant and I proceeded on board, when the Elphinstone got promptly under weigh for Arlen ciu Abd-el-Kuri, on which we desired to have one more hasty run.

Early on the 2-2nd we found ourselves at onr old anchorage in Bandar Saleh, where we remained till the next evening, During our stay Grant was 
fortunate in oldaining a second pair of the Prsser hemilencus, the endemie sparrow of the island (Plate vii.), arlditional speeimens of the fine cormorant figmed on Plate ri., and a single inclividual of the starling which had elurter us on our former visit, and which, on proving to be distinet from the

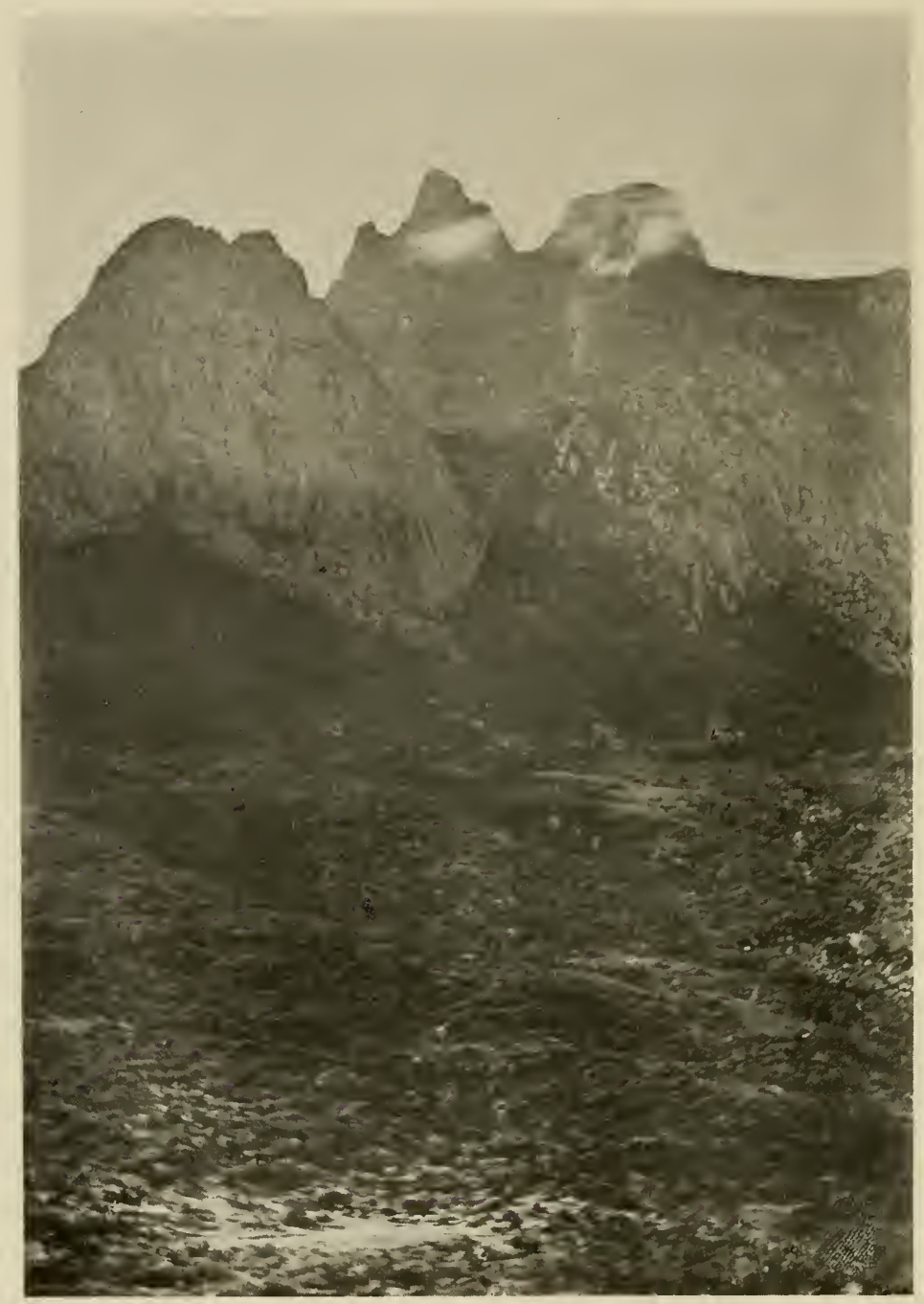

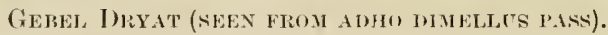

Sokotran species, we bave namerl Amyllus crengli, in homour of the Resident of Aclen, to whom we owed so much during our stiy there. The remark able buphorbia, which I had olserved on our first risit als covering the mountain side like a plantation of rerdant processional candles, I was suecess ful in rooting up, getting safely ahoard with. Jamah's aid, and in eventually transmitting in exeellent condition to Edimhmsh, where it still thrives. 
What struck us very foreibly, after having seen the flori of Sokotra, was the absence here of so many of the characteristic plants of that island. Dragon's-blood, Frankincense, Myrh, and Cneumber trees, Adenium, Aloe, Date-paIms, Exacum, Dorstenu, Hypericum, and many others were conspicuons by their absence.

On the evening of the 23ril of Felnuary we left $f_{0}$ r Aden, where we anchored late on the 25th. Two homeward-bouml steamers, a L'. \& O. and a British Indlia, were due within the next few days. By dint of incessant work omr collections were packed, and all our arrangements made for departmre by the 2Nth. The British India steamer Ghoorlhu, luckily for us once more, arriving first of the two, on the morning of March 1st, we took passage by her. The P. \& O. boat, which reached Aden a few homrs later, to our chagrin p.ussed us in the Red Saa the same evening travelling at a high speed. When we reached Snez, howerer, some days later, we left our rival behind us in strict quarantine with plagne on hoarl, lamenting, while we proceeded happily on our way to Marseilles, whenec Mr. (Arant and I travelled overland to Lombon, leaving our taxilermist, Cutmore, to continue the royage by the Ghoorkh to the Thames, in charge of the colleetions and laggage, whieh all came safely to the end of their peregrinations. 

Zoology

of

Sokotra

and

$\mathrm{Abd}=\mathrm{el}=\mathbf{K u r i}$ 



\section{CHORDATA. \\ VERTEBRATA.}

\section{Mammalia.}

By W. E. De WINTON, F.Z.S.

HENRY O. FORBES, LL.D.

W. R. OGILVIE=GRANT.

PLATE II. 



\section{Mammals.}

The Mammalian Fauna of Sokotra had been very cursorily examined by former expeditions, and, with the exception of a Bat, all the Mammals litherto recorded were such as had undoubtedly been introduced by man. It was therefore thought that some species truly indigenous might be discovered; for it seemed to many highly improbable that an island in such a position could have been so long separated from the mainland of both Africa and Asia as would be suggested by the absence of all Mammals.

The present Expedition has failed in adding to the list, so it may now be said, with a fair amount of certainty, that Sokotra has no indigenous Mammals, and that with the exception of one or two Bats, which may occasionally find their way from the mainland, all the Mammals living on the island have been introduced by man.

The first list of the Mammals of Sokotra of modern times was given by Heuglin in Petermann's Mittheilungen, 1861, p. 149, in a gencral deseription of the island and its products. Camels, goats, wild or feral asses, and civets are mentioned as those most worthy of record, while jackals and gazelles are said to be found in the middle of the island. The two latter may now be disregarded, as no explorer has been able to find either on the island.

The small Mammals were first noticed in a report on Dr. E. Riebeek's collection by Dr. O. Taschenberg in the Zeitschift fiur Nuturuissenschuften, Halle, 1883, Tol. lvi. p. 160. In this list the Free-tailed Bat (lihinopomu microphyllum) is recorded with a rat (Mus ulbipes), and a mouse (Mus gentilis).

The following notes on the Mammals obtained by the present Expedition suggest themselves to me; the full list, with field notes, I leave in the hands of the collectors.

The Rasse (I ivervicule maluecensis) is of the form common to Java and Madagascar, distinguished under the subspecific name of $V$. muluccensis russe, Horsf. (see J. L. Bonhote, Ann. Mag. Nut. Hist., Ser. VII., Vol. i., 1898, p. 119). This animal is now found almost everywhere in the islands of the Indian Ocean and Malayan seas, being carried in ships and dhows for the sake of the civet which it yields.

The Rat (Mus ruttus), of which a large series was obtained, varies in the shade of colour between the two forms found in India, Mus flacescens of Elliott 
and M. rnfescens of Gray. This is no doubt the Mus allipes of Dr. O. Taschenberg's list.

The Honse Mouse may have found its way on to the island, but it is just possible that young specimens of the last mentioned species were taken by Dr. Taschenberg for Mus gentilis, the pale form of Mus musculus found on the borders of the Red Sea.

The African Ass (Equus usimus) was founu in a perfectly wild state, and probably has lived thus for some thousands of years. Failing wild killed specimens of the true wild Ass from Africa, it is impossible to say whether the Sokotran animal has nudergone any modification from the ancestral form.

The Mammalian Fauna of Sokotra, so far as known, comprises eleven species.

\section{I.-Mammals of Sokotra.}

\section{CHIROPTERA.}

EMBALLONURID尼.

Rhinopoma, Geoffr.

1. Rhinopoma microphyllum, Geoffi:

Rhinopoma microphyllum, Taschenb. Zeit. Nat. Wissensch. (4) ii. p. 169 (1893).

[Ricbeck's Collection contained numerons examples of this species captured in the neighbourhood of Tamarida (or Hadibu). We did not meet with the species; and though constantly on the look-out for Bats, only once during the months we remained on Sokotra were we rewarded with a sight of one.

One night at Arlho Dimellus (3,500 feet), while going round the sugared posts in search of moths, a small Bat Hew several times across the front of the lantern within a few yards of me. It was not flying very fast and I saw it very clearly, bnt, of course, can only hazard a guess as to the species. By the time I had returned to the spot with a collecting gun the Bat was nowhere to be seen; and, even if I har succeeded in shooting it, it wonld probably have been lost among the grass and stones. It resembled and may possibly have belonged to the species Hipposiderus tridens, which is common in Sonth Arabia.-WI.R.O.G.]

FELID床.

\section{CARNIVORA.}

Felis, Linn.

2. Felis maniculata, Cret:selem.

[We never sncceeded in procuring or even seeing an eximple of the Wild Cat, though they were said to be fairly common in some of the rocky 
valleys of the interior, and do considerable dimage among the flocks, killing numbers of lambs and kids. An intelligent native, living in in villey to the south of Adho Dimellus, gave me a detailed description of the animal, which he said was fairly nmmerons in the neighbourhood. It apparently varies greatly in colour, some examples being striped or spotted like the IVild Cat, while others are mostly black. I githered from what he said that all are feral deseendants of tame eats which have been introduced into the island. There are a few domestie cats in Hadibn, and no doubt these, from time to time, have taken to the woods and gradually established a wild breed. Thongh not very large, they are silid to be very strong and fieree, and are extremely difficult to trap. One which was actually captured in one of our native-made traps unfortunately managed to escape.II.R.O.G.]

[There are no House- or Sheep-Dogs in Sokotra at the present day, and in neither the earliest nor subseqnent accounts of the island is iny mention made of their presence. This is ruther remarkable, seeing that dogs are found in India, Egypt, Arabia, and Somalilandthe comntries with which Sokotra has chiefly had intereomse,- and that by the Arabs they are employed in the herding of their flocks.-II.O.F.]

\section{VIVERRID冉.}

\section{Viverricula, Hodgs.}

\section{Viverricula malaccensis, $F$. Cur.}

[The Lesser Indian Ciret Cat, which, like the other Mammalia in Sokotra, has been introdnced, is fairly common in the momtains, thongh not very often seen. At most of our camps a few were in the habit of visiting our kitehen at night in seareh of bones and seraps, and our Somili cook, an enthusiastie sportsman, used to sit up for hours waiting for the chance of a shot. At Homhil he suceeeled in killing a fine male, and we trapped two more. During our stay a conple were bronght in by natives. The Arabs extract the civet secreted in the glands below the tail, and greatly esteem it as a perfume. When a cat has been caught, one man slips a string noose round its neck and pulls the bead tight up against the wooden bars of the trap ; a second man then pulls up the dropping loor of the oblong cage, and, seizing the cat by the tail and hind legs, draws it ont backwards, the man at its head paying out the required amount of line. The civet is then squeezed from the glands, between the man's finger and thumb, collected on the blade of a knife, and transferred to his naked forearm. After this operation is complete, the poor cat is allowed to escape, and the precious oil is carefully scraped up and placed in a small that wooden box. Just before we left the island, one of our camel-boys came to my tent and wished to present me with a box of 
civet. I declined it with thanks, and, though I promptly dismissed him, the strong musky smell remained in the tent for the rest of the day.

The following are the measurements of a pair:-Adult male-Head and body, 22 inches; tail, 13.75 ; hind foot, 3.75 ; ear, 1.7 ; weight, $7 \frac{1}{4}$ lb. Adult female--Head and body, 19 inches; tail, 14 ; hind foot, $3 \cdot 2$; ear, 1.8.-Wr.R.O.G.]

\section{RODENTIA.}

\section{MURID屟。}

\section{Mus, Linn.}

4. Mus rattus, Linn. sulbsp. rufescens, Gray.

Mus rufercens, Gray, Charlesw. Mag. N. H. (U.S.) i. 1. 58.5 (1837).

Whes flacescens, Elliott, Madr. Journ. Lit. Sci. x. 1). 21+ (1839).

Mrts albipes, Taschenb. Zeit. Nat. Wissensch. (4) ii. p. 160 (1883).

[We found the Indian Tree-Rat common on all parts of Sokotra visited, from sea-level to an elevation of nearly 4000 feet. During the months we spent on the island they were decidedly more numerous among the hills than on the plains, and most common among the bonlders on rocky hill sides. While at Dahamis, some natives informed me that one or two unoccupied huts were tenanted by rats, and I incantiously crawled in to set some traps. Though the business certainly did not occupy more than a few minutes, I found myself on emerging literally crawling with fleas! My traps in the huts produced nothing, though I caught plenty of rats among some neighbouring rocks.

These rats are evidently in the habit of elimbing trees, for though we never actually saw them among the branches, they constantly visited livetraps set for bircls on the tops of high bushes. This was clearly seen by their droppings. The traps being made of string netting they easily ate their way out.

The following measulements, all taken in the Hesh from six adult specimens, may prove of interest:-

\section{Mules.}

Head and Borly, 146, 166, 172 $\mathrm{mm}$. Tail, $.188,205,190$

Ear,

Hind foot (with-

out nail),.... 32, 30, 33 ,
Females.

Head and Body, 155, 145, $143 \mathrm{~mm}$. Tail, ...........218, 208, 205 , Ear, ...........22, 22, 21\%, Hind foot (without nail),.... 30, 30, 31 , - IV.R.O.G.].

[The variety, or subspecies, rufescens of the Common Black-Rat-the House- and Tree-Rat found over all India, and extending southward into the Malay Peninsula-occurs also in Arabia. Mr. O. Thomas, in his Mummals from Omun (P.Z.S., 1894, p. 450), remarks that the 
Tree-Rats, obtained by Dr. Jayakar at the foot of Jebel Akhdar, "seem to closely correspond with the Indian M. ruttus infescens, Gray." Some of these specimens were "bright rufous," and other's "brown ;" but all had "pure white bellies." Our specimens would seem to resemble more elosely this brown form. In his well-known paper On the Indiun speries of Mus (P.Z.S., 1881, p. 5.34), Mr. Thomas gives in his varietal characters of IIus rufeseens the length of the body "just over 5 inches"; but it will be seen from the measurements of the six specimens set out above that $t$ wo of and one $q$ are over six inches long, while none of them are under $5 \frac{1}{2}$ inches.

The occurrence of Mus rufescens in Solsotra is but a slight extension of its distribution, and is what might be expected, considering the continuous intercourse which from ancient times has sulssisted between India, Arabia and Sokotra.-II.O.F.]

\section{Mus musculus, Linn.}

ILu* gentilis, Taschenb. Zeit. Nat. Wissenseh. (t) ii. p. 160 (1853).

Riebeck procured the Common Mouse at Hadibu, and Professor Balfour records its occurrence, but we did not meet with it.

\section{UNGULATA.}

EQUID 屟.

\section{Equus, Linn.}

6.-Equus asinus, Limu, subsp. africanus, Fitz. (Plate ii.).

Eques africanus, Fitz., Sitzungsb. K. Akad. Wien. liv. p. 588.

[Though it had long been known that a wild ass inhabited the plains of Sokotra, no example had ever been brought to Enrope, and it was conseqnently a matter of considerable interest to obtain specimens and determine the species. It was not until we were traversing the Garieh Plain, a wide stretch of bush-covered country extending from the base of the Haghier range nearly to the north coast, that we came across herds of these animals. We were then marching from our camp at Dahamis to a place called Kamahanu, and all suffering more or less from a severe attack of ferer, probably contracted at our first camp on the Hadlibu Plain. Towards evening our path led us over sereral streams, and here we saw quite a number of Wild Asses quenching their thisst or feeding in the open grassy glades near the water's edge. As they are never shot at and rarely molested loy the natives, they were by no means wild, and allowed us to approach to within 50 yards without displaying alarm. Both Dr. Forbes and I were much struck with their beanty and by the perfect similarity in colour and markings of the large number seen. In all, the nose and a wide ring round the eye, as well as the chest and belly, were white, the legs nearly so, contrasting strongly with the mouse-coloured head and back, while the black stripes on the shoulder and down the middle of 
the back, and a few somewhat irregular dusky rings round the legs, were clearly defined.

It was not until we hal reached our camp at Jena-igahan, on the eastern slopes of the Haghier range, that we had an opportunity of obtaining specimens. Starting early one morning with two of on Somalis, anr a camel to carry in the slain, I renched the plain about 10 o'clock, and, after a somewhat protracted search, discovered three asses having their midday siesta moder the shade of some large stones. They proved to be an old female and two younger animals. When I got within about so yards they became aware of danger, and, jumping up, faced me, the white ehest of the largest offering an easy mark. A bullet in the base of the neck dropped her stone dead, and the other's at once galloped off, but, ifter running about 30 yards, suidenly halted and wheeled round. With a similarly placed shot the nearer of the two collapsed without a struggle. The third animal might easily have been bagged, but it rould have been useless slaughter. After a couple of hours' hard work, we skinned the largest animal, and while thus engaged, with difficulty kept oft' a large number of Egyptian Vultures which had congregated round the other beast. The camel having meanwhile arrived, all hands were ordererl to assist in placing the smaller ass on its back, but the camel-man, Mesingis, a half-bred Alalb, at first absolutely refused, on religions grounds, to touch the carcase. Eventually his scruples were overcome, and we got back to our camp in the hills just as it was becoming dark. Poor Mesingis had rather a bad time of it with the other camel-men, who, on learning of his share in the day's work, refused to eat with him, and, in Arab fashion, sent him to Coventry!

On subsequent expeditions to the plains Dr. Forbes secured an adult male and female, and one of our Somalis shot a male, when the same religious difficulties were again eneountered. So altogether we brought away five fine skins and were content, for the amount of labour in preparing these large animals is great. With a little tronble one might easily have bagged a score of Wild Asses in a day, for, never having been shot at, they were by no means shy, and it was rather unpleasant work killing the few we required as specimens.

There is certainly a small number of the domestic breed of Ass in Sokotra -Dr. Forbes saw at least a couple in Hadibu; but the young of the wild animals are also occasionally captured by the natives, and much esteened as beasts of burden. The endeavoured on several occasions to purchase a living example for the Zoological Garlens in London, but none of the owners were willing to sell.

There can be little doult that the Wild Asses of Solotra are the feral descendants of animals imported many centuries ago. The natives, when questioned on the snbject, stated that they have been there from time immemorial, and the entirc absence of colour varieties among the number we saw leads us to believe that their statement is correct 
They are remarkably stmrdy, thick-set little animals, with beantiful, clean legs and remarkalsly small hoofs. If a mumber of Australian brood-mares were imported and turned ont on the Garieh Plain there can be little doubt that valuable mules might be brerl to supply the Aden market.

Unfortunately we neglected to take exact measurements in the flesh of all the animals killed. An adult female measured $6 \mathrm{ft} .6 \mathrm{in}$. from the tip of the nose to the end of the tail (withont the hair), and the skins and a monnterl example shew that they stand from 91 to 10 hands at the shoulder:-Wr.li.O.(i.]

[In the Procentings of the Zoulogimal Soriety of Londmu (for 1s8t, P. 540, Pl. L.), Dr. Sclater gives a deseription, with a figure (fig. 1), of the Irild Ass which inhabits Somaliland, mider the designation of Equms aximns smmlicms. He there points out that, in possessing only a slight indieation of a dorsal stripe, and in the absence of a cross-line on the shoulders, it is easily distinguishable from the speeies possessing both those characters inhaliting the deserts of Upper Nubia, which he shows onght to be known by Fitzinger's name of Eiques asiuns afirinuts. From the drawings he gives, and the description in the text, which together perfeetly agree with the species seen by us in Sokotral, it is evident that the Wild Ass from both these localities belongs to the same species or subspecies. It is remarkible, therefore, that it is not the species geographically nearest to the island that oceurs on Sokotra. When we remember, however, that the great trade ronte of ancient Egypt, and later of the Romans which started from Bernice, passed down the Red Sea to Arabian and Somaliland ports, this cireumstance is less surprising. It is, consequently, by no means improbable that the progenitors of the Sokotran Wild Ass may have come actually from a Nubian port to their present home; and that the introduction of this race into the island may very likely date back to those fal distant days. The difference of the Equus ufirmus. from the common domestic breed strikes one at once. Among the animals employed in conveying onr baggage from the shore where it was landed from the baghlah, to our first camp on the Hadilm Plain, was a donkey which at once attracted my attention, not only by the burden so disproportioned to its size which it earried (apparently without distress), but by its bright and sharply defined markings. It was only later that I reeognised it as a tamed Wild Ass. When in Hadibu on .Tamnary 31st, 1899, I saw my old friend and a comple of domestic 'mokes,' and the great contrast between them was at once strikingly evident. There is nothing of the 'moke' in the Sokotran Wild Ass.

The only wild species seen by Mr. C. I. Peel in Somaliland (Cf. Simmlitund, 1900, p. 300) was the E. asimns somulicus of Sclater. Mr. Peel has, however, designated it Equns nubimus sommlicus :-II.O.F.] 
[Equus caballus, Linn.

There are at the present day no horses in Sokotra, although in the seventeenth century they appear, from the interesting account that Sir Thomas lioe has left us of his visit to the island in 1612 , to bave formed part of its fauna, for he says: "The Sultan came down to the shore with about 300 men. . . . He was a-horseback, as well as two of his chief servants."-H.O.F.]

\section{BOVID丑.}

\section{7. [Bos taurus, Limn.}

Bos, Linn.

The domestic cattle of Sokotra do not belong, as might have been expected, to the breed of the Zebu, or humped cattle of India (Bos indicus), nor to that of the broad-horned, heary dew-lapped Gayal (Bos fronterlis), another Indian breed, also humped, but doubtfully domesticated. They closely resemble in appearance European domestic oxen, except for their diminntive size. They are more like very small Alderneys than any other lace, with perhaps a somewhat less developed dew-lap. The bulls are fuller in the head, broader in the forehead, and have a thicker neck than the cows. In colour they vary nearly as much as our home herds do ; they may be fawn, red, or these colours dappled with white, but they are more rarely dun or black. All their four legs below the knee are not infrequently white. The cows have small udders, with very short teats. Considerable varialility exists in the for'm and dimensions of their horns, which are not, in proportion to the size of the animal, longer than those of the common mixed breed of cattle of Europein farmyards. They curve either forwards and outwards, or forwards and inwards. It is difficult to conjecture by whom and fiom what country these pretty cattle can have been brought to Sokotra, seeing that in none of the adjacent comntries is a similar breed now found or known to have existed. It is probible they were already inhabitants of the island in the thirteenth century, for Iareo Polo observes that the people of Sokotra lived on "flesh and milk," which may, of course, apply to goats and camels as well as to cattle. The island, however, abounded in cattle in the middle of the sixteenth century, as Francis Navier records.

Some further remarks on the origin of the Sokotran cattle, with illustrations of them, will be found in the Vurratice.

It should be noted also that Sir Thomas Roe, in describing his visit to Sokotra in 1612 , besides mentioning lireves, remarks that he saw "the savage people . . . the ancientest natives of the place, riding abont on Buffaloes," hut of what species they were, or from what country, Africa or India, they came, he is, unfortunately, silent.H.O.F.] 


\section{Capra, Linn.}

\section{Capra hircus, Limn.}

[The Wild Goat of Sokotra, mentioned by the late Mr. Theolore Bent and Mr. Bennett, proved to be a chimisra, for we ascertained beyond donbt that the only wild animals are feral examples of the domestic breed so common on the island. From what we harl heard and read, we had been led to suppose that a really wild animal existed, and had fondly pictured a new species of 'Thar allied to that recently discovered in the mountains of Arabia. We were told by the natives that wild goats were only to be met with in the highest and most inaccessible parts of the Haghier range, and that when we reached our camp at Adho Dimellus, under the great granite peaks, there would be no great difficulty in procuring specimens. We saw plenty of goats in that neighbourhood; some our local guide forburle us to shoot at becanse they were tame, while others, olviously not his property, were pointed out as being undonbtedly wild. The tame and wild animals were quite alike, and every individual varied in colonr and markings. Our guide having informed us that all the goats across a certain valley opposite our camp were wild, I acter on the information and took an early opportunity of shooting one. But the owner of the dead goat promptly appeared and made a terrible outcry, demanding ten dollars to square matters. Eventually, for the sake of quiet, he received three dollars, but after that goat shooting was voted an unprofitalle amusement and a waste of time! We had with us, however, an Indian Sowar from the Aden troop, whose greatest pleasure was to take his rifle and start off for a long day in the hills. Twice he came back staggering under the remains of what was supposed to be an undonbted wild 'billy', but, as on each occasion one or more owners shortly appeared and clemanded payment, we were obliged to curb his love of sport by requesting him in future to leave his rifle at home. The only specimen preserved was a quite young female which we purchased from a native at Homhil before we had ascertained that the wild goat was a myth.-II.K.O.G.]

[The Domestic Goat of the Sokotri, of which the Sultan, the chiefs, and many of the Bedawin possess very large flocks-larger indeed than of sheep-is a much smaller breed than the European. It has rather long hair, which, as mentioned above by Mr. Grant, is of many colours. Many of them have remarkally large and long udders. The horns vary considerahly in shape, size, and direction, but, notwithstanding the alluring deseriptions of their great length and ornate form given us by more than one Bedawin, only here and there did we see a patriarch (generally stalking proudly in advance of a long file of his harem) with what might be termed a "noble" head. The introduction of the goat into Sokotra must date back to a period at least considerably anterior to the beginning of the 
thirtenth century, a time at which the Hocks of the Sokotri were already large.--II.O.F.]

\section{Ovis, Linn.}

[9. Ovis aries, Limn.

The domestic sheep of Sokotra, of which extensive flocks are possessed by the islanders, especially by the mountain Bedawin, are a degenerated stock. Though quite European in general aspect, they are all small, with thin legs, and bearing, it seemed to me, by no means an abundant fleece. Their wool is also poor and rather hair-like, the result perhaps of their long tropical residence and want of cultivation. With few exceptions all are black, and they reminded me very much of black sheep from the Scottish Highlands which had become dwarfed and wasted in body and face. Certainly, all the specimens we were able to buy for the table were small boned, and lean to a degree besides which did little credit to their pastures. Although in the Garieh Plain and on the high plateanx near Adho Dimellus I saw a good many sheep that had been shorn, wool appears not to be an article of export. We noted, as other visitors to Sokotra have done, the absence of the fat-tailed Ethiopian breed abundant in Africa, of which large numbers are annually imported into Aden, often by native craft, which occasionally call at Sokotia on the way. The Oman sheep, according to Wellsted, thongh small and black, have the tail larger than that of the Emropean, but less than that of the Ethiopian breed. "The sheep of Arabia," Palgrave remarks, "are all more or less broad-tailed." The tail in the Sokotran breed is quite small. This is an additional instance of a member of the Mammalian fauma of the island not heing represented by the species or race found in the nearest continental land.-H.O.F.]

\section{CAMELID尼.}

\section{Camelus, Linn.}

\section{Camelus dromedarius, Limn.}

The Camel of Sokotra is the same, single-humped, species which is found in Arabia-whence it has been introduced-only of a somewhat stonter build. The physical characters of its new home differ considerably from those of its old. Here, instead of even sandy deserts, the "plains" that exist are invariably the ronghest and most boulder-dotted tricts of country that can well be imaginerl; while nearly all the island paths, for they cannot be called roads, eventually rise over sharp rock-set or slippery precipitous ascents. To these altered conditions the habits of the camel have become perfectly adapted. Upon snch difficult and dangerous ways, the goat-like agility and sure footedness of the beast elaimed our 
admiration from the first dily we travelled with it, and the carefulness and sagacity with which it would piek its steps at all doubtful and awkward turnings, tended to raise its down-trodden character in our estimation. Although little of the comitry lends itself to a pace faster than a trot, yet over a clear stretch the Sokotran Dromedary seems as tleet as his Arabian brother.-II.O.F.]

\section{CETACEA.}

\section{PHYSETERID死.}

\section{Physeter, Linn.}

\section{[11. Physeter macrocephalus, Linn.}

The Sperm Whale appears to have been a very freruent visitor to the neighbourhood of Sokotra, as "black ambergris" was one of the exports for which the ships of the East India Company traded there in the seventeenth century. Even as early as the thirteenth century the island produced "a great deal of ambergris." This whale is not now so frequently met with in these seas as it was even half a century ago, when it abounded on the Arabian coasts, as did also "myriads of cuttle-fish and cephalopods of all kinds on which it fed." Sir Henry Yule in his "Nareo Polo" quotes the following extract from Mas'ulli - - a traveller and historian of the tenth century - as to the curious ideas of the Arabs in reference to this substance:- "The best ambergris is found on the islands and coasts of the Sea of Zinj [as the Arabs still call Zanzibar]; it is round, of a pale blue, and sometimes as big as an ostrich egg. . . . . These are morsels which have been swallowed by the fish called Awâl. When the sea is much agitated it casts up fragments of amber almost like lumps of rock, and the fish swallowing these is choked thereby, and Hoats on the surface. The men of Zinj, or wherever it be, then come in their canoes and fall on the creature with harpoons and cables, draw it ashore, cut it up, and extract the ambergris."-II.O.F.] 


\section{II. - Mammals of Abd=el=Kuri.}

With the exception of a few small floeks of Goats, no mammals were found by us on Abd-el Kuri; yet it is possible that some species may nevertheless exist there, for we had time to do little more than examine the plain between the two seas and part of the mountain range at the eastern extremity of the island. If it be the case that the "vermin" reported on Kahl Far'un by Captain Haines be rats, murine species may not improbably yet be found on Abd-el-Kuri, whieh is so close to it. Barbosa, writing in the sixteenth century, makes this remarkable statement:- "Near to this island of Sokotra there are two other islands. . . . . In these two islands much amber of good quality is found, and many shells of the valuable and preeions kind in the mine, and much Dragon's-blood and Aloes of Solotra, and there are large floeks of sheep and oxen." The "two other islands" above mentioned evidently refer to Abd el-Kuri and probably Samneh, the larger of the group known as "The Brothers," lut while there still exists in the former a fishery for pearl shells of "the valuable and precious kind," neither Dragon's-blood trees nor Aloes, so far as we saw, grow upon it, and but little vegetation to support even small flocks of any sort. In explanation, we must suppose that Barbosa was writing from second-hand information, rather than believe that so great a ehange has come over the islands since his day as would be indieated by the disappearance of the long-lived, alpine, inedible, roek-loving Drucenu, and the vegetation neeessary to support many oxen. The remaining islets of the Sokotran Archipelago are even more barreu than Abd-el-Kuri.-H.O.F.] 



\section{PLATE II.} WILD ASS OF SOKOTRA, p. 9. 


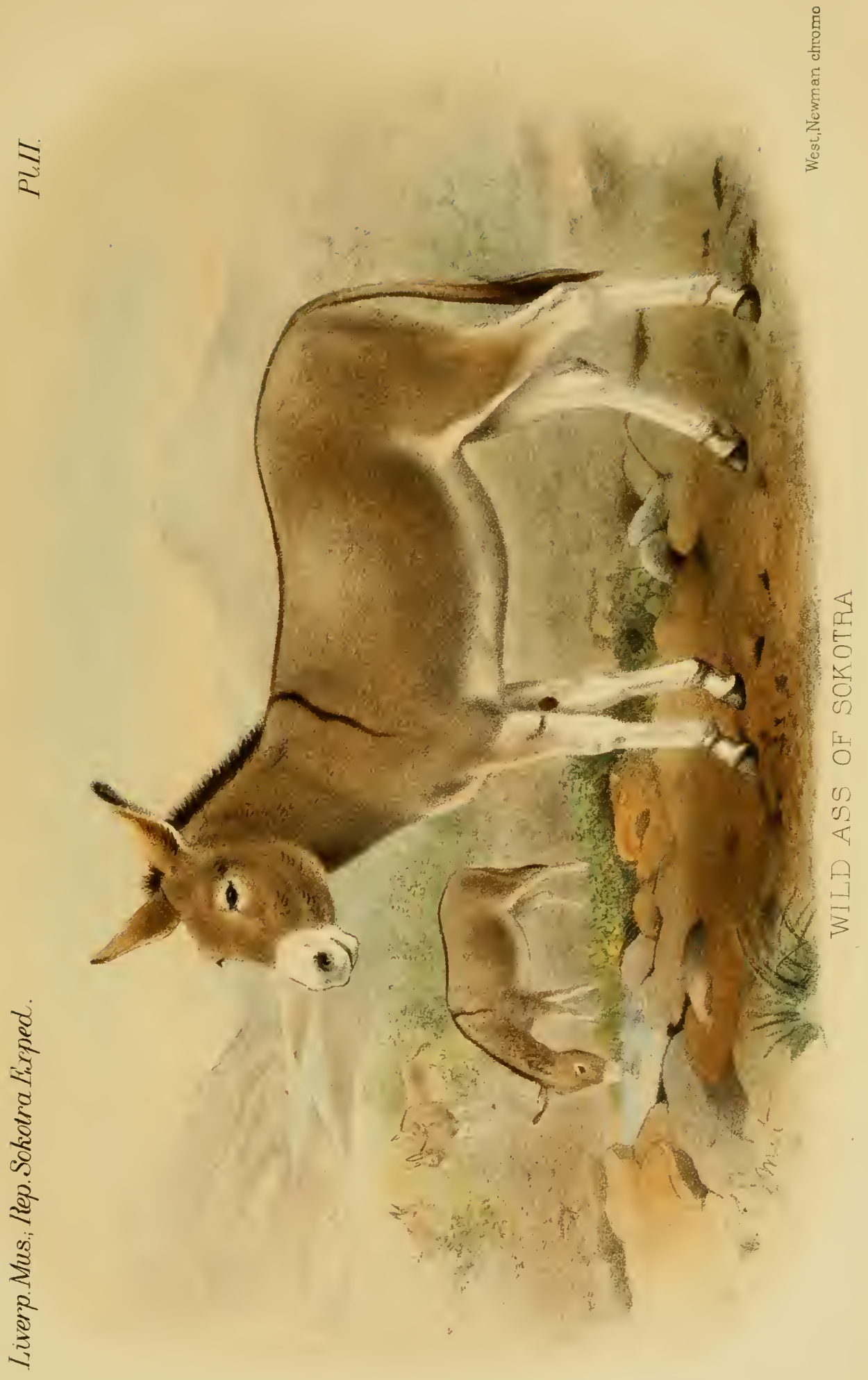





\section{CHORDATA. \\ VERTEBRATA.}

\section{Aves.}

By W. R. OGILVIE=GRANT.

HENRY O. FORBES, LL.D.

PLATES III., IV., V., VI., VII. 



\section{Birds.}

The results of the ornithological work done by us in Sokotra and Abd-el-Kuri may be summed up as follows:-

The number of birds collected by the Expedition was 437. Of these 41 specimens were obtained in the latter island during our two short visits, and 396 in the former. The species represented in the collection number in all 50, 10 from Abd-el-Kuri and 40 from Sokotra. Previous investigators of the larger island have recorded 20 species which were not secured by us, and none of which, save three, did we see; but, on the other hand, we discovered eight species new to science, viz. :-

From Sokotra, Fringillaria insularis, $[=$ Emberiza septemstriata

(scl. \& Hartl.)].

Fringillaria socotrana,

C'uprimulgus jonesi,

Scops socotranus.

From Abd-el-Kuri, Amydrus creaghi,

Pusser hemileucus,

Notacilla forwoodi.

From both islands, Phalacrocorax nigrognluris.

Moreover, the following nine species which had not previously been met with in the gromp were obtained by the Expedition, viz. :-

In Sokotra,

C'otile obsoleta,

Buteo desertorum,

Ardea cinereu,

Totanus culdidris,

Tringu temmincki,

Scolopux stemura.

In Abd-el-Kuri, Coracias? abyssinicus (skeleton),

Sulu sulu.

In both islands, Pandion haliertus.

In addition to these, the following species unrecorded by other observers were seen; but we were unable, for varions reasons, to add them to our collection, viz. :-

In Sokotra,

Cypselus murinus,

¿pupa epops (probably),

Syruimu sp., 
Fulco felilengii,

chenulopex regyptiucus (probably),

Anous stolilins.

In Abd-el-Kini, Falco barlueris: (probably).

Laves fuscus.

In both islands, Sule piscutix.

The female of Amydrus frater, hitherto muknown, was obtained; while likynchostruthus riebecki was proved certainly to be the adult of $R$. socotimus, thus fully confirming the determination of their identity made in 1888 by Dr. Bowdler Sharpe, in the Cutulogne of Birls in the British Musemin, Vol. XII. p. 282 .

\section{I.--The Birds of Sokotra.}

\section{PASSERES.}

\section{CORVID后。}

\section{Corvus, Linn.}

1. Corvus umbrinus, Hedenb.

Corrus umbrinus, Sclat. \& Hartl. P.Z.S., 18s1, p. 172; Hartl. 1'.\%.S., 1881 , p. 955.

The Sokotri name is 'Aäireb', for' one, 'Aäiroop', for a flock of, Cortus. 'Aädip', (I. B. Bulfour).

This Raven is not very mumerous, and in no part of the island did we find it abundant. About all our eamps a few were seen from time to time, almost always in pairs, and at Homhil, where we obtained most of our speeimens, it was, perhaps, commonest. As a rule, it was by no means wild, and when such saroury food as the borly of a dead donkey or goat was to be had, a pair or two would soon put in an appearance, driving off the vultures till they harl finished their meal. At Adho Dimellus a small flock of seren visited the neighbourhood of our camp on two sucessive days, attracted by the carcase of a dead goat. The harsh croak of this speeies is much like that of the Common Raven, but not so deep.-II.I.O.G.

\section{STURNID无.}

\section{Amydrus, cab.}

2. Amydrus blythi, Heugl.

Amydru. Blythi, Sclat. \& Hartl. P.Z.S., 1881, p. 171 ; Hartl. P.Z.S., 1881, J. 955.

The Sokotri name is 'Shēlhè'. 'Shilhay', (I. B. Balfour). 'Arooal,', (I'ellsted).

This handsome Starling was eommon on all parts of the island visited by 11. On the Hadibu Plain it was constantly to be seen in pairs and in 
small flocks, but on the granite mountains surromuling our highest camp, at Arlho Inmellus $(3,500 \mathrm{ft}$.), it was perhaps most numerous. l)uring the daytime the birds might he met with in all sorts of places, on the plains, and patehes of open grass, ats well ats on the bush-clad hill-sirles, hut just before sumset they all retired to the neighbouring precipiees, and might then he seen far orerhearl in pairs and flocks on their way to roost. At Jent-agahan, (ne of our camps in the Haghier lange, small Hocks were constantly to he seen just before sumset, circling round above the granite peaks, much after the fashion of the Common Starling, and ittering their shrill, rather discordant ery, as they flew.

Their food is very varied, consisting of grasshoppers and other insects, as well as fruits of all kinds, especially figs, and the berry of the l)agon's-blood tree. Compared with the allied 1 . frater, hirds of this speeies are wild and nuch more dlfficult to approach. They are, moreover, remarkahly tenaeious of life, and I generally found a twelve-bore more effective for procuring specimens than the small collecting gur. When feeding in pairs, or small flocks, one bird, as a rule a male, is generally on the watch for danger, and keeps a sharp lookout from some bush or roek, while the rest are engaged in gobbling large grasshoppers or other delicate morsels. On the high grass-flats round Adho I)imellus there were some fine cattle, and every evening the herd might be seen accompanied by numbers of this Starling, either following them as they fed, or perched on their backs, busily engaged in searching for vermin. The actions of this bird, both on the ground and in trees, are like those of a Blackhird; it does not walk like the Common Starling, but hops, and when jumping from branch to branch the carriage of the long tail increases the resemblance. The nesting season was apparently over when we reached Sokotra early in Deeember, for though we saw a number of old birds accompanied by young, none seemed to be nesting. Probably one egg is the full clutch, for we never saw the parent birds with more than one young bird. Several of the latter were securerl, and an interesting point with regard to their phumage is that the young female has the hearl and reek black like those of the male parent, the grey plumage of the adult female being subsequently assumed. The call-note of this species Chẽechëe-chēe, -chë-uhoüi,

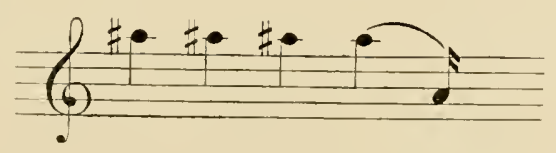

Chēe - chēe - chēe - chĕ - whoŭp.

uttered lond and quick, is much harsher, and quite different from that of $A$. fruter. The female, when suddenly alarmed, emits a curious, harsh "scraich," not unlike that made hy the Jay. 
The natives do not distinguish this species from $A$. fiater, the Sokotri name for both being the same.-IV.Ii.O.G.

Dr. Blanford mentions in his Geology und Zoology of Abysinie that Amydrus blythi was met with between 3000 and 4000 feet, while the temperate regions, from 7000 to 8000 feet, were occupied by Amydrus allirostris (Pilorhinus albirostris, Cabanis). In Sokotra we obtained A. blythi quite abundantly from sea level to 4200 feet, and Mr. Lort Phillips records (Itis, 1898, p. 395) that (in 1897) he found a flock of this species "in the gardens at the Dohar springs, eight miles inland from Berbera," although he had previously noticed them "only on the upper ledges" of the Goolis Momitains in Somaliland.-H.O.F.

\section{Amydrus frater, Sclet. \& Hartl.}

Amydrus frater, Sclat. \& Hartl. P.Z.S., 1881, p. 171; Hartl. P.Z.S., 1881, 1.. 955.

The Sokotri name is 'Shēlhè.'

As only a single male of this Socotran species had been discovered during Professor Balfour's visit in 1881, we were naturally anxious to olitain examples of both sexes, and ascertain whether the plumage of the female differed from that of the male. It subseruently transpired that this was not the case-both sexes being similar in appearance. During our stay in the neighbourhood of Hadibu, I never eame aeross the species, but may possibly have orerlooked it among the numbers of $A$. blythi that daily frequented the plain. This is, however, unlikely, for hoth species were almost always in pairs or small flocks, and the grey-hearled females of $A$. blythi were eonspienous at a long distance. After a brief aequaintance with the two species, one never had any difficulty in distinguishing between them. A pair of entirely blaekplumaged starlings might safely be put down as $A$. frater, and if one wanted further evidence, the much larger bill and shorter tail-a charaeter speeially conspicuous in flight-afforded ample proof. The call note,

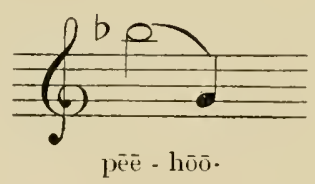

is a elear, soft, bell-like sound, easily distinguished from that of $A$. blythi, but, like that species, the female utters a harsh, Jay-like "seraich" when wounded or suddenly alarmed. The behaviour of the present species is, moreover, very different from that of Blyth's Starling. It is much tamer, and allows one to approach quite close without displaying any trace of alarm. The two species may oceasionally, perhaps aceidentally, he found associating with one another, while feerling, but, as a rule, they are met with separately. The first example we oltained was a male shot at Jena-igahan, on the 
lower slopes of the Haghier range. A pair of black-hearled lirets, conspienously different from Blyth's Starling, with which I was already well acquainted, lit on a tree close hy, and my attention was at once attracted by the different note. Unfortunately, l only had time to secure one-the male-and it was not mutil we reached Homhil, at the east end of the island, that female examples were procured. Both there and at our highest eamp, Adho Dimellus, this hird was fairly common. A few pairs were met with, accompanierl in erery case hy only one young liml, and it may thus be assmmed that only one egg is lait at a sitting.- $W$.l. U.G.

\section{FRINGILLID曆.}

\section{Passer, Briss}

\section{Passer insularis, Sclut. \& Itertl.}

Pesser insuleris, Selat. \& Hartl. P.Z.S., 1ss1, 1. 169, pl. xvi.

The Sokotri name is 'Eseféro' or 'Eseviro.'

The Sokotran Sparrow is by far the most abundant species on the island, being extremely common and rery tame on all parts visiterl, and equally numerous from sea level to an elevation of 4000 feet. When we got to Sokotra on the sth December the nesting season was practically over. Many pairs, accompanied by young broods of fullyHerlged birds were to be seen on the Harliln Plain, especially among the Date-palm groves bordering the rivers at Hadibu and other villages near the coast.

On Gebel Raggit to the south-west of the plain, several pairs were seen flying in and ont of their nests sitnated in the fissures of a huge perpendicular rock, and were evidently engaged in feeding their young. The only occupierl nest examined was one placed in a narrow slit in a rocky place above our camp at Adho I)imellus. It was made of dead grass, lined with a yuantity of feathers, and perfectly similar to that of the Common Sparrow. It contained three naked young, about five days old, and these were apparently a rery late hrood, for wherever one went numbers of full-fledged young, often aceompanied by their parents, were to be found. I examined a number of other nests at rarions places, lut invariahly found them empty, and one's tronble was never rewarded hy so much as an addled egg. The habits of this lind and its mode of life do not seem to difter flom those of the Common Sparrow. The notes, too, are much the same, but the "chirp" is rlecidedly sharper. On one occasion at Jema-agahan I was stalking the female of a magnificent butterty (Hypolimmes jucintha) among the huge boulder's of a dry watercourse. When almost within striking distance a cock Sparrow hegan to mol, me, and so determined and noisy was his attack that I looked mp, missed my footing, am lost the chance of taking one of the rarest insects in Sokotra. Greatly incensed by such an muprovoked assault, I got my collecting gun, and 
shot the oflending hirl. I was lucky enough to capture the buttertly next day, within a few yards of the same spot.--IV.li.O.G.

Both sexes have the iris brown, the hill hlack and the legs and feet Heshy horru-colour.

\section{Rhynchostruthus, Sclat. \& Hart/.}

\section{Rhynchostruthus socotranus, Selet. \& IItrtl.}

Rhyurhostruthus sorotianus, Selat. \& Hartl. P.Z.S., 18s', 1. 170, pl. xii. and woodent.

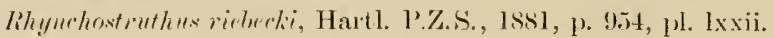

The Sokotri name is "Dehaurlài.'

FIti. 1.

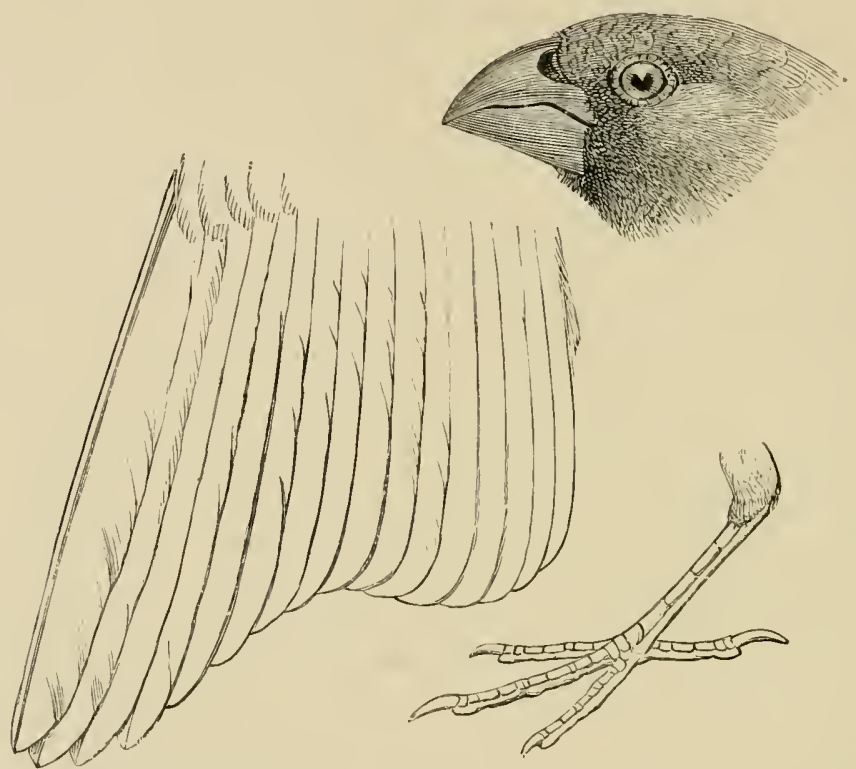

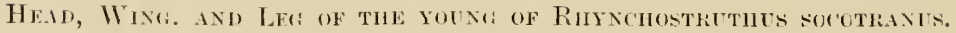

(F'rom the Procedings of the Zoological Society of London.)

I har long suspected that the description of this species had been drawn up from skins of immature binds, and that the second species (li. ridechi), subsepuently described by 13: Hartlaub, was merely the fully adult birel of li. sorotrmus. Un observations in Sokotra, and the fine series of adult and immature birds olntained there, prove beyoud doutht that this is the case.* We first met with the Sokotran Grosbeak on the 18th December in the Arldah valley, to the anst of the Hatlin Plinu, where om taxilermist, Mr. Cutmore, secmed an immatme lirel in the striped plumage of li. sorotrumus. At the same time I observed an adult bird with the black and white head 
(li. rirbecki) in the uet of feeding a second immature bind in striped plumage similar to the one alrearly shot. In attempting to kill both these with one shot, I mnfortmately secmed neither, and they disappeared into the thick jungle, where it was hopeless to follow them up. 'This first meeting clearly showed the birds' relationship to each other. No further specimens were olstained till the 14 th Jamiry, when I)r. Forbes shot on Gehel Bitzobur a specimen in the transition stage, with some striped feathers and a hlack throat, which was final proof of the irlentity of the two forms.

The elear ringing whistle of the adult male, viz. :-
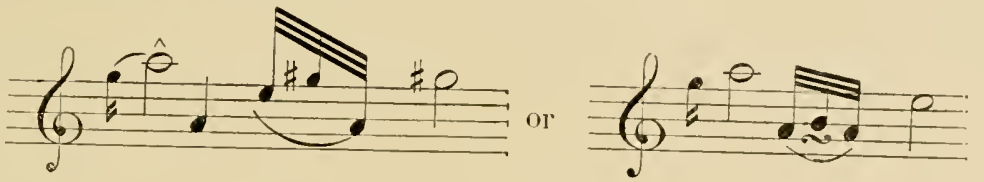

uttered at short intervals, ean be heard at a considerable distance, and is one of the most pleasing of the many lind-roices to he heard among the hills in the early morning. Another variety of the song,

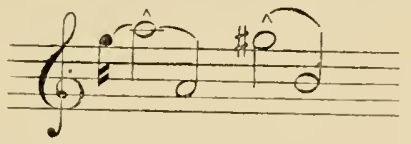

is not infrequently nttered by the male, while feeding during the afternoon, but I never heard it in the morning. Just after smmise numbers commence to sing, lut as the sun gets high, and the birds scatter orer the jungle-covered hill-sides to feer!, the concert gradualy dwindles. About mid-day, when the birch have ferl, the male may often be foumd resting in some thick lonsh, singing quietly to himself - the song uttered at this time heing a prolonged twittering, very agreeable to listen to, and much like that of the Common Goldfinch. Both adult and immature males sing in this fashion while resting. The old male when 'tuning up, or flirting with the female, makes a piping somnd,

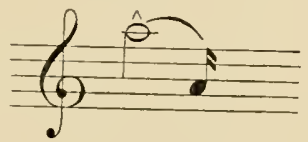

Pèè - youp.

much like the Bullfinch, and, at the same time, puts his tail on one sirle and puffs out the feathers of his sicles and Hanks. The call-note when feeding or alarmed,

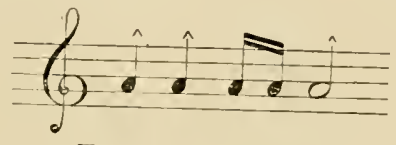

Teet teet te-te teet.
$\mathrm{Ol}^{*}$

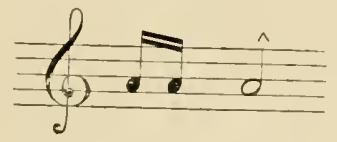

Te- te teet. 
is intered by both male and female, and another note is a rather harsh Sparrow-like chirp.

This lird was fairly common in the Addah Valley, to the east of the Hadibu Plain, and I never visited this spot without olstaining specimens. It was, however, quite exceptional to meet with individuals in fully adult plumage, and though adults of both sexes were occasionally shot at this place, the great majority were immature hirls with striped breasts, in rarious stages of plumage. On the Garieh Plain, and in the Goahal Gorge, at Hombil, Jena-agahan, and in the Dinehan Valley, adults were eyually scarce. On the other hand, at our highest camp at Arlho I)imellus, adults were numerous, but I only on one oceasion eame across an immature hird in their company at an elevation of about 4500 feet. It wouk thus seem that most of the adult birds frequent the high gromm, while the majority of immature birds are met with in the middle and lower valleys. They were generally fouml feeding in small lots of one to three, and sonetimes in larger companies, often associating, but never mixing with the flocks of Sparrows (I'asser insularis). I had exeeptional opportmities of sturlying the habits of this species at Arlho Dimellus. Large numbers eame in ererg night to roost in the dense bush eovering the sirles of the valley below our eamp. Juring the day they were scattered all orer the hillsides and valleys of the surrounding comtry, and generally met with singly or in pairs, though oceasionally in small floeks. The lond ringing song of the male, heing andilile at a long distance, made it no very difficult matter to fall in with him, but the female was much more diffienlt to obtain. The male generally feeds and sings on the ligher luranches of the bushes, lut the female frequents the lower and thicker parts of the jungle, and is generally silent, though she occasionally utters a call-note, Tr-te-teet. It is generally easy to shoot the male, thongh they are by no means rery tame, but the female beats a hasty retreat, never waiting to see what has befallen her mate, and the hest plan of oltaining the pair is to wait till one has an opportunity of shooting the female first, the male being then easily secmerl.

The nesting season of this speeies was eridently orer, for the youngest lirds shot were fully feathered, and all the females examined hart the oraries small, and were eridently not breeding. The food comsists chiefly of seeds and small fruits; those of a Croton, and the small red berries of an abumlant laurel-like tree being their favourite foorl. On one oecasion I came across four old birds feeding in some thick jungle on the high gromel to the north-east of Adlo Dimellus. After watehing their movements for some time, one of the party (a male) took wing and passed over my head with a enrions fluttering tight, nttering as he flew the twittering Goldtinch-like song. Ile flew so slowly that he almost seemed to be hovering in the air, and presently settling on a deat Dragon's-blood tree, fell a victim to science. The 
female, startled by the shot, but mable to loealise the danger, instead of beating a hasty retreat, hit on the same tree, and joined her mate. The other pair were also collected. I hoped that the first pair might he breeding, but a careful search for the nest proved fruitless, and sulsegnent dissection showed that neither of the females were hreeding hirds. About 5 o'clock in the evening the birds began to return to their roosting place in the valley lelow our camp, and an hom later the covert was full of them. They came in with a swift, direct flight, oceasionally uttering their call note as they Hew. Being rery imxious to secure this bird alive, we tried to cateh them with small "clap-net" traps, baited with seed, and placed on the top of the bushes where they came daily to feed: but the only visitors were rats, which sprung the traps and escaped. - Mr. R.O.G.

Drs. Sclater and Hartlaub, in their paper on the birds collected by Prof.

I. B. Balfour in Sokotra, remarked that it was their impression that lihynchostruthus would erentually be "fouml on Cape Guardafui." Mr. Lort Phillips has sinee then recorded a closely allied, lut smaller. species, R. louise, from Somaliland, with a less powerful bill and without a white cheek-spot.-H.(I.F.

\section{Fringillaria, $s w$.}

6. Fringillaria insularis, Gremt of Forless. (Plate III. fig. -2, of q).

Emberize septemstriate, Sclat. \& Hartl. (nec Rüpp.) P.Z.S., 1881, p. 171 : Hartl. P.Z.S., 1881, p. 9.5.

Fringillaria insularie, Grant \& Forbes, Bull. Liverp. Muss. II. p. 2 (1899). 'The Sokotri name is 'Thlafhan.'

Achult male:- Most nearly allied to $F$. tuhupisi, from which it differs in having the inner margin of the secondaries devoid of rufous, and the general colour of the chest and rest of the moler parts pale lirick colour, instead of dull rufous chestnut. Iris brown : eulmen blackish horn; cutting elges of the upper and the whole of the lower mandible orange yellow; tarsi and feet flesh-colour; claws blackish horn. Total length (measured in the flesh), 5.2 inches; culmen, $0 \cdot 38$; wing, $2 \cdot 9$; tail, $2 \cdot \cdot 2$ : tarsus, $0 \cdot 6$.

Adult female:-Similar to the female of $F$. tuturpisi, but the immer margins of the secondaries are deroid of rufons, and the chest and rest of under parts are pale brick-colour. Total length (measured in the flesh), 5.2 inches: culmeu, $0 \cdot 4$ : wing, $2 \cdot 3$; tail, $2 \cdot 25$; tarsus, $0 \cdot 62$.

This Bunting was common on all parts of the island visited by us, heing numerous on the plains at sea level, and met with, though in decreasing numbers, np to an elevation of at least 4,000 feet, where its place is taken by the next species, $F$. socotronu. The females are much less frequently seen than the males, and are much wilder and more diffieult to obtain. The food consists ehictly of fine glass seerls and the seeds of rarious lushes. Many pairs were met with on the 
Hadilu Plain in the heginning of Decemler, hut I harl not the goor fortune to find a nest till later. The first nest I fouml was at Hombil on the 20th of January. It was situated elose to the side of a goat track in thin Boxwood jungle interspersed with large Dragon's-blood trees, and consisted of a slight structure of twigs and glass stems, lined with finer grass, partially hicklen by a small Boxwoor bush at the root of which it was placed. The three small eggs harl the ground colom greyish-white, very thickly spotterl, especially towards the larger end, with chocolate-hrown. Being uncertain whether three was the full complement of eggs. I determined to leave the nest until the next day, but when I went to inspect it early the following moming, I found to my disgust that one of the eggs harl hatcherl. While 1)r. Forbes was engaged in photographing the nest, I obtained loth the old birds. On the 24 th of January I was fortunate enough to find two more nests of this species. The first, containing three very slightly ineulated eggs, was placed beneath a granite boulder (Fig. 2) on a rather hare and open hillside dotted with Cucumber-tree. In the seemd nest there were two well-feathered young binds and ome perfectly fresh eyy. In both cases the parent hirds were shot for identification. In the second week of February several pairs were met with at Adho I imellus, at an elevation of about 4,000 feet, and were generally accompanied by three young birds. There can be no doubt that three is the full number of eggs laid at a sitting. The male has a sharp) metallie call - for it can scarcely he called a song-not milike that of the Vellow Hammer (Emberizu citrinelli)

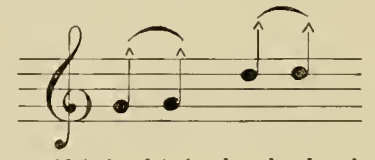

Chink-chink chenk-chenk.

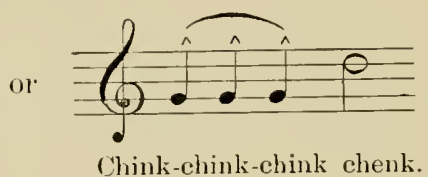

Chink-chink-chink chenk.

which is uttered frequently and at short intervals from trees and stones, or from the ground whilst feeding. A peculiar crooning alarm note

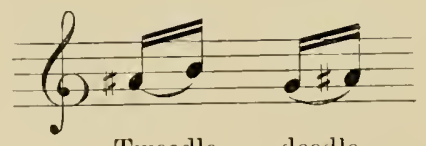

Tweedle - deełle.

commonly uttered ly the female, and sometimes also by the male, may the imitated very fairly by producing the sound nasally.II. R. O.G.

Drs. Sclater and Hartlauh irlentified (I.Z.S., 1881, p. 171) the Fringilluriu olitained by Prof. Balfour in Sokotra as $F$. septemstrivete, of Riuppell, and sharpe in the XIIth volume of the citulumer of Bids, after further comparison refered it to $F$. tahapisi, lnt it now proves to he a distinct species. F. trlurpisi, which extends from Equatorial Afriea to 


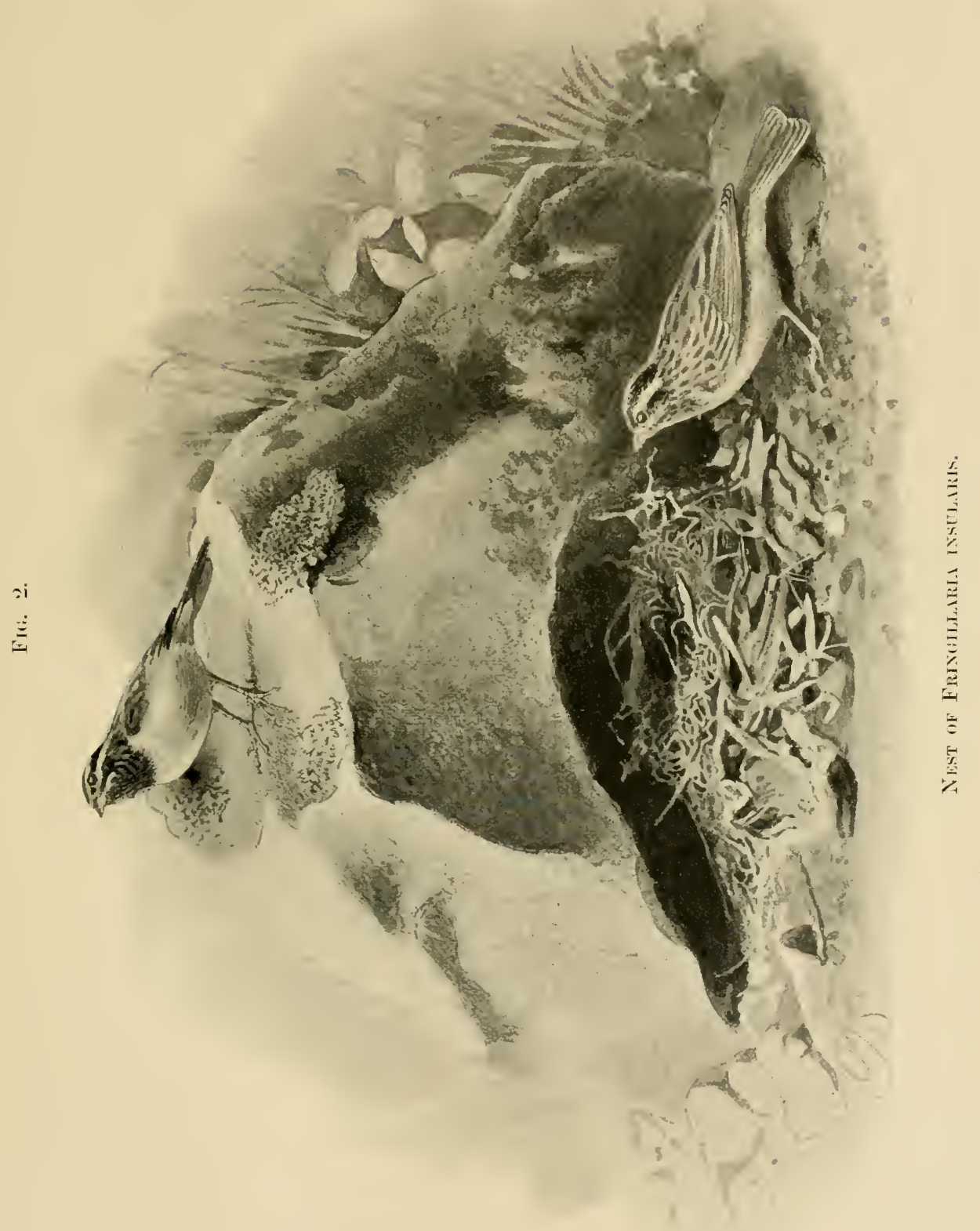


the Cape, has been discovererl in Somaliland by Mr. Lort Phillips, so that the nearest ally to the Sokotran species is also its near geographical neighlour (cf. ('irant, Ibis, 1900, p. 137). - II.O.F.

\section{Fringillaria socotrana, circut if Forbes. (Plate III. fig. 1.)}

Fringillurice soroticum, Grant \& Forbes, Bull. Liverp. Muss. II. p. 2 (1899).

Arlult mule:-A very distinct species, most nearly allied to the male of $F$. insuluris, from which it differs in having the rump feathers tipper with white folming a conspicuous white patch. The wing-coverts and lasal half of the outer edge of the secondaries dull rufous chestnut: the chin and throat white; the chest and upper breast dull rufous chestmut; the lower lueast, helly, and under tail-coverts whitish. Iris dark lrown; eulmen blackish horn ; cutting edges of the upper and the whole of the lower mandihle orange yellow ; tarsi yellowish flesh ; toes dusky; claws blackish holn. Total length (measurerl in the flesh), $5 \cdot 25$ inches ; culmen, $0 \cdot 38$; wing, $2 \cdot 75$; tail, $2 \cdot 2$; tarsus, $0 \cdot 65$.

Adult femile: Similar to the male. Total length (measured in the flesh), $5 \cdot 0$ inches; culmen, $0 \cdot 38$; wing, $2 \cdot 6$; tail, $2 \cdot 2$; tarsus, $0 \cdot 65$.

Though I helieve I saw this Sokotran Bunting on the top of one of the high limestone hills above our camp at Homhil, it was not until we reached Adho Inimellus, at an elevation of about 4,000 feet, that I olitained a specimen. At the latter place I soon became aware of the presence of a strange hird, being attracted by its ringing and somewhat metallic notes, which floated across the valley to our camp from the rlistant ledges of the opposite precipice. It was, however, some days before I olitained the first specimen. The bird appears to feed entirely on the fine grass seerls growing on the almost inaccessible ledges of the highest granite peaks, and, for this reason, is extremely ditficult to oltain. On the 6th of Felruary, I had gone up to a big granite peak ahove our camp in pursuit of Pupilio lemnetti. While waiting for an opportunity to catch this most evasive hutterfly, I saw what at first sight appeared to be a male of $F$. insuluris. The bird was quietly feeding on tiny giass seeds on a narrow ledge above me. All of a sudden it flew on to another ledge, and as it lid so gave rent to the song I had so often heard from the inaccessible precipice opposite our cimp. The hird then disappeared into a little recess in the rock, and taking the collecting gm fiom my boy, I made the best of my way to a leckge above the place where I harl seen it clisappear. When it flew out, I shot it, and found to my great delight that it was apparently a new species of Frimgilluriu. It was disappointing not to find a nest, but the hird was evidently merely feeding. Being naturally anxions to olstain further speeimens of so fine a birl, and also to shoot the hen, the first specimen proving to be a male, I lost no opportumity of hunting for it during the remainder of our stay. The following morning I heard another male, and after following miles over the tops, fimally shot it on a rery steep face orer a deep valley ; 
it chopped on to a ledge, whence it was quite impossible to retrieve it, Jut returning latel with one of our ("umel-men, he snceeeded in securing it after sereral attempts. On the 10th, I again hearl a male on the high ground to the nortl of om camp, and after a two homs' chase orer locks and through thick bush, secured it. This hird, when shot, was sitting on a small tree uttering its ringing metallic notes at short intervals. From the 12 th to the 14 th heary and continuous rain kept us all in cimp, hut early on the morning of the 15th of Felnuary, the weather haring cleared, I was pleased to hear this bird singing on some lerlges not far from our camp. Following up the somml, I soon had the luck to fall in with a pair, and to secure lotls. The female exactly resembled the male in plumage, lut had the alklomen entirely bare; she had evirlently nesterl, and, jurlying from the condition of the orary, would have laid again in about three weeks.* She uttered no note of any sort while I watcherl her. The song of the male

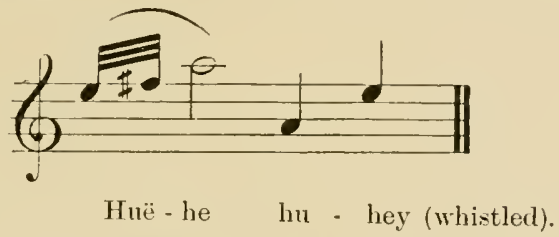

is singularly like that of lifynchostruthus socotranus, and may at first be mistaken for it. It is, however, more metallic, and one was soon able to chistinguish between the two at almost any distance.--Ir.li.O.G.

\section{PLOCEID丑.}

Professol Balfour, in the very interesting "Introductory Chapter" to his Boluny of Solotru, makes the remark: "All orer the island Wearer. Birds, Chats . . . abound." No species of Hyphuntormis or other member of the family came under our notiee, howerer, in Sokotra or Abd-el-Kuri. One is rather surprised not to find them there, as Weaver Birds are plentiful in S. Arabia and Somaliland, and are good Hyers. In the Cocos-Keeling Islands in the Inclian Ocean I found nests of Ploceus alrigule which from time to time (as Mr. Ross, the proprietor of the islands, informed me), visited the atoll and bred there. Ther must have come from Java or Sumatra, which is a much greater distance than that of Sokotra from Africa or Arabia.--II.O.F.

\section{ALAUDID床。}

\section{Pyrrhulauda, smith.}

\section{Pyrrhulauda melanauchen, C'ub.}

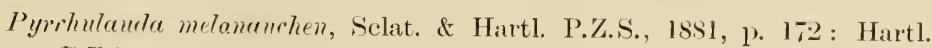
P.Z.S. 1881 , 1. 9.5.).

The Sokotri name is 'Kenfia.'

We met with few examples of this Finch-Lark on Abd-el-Kuri, and fomm

\footnotetext{
* The borly was preserverl in spirits.
} 
them shy and difticult to approach, but on the plains and low valleys of Sokotra they were extremely numerous and very tame. The melancholy wailing note is almost the first sound one hears in the early morning hefore sumrise, and the last at night. When we first arrived in Sokotra the hirds had apparently not hegun to breed, the oraries of the females shot being but little developed, but during January and the early part of Fehruary, while we were on the higher ground, they must have nester, for on our return to Hadilu on the 1sth February, we obtained very small nestlings, and numbers of recently fledged young were to be seen with their parents feeding on the stony plain. Two is apparently the full clutch in each nest, for though no eggs were found, we olbtained sereral nests, each containing a pair of nestlings, and the same number of young were noted among family parties alrearly on the wing.

The black-lireasted males are remarkably handsome birds, and may constantly be seen on the wing, momnting into the air in wide circles like our Sky-lark, but seldom attaining any great height from the ground. Their hovering, floating flight is often remark ably bat-like, and this resemblanee is intensified by the black colouring of their underparts. The song is varied and very pleasant, but nerer long sustained, the birds after a few minutes descending to the gromid or settling on the top of one of the low bushes. On the Harlibu Plain they were so tame that they would often allow one to pass within a few yards of them withont moving. Just hefore leaving the island I shot a female in rery curious plumage. I olserved what I took to be an old male accompanied by threp fullyfledged young-a male and two females. Being struck by the nuustal number, and in want of immature specimens, I shot all four, and then turned my attention to look for the female, but she was nowhere to lie seen. Sulnsequently, when skimning these lirds in eamp, our taxidermist, Mr. Cutmore, ealled my attention to the fact that the lird I har taken for a young male was in reality the female parent. Her lreast was strongly mottled with black feathers like those of the male, but the orary was normal and in no way diseased.-II.L.O.G.

\section{MOTACILLID㞎.}

\section{Anthus, Bechst.}

\section{Anthus sordidus, liiipp.}

Anthu: sordidus, Sclat. \& Hartl. P.Z.S., 1881, p. 167.

The Solotri name is 'Degásagus.'

'This large Pipit was very common on all parts of Sokotra visited, being almost as numerons at an elevation of 4000 feet as it was on the plains and low ground near the sea. It was perhaps the tamest hird on the island, generally allowing one to pass within a yard or two without showing the slighest trace of alarm. When we arrived the breeding season harl allearly commenced, for on the 11 th of l)ecember, with the 
aid of my buttertly net, I eanght young hirds just able to fly, and on the lifth of the same month foumd a nest containing four slightly incubated eggss. The nest, a slight structure of fune dly grass, was pliced at the foot of a thick plant of bush-grass, and so well hidden that it would certainly hare passed mmoticed hard not the female left her exgers.

At Arho Dimellus, 3500 feet, I found another nest with three perfectly fresh eggs on the sth of Fehruary. Ohserving a pair of Pipits showing signs of musual anxiety at my presence, it seemed worth while to hide and watch them, and after waiting for some time the female went to the nest. On this oecasion it was plaeed under a tuft of coarse grass in a glacle between some thiek bush, and probahly the full complement of eggs had not heen laid. The male bird sings a sweet song perched on the top of a bush or rock, and, like other members of the genus, frepuently arises with quivering wings to a consirleralble height in the air, singing as he flies, and descenting after some minutes to his former perch.

At Tena-agahan, one of on camps in the Haghier range, there was a delightful male Pipit which used constantly to sing on a rock just in front of my tent, and his proximity afforded me great pleasure during a slight attack of fever. On coming back one evening I missed him, and found with regret that his skin harl been added to our collection. The halbits of this species are much like those of the Common MeadowPipit, lut its actions, especially when feeding on the gromul, are hearier and slower. During our stay on the island Pipits were generally met with in pairs, and on the more open parts of the comtry the mates might often he seen chasing the females in and out among the houkders and patches of hush, and Hying at a great pace.-II.L.O.G.

Iris lown ; hill l, lackish horn except the basal part of the lower mandible, which is whitish horn; legs and feet fleshy horn colour.

\section{Motacilla, Linn}

10. Motacilla alba, Limn.

Motacille allra, Sclat. \& Hart.. P.Z.S., 1s81, 1. 167.

This Wagtail was fairly common in Sokotra, both on the Harlibn Plain and about the Dimichio Valley. A few were also met with on the higher ground at Homhil.

11. Motacilla flava, Limn.

Burtyte: flerus, Sclat. \& Hartl. P.Z.S., 18s1, p. $16 \mathrm{s.}$

We dirl not ohserve this species in Sokotra.-W.I.O.G.

Professor Balfom olotained three skins of the Bhe-hearled Wagtail;

but he saw it only on the murl Hats extencling inland a short distance from the head of Khor (iarieh. 


\section{NECTARINIID曆。}

\section{Cinnyris, Cuv.}

12. Cinnyris balfouri, Sclut. \& Hurtl.

Cimyris lolfouri, Sclat. \& Hartl. P.Z.S., 18S1, 1. 169, pl. xv. fig. '2. Werfurimin lulfouri, Hartl. P.Z.S., 1851, p. 954.

The Sokotri name is ' Degásagus.'

The Sokotran Sum-birl is fairly common in all the bush-clad valleys and on the slopes of the lills from nearly sea-level to an elevation of at least 4000 feet. Being an extremely noisy and vivacious little lirel, constantly on the move in search of insects, it can scarcely escape notice. Inring our stay on the island this species was generally met with in pairs, and though some must have been nesting (for towarls the end of om stay we shot more than one female eviclently on the point of laying), the majority harl apparently not commenced to hreed. Though I was constantly on the look-out for nests, and, with this eml in riew, spent a good cleal of tine watching the morements of varions couples, I only found one nest on the 10th February from which the young had already flown. This was of the usual lag-shaped type, exactly like the one foumd by Professor Balfour, and figured in the P.Z.S., 1881, pl. xy. It was suspended among thick hush and creepers, and very diftienlt to see. On the 5th February, in the low bush-jungle alowe Arlho Dimellus, at an elevation of at least 4000 feet, I came across a family party of Sun-linds, including two or three young, which, though well-grown and able to fly, were still being tended by their parents. The latter were extremely solicitus for the safety of their offspring, and at once hurvied them off into the thickest covert, the male appearing on the tops of the bushes from time to time, and uttering shrill, rather hoarse alarm notes. The song of this bird is wonderfully loud and raried, and it would be at hopeless task to convey any idea of its many changes by notes of music. To appreciate it one must see the beautiful little male with his grey and white plumage, ornamented with yellow sile-tufts, perched on the highest twig of some bush, pouring forth his whole heart in a sustained flow of melodious sound. It took me a long time to master most of the call-notes, and even when one thought one harl learned all, some new sound would often cause a weary climb only to find some little raseal of a Sun-hird. In ardition to his endless repertoire, this hird is a capital mimic, imitating the calls of some of his neighbours with great aceuracy, especially that of ('isticole inceme. The nales might constantly he seen chasing one another, or the females, up and down the hill sides, their Hight on these oecasions being rapicl in the extreme, ancl the pace at which they ean wheel and turn incredible. The somel produced by their wings when flying is lourl, and quite mulike that of any other birl on the island, and one soon got to know the peculiar "thrip, thrip" of a passing sum-linel. We never obtained any birch in inmature plumage, and all those 
collecter appeared to be perfectly adult, so I conclude that the young attain the alult plumage at the first moult.-IT.li.O.li.

lris redelish hrown; hill and legs back. Total length (measured in the Hesh) 5.5 inches.

\section{ZOSTEROPID压.}

\section{Zosterops, V. \& H.}

\section{Zosterops abyssinica, IIcuml.}

Zosterops helyyswinime, Sclat. and Hartl. P.Z.s., 1ssi, p. 16s: Hartl. 1.\%.S., 1881, 1. 954.

The Sokotri name is 'Degírikum.'

The Ahyssinian Silver-eye was fairly plentiful on all parts of Sokotra, being equally common in the low hush-clad valleys near the sea, and at an elevation of at least 4,500 feet, where the hush ceases. It was generally met with in small parties of two or more, and in its habits reminds one strongly of the Cole-Tit. Its call-note, nttererl when feeding and on the wing, is, moreorer, so exactly like that of the latter bird that, when first heard on Gelel Raggrit, to the west of the Hadilun Plain, imagination pictured some mknown species of Tit. It is an active, lively little bird, scliom still for a minute, and constantly searching for small insects among the branches of the bushes and trees. The nesting season must have heen practically over when we arrived on the 9th December. On the 17 th of that month 1 fell in with a family party of five, including three young hirks. Though able to fly well, they were still being forl hy their parents, and it was a pretty sight to watch, these beautiful little hirds portioning out the dainties they colleeted with such amazing lapidity. They were so tame that one conld olsserve them from a listance of a few yarls without disturbing them. At Jena-agahan, on the lst January, I again saw and olitained a female feeding two young lirds just able to Hy. Though constantly on the look-out for a nest of this speeies, I never sneceeded in finding one. On the high ground at Arlho Dimellus, I feel sure a pair had a nest, probaloly containing young, for they displayed quite unusual agitation, and continued to mol, me while I misnccessfully searched the neighbouring bush. When alarmed they keep up a constant scolding note, "Chü-ì, chu-ì, chu-è,"

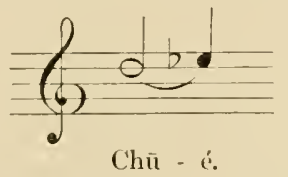

bustling about among the bushes, and are often extremely amosying to the natmalist, for they give the alan to all the neighlombond, sometimes spoiling one's chance of approatehing other desirable birds. Generally speaking, howerer, when moring quietly alsout among the 
bush, they take very little notice of one, and are so tame that they may often be seen feeding in a hush not a rard distant. The silvereye is eertainly one of the most beautiful little binds on the island, and it is delightful to wateh its graceful movenents, as, Tit-like, it elimlss about among the bushes, examining every bud in search of food. - II.R.O.G'.

\section{LANIID必.}

\section{Lanius, Linn.}

14. Lanius uncinatus, Sclut. \&: Hurtl.

Janius uncinatus, Sclat. \& Hartl. P.Z.S., 18s1, p. 168; Hartl. P.Z.S., 1881 , p. 9.54 .

The Sokotri name is 'Dehavifi.' 'Tàvifi' (I. B. Bulfour $)$.

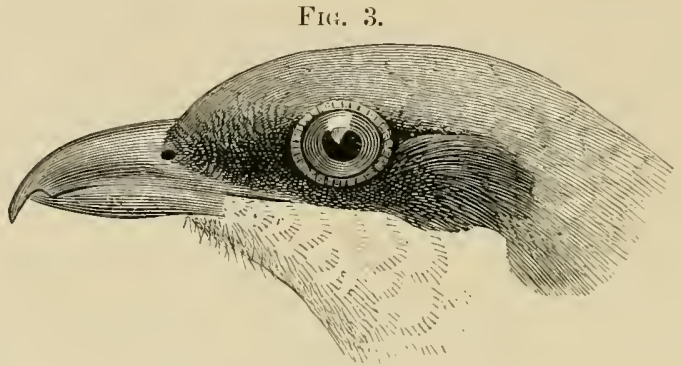

HeAD OF LANiUs UNCINATUS.

(From the Proceedings of the Zoological Soeiety of London.)

We met with the Sokotran Shrike on all parts of the island visited, and finding it as a rule extremely tame, had no diffieulty in obtaining as many specimens as we wallted. It was common among the I)atepalm groves and Acacia trees romd the Hadibu Plain singly or in pairs, and at Homhil we found it abmolant, the open grass country with scattered bushes being specially suited to its habits. At Adbo Dimellus, our highest camp, at an elevation of 3500 feet, this species was seldom seen, and, in fact, during three weeks spent there I only saw it twice. When we got to Sokotral the breeding season was evidently over, and though on December 16, and many subsequent occasions during our stay, I had opportunities of watehing the old birds feerling fnlly-flerged young, no eggs were obtained.

At Hombil I found a nest in a Bosuctliu tree eontaning quite young binds, but probably this was an exceptionally late brood, as it was the only nest we found occupied. The general habits do not seem to differ perceptibly from those of the Common Red-backed Shrike. On one occasion our taxidermist, Mr. Cutmore, having shot a Dove (Turtur semegretensis), and failed to find it, visited the same place next morning. He found his bird transfixed on an Acacia thorn and a shrike (which he shot) sitting beside it. One curions babit of this bird was its custom of feeding late in the evening. When watehing for the little 
Scops Owl at dusk, I often saw it busily engaged in catching beetles among the neighlouring bushes. The male has a harsh, rather mournful song, impossible to reproluee, and the usual call-note, fiequently uttered from the tops of bushes, sounds like "clink, clink." IV.R.O.G.

\section{SYLVIID床。}

\section{Cisticola, Kaup.}

15. Cisticola incana, siclut. \& Itertl.

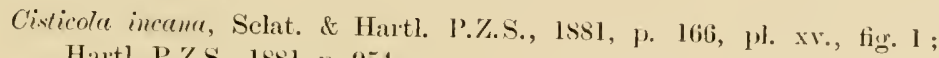
Hartl. P.\%.S., 1s51, p. 9.54.

The Sokotri name is ' Degásagus.'

This small Fan-tailed IVarbler was common in almost all bush-clad parts of the island from nearly sea level to an elevation of at least 4500 feet. It was numerous in the neighhourhood of Elhe, on the east of the Hadibu Plain, and equally abundant at Adho Dimelhs, in the heart of the Haghier range. Of a noisy, fussy disposition, it may eonstantly be heard and seen, and is generally easily seeured. Its ordinary callnote is a scolding sound, chip, chip, chip, chip, chip-it, chip-it, chip-it, chip-it, and it may be exactly reproduced by striking a flint and steel together rather quickly. This may constantly be heard when the birds are moving trom bush to bush in search of food, or playing with one another, and to hear it one would inagine that family disputes were everlastingly taking place. The male has a pretty little song, something like that of the Stonechat, and though not very often heard, there could be no doubt about the songster, for I shot a male in the act of singing. On the lower parts of the island, thongh this species was generally met with in pair's in the end of December and January, the breeding season had hardly commenced. At Jenaagahan, on the 7 th January, I came across a pair of old birds with three young, just able to fly, but these were apparently an early brool. Towards the end of January a good many birds were seen with nest. ing materials in their bills, and several of the females shot were evidently about to lay. Many of the pairs near our eamp at Aclho Dimellus had selected some patch of bush, where they were constantly to be met with, but though we carefully refrained from shooting any of these, and spent many hours searching for their nests, it was not till the 12th of February that I sueceeded in finding one. The beautiful dome-shaped structure, with an entrance at the side (Fig. 4), was built of fine grass, ornamented with patches of orange lichen, and placed in a thick bush about three feet from the gromel. When fonnd it contained no eggs, and by an unlncky accident the birds belonging to it were shot. When hopping about the bush these birds generally carry the tail in a semi-erect position. They are extraordinarily lively little ereatures, constantly chattering and scolding, 
FIG, t.

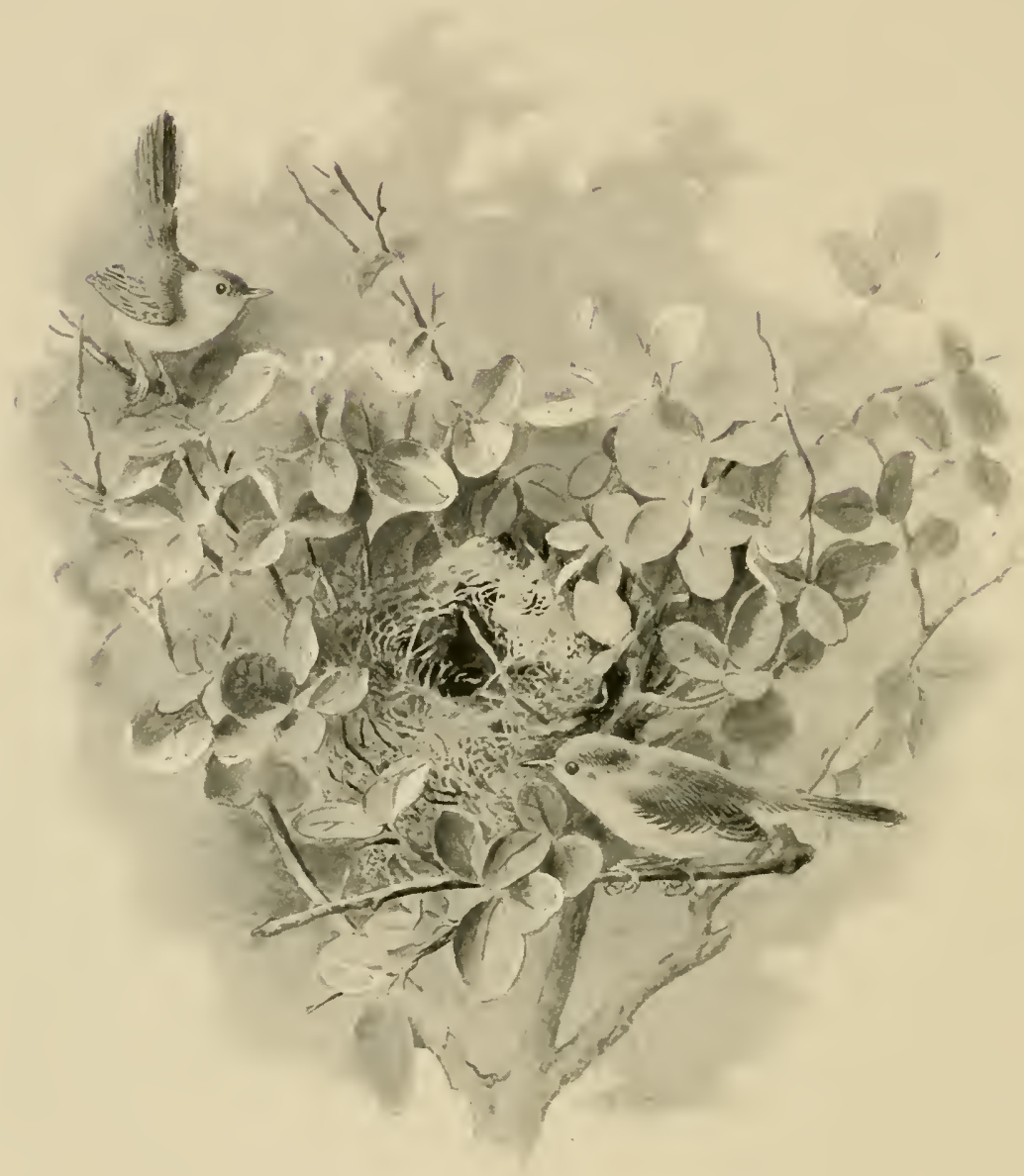

Nest of Cisticula ixcaxa. 
and chasing one another np and down the hillsides. If only winged they are almost always lost, for they run like mice among the thick bush and rocks, and are out of sight in a monent.-Mr.R.O.Cr.

Iris orange hown, upper mandible clark hom, lower Heshy horn, tarsus flesh horn colour ; claws dusky. Total length (measmed in the flesh) $4 \cdot 5$ inches.

Professor Bulfour found this Warbler "on the higher grassy plains," and he records that its note was a sharp "tit." Dr. Riebeck obtained it on (Aebel Fieri.

16. Cisticola hæsitata (solut. of Iturtl.).

Drymace hersitute, Sclat. \& Hartl. P.Z.S., Issi, 1) 166.

'The Sokotri name is 'Degaisagus.'

'This species was only met with on the southern part of the Hadibu Plain, hetween the Hanefu river and the base of the Haghier range, where the stony ground is almost entirely covered with thick bush-like grass ahout two feet high, interspersed here and there with larger bushes. The males are most conspicnous in the early morning, when their sharp note

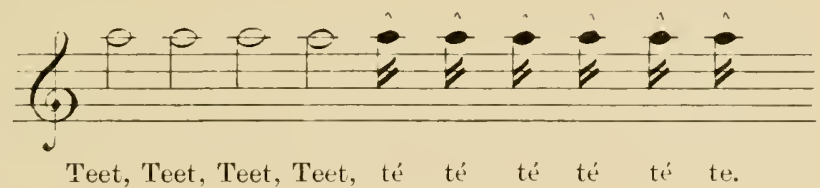

maly be heard in different directions. 'The song, if such it can be called, is wonderfully lond for so small a bird, and generally nttered on the wing, the bird fyying along at some height from the ground in a wide segnent of a cirele with an mudnlating flight, the notes becoming shorter and quicker is he descends once more to the covert. When the male is singing at the top of a bush, as he sometimes does, he looks just like the Common Wren with an abnormally long tail, which is held over his back in a semi-erect position. The male is much less difficult to obtain than the female, for he not infrequently perches and remains for some moments on the tops of the grass or bushes, but the female spenls must of lier time busily feeding in the thick of the covert, only momentarily appearing from time to time. These birds, if only winged, are almost impossible to catch, for they rum like mice, and disappear directly. They were generally found in pairs, each of which seemed to ocenpy an acre or two of gromud of their own, for when a stringe male inadvertently lit within his neighbour's holding he was promptly attacked and chased off by the lawful owner. Adult males have the inside of the month bluish black, while in the female this part is flesh-eoloured. A young male had the gape Hesh-coloured, with a black spot at the base of the tongue. This species did not appear to be breeding, and though I searched earefully for the nest, I never succeeded in finding even an old one.-II.Li.O.G. 
Iris pale straw brown, culmen dusky, entting erlge of npper and lower mandible pale horn; legs and feet flesh colour ; claws chusky.

\section{TURDID承。}

\section{Saxicola, Bechst.}

17. Saxicola isabellina Cretsechm.

Stavicolu ixchlellina, Sclat. \& Hartl. P.7.S., 1881, 1) 167.

This large Chat was not obtained by us in Sokotra, but Professor Balfour met with the species in the Feregeh Valley and on the Plain of Nugret, on the sonth coast of Sokotra.

18. Saxicola montana, Gould.

Saxicola montrune, Sclat. \& Hartl. P.Z.S., ISSI, p. 167.

The Sokotri name is " Degiribool).

This Chat was numerous on the low open flats near the sea, especially on the Hadibu Plain, but on the higher ground it was rarely met with, only a few being seen on the open grass country round Hombil (1500-2500 feet), and at Adho Iimellus (3500 feet) it was equally scarce. Here again most of the males were in full breeding plumage but no nests were found.

The habits of this species are just like those of the Common Wheatear. Then not engaged in searching for small beetles and insects on the ground, they are generally to be seen perched on some low bush or stone, and are not as a rule very timid. The males are constantly playing or sparring with one another, and it is very pretty to see two or more rise into the air and flutter opposite one another with fully extended wings and tail displaying their handsome black and white quills. I shot what was undoubtedly a female at Arlho Dimellus in somewhat remarkable plumage, the feather's of the throat being black, narrowly fringed with isabelline brown, and quite similar to those of the male before attaining the full breeding dress. - IV.I..O.G.

\section{HIRUNDINID床.}

\section{Cotile, Boie.}

19. Cotile obsoleta, c'ul.

Cotile olswoleta, Sharpe, Cat. B. Brit. Mus. x. 1) 111 (18s.j).

The Sokotri name is 'Goab.'

A few pairs of the Pale Rock-Martin were seen abont the rocks in different parts of the Haghier range and about the limestone cliffis at Iomhil. They were first observed at Jena-agahan hawking insects round a granite peak at an elevation of 1500 feet. I subsequently shot a pair on the top of Homhil at about 2500 feet, and again obtaineal one of a pair seen at Adho Dimellus, 3500 feet. None of the pairs seen appeared to be nesting.-W.I.O.G.

This species had not previously been met with in Sokotra. 


\section{CAPRIMULGID层.}

\section{CORACI $\nRightarrow$.}

\section{Caprimulgus, Linn.}

20. Caprimulgus jonesi, Gimnt il Forles. (Plite iv.)

Caprimulyu. jonesi, (arant and Forbes, Bull. Liverp. Mnss. ii. p. 3 (1899).

Alult Mule:- Nearest to C. murcus from Arabia, Palestine, and NorthLast Africa, but at once distinguisher by having the ground colour of the upper parts clear grey instead of sandy brown, and the markings on the top of the head and on the seapulars rufous and buff instead of whitish buft. 'The whole of the black markings on the upper parts are, moreover, much coarser. Total length (measured in the flesh), 9 inches; culmen, 0.4 ; wing, $6 \cdot 1$; tail, $4 \cdot 2$; tarsus, 0.75 .

The only example of the Sokotran Nightjar was shot in the Dimichiro Valley in the Garieh Plain, East Sokotra. It was found squatting on the ground among the stones close to our rest-camp in the Valley (Jammary 16th, 1899). We never came across the species on any other occasion. - II:Ii.O.G.

We have named this species in honour of Monris P. Jones, Esq., of the Liverpool City Comneil, and Chairman of the Museums Sub-Committee, who interested himself greatly in the fitting out of the Expedition.

\section{CYPSELID $Æ$.}

\section{Cypselus, Illiger.}

\section{Cypselus (?) murinus, Brehm.}

Hicropus murinu., Hartert, Cat. B. Brit. Mus. xvi., p. 446 (1892).

Several large Swifts, which I have no doubt belonged to this species, passed over our camp on the Hadibn Plain on the evening of the 12 th of December. They were flying in wide circles and travelling in a south-easterly direction. When first seen by Dr. Forbes they were close at hand, but by the time I had got a gun from my tent they had gone on their way.- $I 1.1$ i.O Gr.

\section{UPUPID必.}

22. Upupa (?) epops, Linn.

\section{Upupa, Linn.}

A species of Hoopoe was seen on the wing both between Sokotra and Abd-el-Kinri, and between the latter island and Aden.-H.O.F.

\section{CUCULID咂.}

\section{COCCYGES.}

\section{Centropus, Illiger.}

23. Centropus superciliosus, Itempn: \& Ehr.

Centropus supereiliowe, Sclat. \& Hartl. P.Z.S. 1881, p. 172: Hantl. P.Z.S. 1881 , p. 9\%.

The Sokotri name is 'Mishigiro-giro.' 
We first met with this Cuekoo in the thick bush covering the steep slopes of Gebel Raggrit, one of the onter hills of the Haghier range. It has two peculiar calls which at once attract attention : a bubbling cry, repeated a dozen or more times in rapid succession, audible at a considerable distance, and a "chucking " note which exactly resembles the sound made by a driver encouraging his horse to trot. The former note is generally a monotone,

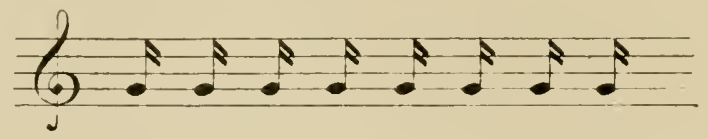

Bub, bub, bub, bub, bub, bub, lub, bub.

but oceasionally, especially in the early hours of the molning, when these birds are most noisy, one hears variations of the "song," if such it un be called, ascending and descending the scale for ahout five notes,

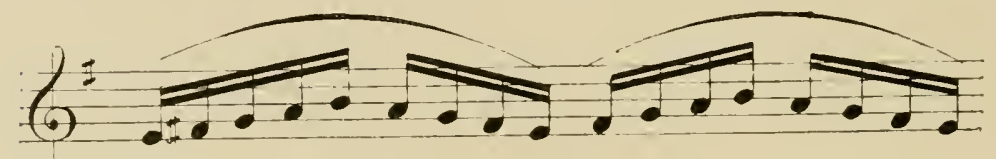

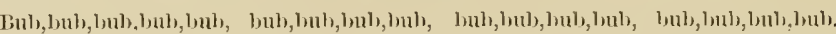

The second cry, consisting of three long, and six or more short, quickly uttered syllables, camot be reprodnced in writing, but may be easily initated hy putting the tongue against the roof of the month and making a sound like tük, tük, tük, tük, thik; tiek, tük, tuik, tuik.

When we reached Sokotra in the beginning of Ileember, the nesting season was apparently orer, for we secured nealy full-grown young birds with the barred wing-corerts denoting immaturity. Though nowhere common, this species was thinly scattered over all parts of the island visited. It was occasionally net with in the Date palm groves bordering the rivers on the Harlibu plain, and in the neighbourhood of Hombil a few examples were obtained, while at Adho Dimellus, our highest eamp in the heart of the Haghier lange, it was most numerous. Here, in the early morning, a good many birds might be heard "bubbling" on the hill sicles. It is always a difhcult bircl to secme, frequenting the denser parts of the bushjungle, where it is more often heard than seen. Its nature is somewhat inquisitive, and to ascertain the eause of any unwonted sound it will occasionally mount to the tops of bushes or trees. This is the best chance of shooting it: we found it almost hopeless to secure specimens ly following up their ery in the dense bush. If only winged, this cuckoo is almost certain to escape, its long legs enabling it to rum almost as fast as a partridge. On the wing its flight resembles that of the Magpie, but is feebler and seldom long 
sustainer. The birds examined contained grasshoppers and other insect food.--II.T.O.G.

\section{STRIGES.}

\section{Scops, Brünn.}

24. Scops socotranus, Girent if Forbes (Plate r.).

scops socotrenu., (itant \& Forhes, Bull. Liverp. Muss. ii. p. 2 (1s!!9).

The Sokotri name is 'Shigidahan.'

Idult mule:-Most nearly allied to S. ynu, but paler and greyer, the oceiput and nape whitish, with fine transverse mottlings of brownish black; primary coverts mostly rufons, forming a rather conspieuous patch; the tips of the primary quills mostly pale rufous, instead of brownish grey; belly white, with very few black arrow-head markings. The feathering on the tarsus less extended, and terminating $0 \cdot 2$ inch from the basal joints of the toes. Iris yellow ; bill blackish horn-colour. Total length (measured in the flesh), $7 \cdot 0$ inches; wing, $5.0 ;$ tail, $2 \cdot 2 ;$ tarsus, $1 \cdot 25$.

When moving to our second camp at Dahamis we spent a night in the Addah Valley to the east of the Hadibu plain, and it was there that we first heard the cry of this new species, and knew that there was at small Owl to be got. Both at Dahamis and Jena-agahan its peculiar cry, liu-kiurue, repeated many times in succession, might be heard every evening, but it was not till we reached the latter place that examples were procured. The rongh nature of the ground surronnding these camps, strewn with granite bonlders and covered with thick bush and scattered trees, made it impossible to get about at night. Each Owl apparently had its own hunting ground and special trees on which it perched and uttered its cry, for the sounds ahways came from the same direction. Olserving these facts, we attempted unsnccessfully to catch them by setting pole traps, but on the 15th of Jantary a number of natives arrived with two Owls which they had eanght among the rocks. These proved to be full-grown young in nearly adult plumage. In his anxiety to see this latest aldition to our collection, our interpreter allowed one of the birds to escape from Dr. Forbes's sextant box, in which they had, for want of a cage, been temporarily placed. The whole camp turned ont in pursuit, and when we had almost giren it up for lost, it was fortunately found, jnst before dusk, among the scrub, and I shot it.

When we arrived in the open country at Hombil the prospects of obtaining specimens were greatly improved, for one conld more about at night without the risk of lureaking one's neck. Several of these little Owls were heard about our camp, and we fonnd their castings full of beetle remains under some of the neighbouring Busicellin trees. I spent a week in attempting to shoot an individual that frequented a 
pateh of neighbouring bush. Every evening at dusk and in the early morning I lay in wait for him, but in vain. The first night I had an easy ehance of shooting him on a Boswellin tree, but having unfortunately taken out a 12 -bore, which would have blown him to pieces I resisted the temptation to shoot, thinking another similar ehance wonld oceur, but it never did. Having fed largely on beetles in the neighbonring bush, the birl wonld almost invariably perch on a particular dead branch to crow and digest his food, and the gromnd heneath was strewn with pellets. He seldom arrived till the light had almost gone, and it was next to impossible to see hims. The only cover within shot was a thin bush, and on the slightest movement the Scops was gone like a flash before one hat time to shoot. Patience was not rewarded. At this time our taxidermist, Mr. Cutmore, had the good fortune to chance on one roosting in at Boxwood (Bucus Hildelrumlti) thicket, into which he had gone in seareh of a Fan-tailed ITarbler (c'isticolu incanu). He was obliged to shoot it at close quarters, and somewhat damaged it as a specimen, but it proved a valuable addition to our collection, being the one fully adult bird we procured. It is only by the merest chance that this lird is met with during the day time. It no doubt roosts among the rocks or in the thick bush. At night it is very timid and watehful, and is off on the slightest alarm. The food appears to consist almost entirely of beetles, which it captures on the ground.-II.R.O.G.

\section{Syrnium, Savign}

25. Syrnium, sp. incert.

Though we failed to seenre a specimen, there can be no donbt that a large Owl occurs in Sokotra. We first became aware of its presence when eamped at Dahamis, on the lower slopes of the Haghier range. From the roeky sides of Dimimi, a hill to the sonth of our camp, it was heard hooting at night on several occasions. The cry closely resenbled that of the common Brown Owl (S. uluco). We made careful enquiries among the Sokotri herdsmen in the neighbourhood, and found that the bird was well-known to them, but offers of baeksheesh failed to produce a specimen.

On the rocks above Adho Dimellus the bird was actually seen by one of our men, who, accompanied by a Sokotri lad, had gone out in search of wild goats. The bird was so elose when first seen that the native struck it with a stone, but failed to kill it, and it disappeared into the thick bush. We naturally asked our man why, when armed with a rifle, he had misserl such a golden opportunity, lut were told that he was afraid of clisturbing the goats! So far as we are aware, this is the one of the few Sokotran speeies of bird of which no example has been procured.-Ir.P.O.G. 


\section{PANDIONES.}

\section{Pandion, Savign.}

26. Pandion haliaetus (Linn).

P'undion huliuetus, Sharpe, Cat. B. Brit. Mus. i. 1) $449(18 i 4)$.

A couple of Ospreys were observert oft the west end of Sokotrit.

\section{ACCIPITRES.}

\section{FALCONID压.}

\section{Falco, Linn.}

27. Falco communis, Gimel.

Falco peregrimus, Sclat. \& Hartl. 1'.7.S., 1881, 1. 172.

Ire observed on several ocensions a large Falcon which was probably the Common Peregrine, but never had an opportunity of procuring one. A specimen was collected in the hills above Hadibu by Professor Bayley Balfour.-II.R.O.G.

28. Falco feldeggii, Schl.

Falco feldey!nii, Sharpe, Cat. B. Brit. Mus. i. p. 38!! (1874).

I saw a pair of Faleons, apparently Lanners, on the slopes of Dimimi, a mountain in the Haghier range to the sonthward of our camp at Dahamis. They eireled round within easy shot, but I had no gum, and was obliged to content myself with watehing them. On the following day they were not to be foumd.

A second pair were seen on the wing in the Dimichiro Talley, but these kept at a safe distance. - II.Ii.O.G.

\section{Cerchneis, Boie.}

29. Cerchneis tinnunculus (Limn.).

Timmuculus alaudarius, Sclat. \& Hartl. P.Z.S., 1s81, p. 173.

The Sokotri name is 'Kash-feno.'

We saw a good many pairs of Kestrels about the Harlibu plain, and found them so tame that there was no difticulty in shooting as many as we wanted with the small collecting gum. They were generally to be seen either on the wing or more often perehed on a bush, gorged with lizards, locusts, and other smaller grasshoppers, which form their principal food. In other parts of the island visiter they were searce. I once saw one on Hombil at an elevation of about 2500 feet, and there were one or two in the neighbourhood of Arlho Dimellus, where a fine male was obtained. This speeies did not appear to be nesting. -IV.R.O.G.

In eomparing our Sokotran Kestrels in the Liverpool Museums, I find that they agree very closely incleed with two speeimens in the Tristram Collection-with one from Teneriffe and one from the Gran Canary. 
The latter is the bird described (Ibis, 1889, p. 17) by Canon Tristram as darker in colour and smaller than Indian and European examples. In size and colour these Sokotra and Canary Island Kestrels agree exactly.-II.O.F.

A specimen was shot by Professor Balfour's expedition on the Shoab Plain.

\section{Buteo, Cuv.}

30. Buteo desertorun, Duml.

Buteo dexertormm, Sharpe, Cat. B. Brit. Mus. i. p. 179 (1sit).

The Sokotri name is 'Nehēene.'

We saw the African Buzzard in all parts of the island visited. On the lower ground they were not very common, though sometimes seen sitting near the top of some high Dite-palm or soaring round above the plain, but the greater number were met with in the Haghier lange, and about the limestone mountains ronnd Homhil. A good many pairs were nesting, and their young might be heard screaming in the steep and ahmost inaccessible faces of the rocks. We obtained a pair of young lyirds from a nest at Homhil, the female being nearly twice as large as the male. The old birds were, generally speaking, wild and diffieult to approach, and I only once succeeded in shooting a fully adult bird, but sometimes, as is so often the case when one has no gun, easy chances would oceur. This species has not previously been recorded from Sokotra.-- II.Ii O.G.

\section{VULTURID㞋。}

\section{Neophron, Savign.}

31. Neophron percnopterus (Lini.).

Neophron pernopterus, Selat. \& Hartl. P.Z.S., 18s1, 1) 172.

The Sokotri name is 'Sau-eido' for one, 'Sau-eid' for a flock of Neophrons.

Egyptian Vultures were very common at all omr camps, and so tame and fearless that they wonld hardly take the trouble to get ont of one's way. They wonld wait outside the tent, where animals and birds were being skimned, ready to ponnce on any scraps of flesh thrown ont, and squealing and fighting with one another over the bodies. They were so bold that we were often afraid they would come inside the tent and help themselves to more than we intended, but they never did any harm, and were most nsefnl in ridding the camp of all sorts of refuse. The only time when they proved distinctly a muisance was when I was setting the 'Schuyler' rat-traps. They would wait abont, and direstly one had gone, try and remove the bait. Sometimes they got canght by the head, but more often they managed to spring the traps and take the meat, a feat which seemed almost impossible. One morning one of the boys brought in a trap in which a Neophron had just been caught by the head. The bird was not quite dead, so 
I took it ont and laid it on the gronnd, and in a few minutes it flew away apparently none the worse. A Neophron's neck nust be tougher than most, for the fall of this trap is sufficient to smash one's finger to pieces. This speeies did not appear to be breeding, but we saw many young birds in their dark first plumage, and apparently only a few months old.-II.R.O.G.

\section{STEGANOPODES.}

\section{PHALACROCORACID压.}

\section{Phalacrocorax, Brisson.}

\section{Phalacrocorax lucidus, Liclit.}

Phalarororax luciches, Hart1. P.Z.S., 1ss1, 1). 95..

Dr. Hartlaub records an adult female of this species obtained by Riebeck at Tamarida [Hadibu]. Though eonstantly on the look-ont for Cormorants, the only species observed was P. nigroguluris, the young of which somewhat resembles $P$. lucilus in having the under parts white. We have been unable to examine Riebeck's bird, but would suggest the possibility that a mistake may have been made in identifying it with the above.

\section{Phalacrocorax nigrogularis, Girunt \& Forbes. (Plate vi)}

Phalacrocorax migrogularis, Grant \& Forbes, Bull. Liverp. Muss. ii. p. 3(1899).

A very distinct speeies belonging to the group with fourteen tail feathers, and with the eulmen exceeding 1.5 inch in length from the feathers on the forehead to the tip of the bill.

Allult mule (fig. a) :- General colonr above and below black with a slight gloss, the wing-coverts and scapulars tinged with bronze and with a black spot at the extremity. The throat and hind neek ornamented with minute scattered white plumes, indicating full breeding plumage. Iris dark emerald green; pouch and naked skin in front of and surrounding the eye dirty black; bill greyish black, paler horn-colour towards the tip and on the terminal half of the latericorn; a greenish band along the basal half of the mandible; legs and feet hlack, webs lorowner. Total length (measured in the Hesh), 30.5 inches; culmen, 3.0 ; wing, 11.5 ; tail, $4 \cdot 3$; tarsus, 2.55 .

Birds apparently in the second year's plumage (fig. b), have the general colour of the head and npper parts brownish black, the new feathers being ornamented with a black spot at the extremity ; the plumage is much mixed with very worn feathers-almost brownish white at the extremity ; the chest and rest of the under parts are whitish brown, mottled with pale brown, an effect produced by the worn feathers, which are brown at the base and whitish at the extremity. Iris steel gray; naked skin on gape and in front of eye dull yellow; legs and feet dusky horn; toes and adjacent part of wels blackish. A speci- 
men in the first year's plumage (fig. c) has the feathers of the head and upper parts dark brown; the mantle, wing coverts and scapulars more pointed than in older examples, and with pale whitish margins; the feathers bordering the naked throat and the chest and rest of the underparts white; the pale brown bases to the feathers of the breast producing a slightly mottled appearance.

On the 7 th December, when the 'Elphinstone' anchored off' the westend of Sokotra, in Gubbat Shoab, below Ras Bacluwa, we saw a number of Cormorants swimming in the bay, some being entirely black and different from any we had seen. Captain MacArthur at once ordered the dingy to be got ready, and we started off in pursuit. There was a rough choppy sea in the bay, which made shooting rather difficult, and for some time we were unable to get within shot of any of the birds. At last we neared a pair, and as they lose I dropped them both, but, to my disgust, saw that both heads were still up. Fortune was, however, kind, for they were so bewildered that they forgot to dive, and swam towards one another. As the boat rose again on the crest of a wave, a lucky snap with No. 4 shot settled the business satisfactorily. I was highly pleased to find that these Cormorants, both adult birds in full breeding plumage, belonged to a new species. It was not until our return to Abd-el-Kuri at the end of February that we had an opportunity of obtaining additional specimens. Again aided by Captain MacArthur and his launch, we steamed up to the east-end of the island and met with several small lots of Cormorants coming to their roosting place. On this occasion we each got two immature birds in the brown or second year's plumage. Two adnlt black birds were also dropped, but neither being quite dead, both were lost anong the rocks and smrf, where we dared not follow in the launch. In habits this species resembles the rest of its kind, but we found them distinctly wild, and the few we got gave us considerable trouble to collect.-II.R.O.G.

\section{SULID尼.}

\section{Sula, Brisson.}

\section{Sula piscatrix (Limn.).}

Sula piscator, Grant, Cat. B. Brit. Mus. xxvi. p. 432 (1898).

On the afternoon of the 7 th December, 1898, while we were lying off Haulaf waiting for the arrival of the Sultan from his imland residence, we had the gratification of witnessing close to the ship a splendid spectacle, lasting nearly half an hour. An immense flock of Gammets and Terns (Sterna bergii) were preying on a horde of minute fishes, thousands of which were leaping out of the water in broad glittering masses in their hot haste to escape being devoured by a great shoal of mackerel, whose ravenous pursuit of them churned up the sea as if it were agitated by a brisk wind. The Terns as a rule swooped into 
the silvery passing cloud and snapped up their vietims while in the air. The Gamnets, on the other hand, dived down from a great altitude, eleaving the water with a big splash, and disappearing beneath the surface only to presently emerge again, each with its prey in its beak. The whole Hoek-Gannets and Terns-in following up the ripidly advancing shoal beneath them, were madly wheeling about, ascending and descending in inextricable confusion, all the while sereaming in the wildest excitement.-H.O.F.

\section{ANSERES.}

\section{ANATID正.}

\section{Chenalopex, Steph.}

\section{Chenalopex ægyptiacus ? (Linn.).}

Chenalopex regyptiacus, Salvad., Cat. B. Brit. Mus, xxvii. p. 167 (1895).

On our way down from Homhil to Adho Dimellus, when our far-extended licfilte (or camel-cade, as one may be allowed to call it) had reached the plain between Matagoti and Hamadern, which the Goahal stream traverses before joining the Wadi Dimichiro, a flock of what at first sight appeared, from their general eolour, to be Egyptian Vultures (Neophron percnopterus), rose in the air, in front of the leading camel, out of the bed of the stream which formed our roadway. Their long necks and manner of flight, however, in a moment showed them to be geese. Their dark backs and wings, in marked contrast to the white or lighter colour of the body and neck, renders it highly probable that the speeies was the Egyptian Goose. I was riding in the eentre of the line, and the guns were far behind, so that it was impossible to secure a specimen. In the air they wheeled several times, rising higher and higher, and then took their flight in a north-easterly direction.-H.O.F.

\section{Anas, Linn.}

\section{Anas boscas, Linn.}

Ana. boscas, Tristram, Ibis, 1898, p. 248.

Mr. Bennett collected the Mallard in Sokotra; but we did not meet with it.

\section{Chaulelasmus, G.R.Gr.}

\section{Chaulelasmus streperus (Linn.).}

Chaulelasmus streperus, Tristram, Ibis, 1898, p. 248.

The Gadwall was fairly common on the brackish estuaries of the rivers traversing the Hadibu plain- $I T$ R.O.G. - and in the swamps near Khor Garieh,-H.O.F. 


\section{Mareca, Steph.}

38. Mareca penelope (Limn.).

Marecu penelope, Salvad. Cat. B. Brit. Mus. xxvii. p) 227 (1895).

We found the Wigeon fairly common abont the mouths of the rivers near Hadibu, and met with large flocks in a patch of marshy ground bordering the Dimichiro river, near its entrance into Khor Garieh.

\section{Nettion, Kaup.}

39. Nettion crecca (Linn.).

Querquedula crerca, Sclat. \& Hartl. P.Z.S., 1881, p. 173.

We did not meet with the Teal, but it was obtained by Professor Balfour and Mr. Bennett.

\section{Fuligula, Steph.}

40. Fuligula nyroca (Gïlld.).

Fuligula nyroca, Hartl. P.Z.S., 1981, p. 956.

Nyroca africana, Salvad. Cat. B. Brit. Mus., xxvii. p. 345 (1895).

As we were marching from Ras Hanlaf to Hadibn on the moming of our landing on Sokotra, we came on a small flock of Ferruginous Ducks swimming in the brackish estnary of the Wadi Dinehan. They were very tame, and allowed us to approach within a short distance, and dirl not even then take wing. Having no gun, I obtained no specimen, and never came across the species again. The female recorded by Hartlaub was shot at Kallansiya.--N.T.O.G.

\section{PHCENICOPTERID压.}

\section{Phœnicopterus, Linn.}

41. Phœnicopterus roseus, Pull.

Phunicopterus roseus, Tristram, Ibis 189s, p. 248.

Obtained by Mr. Bennett; but not by us.

Mrs. Bent observes in the Sokotran chapter to her Southern Arabiu that at Khaloop "there were quantities of Flamingoes on the beach."H.O.F.

\section{PLATALEID压.}

\section{Platalea, Linn.}

42. Platalea leucorodia, Linn.

Platulea lencerodia, Sclat. \& Hartl. P.Z.S., 1881, p. 173.

Professor Balfour found the Spoonbill on the margins of stagnant pools near the villages on the north coast. We did not meet with it, but no time was devoted to making a collection of the shore birds. 


\section{ARDEID 压.}

\section{HERODIONES.}

\section{Lepterodius, Heine \& Reichen.}

43. Lepterodius gularis, Bosc.

Amlea gularis, Sclat. \& Hartl. P.Z.S., 1881, p. 173.

Only the wings of the specineu procured by Professor Bayley Balfour were bronght bome. The eastern form, $L$. ashu, is the species found at Aden, so it may be that a mistake has been made in the identification of the Sokotran bird.

\section{Ardea, Linn.}

44. Ardea cinerea, (Linn.).

Ardea cinereu, Sharpe, Cat. B. Brit. Mus., xxvi. p. 74 (1898).

The Sokotri name is 'Ko-ēita.'

The Heron is fairly common on the rivers and pools near the eoast.-. II. li.O.G.

45. Ardea purpurea, Limn.

Ardea purpurea, Hartl. P.Z.S., 1881, p. 9.56.

The Purple Heron is sometimes met with near the coast. One immature bird was shot near Hadibu.-W.R.O.G.

\section{CURSORIID压.}

\section{LIMICOL $A$.}

\section{Cursorius, Lath.}

46. Cursorius gallicus, Gmel.

Cursorius gallicus, Sclat. \& Hartl., P.Z.S., 1881, p. 173.

We did not meet with the Cream-coloured Courser. Professor Balfour obtained one out of a lot of three seen near Khadoop on the north coast.

\section{CHARADRIID压.}

\section{Arenaria, Briss.}

47. Arenaria interpres ( $\operatorname{Linn}$.$) .$

Strepsilus interpres, Tristram, Ibis, 1898, p. 248.

Obtained by Mr. Bennett; but not by us.

\section{Aggialitis, Boie.}

48. Afgialitis dubia (Scop.).

EEgiulitis curonicu, Sclat. \& Hartl. P.Z.S., 1881, p. 174.

The Sokotri name is 'Degargōri.'

The Little Ringed Dotterel was fairly common on the river's near the sea and about stagnant patehes of water on the Hadibu plain. 
49. Egialitis alexandrina (Linn.).

Eyialitis cuntianz, Sclat. \& Hartl. P.Z.S., 1881, 1. 17t.

A few Kentish Plover were seen feeding with A. Alubiu, and one was procured.-W.li.U.G.

\section{Totanus, Bechst.}

50. Totanus nebularius (Gunn).

Totanus canescens, Sclat. \& Hartl. P.Z.S., 1851, P. 17t.

The Greenshank is common at the months of the rivers traversing the Hadibu Plain.

51. Totanus calidris (Limm.).

Totanus calidrix, Sharpe, Cat. B. Brit. Mius, xxiv. p. 414 (1S96). The Redshank is common on the rivers near Hadibu.-IV.R.O.G.

52. Totanus glareola (Limn.).

Totanns glareola, Hartl. P.Z.S., 1881, p. 956.

The Wool-sandpiper was collected by Riebeck at Kallansiya.

\section{Tringa, Linn.}

\section{Tringa temmincki (Leisler).}

Limonites temmincki, Sharpe, Cat. B. Brit. Mus., xxiv. p. 5.55, 1896.

I found a small flock of Temminck's Stints feeding in the bed of the Hanefu river on the 20th February, and shot one to identify the species.-IV.R.O.G.

\section{Tringoides, Bonap.}

54. Tringoides hypoleucus (Lim.).

Tringoides hypoleucus, Sclat. \& Hartl. P.Z.S., 1881, p. 174: Hartl. P.Z.S., 1881, p. 956.

The Sokotri name is 'Dirihentan.'

The Common Sandpiper was fairly nmmerons on many of the rivers near the sea.

\section{Calidris, Illiger.}

55. Calidris arenaria (Limu.).

Calidris arencria, Tristram, Ibis $1898,1 \% .248$.

The Sanderling was obtained by Mr. Bennett; but not by us.

\section{Gallinago, Leach.}

\section{Gallinago gallinago ( $\operatorname{Limn}$.$) .$}

Gallinago yallinago, Sclat. \& Hartl. P.Z.S., 1881, 1) 174.

The Sokotri name is 'Ko-ēito.'

The Common Suipe was fairly common in suitable places. A few were seen on the rivers near the coast, and numbers in a large marshy 
patch of ground bordering the Dimichiro River. It was eommon in the rushy edges of the stream below our camp at Homhil, and proved a welcome addition to our bill of fare.-W.R.O.G.

57. Gallinago stenura, Boncp).

Gallinayo stemure, Sharpe, Cat. B. Brit. Nus, xxiv. 1. 619 (1896).

The Sokotri name is 'Ko-ēito.'

Two examples of the Indian Pin-tailed Snipe were shot at Homhil among a number of the common species. I was much surprised at meeting with this bird in Sokotra; and so far as I am aware it has never been procured west of the Indian peninsulit.-IV.R.O.G.

Captain Hunter notes that he observed "on the streams, Snippets, and a bird resembling the Painted Snipe of India," Postratula cupensis, Linn.-H.O.F.

\section{DROMADID压.}

\section{Dromas, Payk.}

58. Dromas ardeola, Puyk.

Dromas ardeola, Sclat. \& Hartl. P.Z.S., 1881, 1. 174.

Professor Balfour found the Crab-plorer eommon at Kallansiya at the west end of the island, but we did not come aeross it.

\section{GAVI $Æ$.}

LARIDÆ.

\section{Sterna, Linn.}

59. Sterna bergii, Licht.

Sterna beryii, Sclat. \& Hartl. P.Z.S., 1881, p. 174.

Common along the coasts of Sokotra and Abd-el-Kuri.

\section{Anous, Steph.}

60. Anous stolidus (Linn.).

Anous stolidus, Saunders, Cat. B. Brit. Mus., xxv. 1) 136 (1896).

The Noddy was observed in eompany with Sternx bergii, elose to the shore near the foot of Gebel Bitzobur, January 14th, 1899. This bird has not been previously recorded from Sokotia.-H.O.F.

\section{Larus, Linn.}

61. Larus affinis, Reinh.

Larus affini-s, Sclat. and Hartl. P.Z.S., 1881, 1. 17t.

Common along the coasts of Sokotra and Abd-el-Kuri. 
RALLID压.

\section{FULICARIAE.}

Porzana, vieill.

62. Porzana porzana $($ Linn.).

Porzanu maruetke, Tristram, Ibis. 1898, p. 248 .

The Spotted Crake was eollected by Mr. Bemnett, but not by our expedition.

Gallinula, Briss.

63. Gallinula chloropus (Limn.).

Gallinula chloropus, Hartl. P.Z.S., 1881, p. $95 \%$.

Riebeek procured five examples of the Water-Hen, but the exact locality is not stated.

TRERONID曆.

\section{COLUMBA.}

\section{Vinago, Cuv.}

64. Vinago waalia (Gmel.).

Treron waulia, Sclat. \& Hart1. P.Z.S., 1881, p. 173; Hart1. P.Z.S., 1881, p. 956.

The Sokotri name is 'Demácha-bírhar.' 'Mahabilat,' (I.B. Balfour).

This speeies was far from common in the parts of the island visited, being thinly scattered over the high ground in small flocks of five or six individuals. The first we saw was shot by one of our men with a rifle in the neighbourhood of Aduna, and too much injured to be worth preserving. We sulusequently came across two small flocks during our stay at Homhil, and from the first lot seen in some fig trees below our eamp at an elevation of about 1700 feet $I$ shot an inmature bird. The second lot were also found feeding in the fig trees just below the limestone caves on Matagoti at about 2500 feet, but a bird shot with the eollecting gun was lost among the dense bush and undergrowth. We again saw a small flock in the Dinehan Valley opposite Alilo (1500 feet) on our way to Adho Dimellus, but the birds were very wild, and the flight as usual strong and swift in the extreme.

As there was no particular interest attaching to this well-known African Pigeon, I never took the neessary trouble to ol,tain more specimens, which would have entailed constantly carrying about a 12-bore gun.IV.T.O.G.

\section{PERISTERID尼.}

\section{Turtur, Selby.}

\section{Turtur senegalensis (Linn.).}

Turtur senegulensis, Sclat. \& Hartl. P.Z.S., 18s1, P. 173: Hartl. P.Z.S., 1881 , p. 956.

The Sokotri name is 'Digègo ' or 'Digígo.'

Sokotran examples of the Senegal Turtle-Dove have the forehead, chin, 
and throat, and sometimes also the lower breast distinctly paler than Aralnan examples of this species.

On all parts of the island visiter by us, from sea level to an elevation of about 4500 feet, where the bush-jungle ceases, we found this I ove more or less numerous. In the Date palm groves along the river's running to the north coast it positively swarms, and on the stony bush-clad plains of Hadibu and Garieh it is very abundant, while on the lower and middle slopes of the hills many are met with, their numbers gradnally decreasing as the highest parts of the Haghier range are reached. In the neighbourhood of Adho Dimellus, our highest camp, Doves were, comparatively speaking, scarce. They feed almost, if not entirely, on the ground, and are mostly found in pairs or sometimes in small flocks. When flusherl they fly up into the nearest bush or tree, whence they "take stock" of the intruder, generally allowing one to approach within a short distance before they again take wing. Many pairs were breeding when we reached Sokotra, and I found a number of nests, each containing two eggs, some quite fresh, others on the point of hatching. Young were also met with in every stage of development, from nestlings to fully fledger birds. The nest, a very slight structure of thin twigs, is generally placed in an Acacia or on the branch of a Date-pahn, in many instances only a few feet aloove the ground, but sometimes at a height of at least 20 or 30 feet.

This species is remarkably tame, and often when sitting under a bush pinning out insects, or watching for some small Warbler, a Dove would settle on a branch within a few yards of one, and begin to "coo" or quietly preen its feathers, and with the brilliant sunlight shining on its plumage, it wonld be difficult to imagine a more pleasing piece of colouring. There was never any difficulty in making a large bag of these birds, but they were hardly worth a shot, for when cooked there is almost nothing to eit on their bones.-W.R.O.G.

\section{CEna, Selby,}

66. Ena capensis (Linn.).

Ena capensis, Hartl. P.Z.S., 1S81, p. 956.

Riebeck obtained the Cape Dove at Kallansiya ; but it was not seen by us.

\section{Coturnix, Moehring.}

\section{Coturnix coturnix (Linn.).}

Cotumix communis, Sclat. \& Hartl. P.Z.S., 1881, p. 173.

I twice came across the Common Quail in Sokotra, once at Homhil, and once on a grassy plain a few miles to the south. On both occasions I was without a gun, but there could be no rloubt about the identity of the species.-W.P.O.G.

[Mr. E. N. Bennet mentions Sand-Grouse (Pterucles lichtensteini?) among the birds observed by him on Sokotra.-II.O.F.] 


\section{II. - Birds of Abd=el=Kuri.}

\section{PASSERES.}

\section{STURNID床.}

\section{Amydrus, Cab.}

1. Amydrus creaghi, sp.tt.

Adult mule:-Allied to $A$. blythi, but at once distinguished by having the crown, throat, and rest of the under parts oil-green (exactly like those of $A$. fruter $)$ instead of purplish blue. Total length (tail imperfect) about 12.5 inches ; culmen, 1.25 ; wing, 69 ; tail (only the two outer tail feathers present), $5 \cdot 8 *$; tarsus, $1 \cdot 5$.

Alult female:- Resembles the female of $A$. blythi, having the head and neck grey, but no specimen was obtained.

From the first we were rather seeptical abont the identity of the Abd-elKuri Starling with $A$. blythi from Solsotra, and a careful comparison of the two clearly shows that the former belongs to a different species. A few small flocks frequented the highest parts of the rugged hills bordering the coast, but were so extremely shy that it was only after great exertions that a single specimen was shot. The flocks were composed of about half a dozen individuals, the females being conspicuous by their grey heals. The ery elosely resembles that of $A$. blythi, but the birds were far wilder, and more difficult to approach.-IV.R.O.G.

We have named this species in honour of General O'Moore Creagh, V.C., in remembrance of the great kindness and assistance we received at his hands during onr stay in Aden.

\section{FRINGILLID曆.}

\section{Passer, Briss.}

2. Passer hemileucus, Grtut \& Furbes (Plate vii. fig. i. of and $q$.$) .$ Passer hemileucus, (rrant \& Forbes, Bull. Liverp. Muss., ii. p. 3, 1899.

Adult mule:-Mostly nearly allied to $P$. insuluris, but much smiller and very mueh paler, especially ou the under parts, which are nearly pure white. The black patch on the throat is much reduced in size, as in $P$. pyrrhonotus, which species it closely resembles in plumage, but from this latter it may at once be distinguished by the much longer and stonter bleck bill. Iris brown; bill black; legs and feet fleshy horncolour. Total length (measured in the flesh), $5 \cdot 4$ inches; culmen, $0 \cdot 45$; wing, $2 \cdot 9$; tail, $2 \cdot 2$; tarsus, $0 \cdot 7$.

\footnotetext{
* Total length probably 6.5.
} 
Adult femole :-Most nearly allied to the female of $P$. insuluris, but much smaller and very much paler, the under parts being nearly pure white and the dusky patch down the niddle of the throat absent. Total length (measurerl in the flesh), 5.t inches; culmen, 0.48 ; wing, 2.8; tail, $2 \cdot 1$; tarsus; $0 \cdot 7$.

This spartow was certainly one of the most interesting birds met with on Abcl-el-Kuri. It was never seen in the neighbourhood of the native village, but appeared to be confined to the bush-clad slopes of one of the highest points, where enormous limestone blocks which have fallen awaly from the summit lie scattered over the hillside. Here it makes its home, and we found it by no means an easy task to secure specimens, for they are very shy and not very mumerous. The extremely rough nature of the ground makes progress very slow, and conseruently it was by no means easy to follow up the note quickly. During our first visit to the island, Dr. Forbes and I each obtained a male, and on our returu I secured a pair, the only ones seen during a whole day._W.L.O.ti. A small flock, however, kept flitting about near me on the stems of the bizarre Milk-bushes (Euphorlin Abdelkuri) growing about the middle of the mountain, while I was engaged in digging up the fine specimen of this new plant, which eventually reached hone alive-II.O.F.

\section{SYLVIID丑.}

3. Sylvia cinerea, Bechst.

\section{Sylvia, Scop.}

sylvia cinerea, Seebohm, Cat. B. Brit. Mus. v. p. s (1881).

A female Whitethroat was shot by Mr. Cutmore on the th December among the stunted bushes on the central plain.

\section{Phylloscopus, Boie.}

\section{Phylloscopus rufus (Bechst.).}

Phyllowcopus rufies, Seebohm, Cat. B. Brit. Mus. v. p. 60 (1881).

On our second visit to Abd-el-Kuri I secured a solitary example of the Chiff-chaff, which was feeding amongst the bushes near the top of the highest point in the island.-W.R.O.G.

\section{TURDID平.}

\section{Saxicola, Bechst.}

5. Saxicola isabellina, Cret:sshm.

Saxicole isaliellina, Sclat. \& Hartl. P.Z.S., 1851, 1. 167.

A male of this Chat was shot on the 23 . 1 d February.

6. Saxicola montana, ciould.

Sexicole montane, Sclat. \& Hartl., P.7.S. 1881, p. 167.

This handsome Chat was the commonest species met with on Abd-el-Kuri. It was abundant on the low stony plain hetween the hills, the only 
regetation consisting of dwanferl shrubs scattered here and there over the barren gromol. Some birks were also met with on the higher gromul at an elevation of nearly 1700 feet, where many curions and interesting hushes and plants grow in considerable luxmrianee among enormous blocks of limestone, which have fallen from the crest of the hill above. Though many of the males were in full hreeding dress, with jet liack throats, none appeared to be nesting, and the oraries of such females as we examined were molereloped, but our stay on the island was so short that, common as the hind was, nests might easily have been overlooked. - II.L.O.G.

\section{ALAUDID压.}

\section{Pyrrhulauda, smith.}

7. Pyrrhulauda melanauchen, Cutl.

(See the notes on this species on p. 33.)

\section{MOTACILLIDÆ.}

\section{Anthus, Bechst.}

\section{Anthus campestris (Linn).}

Anthus campestrix, Sharpe, Cat. B. Brit. Mus., x. p. 569 (1855).

This species was only met with on Abr-el-Kuri, where a pair were seen during our second visit to the island on the 23rd February. They were extremely wary, but after some trouble the male was seeured.IV.R.O.G.

\section{Motacilla, Linn.}

9. Motacilla forwoodi, Grant \& Forbes. (Plate vii. fig. 2.)

Motacilla forreorli, Grant \& Forbes, Bull. Liverp. Muss., ii. p. 3, 1899.

Adult femule in winter plumuge:- Most nearly allied to $M$. wlbu in full summer phumage, the top of the head and the entire ehin, throat, and foreneck being deep black, but the forehead is durk grey like the back and rest of the upper parts, instead of pure white. Iris dark brown; bill and legs black. Total length, $\tau$ inches; culmen, 0.45 ; wing, $3 \cdot 3$; tail, $3 \cdot 4$; tarsus, $0 \cdot 85$.

Forwood's Wagtail was only met with on the island of Abd-el-Kuri, where it was common enough on the stony plain outside the native village. Unfortumately we did not at the time distinguish it from $M$. alba, and only secured two examples, an adult and an immature female.IT.R.O.G.

We lave named this species in honour of Sir William B. Forwood, Chairman of the Library and Museums Committee of the Liverpool Corporation, who in the City Conncil warmly supported the proposal that the Municipal Museum should co-operate with the British Musemm in exploring the Natural History of Sokotra. 


\section{UPUPA.}

\section{UPUPIDÆ.}

\section{Upupa, Linn.}

10. Upupa ? epops, Limn.

(See the note on this species on p. 43.)

\section{CORACI $Æ$.}

\section{CORACIID无.}

\section{Coracias, Linn.}

11. Coracias? abyssinicus, Bodd.

Correcias alyyssinicus, Sharpe, Cat. B. Brit. Mus, xvii. p. 19 (1s92).

I picked up on Abd-el-Kuri a skeleton of a Coracias, of which I brought away the skull, which, on comparing it with a specimen in the British Iuseum, agreed exactly with this species.

The members of this gemus which occur in Somaliland, however, belong to the species C. lorti, Shelley, and C. nevins, Daud.-H.O.F.

\section{ACCIPITRES.}

\section{PANDIONES.}

\section{Pandion, Savig.}

12. Pandion haliaetus, Linn.

Pandion haliaetus, Sharpe, Cat. B. Brit. Mus., i. p. 4t9 (187t).

A good many Ospreys frequented the east end of Abrlel-Kuri, where a pair of very old birds was shot.

\section{FALCONID床.}

\section{Falco, Linn.}

13. Falco ? barbarus, Limn.

Falco burbarus, Sharpe, Cat. B. Brit. Mus. i. p. 386 (1874).

A small Falcon, which there is little doubt belonged to this species, was seen.-W.P.O.G.

\section{STEGANOPODES.}

\section{PHALACROCORACID压.}

\section{Phalacrocorax, Brisson.}

14. Phalacrocorax nigrogularis, Gront (' Forles. (See p. 49 and Plate vi.)

The Black-throated Cormorant was seen in considerable numbers near our anchorage at Bander Saleh, and a quite young male specimen 
was, on the morning of the Ind December, 1898, shot by Captain MacArthu' as it was flying over the 'Elphinstone' when in the Gulf of Aden, in $49^{\circ} 30^{\prime} \mathrm{E}$. long., and $12^{\circ} 20^{\prime} \mathrm{N}$. lat., or about 100 miles II. of Caje Guardafui, and about 150 from Abd-el-Kuri.-II.O.F.

SULID屟.

Sula, Brisson.

15. Sula piscatrix (Linn.).

Sula piscator, (1rant, Cat. B. Brit. Mus., xxvi. p. 432 (1s98).

I observed a small flock of the W'bite Booby in one of the baylets to the west of our anchorage in Bander Saleh, February 23, 1899. Gamnets abound, according to Captain Haines, in the serrated islets, known as Kahl Far'un, that lie in view from Abd-el-Kuri, a short way off the north coast. These rocks glisten white in the sum from being covered with the excrement of the birds that breed there.-II.O.F.

16. Sula sula $($ Linn.).

Sula sula, Grant, Cat. B. Brit. Mus., xxri. p. 436 (1898).

I shot a comple of the Common Booly from a small Hock near the east end of Abd-el-Kuri. On lifting them into the lannch several specimens of a eurions parisitic fly (Olfersia? spiniferu) were immediately observed to leare their bodies and fly orerboard. Two were, however, secmed hy tying up the dear birds in a cushion-cover, and afterwards chloroforming the bundle in a zine-lined box.-IT.li.O.tr.

\section{LIMICOL $Æ$.}

CHARADRIID峦.

\section{Egialitis, Boie.}

17. OEgialitis ? dubia (Srop.).

Seen but not ohtained.

\section{Tringoides, Bonap.}

18. Tringoides ? hypoleucus (Limu.).

Seen lout not obtained.

\section{GAVI $Æ$.}

LARID出.

Sterna Linn.

19. Sterna bergii, Licht.

Common along the coast.

\section{Larus Linn}

20. Larus affinis, lieinh.

Common along the coast. 


\section{Larus fuscus, Linn.}

Larus fuscus, Siunders, Cat. B. Brit. Mus. xxv. p. 2.50 (1896).

The Lesser Black-backed Gull was observed along with Sulu piscutrix in one of the biylets to the west of onu anchorage in the Bander Saleh, February $23,1899 .-$ H.O.F.

\section{Coturnix, Moehring.}

22. Coturnix coturnix (Limn.).

Only one example was seen on a small grassy platean near the top of the mountain overlooking our anchorage. I ought to have secured it with the $410 \mathrm{gmn}$, but failed. There could be no doubt alsout the identity of this species. -IV.I.O.G.

As the above lists show, the avifauna of the little Archipelago, of which Sokotrat is the largest island, comprises, so far as ascertained, 77 species, of which 15 are endemic, 11 species being confined to Sokotra and 3 to Abd-elKuri. The Black-throated Cormorant ( $P$. nigioguluris), which is common to both islands, although first described from our collections as new, will, as might be expected, most likely prove to be a more widely distributed species already known but unnamed, as Mr. Grant has suggested in a recent number of Noritutes Zoologirce (vii. p. 264, 1900). I am inclined to agree with his opinion that the "Phulucrocorac, sp. incert." recorded by Colonel Yerbury and the late Lieutenant Barnes from Aden, will turn out to be conspecific with the Sokotran form.

The total bird-fauna of Sokotra comprises 67 species, and of Abd-el-Kuri 22 species. Kahl Far'm is freqnented by large numbers of sea-fowl; but of the birds inhabiting Saboynea and the remaining two nembers of The Brothers gromp (Samneh and Darzi) nothing is yet known.-H.O.F. 


\section{PLATE III.}

Fig. I. FRINGILLARIA SOCOTRANA, Giunt \& Forbes, p. 32.

Fig. 2. FRINGILLARIA INSULARIS, Girent if Forles; p. 29 

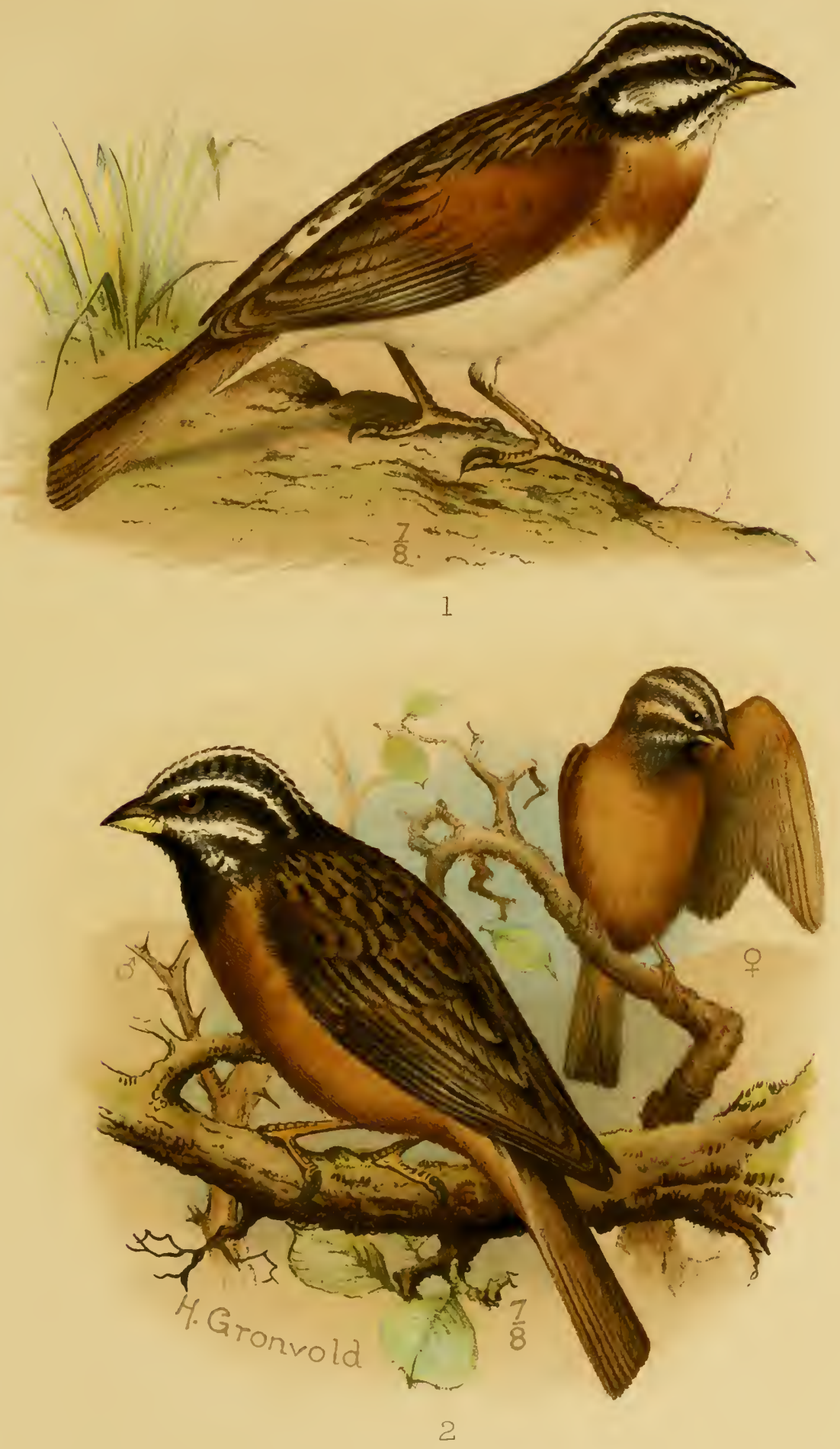

1 FRINGILLARIA SOCOTRANA. 2 F. INSULARIS. 




\section{PLATE IV.}

CAPRIMULGUS JONESI, Grunt \& Forbes, p. 43. 
$\underset{\nabla}{\Sigma}$

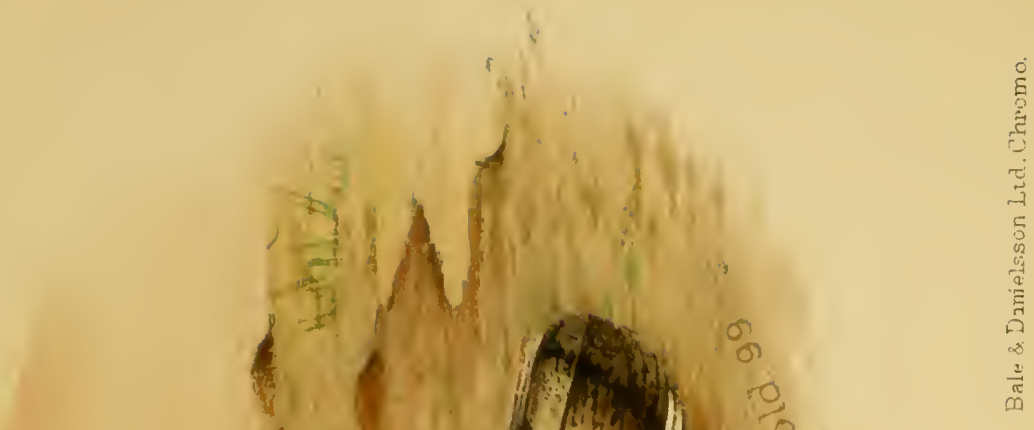

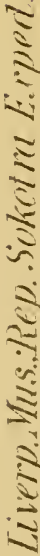






\section{PLATE V.}

SCOPS SOCOTRANUS, Grint \& Forlies, p. 45. 


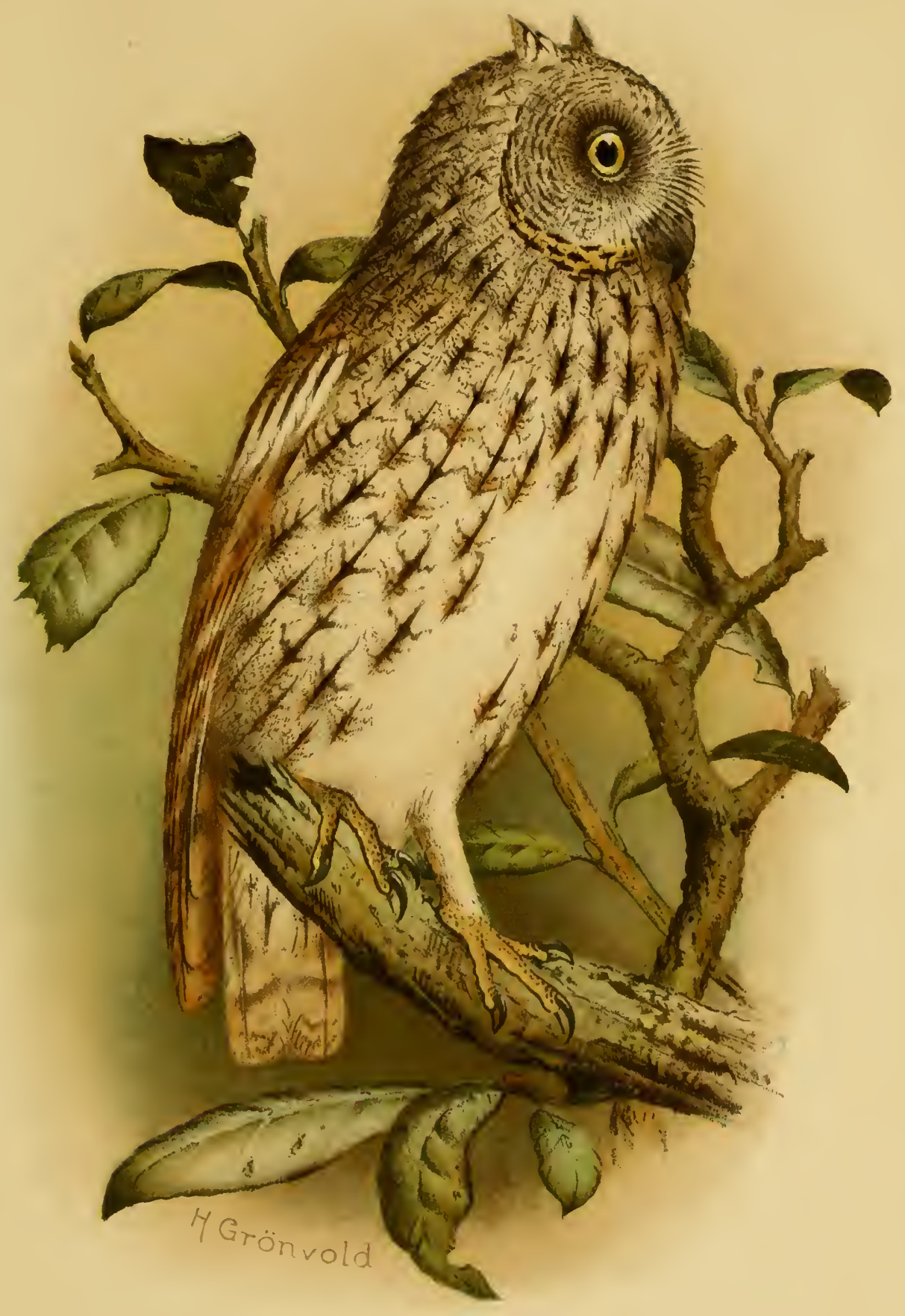

SCOPS SOCOTRANUS. 




\section{PLATE VI.}

PHALACROCORAX NIGROGULARIS, Grunt if Forbes, p. 49.

Fig. a. Alult Mule.

Fig. b. Bird in Serond Tear's Plumage (proludly).

Fig. c. Bird in First Fear's I'lumage. 


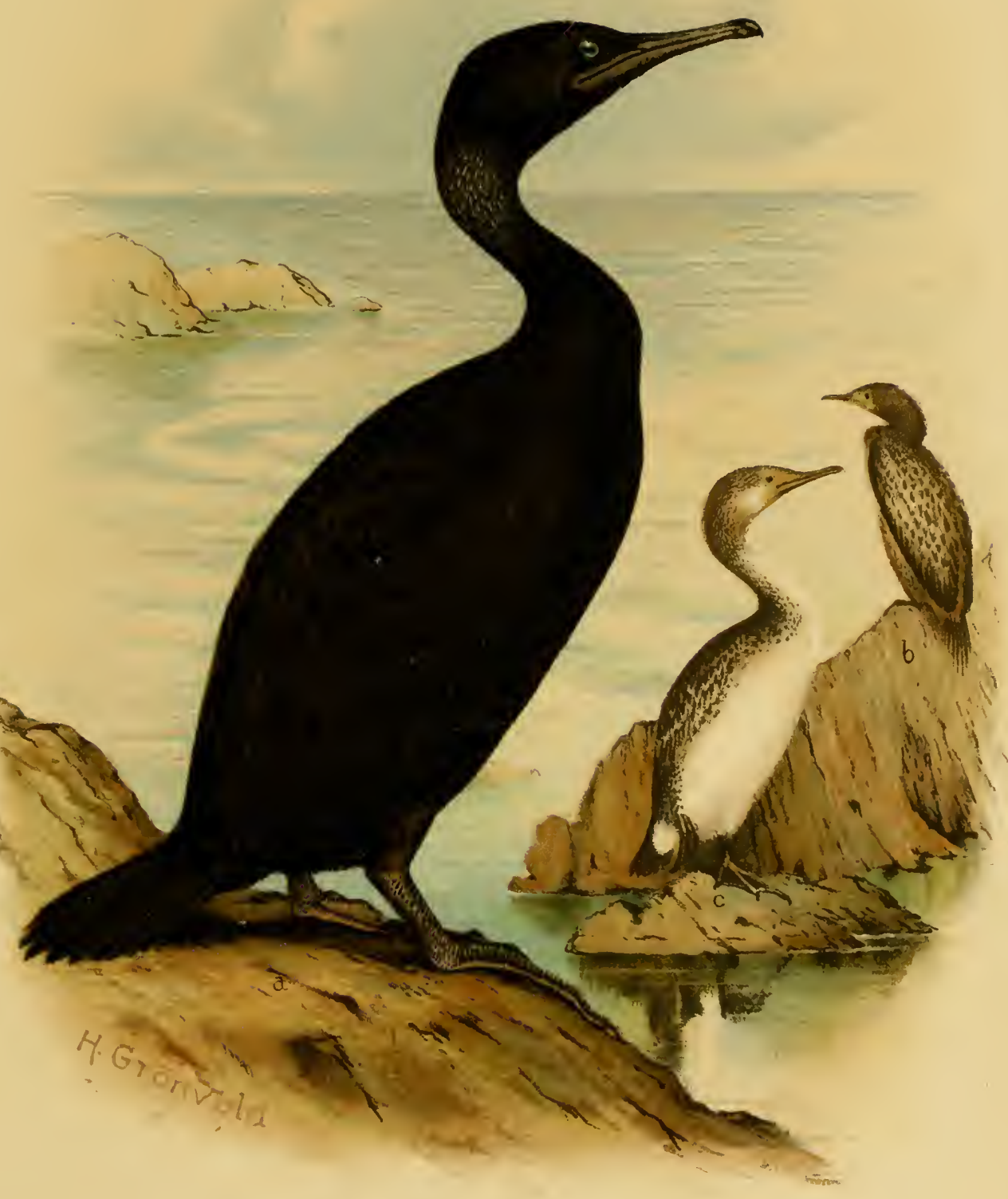

PHALACROCORAX NIGROGULARIS. 




\section{PLATE VII.}

Fig. I. PASSER HEMILEUCUS, Grant d Forles, p. 58.

Fig. 2. MOTACILLA FORWOODI, Grimt if Forb's, p. 60. 
Liverp.Mus.Rep. Sokotra Exped.

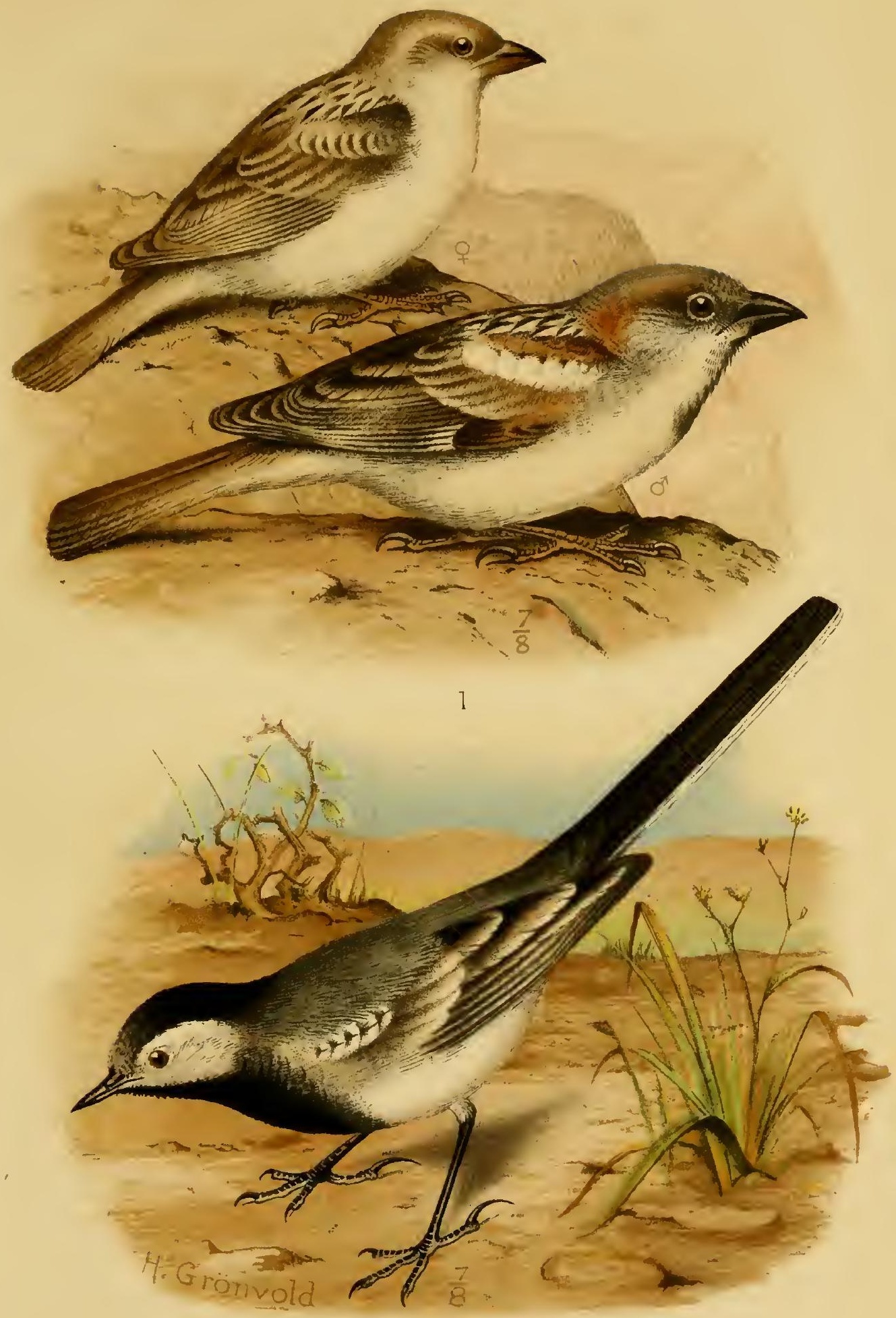

2

1 PASSER HEMILFUCUS. 2 MOTACILIA FORWOODI. 



\section{CHORDATA. VERTEBRATA.}

\section{Reptilia.}

biy G. A. BOULENGER, F.R.S.

Plates VIII., IX̃, X., XI. 



\section{Reptiles.}

The collection of Reptiles brought home hy Mr. Ogilvie-Giant and I)r. H. O. Forthes usefully supplements those previously made hy Professor I. B. Balfour and 1): Rielreck, the former of which was reported upon by Drs. Gianther and Blanford, the latter by the late Professor Peter's. It shows that the fielal was still far from leeing exhansted, when six species, one of which proves to he referable to a new genus, conld be described as new.

The present accomt is divicled into two chapters, the first clealing with Sokotra, the second with Alrl-el-Kuri, a small island hetween Cape Guardafui and Sokotral, the fam of which har not previonsly been explored.

The vicinity of Sokotra to both Somaliland and Sonthern Arabia would, it miori, imply a close attinity with the fammas of hoth these comtries, so similar to each other. This, however, is not the case, and although the Sokotran reptiles show, of comrse, an entirely Afrieo-Arabian general eharacter, it is surprising to find the great majority of the species, and as many as three genera out of thirteen, to be endemic. This, together with the absence of many a species common to hoth neighbouring coasts (Pristurus crucifer, $P$, fhevipunctutus, Acunthorluctylus boskianus, Chalcides ocellatus, Zamenis ihodorhachis, ic.), which eamot be accounted for by the physical conditions of the island, clearly proves Soliotra to have been isolated for a very long period.

The complete ahsence, so far as we know, of Batrachians is another remarkahle feature which this island shares with many other's.

On Ald-el-Kwri, hesides marine Chelonians, only thee species-Geckoswere discovered; two of these belong to undescribed species, whilst the third is common to Sokotra and Arabia.

\section{I.-The Reptiles of Sokotra.} SQUAMATA.

GECKONIDÆ.

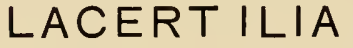

Pristurus, Rüpp.

1. Pristurus insignis, Blenford.

Pristurus insignis, Blinford, Proc. Zool. Soc., 1s81, p. 466, pl. xlii. fig. 1 Bouleng. Cat. Liz. i. p. 53 (1585).

Habit slender, very similar to that of the Ignanoid lizards of the gemus 
Anolis. Hearl short and rleep ; snout subacuminate, longer than the distance hetween the eye and the ear-opening, once and one third to once and a balf the diameter of the orkit: forehead feebly concare ; ear-opening lange, oral, rertical, one third to nearly one half the diameter of the orbit. Limbs very long, the hind limb when stretcher forwards reaching between the ear and the cye; digits very long and slencler ; 25 to 28 lamellie under the fourth toe. Snout covered with large gramules or polygonal convex scales; the remaining portion of the head, as well as the upper parts of the body, limbs, and tail, coverer with minute granules. Rostral suloquadrangular, at least twice as hroat as deep, with median cleft ahove; nostril pierced hetween the rostral aurl two to fom scales; 6 to 9 upper and 5 or 6 lower labials ; symphysial extremely large, rounderl or truncate behind and in contact with 3 to 5 small chin-shields. Tentral scales gramular, a little larger than the dorsals. Tail much longer than hearl and borly, slender, more or less strongly compressed and keelerl ahove, hut withont even the slightest rudiment of a crest. Grey or brown above, with darker and lighter spots, and usually with more or less distinct dark bars across the hack and tail ; small brick-red spots or rlots, or rermicular lines on the sides; helly bright yellow; throat white or bluish, mottled or marbled with grey or hrown, these marblings sometimes extending on to the breast.

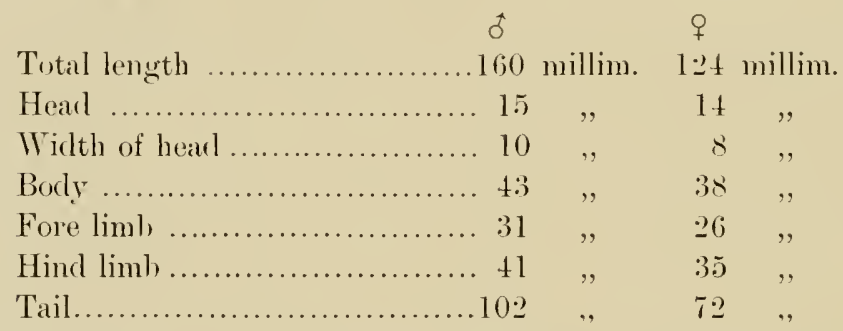

This fine species, one of the largest of the genns, was discovered by Prof. Balfour, lut only two specimens were procured by him, from which D1. Blanford drew up bis excellent rescription The alove description, on the contray, is based on a large number of examples obtained by Mr. Grant and Dr. Forbes at Jena-agahan, Iomhil, and Adho Dimellus.

\section{Pristurus rupestris, Blanford.}

Pristurus rupestrix, Blanf., Amn. \& Mag. N. H. (4) xiii., 1S7t, p. 45t; Zool. E. Pers. 1\% 3.11, pl. xxiii. fig. 1, and Proc. Zool. Soc., 1881, p. 46.5; Murray, \%ool. Sind, p. 365, pl. —, fig. 1 (1854); Bouleng., Cat. Liz. i. p. 53 (1585), and Faun. Ind., Rept. p. 72 (1s90); Anders. Herp. Arab. p. $23(1895)$.

Habit not ynite so slender as in the precerling species. Hearl longer, more depressed; snont more or less acmminate, once and two fifths to once and a half the diameter of the orbit; forehearl scarcely concare; ear-opening rommlish or oval and oblique, one fourth to one third the 
diameter of the orlit. Limbs long, the hind limb when stretched forwards reaching the ear or hetween the shomkler and the ear ; digits long and slender: 2:3 to 26 lameller muler the formth toe. Sinout covered with rather large polygenal comex seales, the remainder of the hearl, the budy, and the limbs with rey small gramules; the gramules on the belly longer than those on the hack, hut smaller than the seales on the smont. Liostral at least twiee as loroal as deep, with merlian eleft alove; nostril pierced between the rostral and two or three seales: 6 to $\lesssim$ mpere and t to 6 lower labials; symphysial very large, very varialile in shape, rombled or trumcate hehind, with straight, convex, or coneare siles, its posterior border in contact with 2 to 5 scales. Tail longer than heal and hody, slenfler, eompressed, kecled above and beneath; in arlult males with intact tails, both keels dentienlate, the upper even forming a reritalule esest, which, however, never extends to the horly ; in females, as well as in some males in which the tail has heen regenerated, the crest is rery feelole. Coloration extremely valdalo: "uper parts greyish, lorowish, or rerldish, with lighter and rarker markings ; the light markings usmally in the form of small romml spots, the dark ones disposed as transterse spots, longitudinal stripes, or in elegant network; a rlark streak on the sicle of the hearl, passing through the eye, is constantly present ; a yellow or orange vertelual stripe, which is absent or but feebly marked in the Arabian and Abd-el-Kuri specimens, is usnally sharply defined; a whitish lateral streak is frequently present, extending from the upper lip to alwove the lind limh. Lower parts white, gular region often spotted or retienlated with blackish; lnick-rerl dots sometimes present on the belly and sides.

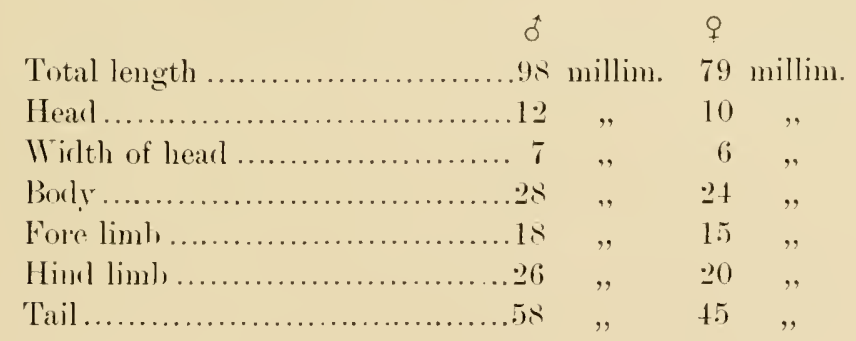

This little Gecko has a rather wide rlistrilution, being known from the island of Karrack, near Bushire, in the Persian Gulf, from Museat and the Hadramant in Arabia, and from Sokotra. J. A. Murray also records it from Sind. On Sokotra it ocems everywhere in great abmolance, and mmerous specimens were collected on Hadilu Plan at Dahamis, Jena-agahan, Homhil, and Artho Dimellus, thus from sea level to an altitude of 4500 feet. The eolomr variations to which I have alluded alove are in no way dependent on the localities. The specimens hronght home by Professom Balfom were likewise very varable in this respect. 
1). Anderson, whose death, as these pages are passing through the press, is so great a loss to zoological science, hats pointerl out that the lizards fiom Sokotra (and, I may ald, from Abd-el-Kuri) have the snout longer and more pointed than the types. This is, however, mot alisolutely constant, as the series hefore ne now shows, and I therefore lo not think anything would lie gainesl, in the way of taxomomic aceuracy, hy rasing the Sokotran specimens to the rank of a sulspecies. The name of the species, eoupled with an inclication of the locality, is amply sufficient for all purposes.

[The habits of hoth Pristurus insignis and P. rupestris are so similar that the same remarks apply to hoth. They were generally foumd among the larger rocks on the hill sides or on the large bonklers in the dry herls of water-conrses, and seemed especially fond of the cracks and fissures in the perpenclicular faces of the cliffs where they might frequently be seen suming themselves. Extremely swift in their movements and constantly on the alert for danger, they were much the most diffienlt lizards to catch withont injury. If pounced on with the hand, one was almost invariably too late, and only a struggling tail remained, the rest of the Gecko disappearing like a flash into some neighbouring crack. Far the best morle of capture is to shoot them with a saloon pistol and a few pellets of clust shot, or, at close quarters, sand may he used with excellent results. By this means eight perfect speeimens were eollecterl one morning at Arlho I imellus in a very short time, three being killerl at one shot.-II.I.O.G.]

\section{Phyllodactylus, Gray.}

\section{Phyllodactylus riebeckii, (Peters). (Plate viii.).}

Diplodactylus riebeclii, Peters, Sitzb. Ges. naturf. Fremde Berl., 1852, p. 43.

Phyllodactylus rielreckii, Bouleng., Cat. Liz. i., p. 94 (185.j).

Head large, with strongly swollen eheeks; snont short, not or lunt slightly longer than the orlit, rounded; forehearl deeply coneave; ear-opening oval, oblique, its greatest diameter ahout half that of the eye; its distance from the latter equal to the length of the snout. limbs strong; digits rather short, depressed, with large subtriangular distal expansions and a regular series of lamella under the non-dilated portion; 5 or 6 lamelke under the inner digit, 7 or 8 muler the fourth. Seales on the hear finely gramular, more coarsely on the snont at the sirles of the frontal concilvity; rostral twice as broad as deep, without merlian cleft; nostril in the centre of a slight swelling, lordered hy the rostral, the first upper labial, and three nasals; the imer masals separated from each other, ahore the rostral, by one or two small scales; 10 to 12 upper and 9 to 11 lower labials; symphysial pentagomal, a little larger than the arljacent labials; a regular series of $6 \mathrm{or}$ 8 chin-shields, the merlian pair as lomg as the symphysial, with which 
they are in contact. Body covererl, above and lelow, with uniform, flat, smooth, juxtaposed granules, as large as or a little larger than the langer gramules on the snout. Tail cylindrical, tipering to an olstuse point, slightly prehensile, covered with uniform flat gramules arranger in rings. Grey-brown above, with small rlark hrown makings nsually disposed in pairs or forming narow cross-bars on the back; romdish white spots, which form regular eross-bars in the young, are sometimes preserver in the arlult; a rlark streak from behind the oye to alove the ear ; intact tail with pale eross-lars, reprodnced tail streaked with dark hrown; lower parts white, throat sometimes spotted with hrown.

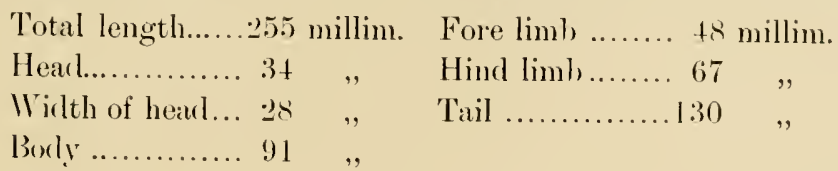

This speeies, the largest known in the genus Phyllodurtylus, was discovered in Sokotra by Dr. E. Riebeck. Several specimens were olitained by Mr. (Grant and I)r. Forbes at Homhil and Arlho Dimellus.

[Most of the specimens brought home were capturerl in holes in the partially decayed stems of large trees (mostly boscellin). One individual was found under a large stone in the bed of the river to the sonth of Adho Dimellus. These large Geckos are rery muscular and extremely tenacions of life. When placed in the strongest spirit of Wine they contimed to struggle violently for fully a quarter of an hour, and it was painful to watch their efforts to escape. The species was only met with between about 2000 and 4000 feet._Ir.li.O.G.]

\section{Phyllodactylus trachyrhinus, Boulen!. (Plate ix. fig. 1).}

Phyllodactylu.' trachyrhinu*, Bouleng., Bull. Liverp. Muss., ii., 1899, p. 4.

Snout short, broadly rounderl, covererl with large sub-conical tubercles arlherent to the skull; forehear convex; ear-opening small, rouml, its distance from the eye equal to the length of the snont. Limbs rather short; digits short, depressed, with well developed distal expansions, and a series of transrersely enlarged lamellar seales on the lower surface. Seales on the head much larger than on the hody, gradually decreasing in size on the occiput : rostral completely divided into two shields, which are not larger than the adjacent labials ; nostril between the first labial and two small nasals ; 8 to 10 upper and 9 lower labials; symphysial small, trapezoid, not larger than the adjacent labials; a series of small shields bordering the symphysial and the anterior lower labials. Borly corered, above and below, with uniform, Hat, smooth, juxtaposed gramles, smallest on the sides. Tail thick, cylindrical, prehensile, covered with uniform flat granules arranged in rings. Pale brownish alove, with blackish marthlings; a black streak on each side of the head, passing thromgh the eye; white bencath. 
Total length .....95) millin. Fore linb .......13 millim.

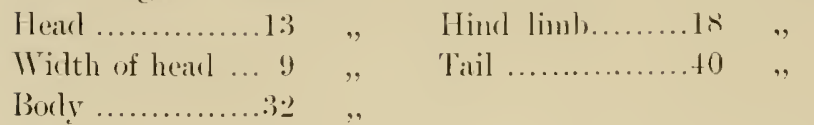

I escriber from two specimens from . Jena-igahan (1200-2500 ft.) and Arlho Jimellus (3500-4500 ft.).

\section{Hemidactylus, Cur.}

\section{Hemidactylus homœolepis, Blunforl.}

Hemidartylue (Liurus) homudepis, Blanf., Proc. Zool. Soc., 1881, p. 464, pl. xlii. fig. 2.

Hemirlartylux homelepix, Bouleng., Cat, Liz. i., p. 11 - (1885).

Snout olotuscly pointed, longer than the rlistunce between the eye and the ear-opening, once and one-third the diameter of the orbit; forehear scarcely concave : eal-opening small, oval, oblique. Borly and limbs morlerate. I)igits morlerately rlilater, free, with rather short distal joints; 5 or 6 lanellie under the thumb, 7 or 8 under the fourth finger, $t$ or 5 under the hallux, s or 10 under the fourth toe. Hearl corered with small convex gramules, largest on the snout; rostral not twice as loroad as leep, with median eleft above : nostril pierced lotween the rostral, the first upper labial, and 5 nasals : 8 ol 9 upper and 7 or 8 lower lahials: symphysial large, triangular, more than twice as long as the arljacent lal,ials ; fon chin-shields, median pair largest and in contact behind the symphysial. Back covererl with flat, subimhicate, smooth, ronud scales, largest on the sides; rentral scales small, imbricate, searely larger than the dorsals. Male with 4 preanal pores. Tail cylindrical, tapering, covered above with uniform, small, smooth, sulbimbricate, flat scales, bencath with a median series of transversely dilated plates, commencing some distance behind the rent. Grey or fawn alwre, spotted with brown: a rlark streak on the sicle of the hearl, passing through the eye : tail with blackish anmuli : lower parts white.

\begin{tabular}{|c|c|c|}
\hline Total length ...... & nillim. & Fore $\operatorname{liml}$ \\
\hline Hearl .............. 10 & 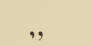 & Hind $\lim l, \ldots$ \\
\hline Width of head ... 6 & ", & Tail .............40 \\
\hline
\end{tabular}

This small Gecko, discovered in Sokotra by Professor Balfour, has been obtained on Harlibu Plain, at Dahamis, Jena-igahan, Homhil, and Artho Dimellus by Messrs. Glant and Forbes. In giving an acconnt of the Reptiles collecterl by In. Riebeck, the late Professor Peters, (l.c., p. 43), adcls some remarks on $H$. homeolepis, which tent to show that he has confomeded $I I$. flutivirilis (= roctei) with this species. Professor Bottger's 1 . humirolepis (Zoul. Ans. 1893, p. 114) from Somaliland is a rlistinct, thongh elosely allierl speeies, which I have 
described as H. isolepis (Poc. Zool. Soc., 1895, p. 531, pl. xxix., fig. 1).

[Fairly common, fomnd under rocks and stones generally in the dry beds of the streams. - II.R.O.G.

6. Hemidactylus pumilio, nom. nm. (Plate x. fig. 1).

Hemiductylus pumilus (non Hallow.), Bouleng., Bull. Liverp. Muss., ii., $1899,1) .6 .^{*}$

Hearl elongate, nearly twice as long as loroad: snout rounded, longer than the distance between the eye and the ear-opening, once and a half the diameter of the orbit; forehead slightly concave; earopening small, oral. Borly and limbs moderate. Digits short, free, with rery short distal joint, morlerately dilated: inner digit with sessile claw: + lamellie under the inner digit, 6 moler the fourth finger, 7 or \& under the fourth toe. Head covered with miform gramules, which are larger on the snont; rostral tetragonal, nearly twice ats broad as deep, with median eleft above; nostril pierced between the rostral and 4 small seales: 8 or 9 upper and 6 to 8 lower labials; symphysial triangular, twice as long as the arljacent labials : 4 chin-shields, inner pair largest and forming a suture behind the symphysial. Body covered ahove with fine gramules intermixed with small round or oral feebly keeled tubereles disposed irregularly. Ventral scales small, eyeloid, imbricate, smooth. Male with an angular series of 5 or 6 pratanal pores. Tail eylindrical, tapering, covered with small flat scales, above with transverse series of pointed tubercles: no trausversely enlarged scales below. Pale brown or buff above, with or withont small hrown spots; a dark hrown streak on each side of the head, passing throngh the eye; white beneath.

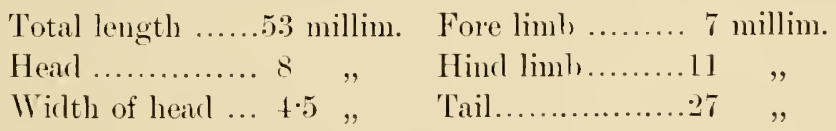

Body .............18, ,

Several specimens from Dahamis (350 ft.) and .Jena-agahan (1200-2500 ft.).

[This little Gecko was only met with on the lower and middle slopes of the Haghier range. The specimens collected were all found under the houlders and stones in or near the dry heds of streams. - II.R.O.Cr.]

7. Hemidactylus granti, Bouleng. (Plate x. fig. 3).

Hemidactylus granti, Bouleng., Bull. Liverp. Muss., ii., 1899, p. 4.

Closely allied to $H$. mubuiu, Mor. Head regularly oviform; snont longer than the distance between the eve and the ear-opening, once and a half the diameter of the orbit; forehead concave; ear-opening

* In describing this species I overlooked $H$. pumilus, Hallowell, 1860, a probable synonym of $H$, fienatus, D. \& B. I have therefore changed the name to $H$. pumilio. 
large, oral, oblique. Borly and limbs moderate. Digits moderately dilated, free; $\tau$ or \& lamellie under the thumb, \& or 9 under the fourth finger, 6 or 7 under the hallux, 9 to 11 under the fourth toe. Hearl covered with uniform granules, whieh are much larger on the snont than on the oceiput; rostral sulupaldrangular, not twiee as hroarl as deep, with median eleft above; nostril pierced between the rostral, the first upper laloial, and three small scales; 8 to 10 rpper and 7 to 9 lower labials; symphysial large, triangular or pentagonal, twice as long as the adjacent lalials; four chin-shields, merlian pair largest and in contact with the symphysial. Back covered with very small granules intermixed with numerous small, round, feebly keeled or suliconical tubercles rlisposed irregularlyr; rentral scales small, cycloid, smooth, feehly imlricate. Male with an angular series of 8 to 1.2 prieanal pores. Tail feebly depressed, tapering to a fine point, covered with granular scales intermixed with enlarged pointed tubereles forming regular transverse series; a series of transversely enlarged plates inferiorly. Greyish or brownish above, with dark irregular marblings or rlark black-edgerl wary eross-bars, t in number, on the nape and back; a clark streak on each sicle of the hearl, passing through the eye; tail with regular dark cross-bars: lower parts whitish.

Total length.....17:2 millim. Fore limb....... 26 millim.

Head............ $2.2 \quad, \quad$ Hind limb...... 3.3 ,"

Wirlth of head... 16 , Tail ........... 94,

Borly........... 56, ,

Numerons specimens from Arlho Dimellus, Sokotra (3500-4500 ft.).

[Common on the high gromel round Adho Dimellus, the highest pass in the central Haghier range: fond below stones on the hill sides.II.M.O.C:.]

\section{Hemidactylus turcicus, Linn.}

Hemidactylus turricus, Bouleng., Cat. Liz. i., p. 126 (1885).

This widely-listributerl Geeko, the range of which extends from the borders of the Mediterranean to $\mathrm{N}$. II. India, has not heen recorded from Sokotra before. Specimens were olstained on Hadibu Plain and at Homliil.

\section{Hemidactylus flaviviridis, Rüpp.}

Hemirlactylus coctur, Dum. \& Bibr. iii., p. 365 (1836).

Hemidactylu: homeolepis, Peters, Sitzb. (ies. naturf. Freunde, Berl., 1882, p. 43.

Another widely-distributed Gecko, ranging from the borders of the Red Sea to the Malay Peninsula. It was first obtained in Sokotra by Dr. Riebeck, but the specimen brought home by him was recorded under H. homcenlepis. Mr. Grant and Dr. Forbes collected a single specimen on Harlibu Plain. The British Museum possesses specimens from Suez, 
Suakin, Mren, Museat, Hadramant, Fano (Persian Gulf), Jask (Persia), Benares, Patna, Eillore, Bombay, Caleutta, Penamg.

The family Ayminle appears to be mrepresented in Sokotral. I strongly suspect Uromestix ocellutus mentioned hy Peters (Op. cit., p. 4.5) to have loeen olstaned in Srahia ly 1)r. likeleck on his way to Sokotra, together with the Chemeleon culyptretus, Peters ne A. 1)um. ( = C. culcurifer), recorded by the sime author (p. 4:3).

\section{[VARANID曆.}

Although we neither saw nor hearl of the presence of Monitors in Sokotra, yet the olservation by the author of The Periplus of the Erythrean Sea that the islaurd of I)ioseorides had . . . "lizards of enormous size, of which the flesh serves for food, while the grease is metted down and used as a substitute for oil," ean hardly apply to any other than a species of Firmun.s. I have seen the Malayau Monitors applied loy the matives to both the uses here stated. A widespreal belief exists in the efficacy of their fat when mubed orer the hodly as a curative renedy in all sorts of illness. The speeies would probally be either the Farmus grisen: (Dand.), which is distributed over Northern Afriea, South-Mest Asia, from Arabia to the Casplin Sea aud North-llest Intia, or $T^{r}$. nitoticus (Lim.), Its extinction in Sokotra may be due to the fact of its being used as food and medicine in an island where both are scarce.-II.O.F.]

\section{AMPHISB压NID压.}

\section{Pachycalamus, Günth.}

Pachyralamus, Giinth., Proc. Zool. Soc., 18s1, ए. 461 (figs. in text); Peter's, Sitzl. Berl. Ac., 1852, p. 583 ; Bouleng., Cat. Liz. ii., p. 461 (158.5).

Acrolont. Nostril inferior, between two small nasals, on the side of the lange rostral; thee large upper head-shields. No limbs. A rentral line, no rertelual or lateral lines. Tail depressed, obtusely pointed. Preanal pores.
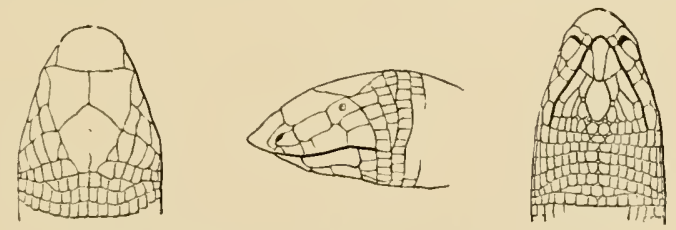

He.D-SIIELTS of P'ACHYCALAMUS BREVIS.

(From the Proceedings of the Zoolowical Society of Lonton.)

This gents is, like Promchulcides, peenliar to Sokotral. Although first described ly Giinther, from Professor-Balfour's collection, its eorrect systematic position was not aseertained until specinens, obtained by Dr. Rieheck, fell into the hands of Peters, who showed it to belong to the Acrodont section of the family, and to be allienl to the North African Trogonoplis and the Somali Agumoton. 


\section{Pachycalamus brevis, Günth.}

Pachyralumus lrevis, Günth., loc. cit. ; Bouleng., loc. cit.

Premaxillary teeth 3: maxillaries 3-3; mandilulars 6-6. Head depressed, with truncate projeeting suout. Rostral large, trapezoid, its posterior border largest, straight, in contact with a pair of large prafrontals : a large frontil, angular anteriorly, nearly as long as broad, sometimes with more or less rlistinct traees of median division; eye slightly distinet through the ocular, which is sometimes in contact with the fourth upper labial; a large preoenlar; a subocular (rarely divided into two); 5 upper lalials, first very small, fourth and fifth largest. Symphysial narrow, elongate, a little broarler anteriorly ; chin-shields very small, median hexagonal; 3 lower labials, second largest. Body short. 161 to 173 anmuli on the body, and 16 to 20 on the tail; in the middle of the borly an anmulus contains 48 to 50 segments. Anal segments narrow, 6 to 10 . 4 preanal pores. Brown or diurk purplish above ; hearl and lower surfaces yellowish white.

Length to vent, 198 millim. ; tail, 15 ; diameter of borly, 9.5 .

Discovered, in numerons speemens, by Professor Balfour. Further examples were olitained by Dr. Forbes and Mr. Grant on Hadibu Plain, at Dahamis, Jena-agahan, and Homhil.

[This Amphisbenicl is common from sea-level to an eleration of abont $2000 \mathrm{ft}$. It is found below stones and is easily captured.-W.I..O.C.]

\section{LACERTID压.}

\section{Eremias, Wiegm.}

11. Eremias guttulata, Licht.

Eremias (1Yesalina) balfouri, Blanf., Proc. Zool. Soc., 1881, p. 467, fig. 2 p. 468.

Sokotran examples of this widely distributed (Moroceo to sind) and highly variable species have been described in detail by Mr. Blanford, and copious notes on the variations in scaling are to he found in the late I)r. John Anderson's heautiful work on the lieptiles of Eyypt, p. 174. I will therefore content myself with reeording the numbers of scales and pores in the specimens collected on the recent expedition.

\begin{tabular}{|c|c|c|c|}
\hline o Hadibu Plain .............. & $\begin{array}{l}\text { Scales } \\
\text { round body. } \\
50\end{array}$ & $\begin{array}{c}\text { Transverse rows } \\
\text { of ventrals. } \\
26\end{array}$ & $\begin{array}{c}\text { Femoral } \\
\text { pores. } \\
13-12\end{array}$ \\
\hline „, Hadibu Plain ............... & 50 & 28 & $14-14$ \\
\hline ", Hadibu Plain.............. & 52 & 27 & $14-15$ \\
\hline „, Dahamis................. & 48 & 28 & $1+-14$ \\
\hline ,, Homhil ................... & 50 & 27 & $13-12$ \\
\hline ", Jena-agahan .............. & 47 & 26 & $12-13$ \\
\hline , Jena-agahan ................ & 52 & 26 & $14-15$ \\
\hline
\end{tabular}


q Hadibu Plain

„ Hadilu Plain

, Harlihu Plain

, Homhil

". Jena-igaham

,. Jella-agahan
Scales romud body.

t8

48
Transverse rows of ventrals.

30

30

30

29

30

30
Femoral

pores.

$14-14$

$13-13$

$12-12$

$15-14$

$11-11$

$13-13$

The number of scales round the borly includes the ventrals, which are constantly in 10 longitudinal series.

[Common from sea level to an elevation of about 2000 feet. Generally scen basking on the ground or on small stones, it is more a lizard of the stony plain than of the rocks. - II.R.O.G.]

\section{SCINCID尼.}

\section{Mabuia, Fitz.}

12. Mabuia socotrana, (Peters).

Euprepes perrotteti, rar., Blanf., Proc. Zool. Soc., 1S81, p. 469.

Euprepes socotranu., Peters, Sitzl). Ges. naturf. Fr Berl., 1852, p. 45.

Maluia socotrant, Bouleng, Cat. Liz. iii. p. 168 (18s7).

Snout moderate, ohtuse. Lower eyelid with a transparent disk. Nostril just ahove or behind the suture letween the rostral and the first labial; a postnasal: anterior loreal usually in contact with the first labial: supranasals in contact behind the rostral; frontonasil broader than long, sometimes in contact with the frontal: latter as long as the frontoparietals and interparietal together, in contact with the second, or second and third supraoculars; four supraoeulars, seeond largest and usually touching the præfrontal; four supraeiliaries, second longest; frontoparietals distinct, smaller than the interparietal; parietals entirely separated; a pair of nuchals ; suboeular hetween the fourth and fifth upper labials, nearly twice as long as these shields, not narrowed inferiorly. Ear-opening oralsubtriangular, not quite so large as the eye-opening, with three or four long pointed lobules anteriorly. Dorsal scales mostly tricarinate, sometimes quinque-or septemearinate ; muchal and lateral scales feebly keeled; 30 to 34 scales round the mirldle of the body. The hind limb reaches the wrist of the arlpressed fore limb, or a little heyond. Subdigital lamella smooth. Tail about onee and a half as long as head and borly. Uniform olive, or with two to six rather indistinet darker longitudinal stripes, head rufous lrown; lower parts yellowish white, throat sometimes spotted with black. Young blaek above, with six white longitudinal lines.

Total length.....218 millim. Fore limb....... 27 millim.

Head.

Hind liml $38 \quad$,

Width of head... 1:3

Tail

125

Body.

,

, 
Numerous specimens from Hatibu Plain, Dahamis, Jena-agahan, Homhil, and Adho Dimellus.

[Very common. Frequents the stony plaims, and open places and paths on the higher groumel.- II.Ti.O.1t.]

\section{Parachalcides, Bouleng.}

Puruchatcides, Bouleng., Bull. Liver[. Muss. ii., 1899, p. 6.

Allied to Clulcides, Laur., and Sepsinu, Bocage. Palatine bones not meeting on the mirllle line of the palate, which is toothless. Teeth conical. Eyclids developed. Ear rlistinct. Nostril pierced in the rostral, hordered by a supranasal and the first lalial ; profrontals and frontoparietals alsent. Body much elongate : limbs short.

13. Parachalcides socotranus, Bunleng. (Plate xi. fig. 1).

Parachalcides socotranus, Bouleng., loc. cit.

Snout short, obtuse, not projecting beyond the latial margin; eye morlerate: lower eyelid with a transparent disk; car-opening small. Frontal more than twice as long as the flontonasal, longer than hoad, brownish hehind, angularly notehed on each side by the suparocular ; interparietal nearly as long as the frontonisial ; 5 supraculars, second largest; 110 postriasal ; first upper labial nearly ats deep as the rostral ; fourth upper labial entering the orbit. 24 smooth scales round the mirlle of the body, subequal in size. Limbs short, pentadactyle; the fore limb, stretched forwards, cloes not prite reach the ear ; hind limb a little longer than the head; third finger longest; fourth toe a little longer than third. Tail thick, erlindrical. Reddish brown above, each scale with a black spot; sides blackish, or elosely spotter and dotted with black; yellowish white beneath, uniform or dotted with black.

Total length......118 millim. Fore limh....... 7 millim.

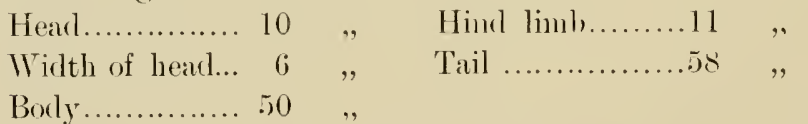

Numerous specimens from Dahamis (350-1000 ft.), Jena-agahan (1200$2500 \mathrm{ft}$.), Homhil (1500-2500 ft.), Arlho Dimellus (3500-1000 ft.).

[This interesting new Skink was met with on the granite from the lower slopes of the Haghier range, to an elevation of about $4000 \mathrm{ft}$. It was also fairly common in the limestone ranges round Homhil, at the east end of the island. In spite of its short legs it is extremely active and rather difficult to eatch, without injuring the tail. It was never seen moving about in the daytime, nuless disturber from heneath stones, and it may therefore be conchuled that, like the varions species of Gecko, Hemiductylus and Plyyllorluctylus, its habits are nocturnal._H.R.O.C.] 


\section{RHIPTOGLOSSA.}

\section{CHAM尼EONTID无.}

\section{Chamæleon, Laur.}

14. Chamæleon monachus, Cir!!y.

Chamweon monachus, Gray, l'roc. Kool. Soc., 1sit, 1) 470, pl. xxxi.; Bliunf., Proc. \%ool. Soc., Is81, J. 464 ; Bouleng., Cat. Liz. iii., p. 451 (185\%).

Casque morlerately raised posteriorly: a strong parietal erest: the distance between the commissure of the mouth and the extremity of the cascue eypals or slightly exceeds the length of the mouth; no rostral appendages: lateral crest strong, not extending to the oeciput; occipital holos very large, united behind the extrenity of the easque, eovered with large, flat, roumdish tubereles separaterl hy fine gramulation. Borly and throat covered with small granules intermixed with strongly enlarged, romd, flat or subconieal, equidistant tubercles; large eonical tulsereles form a listinct erest along the vertelinal line; a crest of long pointed tubereles along the throat; a series of slightly enlarged gramules along the rentral line, not forming a erest. Male with a tarsal process or spur. Tail as long as or a little longer than head and body. Gular-rentral line white; many of the tuhereles of the dorsal crest white; mouth margined with white; sides with white spots or marlilings.

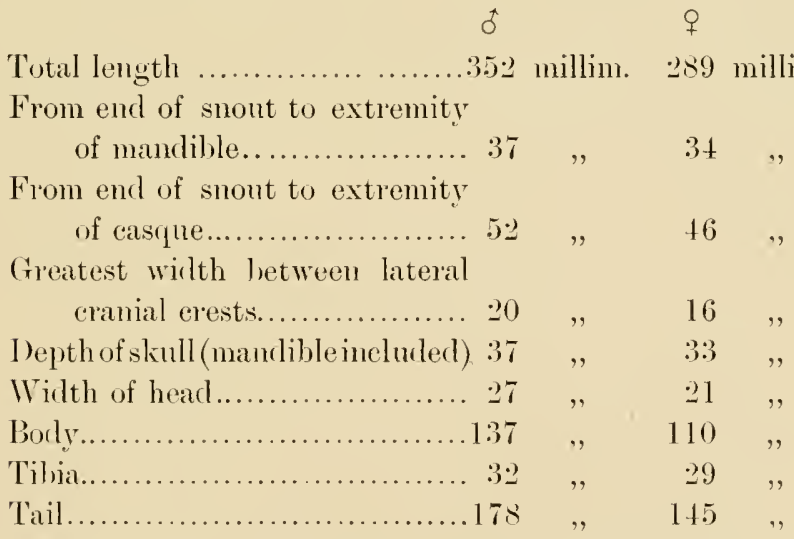

Numerous specimens were obtained hy Professor Balfour, and hy Mr. Grant and Dr. Forbes in the following localities: Harlibu Plain, Dahamis, Homhil, Artho Dimellus.

[The Chameleon was fairly common on all parts of the island risited, ranging from sea-level to the highest gromml. One finds it walking slowly and serlately alout among the banches of the low hushes or perched motionless lazily enjoying the hot sunshine, its goggling eyes 
fixed apparently on space, and with an air of sleepy indifference to the world in general. It always cost one a pang to have to put this delightful reptile in spirits, for it makes no attempt to escape, and is apparently deroid of all fear. One hrought off alive to the 'Elphinstone' lived happily in a calin for some days till a wretehed cabin-hoy knoeked it on the head and threw it ont of the port.II.li.O.G.]

\section{TYPHLOPID厯.}

\section{OPHIDIA.}

\section{Typhlops, Schn.}

15. Typhlops socotranus, Bouleng.

T'yphlops sorotranus, Bouleng., Cat. Snakes, i., p. 221, pl. ii., fig. 22 (1893).

Snout rounded, rery prominent; nostrils lateral. Rostral alout one-third the width of the hearl, not extending to the level of the eyes: nasal incompletely dirided, the cleft proceeding from the second lalial; preocular present, broader than the nasal or the ocular, in contact with the seeond and third labials; eyes distinct; upper head-scales slightly enlarged : 4 upper labials. Diameter of horly 31 to 50 times in the total lengtlı; tail as long as broad, encling in a spine. 24 or 26 seales romd the body. Yellowish white, with brown or black lines ruming between the dorsal series of scales.

Total length, 260 millim.

The types of this burrowing snake were olstained by Professor Balfour. A larger speeimen, from Dahamis, forms part of Messis. Grant and Forbes's collection.

\section{GLAUCONIID曆.}

\section{Glauconia, Gray.}

16. Glauconia filiformis, Bouleng. (Plate xi. fig. 2).

Glauconia filiformis, Bouleng., Bull. Liverp. MIuss., ii., 1899, p. 7.

Very elosely allied to G. macrorhynchus, Jan, with which it agrees in the very prominent, hooked snout, the number and arrangement of the head shields, and the extremely slender form. It differs in the more pointed snout, and in the rostral shield not extending so far back as the level of the eyes. 14 scales rount the body. Iiameter of body, 100 to 140 times in the total length, length of tail 13 times. Caudal spine small. Flesh-coloured, each dorsal scale with a pale brown spot. Total length, 155 millim.

Four specimens from Dahamis (350 ft.), Jena-agahan (1200-2500 ft.), and Homhil (1500-2500 ft.). 
[This eurious species, met with on the lower and middle zones of the granite and limestome hills, was either very rare or diftienlt to fund, for after catching the first at Dahamis, we made every effort to olstain more, but without much result. It lives in holes in the ground helow stones, and when one has heen lucky enough to turn up the right one, a portion of the worm-like hody maty been protruding from the hurow. The morements are fairly swift, and, when once exposed to the light, the body, unless promptly seized, is quiekly withdraw._II.R.O.(r.]

17. Glauconia macrura, nom. not. (Plate xi. fig. 3).

Glatuconia longircuda (non Peters), Bouleng., Bull. Liverp. Muss., ii., 1899, p. 7.

Snout pointed, strongly projecting, slightly hooked; supraocular present; rostral moderately large, not extending to the level of the eyes, its upper portion a little longer than broad; nasal completely divided into two, the lower part rery small ; ocular covering the lip, between two lahials, the anterior of which is rery small ; five lower labials, 14 sciales round the hody. Diameter of lody 40 to ts times in the total length; length of tail 5 to $\vec{T}$ times. Cauclal spine strong. Brown above, white beneath. Total length 170 millim.

Numerous specimens from Dahamis, 350 feet; Jena-agahan, 1200-2500 feet; and Homhil, 1500-2500 feet.

In rescribing this snake for the first time I overlooker the fact that the name longicuda had already been bestowed on a species of the genus Gileuconice.

[The range and habits of this reptile are similar to those of the last, but it was much more abundant.-II.K.O.G.]

\section{COLUBRIDÆ.}

\section{Zamenis, Wagl.}

\section{Zamenis socotræ, Gürth.}

Zamemis socotre, Günth., Proc. Zool. Soc., 18s1, p. 463, pl. xli. ; Bouleng., Cat. Snakes i. p 408 (1s93).

Snout feebly projecting, obtuse. Rostral once and one third to once and a half as broad as leep, the portion risible from abore measuring one fourth to one third its distance from the prefrontals; frontal much wider than the supraocular, once and a half to once and two thirds as long as broal, longer than its distance from the end of the snout, as long as or a little shorter than the parietals; loreal nearly twice as long as deep; two preoculars, separated from the frontal, with a suhocular helow them : two postoculars, and a subocular separating the eye from the sixth and seventh labials; temporals $3+3$ 
or $2+3 ; 10$ upper labials, fifth entering the eye; 4 or 5 lower labials in contact with the anterior chin-shields ; posterior chin-shiekls longer than the anterior, lut extremely narrow and separated from each other by two or three series of scales. Scales smooth, in 2.3 rows. Ventrals obtusely angulate laterally, 219-2.28; anal dividerl: suhcaudals 107-123. Head olive above; body with olive, sometimes hlack-erlged transverse bands, separated by narrower salmon-red interspaces; helly yellowish or pale olive.

Total length 860 millim.; tail 225.

This heantiful snake is only known from Sokotra, three specimens having heen lorought home by Professor Balfour. The present expedition vielded lut a single specimen from Hadiln Plain, a female with 2.27 ventral shields and $12: 3$ pairs of candals.

[Only once seen, the day we landed on Soliotra, by the side of a path near the sea.-II.R.O.G.]

\section{Ditypophis, Gunth.}

Ditypophix, Guinth., Proc. Zool. Soc., 1s\$1, 1) t6iz ; Bouleng., Cat. Snakes, iii., p. $46(1896)$.

Maxillary teeth 8 or 9, strongly increasing in length to the last but one, followed, after an interspace, by a large, groover fang; second to fifth mandilular teeth strongly enlangerl, fang-like. Head distinct from neck; eye morlerate, with rertically elliptic pupil. Borly short, cylindrical; scales smooth, with apical pits, in 21 or 23 rows; ventrals roumled. Tail short; subcaudals single. Hypapophyses developed throughout the rertebral column.

Like Puchycalamus and Paruchalcides, this genus is represented by a single species peculiar to Sokotra.

\section{Ditypophis vivax, Gieinth.}

Ditypophis rivex, Giinth., loc. cit. pl. xl. ; Bouleng., loc. cit., fig. 3.

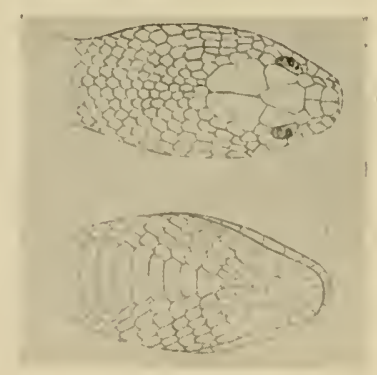

HEAD-SHELDS OF DITYPOHPHS VIVAX.

(From the Proceedings of the Zoulinical Society of London.)

Snout short, hroad, truncate, with rlistnet canthus and feebly grooved 
loreal region: restral more than twice as broad as deep, scarcely visible from aloove; internasals as long as broul, or a little longel than lorad, as long as or longer than the preforoutals; fiontal not broaler than the supraocular, once and two-thirds to twice as long as boarl, as long an its ristance from the end of the smont, shorter. than the parietals; mostril piereed in the upper part of all $111-$ divided nasal; loreal a little longer than deep; one preocular, forming a suture with the frontal ; a sulwoular helow the preocular : two postoculars: temporals small, scale-like, $2 \times: 3$ or 4 ; 8 rpper labiak, fonth and fifth entering the eye; 4 or 5 lower labials in contact with the interior chin-shields, which are nearly as long as the posterior. Siales in 21 (ancly 233 ) lows. Ventrals 14:2-154; anal enture; sulxaudals $34-4$. Reddish, sandy, or olange-red alwove, mifolm, or with indistinct darker elondy spots on the lack, and a dark streak on each side of the hear, passing through the eye ; grey or grey-brown with black spots disposed alternately, with two principal series along the latek, a black streak on the side of the hearl, and blate vertical hars on the lips: lower parts white.

Total length, $4+0$ millim. ; tail, 60 .

This remarkalde snake, of viperine aspect due to its short body and vertical pupil, was known from a single specimen in Professor Balfour's collection. The present collection contanins s specimens, one of which (from Hadibu I'lain) is remarkalule for its miform orange-red coloration and the presence of 2.3 series of scales instead of 21 . The $11 m$ mers of rentral and candal shiclds are as follows:-

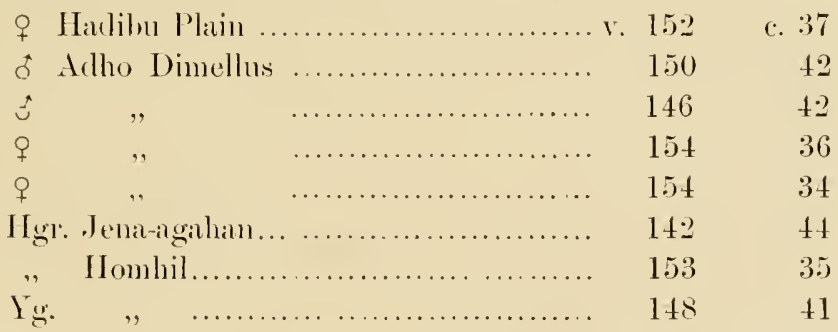

[Apparently most numerons on the higher hills of the Haghier range where most of the specimens were secured._Ir.li.O.G.]

\section{VIPERID君.}

\section{Echis, Merr.}

20. Echis coloratus, Giinth.

One specimen of this species, which inhabits Palestine, Egypt, and Arabia, was fonnd hy Professol Balfour. It is the only Soliotra Reptile which wals not re-discorered by Mr: Grant and Dr. Forbes.

[The Periplus of the Erythrem Sen (A.I). 100) mentions the presence of "a great many vipers in Sokotra," a note which mal refer to the very viper-like Ditypenthe vieux.-H.O.F.] 


\section{[TESTUDINID尼.}

\section{CHELONIA.}

Among the products of the Island of Lioscorides mentioned by the author of the Periplus, besides turtle-shell of the largest size and best kind, are also tortoises, "the gemuine land, white and mountain sort, with shells of extraordinary size," "the lower shell of a ruddy yellow and too hard to he cut." Considering that the investigation of the Flora of Sokotra unquestionably indicates that in former times there existerl hetween Sokotra and the Mascarene Gromp, if not an actual union (which is highly probal,le), at least a near approximation of the latter to the larger Afriea of which Sokotra then formed a part, this observation appears to me to be peculiarly suggestive. Could this mountain tortoise really be a Testudo related to those of the Scychelles, Allabra, and others of the Masearene archipelago? I think it highly prohahle. I regret that I did not sufficiently note this passage in the l'eriplus. before setting out for Sokotra, and so made no enquiries as to the remains of such a tortoise now in any of the limestone caves or sequestered valley-heads of the Haghier lange. Were any survivor of those giant reptiles still to be found, I think we could hardly have failed to hear of it, for I was constantly making enquiries of the natives about bone-deposits and all the products of the island through our most intelligent interpreter : lut it would he specially interesting and important to discover if any traditions of their former presence be still lingering among the people. I trust that some future visitor to Sokotra may try and oltain information on this subject. None of the limestone cares I examined contained osseous remains of any kind.-H.O.F.]

\section{CHELONID压.}

\section{Chelone, Brongn.}

\section{Chelone imbricata?(Linn.).}

Chelone imbricata, Bouleng., Cat. Chelon., p. 183 (1889).

The Hawk's-bill Turtle, we leamed, frequents the south coast of Sokotra, but in former times it appears to have heen captured more abundantly than now. We did not see it on the north eoast, and its shell was not, so far as I conld learn, much collected as an article of commerce. It would seem to have been far more so eighteen centuries ago, when the merchants of Mooza [on the Arabian shore of the Red Sea] and Barugaza [in the Gulf of Cambay] visited the island and reeeiver in exchange for their Indian and Arabian wares "as fresh cargo, great quantities of turtle shell."

[Although we did not hear or see any evidences of the presence of Chelune mydus, there can be no doubt it also oceurs in Sokotra.-H.O.F.] 


\section{EMYDOSAURIA.}

[We are again indelsted to the Periplus of the Erythean Sec for the record that in the first century of our era Crocodiles were inchided in the fauma of Sokotra, which has "rivers and crocodiles and a great many" vipers and lizards of enormous size . . ." They have now, however, gone the way of, no doubt, many another species, and we did not even hear of their former existence. The species one would expect to have found would be Cracolilus niloticus.-H.O.F.7 


\section{II. - Reptiles of Abd=el=Kuri.}

Examples of three species of ficekos are all that was eollected in the way of Reptiles on this small island. lut two of them eonstitute rery well markerl new species.

GECKONID压.

\section{LACERTILIA.}

\section{Pristurus, Rupp.}

\section{Pristurus rupestris, Blonf.}

See remarks above, 1) 66.

The few specimens collected do not show the stripes whieh are so well defined in many of the Sokotra cxamples. In this respect they are quite similar to the types from Aralia and the Persian Gulf.

\section{Hemidactylus, Cuv.}

2. Hemidactylus oxyrhinus, Bonleng. (Plate x. fig. 2).

Hemidartylus oxy.hinu., Bouleng., Bull. Liverp. MIuss., ii., 1899, p. 5.

Snont pointed, slightly longer than the distance letween the eye and the ear-opening, which equals the diameter of the orbit ; forehead slightly coneare; ear-opening small, oral, oblique. Body and limbs moderate. Digits morlerately dilated, free : 7 or \& lamellie muler the thumb, \& or 9 muler the fourth finger, 6 or 7 moler the hallux, 11 or 12 under the fourth toe. Hearl covered with small convex gyanules increasing in size posteriorly ; rostral snlyprarlrangular, not twice as broarl as deep, with median cleft alove; nostril pierced hetween the rostral, the first upper labial, and 3 small scales: \& to 10 mpper and 7 or \& lower labials; symphysial large, triangular, more than twice as long as the adjacent labials; four chin-shields, median pair largest and in contact behind the symphysial. Back covered with cyual or suberuil, rather large, obtusely keeled, juxtaposed tubercles; ventral scales much smaller, cycloid, smooth, subimbricate. Male with two praanal pores. Tail cylindrical, tapering, covered with miform small smooth seales, with a median series of transversely enlarged plates inferiorly. Pale buff or greyish brown, with more or less distinet dlarker markings in the form of + wavy cross-lans on the nape and back and anmuli on the 
tail: the eandal ammli black in the young, separated by white interspaces; a dirk streak on each sile of the hearl, passing through the eye.

Total length......95 nillim. Fore limb.........5 millim.

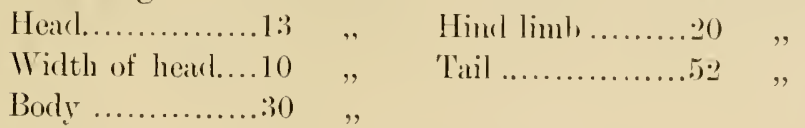

The largest speemen, with reprorlneed tail, measmes 50 millim. from snont to vent.

Several specimens were obtained by the Expedition.

[Not very common.--M.Ii.O.G.]

3. Hemidactylus forbesii, Bonleng. (Plate ix. fig. '2).

Memidactylus forlesii, Bouleng. Bull. Liverp. Muss., ii., 1899, p. .5.

Closely allied to $I I$. flevirivitis, Riipp. (rocteri, D. and B.). Snont obtusely pointed, longer than the distance between the eye and the ear-opening, once and one-third the diameter of the orbit; forehear concave; earopening large, oval, oblique. Body and limbs moderate. Digits moderately dilated, less than in $H$. Aluriviritis, free; 11 or 12 lamellet moder the thmml, 11 or 12 under the fourth finger, 10 or 11 mucler the hallux, 14 or 15 under the fourth toe. Hearl covered with uniform granules, largest on the sides of the snout; rostral not twice as loroal as deep, notched and cleft above; nostril piereed lotween the rostral and 3 small seales; first upper labials sometimes entering the nostril; 10 or 11 upper and 8 or 9 lower labials; symphysial large, triangular, at least twice as long as the adjacent labials ; a pair of large chin-shields, forming a snture behind the symphysial, usmally flanked by a pair of much smaller shields. Back covered with minnte granular seales, among which slightly enlarged, round tubercles may be irregularly scattered; rentral scales slightly larger, much smaller than in II. fluivirilis, juxtaposed or subimbricate. No praanal or femoral pores. Tail moderately rlepresserl, tapering to a fine point, covered very small smooth scales, and a few scattered pointed tubercles on its hasal part; no regular series of transversely enlarged, lamellar plates on the lower surface. Pale greyish alove, with rather indistinet lown spots and marlolings on the head and body and eross-bars on the tail; white beneath.

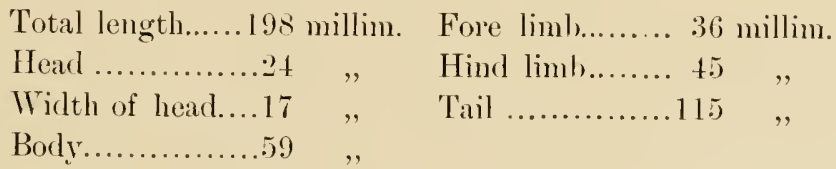

Numerous specimens were collected.

[Very common below stones. - II.M.O.li.] 


\section{[CHELONID压.}

\section{CHELONIA.}

\section{Chelone, Brongn.}

4. Chelone mydas (Limn.).

Chelone mydas, Bouleng., Cat. Chelon., p. 180 (1889).

I saw fragments of carapaces of the Green Turtle in the neighbourhoorl of the hut-cluster inland from our anelorage at Abd-el-Kuri.-H.O.F.

\section{Chelone imbricata (Lim.).}

Chelone imhricata, Bouleng., loc. cit., p. 183.

Romnl the huts of the natives were scattered great numbers of the entire but stripper carapaces of the Hawk's-lill Turtle, showing that they colleet the shell in eonsiderable quantity This small islancl, with its numerous sandy beaches, is quite a tempting place for these reptiles to reposit their eggs upon. I purchasert a small quantity of shell of excellent quality.-H.O.F.

\section{Thalassochelys, Fitzing.}

\section{[6. Thalassochelys caretta (Linn.).}

Thalas:ochely: caretta, Bouleng., loc. cit., p. 184.

I found on the beach at Bander Saleh the bones of the Loggerhear Turtle in great numbers. The length of a femur, which seemed to me to be unusually large, measured 17.5 eentimetres; the mandible, of apparently the same skeleton, was 18 eentimetres long.-H.O.F.] 



\section{PLATE VIII.}

PHYLLODACTYLUS RIEBECKII, Bigr., p. $\mathbf{7 8 .}$ 


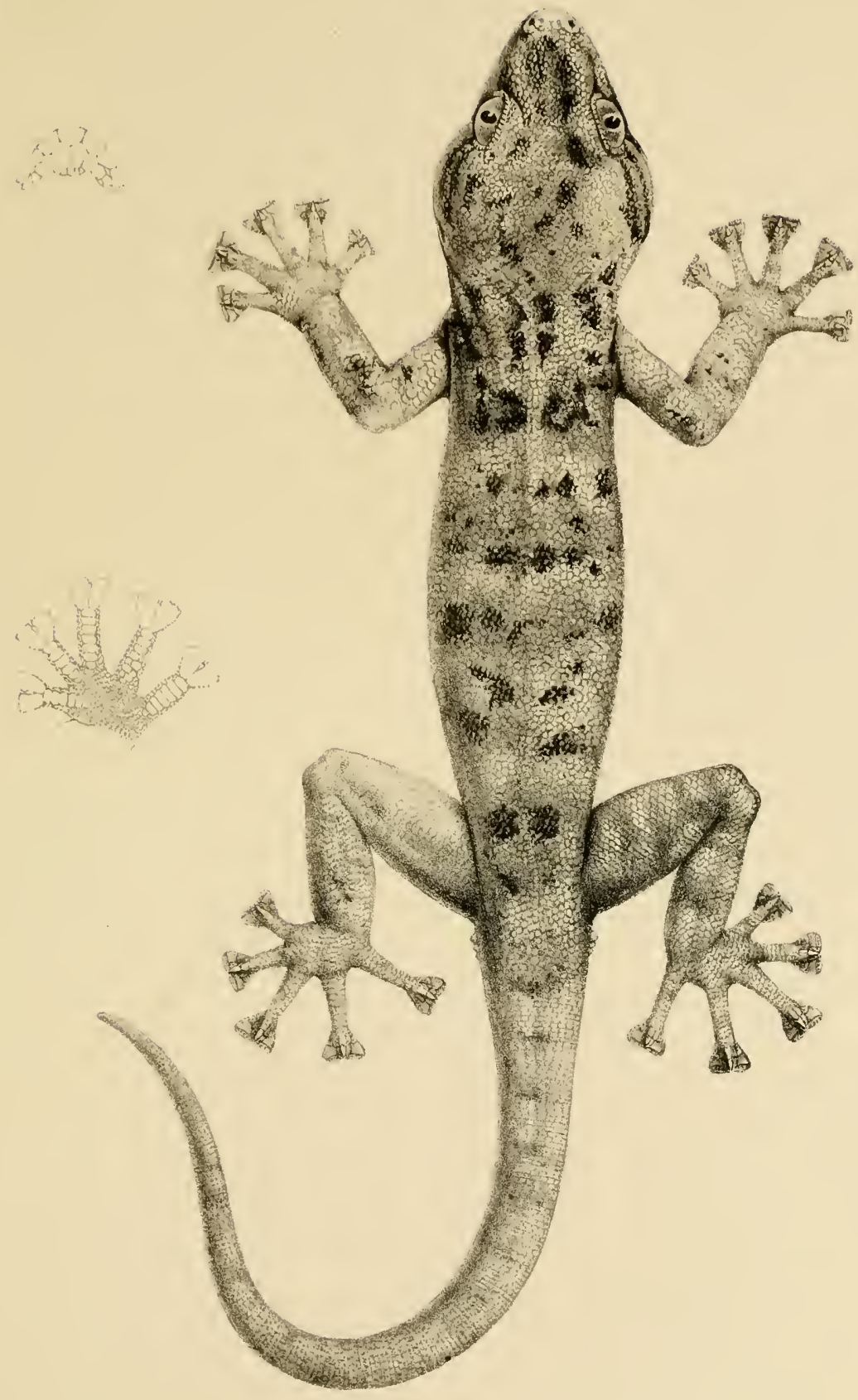




\section{PLATE IX.}

Fig. 1. PHYLLODACTYLUS TRACHYRHINUS, Blgi., p. 79.

Fig. 1a. Latiul scules of sume.

Fig. Ib. Under surfuce of foot of sume.

Fig. 2. HEMIDACTYLUS FORBESII, Bigr., p. 95.

Fig. 2a. Labiul sicules of semme.

Fig. 2b. Under surface of foot of situte. 


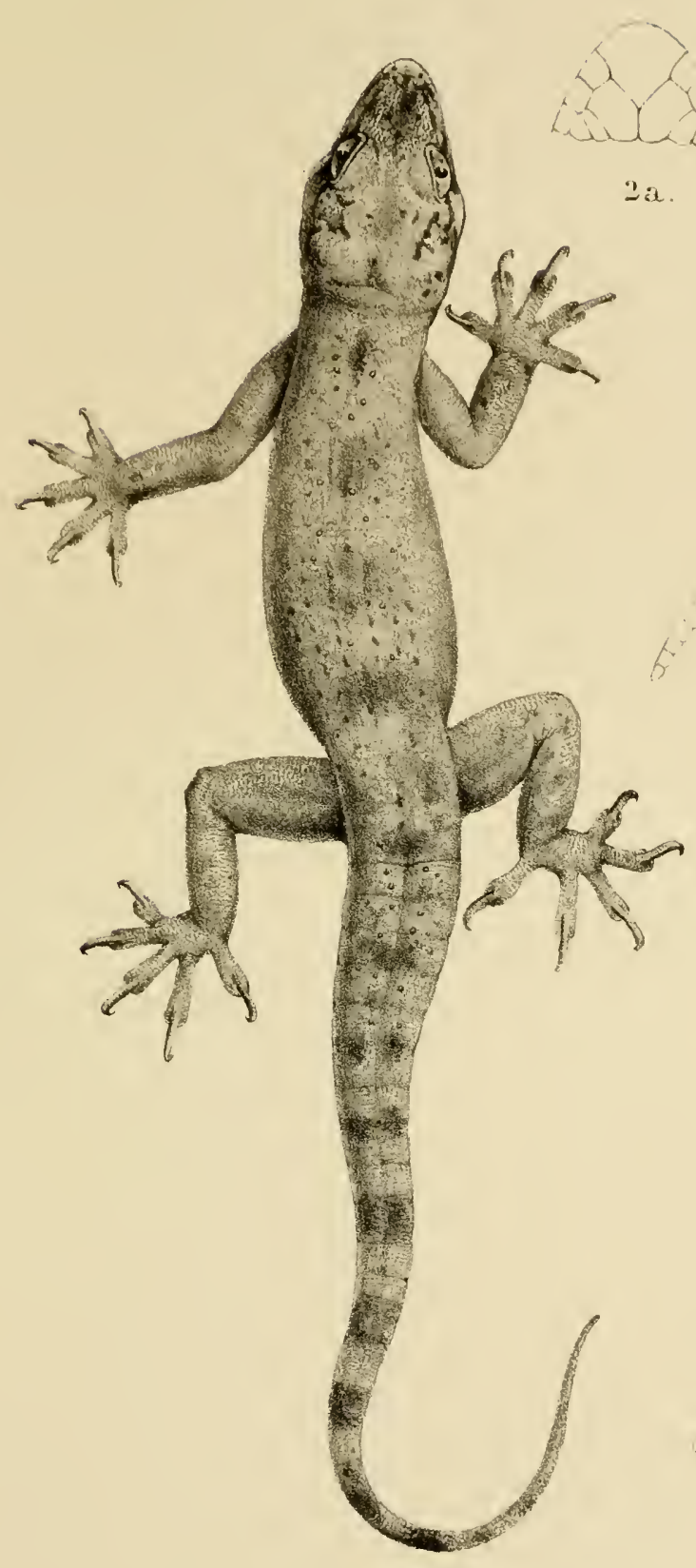

2

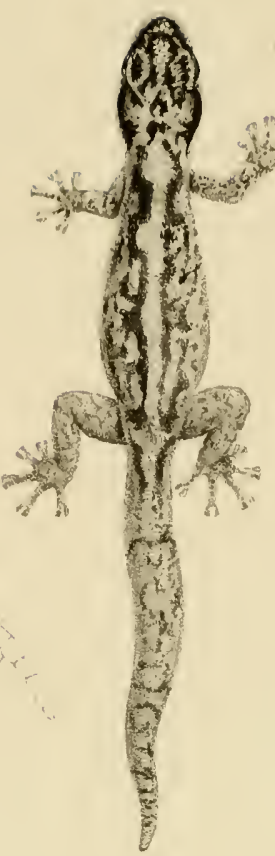

1 .

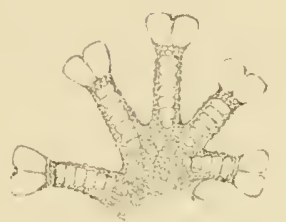

16

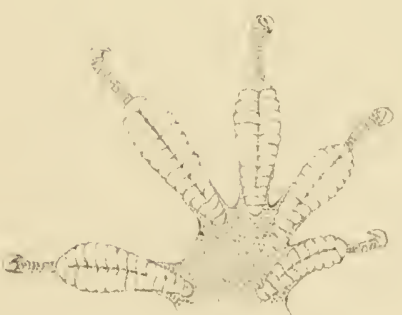

26 


\section{PLATE X.}

Fig. 1. HEMIdACTYLUS PUMILIO, Blgr., p. 81.

Fig. Ia. Lethicul sireles of sume.

Fig. Ib. Under surfare of foot of sume.

Fig. 2. HEMIDACTYLUS OXYRHINUS, Blyr., p. 94.

Fig. 2a. Labiul scules of sume.

Fig. 2b. Umoler surfure of foot of sume.

Fig. 3. HEMIDACTYLUS GRANTI, bilyr., p. 8I.

Fig. 3a. Labial scules of same.

Fig. 3b. Under surface of foot of same. 

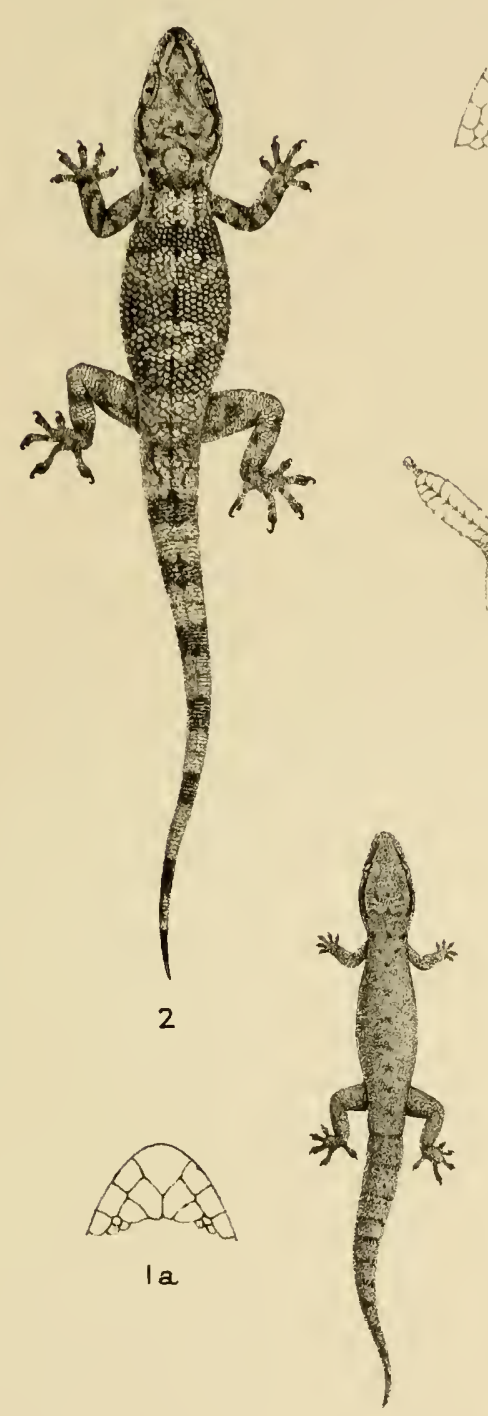

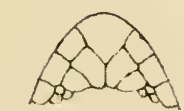

la

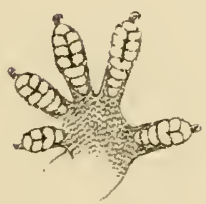

Ib
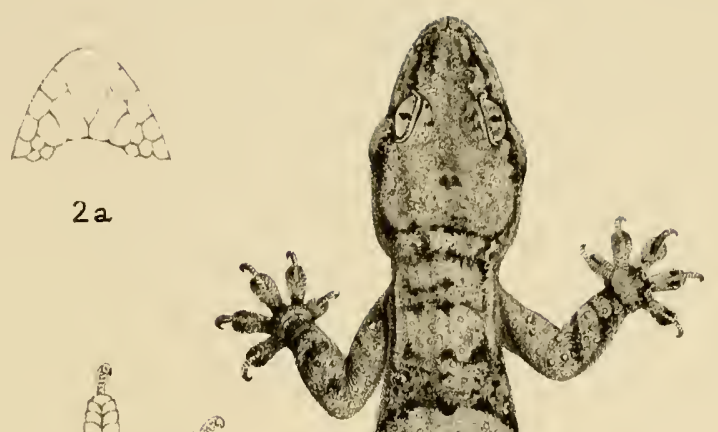

$2 b$
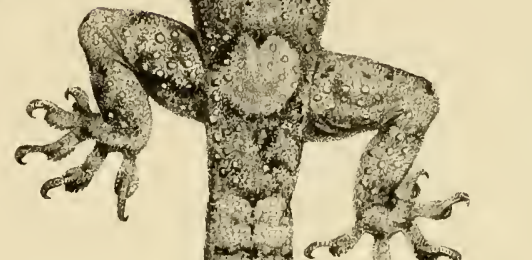

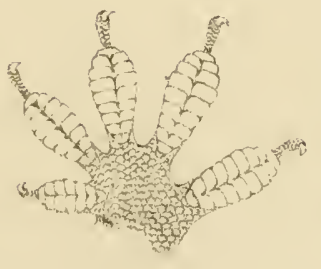

$3 b$ 


\section{PLATE XI.}

Fig. I. PARACHALCIDES SOCOTRANUS, bilyr., p. 86.

Fig. Ia. Houd of seme from above.

Fig. Ib. Heal of sume, sitle view.

Fig. 2. GLAUCONIA FILIFORMIS, Blyr., p. 88.

Fig. 2a. Heud of sume from abore.

Fig. 2b. Head of seme, side view.

Fig. 3. GLAUCONIA MACRURA, Btyir, p. 89.

Fig. 3a. Head of same from aliore.

Fig. 3b. Heal of same, side vieu. 
Liverp.Mus.; Rep.Sokotra Exped.

Pl.XI.
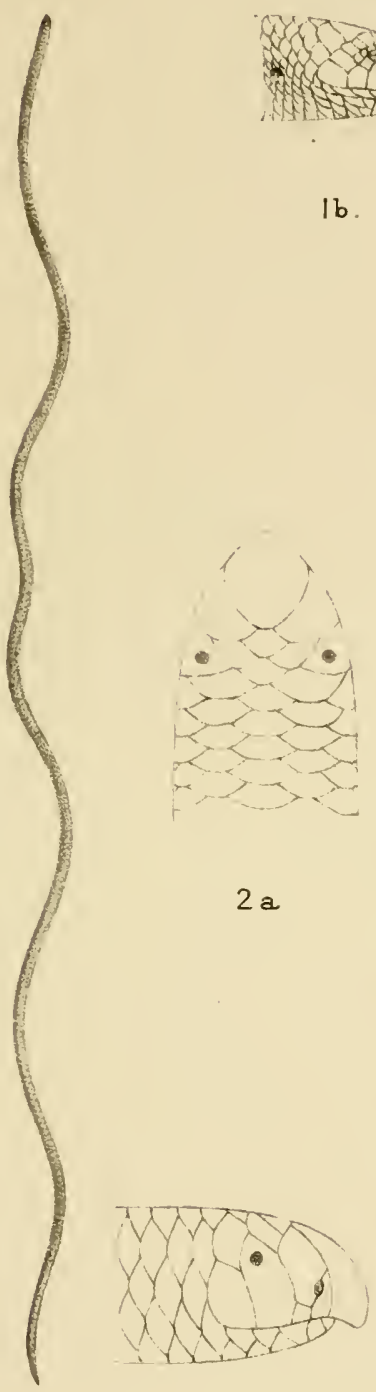

$2 b$

Ib.

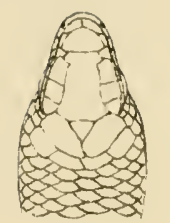

la

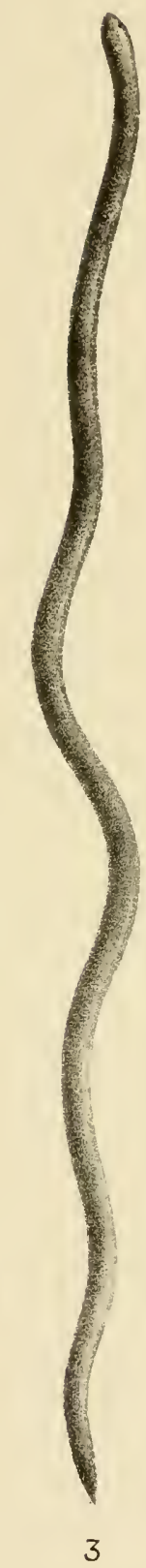

J.Green del et lith.

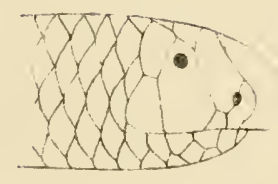

$3 b$

2

I

3

Mintern Bros.imp.

1.PARACHALCIDES SOCOTRANUS.

2.GLAUCONIA FILIFORMIS 3.G.MACRURA. 



\section{CHORDATA. \\ VERTEBRATA.}

\section{Batrachia.}

Pisces.

lote by HENRY O. FORBES, LL.D. 



\section{Batrachians and Fishes.}

The alsence of indigenous Mammals in Sokotra prepanes us for the alisence of Frogs, Toads, and Newts also from the islands. Neither in Sokotra nor in Abd-el-Kuri did we discover any signs of these forms of life, a fact which indicates a very long severance of the islands from the nearest continental lands.

As the main olject of om expedition was to investigate the Land and Fresh-water Fauna of the islands, little or 110 attention was paid to their marine zoologr. We hrought home only, therefore, a few of the more portable specimens of Sea-Fishes, kindly eanght for us orer the sirle of the 'Elphinstone' or in the rock pools on the shore, for the most part by the otticers of the ship while she was lying at Sokotra and Abd-el-Kuri. These were all well-known species of sermuns, Luburd, Cumer, Pristipome, Murcenu, Mugil, and Beryix.

As to Fresh-Water Fishes, none exist in Abd-el-Kuri, for the sufficient reason that there are no permanent streams there. We saw no r'umning water anywhere furing our visit, and no rock pools in the ravines in which a fish conkl survive the dry season. Even in the wet season the rains, which must, from the evidenees we saw, he very heary, find their way to the sea through a high sand barrier which skirts the shores of the island.

In Sokotra the majority of the rivers have also no exit into the sea in the dry season, being lost in the soil hefore reaching it. In the wet season they must all at times loe torrents of large size, flowing with great velocity and violence, judging by the enormous houlders now lying in their beds which they have transported into the plains. Of those crossing the Hartibn Plain, howerer, all have estuaries. In a deep pool in the Hanefu river, above the town of Hadilun, and about a mile and a quarter from the sea, I saw several dark-colonred, tront-like fishes, about of to 10 inches in length, in form and action resembling solmonider : but losth I and several of onr servants, who tried to capture specimens, unfortunately failer. It is, consequently, still a question whether they were truly river species or marine forms which had come thus fal up from the sea. Ahove the estuarine waters 
of rivers reaching the sca, and in all the streams, without exception, in the mountains, everyone of them just such as might he expected to harbour river fishes, not a single specimen was seen. The natives also told us that none existed away from the sea. The probalibity, therefore, is that those seen in the Hanefu were marine species. Captain Hunter, an accurate olserver, who, when Political Resident in Aden, paid a visit to Sokotra in 1876 , notes that:- "In the rivers, two kinds of fresh-water fish are to be found, both in size about a finger's length, and one kind having a series of concentrie, alternately black and yellow, oral rings on the back, making the fish resemble an elongated target. The natives assert that these fish went down to the sea when they grew larger." From their hrilliant colonring, it is likely that these were fry of marine species also.

A conple of specimens hrought home hy Professor Balfour from one of the rivers of Hadiln plain proverl to be Kulthe temium (Blgr. Cat. Fishes B.M., Vol. i., p. 39), a marine form common to East and South Africa, and the islands of the Indian and tropical Pacific oceans. 
MOLLUSCA.

\section{Gastropoda.}

By EDGAR A. SMITH, F.Z.S.

PLATES XII., XIII. 



\title{
Land and Fresh= Water Shells.
}

A very complete account of the Mollusean fauna of Sokotra and Abd-el. Luri was given by the late M. Crosse in the Jominal do Comrlygliologir for 1884, pp. 341-375, in which all the known species were enumerated with synonymy and references. Some remarks upon the character and relationship of the famna were also appended. Little, therefore, remains to be done, except to bring this Catalogue up to date, and to discuss certain points in synonymy which an examination of many of the types has marle necessary. The present writer is fortunate in having the types described by GodwinAusten available for study, also a fine series of specimens collected by Mr. and Mrs. Theodore Bent in 1896, besides the collections made by Dr. Forbes and Mr. Grant.

Forty species of land shells were catalogued by M. Crosse from Sokotra, 28 inoperculaterl and 12 operculated. Fifteen additional species of the former and one of the latter are now added to the list. Of these it is worthy of notice that only one, the Succinen solvotrensis, belongs to a genus previonsly unknown in Sokotra.

\section{I. - The Land and Fresh=Water Shells of Sokotra.}

\section{TESTACELLID里.}

\author{
Ennea, H. \& A. Adams.
}

1. Ennea cylindracea, smith.

Ennea cylinelrarea, Smith, Journ. Malac., vol. vi. p. 34, pl. v. fig. 1.

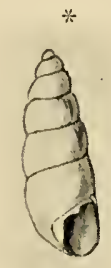

(ENJARGED).

* Figmes in the text of this paper with an asteriak over them are from drawings most generously made for me hy Mr. E. A. Smith: the others are from the Proceding: of the Zooloyicul Society of London with the kind permission of the Council. - Exlitor. 
Shell small, narrow, cylindrical, imperforate, white, pellucid ; spire elongate, mammillated at the apex: whorls six, slowly increasing, the first globose, the three following sonewhat convex, the last and penultimate flattish, divided by a deep oblique suture, striated with fine lines of growth, the last subascending in front, finely costulatestriated behind; aperture irregularly subquadrate, small, equalling $\frac{1}{4}$ the whole length, with a single parietal tooth; peristome slightly thickened, margins joined with a conspicuons callus, the outer slightly simuated near the suture, the columellar dilated, prominent and subplicate within.

Length 7 , diameter $2 \mathrm{~mm}$; aperture 1.6 long. $1 \cdot 25$ broad.

Sokotra.

[This species was collected by Mrs. Theodore Bent; but not by us.]

[The occurenre of the following sprecies in solotin is doubtful :-

Ennea ovoidea ( Brmy. $_{\text {. }}$.

Buliminu* oroidens, Bruguière, Encyl. Méth., i. p. 33.j (1792) ; Crosse, Op. rit. p. $3 \pi \%$

East Africa.]

\section{SUCCINEID丑.}

\section{Succinea, Draparnaud.}

2. Succinea sokotrensis, $8 \% .1 \%$ (Plate xiii. fig. 17.)

Shell small, morlcrately solid, reddish; spire moderately elongate, mammillated at the apex; whorls $3 \frac{1}{2}$, very convex, rapidly increasing, the last descending in front, striated with fine oblique lines of growth; aperture small, irregularly ovate, slightly exceeding half the whole length; peristome slightly thickened, margins joined with a thin callus.

Length $7 \cdot 5$, diameter $4 \mathrm{~mm}$. ; aperture $4 \mathrm{~mm}$. long and $2 \frac{1}{2}$ broad.

Sokotra (Type collected by Mrs. Bent).

In form somewhat resembling the European S. oblonyu.

Some specinens are thinner than others, being perhaps less adult shells.

It seems probable that, had they survived longer, they would have become more solid.

[This species, discovered by Mrs. Bent, was not met with by us.-H.O.F.]

\section{PUPID曆.}

\section{Buliminus Beck.}

\section{Buliminus (Passamaiella) passamaianus (Petit).}

Pupu passemaiena, Petit, Journ., Conch., 1853, p. 366, pl. xiii. figs. $7,8$. Buliminus passemuiume: Crosse, Op. cit. 1. 344; Kobelt, Conch. Cab. (Ed. 2), p. 616, pl. xciv. figs. 1-3.

Ennere passamaiana, Godwin-Ansten, P.Z.S., 1881, p. 808, pl. lxviii. fig. 11. 
"Shell shortly conical, wirlely umbilicated, white; spire subohtuse, whorls 6 , somewhat convex, ormamented with oblique regular striar,

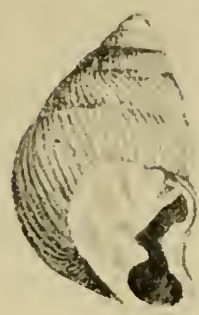

Fit: a

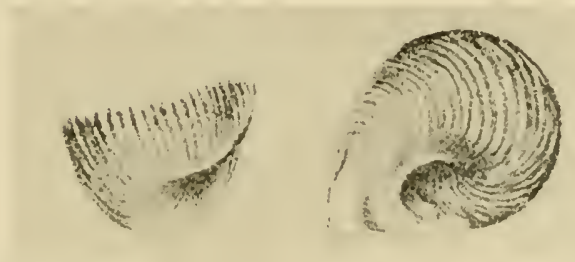

(ENLAR:LE).

FIr: b.

the last dilated; aperture contracted, dentate; columella angalate in the middle, toothed below; labrum much eurved within at the middle, and toothed, searcely reflexed."

"Height $11 \mathrm{~mm}$., diameter $8 \mathrm{~mm}$. "- (Translation from Petit).

Var. euryomphala, mır. ". (Plate xiii. fig. 3.)

Shell like the Type, but shorter, more widely excavater below, with more convex whorls, and a stronger labral tooth.

A single specimen collected by Mrs Theodore Bent differs from the typical form in the above particulars. It is quite possible that these differences may eventually prove constant when further specimens have been obtained, for, jurlging from the series of I'ussmuielle examined, the speeies do not exhibit much variation.

[This speeies was not colleeted by us._II.O.F.]

4. Buliminus (Passamaiella) isthmodon, Muitens.

Buliminus isthmorlon, Martens, Nachrbl. Dentsch. Malak. Ges., xiii. p. 136 (1881).

Butiminus inthmorlon, Crosse, Op. cit. p. 345; Kohelt, Conch. Cab. (Erl. 2), p. $6: 21$, pl. xeiv. figs. 10,12 .

The following is a translation of the original description of this shell :-

Shell conic-glohose, arenate-rimate, costulated, somewhat glossy, unifor'mly reddish-yellow; whorls 5 , the first papilliform, smooth, the antepemultimate and penultimate with very oblique riblets, the last globose, with curved costule, subeompressed at the base; aperture small, contracted by two coarse sub-bituberenlar opposite teeth, one external, the other on the columella; peristome thickened, reflexed, white, the margins subparallel and prolonged downwards, the columellar side incised at the point of insertion.

Length 15 , diameter $12 \frac{1}{2} \mathrm{~mm}$. : aperture, including peristome, 10 long and 7 wide. 
Sokotra: Dahamis (350-1009 f't.).

[In crevices of the granite rocks: and muler stones in the dry Wadis.II. U.F.]

5. Buliminus (Passamaiella) bentii, simith.

Buliminus (l'assamaiella) bentri, Smith, Journ. Malacol., vol. vi. p. 3.5, 1]. v. fig. 3 ; Kobelt, Conch. Cab. (Ed. -2), p. (11s, pl, xeiv. fig. 5.

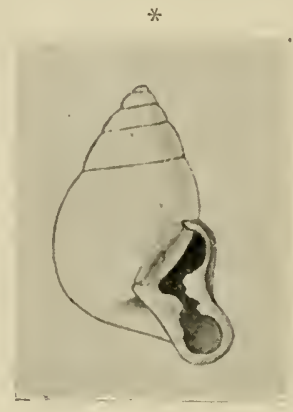

(ENLARAED).

The following is the original description of the species:--

Shell irregularly ovate, acuminate above, white (?), or brownish, rimate; spire convex-conoil, obtusely mammillated at the apex; whorls 5, somewhat quickly increasing, the first two convex, smooth; the two following less convex, very obliquely striated, the last obliquely descending behind, but close to the lip subascending, deeply impressed behind the middle of the lip and beneath the umbilical chink : aperture irregular, oblique, ear-shaped, contracted ; peristome slightly incrassate, narrowly expanded and reflexed, the margins almost nnitel with a conspicuons straight but oblique callus, the onter bituberculaterl within in the middle, and the colmuellar with a strong, elongated, oblique fold.

"Length $18 \cdot 5$, diameter $10 \mathrm{~mm}$.

"The form of this interesting species is rery remarkable, and at once clistinguishes it from the other allier species. The great contraction of the aperture is very peculiar; it is also remarkable in that the parietal callus does not actually join the extremities of the peristome, but is separated both above and below by a slight noteh or channel."

[Not oltained by the present experition.-H.O.F.]

\section{Buliminus (Passamaiella) bayleyi, nom. nov.}

Ennma balfouri, Godwin-Austen, P.Z.S., 1ss1, 1). 809, 1). Ixviii. fig. 12; Crosse, Op. cit. 1) 340 : Kobelt, Conch. Cab. (Ed. 2), pl. xeiv. fig 7 , exroneously placed as synonym of b. exodon. 
Col. Godwin-Ansten's original description is as follows :-

"Shell elongately fusiform, rather solid: sculpture very regular shallow

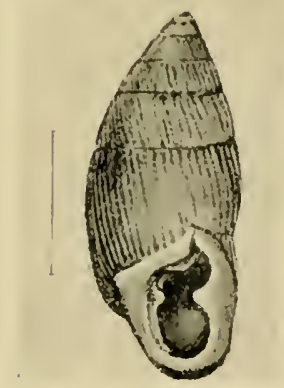

Fin: a.

(ExhaniET.)

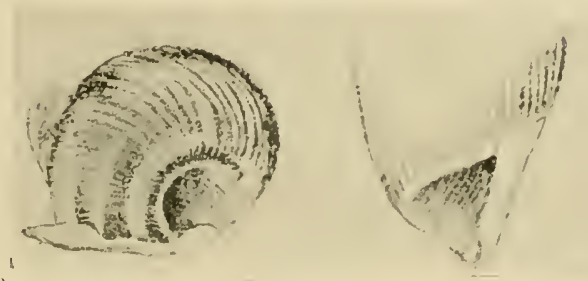

Fitr. b.

ribbing; colour wax-white, or dull pale umber; spire elongated, sides convex, apex blunt; suture shallow: whorls 6 , flatly convex aperture sulvertical, oval, one flat-shaped tooth on body whorl peristome continnous, with a narrow notch on the upper onter margin of the aperture; columellar margin strong, with a single tooth, and one largely dereloped triangular tooth on the onter margin.

"Major diameter $6 \cdot 1$, alt. axis $14 \cdot 5$, alt. apert. $6 \cdot 2 \mathrm{~mm}$."

"On the slopes of the ridge bounding the Gollonsir Valley, at an altitude over 500 feet." - Balfour.

This species was originally placed in the genus Ennum by Godwin-Austen, and consequently he was justified in employing the specific name bulfouri which he had already assigned to a species of Buliminus. As the present species is now considered to belong to the latter genus, it becomes necessary to give it another designation, and I therefore propose to associate it with the christian name of Professor Balfour, who collected it.

[This species was not obtained by us.-H.O.F.]

\section{Buliminus (Passamaiella) mirabilis, smith. (Plate xii. fig. 12.)}

Buliminus (Poswcemaiellu) mirablilis, Smith, Journ. Malacol., vol. vi. p. 34, pl. ı. fig. 2 ; Kobelt, Conch. Cab. (E1. 2), p. 617, pl. xciv. fig. 4 .

"Shell subglobose, acmminate above, purplish-brown, rimated, striated with sleuder oblique lines of growth; spire conoid, mammillated at the apex; whorls $5 \frac{1}{2}$, the two upper convex, smooth, the succeeding ones but very slightly convex, the last large, globose, slightly descending behind, but towards the aperture sub-ascending, showing behind the lip a deep pit, and being deeply excavated beneath the umbilical cleft; aperture ear-shaped, slightly exceeding balf the whole length; peristome incrassate, expanded, reflexed, livid brown, the margins united by a callus more or less thick, the outer within in the midlle furnished with a double white very prominent tooth, the columellar almed with a thick white penetrating fold.

"Length 23 , diameter $16 \mathrm{~mm}$. 
"Distinguished hy its globose form, colour, and the cluaracters of the aperture. In form this species bears a striking resemblance to a shell from Fernando Noronha, described by the anthor undel the name of

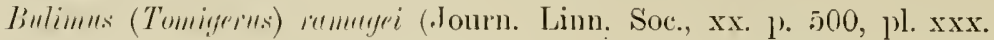
fig. 8), and the armature of the aperture, although different, is of the same character.

"B. isthmorlon, Martens, is smaller, differently coloured, and has a more oblique aperture, and the sculptme apjears to be rather coarser."

Sokotra : Arlho Dimellus (3500-4000 ft.).

One of the specimens from the above locality, in nice fresh condition, is light olivaceous lrown, becoming somewhat purplish towards the apex. The sutmre exhibits a very fine white threar-like line, bordered below with a broader purplish line. The entire surface of the shell also is microscopically spirally closely striated, giving to it a somewhat dull silky appearance.

[Under roots of shrubs, and bonlders. -..H.O.F.]

\section{Buliminus (Passamaiella) rotundus, Smith. (Plate xiii. figs. 1, 4.)}

Bulimimus (Passamerelle) rotundu., Smith, Journ. Malacol., vol. vi. p. 35, pl. v. fig. 4; Kobelt, (onch. Calb. (Ed. 2), p. 619, pl. xciv. fig. 6.

The following is my original description :-

"Shell glolose, conoid superiorly, excavated inferiorly, very little rimated, white; spire shortly conoid, submammillated at the apex; whorls $5 \frac{1}{2}$ slowly increasing, joined together by a moderately deep suture, the two npper convex, smooth, the following less convex, ohliquely, very finely and closely costulated, the last globose, not descending in front, excavated in the umbilieal region, and round the depression in front obtusely carinate, behind the lip deeply scrobiculate; aperture irregularly ear-shaped, contrieted; peristome white, slender, the margins almost united at both ends by a conspicnons callus, the onter within in the midrle produced and bidenticulated, the columellar reflexed, furnished with a slender penetrating fold, chamnelled at the insertion.

"Length 13 , diameter $11.5 \mathrm{~mm}$.

"Remarkable for its globular form, the fine costulation being finer than in F. Ins:amuiumus, the contracted, denticulate aperture, ice. The parietal calhus is separated from the extremities of the peristome, both above and below, by a narrow groove or channel."

Sokotra : Homhil, East Sokotra (1500-2500 ft.).

The series of specimens obtained by Dr. Forbes and Mr. Grant shows that this species, hitherto known from a single specimen only, varies somewhat both in size and form. The largest example is $16 \mathrm{millim}$. in length, whereas the smallest is only 11 . The difference in form chiefly relates to the greater elevation and aeuteness of the spire. The form of the aperture, and the charaeter of the peristome and the teeth within are very similar in all the specimens. 
[Almost all olitained on the top of Gebel Matagoti under the roots of plints and shruls. - Ir.li.().(t.)

9. Buliminus (Passamaiella) exodon, Murtens.

Buliminus rarlon, Martens, Machrbl. Dentsch. Malke. (ies, xiii. 1) 1336 (ISSI).

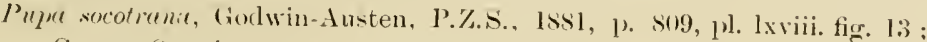

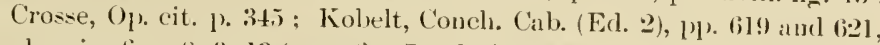
pl. xcir. figrs. \$, 9, I3 (non. fig. $7=$ B. bayleyi).

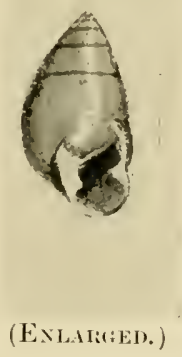

Lient.-Col. Godwin-Ansten original description is as follows :-

"Shell fusiform, oblate: sculpture smooth, covered with pale umber epiclermis ; spire with slightly convex sides; suture shallow ; whorls 6 ; aperture elongately oval, subvertieal ; peristome moderately thickened, slightly rimate on the middle of the onter margin, where there is a single rounded solid tooth : columellar margin strong, perpenclicular, with a well developed tooth.

"Major diameter $4 \cdot 0$, alt. axis $8 \cdot 0$, alt. apert. $3.5 \mathrm{~mm}$."

Sokotra: Aclho Dimellus (3500-4500 ft.).

[Found under stones. - H.O.F.]

10. Buliminus (Aehatinelloides) socotorensis, Pfeitfer.

Bulimu. (Achatinellojdes) rocotrensis, Godwin-Austen, P.Z.S., ISSI, 1. site. pl. lxviij. fig. I.

Bulimus vorotorensis, Pfeiffer, Zeit=ch. f. Malak, ii. 1) 1.57 (1845): ('rose, O1. cit. 1) 347 : Kobelt, Conch. Cab. (Ed. 2), 1. (i11, pl. xeiii. figs. o- (6.
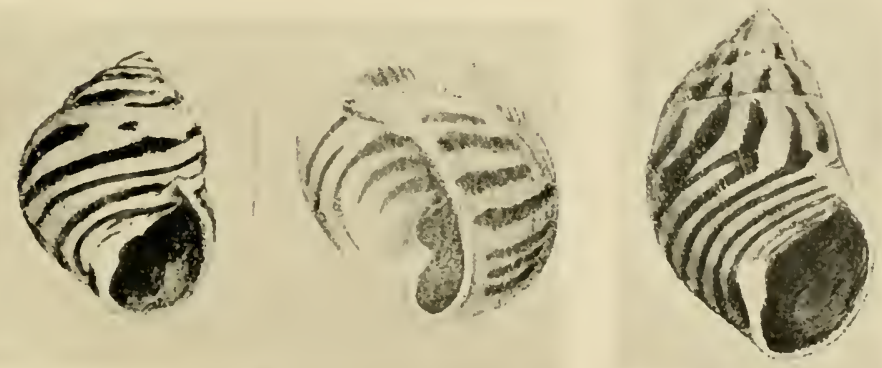

Flci, a.

FI:. b.

(ExuAR(ED.)

Fir: c. 
"Shell dextral, rotundately oval, very closely and narrowly rimate; sculpture close regular ribbing; colour white, the last whorl ornamented with very oblique regular lands of madker-brown crossing the eostulation at right angles, beeoming broader and more irregnlar on the apieal whorls but still very oblique; spire conical, apex subacuminate; suture slallow; whorls 5, rounled ; aperture sub-oblique, oval, angular above, with a strong callus on the body whorl ; peristome thin ; the colmmellar margin flat, with a strong plication.

"Largest specimens : major diameter $7 \cdot 0$, alt. axis $10^{\circ} 1$, alt. ap3rt. $62 \mathrm{~mm}$.

"Animal. Eye tentacles morlerately long, the oral tentacles long and dirk ; animal pale coloured, foot pointed."-(Gorluin-_usten.)

Sokotra: Wahamis (350-1000 ft.), and Dimichiro Valley.

[.Estivating in large colonies on the stems of trees and bushes.-H.O.F.] [This species is rery common on trees ('rotom, sp. ind.) on the plain of the valley at the mouth of which is the village of Gollonsir.-B.P.]

11. Buliminus (Achatinelloides) dahamisensis, sinith. (Plate xii. figs. 10, 14.)

Buliminns (Orlla) duhamixensis, Smith, Bull. Liverp. Mus.s, ii. p. 11.

Shell similar to the next species R. homlitemsis, but differently colonred, whitish or greyish, with oblique brown stripes more or less irregular, which often in the penultimate and nltimate whorls are very dark, almost black. Some specimens have very little painting upon the body-whorl, which is of an uniform greyish tint. Having seen a good series of both, it seems to me adrisable to consider them distinct species. These specimens in which the markings are very faint are very like the pale variety of $L$. homhilensis.

Sokotra: Hadibu Plain; Adho Dimellus (3500-4000 ft.); and Dahamis, $(350-1000 \mathrm{ft}$.).

Some very pretty examples obtained by Mrs. Bent are smaller than the type, being only 13-14! millim. in length instead of $18 \frac{1}{2}$.

[Astivating on stems of shrubs.-II.O.F.]

12. Buliminus (Achatinelloicles) homhilensis, simith. (Plate xii. fig. 13.)

Bulimimus (Orella) homhilen.is, Smith, Bull. Liverp. Inss., ii. p. 11.

Shell narrowly perforated, ovate acrminate above, obliquely finely and closely costulated, dirty white or greyish blotehed and striped with dark lorown, the stripes in the last whorl being interrupted at the periphery, which is generally encircled with a pale zone. Below this the shell is paintel with fue irregular lineation and punctulation of a lighter brown colom ; whorls 7 , slightly comvex, divided by an almost horizontal snture; the two apical are pellucid, smooth, and shining, the last slightly ascending; aperture inversely ear-shaped, rich brown, often excseding half the entire length of the shell; the onter lip is paler than the aperture, slightly thickened and faintly expanded; 
columella expanded and reflexed above, white stained with brown, subdentate or plicate upon the inner ellge.

A variety is almost entirely white, with the exception of a few scattered brown dots and some faint striping npon the npper part of the spire.

Length 19! , dianeter $11 \mathrm{~mm}$; aperture $10 ! \frac{1}{2}$ long, 6 broad. $\Lambda$ small specimen is 13 millim. long and 7 in width.

Hombil, $1500-2500$ feet, and Imichiro Valley.

Allied to B. virberli, Martens, hut shorter, more ovate, with a less prodnced spire and a wider and differently shaped month.

[.Estivating in colonies on trees and shrubs. - II.O.F.]

13. Buliminus (Achatinelloides) lævior, simith. (Plate xii. fig. 8.)

Buliminus (Orella) lerior, Smith, Bull. Liverp. Muss., ii. p. 11.

Shell perforate, ovate, white, striped with brown, the longiturlinal stripes on the last whorl intermpted in the middle; below, the shell is ornamented with narower oblique brown lines, almost smooth, striated with the oblique lines of growth: whorls $6-\bar{\tau}$, somewhat convex, the two apical pelheid, the last sub ascending ; the aperture inversely carshaped, brown inside ; the hip is white and not expanded ; the colnmella white, marked with a brown spot, dilated, reflexed, plicate-dentate. Length $14 \cdot 0$, diameter $96 \mathrm{~mm}$; aperture $9.0 \mathrm{~mm}$., + broad.

Sokotra: Jena-agahan (1:200-2500 ft.).

In form and colour very like B. dulumisensis, homhilensis, and sorotorensis, but wanting the fine costulate sculpture of those speeies, the surface being almost smooth. The longitudinal colour-markings in the "pper' whorls are nearly upright, not obligne.

14. Buliminus (Achatinelloides) hadibuensis, Croduin-Ansten.

Buliminus (Achatinflloirles) hadibuensis, Godwin-Austen, P.Z.S., 1881, 1. S03, pl. Ixviii. figs. 3, 3a, 3b ; Crosse, Op. cit. p. 350 : Kobelt, Conch. Cab. (Ed. 2), p. 6h0, 1). xciii. figs. :2, 3.

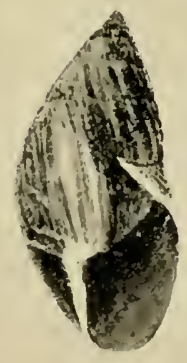

FIria. a.

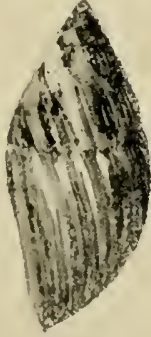

Fir. 1.

(ENLARI:ED, )

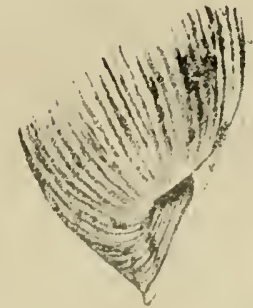

Fir: c. 
Lieut.-Col. Gorlwin-Austen's original description is as follows :-

"Shell elongately fusiform, rather broadly rimate in well-grown shells, closer in the younger specimens, coarse but regular costulation; colour ochraceous-brown with streaks of madder-brown rumning parallel to the costulation, these again overlaid with minute specks of black, apex nearly black; spire elongately pyramidal, slightly convex, subacuminate; suture shallow, adpressed; whorls 6, body whorl the largest, sides very flatly convex: aperture orate, more than half the length of the axis ; peristome with sharp edge, slightly reflected over the rimation, regularly curved on the outer margin ; columellar margin straight, with a slight sinuation within the aperture.

"Longest specimen $10 \cdot 2$, alt. axis $21 \cdot 7$, alt. apert. $12.5 \mathrm{~mm}$. Shortest specimen 90 , alt. axis $19 \cdot 7$, alt. apert. $11 \cdot 2 \mathrm{~mm}$.

"This shell is closely allied to B. (Arhutinelluiles) bulfouri, Godwin Ansten ; but it may be known at once by its more elongate form, coarser senlyture, and elaborate ornamentation."

["Most abundant on the trees upon the plain in the vicinity of Harlibu, on a Croton, being the commonest unter-shrul.."-li.b.]

Sokotra: Dahamis (350-1000 ft.).

The varieties (Vars. allu ef mino') mentioned by Godwin-Austen are, in my opinion, specifically distinct, and constitute the next species.

Two specimens of the present form were kept alive for some time. The animals were uniformly pale, excepting the eyestalks. These in one specimen were slender, of a darkish tint, and slightly knobbed at the tips. In the other example they were semi-tramsparent white, and quite short and stumpy, having a rery abrormal look.

[Abundant on trees, restiviting in immense colonies, strongly adfixed to the bark, often simulating its colomr.-H.O.F.

Some of the largest colonies oecupied an area of about two square feet, and must have included thousands of individuals of all ages, so elosely approximated to one another that the stem of the tree was entirely concealed._II.I.O.G.]

15. Buliminus (Achatinelloides) mistus, s\%. n. (I'late xii. fig. 9.)

Bulimimus (Achatinelloides) harlibuensis, vars. albe et minor, Godwin. Austen, P.Z.S., lss1, p. 804, 11. Ixviii. fig. 4.

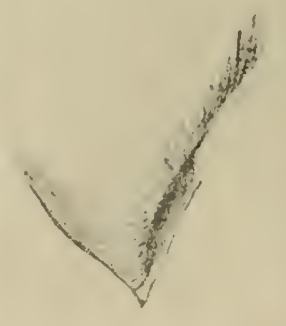


Shell elongate-orate, pointed ahove, rimate, pale hrownish, with longitudinal white streals, which are interrupted at the periphery in the last whorl, obliquely tinely costulate; whorls 7 , regularly slowly increasing, the two llpermost smooth, convex, brownish, the rest slightly conver, with a somewhat oblinne suture, the last slowly descending, roundly erested around the rimation; aperture inversely anriform, a little less than half the entire length, brownish within; peristome white, a trifle thiekened, expanderl, the margins joined by a thin callus, the columellar twisted or plicate within, and forming an ubtuse angle with the basal edgre.

Leugth $17 \cdot 0$, thiameter $8.0 \mathrm{~mm}$; ; aperture $8 \cdot 5$ long, $5 \cdot 0$ broat.

Siskotra. - (Bulfiuri)

Quite distinet from li. luulibuensis. The form is difierent, the aperture being shorter in proportion to the whole length of the shell. The costulations are finer, sharper, and more numerous, the style of coloming is different, and the peristome, besides being white, is more expanded.

The shell upon which Gorlwin-Ansten founded his var: cllu of li. hutiburnsis is merely a sm-bleached specimen of the present species. It is + millim. longer than the fresher specimen, which has been regarded as the Type.

16. Buliminus (Achatinelloides) densicostulatus, $\%$ \%. (Plate xiii. fig. 10.)

Shell ovate-fusiform, rimate, white, with slightly ollique, very close-set, very fine, elevated strie; spire conical, with straight sides; whorls 7-s slowly enlarging, separated by a nearly horizontal suture, the first two corneous, rounded, the rest flat, the last slightly angled at the middle, the angle gradnally disappearing in front, not descending; aperture small, light brownish, inversely ear-shaped, less than half the entire length: peristome white at the edge, slightly thickened and brown within, the right margin not expanded, the columellar reflexed, in the middle conspicuonsly miplieate within.

Length 18.0 , diam. $9.9 \mathrm{~mm}$, ; aperture 8.0 long, 4.0 broad.

Sokotra.--(Mr: Bent.)

Two specimens collected by Mrs. Bent. Very distinct on aceount of the conical spire, flat whorls, small aperture, and the excessively fine crowded costulations.

[This species was not obtained by us._H.(1.F.]

17. Buliminus (Achatinelloides) balfouri, truluin-Ansten.

Buliminns (Arhatinelloides) belfouri, Gorwin-Austen, P.Z.S., 1ss1, p. s04, pl. lxviii. fig. 5, sit.

Orella rielecki, Martens (part.), Kobelt, (Jonch. Cab. (Ecl. 2), p. 61:2, pl. xeiii. fig. 7 . 
Lient.-Col. Gorlwin-Austen gives the following description of the type :-

"Shell narrowly and deeply rimate, ovately fusiform, solid: sculpture

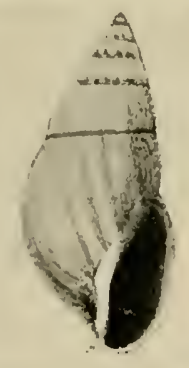

FIr: a.

(ENLIRTED,

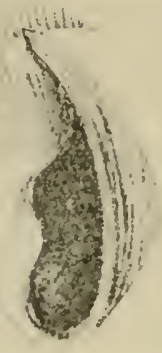

Fir:. 1).

regular elose oblique costulation; colour generally white, with a few dark distant longitudinal splashes on the four apical whorls; spire elongately conoid, sides convex, apex moderately sharp, suture shallow; whorls 7 , last the largest, sides convex; aperture elongately orate, nearly half the length of the shell, with a strong callus on the borly whorl in many specimens; peristome sharp, straight on the outer margin ; colmmellar margin straight, reflected orer the rimation, with a well-marked internal fold.

"Size : Longest specimen-major dimeter $10 \cdot 0$, alt. axis $21 \cdot \overline{0}$, alt. apert. $10.0 \mathrm{~nm}$. Shortest specimen-mijor diameter $9 \cdot 5$, alt. axis $17 \cdot 8$, alt. apert. $9.5 \mathrm{~mm}$.

"Animal pale ochraceons with minute speckling of brown; tentacles pale, elongate, attemute, pointed. In some the head is mottled dark olivaceous; no pallial line."

[Not obtained ly us. - H.O.F.]

Var. elongata, $\varkappa \cdots \cdot \pi$. (Plate xii. fig. 11.)

Bulimine (Ovella) theodore, Smith, Bull. Liverp. Muss., ii. No. 1, p. 12.

Shell fusifornt-ovate, umbilicate, obliquely costulate-striated, white, painted with brown stripes and irregular spots : the stripes in the last whorl interrupted in the middle; adorned below with fine oblique brown lines; whorls 8 slowly increasing, somewhat convex, the two upper smooth, dirty white, the last slightly ascending in front; aperture narrow, deep brown, equalling half of the entire length of the shell; lip pale, hardly expanded; columellar white, tinged with brown inside, dentate-plicate, and reflexed.

Length 25.5 , diameter $11.0 \mathrm{~mm}$; aperture $12.0 \mathrm{~mm}$. long and 5.0 broad.

This form is allied to $B$. riclveclit, Martens, but is more elongate, with higher whorls and a somewhat differently shaped aperture. The body whorl also is somewhat saccate.

Since the publication of the original description of 1 , theolore (Op. cit.) further study of the shells induces me to consider them merely as an elongate form of this species, which at present I am unable to unite with $L$. riebecli, as has been done by Martens and Crosse. In the 
deseription the term "grossiuscule eostulata" does not apply to B.

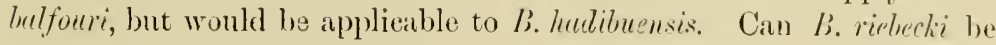
a pale variety of that speeies? The figure given by llartens is certainly more like hulihirusis than the present species, and the rlescription of the style of eoloration, "maculis parvis ferrngineis vel griseis adsper'sa," agrees hetter with the former.

The animal of the var. elongute was of a dirty white colour, finely marbled with grey, darker alowe the heal in front of the eye-tentacles, with a black streak extending barkwards from each.

[This species was not obtimed hy us. - II.(). F.]

18. Buliminus (Achatinelloifles) riebecki, Murten:

bulimimu richeli, Martens, Nachrbl. Dentsch. Malak. Ges., xiii. 1) 137

(Iss1) ; Crosse, O1). cit. p. 34! ; Kobelt, Conch. Cab. (Erl. 2), 1) (i)!2, pl. xeiii. figs. $12,13$.

The original description may thus be translated :-

Shell ovate-olsong, rimate, rather coarsely costulaterl, whitish, with seattered small redklish or greyish spots: whorls 7 , regularly increasing, with a molerately impressed suture, the first smooth, small, the last attenuate below the midlle: the aperture occupying half the shell, narrowly ovate; peristome thickened, outer margin much curved above, then straight, the lasal somewhat expanderl, sharply curved, the colmuellar dilated alove.

Length 19, flimeter $10 \mathrm{~mm}$; apertme 10 long, 5\%) loroar.

Sokotra : Wadi Kisehen (at 1000 metres).--(1/erters.)

Not obtained by Mr. Grant and Dr. Forbes, muless this species proves to be a form of $B$. hatiluensis. Distinct from $B$. (Aclutimelloiles) lualfonri of Godwin-Austen.

19. Buliminus (Achatinelloides) gollonsirensis, Guluiu-Austen.

Butiminus yollonsivensix, Godwin-Austen, P.Z.S., 1881, 1) 805, pl. 1xix. fig. 10 ; Crosise, Op. cit. p. 350 ; Kobelt, Conch. Cab. (Ed. 2), 1) 609, pl. xeiii. fig. 1.

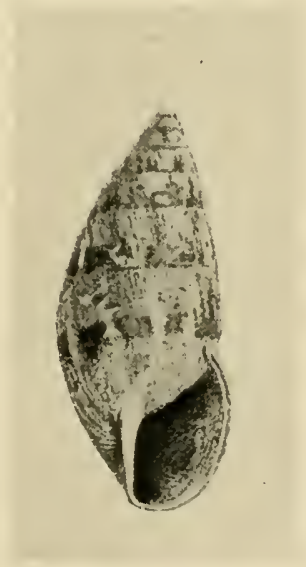

(ENI.IRGED.) 
The following is Lieut. Col. Godwin-Austen's original description :-

"Shell ovately fusiform, narrowly rimate, solicl; sculpture regular, rather pronounced costulation; colour white or yale buff, minutely mottled with brown, with very irlegular, jaggy, transverse, short strealis or patches of darker brown, slightly oblique to the costulation, which do not reach to the suture above; spire elongately pyramidal, sides flatly convex, apex subacuminate, suture shallow; whorls $\bar{T}$, sides flat; aperture ovate, consiclerably more than one-third the length of the axis ; peristome sharp, flatly convex on the outer margin and rounded below ; columellar margin reflected, nearly covering the rimation, with an internal fold.

"Longest specimen-majol diameter $7 \cdot 3$, alt. axis $16 \cdot 8$, alt. apert. $8 \cdot 0$ mm. Shortest specimer-major diameter $5 \cdot 5$, alt. axis $13 \cdot 0$, alt. apert. $6.8 \mathrm{~mm} . "$

["On trees, not nucommon on hill slopes, these are from those bounding the Gollonsil Valley."-B.b.]

[This species was not obtained by us.-H.O.F.]

20. Buliminus (Achatinclloirles) longiformis, truluin-dusten.

Buliminus (Achatiulloiles) longiformis, Godwin-Austen, P.Z.S., 1881, p. s06, pl. Ixviii. fig. \&; Crosse, Op. cit. 1. 351; Kobelt, Conch. Cab. (Erl. 2), 1). 614, pl. xciii. fig. 10.

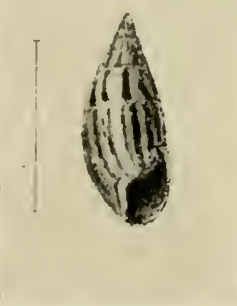

(ENJARGEJ).)

The following is the original description of the species given by Lient.-Col. Godwiu-Austen :-

"Shell very narrowly rimate, polished, solid, very elongately fusiform ; sculpture indistinct transverse strix; colour white, with elongate more or less dark-brown streaks of colour extending to apex, less defined on basal end ; spire elongately pyramidal, sides flatly convex; suture shallow ; whorls $\bar{\tau}$, sides flot; aperture ovate, rather more than half the length of the axis: peristome sharp on the outer margin which is slightly convex; columellar margin rather thickened, almost concealing the rimation, with an internal fold.

"Longest specimen-major diameter $7 \cdot 2$, alt. axis $19 \cdot 5$, alt. apert. $8.0 \mathrm{~mm}$. Medium specimen-major diameter $6 \cdot 9$, alt. axis $17 \cdot 0$, alt. apert. $7 \cdot 5 \mathrm{~mm} . "$ 
Soliotra: Homhil (1500-2500 ft.).

'This and the preceding species are very closely related, differing only in colour marlings. L. lonifformis varies in size, some specimens being 20 millim. long, whilst others, equally adult, are only 14 . The number of the whorls ringes from $6 ! 2$ to $8 !$

[In the erevices of the limestone rocks, and under stones and the roots of plants on the top of Matagoti.-H.O..F.]

21. Buliminus (Achatinelloides) tigris, Goluin-A usten.

Bnliminus (Adhatinelloides) tigrix, Godwin-Ansten, P.Z.S. ISs1, p. so.,

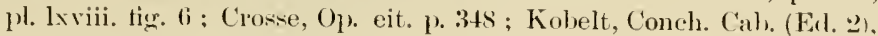
p. 611, pll. xciii. fig. 4 .

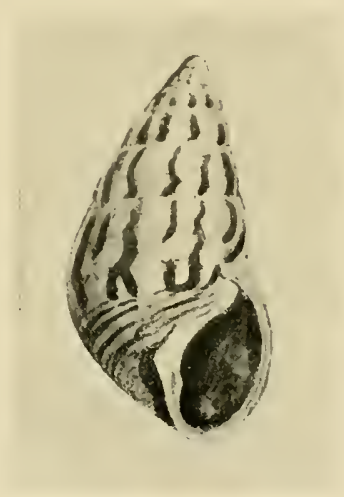

(EXLAREET.)

Lient.-Col. Godwin-Ansten gives the following description of the type :"Shell rimate, ovately fnsiform, solid, smooth and polished ; senlpture, lines of strix discemible under lens; colom white and buff-brown, streaked diagonally below with narrow bands of brown; above, each whorl ornamented with jagged regularly disposed transverse bands of the same colour ; spire elongately pyramidal, sirles slightly convex; suture shallow; whorls 6 , sides slightly convex; aperture oval, subvertical; peristome thick, regnlarly convex on the onter margin; columellar margin with a strong plication, very little reflected,

"Longest specimen-major diameter" $6 \cdot 0$, alt. axis $12 \cdot 5$, alt. apert. $5 \cdot 7 \mathrm{~mm}$. Shortest specimen-major diameter $5 \cdot 5$, alt. axis $10 \cdot 8$, alt. apert. $4.5 \mathrm{~mm} . "$

[Taken on stems of Irucremu on limestone at altitules of 2000 feet.B. B.]

Very near B. longiformis and gollonsirensis, but shorter, with slightly more rounded whorls, and a more open umbilical fissure.

[This species was not met with by 11 s.-II.O.F.]

22. Buliminus (Achatinelloides) zebrinus, ciuluin-ilnsten.

Butimimus (Ovella) sebrimus, (Gorlwin-Austen, P.\%.S., 1881, 1. sot, pl. Ixviii. fig. 7 ; Crosse, Opl. cit. p. 34 个. 
Lieut.-Col. Godwin-Austen thus describes the type specimen of this species :-

"Shell rimate, elongately fusiform, polished, solid ; senlpture indistinct

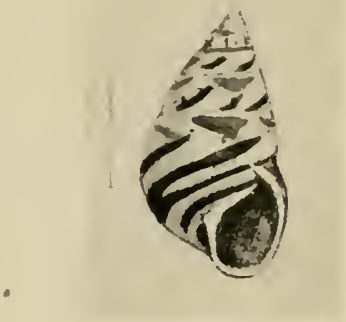

(ExLiRtien,)

transverse strie under lens; colonr milky white, with fine welldefined spiral bands of madder-brown on the last whorl, which near the suture turn sharply and change to a dark ochre tint; the dark bands are more irregular and jaggerl towards the apex; spire elongately pyramidal, very slightly convex; suture shallow ; whorls $6 \frac{1}{2}$, sides somewhat flattened; aperture subrertical; peristome thickened; columellar margin with a slight fold.

"Longest specimen--major (liameter $5 \cdot 0$, alt. axis $10 \cdot 8$, alt. apert. $5 \cdot 2 \mathrm{~mm}$. Shortest speeimen - major diameter $4 \cdot 0$, alt. axis $9 \cdot 4$, alt. apert. $4.0 \mathrm{~mm}$."

[On the stems of Iracrum on limestone at orer 2000 feet with B. figris.b.B.]

A smooth species, with very remarkable colour malkings, of a perfectly different form to B. socotoreusis, with which it is compared by M. Crosse.

[This species was not observed hy ns.-H.O.F.]

23. Buliminus (Achatinelloirles) acutus, śmith. (Plate xii. fig. 7.)

Bulimimus (Orelle) arutus, Smith, Journ. Malacol., vol. vi. p. 36, pl. v. fig. 5; Kobelt, Conch. Cah. (Ed. 2), p. 614, pl. xciii. fig. 9.

Shell ovately fusiform, narowly perforate, shining, black and brown horn-colour, ornamented with white longitndinal, narrow, irregular stripes which, below the middle of the last whorl are oblipue, sculptured with searcely pereeptible lines of growth; spire elongately pyramidal, obtuse at the apex; whorls 7 slowly inereasing, the two superior yellowish, convex, the rest rather flat, the last not deseending, subacuminate in front; aperture narrowly oval, deep brown insicle, a little orer one-third of the entire length of the shell; peristome yellowish, somewhat thin, with the external margin not expanded, the colnmellar narrowly reflexed, white at the insertion, slenderly uniplieate in the middle within.

Length 13.0 , diameter $5.4 \mathrm{~mm}$; ; aperture $5.0 \mathrm{~mm}$. long, 2.5 broad.

Sokotra (1/is. Beret.) 
The acmminate spire, flattened whorls, and style of coloning are the distinguishing features of this pretty speeies. The ground colour of the last whorl is lighter than that of the two preceding whorls, and, besides the irregular white lines and stripes, a few white dots are scattered irregularly over the smifice. The sliell is very smooth and glosis, and the embryonic shell consists of two convex whorls of a yellowish horn eolour: Allied to bi. lompitmanis, Gorlwit-Ansten, but smaller, with a more amminate spire, and with slightly more convex whorts, at larger umbilical perforation and obligne basal colontmarkings.

[This species was not obtained by us. - H.II.F.]

24. Buliminus (Achatinelloiles) semicastaneus, Guluin-Awsten.

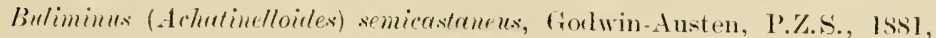
p. S11, pl. Ixviii. figs. 9, 10; Crosse, Op. cit. 1) 349 ; Kobelt, Conch. (ab. (Ed. 2), p. (il:3, fl. xciii. fig. s.

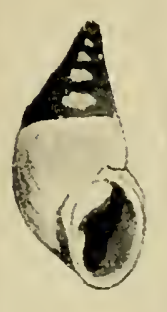

Fici. a.

(EXILIIIEI)).

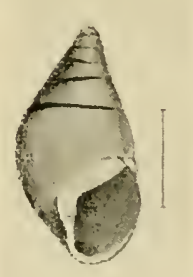

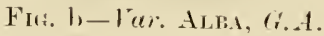

Col. Gorlwin-Austen gives the following rescription of the Type:-

Shell rinate, solid, fusiform ; sculptme fine oblique striation, to the naked eye polished; colour milky white on last two whorls, chestunt or siennathown on the five apical ; spire elongately yytamiclal, becoming rapilly extemate at the apex, sides convex; suture rather shallow; whorls $\bar{\tau}$, body-whorl tumicl, side convex; aperture ovate, suboblique; peristome contimuons as a strong callus on the body-whorl, rather flattened on the onter margin; colmmellar margin with wellmarkerl fold, oblinne, somewhat thickened and angulate near the upper inner margin.

"Longest specimen--major diameter 5.5, alt. apert. $5 \cdot 5$, alt axis $100 \mathrm{~mm}$. Shortest specimen-major diameter $5 \cdot 5$, alt. apert. $5 \cdot 5$, alt. axis $95 \mathrm{~mm} . "$

[South sille of the island on limestone rocks, nearly 1000 feet. Nine specimens were found. - b.li.]

Sokutra : Arlho Dimellus (3500-4500 ft.).

I do not feel at all convinced that the shells, consielered by Godwin-

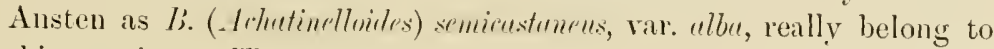
this species. 'They have flatter whorls, and conseguently a less impressed suture, ami the labrum appears to be less thickened. 
The two specimens in the British Musenm-one of them (see fig. b., p. 1.27), that figured by Godwin-Austen, P.Y.s.s., 1881, pl. Ixviii. fig. 10-alre both dead bleached shells.

The single specimen obtained by Dr. Forbes and Mr. Grant at the alove loeality is uniformly brown, and has a slightly thinner onter lip than the type, and seems to have relationship to li. arlonensis.

25. Buliminus (Aehatinelloiles) innocens, Simith.

Buliminu: (Orelle) innoren., Sunith, Journ. Malacol., rol. vi. p. 36, pl. v. fig. (; ; Kobelt, ('onch. Cab. (Ed. 2), 1) (i1, pl. xeiii. fig. 11.

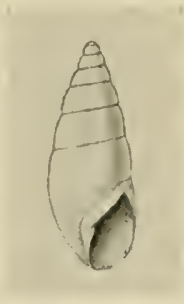

(ENTARTIED.)

Shell small, narrow, ovately fusiform, rimated, white; whorls 7 , gently inereasing, the two apical smooth, convex, the rest flattish, striated with oblique and closely set costula, separated hy a shightly oblique, distinet, suture, the last not lescending; aperture small, narow, a little exceeding one-third the whole length of the shell, white; peristome thin, the outer margin hardly expanded, the columellar slightly reflexed, furnisherl within with a slender obliqne fold.

Length 12.0 , diameter $4.0 \mathrm{~mm}$; apert. $4.0 \mathrm{~mm}$. long, 2.0 broad.

Two dead speeimens colleeted by Mrs. Bent are all that are known of this speeies, which may be recognised by its slender form, and rery fine, close-set costulas.

26. Buliminus (Achatinelloiles) adonensis, Goluin-Austen. (Plate xiii. fig. 11.)

Butiminus: (Puchnodus) udonensis, Godwin \& Austen, P.Z.S., 1881, p. s08, 1). lxix. tigs. !, 9a ; Kobelt., Conch. (ab. (Ed. 2), 1. 641, pl. xevii. fig. 13 .

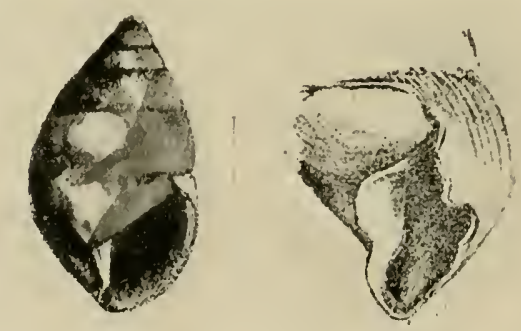

(ENLARGEU.) 
Lient.-Col. (xorlwin-Austen gane the following description of the Type :

"Shell dextral, orately fusiform, thin, semi-transparent: sculpture under. high power, epirlermis rough with a few irregular transverse ridges; colour olive-hown; spire elongate, sides Hatly convex; apes blunt, suture well marked: whorls 6 , sirles rather Hat; aperture wal, oblique : peristome thin ; collumellan malrgin Hat. triangular, with a slight enrve or twist.

"Size majon" diameter 9.5, alt. axis s.5 mm."

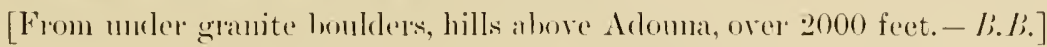

The above deseription has, howerer, heen founded upon immatme specimens. An arlult shell collected ly Mrs. Bent shows that the species is elosely relaterl to li. semirusturrms. It is a very small form, consisting of six slightly comex (not "lather that") whorls, narowly marginate beneath the suture. The apertme is inversely aniform, the peristome thin, hut a little expanded, the columella margin being lowadly dilated, with a prominent fold on the immer adge.

[This speeies wats not olutiuned by 11s,--11.O.F.]

27. Buliminus (Pachnodus) fragilis, Gorlwin-Austen. (Plate xiii. fig. 13.)

Buliminus (Pachnolus) fregilis, Godwin-Austen, P.Z.S., 1ss1, p. Sus, pl. lxix. fig. s ; Kobelt, Conch. Cab. (Erl. -2), p. 640, pl. xevii. fig. 11.

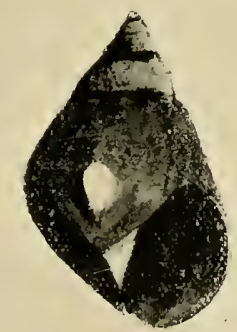

(ExlaAigen.)

Lient.-Col. Godwin-Ansten gives the following description of the Type:"Shell dextral, narrowly rimate, obtusely pyriform, very thin ; sculpture fine irregular transverse lines of growth; colour olive-green; spire pyramidal, sides flat, apex sharl, tapering rapidly, suture moderate; whorls 5, sides flat, last whorl large: aperture obliqne, ovate; peristome thin ; colnmellar margin straight, thin and reflexerl.

"Major diameter $4 \cdot \bar{\tau}$, alt. axis $7 \cdot 5$, alt. apert. $3 \cdot 2$ mm."

[From mider granite boulders, hills above Arlomia, orer 2000 feet.-B.F.] Sokotra : Arlho Dimellus (3500-4500 ft.).

A single specimen was obtained at this locality, and is now in the Lord

Derby Museum, Liverpool. Some examples received from Mrs. Bent are much larger than the Type, which is merely a half-grown shell. 
They have an additional whorl, and are 11 millim. in length. The whorls, althongh described as flat, are in reality slightly convex, as shown in the figure above from the P.Z.S., 188], pl. lxix. fig. 8.

28. Buliminus (Pachnodus) heliciformis, Golwin-Anston.

Buliminus heliciformis, (iodwin-Austen, P.Z.S., 1881, 1) s07, pl. lxix. figs. 7 , Ta; Crosse, p. 3.5] ; Kobelt, Conch. Cab. (Ed. 2). p. (j40, pl. xerii. fig. 12 .
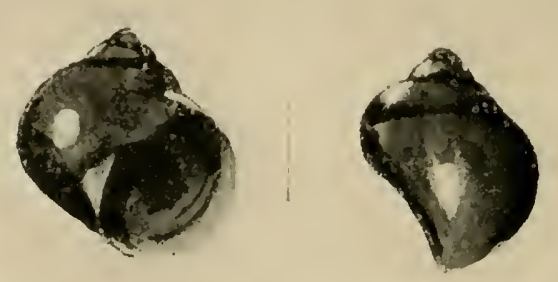

(ENLATRED.)

The single specimen upon whieh this species was founded is evidently only the young state of a shell, which may not eren belong to the genus Buliminus.

[The urrurrence of the following speries in Soloton requires comfirmution :-

(a) Buliminus candidus (Lemmerk).

Pupu candirla, Lamarck: Anim. S. Vert., vi. part 2, 1. 106 (1822); Arabia. Crosse, Op. eit. p. 3.5.2.

(b) Buliminus labiosus (Miiller).

Melix Inbionus, Müller, Verm. Hist., ii. p. 96(17it) : Crosse. Op. cit. p. $35 \overline{3}$.

Arabia. (Kiister and Brit. Mus.)

Reported also from C. Guardafui.

(c) Buliminus prochilus, Bour\%.

Bulimus mochilus, Bourguignat, in Révoil, Voy. Comalis, Moll., p. 18, pl. ii. fig. 21 (1852) : Crosse, Op. cit. p. 3.53.

Probably Arabian.

(d) Buliminus albatus, F'́rs.

Melir albatre, Férussac. Mss. Pfeiffer, Symbolit, ii. p. 42.

Bulimus bicinctus, Réchuz., Revue Zool., 1843, p. 4.

Bulimus condirlissimus, Pfr., Malak. Bl., v. p. 239 (1S5s) ; Crosse, Op.

Arabia. cit. 1. 352 ; Kobelt, Conch. Cal). (Ecl. 2), p. 61., pl. xciii. figs. 14, 15.

b. bicinctus and $B$. cundilissimus were both deseribed as Sokotran species. The latter was founded upon young specimens of the unbanded variety of $B$. albutus. 
(e) Buliminus contiguus, Rierte.

Bulimus contiguus, Reeve, Conch. Icon. v. Bulimus, is: (1849) ; (rosse, Op. cit. 1. 3.5.3.

Abci-el-Kuri.

(f) Buliminus artufelianus, . Ineey. (Plate xiii. fig. 19.)

Buliminns urtufelianu., Ancey, Crosse, Op. cit. p. 348.

Althongl the locality of this species is not known with certainty, there seems a strong probability that it is either Sokotra or Abcl-el-Kuri, judging from the great resemblance the shell bears to certain forms from these islands. It is not at all related to $B$. socotorensis, to which species М. Crosse relegated it, as a variety. It is much more nearly allied to B. fusentepicutu, Smith, from Abd-el-Kuri. In coloration it is almost identical, but differs in general form, in having more convex whorls, and in being much more finely striated. I am enabled to note these differences through a comparison of the mique type kindly lent me liy Mons. Ancey.]

\section{STENOGYRID尼.}

\section{Stenogyra, shuttleworth.}

29. Stenogyra (Riebeckia) sokotorana (1Mutrus). (Plate xiii. fig. 15-a young shell.)

Stenogyra fumifirata, Godwin-Austen, P.Z.S., 1581, p. 810, 11. lxix. figs 2, Lat : Crosse, Op. cit. p. 354.

Achritina solotorama, Martens, Nachr. Mal. (ies., xiii. p. 13: (1S81).

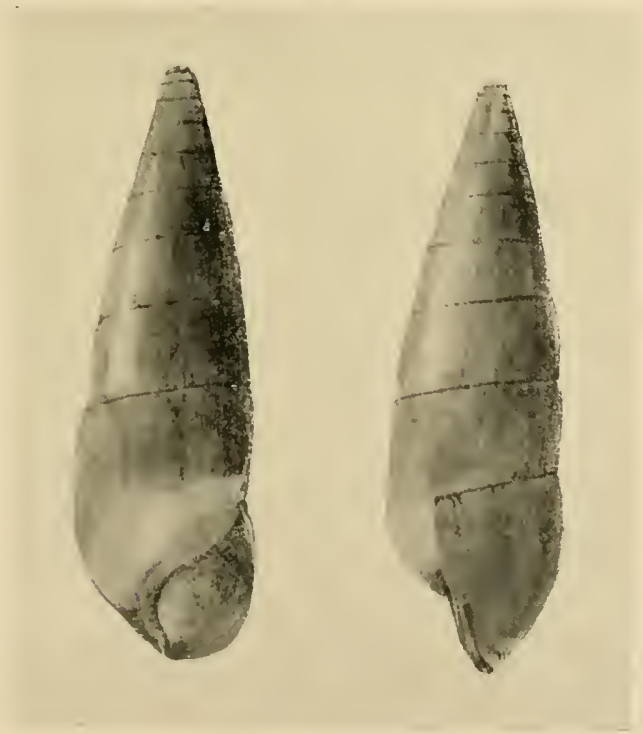

FIti. a.

Fur. b. 
Lient.-Col. Codwin-Austen gives the following rlescription of the Trpe of S. fumificutu, olstained lir Professor Balfonr:-

"Shell dextral, elongately tureterl, solis, not rimate : sculpture irregularsized fine transverse lines of growth crossed by spinal lines, giving a cloth-like appearance: colom rudrly oche: spire elongate, sides eonvex : apex entracting lather rapilly at the sixtl whorl, rounderl : suture shallow, lut well marked; whorls 11, regular, flat-sirlerl: aperture semiovate, angular ahove, rounderl below, nearly vertical ; peristome thin, eolumellar margin strong, simple, slightly curved inwards at lase.

"Size : major cliameter 18.5 , alt. apert. $17 \cdot 5$, alt. axis, $59 \cdot 0 \mathrm{~mm}$."

[Common on limestone at east end of islancl. This shell is used often lyy the natives for a pipe lowl. - B.D.]

"This is a remarkal,le form, also with characters somewhat like Burillum, and may eventually be placed in a sub-gems of its own next it amd Piosopeus."

Sokotra: Dahamis.

In this species the apex is large, and the suture, especially in the upper whork, is distinetly channelled.

[In the ground (often deeply buried), almost always dead, in enormous numbers together, under ledges of roek.--H.O.F.]

30. Stenogyra (Riebeckia) decipiens, smith. (Plate xiii. fig. 14-a young shell.)

Stenogyme (Riebeckice) deripiens, Smith, Joum. Malacol, vol. vi. p. 3i.

"Shell similar to that of $s$ soliotormu, lut more attenuated at the apex : sutme not chamelled : senlptme finer and not eancellated.

"Length, 8s.0, diameter $30 \cdot 0 \mathrm{~mm}$. ; apert. $:-7 \cdot 0 \mathrm{~mm}$. long.

"Length $7 \AA 0$, diameter $25 \cdot 0 \mathrm{~mm}$. : apert. $2.0 .0 \mathrm{~mm}$. long."

Sokotra: Arlho Dimellus (3500-4000 ft).

Larger than S. soliotomu. "Althongh quite similar in general appearance," as I have stated in the Jomrmul of Mulucology (loe. cit.), "this species is eertainly distinct from $S$. soliotorum. The top of the spire is more slender, the suture is not deeply cut or chimnelled, and the seulpture is much finer, consisting of fine lines of growth and excessively fine spiral strie. It is possible that some of the shells figured by Martens (Courh. Miftlieil. vol. ii. pl. xxix.) may helong to this species, figs. $7 \mathrm{a}, 7 \mathrm{~b}$, and $\&$ especially lawing a very striking resemblance to it."

[ Under gromud at the hase of high granite eliffs.-II.0.F.]

31. Stenogyra (Riebeckia) gollonsirensis, Guluin-Austen. (Plate xiii. fig. 12.)

Stenoyyru gollonsirensi., Gorwin-Austen, P.Z.S., IS81, p. 809, pl. lxix. fig. 1: Crosse, Op. cit. p. 3\%.r. 
Lient.-Col. Golwin-Ansten wives the following description of the Type specimen, collected by Professor Bilfom: :-

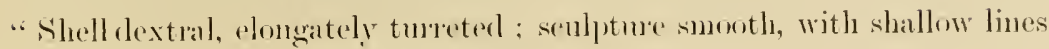

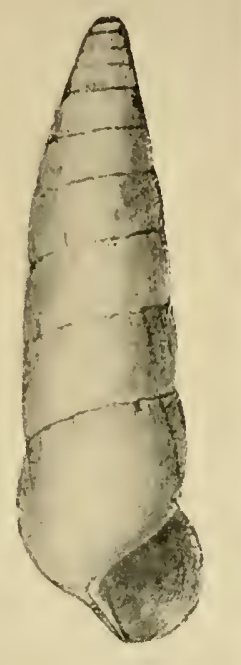

of growth: colour dull white; spire turreted, apex romoled, solid; suture moderately inpressed; whorls 12 , sides very slightly convex: aperture fusiform ; peristome thin ; colmellar margin solid, straight and scarcely reflected.

"Size: major" cliameter $18 \cdot 2$, alt. axis $61 \cdot 8$, diameter apert. $9 \cdot 2$, alt. apert. $14 \cdot 3 \mathrm{~mm} . "$

[On limestone at an altitule of 1000 feet on the top of the ridge wrerlooking Gollonsir village, and on the sonth-west of it : not almumant in this locality.-.-li.li.]

"In the form of its aperture this shell approaches the sul-gems Ibucillum of Theribald from Eistern Indlia."

Sokotra: : Hombil (1500-2500 ft.).

This speeies is about the same size as solotomu, lut differs in form and sculpture. The body whorl is rery much shorter and the other whorls higher than in that species. In fresh specimens the senpture consists of fine lines of growth, crossed by excessively fine crowded spiral strix, giving the surfice a subgranular textured appearance. The epidernis is yellowish olive, interrupted at the midcle of the body-whorl, so that the lower half is whitish. Here and there oecur a few brown streaks in the direetion of the lines of growth. The 
Type of the species is a dead bleached shell which has lost most of the surface sculpture through exposure to the weather.

[Under roots of bushes on the top of Hamarlerı. - II.O.F.]

32. Stenogyra (Riebeckia) adonensis, fuluin-Austen.

Stenogyru alonensis, Godwin Austen, P.Z.S., 1S81, p 810, pl. lxix. figs. 4, ta : Crosse, Op. cit. p. 3.56.

Stenoyyre sorotoruna, Martens, Conch. Mittheil. Vol. II. p. 149, pl. xxriii. figs. $14,16$.

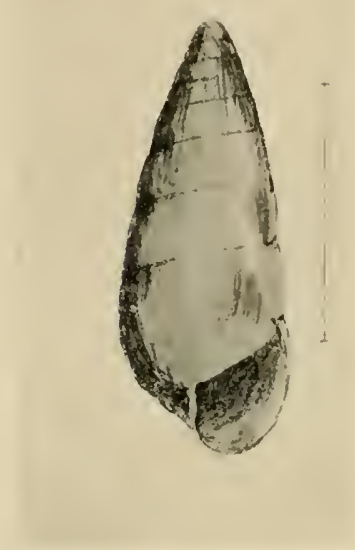

F11: a.

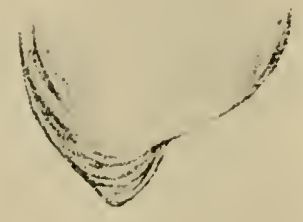

FIr. b.

Lient.-Col. Godwin-Austen gives the following description of the Type of the species:-

"Shell not rimate, dextral, elongately turreted, glassy, polished ; a few faint longitudinal shallow lines of growth ; colour reey pale ochraceous; spire high, sides slightly eonvex ; apex hlunt, lounderl and rather lapidly tapering at the fifth whorl; suture shallow, arlpresserl: whorls 10 , somewhat convex : aperture elongately oral, subrertical: peristome thin, colnmellar margin thin, straight.

"Size : major cliameter $\$ \cdot 5$, alt. axis $24 \cdot 8$, alt. apert. $7 \cdot 0 \mathrm{~mm}$.

Sokotra : Adho Dimellus (3500-4500 ft.) ; also Hombil (1500-500 ft.).

This species varies considerably in stontness, some examples being much more slender than others. The type is 25 millim. long and $8 \frac{1}{2}$ broad. A narrower speeimen is $26 \mathrm{long}$ and $\tau_{2}^{\frac{1}{2}}$ broad, whereas the broadest eximple is $23 \frac{1}{2}$ long and 9 in diameter. Although the extreme forms have a very dissimilar look, they appear to be connected by the intermediate links ocurring in the series of the specimens examined. 
A comparison of a typical specimen of $S$. soliotorana kindly submitted by Professor E. ron Martens, proves that that species is identical with the present and not with s. pmolix, as he originally supposed. The latter, the Type of which was a very young shell, is a very much more slender form altogether, and of a pellucid white colour, the present species being greenish yellow.

33. Stenogyra (Riebeckia) enodis, Gortucin-Alsten. (Plate xiii. fig. 16.)

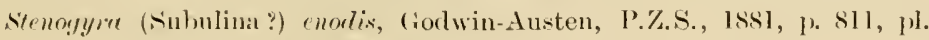
lxix. fig. 5 ; Crosse, p. 33.5.

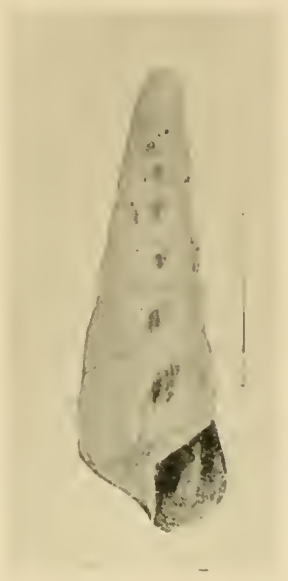

(ENL.IR(:LD.)

The following is the original description of this species given by Lient.-Col. Godwin-Ansten :-

"Shell dextral, elongately turreted, not rimate, rery thin, glassy, diaphanons; no sculpture ; colour milky-white : spire long, apex blunt and roumlerl, suture molerately deep; whorls 9, sirles convex, regularly increasing; aperture quadrate, sulvertieal (not fully formed) ; peristome thin ; columellar margin straight, rertieal.

"Size : majo diameter $4 \cdot 0$, alt. axis $13 \cdot 0$, alt. apert. $2 \cdot 8$ mm."

Sokotra: Jena-agahan (1200-2500 ft.).

The unique type, heing a very young shell, gives only a poor idea of this interesting species. The largest specimen examined consists of 15 whorls, and is 37 millim. in length and $s$ in diameter. The aperture is inversely auriform, and the columella a little thickened and arcuate, and exhibits a slight anterior truneation. The last whorl is rounderl at the periphery.

[Under stones on Gebel Fedehen.-M.O.F.] 
34. Stenogyra (Riebeckia) insculpta, Smith.

Stenoyyre insculyta, Smith, Journ. Malacol., vi. p. 37, pl. v. fig. 7.

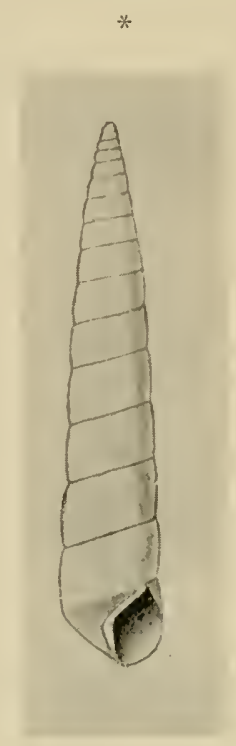

(ENT.ARUEU.)

"Shell subulate, imperforate, white; whorls 15, very gently increasing, separated by a deep olligue suture, the two apical smooth, eonvex, talnlite alove, forming an ol,use apex, the following 5 - 6 somewhat convex, the rest less convex, flattish, sculptured with slightly oblique strie, close and peculiarly crenulated, the last angulated at the periphery, not descending; aperture angularly oval; peristome slender, simple: columellar margin narrowly reflexed.

"Length $37 \cdot 0$, dimneter $6 \cdot 0 \mathrm{~mm}$. ; apertme $5 \cdot 0 \mathrm{~mm}$. long and 3 lnoad.

"This species is remarkahle for the peculial" sculpture, consisting of closeset slightly oblipue raiserl lines of growth, which being crossed by numerons transterse impressed stria, have a prettily festooned or crenulated appearance. It differ's from s. aryntu, Martens, in seulpture, in the angulation of the luxly-whorl and more tapering form.

Collected by Mrs. Bent, but not fouml by Dr. Forbes and Mr. Grant.

35. Stenogyra (Riebeckia) arguta, Huitens.

Sfenoyyra aryuta, Martens, Nachrbl. Deutsch. Malak. Lies., xiii. p. I3s (18S1).

Stenoy!ra jessire, (todwin-Austen, P.Z.S., 1881, 1). 810, 1)l. lxix. fig. 3.

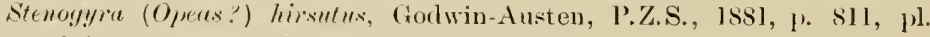
lxix. figs. (5, 6a : Crosse, Op. cit. p. 3.s6. 
The following is the description given by Golwin-Austen of the typical specimen of stenomyru hirsutus:-

"Shell dextral, elongately turreted, scarcely rimate, covered with a thick

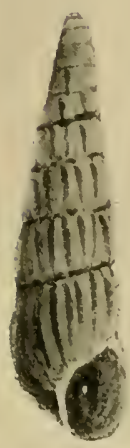

Fit. b. (S. Hiksutis, G.-A.)

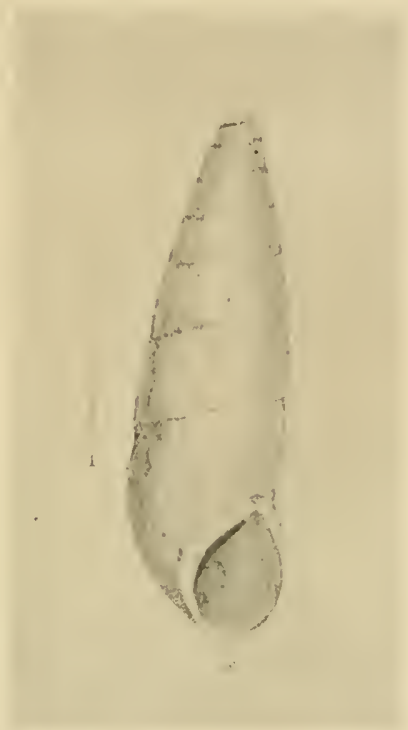

Fis. a. (S. J Jessica, (i.-A.)

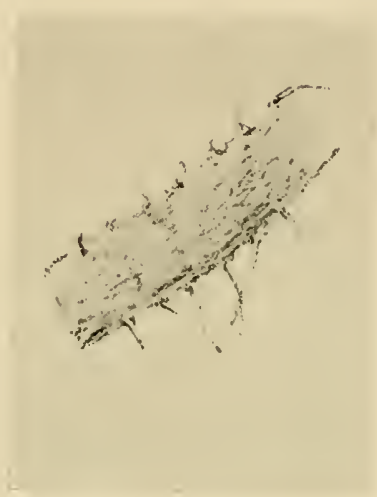

Firi, c.

(ENILAR(EED.)

epidermis: sculpture a rough surface with regularly disposed longitudinal lines of fine hairs (Fig. c) : colour dull ochre; spire elongate, sides flat, apex hlunt, sutme well impressed : whorls 11 , sides slightly convex : apertme oval, oblinne; peristome thin ; columellar margin thin, slightly reffected.

"Size : major diamater $3 \cdot 0$, alt. axis $11 \cdot 0$, alt. apert. $2 \cdot 0 \mathrm{~mm}$."

Sokotra: Hadibu Plain ; Adho Inimellus (3500 4500 ft.), Homhil (1500-2500 ft.).

After carefully examining the Types of $S$. jessire and $S$. hirsutus, and the series of specimens olstained by 1$) r$. Forbes and Mr. Grant, I feel convinced that only one speeies is represented. The types of $S$. jessicu are worn bleached shells which have lost the "hairs" retained by $S$. hirsutus, the unique type of which is merely a very young shell, but in fresh condition. This was commented upon by Martens when describing his S. urgutu. Specimens vary somewhat in form, some being longer and more slender than others. The largest specimen examined is 23 millim. long and 6 broal. A shorter example is 17 in length and $5 \frac{1}{2}$ in diameter. One of the specimens from Homhil is 
in perfect condition, being clothed with a beantiful hairy periostraeum, the "hairs" being arranged in rows upon the lines of growth, and longer than in the Type.

\section{POMATIID床.}

\section{Otopoma, Gray.}

\section{Otopoma naticoides (limlu:).}

Cyclostoma ualicoidten, Réchu, liev. Zonl., 1843, 1\%. 3.

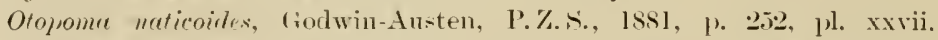
tigs, 1, la, 1b ; Crosse, Op. cit. p. 3ib : (rodwin-Austen, Moll. India, vol. ii. 1) :29, pl. lxvii. figs. 1, Ji (anatomy and rulula).

Georyiu "ustemi, Boureguignat, in Réroil's Voy. pays Comalis, Moll., p. (is (1Si:2).

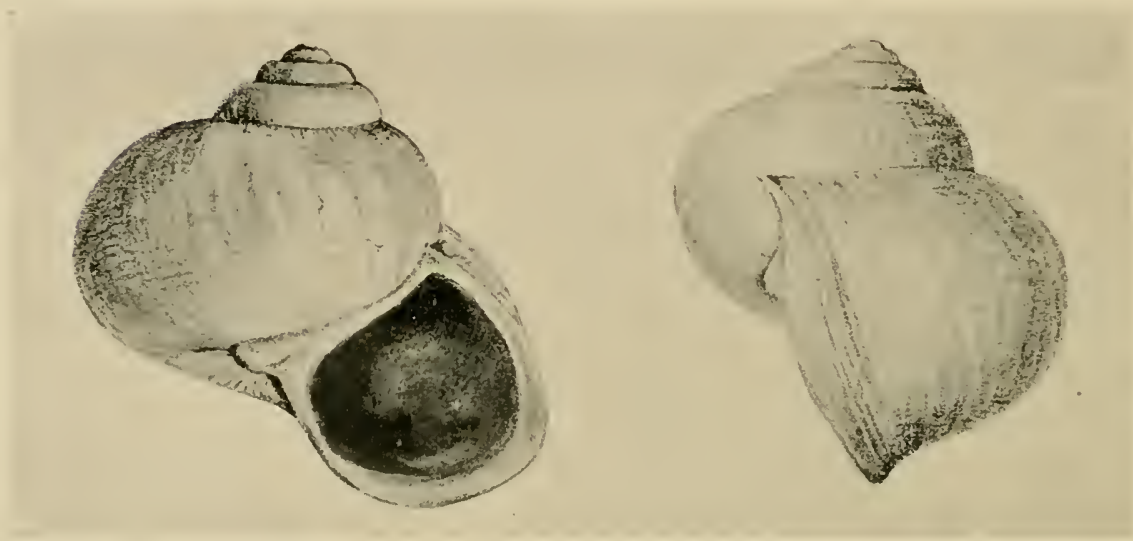

Fir: a. FIt. b.

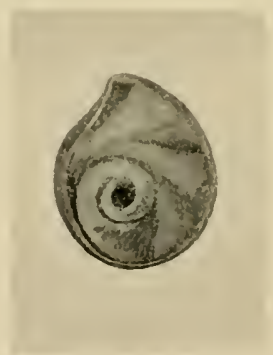

Fíc. c.

Col. Gorlwin-Ansten thus descrilues a specimen oldained by Professor Balfour :-

"Shell globosely turhinate, very solit : sculpture well marked transverse inregular lines of growth crossed by distant indistinct spiral sulcation : colom white, fine orange within the aperture; spire rather high, the extreme alex generally decollate; whorls 5, well rounded; aperture 
oblipuely and broally ovate, angular above, subolslique; peristome thick and solicl, particularly on columellar margin, where it spreals out and eompletely conceals the mmbiliens ; this is a greater derelopment aml exaggenation of the angulate noteh which is to he seen in

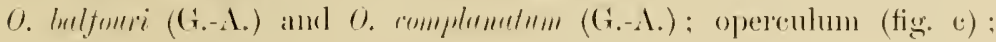
situater well within the aperture, flatly concave in front, shelly, smooth, of alout $3 !$ whorls, nuclens sulocentral.

" Size of largest specimen : major diameter 59-5, alt. axis :3155."

[Balfonr, Richeck, and schweinfurth obtained this species.]

37. Otopoma balfouri, Gimluin-Ansten.

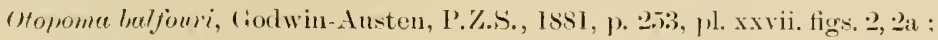
Crosse, Op. cit. 1. 36:.

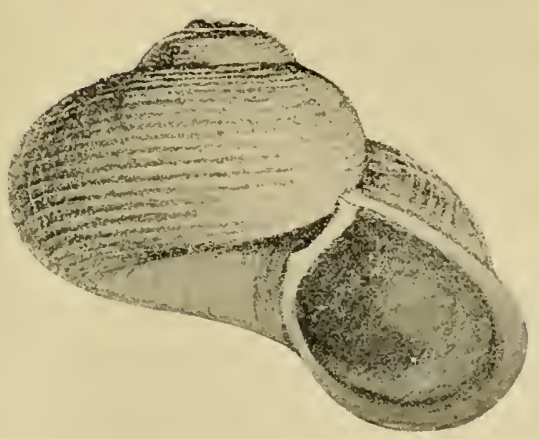

Fig. a.

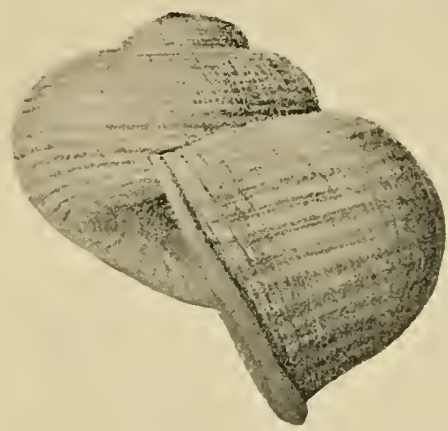

Fir. b.

Godwin-Austen has given the following deseription of the Type :-

"Shell glohosely turbinate, solirl, very openly uml,ilicated, riblsed regularly and spirally throughout: hut the rilibing does not extend within the umbilicus ; colour white : spire pyramiclal, recollate usually for $1 \frac{1}{2}$ whorls; suture well impressed: whorls t, well rouncted: aperture sulsertical, ovoid, angular above; peristome continuous, solid, and reflected slightly on the onter margin, less solid on the columellar sicte, which presents a slight dentation with angularity just below the upper inner margin, well romeded lelow.

"Size : major diameter 5.50, minor diameter $40 \cdot 0$, alt. axis $2 \cdot 2 \cdot 0 \mathrm{~mm}$.

"Dwarf varicty-major dianeter $32 \cdot s$, minor (liameter $26 \cdot 5$, alt. axis $14.0 \mathrm{~mm}$."

[Common on the land towarls the east end of the island ; this portion is elevated orer 700 feet, and is of limestone. - D. I. .1

[This speciess was not met with by us.-H.O.F.] 
38. Otopoma complanatum, frolucin-tusten. (Plate xii. figs 4, 5.)

Otopoma complanatum, Gorlwin-Austen. P.\%.S. 18s1, p. 2.54, pl. xxrii. figs. 3. 3a : Crosse, Op. cit. p. 362.

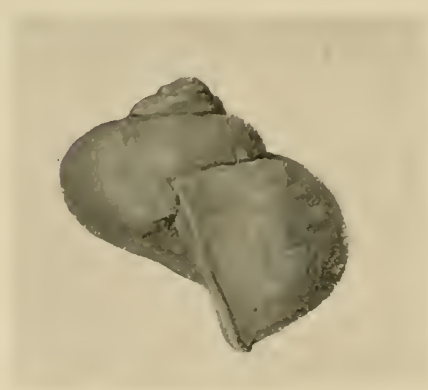

FIt: a.

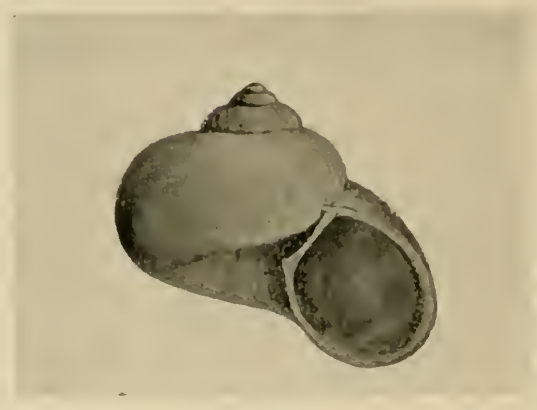

EJu, b.

Lient.-Col. Godwin-Ansten gives the following description of the Type :-"Shell turhinate, openly umbilicated, fine spiral ribhing. crossed by transverse finer libling, smooth on lase: colom white: spire pyramidal : 1.] whorls at the apex smooth: siture impresserl: whorls 5, sides well romeler: aperture ovate, sub-oblique, angular alove: peristome continuons, thickened and scarcely reflected on the onter margin, which is well romoled : columellar margin oblique to axis, thin, with a well markerl sulmerlian angulation near the mmbilicus, lut with no tendency to an expansion in that direction.

"Size : major diameter $36 \cdot 8$, minor diameter $29-5$, alt. axis $16 \bullet$ mm."

Sokotra: Dahamis (350-1000 ft.) ; Jena-agahan (1200-2500 ft.): and Hadibu Plain.

The Types deseribed, being deroid of colom, give no idea of the ornamentation of this fine species, nor do they show the great variation in size which it exhibits. The largest example from Jena-agahan (fig. 5) is $43 \mathrm{~mm}$. in its greatest width. whereas the smallest and equally adnlt specimen from Dahanis is only 25. The prevailing colon is purplish, with numerous spiral dark zones and lines, except at the lower surface, which is paler and mbanded. A light zone almost invariably marks the periphery. One specimen (fig. 4 ) is of a uniform bright reddish tint alove, a little paler heneath, and withont any spiral lineation whatever. Another example, of the same tint, has a single blackish line around the borly-whorl, a little above the middle. The sculpture of this species is also somewhat variable. In some specimens the decussated sculpture of the spire is contimed upon the body-whorl, whilst in others this rolution is smoother. Sonce examples also show more malleation than others, and this feature, althongh not referred to by Godwin-Ansten, is present in both specimens which he examined. The interior of the aperture in coloured specimens exhibits the external coloration, but intensified. A distinguishing feature of this species, besides the open perspective umlilicus, is the short dentiform prominence upon the columellar margin reflexed 
towards the mmlilicus. 'The thickened peristome is generally whitish or eream-colonred, but in some very dark examples it is orange.

[Unler lushes. M.(1.F.]

39. Otopoma socotranum, Bunignigfunt. (Plate xii. fig. 6.)

Otopome socotretum. Bourguignat, Révoil's Voy. pays ('omalis, Moll., p. $144(1592)$.

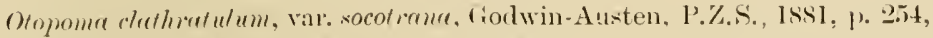
pl. xxvii. 4, ta : ('rosse, Op. eit. p. 363 .

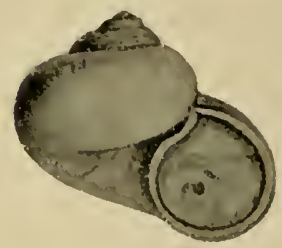

Fili, at.

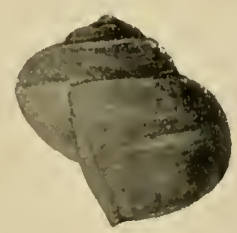

Fir: 1)

The following is Col. (rodwin-Ansten's deseription :

"shell very gholosely turlinate, closely umbilicaterl, spinal ribhing on the apical whorls erossed by transrerse striation, becoming smoother on the body whorl, which mly shows the latter: colom white, also pale purple, stmonger on the apex: borrlering the sutmre in one specimen muncrons pale purple bands of colom ocem, showing darkish above the periphery (fig. ta) ; spire prramidal: sutme impressed: whorls t, well romiled ; aperture subrertical, oval, angulate above; peristome contimus, almost separated from the penultimate whorl, lut reflected, thickener on the outer margin: colmmellar margin snl-oblipne, nealy straight with only a rery slight tendeney to angulation : opereulum shelly, situated close to the peristome, paneispiral, of three whorls rapidy increasing, nuclens sulseentral, flat in front.

"Nize : major diameter $25 \cdot 5$, minor diameter $2 \cdot 2 \cdot 6$, alt. axis $13 \cdot 5 . "$

This species is much more closely related to 0 . complumulum than to dothutulum, as Godwin-Ansten considered, and seems to be ratliel distinct. It has a more contracted umbilicus than complumetrm, through the lody-whorl being more tightly coiled, and more raised spire, and none of the four specimens examined exhibit the short dentiform prominence upon the colunellar margin which occurs in that species. The body-whorl is almost smooth anteriorly. The two specimens which were deseribed by Godwin-Austen were both more or less faded. Four fresh examples, obtained by Mrs. Bent, exhibit a style of coloration similar to that of the lineated forms of 0 . complenutum. 
The species was founderl ly Bonrguignat, only upon Godwin-Ansten's description and figures, and not upon an actual examination of specimens.

\section{Otopoma clathratulum, lierlu:}

Otopoma clathratulum. Rieluz. Pier. Zool. Soc. Cirr., p. 3 (1S43) : Reeve, Conch. Icon, pl. xviij. fig. 116h: Crosse, Op. cit. p. 363 ; (iodwinAusten, Moll. Inclia, vol. ii. p. 30.

Otopomu cluthretulnm, var. minor, Godwin-Ansten, P.Z.S., 1881, p. 25.5.

"Shell orbiculate-conical, yellowish-orange ; whorls 5, eomvex, Hattish at the suture, transversely, regularly, and finely suleated, very closely elathrated ly fine longitudinal striae, with more or less lownish transverse lands ; nppermost whorls with a black zone at the lase: the last handerl with pale orange at the midulle, the land lreing bordered with hrown, smooth beneath: apertme orange within, banderl with redrlish-brown, acute at the margin; umbilicus reep, pervious.

"Length, 2.2 nmm. ; liameter of last whorl, 2:35) ; height of spire, $11 \cdot 3 . "$ (Translution from l'etit.)

Sokotra: Dimichiro Valley, East Sokotra.

The var. minor of Godwin-Austen differs only from the typical form in the absence of the spiral colonr-lines, the form and seulpture being almost identical. The size quoted by the author (major diameter 18 millim.) is altogether misleading, as the largest of the specimens placed by him as this variety is 25 millim., the normal size of the species. All the examples have the dark purplish zone above the suture upon the upler part of the spire.

This variation in size is of no importance whaterer in a varietal point of view, for all sizes of the typical form were collected by Dr. Forbes and Mr. Giant, ranging from 25 to 15 millim. in the greatest diameter, the smallest, judging from the thickened peristome, being as adult as the lal'gest.

The var. sorotron (Godwin-Austen) appears to be very distinet from this, and has, in my opinion, been rightly raised to specific rank by M. Bourguignat.

[Under bushes in the dimp sand of the dry river bed; on the foliage of the bushes also.-II.O.F.]

\section{Otopoma conicum, Guturin-Austen.}

Otopome conirum, (iodwin-Austen, 1'.7.S., 18s1; p. 25.5, pl. xxriii. fig. 1, $1 \mathrm{~b}$; Crosise, Op. cit. p. 364.

Rochelerunie conicu, Bourgnignat, Voy. pays (Comalis, Moll., p. 84 (1885).

Col. Godwin-Austen has given the following deseription of the Type :-

"Shell conoid, closely umbilieated, solid; seulpture fine, regularly disposed spiral riblung erosserl hy fine costnlation, eontinued to well within the mubilical region ; colour white; spire eonie, sirles rather flat, apex subacute; sutme, rather shallow; whorls 5, the last well 
romuled, slightly descending : aperture circular, subohlique ; peristome very thin: colmollar mangin simple, but reflected; opereulum shelly, solicl, paucispinal, of :3 whorls, smooth suldeentral muclens depressed, concase beliniml.
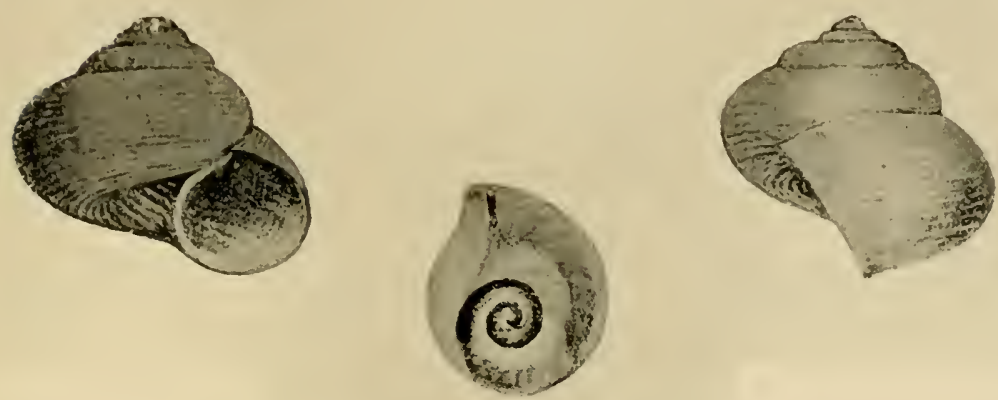

Fir: a.

FIr: c.

Fis: b.

(Exilatied.)

"Size : major diameter $11 \cdot 0$, minor diameter $10 \cdot 0$, alt. axis $7.0 \mathrm{~mm}$."

The types of this speeies appen to be bleached shells, for a careful examination of them reveals faded colour markings upon the upper surface.

[This species was not obtained by us.-II.O.F.]

\section{Otopoma (?) radiolatum (Martens).}

('yclosfoma irdliolutum, Martens: Nachrbl. Dentsch. Malak. Ges., xiii. p. 135 (1s81); Crosse, Op. cit. 1). 366.

The following is a translation of the original (lescription :-

"Shell subdepressed-turbinate, moderately umbilicated, sculptured with rather close spinal costa, $7-8$ in the penultimate whorl, pale eimamon colour, with raliating straight or Hexuous yellow-white lines ahore; whols $4 \frac{1}{2}$, the first papilliform smooth, the last rounderl, with the hasal coste more distant; aperture circular, peristome thin, scarcely expanted, pale.

"Greater diameter, 1:3 mm. : minor diameter, 10.5 ; height, 11 ; aperture, 6 widle."

The generic position of this species is at present uncertain, the operculum being unknown. It seems, however, rather elosely related both to the preceding and following species.

[This species was collected by Drs. Riebeck and Schweinfurth near Hadibu, and on the Wadi Kischen (1900 ft.).] 
43. Otopoma turbinatum, Gimluin-Alustrn. (Plate xiii. figs. 7-9.)

Otopoma furlinatum, Godwin-Austen, P.Z.S., 1881, p. 255, pl. xxviii. fig. 2 ; Crosse, Op. cit. p. 364.

Rorhelmunire turthinata, Bourgnignat, Voy. pays Çomalis, Moll., p. $\$ 4$ (18s2).

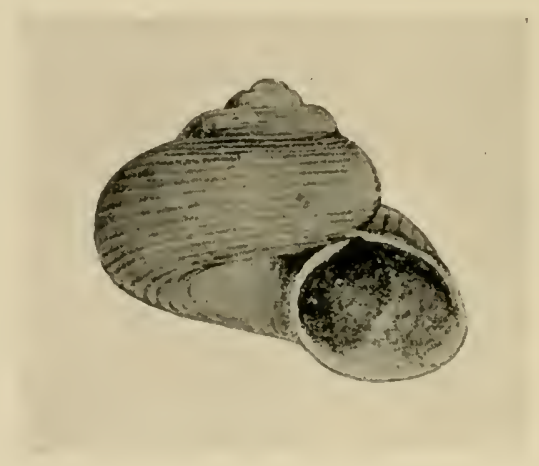

(ENLATaED.)

The following is the description of the Type specimen:-

"Shell turbinate, umbilieaterl: sculpture regular, fine, equally distributed, spiral ribling smooth on the last whorl near the umbilicus ; apex smooth : colour white ; spire prramidal ; sutme impressed : whorls $4 \frac{1}{2}$, well rounded; aperture nearly circular, slightly angular above: peristome thin, mueh curverl on the columellar margin.

"Size: major diameter $\$ \cdot 8$, minor diameter $7 \cdot 9$, alt. axis $5 \cdot 0$ mm." (Godwin-Austen.)

Sokotra: Adho Dimellus (3500 $4000 \mathrm{ft}$.).

The type is a dead bleached shell, and consequently was described as "white." Traces of colour are, however, observable, and it seems probable that its style of coloration was similar to that of $O$. recliolutum, Cyclotopsis ormatu, and the following variety.

$V$ ar. Shell very similar to those from Adho Dimellus, but a little more coarsely costulate below, and smooth within the umbilicus (fig. 9).

Sokotra : Homhil (1500-2500 ft.).

The operculum is very similar to that of Cyclotopsis omata, but the outer whorl is larger in proportion, and the spire is more rapidly coiled. It is, in fact, a link between tlat of a typical Otopome and that of Cyclotopsis.

Fresh specimens are very prettily banded with brown, with a pale zone at the periphery, and rayed and clotted with white above, the lower surface usually being destitute of markings and translucid dirty whitish. 


\section{Cyclotopsis, Blanford.}

44. Cyclotopsis ornata, liveluin-Austen.

('ylotopsis omutus, Godwin-Austen, 1'.7.s., 1s81, 1). 2.7, pl. xxviii. fig. 5, 5a ; Crosse, Op. cit. 1) 366.

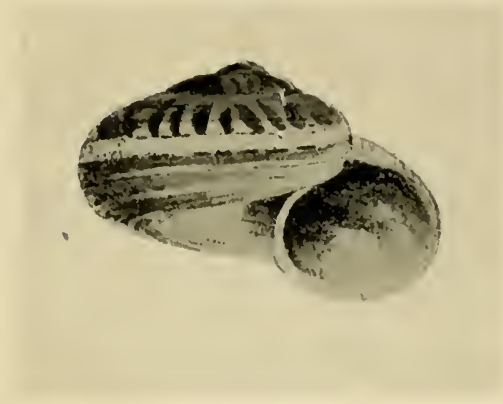

Fir. a.

(ENILARIED.)

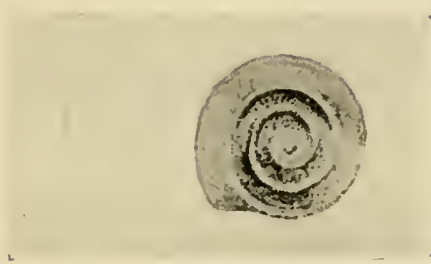

Fi(i. b,

The following is the deseription of the Type :

"Shell openly mmlilicated, lepressedly conoil, thin; sculpture spiral, suleation, every other rib being more strongly developed, crosserl transversly hy fine costulation : colom pale sienna with a pale ochre baud on the periphery and with zigr-zag markings of the same colour on the second whorl, this colouration only seen well on young shells; spire somewhat low, apex smooth: wholls $t$, well romiderl, the last very slightly descending: aperture circular, obliyne: peristome thin, searcely reflected on the inner margin : operculum shelly, concentric, of $t$ wholls ; the margin well reflected ontwards, its edge forming a eontinuons raised smooth spiral rih.

"Size : major diameter \&־-, minor diameter $6 \cdot 8$, alt. axis $3 \cdot 8 \mathrm{~mm}$." ['This species was oltamed by Professor Balfour on the slopes of Aduma (at alout $2000 \mathrm{ft}$.); but not ly us.-H.O.F.]

\section{Tropidophora, Troschel.}

45. Tropidophora socotrana, Goluin-Ansten. (Plate xiii. figs. 5, 6.)

Tropridophore socotirne, Godwin-Austen, P.7.S., 1581, p. 255, pl. xxviii. figs. 3-3b ; Crosse, Op. cit. p. 36..

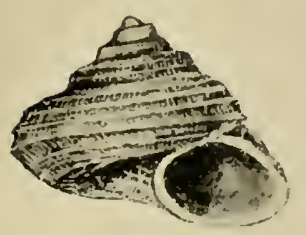

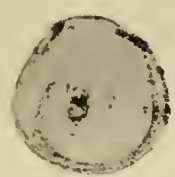

FIt:, .

Frit.

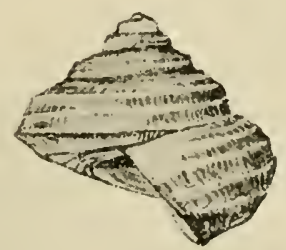

Fir: b. 
The following is Godwin-Austen's original description :-

"Shell trochiform, umlilicaterl, rather solid; seulpture three strong longitudinal ribs on the periphery with a fine intermediate one, and two alwove near the suture, crossed by strong lateral close ribhing or lines of growth; similar longitudinal sulcation on the base, smooth on the apex; colour white, ruddy within the aperture; spire pyramidal, sides Hat; suture shallow; whorls 5: descending near the aperture; this is circular and oblique; peristome rather thin ; opereulum sultestaceous, paucispiral, rapidly increasing, nucleus sulycentral.

"Size : major diameter $10 \cdot 0$, minor diameter $9 \cdot 2$, alt. axis $6 \cdot 4$, total alt. $9 \cdot 0 \mathrm{~mm}$."

Sokotra : Hombil (1500-2500 ft.).

Very variable in size and form, the largest specimen (fig. 6) from the above locality, 14 millim. in diameter, being much more depressed than the type, acutely keeled at the periphery and much more openly umbilicated. Other specimens, however, in the collection form connecting links between this depressed form and the type. Some fresh examples collected by Mrs. Bent (fig. 5) are pale cinereous, rayed and spotted above with a darkish tint, the aperture being deep brown or orange within, but pale at the peristome.

46. Tropidophora balfouri, Gorluin-Austen.

Tropilophora lulfouri, Godwin-Austen, P.Z.S., 1881, p. 256, pl. xxriii. fig. 4 ; Crosse, Op. Cit. p. 365.

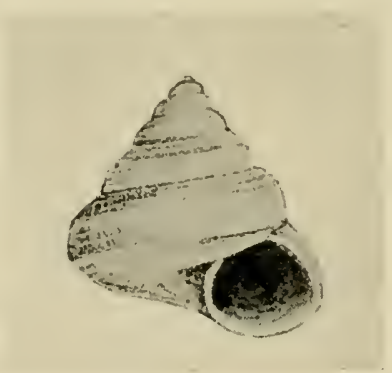

(ENLARGED.)

"Shell elongately pyramirlal, umlilicaterl, keeled, solid; first two apical whorls smooth, rest of shell ribhed spirally and on the base; seven ribs on each whorl, crossed hy well-developed transverse ribling; colonr marly white, ruddy hrown or olange within; spire pyramidal aeuminate, sides flat; suture shallow; whorls 6 , sirles convex, the last descencting very slightly near the peristome; aperture lroarlly ovate; peristome rather thin, continuous.

"Size: major diameter $7 \cdot 5$, minor diameter $7 \cdot 0$, alt. axis $6 \cdot 3$, total height $8.7 \mathrm{~mm} . "$

[Professor Balfour found this species on the top of the limestone ridge to the S.IV. of Gollonsir; but we did not find it at the east end of the island -.-H.O.F.] 


\section{Lithidion, Gray}

47. Lithidion lithidion $(S(x), \cdot y)$.

Cyclostoma lithidion, Sowerby, Thesaurns Conch., vol. i. p. 111, pl. xxxi. fig. :202.

Lithidion sulculum, Gray, Cat. Cyclophoridre, Brit. Mlus. p. 3.5.

Lithilion marmorosum, Gorwin-Ansten, P.Z.S., 18s1, p. 2.56, W. xxriii. fig. 6 6e ; Crosse, Op. cit. 1) 365.
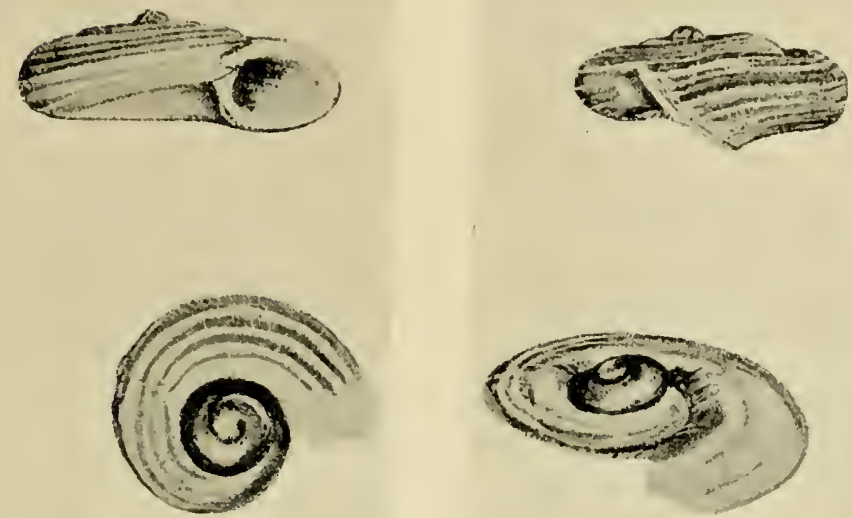

Fig. a.

Fig. b. (Exlakited.) Fig. d.

Fig. e.

"Shell discoid, very solid, widely and openly unlilicated, sharply keeled; seulpture, strongly ribberl longitudinally, with 5 sulcations below and 4 above the peripheral suleation, erossed ly very fine lateral regular striation; colour marbly white: spire thatly depresserl, apex papillate, polished ; suture shallow; whorls 5, excentrieally wound at the apex, the axis therefore not being perpendicular to the planes of the last whorl (Figs. b, d) ; aperture circular; oblique; peristome refleeted, strongly developed on the eolmmellar margin ; operculum shelly, concentric, of 3 whorls ; the margin reflected, forming a raised spiral rib."

"Major diameter $10 \cdot 7$, minor diameter $9 \cdot 2$, alt. axis $3 \cdot 2 . "-(G o d u i n-$
Austen.)

Sokotra: 1)ahamis (350-1000 ft.) ; also Jena-agahan (1200-2500 ft.).

This species, which was first described as from "Yemen, Arabia," is very variable in size, also in form, some specimens being much more depressed than others and more widely umbilicated. Those from Jenaagahan are remarkably that and strongly earinate, only the apex of the spire being above the level of the body-whorl, and with the lire within the umbilicus stronger than usual The fine series of specimens, obtained by Mrs. Bent, Dr. Forbes, and Mr. Grant, clearly proves that $L$. lithidion and $L$. mumorosum are one and the same species ; indeed the loeality, "Yemen, Arabia," assigned to the former 
has yet to be confirmed. To show the variation in size, the measurements of two extreme but equally adult examples are given :-

Major cliameter 12 millim., minor 10.

Godwin-Ansten motes that "the animal is pale ash-grey ; tentacles black; foot divided longitudinally, prohoscis long, bilubed."

\section{Lithidion bentii, smith.}

Lithidion bentii, Smith, Journ. Malacol., vol. vi. p. 38, pl. r. fig. 9, 98.

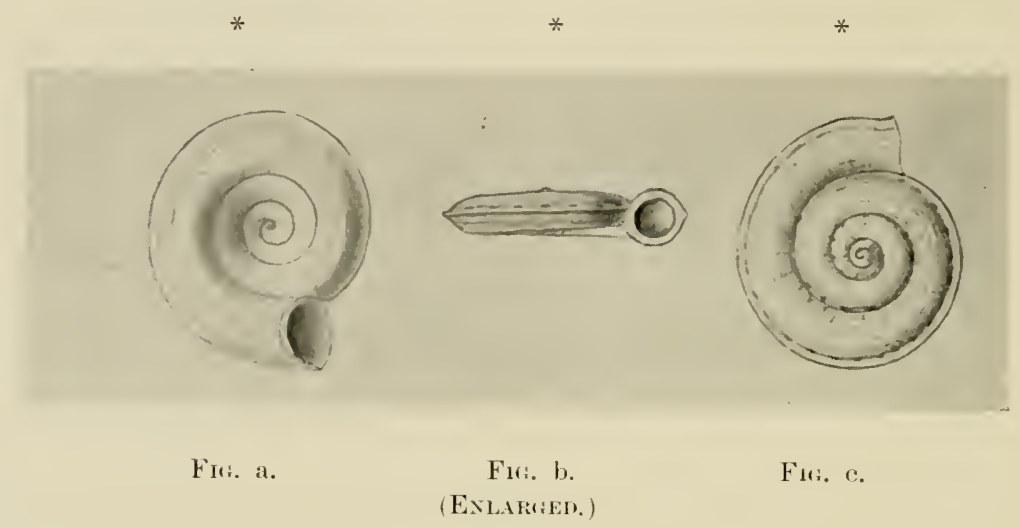

Shell diseoid, very openly umbilicate, shaply carinate, white or pale rufeseent ahove, slightly shining: spire flat; whorls 5, the two apical whorls (protuconch) smooth, very convex, the rest with four slender spinal line abore, slightly convex, here and there rarliately subplicate, the last ornamented with a sharp eompressed peripheral keel, reddish beneath, having four or five concentric lire: aperture rounted inside ; peristome white, the margins joined by a eallus, the upper margin dilated above, the lower thickened, scarcely reflexerl.

Size : majos diameter $13.0 \mathrm{~mm}$, minor diameter $11 \cdot 0$, height $3 \cdot 0$.

Tery depressed, with an acute peripheral keel, a small aperture, and almost smooth within the umbilieus, which is shallower than that of L. lithilim, and the whorls within it are also less convex.

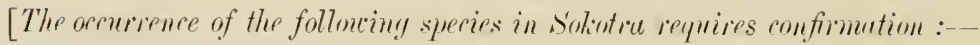

\section{Lithidion desciscens (l'feiffer).}

Cyclostoma dexciscens, Pfr., P.Z.S., Lond., 1s.51, 1. 243 ; Crosse, Op. cit. p. 366 .

Cyclostomu desciscens, the type of which is in the British MInsenm, is identical in every respect with Lithirlion souleyetiunum from Abd-elKini.] 


\section{MELANIID冉.}

\section{Melania, Lamarck.}

49. Melania scabra (1/iiller).

Burcimum seahrum, Miiller, Verm., .209, 1. 156 (17-5).

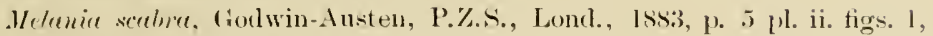
la, 2, 3 ; et var. pl. ii. fig. 2 ; var. pl. ii. fig. 3.

Melaniu payolu, Godwin-Austen, Op. eit. p. 7 pl. ii. fig. 10 ; et var. pl. ii. fig. !).

Melenire screbre, Crosse, Op. eit. 1\% 359.

Most of the specimens from Sokotra belong to the form eleyuns, Benson, which apparently is specifically inseparable from the present species. A few shorter examples, however, with longer and more pronounced spines, have been met with. These are fignred by Godwin-Ansten as I. puryule of Lea. It seems impossible to draw any line of separation between this species, M. puyodu, M. denticulutu, Lea, M. duturu, Dohrn, and some other forms.

\section{Melania tuberculata (1Liller).}

Nerita tubereulater, Miiller, Verm., 37s, p. 191 (1775).

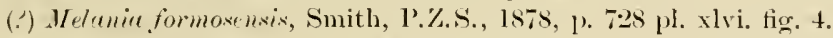

Melenia tubereulate, (rodwin-Austen, P.Z.S., 18s3, p. s pl. ii. figs. and 6 ; and smooth var. fig. 4 .

Melania sclateri, Godwin-Austen, $\mathrm{O}_{\mathrm{p}}$. cit. p. 7 pl. ii. fig. $\mathrm{S}$.

Melania tuberetata, Crosse, Op. eit. 1) 359.

Melenice tuberculute, var. sublerix, C'rosise, Op. eit. p. 3.59.

Typical specimens of this species occur in Sokotra, besides several varieties. A smooth form (var. $\beta$. subleris, Crosse, Op. eit. p. 359). figurerl by Godwin-Ansten (P.Z.S., 1883, p. 5, pl. ii. fig. 1), has only faint traces of longitudinal costulations, and the spiral sulci are also rather feeble. The "milky white" aperture is merely occasioned by a chalky deposit, which disappears on being wetted, revealing the usual colour markings Other examples, collected by Mrs. Bent and Dr: Forbes and Mr. Grant at Jena-agahan, are searcely separable from .U. foimosensis, Smith, (P.Z.S., 1878, 1. 728, pl. xlvi. fig. 4), also probably merely a smooth variety of this polymorphons and wirlely distributed species, which also occurs in Formosa in its normal form.

M. scluteri, Godwin-Ansten, founded on fragments and very young shells, is a banderl form, of which two specimens, 17 and 25 millim. in length respectively, were collected by Mrs. Bent. The larger one, however, has red spots in place of the infrusutural band. Althongh not mentioned ly Godwin-Ansten, distinct traces of longitudinal plications ocenr on the spire of the type, which are well developed in Mrs. Bent's specimens.

An example from Hadibu Plain, obtained by Dr. Forbes and Mr. Grant, has the two last whorls black, excepting a pale zone beneath the suture, and the white columella. The upper lart of the spire, however, is paler, and streaked with red upon the granose costulations. 
Sokotra: Hadibu Plain; Jena-agahan.

This species has been reeorded from Madagasear, Mauritius, India, Ceylon, Syria, Persia, Arabia, Java, Siam.

\section{AURICULID床.}

\section{Auricula, Lamarck.}

51. Auricula socotrensis, simith.

A uricula rocotrensis, Smith, Journ. Malacol., vol. vi. p. $3 \overline{7}$, pl. v. figs. s, sa.

$*$

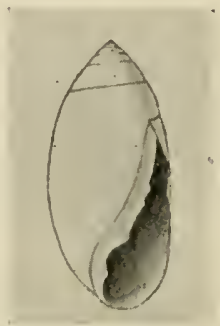

(EvLARG:ED.)

Shell elongate-ovate, imperforate, olive-hrown, smooth, striated with fine lines of growth; spire short, convexly conoid, mammillated at the apex; whorls 7 , the first convex, the rest searcely convex, sometimes more or less spirally punctate, the last elongate, with the sides slightly convex; aperture inversely elongately ear-shaped; labrum thin, very slightly thickened within; columella with fourfolds, the two upper subjoined, the lower ones stronger.

Length 9, diameter 4 mm., aperture 7 long.

Allied to A. pusillu, H. \& A. Adams, A. nevillii and yussiesi of Morelet, and a few other speeies, but quite distinet.

Sokotra.

[This species, the Type of which was collected by Mrs. Bent, was not found by us. - H.O.F.]

\section{LIMN止ID压。}

\section{Planorbis, Guettard.}

52. Planorbis exustus, Deshecyes.

Planorix exustus, Deshayes, Voy. Belanger, p. 417, pl. i. figs. 11, 13 (1854). Planorbis exustus, var. muculutus, Godwin-Austen, P.Z.S., 1883, p. 3, pl. i. figs. 1, la, 1b.

Planorbi. exustu*, Crosse, Op. cit, p. 358.

Sokotra: Harlibu Plain.

[Under and on hushes.-H.O.F.]

Riebeck, Schweinfurth, and Balfour all found this species.

An Indian species. 
53. Planorbis socotrensis, Golurin-A usten.

Planorbis socotrensis, Godwin-Austen, P.Z.S., 1583, p. 3 pl. i. figs. 3, 3a, 3b, 3c ; Crosse, Op. cit. p. 3558.

The following is the description of the Type :-

"Shell minute, diseoid, apieal and hasal sides equally eoncave ; sculpture,

obliguely striate with lines of growth, otherwise smooth with very minute pitting or malleation; eolour pale ochraceous; suture well impressed; whorls :3, flat on the periphery, angular above and helow, side subrertical; aperture rhombiclal, rather willer than high ; peristome thin, continues ats a thin callus on the borly whorl, arched ahove, straight below.

"Size : major diameter, $3 \cdot 4$; alt. axis, $0.5 \mathrm{~mm} . "$-(Gorluin-Austen.).

Soliotia.-(Belfime:)

54. Planorbis cockburni, Guluin-Austen.

Planorlix corklumi, Godwin-Ansten, P.Z.S., 1£83, p. 4, pl. i. figs. 22, 2:al, 2:b ; Crosse, Op. cit. p. 358.

The Type was deseribed hy Godwin-Austen as follows:-

"Shell discoid, diaphanons; seulpture, fine oblique striation, almost costulation, on the first whorls ; colour pale horny-brown; suture impressed: whorls $2 \frac{1}{2}$; aperture hroadly ovate.

"Size: major liameter, $4 \cdot 3$; alt. axis, $1 \cdot 1 \mathrm{~mm}$."

Solotra. - (Bulfour:)

\section{PALUDESTRINID死.}

\section{Paludestrina, d'Orbigny.}

55. Paludestrina balfouri (Goluin-Austeu).

Hyilrobice? balfouri, Godwin-Ansten, P.Z.S., iss3, p. 4 pl. i. figs. 4, 5; Crosse, Op. cit. p. 359.

Col. Godwin-Austen deseribes the Type as follows :-

"Shell elongately oral : senlpture, quite smooth, a few eroded patehes on

the apical whorls; eolour white, another (smaller) specimen ash-

lrown; spire high, somewhat attemate; whorls 5, penultimate the largest, its sides convex; aperture subvertical, lroally ovate or' nearly cirenlar; peristome thin, well-rounded below ; opereulum not seen.

"Size: major diameter, 1.3 ; alt. apert., 0.9 ; alt. axis, $2 \cdot 1 \mathrm{~mm}$." 


\section{II.-Land Shells of Abd=el=Kuri.}

The known Land Shells of this island, with the exception of Tropidophore morlestu, are all vary small forms in comparison with those from Sokotrat, and do not rauge outside the island. Nine species, belonging to the genera Butiminus, Troppilophorn and Lithition, are now known As all were obtained by Dr. Forbes and Mr. Grant during their two short visits of three or four days only, it seems probable that much still remains to be done in the investigation of the fama, and dombtless other forms will eventually be discovered by future collectors. No fresh-water forms have yet been noticed, and possibly they do not ocem, there being no water on the island except during the wet season.

\section{PUPID屟.}

\section{Buliminus, Beck.}

1. Buliminus (Chondrnla) granti, Simith. (Plate xiii. fig. 2.)

Buliminus (Chomlrula) yranti, Smith, Bull. Liver. Muss., ii. 1. 12.

Shell ovate, acuminate above, rimate, subpellncil, pale brownish horncolour, smooth; whorls $5 \frac{1}{2}$, somewhat convex, sculptured with ol,lique very fine lines of growth, margined below the suture with a pellueid line, the last slightly obliquely descending behind, but slightly ascending at the labrum; aperture inversely anriform, with two teeth; peristome thickened, white, the margins almost joined by a slender callus, the right scarcely reflexed, with a prominent tuberele within in the middle, columellar unidentate above, expanded and reflexed.

Length 11, diameter $5 \frac{1}{2} \mathrm{~mm}$. ; aperture 4 long, 3 broad.

Abd-el-Kuri.

The parrietal callus does not quite join the upper end of the labrum, so that a narow sinus or slit is formed at this place.

2. Buliminus (Mastus) contiguus, (Reere).

Bulimus contiguus, Reeve, Conch. Icon. v. Bulimus, fig. 5s'2 (1849); Crosse, Op. cit. p. 367 .

Bulimus teres, Pfr., Zeitschr. Malak., 1849, p. 90.

"Shell elongately cylindrical, not mmbilicated, whorls nine in number, Hatly convex, smooth, polishert, faintly impressly cremulaterl at the sutures, colmmella broad, rertical; aperture minnte, margins thickened, reflected, joined above ly a callosity ; ivory white."-(Lieeve.)

Length 12, diameter $3 \mathrm{~mm}$.

Abd-el-Kmi (800-1500 ft.).

[Under stones on sile of the high peak Gebel Saleh, overlooking om anchorage at Bandar Saleh.--I.O.F.] 
3. Buliminus (Achatinelloides) guillaini, l'otit. (Plate xii. figs. 15-17.)

Buliminus (Orella) guillaini, Petit, Journ. Conchyl., i. p. it pl. iv. figs. 4 , $5(18.50)$; Crosse, Op. cit. p. 368.

"Shell oblong, cylimbieal, thickish, imperforate, hownish, rariegaterl with white, sometimes subhanderl, whorls s-9, flatly comvex, ohlinnely and elosely striated ; colmmella very much curved, sulplicate helow ; aperture ovate: labrum acute, subreflexed; labium consolidated in arlult specimens."-(Petit.)

Length $6 \mathrm{~mm}$.

Abu-el-Kuli (1600-1750 ft.).

Very variable in colour. Most of the specimens are brown, mottled with creamy white, and often bauded at the periphery with brown or white. Some examples are rich brown, with a white zone at the suture and round the midrlle of the body-whorl. Others are pellucid white, with opaque white mottling.

[On the upper regions of Gebel Saleh (1750 ft.), overlooking our anchorage in Bandar Saleh, filling the erevices of the limestone rocks in immense numbers - H.O.F.; and in numbers under loose stones below the crest of the hill._M.Ii.O.(i.]

4. Buliminus (Achatinelloides) fuscoapicatus, Simitl. (Plate xiii. fig. :20.) Buliminus (Orella) fuscoapicuta, Smith, Bull. Liverpool Muss., ii. p. 13.

Shcll ovate, acuminate above, scarcely rimate, pale grey, brown at the apex, obliquely very finely costulated; spire conical; whorls 6 , two uppermost brown, globose, smooth, the rest somewhat convex, the last subglobose ; aperture broadly ear-shaped, brown within ; labrum thickened, not expanded or reflexed externally, whitish, the columellar margin being dilated and reflexed.

Length $8 \frac{1}{2}$, diameter $6 \mathrm{~mm}$.; aperture 4 long, 3 broad.

Abd-el-Kuri (800-1500 ft.).

A few darkish dots are gencrally seattered over the grey surface.

\section{Buliminus (Achatinelloides) pauxillus, simith. (Plate xiii. fig. 18.)}

Buliminus (Orella) pauxillu., Smith, Bull. Liverp. Mnss., ii. p. 12.

Shell small, orate-conical, rimate, grey, striped with brown, generally with a white hand at the periphery, brownish at the obtuse apex; spire conoid; whorls 5, two mppermost convex, smooth, brown, the rest convexish, obliquely finely costulated ; aperture brown; peristome pale, slightly thickened, the margins almost joined by a slender callus, the external not expanded, the colmmellar dilated and reflexed.

Length 6 , diameter $4 \mathrm{~mm}$. ; aperture 3 long, $2 \frac{1}{2}$ lroad.

Abd-el-Kuri (800-1500 ft.).

Snaller than B. fuscoapirutu, more strongly estulate and differently coloured. The body-whorl often has a somewhat shouldered appearance. 


\section{POMATIID床.}

\section{Tropidophora, Troschel.}

\section{Tropidophora modesta (Petit).}

Cyclostomu modestum, Petit. Journ. Conchyl., i. p. 50 pl. iv. fig. 2 (1850): Crosse, Op. cit. 1). 368 .

"Shell orbieulately depressed, widely umbilicaterl, very pale brown, spirally strongly sulcated subtricarinate, transversely, finely, and closely striated; whorls 5, depressed-convex, divided by a deep suture : aperture suborbicular, oblique: lahrum reflexed, anteriorly subquadrangular, the median angles the largest.

"Diameter 26 , height $12 \mathrm{~mm} . "-$ (Petit).

Abd-el-Kuri (800-1500 ft.).

Dead shells only and without operenla.

FFound abundantly under stones and roots of grass on the upper slopes of the mountain over against our anchorage.-H.O.F.]

\section{Lithidion, Gray.}

7. Lithidion souleyetianum (Petit). (Plate xii. fig 2.)

Cyclostoma souleyetianum, Petit, Journ. Conchyl., i. p. 52 pl. iii. fig. 6(1850). Lithidion soule yetiunum, Crosse, Op. cit. 1. 369.

Cyclostome disciscens, Pfr., P.Z.S., Lond., 18.51, p. 293 ; Conch. Cab. (Ed. 2), p. 26:2, pl. xxxy. figs. 25,26 .

"Shell orlicular, conic-depressed, deeply umbilicated, fleshy-brownish, or tinted with rose; whorls 5, spirally sulcate, transver'sely subeancellated, the last smooth beneath, shining: aperture oblique, semilunate, yellowish : labrum white, scarcely reflexed ; labium callous.

"Diameter 8-10, height 3-5 mm."-(Translution from Petit).

Abd-el-Kmi (800-1500 ft.).

A few specimens exhihit two narrow spiral brown bands mpon the last whorl, one above and one below the periphery. Others are miformly white.

8. Lithidion forbesianum, Smith. (Plate xii. fig. 3.)

Lithidion forthesianum, Smith, Bull. Liver. Mus., ii. p. 12.

Shell depressed, orlbicular, widely umbilicated, spirally costulated, subclathrate with conspicuous oblique lines of growth, above pale or dark brown, paler below; spire short; whorls 5 , convex, separated by a deepish suture, two uppermost smooth, the last descending in front, with the lire less conspicuons below than above, smoother; aperture almost circular, brown within; peristome white, with the margins joined by a thin callus, almost continnous, the outer slightly expanded, the columellar thickened, less reflexed.

Greater diameter \&, lesser diameter $6 \frac{1}{2} \mathrm{~mm}$, height 5 .

Abd-el-Kuri (800-1500 ft.). 
Quite distinet, althongh very closely allied to $L$. souleyetiunum, but differing chiefly in the form of the aperture and the opercnlmm, which is more concave externally. It is extremely variable in size, ranging from 10 to 7 millim. in diameter.

9. Lithidion gratum, (Petit). (Plate xii. fig. 1.)

Cyclostoma gratum, Petit, Journ. Conchyl., i. p. 53 pl. iii. fig. 10 (1850). Guillainia yrata, Crosse, Op. cit. p. 370.

"Shell conic, pale rose; whorls 5-6, rounded, spirally finely suleate, transversely very finely eancellated; suture distinct; apex brownish ; aperture rounderl, lright red within: labrum single; umbilicus bordered by an angle.

"Diameter 5, height $6 \mathrm{~mm} . "-($ Translution from Petit $)$.

Abd-el-Kuri (1750 ft.).

The opereulum of this species, which was unknown to M. Crosse when he described the genus Guilluiniu, is almost precisely similar to that of L. souleyetianum. The elevation of the spire and the keel around the nmbiliens are specific rather than generic characters, and the form of the aperture and peristome is almost identieal with that of $L$. forbsiunum. There seems, therefore, no reason for the employment of the socalled genus Guilluinic for this species. Some specimens have a bright red zone below the middle of the body-whorl. Considerable variation occurs, both as regards the height of the spire and the coarseness or fineness of the spiral seulpture.

Two dead specimens, apparently belonging to this species, are remarkable for their size, the larger being 11 millim. long and $6 \frac{1}{2}$ broad. This specimen has a very narrow nmbilicus, the faint keel or angle which usually surrounds it is wanting. There is a faint trace of it in the second smaller example.

[Many living specimens were found among the ereviees of the rocks on the summit of Gebel Saleh, the highest point on the islancl.]

[The ocrurence of the following spreies in Abu-el-Kuri requires confirmution :-

Otopoma naticoides, Réclus.

Cyclostoma naticoides, Récluz., Rev. Zool. Soc. Cuv., p. 3 (1843); Crosse, Op. cit. p. 369.

This species is probably restricted to Sokotra.] 


\section{PLATE XII.}

Fig. I. ........ LITHIDION GRATUM, p. I55.

Fig. 2....... , , SOULEYETIANUM, p. 154 .

Fig. 3...... , FORBESIANUM, p. 154 .

Figs. 4, 5..... OTOPOMA COMPLANATUM, p. 140.

Fig. $\quad 6 . \ldots \ldots \ldots$, , $\quad$ SOCOTRANUM, p. I 4 I.

Fig. 7....... BULIMINUS (ACHATINELLOIDES) ACUTUS,

p. 126.

Fig. 8....... , , ， ， ， LEVIOR, p. 119.

Fig. 9...... , , , $\quad$, MISTUS, p. 120.

Figs. 10, 14. . , , , ( ) DAHAMISENSIS,

p. 1 I 8.

Fig. I1....... , , （， ） BALFOURI, var.

ELONGATA, p. 122.

Fig. 12....... , , (PASSAMAIELLA) MIRABILIS,

p. 115 .

Fig. 13....... , (ACHATINELLOIDES) HOMHIL-

ENSIS, p. II8.

Figs. 15, 16, 17. $\quad, \quad \quad(\quad, \quad)$ GUILLAINI, p. 153. 


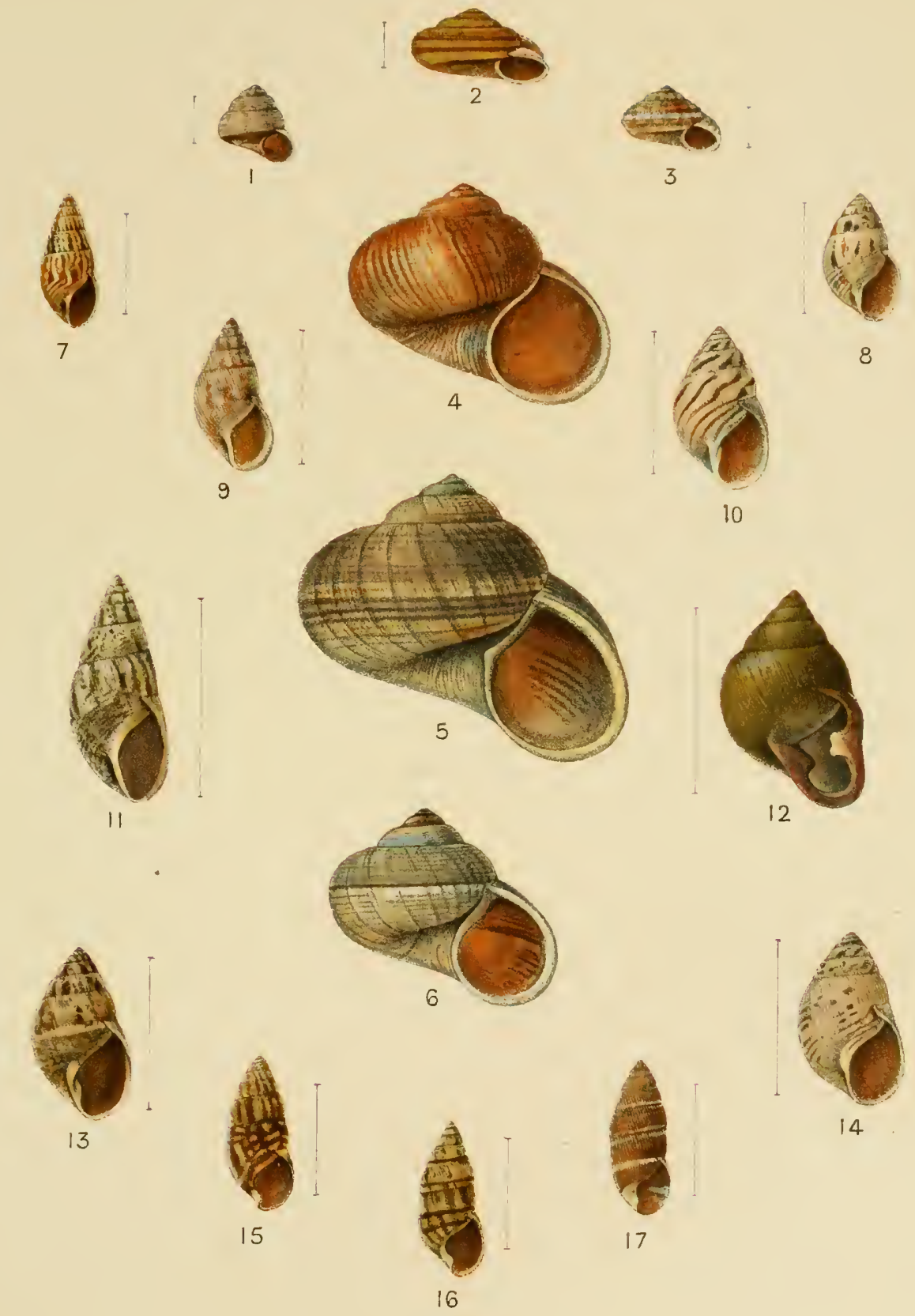




\section{PLATE XIII.}

Figs. I, 4..... BULIMINUS (PASSAMAIELLA) ROTUNDUS,

p. 116.

Fig. 2....... , (CHONDRULA) GRANTI, p. I52.

Fig. $3 \ldots \ldots \ldots, \quad, \quad$ (PASSAMAIELLA) PASSAMAIANUS, var. EURYOMPHALA, p. 113.

Figs. 5, 6..... TROPIDOPHORA SOCOTRANA, p. 145 .

Figs. 7, 8, 9. OTOPOMA TURBINATUM, p. 144.

Fig. 10........ BULIMINUS (ACHATINELLOIDES) DENSI = COSTULATUS, p. I 2 I.

Fig. I1....... , , $\quad(\quad, \quad \quad)$ ADONENSIS, p. 128

Fig. 12....... STENOGYRA GOLLONSIRENSIS, p. 132.

Fig. 13........ BULIMINUS (PACHNODUS) FRAGILIS, p. 129.

Fig. 14....... STENOGYRA (RIEBECKIA) DECIPIENS (top of spire), p. 132.

Fig. $15 \ldots \ldots \ldots, \quad, \quad$, , , ) SOKOTORANA (top of spire), p. 131.

Fig. 16....... , , ， ， ) ENODIS, p. I35.

Fig. 17........ SUCCINEA SOKOTRENSIS, p. I12.

Fig. I 8........ BULIMINUS (ACHATINELLOIDES) PAUXILLUS, p. I53.

Fig. 19....... , $\quad$ ARTUFELIANUS, p. 131.

Fig. 20....... , (ACHATINELLOIDES) FUSCOAPI = CATUS, p. 153 . 

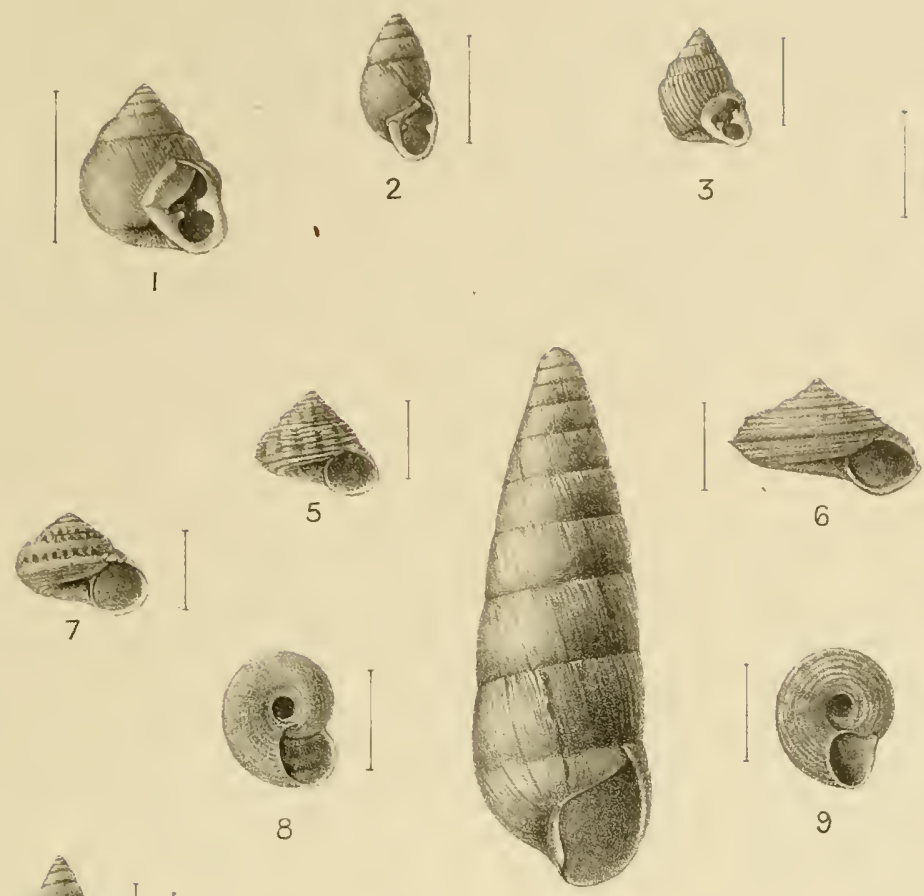

6

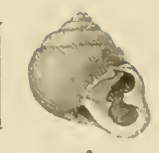

4

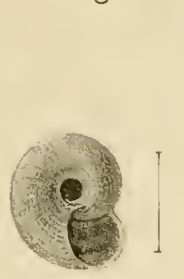

8

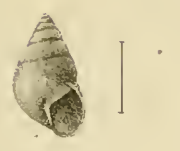

II

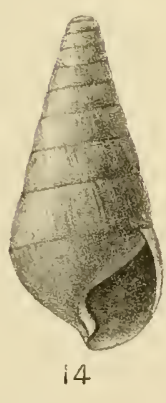

12
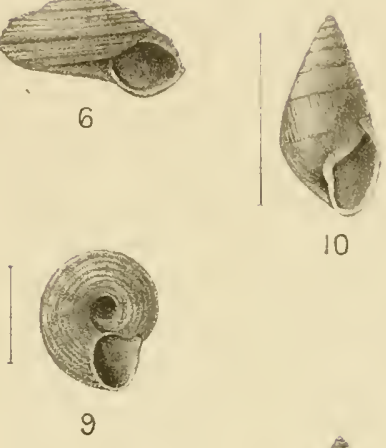

10

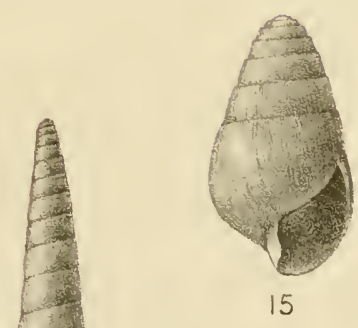

15

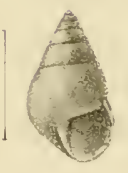

13

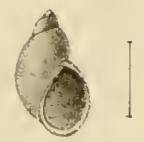

17

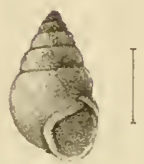

19

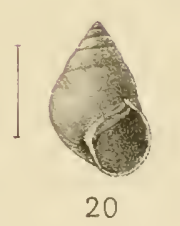

20

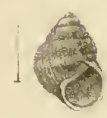

16 



\section{Morphological}

Observations

On Genera of the Families.

Cyclostomidæ and Helicidæ.

By Lieut. = Colonel

H. H. GODWIN-AUSTEN, F.R.S.

PLATE XIIIA. 



\section{Morphological observations on species belonging to the Families Cyclostomidæ and Helicida.}

The late expedition to the islands of Solotra and Abl-el-Kuri, so snceessfully earried ont ly l)r. H. O. Forbes and Mr. Ogilvie-(rrant, has hrought latek even among the Mollusea some valuahle material. After the fine series collected hy Professor Bayley Balfoul in 1880, and the interesting shells olitined ly Mr. and Mis. Theorlore Bent during the short time they spent on the island in 1897 , it was not to be expected many new species wonld be founcl, and such is the ease among the operenlated land shells. We are enriehed, lowerer, ly examples of species preserver in spirit, and, among them, genera of mol interest, Otopmm, Buliminus, and Lithidim, the animal of the latter not having been examined as to its internal anatomy. Another genns is Guilluinin, of the animal of which nothing was known. These forms I now deseribe, with a few remarks on the distribntion of some of these Sokotran C'yrlestomide; and I have to thank Mr. Edgar Smith for supplying me with some of the specimens which the ahove-named naturalists had placed in his hancls. I shall not refer in any way to the shells, Mr. Smith having, on pages 109-15.5, given a complete aceonnt of the whole collection.

\section{Otopoma, Gray.}

Animal with a short, oval, rliviled foot. Mantle margin free in front.

The muzzle divided into two lobes.

Fyes prominent on the outer side of the tentacula near the base.

The male organ is exophalliate, situated elose to and just above the rectum at the right posterior sicle of the hanchial chamber.

The teeth of the rudule are narrow and elongate, with minnte serration arranged 3-1-3. No buecal plates.

Two species have been examined O. nutirnides, Ríchuz, and O). cluthrotula, Récluz, var. minor, G.-A.

\section{Otopoma naticoides, Tiéchu:}

I have describer this speeies in The Lumd and Fiesh-ll inter Mollusen of Inliu, p. 30, pl. lxvii. figs. 1-6 as follows:-

"The animal is very pale ochrecolomed, with a short, hoarly oval, divided foot; the muzzle is transversely striated. The penis is large, lnoarly thiekened, and tongue-like, diminishing rapilly at the free end into a sharp point; the seminal duet appears to l'un down the sicle of the muscular sheath, and the seminal orifice is situated on 
the flat underside, a very short distance from the pointed end. The rectum is situated immediately to the right, and runs as a tube attacherl to the side of the branchial chamber for some distance, and then has a short free end at the anal orifice. In the female the reetum is not so long, and the female orifice is just above it.

"The centre tooth of the radula (fig. d. p. 165) is straight-sided, gradually narrowing from the lase, elongate, bearing five minute cusps on a slightly curved edge. The first side-tooth is rery long, gradnally widening from the hase, and curving over and inwards at the cuttingedge, with ahout six or more small teeth. The seeond and third are ahmost similar in form, narrowly elongate, sides parallel, with eight or ten minute serrations like the blunted teeth of a saw. On the underside of the lunceal mass a eongeries of fine convoluted tubes was seen, representing the salivary glands."

Otopoma clathratula, lieclu:.

A spirit-specimen of Otopuma cluthrutulu, var. mimm; G.-A., the shell of which was deseribed by me in the P.Z.S., 1881, p. 255, was also examined. The male organ is in the same position, hut has a more elongated form and of the same diameter throughout. The radula is preeisely like that of 0 . muticoites.

\section{Lithidion, Gray.}

This genus is represented loth in Sokotra and on the neighbouring island of Abrl-el-Kuni.

\section{Lithidion lithidion, Sorerly. (Plate xiii a figs. 3, 3a.)}

L. maimorosnu, G.-A., was discovered on Sokotra by Professor Bayley Balfour, and its shell described in the P.Z.S., 1881, p. 256, pl. xxviij. figs. $6,6 \mathrm{c}$ (see above, p. 147). Of this, one fine specimen reached this country alive, and lived through the summer. It was very sluggish, and did not shew itself often. It was eventually put into alcohol, and, being a typical specimen, I did not then like to break the shell to extract the animal, for very few specimens occurred in the collection. I have now done so, as we have examples of the genus in another species from Abd-el-Kuri, and a comparison of the two cannot fail to be of interest, and, combined, will give a better knowledge of its characters.

Original description of the animal from life :-

"Animal pale ash-grey ; tentacles l,lack; foot dividerl longitudinally; proboseis long, bilobed"; and Balfour records it as "very common everywhere on the ground." Forbes and Grant obtained a fine series of this species. The specimen now examined shows the division of the foot well (pl. xiii A. fig. 3). The tentucula are broad at the base, and of dark colom together with the top of the head. This specimen is a male, and shows that the genus is exophalliate. The penis is very long and pointed, and its base is situated close to the 
anal aperture. In the diawing the lomehial wall has been slit and turned back. The opereulum (pl. xiii 1 . fig. 3ia) is spiral, of 3 whorls, regnlarly inceasing, bounded by a thin raserl rib: it is shelly, with a thin transparent horder on the basal side. The rulula is a beantiful structure (fig. a) with a formulis.

$$
\frac{3.3}{15-5} \quad \frac{2}{5} \quad \frac{1}{5} \frac{\mathrm{e}}{7} \frac{1}{5} \frac{2}{5} \frac{3.3^{1}}{8-15}
$$

The eentral tooth (c) rather lnoarl, and romoled at the cutting edge, long, and gradnally widening at the base: the 1st tooth is narrower, and widens more rapidly ; the zul has nenly parallel sides with a curved erlge and well-developed eusps; the 3rd is distinctly divided into two separate parts, lenoted hy a longer or shorter eleft, and the greater size of the eight small eusps upon the imer side of the large broad plate. Those who have attentively examined snch ralulie as these under a high power know how the enrvature of the entting edges alters their ontline, as they are viewed from different points. I give a sketch of the centre and outer teeth to show their eurature.

$$
\text { Fir: a. }
$$

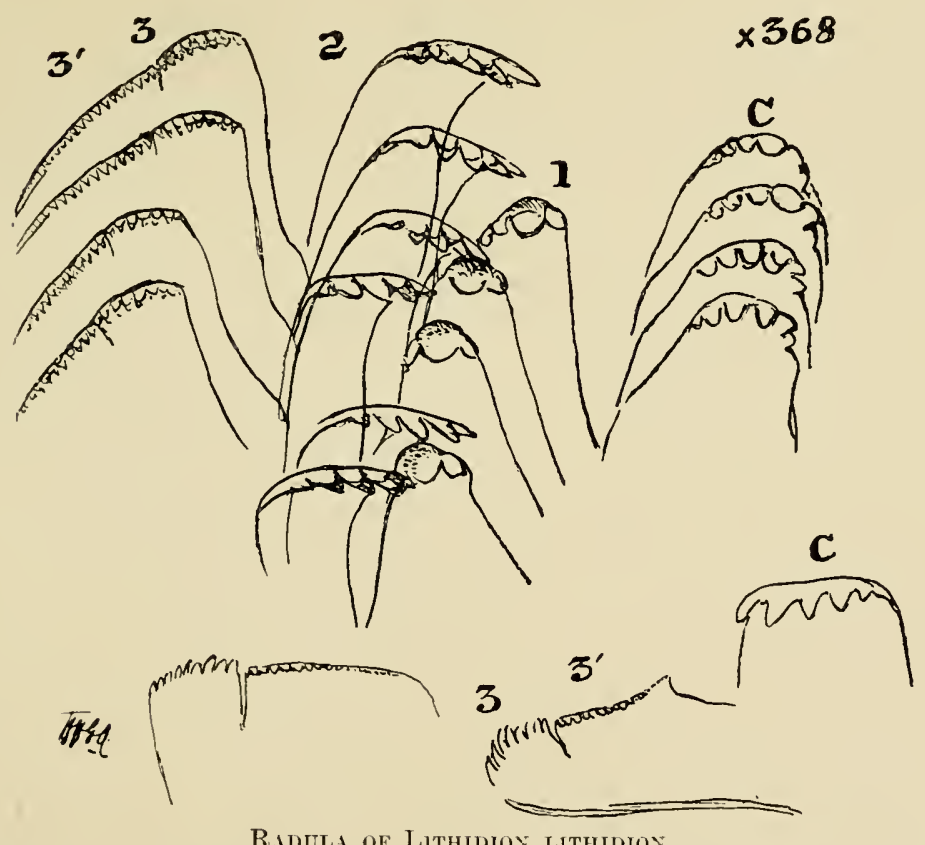

Lithidion souleyetianum, Petit. (Plate xiii $\Lambda$. figs. 2-2e.)

This speeies inhabits the island of Abd-el-Kuri, and was collecter there by Messis. Forbes and Grant. The shell differs in form from the species previously deseriber. The whole animal is very pale in colour. On removing the shell, the shell muscle is conspienous, roller at the end by the action of the spirit in which it was preserverl, pointing to a 
lengthened spiral form (pl. xiij A. fig. Dal). The tentaenla are short, eye at base on a slight swelling on the lower posterior side. The pulmonary reins are well seen, from leing margined with l, lack and cross the wall of the respiratory cavity transversely to join the main sinus on the right hand margin of the visceral satc (pl. xiii $A$. figs. 2 and $2 \mathrm{l}$ ). The operenlum is shelly, with a plane surface in front, spiral in structure, with about three broat whorls (pl. xiii A. fig. 2e). 'The imlulu-formula is this :--

$$
\frac{33^{1.3}}{8-1-5} \frac{2}{5} \quad \frac{1}{4} \frac{e}{5} \quad \frac{1}{4}-\frac{2}{5} \frac{3.3^{1}}{5-1-8}
$$

The centre tooth has a long loroarl plate, wider lielow than at the toothed edge. The 1 st and and teeth are very similar in form, the inmer having a wider basal plate. 'They hoth have nearly parallel sides, and are very long. The thirl tooth on the ontsicle appears at compomel of two originally distinct teeth nerged into one hroad plate. The cusps on the inner portion are larger than those on the onter, and there is a single distinct ensp between the two sides, vide figs. H and e, $3,3^{1}$. I have not heen fortunate in getting a male specimen, but it is no dionbt similar to L. lithirlion $(=L$. marmorstum $)$ in being exophalliate, nor have I been ahle with the 3 specimens I have examined to give satisfactory drawings of the frenitulin. They are not likely, however, to present any remarkable variation from the usnal type.

Fici. b.

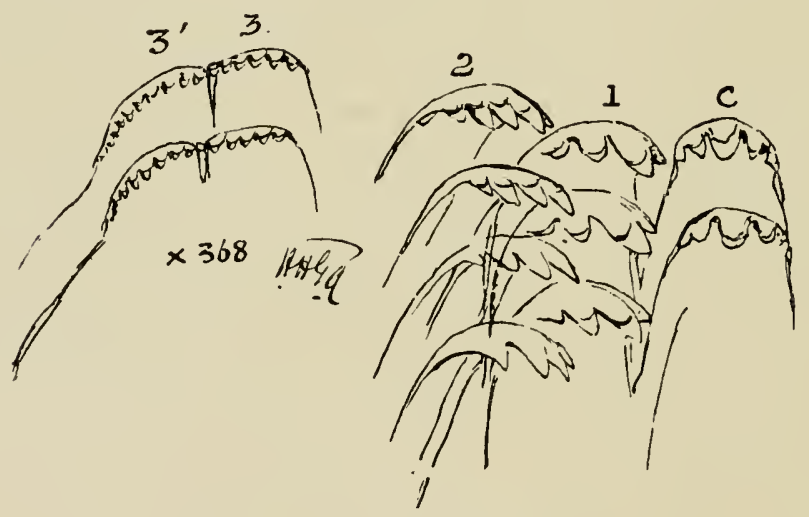

PADULA OF L. SOULEYETIANM.

Comparing these together, the most striking variation is fomm in the operculum. 'That of L. lithirlion (pl. xiii A. fig. 3a) is exactly like that of Cyclotopsis ormutu, G.-A., of Sokotra, fig. 5a on pl. xxviii., P.Z.S., 1881 (see p. 145 above), while the smooth operculum of $L$. souleyetianum (pl. xiii A. fig. 2e) is neares to that of Tropidophen socotrum, G.-A., 3b of ahove plate (p. 145), hut is not so distinctly pancispiral. This last species was placed by me in the alove genus on shell-characters alone. 
It is quite apparent these rudule are of the same type, with only that extent of variation we might expect to find in two distinct species from islands long separated by a deep sea. It is of great interest to find this type of redulu in these Sokotran molluses, for it leaves no doubt as to their true relationship, not lyy shell alone, to the genus

Firi. c.

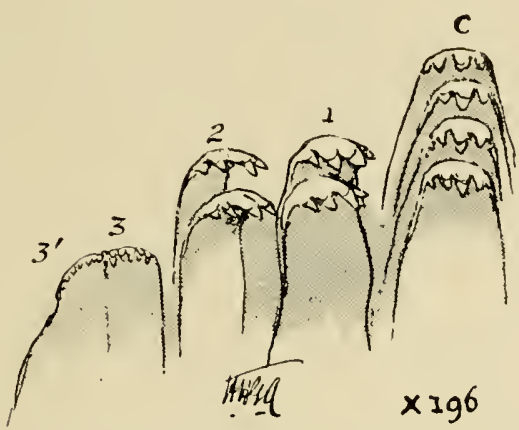

R.HeLA OF L. SOULEYETANUM ON A MOKE REDUCED SCALE.

Tropidophore, the headquarters of which is Madagascar. Neither of these species bear eomparison with Otopomu. The ralula of 0 . nuticoinles, the Sokotran speeies which I rleseribed and fignred in Part VII., Lamel and Fiesh-IV Ter Mollusen of India, p. 30, pl. lxvii. fig. 4, is reproduced below (fig. (l), and both $O$. muticoviles and $O$. sluthrutulu have a similar odontophore with this formula,

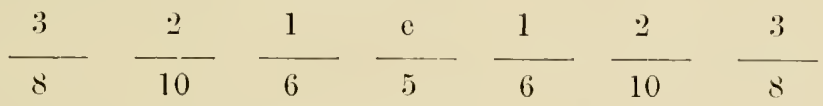

the two onter teeth being of similar form.

F1:, d.

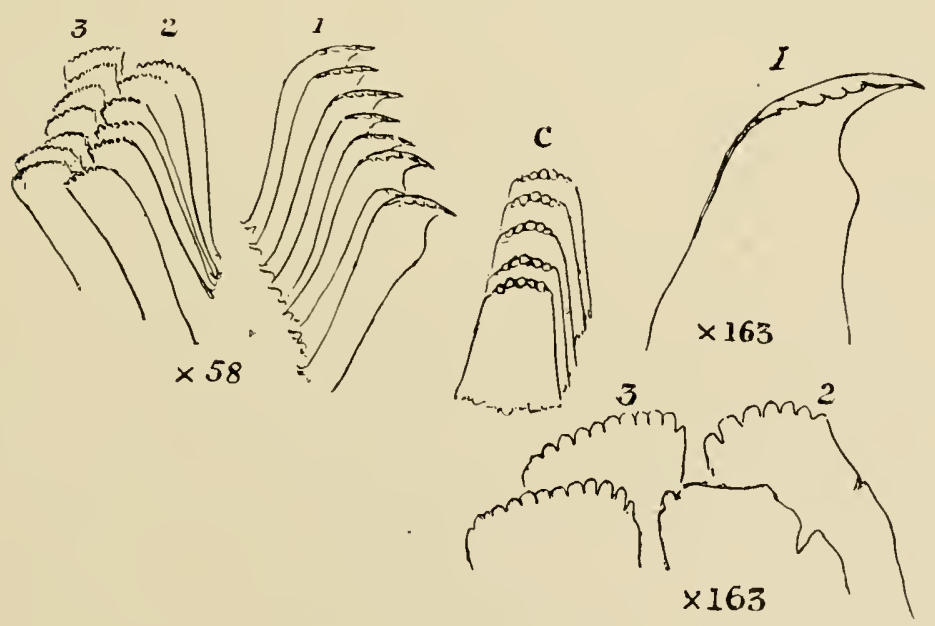

R.ADELA OF O. NATICOINES. 
At the time I was working at Otopom I was led to look for operenlated land shells from South Africa, \&c., preserver in spirit in the Natural History Colleetion of the British Museum. The only one to be found was a single specimen of Tropridophere lertsileopnsis, E. Snith, which he kincily allowed me to examine. It was described and figured (np. cit. p. 32), and I caunot do better than copy what I then wrote:-

"It is a female specimen, and was rely ditficult to extract withont hreaking the shell, which I refrained from doing, as the animal was too harr to do much with. The rudulu proved most interesting, and it rlffers altogether from that of otopoma, even in the formula, which is

$$
\begin{array}{lllllll}
\left(3^{1} .3\right) & -2 & 1 & c & 1 & \underline{2}
\end{array}
$$

Before receiving this, Mr. IT. Moss rery kindly forwarled me some well-mounted examples of rulule, among them one labelled Otopomu unifusriata, Mauritius. Nevill, in his 'Amended Hand-List,' records two speeimens of this species in the Indian Museum, received from the collection of Dr. Dohrin, but stated to be from Madagascar. Whether the species is fomm in hoth these islands is therefore cloultful. The rurlulu of this species (fig. e, p. 166) differs remarkably from that of true otonume, and is altogether a beantiful

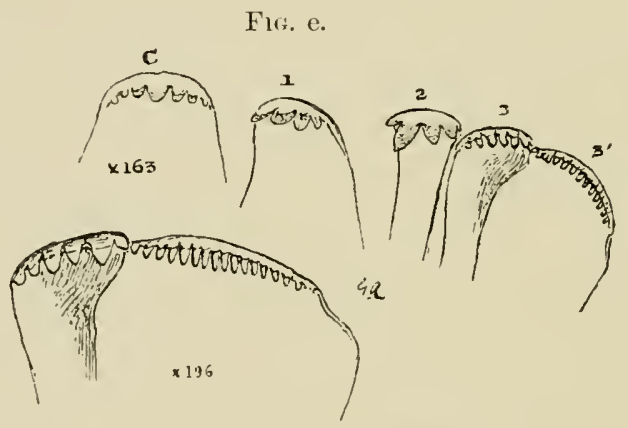

RADCLA OF TropidophokA? IXHFASCIATA.

object. It indicates so considerable a chvergence from Otopom, that when the animal comes to be examined and deseribed, it may give it a rery distinctive position among the Cyrlostomidre. The centre tooth is broad, silles sloping inwarls from the hase, with a large centre cusp, and three smaller on each sicle of it; the first sicle-tooth has similin sloping sides, roumled above, with four eusps : the second sirle-tooth has parallel sides, ind is five-enspid ; instearl of the usual third side-tooth there are, to all appearance, four, the outermost being broad, like a rake in form, with very fine narrow sharp-pointed teethlets, set elose together, abont $14 \mathrm{in}$ number; the next or true third sile-tonth is narrower, with fire ensps, mueh larger. and more romeder in form, contrasting strongly with those on the ontermost tooth ; it is also apparent that this onter tooth ean fold 
ahmost upon itself, the insirle margins being attached. The formula is therefore :-

$$
\frac{3^{\mathrm{I}} .3}{6-14} \frac{2}{5} \frac{1}{4}-\frac{\mathrm{c}}{7} \frac{1}{4} \frac{2}{5} \frac{3.3^{1}}{6-14}
$$

The rutulu of the Tropidophore (fig. f) in the British Musemm, undoubtedly from Mardagascar, wis equally interesting, as it is of the Type just deseribed, not that of oteproma.

FIt. f.

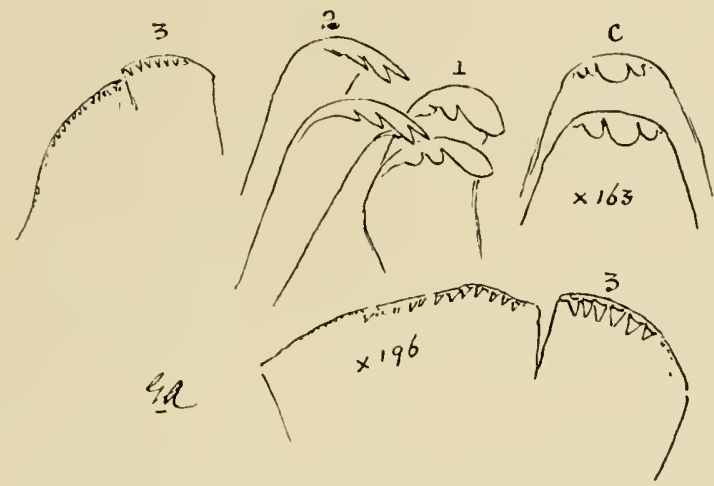

R.NDELA OF TROPIDOPIORA BETSILEOEXSIS.

The centre tooth is rounded above, with straight sirles sloping outwarks to the broad lase, tricuspirl, lut on some the large side cusp is replaced by two smaller ones; the second tooth has nearly parallel sides, sharply bent over on the cuspid elge, with four sharp narrow cusps ; the third is made up of two very distinct portions, the inner one having 6-8 sharp-pointed teeth on a clured edge; then intervenes a long slit, ancl the next and outermost part is a curved edge, set with ahout twelve vely fine saw-like cusps. In every respect it is like mifuscintu, except that the ontermost tooth is not so decirledly divided into two, the formula being :- -

$$
\frac{3^{1} .3}{12-8} \frac{2}{4} \frac{1}{3} \frac{c}{3}-\frac{1}{3} \frac{2}{4} \frac{3.3^{1}}{8-12}
$$

Dr. F. H. Troschel, in his excellent work Dets Geliss dei sihnerken, which tontains such a mass of valuable detail, figures on fig. 11 a row of teeth of C. ligutins, from the Cape of Good Hope. In this species, which is said to be Mauritian, it is interesting to find the outermost touth corresponding with those I deseribe in the Madingasear shell. In C. liqutus the cuspiel edge of the last tooth is divided into nearly three equal curverl sections, that on the inner having langer teethlets than the midrlle section. In fig. 1:2 Dr. Trosehel gives a rmlule of Lomin memmilluris, an African (Oran.) genus and species. In this species the ontermost tooth shows also three distinet and differently 
cuspid divisions on eurved erlges. The West Indian species (ivitr Troschel, from figs. 1:3-26 of (hemelinpmme) have a type of their own, very different from the European gemus cyrtestome, and depart in a greater degree from Otoprome on the one hand and Tropridophora on the other.

\section{Guillainia ? grata, l'tit. (Plate xiii A. figs. 1-1c.)}

Lithidion yratum, Smith, see ahove, p. 15.5.

This species was oltained in the island of Alxl-el-Kuri. The shell differs often in its sculpture and in the height of spire. These valliations ale not numerous when compared with the mumber of nsual size ancl for'm. The animal is very pale in colon', with no markings of any kind. Foot divided, see pl. xiii A. figg. 11. Tentacula are apparently rather short; eyes at the posterior lower hase. The opereulum (pl. xiii A. fig. 1c) is shelly, thin, with about $3 \frac{1}{2}$ turns, smooth and concave in front. The two specimens examined are apparently females. There is every reason for supposing the genus to be exophalliate, like Lithidion and otopmen, the animals in general form being so much alike.

The rululu presents the following formulia:--

$$
\frac{3.3}{10-4} \frac{2}{7} \frac{1}{5} \frac{\mathrm{c}}{7} \frac{1}{5}-\frac{2}{7} \frac{3.3^{1}}{4-10}
$$

It is, however, somewhat difficult to arrive at the exact number of the minuter denticles, as they are seldom all in focus, and not invaliably

Fit: g.
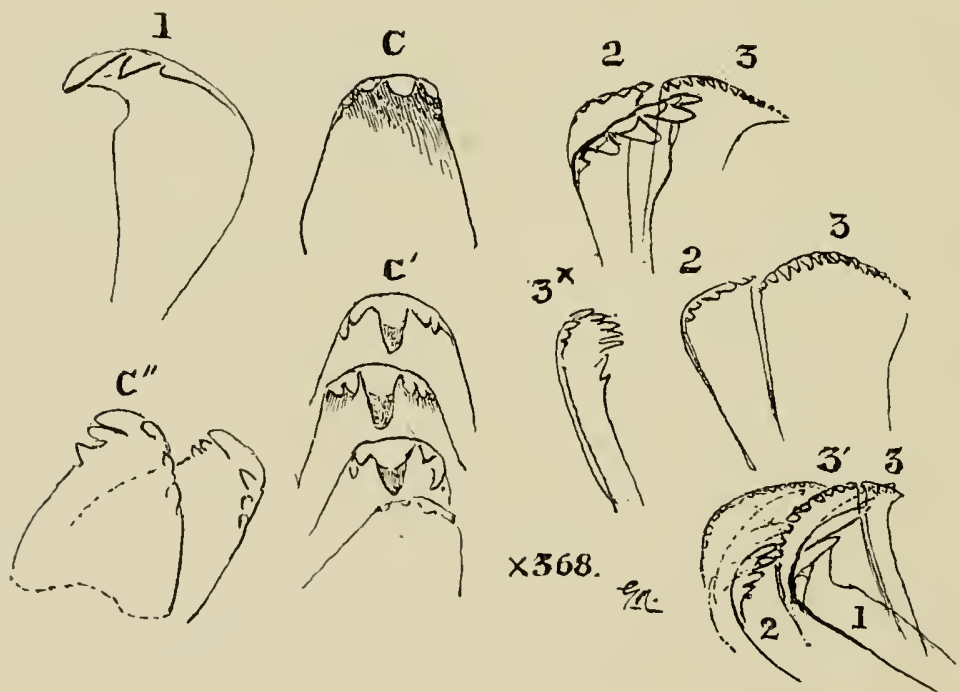

RADULA OF GUILLAINIA GRATA.

the same. The central teeth appear generally as shewn in fig. g. looking at it more from above $\left(\mathrm{C}^{1}\right)$ the cusps are better hronght into view, and the central one is long and pointed, longer, in fact, than in 
any other species from this part of the world which 1 have examiner. $\mathrm{C}^{\prime \prime}$ is a drawing as riewert from the sicle. The first tooth is the largest, with five large eusps, turmed orer sharply; the second is much smaller, narrow, with seven ninute cusps: the third is very broarl, slightly curved on the cutting margin. This tooth has in imer narrow portion ( $\left.3^{x}\right)$ shewn in profile, slightly separated from a wider one bearing minnte cusps - 4 and 10 respectively. It can be seen at once that this reululn assimilates more to that of Lithintion than it does to ofopremme metirendes, which I have referred to ahove, its 3rd tooth heing a composite one. Monsiem J. R. liomrguignat in Mol-

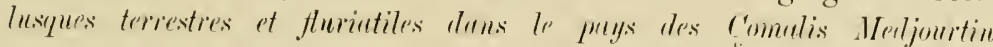
$(18 \times 1)$, placed this species muler the name of trirolor, Pfr., p. s:3, in

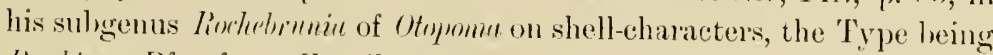
li. olinser, Pfr., from Zanzilar and the Somali comntry. The shell of oltusen, figured by Bomrguignat on pl. iv. fig. 60 to 64 , presents the same high kind of spire as in yrutu, but the opereulum of olitusu is not quite the same. Under whaterer generic title the species frotu may he known, it must be considered a sub-genus of Tropidophura, not of Otopom:

Without going beyond the species of the Cyclostomide? inhal,iting Sokotra and its outlying islands, there is moch in the matter of distribution to attract attention. Their extension north, east, and west, is circumscribed, and, when found at all, they are sparsely representer. They are thus, as it were, isolated here, represented by a greater number of forms, the relationship of the majority being in the direction of a very characteristic fauma in the south.

Commencing with Otoponu, exeluding mere varieties and including Georgia, a subgenus of Bourguignat, in Peninsular India we have only one species, $O$. hindurum, $T$. T. Blf. The animal has never been examined, and when it is, it will be interesting to sec how far it will agree with those of Sokotra. On the East African and Somali coast Otrymm is represented by two species: we do not know whether it is a coastal form or how far it may inhabit the conntry towards the west. From Arabia two species are recorded. In Sokotral we have the greatest number, viz., eight, and the finest forms.

Guilluimin has not yet oceured in either Inclia or Araloia or the African coast near Guardafui, which has been explored. limblemmin, in which grute is inchuded hy Monsienr Bonrgnignat, would appear to he a suhgemus of Otopome, the Type being obtusi, Pfr., from Zanzibar and south of Cape Guardafui. The opereulum as figured is quite like that of Otopomu. The perforation in the centre is not important: Mr. Bourgnignat shows this also in the operculum of Otopome (Georgia) meticopsis. It represents the softer portion attaching it to the foot, torn ont after the animal has dried 11 . Neither can o.

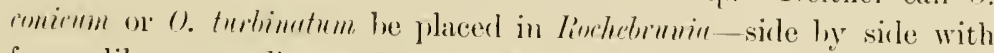
forms like communtiumm, Petit, of Madiagascar, for this shell has no 
trace of spiral liration; on the contrary, the senlpture is strongly transverse. It is narrowly umbilicated with a high, uell-pointed spire. Most of the shells inchuded in liorlemenum are of this type. $R$. plitipnunu, of Marlagascar, is also elosely umbilicate, not ribhed and banded with colour. The species ronum Otopome: but nothing but an examination of the animal ean settle this. I have shown how very different the ralule of Otopenu is from that of Tropidoptene and Lomiu, an Afriean genus; and it seems probable that the animals of all the C'yclostomider of this rast African area, with its islands, will fall into one or other of these two groups, which may even now be marked off as the Otopmince and the Tropidophorime respectively, while shell character may allow them to be ultimately sub-rlivirled into genera and sub-genera.

Lithition of typical form is represented on Sokotra and Abrl-el-Kuri hy four species, two in each island. As Mr. Edgar Smith points out, it is very doulutful whether L. lithiliom has been found in Aralna ; it has not oecurred in the latest collections from that side; nor has it leen found in Africa or India. On looking over the shells of this group in the Natural History Collection, there is a Lithirlion nicem, Petit, from Marlagascar. If we inclucle shells departing more or less from the typieal form, there is Tropiloplora molestu, Petit, of Alul-elKuri, which is a Lithirlion of a large tumid shape, and even TropiIophure socotrun shows a clear approach in its style of sculpture, open umbilication and high spire. Then Mr. Smith plaees Guilluiniu grotu in Lithidion, althongh in this shell the wide umbilicus is no longer a eharacter. I consider, in spite of the similarity of the animals, the form of the shell is sufficient to keep it separate subgenerically.

Cyclotopsis is an Indian genus, represented there by only two species, subuliscoileum, Sowerby, from Orissa; and semistrutum, Sowerlyy, in Peninsular India. C. conoidenn, of the Mauritius, has been put into this gemus, and Morelet has describer filirum and neritli from Anjonan, one of the Comoro Islands. I descrihed wometrs from Sokotra. I may mention that the animals of all the above speeies are mknown, and until they are examined we cannot feel quite sure they will all be generieally alike. The operculum of C. muntus is similar to Lithiution lithirlion; Cyclotonsis may, therefore, turn out to be very near Tropidophora. Sokotra on the north is at present the limit of the genus.

\section{Buliminus, Beck.}

\section{Sub=gen. Achatinelloides, Nevill.*}

The Type of Achatinelloirles is B. socotwensis, Pfr. The original description of the sub-genus is as follows:- "I suggest the ahove name for the curious Achotinellu-like form, distinguished from likurhis by the

\footnotetext{
* Hand List of Mollusca in the Indian Museum, Calcutta, 1. 131.
} 
remarkable distinet fold on the columella, and hy its more solid textmre; the oblique raided and regular sculpture is also musual in the genus."

The dissections of species in this sub-genus were made many years ago from specinens brought home alive by Professor Bayley Balfour, and have heen waiting publication in Land and Fresh-II wer Mollusin of Indin, together with dissections made of Indian species of the genus, such as P. (Patraens) yriffithii, from the Kuram Valley, North-lVest Frontice of India. As an opportunity now ocen's of adding to what is known of the land shells of Sokotra, I give the results here.

Buliminus (Achatinclloides) balfouri, $r_{\text {r. }}-$ t. (Figs. h, j.)

Buliminus (Achatinelloides) socotorensis. (Fig. i.)

The generative organs are in every respect similar to a typical Buliminus, for instance that of $B$. (Napieus) montumus, Drap., of the European

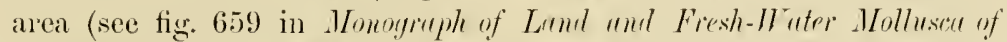
the British Isles, by Mr. John W. Taylor; p. 361), the most striking chanacter being the long thin flagellate appendix rising from a long, thickencel, and distinct hase, opening into the common atrium elose alongside that of the penis, from which it scems quite distinct. Its function, whatever it may he, is associated with this organ, indicated by the retractor muscle being common to both, that is, it hifurcates as

FIri. h.

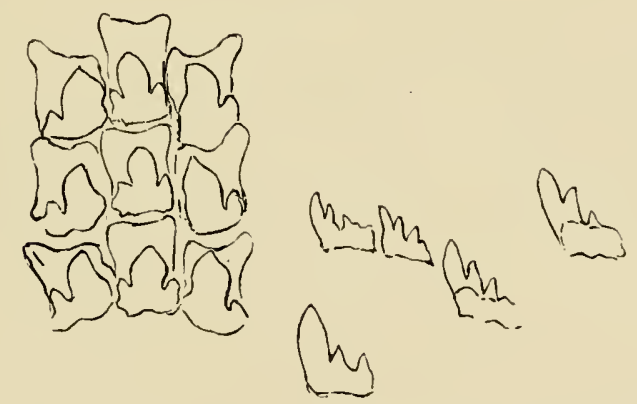

RAMLA of BULIMNUS (ACHATINLLOIDES) B.ALOURI.

is shewn by Mr. Taylor in D. monterms and as I observed in both $B$. luelfonri and B. yriffithii of the Panjal. In this Sokotran species the flagellate appendix is hasal with regard to the penis sheath; in the Intian species above-mentioned it is a diverticellum on the side of the penis sheath, given off about half-way between the generative orifice and the penis papilla. Mr. Taylor says "it would appear not improbable that the appendix to the penis sheath of certain Gastropods is homologous with this organ," and it is apparent that if the forked retractor muscles were hought together into one, and the lasal tube of the flagellum laid alongsicle to coalesee with that of the penis so 
eompletely as to lecome a single tube, we should he presented with the normal form of the flagellate penis in so many genera of the

Fiti. i.

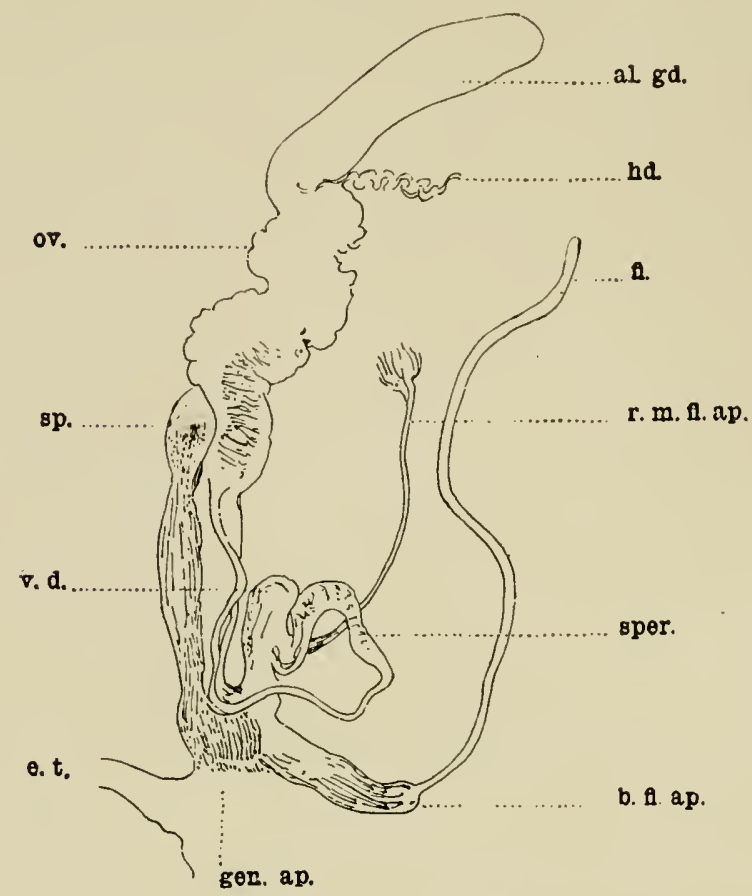

(inNTALA OF B. (ACHATINELLGIUES) SUCOTORENSIS.

hd., hermaphrodite duct ; al. gd., illbumen gland ; ov., oviduct; sp., spermatheca ; fl., flagellum ; v.d., ras deferens; sper., spermatophore; b. fl. ap., base of flagellate appendix ; r. m. fl. ap., retractor muscle of flagellate appendix; ge... ap., generative aperture; e.t., eye tentacle.

Helivile. The genitulir of the gemus I'nm is sairl by Mr. Taylor to be similar to that of Lulimiurs montrum. I have not myself examinerl a sutficiently large number of speeies in these elongate, elose and many whorled genera, to know if there is any inclication towards such a course of evolution in the relative eloser position to each other of the flagellate appendix and penis ; it would he of interest to find such.

A spermatophore is developed, and in the generative organs of $l$. bulfonri one may he seen in process of formation (sper. fig. i).

In Buliminus bulfouri, the odontophore formula (fig. h) is :-

21

$$
\begin{array}{lll}
12 & \frac{1}{33} & -12 \\
1 & \frac{12}{33}
\end{array}
$$

with 111 rows of teeth. The ecntral tooth is trienspicl, short, the point well helow the anterior edge of the basal plate; the admerlian teeth are bienspid, with the points also short, this may he due to 
wear, for in b. (Achatinelloiles) sorotorensis, P'fis, they are much longer, longer even than the hasal plate. The lateral teeth are unevenly hicuspirl with another smaller ensp on the exterior sicle. In li. soroturensix, there is generally one long tooth with two smaller on the exterion lase. The plates are namow. The lental fommla of this last is :-

18 $\frac{10}{28} \quad \frac{1}{1} \quad \frac{10}{28} \quad 18$

9ri rows were comiterl.

FIs. i.

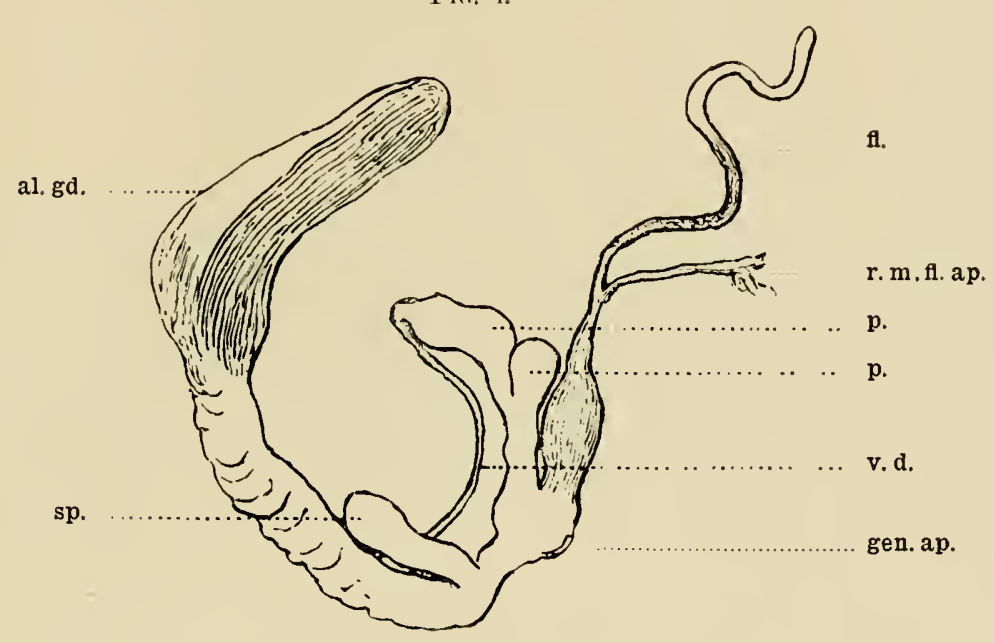

Gexitala of B. (achatineldoides) b.h.folti.

al.gd., albumen gland; sp., spermatheca; v.d., ms deferens;

fl., flagellum; gen. ap., generative aperture; p., penis;

r. m. fl. ap., retractor musele of flagellate apprendix.

In my paper on the Land Shells of Sokotra, eollecterl by Professor B. Balfour, I marle a few remarks on the past conneetion of Sokotra with some former and very different listribution of Land and Water in this part of the world. It is not for me to enter on this sulject here. It is one which can only be properly treated by those who have seen the country, and on a review of the whole collection.

I wonld, however, again refer to one point in the generie ristribution of the Land Mollusea. Although since 1880 further eollections have been marle, inereasing the number of known species, the remarkable absence of Helir still remains true. 


\section{PLATE XIII A.}

Fig. I. GUILlainIA GRATA, Petit. Aluimul, riglt side, $\times 12$.

Fig. ı. The stume, Auimul, left side, $\times 12$.

Fig. Ib. The seme, Animul from abore, showing divided foot, $\times 12$.

Fig. Ic. The sreme, Operculum, $\times 12$.

Fig. 2. LITHIDION SOULEYETIANUM. \& Animel from riglit side, $\times$ s.

Fig. 2a. The sume, Shell muscle.

Fig. 2b. The setme, Inimul from above.

Fig. 2c. The seme, showing umel aperture, $\times 8$.

Fig. 2d. The setme, from right sule, $\times 8$.

Fig. 2e. The sume, Operculum, $\times 12$.

Fig. 3. LITHIDION LITHIDION, G.-A. of Alimel from whore, $\times 8$,

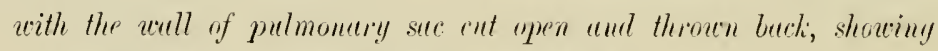
amel orifice and exophallinte male oryan.

Fig. 3a. The setme, Operculum, $\times 12$. 
Liverp.Mus.; Rep.Soketra Exped.

Pl. I7IIA.

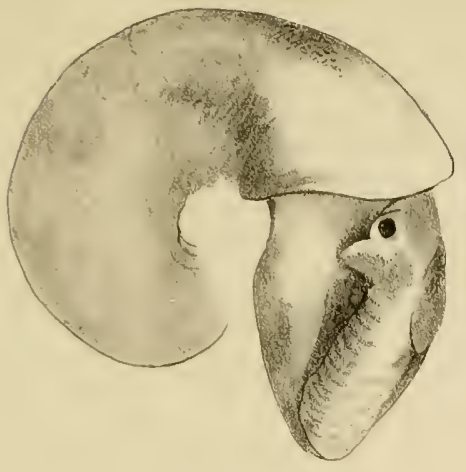

1

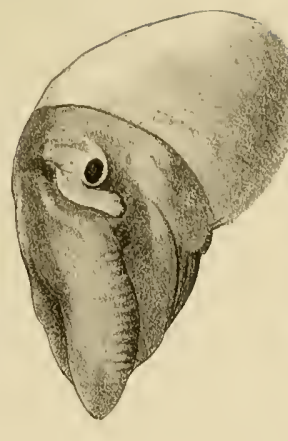

12

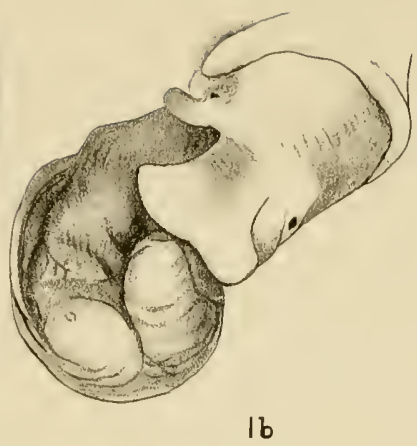

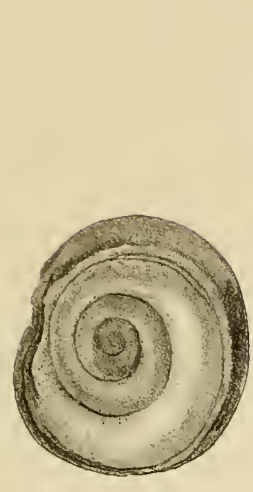

Ic

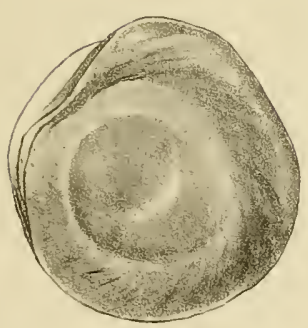

$2 e$

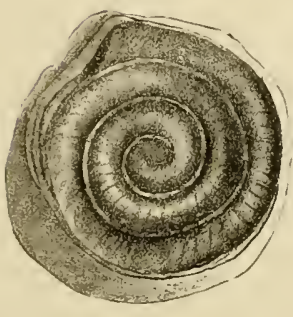

$3 a$
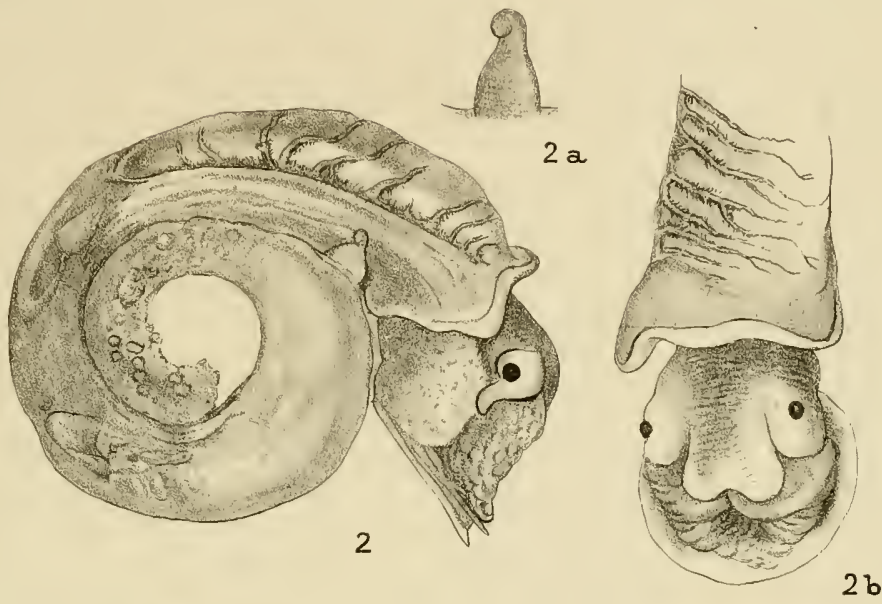

$2 b$
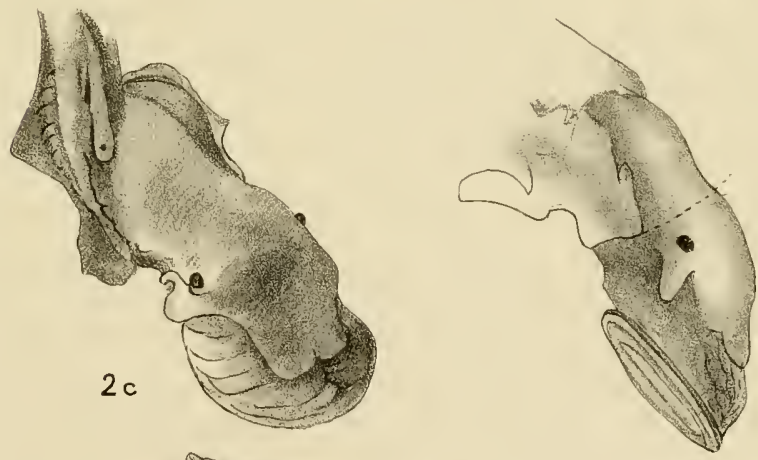

$2 d$

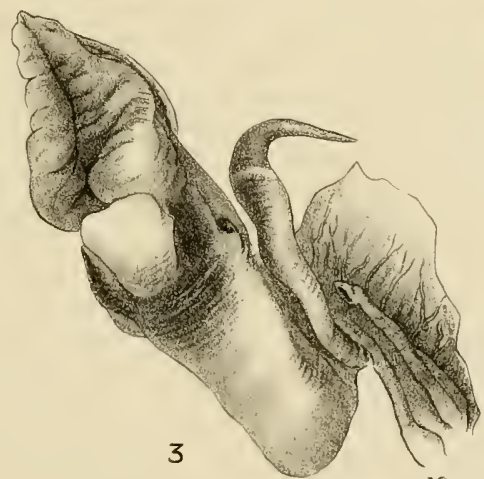

Mintern Bros. Jith

H.H. Godwin-Auster del

MORPHOLOGY OF GUILLAINIA AND LITHIDION. 



\section{ARTHROPODA.}

\section{Arachnida.}

By R. I. POCOCK, F.Z.S.

PLATES NIV., XXVI. 



\section{Scorpions and Spiders.}

The literature of Sokotran Arachuida is at present scanty and scattered. A complete list of the papers that have been written and of the species that have been recorderl from the islands of Sokotra and Alol-el-Kuri are given at the enrl of this report.

The fauna is a mixture of elements showing affinities both with the fanna of the Ethiopian and the Mediterranean areas, the Mediterranean elements on the whole prerlominating. The Scorpions - a group which furnishes valuable evidence for the determination of geographical areas - are distinctly more Mediterranean than Ethiopian. IIrmiscorpius and Butheolus have their hearquarters in the resert comtries of South-Western Asia. The one species of Buthus, too, belongs to a section of the genus which is represented by several forms in these same countries, has penetrated Africa as far sonth as the Zambesi, and has reached Cape Comorin in India, though its absence from Ceylon and Burma points to it as a late immigrant into Hindostan. The two Scorpions from Abd-el-Kuri attest the same fact, both heing related to the Arabian and Syrian genus Tebo, and occupying an intermediate stage between the latter and its only other known ally, the Central Anerican Jiplorentrus. The one Solpugirl met with in Sokotra also belongs to a gemus known hitherto from Asia Minor, Arabia, and North India. Aryyope clurliii is auother Meditesranean form. On the other hand, the Mygaloid Spirler Monocentromus, although peculiar to Sokotra, forms a unit of the sul,-family Eumernophorinu, which is confined to tropical Africa and Marlagasear. Teplitu hymenere, too, and the one single known Gesteraconthe are certainly African and not Merliterranean elements. The same may be sair of the two forms of Lutrodectus and of the one genus of Zorlariidie, Cupheris. The remaining species of spirlers do not supply very satisfactory evidence either in favour of an Ethiopian or Merliterranean origin of the fauna.

On the negative sille it is interesting to note the apparent absence from Sokotra of such forms as the Spirlers Heteropoule vemetorin, Arteme atlentu, and the Scorpion Isometrus encoperus (= muculutus), which have been artificially introduced hy human agency into all tropical and sulbtropical conntries to which commerce has extended. 


\title{
The Scorpions and Spiders of Sokotra.
}

\section{SCORPIONES.}

\section{BUTHID虑。}

\author{
Buthus, Leach.
}

1. Buthus socotrensis, Pocock.

Prionurus hottentottu., Fabr.; Taschenberg, Zeits. Naturwiss. (t), ii. p. $173(1883)$.

Buthus sorotrenxis, Pocock, Ann. Mag. Nat. Hist. (6), iii. p. 337, pl. xv. fig. 3 (1889); Kiraequelin, Das. Tierr. Scorq., ete., 1). 20 (1899).

My original deseription of the Type, with a few emendations, is as follows:

"Coluur very characteristic. The whole hody, above and below, with palpi, legs, tail, and eephalothorax uniformly ochraceons, testaceous, or a combination of the two; the distal end of the chelicera, the area of the lateral and median eyes and of the anterior cephalothoracic keels, black.

"The spreirs bears considerable resemblance to $b$. lootentottu and $b$. fumulus, and molonbtedly appertains to that section of the genus of which hottentottu may he regarded as the type.

"Ceplututhorkx.-Much the same shape as in B. hottentott", but the median eyes are larger and considerably more widely separated; anterior keels not smooth between the eyes, diverging normally in front and joining each other in the middle line of the front erlge of the cephalothorax; the area between them ahmost smooth. The posterior keels almost parallel, joining, and being in almost the same straight line with the internal median keels, which are consequently themselves nearly parallel, the two on each side constituting only a slightly sinuous line; the external median keel not prominent and not united by a transverse line of tubercles with the anterior end of the posterior keel, as it is in B. europues. The rest of the cephalothorax sparsely granular.

"Teryites. - The first six marked with three kecls, although the lateral keels of the first may be represented by a single large gramule only; these keels granular and becoming progressively more expressed from before backwards, the lateral diverging in front, but none of the keels are conspicuous on account of their being of the same colour as the rest of the segment; keels of the seventh segment like those of, e.g., B. hottentotta. 
"Siternites as in li. hottentolte, except that the fom keels of the fifth are of the same colour as the rest of the segment.

"Tuil. Slightly narrowed from hase to apex, considerat,ly more shallowly

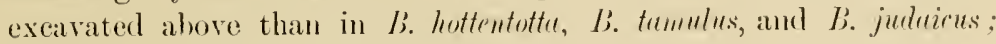
upper surface of the fifth segment with a shallow depression in its posterior half. The first four segments provided each with ten keels, for the most part feelyly gramular: the inferior keels, almost smooth in front, become more granular behind; the superior keels, on the other hand, beeme less gramlar behind: the inferior interearinal spaces smooth behind, and beeoming more gramular in front ; the superior interearinal spaces sparsely granular behind, more thickly so in front : on the fourth segment the granules of the upper surface are arranged in a definite longitudinal series, and constitute a distinct keel ; conseruently this segment, having a eomplete though feeble median lateral keel, is supplied with twelve keels. Fifth segment much like that of $I$; hottentotte, lunt less narrowed behind and less excavated ahove : superior. keels alsent, the segment heing merely gramular alove at the sides; inferior and lateral keels evenly grannlar throughont and nowhere denticulate; the granules of the inferior interearinal spaces are arranged on each side in a definite series, thus constituting a keel, so that when viewed from below this segment appears to be furnisher with five keels.

" Tesicle large, dilated, its height leing as great as, or greater than, its width, and as great as, or a little greater than, the wilth of the anterior and of the fifth caudal segment; granular beneath; aculeus sharply curved backwards, considerably, or a little shorter than the resicle: together the two are about as long as the fifth candal segment.

"P'ulp.-Humerus almost as in B. hottentottu, except that the granules are finer; brachium not eostate behind; superior keels very finely granular; anterior keels more coarsely granular. Manus not costate ; a little narrower than the lrachium and shorter than the dactyli; dactyli long, slender, ineurved ; the movable dactylus in one specimen about twice the length of the 'hand-lack,' in the others considerally less so; the movalile dactylus fumished with a small hasal lobe. External surface of femora of legs granular.

"Pretiues (exclusive of the teeth) shorter than the cephalothorax; number of teeth $24-25$ ( $q)$, in one specimen 28-29 (o). All the appendages are hairy, mostly sparsely so, but on the manus and dactyli the hairs are very short, and elose-set; the anterior margin of cephalothorax is furnished with a row of hairs, and on the under surface of the tail the hairs are few but symmetrically arranged.

"Measurements in millimetres of largest specimen:- Total length 76, of tail 44 , of cephalothorax 9 : width 10 ; first tail-segment, length $5 \frac{1}{2}$, width $5 \frac{1}{2}$, height $4_{4}^{3}$; fifth tail-segment, length $9 \frac{1}{4}$, width $4_{4}^{3}$, height $4 \frac{1}{2}$; visicle, length $6 \frac{1}{4}$, width $4 \frac{1}{4}$, height $4 \frac{1}{2}$; palp, length of 
humerus 7 , of brachium $8 \frac{3}{4}$; width of latter 4 ; width of hand $3 \frac{3}{4}$ : length of 'hand-back' $5 \frac{3}{4}$, of movable finger $10 \frac{1}{2}$; length of pecten $7 \frac{3}{4} . "$

In the length of the fingers and slentemess of the hand this species somewhat calls to mind the female of B. tomulus; but the movable dactylus is furnished with a much more conspienons lasal lobe than in the female of that species. It differs from both $B$. hottentoter and b. tumulu. in its larger and more widely separated median eyes, in its more willely separated and more parallel posterior cephalothoracic carine, in its larger vesicle, and, above all, l,y the additional twelfth row of gramules on the superior surface of the fourth candal segment; this last is, in fact, a characteristie by which it may be separated from, I helieve, all the speeies of Buthus that have been hitherto describer, althongh it is at the same time a eharacteristic which is faintly foreshadowed in the reduplication of the series of granules which constitute the superior keels of the fourth and fifth caurlal segments in some of the species allied to Parabuthus liosoma.

This Scorpion is extremely abundant in the island. Large numbers were procmed by Messrs. Giant and Forbes.

Sokotra: Hadibu Plain: Dahamis (350-1000 ft.); Homhil (1500-2500 ft.); and Jena-agahan ( $1200-2500 \mathrm{ft}$.).

Unler stones; rarer in tents.

\section{Butheolus, simon.}

\section{Butheolus insularis, l'orock.}

Butheolus insuluris, Bull. Liverp. Muss., ii. p. 8 (1899).

Colour.--Tail and upper sile of trmuk olive-lilack, appendages rather paler ; digits, distal end of legs, and rentral surface, olive-yellow.

C'urupue gramular, its ante-ocular portion sloperl ; terga granular, espeeially along the posterior margin ; terga $3-6$ tricostate. Tuil incrassate to midlle of fourth segment, inferior surface of segments $1-4$ grannlar and furnished with four strong and gramlar keels; inferior surface of fourth and fifth smooth, impressed with large but shallow punctures, the former with very short granular keels in front, the latter gramular posteriorly, its lateral keels only obsolete in front, upper surface of segments smooth; the first normally keelerl, the seeond with weaker and smoother keels, third, fomth, and fifth pmetmed at the sides, the two former with searcely a trace of lateral keels ; vesicle puncturerl; not geniculate beneath the aculens. Chele with humerus gramular and gramlarly crested above, brachium smooth, with smooth erests; hand smooth, scarcely eresterl; digits short, the movahle heing twice the length of the hand-baek, shorter than the earapace, furnished with eight rows of teeth. Movable and immovable digits of momilules furnished with two inferior teeth. Coxæ of legs grannlar; external surface of legs granular and carinate. Pectinul teeth, 17.

Total length, $2 \cdot 2 \mathrm{~mm}$. 
Sokotra: Gebel Raggit (700 ft.).-A single specimen.

Found under a stone in the dry upper parts of the bed of the Hanefu River.

Recognisable at once from the Ambian and Persian B. melumurus by the smoothness of the upper caudial erests, ife.

\section{ISCHNURIDÆ.}

\section{Hemiscorpius, Peters.}

3. Hemiscorpius socotranus, Porork.

Hemiscorpius socotranus, Bull. Liverp. Muss., ii. 1). 8 (1899).

q Colou:- Olive-hown alove: ehelie ferruginous, with erests and cligits infuscate; legs olire-yellow.

Curupure and tergal plates densely punctured ; very finely and closely granular laterally and in the merlian depression; coxie and sterna finely punctured. Titil ahout four times as long as the carapace; superior and inferior lateral keels strong and granular on all the segments ; median lateral keel absent on first and all the following segments, exeept the fifth, where it is posteriorly abhreviated; inferior lateral keels distinct on all segments, but weakly granular on the anterior ; inferior median keel alsent on segment 1, present in the posterior half of segment 2 , developed on segments $3-5$; intercarinal spaces finely gramular; resiele finely and coarsely puncturerl, finely granular. Clome rery finely and closely punctured; hand nearly flat above, with smooth external finger keel and median longitudinal keel. Legs punctured and finely granular. Genital operculum broadly cordate, without median suture, except in front. Pectimal teeth 10.

of Differing from $q$ in its more slender build, longer tail, and much more strongly gramular upper surface of body and ehelæ. Carapace as long as first and half the second eaudal segments. Tail abont fire times as long as carapace, its fifth segment much longer than earapace; resiele more elongate than in . P Pectinal teeth $12-13$.

Measurements in millimetres — $q$ Total length 38 , length of tail 19.5, of earapaee 5, fifth segment of tail 4.5 . \$ Total length 38 , length of tail 22 , of earapace $4 \cdot 2$, fifth segment of tail $5 \cdot 2$.

Sokotra: Hadilı Plain; Jena-agahan (1200-2500 ft.); Adho Dimellus $(3500-4500 \mathrm{ft}$.$) .$

Under stones.

Reeognisable from the Arabian $M$. leptrus by the obsoleteness of the median inferior keel on the first and second candal segments, ete.

\section{SOLIFUG $\nexists$.}

\section{SOLPUGIDÆ.}

\section{Gluviopsis, Knaep.}

4. Gluviopsis balfouri, I'orork.

Parmeolis bulfouri, Poeock, Ann. Mag. Nat. Hist. (6), 1. 95 (1895).

o Colou entirely pale yellow, with the exception of the hlack ocular 
tubercle, black mandibular fangs, and a broad black band round the distal half of the tihia of the palp; distal extremity of the tarsus pale.

Carmpae with its anterior border lightly convex; tuberele with a series of hairs surromuling the eyes on the inner side and a eluster in front, of which two are stronger than the rest; space between the eyes ahout erpual to a diameter:

Maulibles with long, sharply defined, stridulating ridges; the lower jaw dentate, somewhat as in I'. dorsulis, but in the upper the anterior two teeth are large and sulb-equal, as large, in fact, as the fourth-the third, fifth, and following ones being small.

Pulp with its tibia sturded below with two series of longish spines.

Measurements in millimetres.-Total length, 16 ; wirlth of head 4 , length 3 ; length of mandible $5 \cdot 3$, of palp 12 , its protarsus and tarsus 4 , of fouttl leg 18 .

Sokotra.-(I. Li. Bulfortr.)

\title{
ARANEA.
}

\section{MYGALOMORPHÆ.}

\section{THERAPHOSID压.}

\section{EUMENOPHORINÆE.}

\section{Monocentropus, Pocock.}

\author{
Monocentropus, Pocock, Proc. Zool. Soc., 1897, p. 758.
}

Carapace oval, longer than wide; fovea shallow, transverse, wider than ocular tuberele; tuberele small, subeircular; eyes of anterior row somewhat strongly proeurved, of posterior row reeurved; clypeus very narrow.

Muntililes without external scopula; a single row of teeth below; the posterior portion of the lower surface weakly granular.

Lulium a little wider than long; its border gramular like the imner angle of the maxilla.

Stermm oval, longer than wirle; the posterior sigilla distinctly removed from the margin.

Leys: tarsal seopulie entire; protarsal seopule also undivided, except partially so on the fourth; on the first and second legs, extending praetically to the base of the segment ; covering alout two-thirds of the segment on the third leg and half on the fourth; legs unarmed, except for a pair of spines at the tips of the tibice and protarsi beneath : length $4,1,2,3$; patella and tibia of fourth about equal to those of the first; claws marmed. Spinuers considerably more than half the length of the carapaes.

Tithin of ormed with a single spine-tipped tuberculiform process. 
5. Monocentropus balfouri, Porock. (Plate xiv. fig. 1.)

Monocentropus balfouri, Proc. Zool. Soc., 1s97, p. 758, pl. xli. figs. 1, la.

Colour.-Carapace covered with olive-yellow julsescence, showing pinkish tinge towards the margin; legs covered with olive-lyown hairs: the base of the femora and upperside of the trochanters greyish-white; the lower side of the femora clothed with whitish or yellowish-white hairs and contrasting very foreibly in colour with the chocolate-hrown tint of the eoxa and of the segments on the distal side of the femora; ablomen furnished with long greyish-red hairs at the sirle, black beneath.

Curume molerately convex, its eephalic area not strongly elevated; a little longer than the fourth protarsus, shorter than patella and tibia of formth leg.

Eiyes not very unerual in size; the anterior merlians if anything the smallest, distinctly smaller than the anterior laterals, and separated by a space that about equals their diameter, a little nearer to the anterior laterals : a straight line touching their front lorrlers cutting near the centres of the laterals; posterior median about as large as the posterior lateral and eloser to it than to the median.

Tiliu of s armed with a low tuberenliform process heset with two tufts of rigid lanceolate spines; the lower surface of the anterior two pairs of femora as well as the femur of the palp furnished externally with long thickly-set hairs, tilia of palp also thickly hairy below ; tarsus of palp apically thickly seopulate; the bulb globular, the lightly areuate spine rising abruptly from its posterior portion.

Measurements in millimetres.-Total length 34; length of carapace 16 , width 13 ; length of first leg 50 , of second 47 , of third 45 , of fourth 53 ; patella and tilia of first 18.8 , of second 16.5 , of third 15 , of fourth 18 .

Sokotra: Homhil (1500-2500 ft.); and Arho Dimellus (3500-4500 ft.). Collected also ly Prof. Balfour and Mrs. Bent.

All the known specimens of this spider, the largest found in Sokotra, are males that have been met with wandering about after rlark in seareh of females. The latter, no doulst, live in burows, and have on that account eluded up to the present time the search of collectors. The example eapturerl by Mrs. Bent was caught in the tent at night. One of the other specimens was met walking along a steep path in the bush at alont $5: 30$ p.m. Instearl of attempting to escape ly flight, it immerliately rose up in an attiturle of defence, showing fight in the manner rlepicted on the Plate referred to ahove.

\section{BARYCHELID平.}

\section{Atrophothele, gen. nov.}

C'urupues low; eyes aggregater on a tuberele: the oeular area a little wider than long and a little narrowed anteriorly; anterior medians 
elose to edge of clypens subequally separated from each other and from the posterior laterals, the spaces hetween then slightly exeeeding the long diameter of an anterior lateral eye; posterior laterals and posterior medians suleyual, much smaller than the remaining eyes; anterior medians a little more than a raclius apart and a little less than a diameter from the anterior laterals. Lirstellum scarcely developed, merely represented hy ahout a dozen irregularly arranged long, curved, stout, but apically filiform bristles. Cretrum wirler than long, with a row of ahout six cusps along its borter; murille studed basally with cusps, about twenty in number, arranged anteriorly in about three rows. Legs slender, anterior pairs and palpi seantily spinerl : posterior pairs more strongly spined; scopule scanty. Anterior spinners very small, quite short and slenrler, set close together in the middle line.

Type A. soliotiana.

In the small size of its anterior spinners this genus lies midway between Diplothele and the rest of the genera of the family Brorychelirle. Other distinguishing features are the weak rastellum, the straight thoracie forea, cuspulate mouthparts, and small posterior lateral eye.

\section{Atrophothele socotrana, sp. $n$.}

Colom: carapace deep rudrly-hrown, scantily clothed with silky-yellow hairs ; logs pale orange yellow ; abdomen pale olive grey.

Cumpare about one-fourth longer than wide, its length about equal to patella and tibia of fourth leg, longer than patella and tibia of first leg. I'ulpi with tibia armed internally with about three spines. Leys: : first leg unspined, except for two spines at the base of the protarsus, and a few stout bristles on the underside of the tibia; second leg armed like the first, but the bristles on the tibia shorter, one of them being spiniform; third leg alsent; fourth leg with about half a dozen spines on the underside of the tibia, three being apieal; one posterior spine on the patella, and many strong spines and spiniform bristles on the protarsus ; seopula scanty : protarsal scopula of first leg scareely reaching, that of seeond not reaching, base of segment; absent on fourth leg; tarsal scopule divided ly land of sete, the divisional line indistinct mesially on the tarsus of the palp and first leg, distinct throughout on the second leg, and so broad on the fourth leg as to oecupy the whole of the lower surface of the segment, the scopula being represented by only a few hairs at the sides of the segment; claws armed with from one to two teeth placed near the midcle of their length.

Meusurements in mm. :-Total length 14, earapace 5.5, first leg 13, second 11 , fourth 17 .

Sokotra : Jena-agaban (1200-2500 ft.). A single female specimen found under a stone in dry bed of torrent helow the camp. 


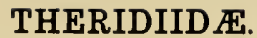

\section{ARACHNOMORPHE.}

\section{Latrodectus, Walck.}

7. Latrodectus geometricus, $C$. Koch.

Latrodectus geometricus, C. Koch, Die Arachniden, viii. p 117, fig. 684 (1841); Simon, Ann. Soc. Ent. France (6), x. p. 99 (1890); id. Hist. Nat. Aringn, i. p. 569 (1894).

Sokotra: Dimichiro Valley ; Homhil (1500-2500 ft.).

This species occurs in the tropies of America and Africa, in Arabia, and as fur cast as kianchi, on the border of Hindostan.

8. Latrodectus tredecem-guttatus, linssi.

Arcenca trudecem-Inttutu, Rossi, Famna Etrusc, ii. p. 136, pl. ix. fig. 10 (1790); Thorell, Synonyms of European Spiders, p. 50s (1873) (for synonomy).

Speeimens of the black rariety of this species (var. erelus) were taken.

Sokotra : Hadibu Plain.

\section{Argyrodes, Simon.}

9. Argyrodes argyrodes ( $W_{\text {utlck. }}$.

Linyphia cryyrodes, Walck., Ins. Apt., ii. p. 282 (1837).

Aryyrodes aryyrodes, Simon, Arachn. de France, v. p. 16 (1Ss1).

Sokotial: Dahamis (350-1000 ft.); Homhil (1500-2500 ft.); Adho Dimellus (3500- $4500 \mathrm{ft}$.).

Widely distributed in the tropics, where it follows the distribution of cyrtophora citricule, with which (according to Simon) it lives commensally.

\section{ARGYOPID糜。}

\section{Tetragnatha, Latr.}

10. Tetragnatha boydi, O.P. Cambr.

Tetragnathe boydi, O.P. Cambridge, P'roc. Zool. Soc., Lond., 1898, p. 389, pl. xxxi. fig. 4.

Adult female, length + lines : length of cephalothorax 2 lines: length of falces $2 \frac{1}{4}$ lines nearly

Cephulothorur: oblong-oval, truncated at each extremity, and widest near the middle; length domble its breadth; lateral marginal impressions of caput vely slight: caput and margins of thorax darker than the rest: yellow-brown, but in the dry specimen the colour is unreliable.

Eyes of posterior row equally scparated; in a very slightly emred line, the eonvexity of the curve directed forwards; anterior row much more strongly curved, but with the same direction of the curve; central quadrangle slightly hroarler than long, and the fore side distinctly shorter than the hinder one: the fore-central pair of eyes longest, and seated on a strongish rounded tuberenlar prominence; 
each of the lateral cyes also on a tuberele. The eyes of each lateral pair are much neares to each other than the fore-central pair are to the hind-centrals. Clypens rather less in height than half the facial space.

Fules very long and projecting forwards, slightly longer than the cephalothorax; considerably divergent; slightly curved, rather eonstrieted at the fore extremity. Fang more than three-fourths the length of the falx, strong, alnuptly bent at the base where it is somewhat enlarged, and there is arrother somewhat shallow dentiform colargennent towards the middle on the immer side: and each of the falces is armed with a strong, somewhat curved, pointer tooth at its extremity, just below the onter side close to the insertion of the fang : also on the imner sicle nearly beneath the lase of the fang is another strong sharp-pointed tooth; hesides these teeth each falx has a clouble longitudinal row of others along the molersicle; those on the ontside are most 11 merous (10?) and more equally separated, the imer ones ( 7 or 8 ?) strongest and more eonfined to the posterior portion of the falx, those of both rows climinishing in strength as they run baekwards.

Legs very slender: 1, 2, 4, 3, very little difference between 2 and 4 ; furmished with hairs and a few short slender spines.

Maxillat, lalium, and sternum normal.

The ahrlomen was so shrivelled and devoil of colnur that nothing can be said as to its colours or markings, which, however, are most probahly distinetive of the species.

This Spicter is nearly allied to Tetrrymethe tuylori, Cambr. (South Africa), but the relative position of the eyes is different, as well as the form of the fang and the denticulation of the falces.

Sokotra.-(E. II. Bennett.)

\section{Tetragnatha granti, sp. $n$.}

Colour: carapace, legs, and mouth parts ochracems, clourled with hlack; earapace with two broad submedian fuseous bands and with stripes rarliating from the forea to the fuseous lateral horler : maudible with hroad external fuscons stripe; legs banderi and spotted ; maxille handed ; sternum ancl lahinm hlackish, borker of the former pale and elear : ahdomen olive grey sturlded with silvery spots, the upper side furnished with two rows of spots and lines forming an irregular interrupterl lateral band, the rentral surface adormed with three-il median and two lateral _dark hands, separated by two narrower silverspotter stripes, which start-one on each side-from the pale pulmonary opercula, the lateral dark hands extending on to the sides of the abromen, with external border simuous.

Carapure alout half the length of the femur of first leg, less than half but more than one-third the length of patella and tibia, ahmost as long as tibia of fourth, and as patella, tilia, and half the protarsus of the third. 
Eyes of posterior line subequal, suhequally spacerl, slightly recurved, ahout two diameters apart; oenlar quadrangle rery slightly wirler behind than in front, about as wide as long; anterior median eyes larger than posterior medians, about a diameter apart and above the clypens, eonsiderably more than a diameter from the laterals, which are much smaller and stand higher, their upper elges in a line with those of the medians, their lower edges in a line with the centres of the latter' hence the eyes of the anterior line which is as wide as the posterior are recurverl, the two lateral eyes on each side alout as far apart from each other as are the anterior and posterior medians.

Mumlibles short, fusiform, ahout half the length of the carapace; armed below with two rows of nine teeth each, the teeth start at the artienlar socket of the fang and extend about half way up the jaw, decreasing in size proximally, the teeth of the anterior (upper or onter) row extending farther than the other's owing to the wider-spacing of the distal teeth. Fang short, ummorlified, extending, when eloserl, barely half way back along the basal segment. Mrrille abont three times as long as the labium, and rather more than twice as long as their distal wirlth.

Leys 1, 2, 4, 3 (cf. measmrements) : sparsely aml weakly aculeate.

Abdomen subcylindrical, higher anteriorly than pusteriorly, a little narrowed posteriorly, ending in a bluntly romeded supra-anal prominence: genital orifice more than one-thirl but less than one-half way along the ventral surface of the alklomen, and nearly as far from pulmonary stigmata as the latter are from the anterior end of the abdomen.

Measurements in mm.- Total length 11 , carapace 4 , first leg 24 , second 15 , third 6.5 , fourth $1 \cdot 3$.

Sokotra: Dahamis $(350-1000 \mathrm{ft}$.).

By the arrangement of its eyes, this species apparently falls into section $c$ of Simon's division of Tefrenmethe, lut differs from the rest of the species in having the legs spansely and weakly spinose, as in section ". (Hist. Sint. Amiyn. I., p. 7:23, 1894).

This specimen was taken while sitting with legs extended in its web, made over a ruming stream.

Two known Sokotran species of this genus, of whieh only the females have heen deseribed, may he rliagnosed as follows:-

(11) Basal segment of mandible longer than carapace $\left(2 \frac{1}{4}: 2\right)$, toothed nearly to the lase aloug the posterior horder of the fang groove, the teeth of this row wjolely spaced distally, the distal tooth of each row much larger than the rest and projecting above and helow the base of the fang: fang abont three-quarters the length of the hasal segment, sinuous, almuptly hent at the bise, and with an anguliform tooth near the middle of its biting erlge . 
(b) Basal segment of mandible about half the length of the carapace; toothed in the proximal half, the teeth of the posterior row evenly and closely set starting from socket of fang; distal teeth of each row only a little larger than the rest; fang short, ahout half the length of the basal segment, evenly curved, unarmed

gronti.

\section{Argyope, Aud.}

12. Argyope clarkii, likerku. (Plate xiv. figs. 3, 3ia, 33, 3c.)

Aranere sector, Forskal, Icones rerum nat., \&c., p. 85, pl.x xv. fig. c $(177.5)$.

Aryiope clarkii, Blackw., Ann. Mag. Nat. Hist. (3), xvi. p. 98 (1865).

Aryiope sericea rar. caboverdiana, Brit. Capello Jorn. Ac. Sc. Lisbon, i. 1). 82, pl. ii. fig. If (1868).

Aryiope lordii, O.1'. Cambridge, Proc. Zool. Soc., 1570, p. 820, pl. l. fig. 1. Aryiore fixsiloba, L. Koch, Egypt, Abyssin., Arachn., p. 15, pl. ii. fig. 1 $(1875)$.

Not Argiope clurki, Simon, Ann. Soc. Ent. France (6), x. p. 101 (1890).

This species has a wide range thronghout the southern half of the Mediterranean area, extending from the Cape Verde Islands, whence the type of $A$. clertiz was collected, to Alyssinia (A. Horlii and $A$. fissilolui), thence into Arabia, Sokotra, and as far east as Bushire on the Persian Gulf. The female may be at once recognised from the females of the rest of the species forming the group of which $A$. sericen is the type, by the form of the rulva (Pl. xiv. fig. 3b), in which the 'earina' and the two cavities, when viewed from below, are completely roofed over and overlapped posteriorly by a rugose convex plate, of which the posterior border is smooth, thickened and notched in the middle, the thickening of the horder being emphasised by a pair of deep sulmarginal grooses which sometimes extend so as to circumscrilse a median eminence situated at the apex of the posterior notch. Both the eminenee and the notch vary considerably in degree of development in specimens from the same locality.

The Types of hoth $A$. clurlizi and A. lorlii are in the possession of the Rer. O. P. Cambridge, and I am indebted to $\mathrm{Mr}_{1}$. F. Cambridge for an examination of the vulve of the two whieh eonfirmed their specific identity-a conclusion of which I had already surmiserl the accuraey from examining a large series of the species from the Cape Verde Islands, Aralia, and Persia. The species identified by Simon as $A$. clarkii is evidently not the same form sinee he compares it with $A$. nirgro-ittute of Thorell. Aceording to Simon A. sector of Forskal is iclentical with his clurkii. A. sector may, howerer, be equally well irlentical with the true A. clurkii.

The male and female of this species, which is very abundant in Sokotra are figured side by side on the ahore-quoted plate. 
The male is much smaller than the female. The carapace has a merlian pale band covered with silvery hair, and a pale margin, the rest of its area being lorown; upper sicle of abdomen covered with an olive brown fiekl with a sinnous black external border and a median pale hand adorned with silvery hair; the sirles of the alolomen are yellowish ahove, deep hown helow, the two colours sharply contrasted; the onter surface has a silvery white band on each side, separated by a median deep hown stripe bordered externally with black; stermum back with median silvery band; legs yellow spotterl with black. Aldomen at least twice as long as wille, withont lateral lobes, but with a longish conical caudal process.

Total length- o $9 \mathrm{~mm}$., $q u$ p to about $25 \mathrm{~mm}$.

Sokotra.-(Belfour). Gebel Raggit (600 ft.); Jena-agahan (1200-2500 ft.); Haclibu Plain ; Iahamis (350-1000 ft.) : and Homhil (1500-2500 ft.) : also Alrl-el-Kiri.

\section{Nephila, Leach.}

13. Nephila sumptuosa, Gerst. (Plate xir. figs. 2, 2a, 2l.)

Nephila sumptuosa, Gerstäcker, in Von der Decken's Reisen in Ost. Afrika, iii., 2, 1. 501, pl. xriii. fig. 12 (1873) : Pocock, Ann. Mag. Nat. Hist. (6), xviii. 1. 182 (1896).

Nephila bemetti, O.P. Cambridge, P.Z.S., 1898, 1. 357, pl. xxxi. fig. 2.

Sokotra. (Balfour aul Bennett). Homhil (1500-2500 ft.): Dahamis (350-1000 ft.) ; and Jena-agahan ( $1200-2500 \mathrm{ft}$.).

This species is not meommon in Sokotra. It was collecterl in considerable quantities loth by Professor Balfour and hy Messis. Grant and Forbes. Mr. Bennett also procurerl a specimen which serverl as the type of Nephili benuetti, O.P. Cambridge.

Although.$Y$. sumptuose is an extremely abmolant species in Fast Africa, extending from Somalilanr to Natal, and was recorled from the island of Sokotra in 1896, Mr. Cambrilge mfortmutely makes no comparison between this species and the Sokotran form he named lennetti. There appears, however, to be no justification for regarding the latter even as a distinct sulspecies.

The material colleeted by Messrs. Grant and Forbes contains both males and females. A specimen of the female has been figmerl (Pl. xis. fig. 2) to illustrate a very conspicuous element in the Sokotran fama. The diminutive male which has, I believe, never loen described, is also figmerl for comparison with the female. Its essential structural features may be rliagnosed as follows:-

o. Prevailing colour yellow, clonded with black. Leg. armed with long spines, the tarsi, protarsi, and unclerside of tihia clothed with short, close-set stiff hairs.

Ocnlar qualiongle about as widle as long, the anterior median eyes much larger than posterior medians, less than a diameter apart, posterior 
medians little more than a cliameter, much nearer to each other than to the laterals : eyes of posterior line straight : laterals smaller than medians; eves of anterior line strongly recurved. Palp with patella globnlar, armed above with a long bristle: tibia ahout as long as the patella, wirler than long, the bull, liack, globular, the spine long, mjointed and sinnous.

Total length $\&$ mm.

[This handsome species was particularly numerous below our eamp at Homhil, the bushes bordering the reerly leel of the stream being covered with its great webs. These are of so strong a texture that when one accirlentally walks through a web suspended between two bushes one can feel and hear the net tear as one passes through it.II.Ti.O.(r.]

\section{Araneus, Clerck.}

14. Araneus hoplophallus, Pucock.

Aruneus hoplophallus, l'ocock, Bull. Liverp. Muss., ii. p. 40 (1899).

o. Colomr: Carapace and legs yellowish-red, the latter marked with leep brown transierse bands and armed with spines, mostly white with black tips, except those on the front of the tilia of the second leg, which are nearly llack throughout: upper side of alsdomen mottled with olive hlack spots and marks on a greyish ground; the anterior area between and in front of the shonder points markerl mesially with an olive black stripe which behind is continnons with a transverse, slightly procurved band of the same colour extending between the shoulder points; no pair of cireular white marks on this area : the rest of the dorsal surface marked with narrow transverse olive-

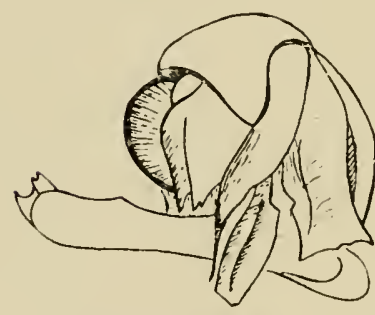

Palpes (marmified) of ARANELS HOPLOPHAJLA's. black lines, with their extremities emred forward and bordered behind by a paler line. Structurally the type of this species is very closely allied to the males of $A$. streptuceros, Poe, from Rhorlesia and Nyassaland (Amm. Mag. Nat. Hist. (7), ii. p. 436,1898$)$, and to A cyrtosectins, Poc., from Natal (Amn. Mag. Nat. Hist. (7), ii. p. 206,1898$)$, hut differs from them in the structure of its palpal organs, as is shown in the accompanying illustration.

Total length $11 \mathrm{~mm}$. : length of earapace 6.

Sokotra: Adho Dimellus (3500-\$500 ft.).

A single male example.

This species was hased upon a single male example. Since deseribing it, I have seen a specimen from Abian in S. Arabia, collected ly Mr. A. B. Percival, and one from Berbera in North Western Somaliland, collected by Mr. C. I. A. Peel (see I'Z.S., 1900, p. 5.2). These cliscoveries lend considerable probahility to the view that $A$. hoplophullus is founded on the hitherto mnknown male of $A$. suedicolu--a speeies originally recorded by Simon from Aden (Ann. Soc. Ent. Fr., 1890, 
p. 103); and subsequently from Somalikund hy Patresi (Alun. Mus., (renore, xxxv. p. 49s, 1895).

15. Araneus cardioceros, l'ocuck. (Plate xiv. fig. 4.)

Arunens curdiocero.s, locock, Bull. Liverp. Muss., ii. p. 40 (1899).

o. Colour : carapatce yellow, with a lakek elypeal baurl, and an olliquely longitulinal arehed stripe on each side of the head; mandilses yellow, clomded with black in front : palpi and legs yellow, clothed with white hairs, ammed with black spines, and landerl with black; sternum borlered with black; aldomen greyish white above, markerl with distinct olive green "folinm"; rentral surface with two whitish lands, separated hy a larrower dark interspace, extending from the epigastric fold to the spinners, which are hlackish.

C'aruper about as long as tibia of first leg: moderately high, its upper surface from the ocular area to the apex of the fovea nearly flat longiturlinally; merlian quadrangle of the eyes considerably wider in front than behind, the anterior medians perhaps a little larger than posterior medians, the latter about a diameter and a half apart; anterior medians abont two diameters apart, about a diameter above the elypens, more than twice as far from the laterals as from each other: eyes of the anterior line distinetly thongh not very strongly procurved: the two laterals not quite in eontact. Leys spined; abdomen heart-shaped, a little longer than wide, convexly romded in front, with prominent but ohtuse shoulder points from which the two sicles of the anterior margin are inclined forward and inwards at a right angle: posterior extremity not produced. I rulve consisting of a vertically direeted heart-shaped tuberele, withont any distinet seape. Total length $7 \mathrm{~mm}$. ; carapace less than 3: width of alolomen 4 , length $4-5$.

Sokotra: A tho Dimellus (3500-4500 ft.) ; Jena-agahan (1200-2500 ft.); and in Alıd-el-Kuri Island.

\section{Cyrtophora, sim.}

16. Cyrtophora citricola (Forsk).

Areneq citricolu, Forskail, Icones. rerum, nat., \&c., p. 86 (1775).

Elyeire opuntir, Dufour, \&e.

Sokotra: Homhil (1500-2500 ft.) ; Dimichiro Valley, in the Garjeh Plain. [This species, which is by no means common in Sokotra, makes a eurions circular concave weh very different from that of any other species I have observed. In the Dimichiro valley I came across several wehs placed in thick "yew-like" bushes, and apparently occupjed by only one individual ; but at Hombil a web in a hoxwood bush eontained, so far as I recollect, at least eight examples of varions sizes. - II.R.O.(r.]

This species is of common oceurrence throughout Africa, the Mascarene Islands, and the Oriental Region. It also extends into Arabia and S. Europe. 


\section{Gasteracantha, sund.}

\section{Gasteracantha sodalis, O. I. C'emlynillye.}

? Gasterecantha lepida, O. P. Cambridge, Proc. Zool. Soc. Lond., 1870, p. 8:21, pl. l. fic. 2; L. Koch, Egypt. Abyssin. Arachn., p. 11, pl. i. fig. $4(1875)$; Simon, Amn. Soc. Ent. Fr. (6), x. p. $100(1890)$.

Gasteractentha sorlutis, O. P. Cambridge, Proc. Zool. Soc. Lond., 1898 p. 38s, pl. xxxi. fig. 3 (= G. leyiclu, Taschenberg Zeit. Naturwiss. (4), ii. $173(1853)$.

I lave reserved for the Sokotran species of Grosterutunth the name given to it by Mr. Cambrilge in 1898, althongh Sokotran examples were identified as G. lepidu, Cambr., by Taschenberg, in 1883. Tasehenberg's identification is, I think, probably eorrect; but I have no genuine specimens of $G$. lepide available for comparison with the Sokotran material. There are, moreorer, certain diserepancies letween the figure and deseription of $G$. lopide, which make it impossible to determine with certainty the characters of the species. Both description and figure cannot he correct; either may be, or neither may be. G. Irpid, was recorded originally from Massowah, and subsequently by L. Koch and Simon from the neighloming island of Cheikh-, Scheeh-, or Saik-Saicl. The figure of the species given by L. Koch, represents an animal resembling the typical form of L. sodulis in colour, but the spines are longer, and the interval between the anterior and merlian spines much greater. According to Simon, howerer, this interval is much smaller than it is represented to he by Koch. Unfortunately Mr. Cambrirlge, who possesses the types of the two forms under consicleration, makes no eomparison hetween them in his deseription of $L$. somldis, hut compares the latter to $L$. madergersariensis, Vinson.

The typical form of the Sokotran species has the alydomen yellow above, and handed with deep red transverse stripes, the underside leing black and thickly marked with large yellow spots which often anastomose. Of almost efually eommon oceurrence, howerer, is a second type, in which the upper side of the abdomen is of a tolerally nuiform dark red or nearly black colour, withont trace of bancls, the mulerside being almost black and unspotted. The two forms occur together in the same loeality, but do not appear to cliffer in any structural points. The speeies is evidently common in the island. Messrs. Grant and Forlues seened specimens.

Sokotra: Dahamis (350-1000 ft.); Homhil (1500-2500 ft.) : Jena-agahan (1200-2500 ft.); and Arlho Dimellus (3500-4500 ft.).

[A common speeies on most of the higher bush-elar ground. No two individuals appear to be exactly alike, and every intermediate type was observed between the barred form and those with the abdomen uniform dark crimson or blackish. The web is almost always placed in hushes about 4 or 5 feet from the gromud._Ir.R.O.G.] 


\section{AGELENID必。}

\section{Agelena, Walck}

18. Agelena pusilla, sp. $n$.

Colmer: integmment of carapace vellow with radiating black lines and patches; stermm black: palpi yellow with black wings; legs mostly black varied with yellow lings or patehes; tarsi wholly yollow and yellow predominating on the coxie ; ablomen with a median dorsal palc baurl bordered with black: spotted and lined with black on the sides : ventral surface elourled with black and marked with two black lines extending backwards from the genital fold, hairy coating of carapace forming a median and on each side a lateral white band, the legs and abdomen also varied with white plumose hairs.

Orulur yumblumgle oblong, nearly parallel-sided, the anterior merlian eyes larger than posterior medians, less than a ladius apart; posterior. medians more than a radius apart. Houdille armed with two teeth on the posterior horder of the fang groove. Area of rulva bordered behind by a lightly procurved thick horny transverse har, the excavation undividerl, slightly wider than long, slightly wicler in front than hehind, its margins low and not shamply defined, except anterolaterally, where they are strongly raised and sharp.

Total length $6 \mathrm{~mm}$.

Sokotra : Jena-agahan (1:00-2500 ft.).

This species, remarkalle for its small size, may he recognised by the form of the vulva.

\section{LYCOSID压。}

\section{Pardosa, c. Koch.}

19. Pardosa spilota, sp. $u$.

q Colmer: earapace and sterum blackish, scantily dotted with whitish hairs; legs handed lilack and yellow: alulomen black above and laterally, ornamented above with symmetrically disposed yellow spots, which posteriorly unite in the middle line and form transverse $\Lambda$-shaped bars: ventral surface testaceous: lower surface continuonsly clothed with white hairs, upper surface ormamented with spots of white hairs.

THlu consisting of a large semi-cireular hairy punctured plate, which in its posterior half is marked with a deep excavation hroad behind and alonptly narrowed in front; its edges, which are sinnous, ending behind on each side in a rounderl lobe, the midrlle of the excavation oceupied by a large lackwardly directed lobe, which is itself impressed by a pair of parallel longitudinal pits, separated by a median carina. The median lobe represents the normal hammershaped sclerite of the lycosine rulva, with the hearl of the hammer large and its two halves strongly recurved.

of smaller than $q$, with the patella, tibia, and hase of tarsus of palp snow 
white, the rest of the tarsus jet black. Tarsus of palp long, as long as tibia and patella and much lroader, the tarsus and palpal organ together elongate and basally globular.

Measurements. - $q$, total length $7 \cdot 5$, earapace $3 \cdot 5$, first leg $10 \cdot 0$, fourth leg $14 \cdot 0 \mathrm{~mm}$.

Sokotra: Hadilu Plain; Imimichiro Valley, in the Garieh Plain.

\section{PALPIMANID E.}

\section{Scelidomachus, Pocock}

Scelidomachus, Pocock, Bull. Liverp. Muss., ii. p. 41 (1899).

Genus of the section Chedimere with the lateral eyes in contact, and allied to Steriplopms, Bongrius, and Suruscelis in having the anterior median eyes at least twiee as large as the laterals, and the ocular quadrangle nearly parallel-sided : also further resembling steriphopus in having the quadrangle nearly square (in Bougrius and Suruscelis it is much wider than long), but differing from it in having the eyes of the anterior line straight hy their inferior horders, not recurverl, and the anterior median eyes separated by a space which barely equals their radius (in Surescetis the space equals the diameter of the eye).

\section{Scelidomachus socotranus, Pocock. (Plate xxvi. fig. 3.)}

Scelitomachus socotrant., Pocock, Bull. Liverp. Mluss. ii., p. 41 (1899).

ofolmi: carapace and sternum deep red, legs of first pair paler yellowish-red, those of the remaining pairs still paler, abrlomen of a uniform reddish-grey or testaceous tint.

C'urupue coriaceous alove, closely gramular at the sides, its upper surface between the eyes and the forea lightly convex longitudinally, scantily clothed with short black hairs. Ley. normal for the family; femur. and patella of first pair sparsely lout distinctly gramular beneath and on the imer side: tibia, protarsus, and tarsus normally scopulate on the inner side; the protarsus, which is alout as long as the tarsus,

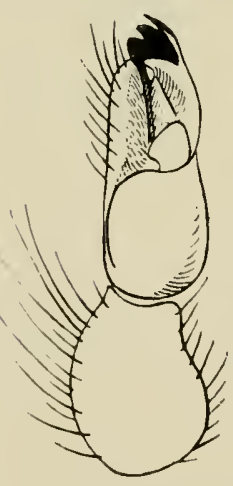

Palpus of

SeELTDOMACHUS SOCOTRANUS. (IIighly magnified.) armed apically beneath with a short downardlydirected spiniform process: second, third, and fourth legs muspined, eovered with greyish-black hairs, the tarsi and protarsi apically scopulate. Sternum gramular; ablomen thickly covered with a coating of short olivegrey hairs. Prtlpus (sce accompanying figure) with femm slender ; patella short, subglohular; tihia much larger than patella, twice its length, and nearly or yuite three times its height, also sulghlohular; tarsus almost as long as patella and tilia taken together, slender and cylindrical distally ; the palpal organ ruming out into a forwarlly-directed process with a dilated tridentate extremity ; a membraneous lobe at its lase, and a sulbspirally twisted shorter piece on its imner side.

Total length $6 \mathrm{~mm}$.

Sokotra: Dahamis (350-1000 ft., Type); Jena-agahan (1200-2500 ft.). 
ZODARIIDÆ.

\section{Capheris, simon.}

21. Capheris insularis, Porock. (Plate xxri. figs. 4, 4a.)

Cupheris insulurin, Pocock, Bull. Liverp. Muss, ii., No. 2, 1. 41 (1899).

ๆ. ('olum : canapace deep castaneous; legs infuseate, banderl and mottled with paler markings: protarsi and tarsi yellowish; ahdomen deep greyish-black alove and at the sides, and variegated with pale yellow spots, which posteriorly and laterally arrange themselses in refinite transverse and rertieal stripes; lower sicle yellowish-white, with two black stripes rmming longitulinally from the epigastrie fold and dividing the pale field up into three hroarl yellow lands ; area in front of stermum black.

C'rrupues high, higher in front of the forea than on the ocular area. Eyjes apparently arranged and pratically of the same relative size and distance apart as in the only other species of the genus, the South African Cupheris ceussimunus, Sim. (see Simon, Hist. Nat. Araignées, Vol. I., p. 417 figs. 383 and 384). Legs longish and rather slender; first and seeond pairs unarmed, except for a singte apical spine on the lower side of the second protarsus; third and fourth pairs with patella, tibia, and protarsi strongly spined, the patella with one pair of spines only, the tibia and protarsi with many. Palpus with the tarsus strongly spined inside and beneath, very slightly longer, or, at all events, not shorter than the tibia, and not conieally acuminate. (In crosimenus the tarsus is shorter than the tiloia, and acuminate). Trulu eonsisting of a large, hairy, horny plate, with a pair of impressions in front, and a smooth, transversely semi-cirenlar, or subpuadrate lobe projecting from its posterior border.

Total length $11 \mathrm{~mm}$.

Sokotra: Homhil (1500-2500 ft., Type) ; Dimichiro Valley, in the (Garieh Plain.--An arlult $q$ and an immature of.

\section{CLUBIONID床.}

\section{Chiracanthium, Koch.}

\section{Chiracanthium socotrense, sp. u.}

of Colme: cephalothorax and limbs a rich yellowish; abdomen oliveyellow; loth elothed with greyish-white hairs: mouth-parts rather larker than carapace. Curpuep about as long as tibia of fourth leg. Eyes of posterior line very slightly proenrved, subequal in size and sul, equally spacer, the medians only a little closer to each other than to the laterals, barely two diameters from the laterals; ocular yuarlangle a little wider than long, a little narrowerl in front; anterior median eyes the largest of the eight, not quite a diameter apart, abont a diameter from the laterals. Logs long (cf. measurement), patellix unspined; tibice armed beneath with $8-10$ spines arranged on the anterior legs irregnlarly in pairs, and long; protarsi of first and second legs 
armerl with a pair of long basal spines beneath, a short sub-median pair, and an inferior apical. Pulpi unspined; patella larely half the length of the tibia, the two together scarcely as long as the femur; tibia subcylinclrical, a little more than twice as long as high, the apophysis consisting of a pair of short suberfual processes with obliquely truncate extremities, directerl obliruely outwards and forwalds, the upper side of the superior of the two is lightly emarginate and bears a small basal prominence: tarsus long, longer than tibia and patella, constricted at the base, and furnished with a short external, slightly sinuous process, which is stout at the base, pointed at the apex, and directed obliquely ontwards and hackwards, and resting upon the emarginate upper edge of the superior process of the tihial apophysis ; tarsus rery wide in the middle, its external border produced into a large flap-like lobe, which auteriorly projects almost at right angles to the subeylindrical terminal portion of the palp.

Measurements in mm. - Total length, $11 \cdot 0$; carapace, $5 \cdot 0$; first leg, $25 \cdot 0$; second $\operatorname{leg}, 20 \cdot 0$; fourth $\operatorname{leg}, 25 \cdot 0 \mathrm{~mm}$.

Sokotra: Hadilı Plain.

Recognisable ly the two short subequal external tibial apophysis.

\section{Sparassus, Walck.}

\section{Sparassus socotranus, sp. 1 .}

o colour of integument mostly uniformly pale on lody, month-parts, and limhs; hairy clothing silky white, intermixed with blackish bristles on the head legs and upper side of abdomen; spines black; upper side of abdomen irregularly spotted with small dark patches, which in the miclle line form a long but rather inclistinct $Y$-shaped stripe, the area between the arms of the $Y$ heing elongate and fusiform or subelliptical. C'umpere heart-shaperl, abont as wide as long, abont as long as tibia of first leg, a little shorter than that of second, shorter than patella and tibia of third. Eyes of posterior line straight, subequal, and suberually spaced ahout three diameters apart; eyes of anterior line nearly straight by their centres, the medians larger than the laterals, abont a diameter and a half apart and a diameter from the laterals. Mumlible armerl below with four posterior and two anterior teeth; beneath the fang arise four long 'gusatory' bristles. Hurille short, convex, not emarginate externally' ; lithium very short, about twice as wide as long. Leys 2, 1, 4-3) in length ( $f$. measurements), the tibice and protasi with two pairs of inferior spines, no apical spines at extremity of tilice below. I "ulue large, impressed with a deep, median,

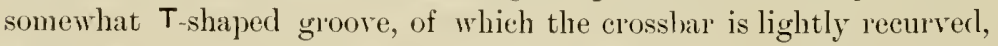
while the stem dips down between the two lobes or sclerites; each lobe consists of two selerites-one that is uppermost and lies horizontally when the organ is viewed from below, and is pale colonred; the other, being undermost, thickly chitinised dark coloured, placed 
rertically, its posterior surface forming a smootl wall at right angles to the pale sclerite.

Measurements in mm. - Total length 11, length of carapace $1: 5$, of first leg 1s, second leg (to end of tilia) 1:3, third leg 1t, fonth leg 17.

Sokotar : Homhil (1500-2500 ft.). - 1 single alult female.

This species appears to belong either to the Olios or Mirlanens section of the genus spmrossus, and in the form of its vulva approaches certain Oriental species, e.y., Mirlemms lutricens, 'Thorell, from Burma.

\section{Selenops, Latr.}

24. Selenops radiatus, Lutr.

Selenops redicetus, Latrelle, Nour. 1)ict. Hist. Nat., xxx. p. 579 (1819.)

Selenops omalosmu, L. 1)ilfour, Ann. Sei. Phys., iv. p. $\overline{7}$, pl. lxix. fig. 4 $(18: 0)$.

Selenops regyptiucu, Aud. in Savigny, Egypt, Arachn., 1) 16:2, pl. vi. fig. 6 (18:29).

Selenops enmulipes, Walck., Ins. Apt., i. 1. 546 (1837).

Selenop weregrinctor, id. loc. cit.

Stenops dufouri, Vinson, Araign., Rémion, etc., 1. 79, pl. iii. fig. 1 (1s(it).

Sedenops mudagascuriensis, id. tom. eit., p. 8:3, pl. iii. fig. 3.

Selenop ulacer, Blackwall, Ann. Mag. Nat. Hist. (3), xvi. p. 5.5 (1865).

Selenops sansilurica, ('ersticker, in Von der Decken's Reisen in Ost Africa, 1. 479 (1873).

Selenops lutreillei, Simon, Arachn. de France, ii. p. 346 (1875).

Selenops malabriensis, Simon, Act. Soc. L. Bord., xxxiv. 1). 234 (18\$1).

Selenops birmanicus, Thorell, Spiders of Burma, p. 261 (189.5).

Selenops diversus, O. P. Cambridge, Proc. Zool. Soc., 1898, 1. 390, pl. xxxi. fig. 1.

Most of the above-given synonymy is eited on the authority of Mons. Simon, who has had the opportunity of studying either the actual specimens deseribed by Latreille, Walekenaer, Dufour, Vinson and Andonin, or topotypieal examples of their speeies. Moreover, I have myself examined speeimens from various localities ranging from the Cape Verde Islands to the Zambesi and Burma, without discovering any reasons for dissenting from Simon's conelusions. The species also oecurs in Madagasear and Rémion. It commonly comes to haud with almost every collection made within the limits of its range, and henee is abundantly represented in all collections with any pretensions to be extensive.

Consirlering its wide distribution, its oceurrence in Sokotra is not a matter for surprise. It was first procured in this island by Mr. Bennett, whose speeimen served as the type of S. dicersus of Mr. Cambridge. A second example was eollected hy Messis. Grant and Forbes on the Hadibn Plain. This speeimen and the figure of the type of $S$. dirersus leave no room for doulut that the latter must he added to the already lomg list of synonyms of studintus, latreille.

[This large Lycosa-like species was eaught among the stones in a diy backwater of the Hanefu River, Hadibu Plain. It was remarkably 
active, escaping in a moment every time it was uncovered, and in at last securing it some of the legs were unfortunately injured.II.R.O.G.]

\section{THOMISID坧.}

\section{Thomisus, Walck.}

25. Thomisus spinifer, O. I'. C'mmlirilye.

Thomisus spinifer, P.Z.s., 1s:2, p. 3แs, pl. xiv. fig. 14.

Sokotra: Hadilm Plain.

This species ranges from Somalilant into Egypt and Syria, thence eastwards to Bombay.

\section{Bassaniodes, gen. nov.}

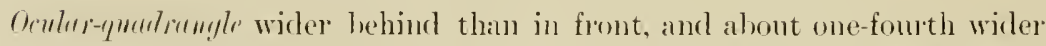
than long, distance between anterior merlian eyes greater than hetween anterior and posterior merlians on each sille, and a little greater than that hetween anterior medians and anterior laterals ; eyes of anterior line recurved, inferiol edge of laterals on a level with centres of merlians, the laterals about twice the diameter of the medians; eyes of posterior line strongly recurved, wiflely separated, the metians a little nearer to each other than to the laterals. Cinnpece evenly convex, not compressed, and not flattened in the region of the forea.

Fermer of first leg with three superiol spines: tibia with four pairs of inferior spines, and no lateral spines: protarsus with four pain's of inferior spines and three lateral in front and two lateral behind : second leg armed like the first, but with one spine on the upper sicle of the femur, the proximal posterior spine on the tibire and protarsi sometimes ohsolete. Tibia or protarsus of first and second legs shorter than carapace.

Type B. socotiensis.

This genus differs from bussemin, Nystirns, and Orryptilu in the spine armature of the anterior legs and the risposition of the eyes.

26. Bassaniodes socotrensis, sp.n. (Plate xxvi. fig. 2.)

Colow: carapace dark hrown with paler spots ; sternum and legs chalky greyish-yellow, with rark brown or blackish markings, femora nearly black alove, upper sirte of remaining segments longitudinally bandert : abdomen chalky grey, spotted and mottlerl with brown or black and with indistinct transverse bands on the upper sicle. Integnment studded with short stiff setie; sulgeranular on the carapace and legs. Tuler as in fig. 2. pl. xxvi., the shaded $\wedge$-shaped portion representing a horny plate of that form overhanging a median narrow bristly eavity bordered on each side hy a smooth horny sclerite represented by the minsharled area on each sile of the $\Lambda$-shaperl piece.

Total length $7 \cdot 0$, carapace $2.5 \mathrm{~mm}$.

Sokotra: Adho I)imellus (3500-1500 ft.). 


\section{Dimizonops, gen. nov.}

Eyes of pesterior line subequally spateed, very strongly recurved, the medians very small, 6i-7 diameters apart ; the laterals large, nearly four times the diameter of the medians. Median ynudrangle much wider than long, nalrower in front, its anterior wirlth much greater than the length; anterior median eyes abont twiee the dianeter of the posterior medians, about three diameters apurt, and slightly farther from each other than from the laterals ; laterals enormons, considerably less than their own diameter alowe the elge of the elypens, alout three times the diameter of the anterior medians, their centres almost on a level with the upper erge of the laterals; elypens vertical, low, ahout onethird of the length of the ocular cuadrangle, and twice the diameter of the anterior medlian eyes.

Cerapere longer than tibie or protarsi of anterior legs. Femora of first and second legs with many spines above, tibice with six pains of inferior spines and three anterior and three posterior spines; protarsi with five pairs of inferior spines, three anterior, three posterior, and one superior hasal spine.

Allied to Firmirns, Simon (IHist. Nat. Araign. i. p. 1036), lut with the femora and tiliae of the anterior legs not compressed, and apparently differing also hy the very great disparlity in size between the median and the lateral eves of each row.

27. Dimizonops insularis, s\%." . (Plate xxvi. figs. 1, 1ı, 1h.)

Colour: carapace yellowish-red, infuscate laterally and on the head ; legs yellowish-red, with apex of tilia and protarsus of first and second pains black; alokomen testaceous, blackish at the sides, ornamented above with dark transverse hands and spots, set off with ehalky-white patches as in Syneme theme, rentral surface with a pair of ill-defined eonverging fuscons bands.

Tulue consisting of a transversely oval plate, shallowly impressed in its anterior half, and with its posterior horder semicircularly emarginate in the mirldle.

Total length $7 \cdot 0$, earapace $3 \cdot 0$, first leg $10 \cdot 5 \mathrm{~mm}$.

Sokotra : Hadilou Plain : Dabamis (350-1000 ft.).

28. Tibellus, s\%. (?).

\section{Tibellus, Simon.}

A single immature female very like the European species, T. dolominu, Walck., in colour.

Sokotra : Dahamis (350-1000 ft.).

\section{Thanatus, c. Koch.}

29. Thanatus forbesii, $5 \%$.

o Colour: integrment of carapace yellow, marked with three black bands, one median, wider in the mirlille, passing from a point behind 
the posterior median eyes on to the posterior slope, and one on each side, which, meeting its fellow of the opposite side in the midrlle of the elypens, passes loackwarls, involving the anterior median, anterior lateral, and posterior lateral eyes; mandible with a large black patch on the upper half in front; palpi transwersely banded; legs mottled with black, blackish beneath and in front, espeeially on the femola ; upper sirle of abrlomen ornamenter with a luroat, posteriorly narrowing dark banci on each sicle, lateral surface clouded with black, ventral smrace marked with three black stripes: integument sparsely covered with shortish, thick, white plumose hairs, with some yellow hairs of the same kind on the carapace, the superior abdominal bands thiekly covered with deep hrown hair.

Corrfure scarcely or only a little longer than tibia of fourth leg. Eyses of posterior line very strongly recurved, the distance hetween the meelians about two-thirds of the distance between the median and lateral on each sicte, posteriors lying so far back that a straight line joining their anterior edges would lie about three diameters behind the posterior mertian eye: upper eclge of anterior medians higher than lower erlge of anterior laterals. Height of elypens less than length of oenlar-ynadrangle, which is ahout as wirle as long. Area of rulue, with its posterior horder emarginate, marked with a pair of pits set tolerably wirlely apart, with shaply defined edges, angular in front and romeled behind, each pit alwont as long as wide, the partition between them hairy, and mueh wider in front than behind; beneath the integument of the smooth area of the vulva are to be seen two conspicuous dark lnown piriform patches, lnoader in front than hehind, and converging posteriorly.

Total length $10 \mathrm{~mm}$, earapace 4 .

Sokotra: Actho Dimellus (3500-4500 ft.).

A single female specimen.

BIANTID曆.

\section{OPILIONES.}

\section{Biantes, Simon.}

\section{Biantes flaviventris, sp. $n$.}

Colone : dorsal surface of ahdomen brown, becoming paler, almost reddishyellow on the cephalic area, eyes black, coxie and anterior abrominal stema hright redclish-yellow: mandibles flavous, legs flarous at the base, infuseate distally. Itorsel suffece of body, coxa and sterna of abdomen densely and coarsely granular. Ceplutir plete unarmed, its anterior border with a low, wide, bluntly-rounded median elevation. The third and fourth aludominal terye armed with a pair of sharp upstanding tubercles on each sicle of the midclle line, sometimes a trace of these is visible also on the second, ant on the third and fourth there are sometimes additional enlargerl tulberculiform granules; fifth, 
sixth, and seventh tergal with a transverse row of sharp tubercles, eighth with two or more rows of tubercles.

Mundibles robust, mamed, except for a pair of tubercles above at the bise. I'atpi a little longer than the horly, the coxa unarmerl externally, trochanter manmed, femmr long and slemler, overlapping the femm of the first, but shorter than it; patella piriform, elongate, basally attenuate and bent, manmed, about half the length of the femur ; tibia a little longer than patella, twice as thick, piriform, distally attemate, normally armed; tarsus of the same form as the tibia luit thicker, normally spined. Leys with coxie and trochanters granular ; coxal of the first with a pair of longer hair-tipped tubercles in front below.

Total lengeth $4.5 \mathrm{~mm}$.

Sokutra : Homhil (1800-2500 ft.); .Jena-agahan (1 200-2500 ft.).

[These phalangids, like those recorded helow from Aly-el-Kuri (p. 204), were found under stones, often in colonies. There movements are very slow and deliberate, and resemble those of mites rather than spirlers. - II.li.O.Cr.]

This species differs from li. vittrtus, Sim., from Madkugascar, and b. Longinumus, sim., from S. India (Bull. soc. Zool. Fi., 1885, p. 25), in the alsence of a long conical tubercle on the coxa of the palp and of spine on its patella. From B. lecithoutos, Thorell (Amm. M Hus. Cienew, xxvii. p. 6il), from Buma, and b. ritellime (icl. op. eit., xxx. p. 727), from Sumatra, ly the shortness of the patella of the palp and the absence of the spine.

\section{[ACARIDA.}

Occasionally I found on the paths frequented by camels and cittle a large pale blue tick, in size abont $\frac{1}{2}$ inch long by $\frac{1}{4}$ inch wide. Our interpreter informed me they greatly infested the camels.-H.O.F.] 


\section{II.-Scorpions and Spiders of Abd=el= Kuri.} SCORPIONES.

\section{DIPLOCENTRID曆.}

\section{Heteronebo, Pocock.}

IIeteroncl,o, Pocock, Bull. Liverp. Muss., ii. P. T (1899).

Gemus of the Iliplocentrini, with the orular-tuberle shallowly sulcate or entire. Houl that above, with strong external keel, or convex alove and obsoletely keeled. Tarsi not distally lolate, the inferior angle nearly rectangular (ahout $\left.85^{\circ}\right)$. Tuil without lefinite half-moon shaped area at the posterior extremity of the lower surface.

Tilpe of genus, H. Irunti.

Intermediate in character between the Arabian genus Nolm, and the Central American and Antillean genus Iriplurentrus. Resembling the former in the conformation of the fifth caulal segment; the latter, in the structure of its tarsi and ocular-tubercle.

\section{Heteronebo granti, I'or'orl:}

Heteronebo :frenti, Pocock, Bull. Liver'1. Muss., ii. p. 7 (1899).

q Colour : dorsal integument of horly yellowish-olive brown; legs elearer reddisli-yellow, paler distally, tail deep olive brown, nearly black posteriorly ; chelie darker than trunk, deepreddish-lorown with blackish crests and fingers.

Curnuce very finely and closely granular at the sirles, punctured; ocular tubercle not sulcate. Tergu punctmerl, very finely gramular laterally and in the central icpression ; the last more gramular than the others, with two short granular crests on each sicle. Stermu smooth, pumetured, the last olsoletely cresterl. Tail alout four times as long as carapace, which about equals its first and second segments taken together in lengtl, the first segment with eight keek, the inferior median olsolete, second keeled like the first with median lateral weaker, thirel and fourth like the second, hut median lateral still weaker, practically obselete on the fourth, the keels of these segments only cremulate or olssoletely granular, the superior crests high, angled lehind, inferior lateral strong on all the segments, the superior and lateral interearinal spaces lightly concave; fifth segment with strong keels, the three inferior being coarsely granular : vesicle granular below, with small tooth. Chele' : humerus with its upper sirle coarsely gramular in front, without definite crest, bounded behind by a gramlar crest; 
no distinct antero-inferior crest, the anterior surface being meroly coatsely gramula below ; bachim nearly smooth, its mper sicle with two erests, the anterior of which is the strouger, furnisherl with hasial angular prominence ; hand flattish above, with strong smooth external finger-keel and weaker median finger-keel, the inner surface weakly gramular in front. Leys nearly smooth, tarsi withont lateral lobes, armed with six pairs of spines. Pertimel treth 8.

Measmements in mm. - Total length 48, earapace 5.5, tail $2 \cdot 2$.

Abl-el-kimi, (iebel salch (800-1500 ft.).

2. Heteronebo forbesii, Pororli.

Heteronebo forbesii, Pocock, Bull. Liver|). Muss. ii., p. S (1s99).

o Very distinct from the foregoing.

Coloni more miformly oehre-yellow, the tips of the mandibles, the fingers of the chele, the oenlar region of the carapace, and the posterior end of the third, fourth, and fifth candal segments infuscate. Upper side of trunk very finely gramular. Oculur tuberde distinctly sulcate. Crests on the last abolominal tergite weaker than in $H$. yrenti, lunt strinite with forr cremlate keels. Thil with the median lateral crest ohsolete even on the first segment; first and seeond eaurlal segments with strong, smooth, inferior keels, these keels olsolete on the third and fourth segments, the remaining crests weaker that in $H$. grouti, the superior not angular posteriorly, the lateral intercaninal spaces lightly convex; resicle wider as compared with its length than in $I I$. grouti, with the tuberele distinctly larger. Chele with hand very different from that of $H$. yranti, being evenly convex above from the keel of the hand back to the imner erge, without distinet finger keels. I'ertines and tarsal spine-armature as in $\mathrm{H}$. grunti.

Total length $42 \mathrm{~mm}$.

Alxl-el-Kuri, Gebel Saleh (800-1500 ft.).

[Both this and the precerling species were found under stones on Gebel Saleh at an elevation of about $1000 \mathrm{ft}$. Both were apparently rare, as dming several days' seareh only two examples of each speeies were met with.-II.li.().G.]

These two species may be hriefly diagnosed as follows :-

(i) Median keels on last abdominal sternite and first and second candial segments olssolete; hand with strong external and weaker median finger keel.

grunti.

(b) Merlian keels on last alolominal sternite and first and second candal segments strong; hand convex above, practically keclless.

forbesii.

\section{ARANEA.}

\section{ARGIOPID正.}

3. Argyope clarkii, Iilucke.

[Very common on the low hushes neal the sea, -IV.li.(l.6.]

See page 188. 
4. Araneus cardioceros, l'orock.

Araneus cardioceros, Pocock, Bull. Liverp. Muss, ii. p. 40 (Is99).

See page 191 .

\section{BIANTID床.}

\section{OPILIONES.}

5. Biantes bicolor, sp. $n$.

Closely resembling the Sokotran species li. fluviventris, p. 200, in structural featmes, but differing entirely in colour. The whole hody above and helow, with the coxie of the legs, jet black: mandibles and palpi entirely flavous; first and second legs yellowish-white, with the tilise and protarsi hlack; third and fourth legs entirely yellowishwhite, with the trochanters and basal half of femur black.

Total length $3 \cdot 5 \mathrm{~mm}$.

\section{Literature regarding the Arachnida of Sokotra and $\mathrm{Abd}=\mathrm{el}=\mathrm{Kuri}$.}

Taschenberg, /eits. Naturwiss. (4), ii. p. 17:3 (188:3), records the following forms as collected by Rieleck :-

(a) Acarina.-Some specimens of Irodiate off Cortus umbrinus.

(b) Araneida.-Gresterucuntha lepida, O. P. Cambr.

(c) Scorpionida.-Prionurus hottentottus, Fabr.

R. I. Pocock, Amm. Mag. Nat. Hist. (6), iii. p. 337, pl. xv. fig. 3 (1889).

Buthus socotrensis, sp. n.

R. I. Pocock, op. cit. (6), xvi. p. 98 (1895).

Paracleolis balfouri, sp. $\mathrm{n.}$

$$
\text { ( = Gluciopsis bulfouri.) }
$$

R. I. Pocock, ill. op. cit.

Nephila hymena' , Gerst.

R. I. Pocock, Proc. Zool. Soc., Lond., 1§97, p. 75๙, pl. xli.

Monocentropus lualfouri, gen. et. sp.n.

0. P. Cambridge, Proc. Zool. Soc. Lond., 1898, pp. 387-391, pl. xxxi.

Neplitu bennetti, sp. n., p. 387 fig. 2.

$$
\text { ( = Nephilu hymencu, Gerst.). }
$$

Selenops diversus, sp. n., p. 390 fig. 1.

(= Selenops rutiutus, Latr.).

Giesteracunthe salulis, sp. 11., 1). 388 fig. 3.

(= ? Gosterucantha lepiili, O. P. Cambr.).

Tetiagnutha boydi, sp. n., p. 389 fig. 4. 
R. I. Pocock, Bull. Liverp. Muss., ii. (1899).

Scorpiones.-Heteronelo, grenti and forlesii, gen. et. spp. nov., pp. 7-8. Hemisconpius socotrunus, sp. 11., p. 8.

Butheolus insularis, sp. n., p. 8.

Araneæ.-Aruneus hoplophullus, sp. n., p. 40.

Arencus curtioceros, sp. n., p. 40.

Scelidomachus socotrenus, p. 41.

Cupheris insuluris, p. 41. 


\section{PLATE XIV.}

Fig. I. MONOCENTROPUS BALFOURI, I'o. In an attitude of defener, p. $\mathbf{1} \mathbf{8} 3$.

Fig. 2. NEPHILA SUMPTUOSA, Gerst. Frmmle, p. I89.

Fig. 2a. The seme, Mule.

Fig. 2b. The sume, Pulpul Bull of Mule.

Fig. 3. ARGYOPE CLARKII, bliteliw. Femmle, p. 188.

Fig. 3a. The sume, Mrule.

Fig. 3b. The smue, Tulue of Femule.

Fig. 3c. The semere, Pulpul Bulb of Mule.

Fig. 4. ARANEUS CARDIOCEROS, Pue. Showing liulue of Fermule, p. 191. 
Liverp. Mus.; Rep Setictra E.cpert.
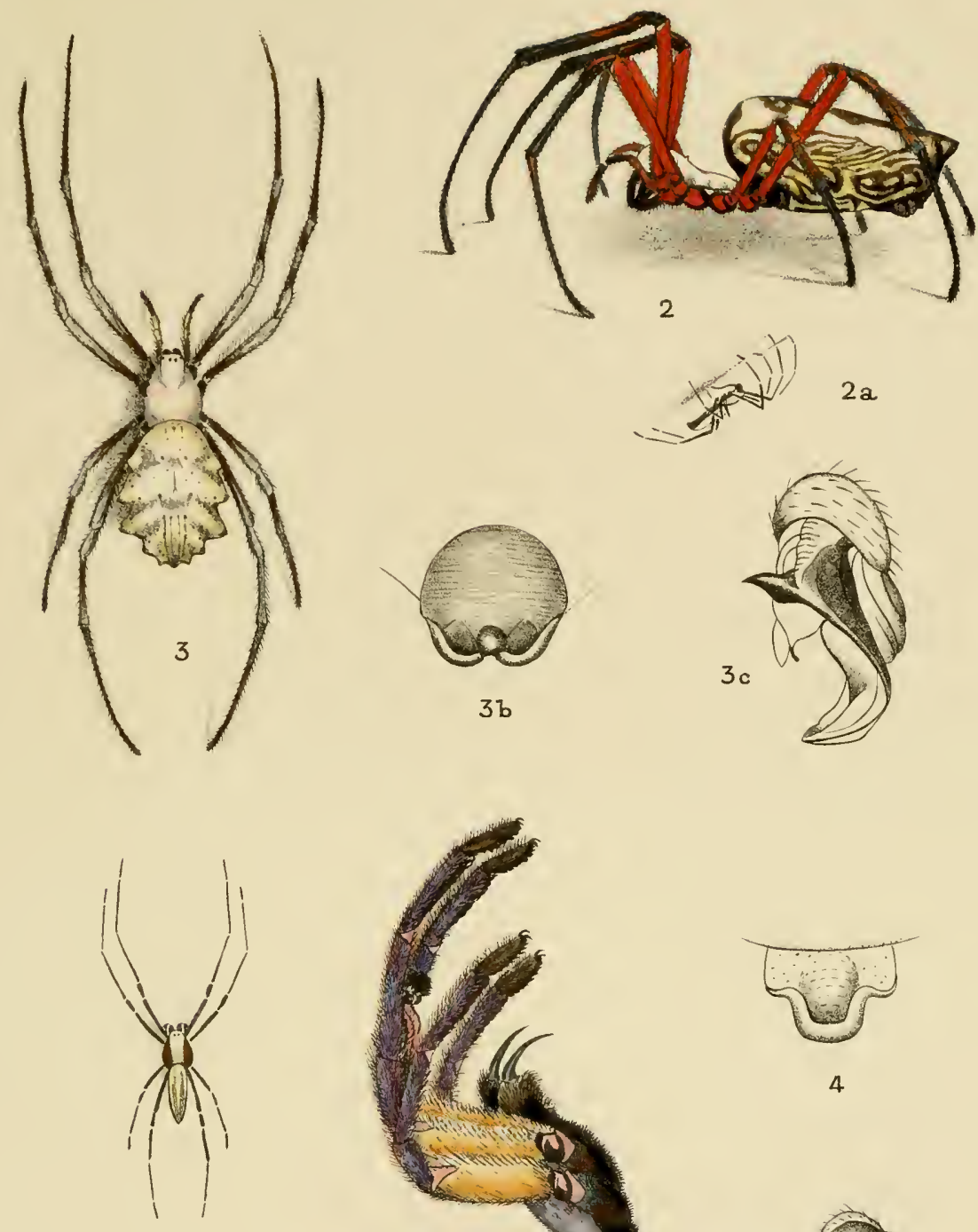

$3 \mathrm{~b}$

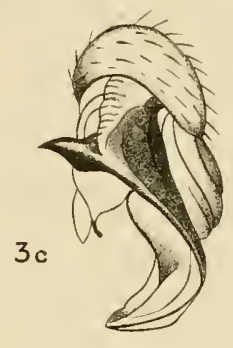

$3 a$

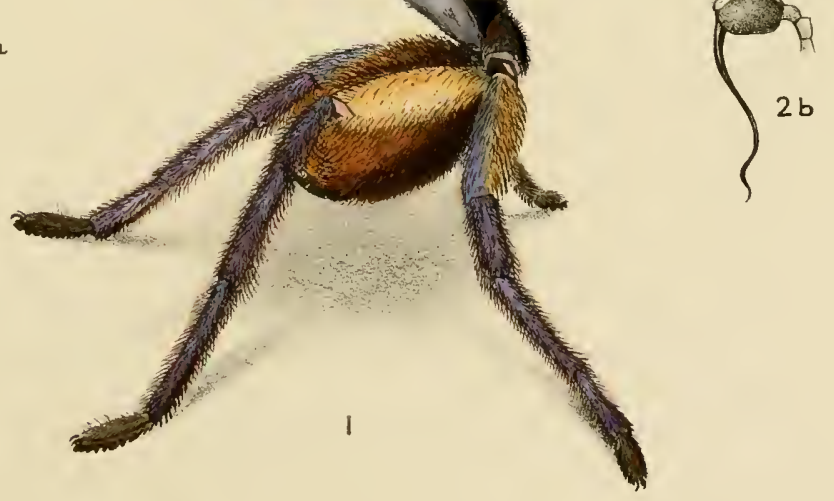




\section{PLATE XXVI.}

Fig. 1. DIMIZONOPS INSULARIS, Poe. Femule, Eyes from aliore,

Fig. 1a. The steme, Eyles from in front.

p. 199.

Fig. Ib. The snme, Trulen of Femule.

Fig. 2. BASSANIODES SOCOTRENSIS, Por. Inliu of Femule,

p. 198.

Fig. 3. SCELIDOMACHUS SOCoTRANUS, Por. Eyes fiom in fromt,

p. 194 .

Fig. 4. CAPHERIS INSULARIS, P'or. Pulpus of Femule, profile vien,

Fig. 4a. The stime, Inlir.

p. 195 .

Fig. 5. SCOLOPENDRA BALFOURI, P'of., p. 431. 


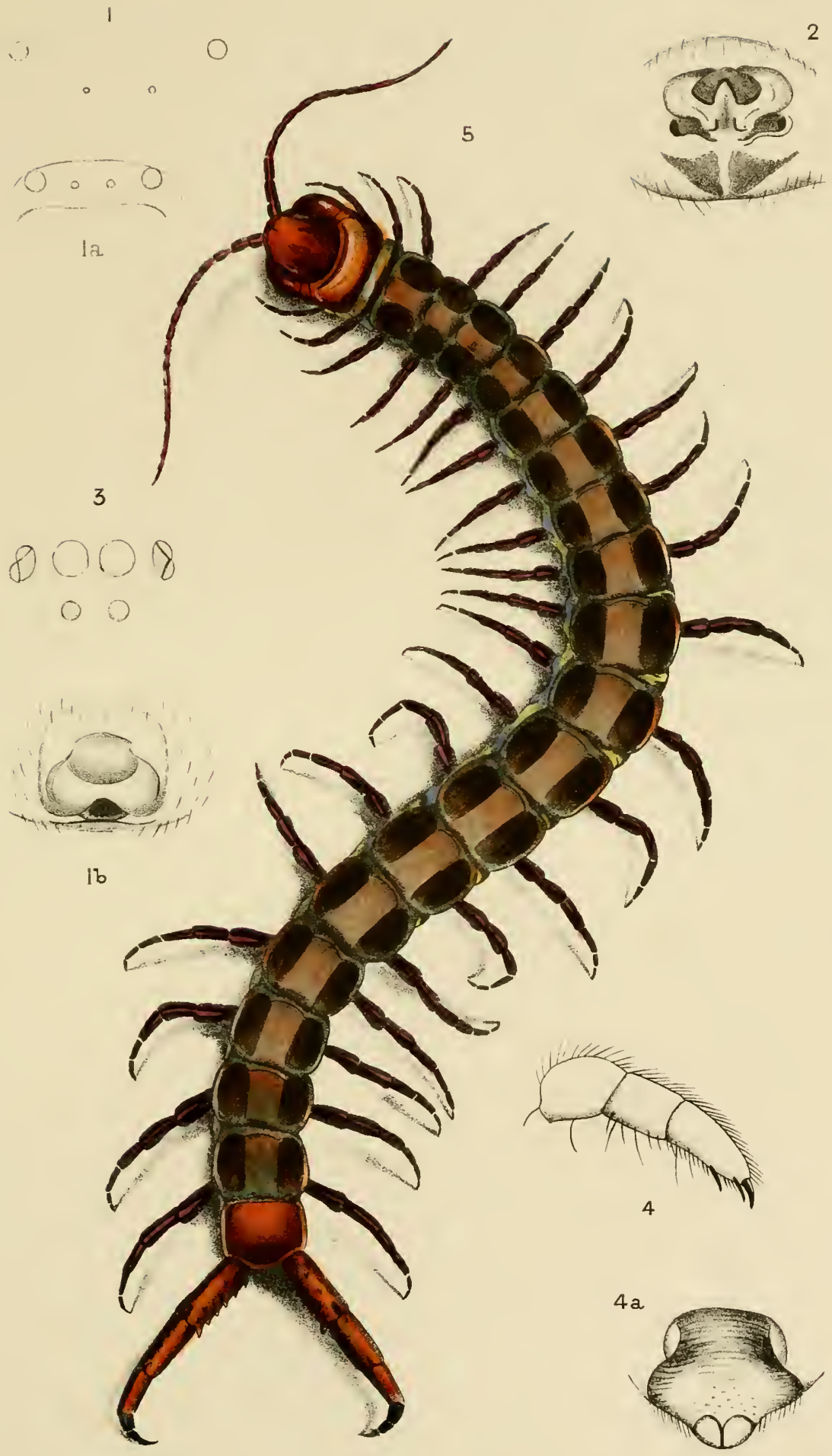





\section{ARTHROPODA.}

Crustacea:

Malacostraca.

By R. I. POCOCK.

$\left\{\begin{array}{l}\text { A. O. WALKER, F.L.S } \\ \text { ANDREW SCOTT. }\end{array}\right.$

PLATES XIVA, XIVB. 



\section{Crustaceans.}

It is hardly necessary to say much by way of introduction to this short chapter on the Malacostraca of Sokotra and Abd-el-Kuri. With exception of the strictly fluratile species l'otemon socotiensis, which, so fall as is at present linown, is confined to the island whose name it bears, and the littoral species, Uen inversu and ceypole ceyyptiucu, all the forms recorded below enjoy a wile distribution in the Inclian and Western Pacific Oceans. * Hence, apart from the fact that, excepting Cardisomu curnifer, they have never before been collected actually in the islands now under discussion, their ocenrence, which might have been confirlently predicted, is a matter of $n 0$ very special interest.

Taschenherg's summary of the Sokotran fauma contains only two species of Crabs, namely, Curdisoma carnifex and I'otumon socotiensis, the latter being then for the first time described by Hilgendorf. In faimess to Professor Balfour, however, it shoukl be explained that he brought back large numbers of this species before Dr. Riebeck made his visit to the island. Unfortunately, the specimens, together with the rest of his Crustaceans, fell into wrong hands, and were nerer systematically worked out.

As may be seen from the subjoined list, all the species here recorded from Sokotra form part of Professor Balfour's collection.* Mr. Ogilie-Grant and Dr. Forbes, wisely confining their attention to the investigation of the landfauna, only brought home, so far as Crabs are concerned, the strictly freshwater Potumon, which was rightly considered likely to prove of great faunistic importance.

The determination of most of the species was a matter of little diffieulty. The Potumon and $U c a$, however, about which I was in doubt, I sent to Dr. de Man for examination, and he, with his customary courtesy, kindly furnished me with their names, synonymy, and bibliography

* This observation does not apply to the small collection from rock-pools at Abd-el-Kuri described below by Mr. A. O. Walker and Mr. A. Scott, subsequent to the penning of Mr. Pocock's remarks,-H.O.F. 


\section{I.-The Decapods of Sokotra.}

\section{DECAPODA.}

\section{PORTUNID压.}

\section{BRACHYURA.}

Scylla, de Haan.

1. Scylla serrata, Forsk.

Scylle serreta. A. Milne-Edwards, Arch. Mus. Hist. Nat. Paris, x. p. 349 (1861).

Sokotra.-(Bulfour.)

Ranging over the whole of the Indian Ocean from the Rerl Sea and the Fast Coast of Africa into the Pacific Ocean.

\section{POTAIMID尼.}

\section{Potamon, Leach.}

Telphusa, Auct. plurim.

2. Potamon socotrensis, Hilg.

Telphusa socotrensix, Hilgendorf, Zeits. Nat. Wissen., 1vi. p. 171 (185:3); A. Milne-Eilwards, Ann. Sci. Nat. (7), iv. p. 133 (1887); also in Bibl. hautes Etudes, xxxiii. No. 4, 1) 13 (1857).

Telphuar yrunosu, Koelbel, SB. Ak. Wiss., Wien., xc. pt. i., p. 321, pl. i. fig. $6(1885)$.

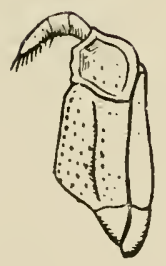

c.

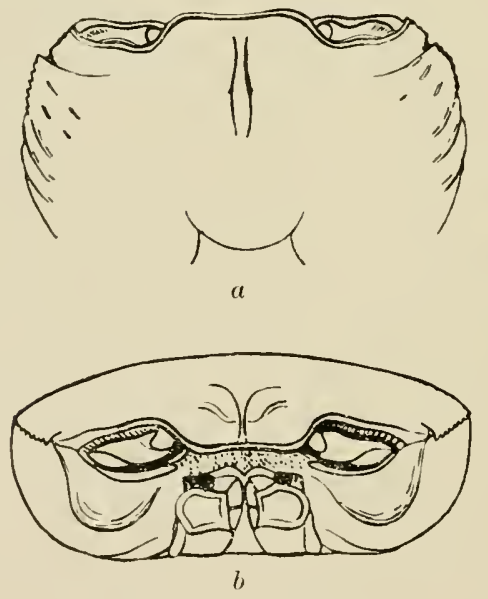

Potalion Socotrensis $q$.

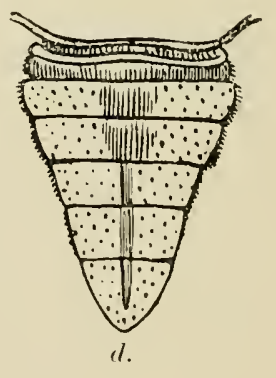

c External maxillipede.

The following is a translation of the description which Mr. A. MilneEdwards gives of this crab:- 
"Canapace flattened, but little widened, the front but little advaneed, sloping, with straight elge; eyes large. No postpontal erest. Anterior portion of the shell lightly wrinkled. Antero-lateral border but little arehed, and bearing a rery small and sharp epibronchial touth. Interregional grooves searcely distinet, except in the central portion of the ealapace. Chele weak, with fingers not separated, and with the surface a little wrinkled. Legs long and compresserl."

Length of carapace 21 mm., width $27 \mathrm{~mm}$.

This interesting speeies has been described at length in the works eited above. It woukl be superfluous, therefore, to re-deserilse it in mere detail on the present occasion. At Dr. de Man's suggestion, howerer, the accompanying figures have been prepared to illustrate the principal systematic features of the species.

Soliotra: Dahamis (500 ft.); (roahal Gorge, near Homhil (900 ft.).

Prof. Balfour and Dr. Riebeek hoth oltained this speeies.

[This species was rely common in all the streams from sea-level to an elevation of aloout 1500 feet. At Homhil they inhaloited rat-like boles in the lanks of the stream. Sichuyler traps baited with potato and set for what I at first supposed to be Water-rats, produced several mutilated crabs.-WT.R.O.G.]

\section{GRAPSID无。}

\section{Grapsus, Lamarck.}

3. Grapsus strigosus, Herbst.

Grepsus strigosus, Ortmamn, Zool. Jahrb. Syst., vii. 1. 705 (1894) (for syuonymy).

Sokotra.-(Belfour:)

Wiclely distributed along the coasts of the Indian and Pacifie Oceans.

[This speeies was not colleeted by the expedition.]

\section{GECARCINID无.}

\section{Cardisoma, Latr.}

\section{Cardisoma carnifex, Herbst.}

Cardisoma camifex, H. Milne-Erlwurls, Hist. Nat. Crust. ii. p. 23 (1837).

Curdisoma guenhumi, var. carnifex, Ortmann, Zool. Jahrb. Syst., vii. 1. 735 (1594).

Sokotra._-(Ricleck.) Tamarisla (= Harlibu).--(Bulfour.)

Distribution.-Inclian and Pacific Oceans.

\section{OCYPODID床.}

5. Uca inversa, $/ 10 t f m$.

\section{Uca, Latr.}

Gelasimus inmorus, Hoffmann, Crust, de Madagasear et de l'ile de la Rémion, 1. 19, 13. iv. fiers. 23-26 (1574); De Man, Notes Leyden Mus., xiii. p. 44, pl. iv. tig. 1:2 (1891).

Gelusimus chloroplithalmus, Hilgendorf, Mon. Ak. Wiss. Berlin, 1875, 1) Soli.

Sokotra.-(Bulfour.) 
Previonsly known, aceording to De Man, from Nossi-Faly, Natal, Mozambique, Lindi, and Dar-es-Salaam. Up to the present time Sokotra is the most northerly point known in the range of this species.

[Alumelant on the shore at Hadibu and Haulaf.-II.O.F.]

\section{Ocypode, Fabr.}

6. Ocypode ægyptiaca, Gerst.

Ocyporle "Iyyptiace, Gerstäcker, Arch. Naturg., xxii. p. 134 (1856); Heller, SB., xliii. (1) p. 361 (1861) ; Hoffmann, Pecherches Famna Madag., etc., Crnst., p. 1 ! (1874) ; Miers Ann. Mag. Nat. Hist. (.5) ii. p. 409 (1878) ; I (1. Op. eit. (5), x. p. 381, pl. xvii. fig. 3, 3a (1882); De Mlan, Notes Leyclen Mus., iii. p. 247 (1851).

Sokotra.-(Bulfour.)

Common on the shores of the Iied Sea, and also recorded from the island of Nossi-Faly, near Madagascar.

\section{CCENOBITID屟.}

\section{MACRURA.}

\section{Conobita, Latr.}

7. Cœnobita rugosa, Milue-Eidu.

Crenobite rmgo:a, H. Milne-Edwards, Hist. Nat. Crust, ii. 1. 241 (1837).

Sokotra. - ( Bullfour: $)$

Accorling to Ortmam this hermit Crah ranges from . Tapan and Sydney in the Pacific Ocean orer the whole of the coast of the Indian Ocean as far as the Rerl Sea and Natal.

[Common on the beach at Haulaf.-H.O.F.]

\section{PALINURID尼.}

\section{Palinurus, Gray.}

\section{Palinurus dasypus, Lutreille.}

Pulinume dusypus, Latreille, H. Milne-Edwards, Hist. Nit. Crust., ii. p. $300(1837)$.

Srnex daxypus, Ortmann, Zool. Jahrb. Syst, vi. pp. 23 and 32 (1892).

(?) P'elinume bürgeri, de Haan, Fauna Janonica, p. 159, pl. xliii. (1859).

(?) Senex bürgeri, Ortmann, Zool. Jahrb. Syst., vi. pp. 22: and 32 (189:2).

\section{Soliotra.-(Bulfour.)}

The specimen here referred to $P$. desypur., Latr., as well as one in the British Museum from Muscat, partake of the characters both of $I$. resypus and $P$. biirgeri as descrihed by Dr. Ortmann, the tergal grooves of the abdomen being uniformly deep and uninterrupted, as in $P$. biryeri, and the sulhordinate spines on the antenual segment small, as in l'. desiypus. In his synopsis of the species of the genus, Ortmann relies upon the completeness of the tergal grooves as the chief feature to distinguish I'. biurgeri; nevertheless the statement in his descriptive part, that these grooves in 1'. dusypus show a tendency to hecome obliteraterl, suggests that their depth and completeness are sulject to 
variation. $\quad P$. biirgeri appears to be a little-known Japanese form. P. dusypus, on the contrary, has been recorded both from Ceylon and Markas, and the British Museum possesses a specimen from the latter locality - a specinen which, in eonjunction with the example from Muscat mentioned above, was identified by Mr. Miers as $I$. spinosus, Edw. Although apparently erroneous, this determination by an experiencel carcinologist is interesting as demonstrating his opinion that the two specimens are conspecific in spite of the dorsal interruption of some of the tergal grooves in the Machas specimen and the umbroken eontinuity of all of them in the other. In fact the evirlence supplied by these two specimens, which are to all intents and purposes alike in other particulars, seems to show that the interruption of the tergal grooves is, at all events in $P$. dessymus, a feature searcely of speeific value. $P$. biargeri is unknown to me. Hence I have not ventured to do more than suggest in the above-giren synonymy the possibility of its heing merely a variety or subspecies of $P$. dusypus. 


\title{
II.-Decapod and Sessile=eyed Crustaceans from Abd=el=Kuri.
}

\section{OCYPODID无.}

1. Uca inversa, Hoffm.

\section{DECAPODA. \\ BRACHYURA}

\author{
Uca, Latr.
}

Gelasimus inversus, Hoffman. See p. 213.

Alol-el-Kururi.

[Olserved in abundance on the shores. - H.O.F.]

\section{Ocypode, Fabr.}

2. Ocypode kuhlii, the Hetur.

Ocypole liuhlii, De Haan, Fauna Japonica, Crust., p. 55 (1859); De Man, Notes Leyden Mns., iii. p. 250 (1s\$1); Miers, Ann. Mag. Nat.

Hist. (5), x. p. 384, pl. xvii. figs. S, Sb (1852).

Abd-el-Kuri.

Distribution.-Fanging, according to Miers, from Japan, Torres Strait, and Java as far as Madagascar.

\section{MACRURA.}

[Amid a few handfuls of Seaweeds hastily collected by me from rockpools, on our second visit to Abd-el-Kuri, a number of minute Crustaceans and Zuophytes were found includer. From among the former Mr. Alfred O. Walker and Mr. Andrew Scott were good enough to separate out for identification the forms to which they have deroted special sturly, and now eontrilute the remainler of this memoir. The figures are all from the accurate peneil of Mr. Seott.-H.O.F.]

The small collection, which forms the subject of the following memoir, was picked out of the residue from a collection of Algae. It was gathered hy Dr. Forbes at low water at Abd-el-Kuri, in February, 1899, from rocks and tidal pools, and the Crustaceans were apparently only accidentally present among the weeds. It is instructive, as showing how small is our knowledge of the Eidriopllthalma in tropical seas, that of the 13 speeies of this sub-class in the collection 6. at least, are new to science, two of them requiring the formation of new genera for their reception. One of these genera (Kuria) camnot be referred to any of the recognised families of Amphipodu. 
The following list shows approximately the geographical distribution of the old species and the nearest allies of the new :-

llimpolyte leptucerus, (Heller) Mediterramean.

Spharome groutii, n. sp.

Genus probubly eosmopolitan hetween the 50th parallels of $\mathrm{N}$. and $\mathrm{S}$. latitude.

Edotia, sp.

Hyule vilssmii (kathlie)

South Africa, if $E$. lirtipes.

Lysicunet: wrodus, n. spe.

Norway, British Seas, Mediterranea, Azores.

Near L. cingluelensis, Stebling, C'eylon.

I'arambusiu forthesii, n. gen. and Near Ambusia integricauda, Stebbing, from sp.

Ampeliscu, sp.

Atylopsis lutipulpus, n. sp.

Kerguelen Island.

Genus eosmopolitin.

The other puhlished species of this gemus are all from the temperate regions of the southern hemisphere.

Elusmopus soliotice, n. sp.

Near E. insignis, Cherreux, Seychelles Islaurls : E. subcurinutu (Haswell), Australia, and E. repeci, Costa, Europe.

Audulla cheliferu, Cherreux, ${ }^{*}$ Seychelles Islands.

I'ereionotus testudo (Montagu) Mediterranean, with a clearly allied speeies (P. thomsoni, Steblong) in Australia.

Kuric longinumus, 11. gen. and Nearest ally Bircennu fullus, Chilton, New sp.

Cerupus flindersi, Stebbing, Zealand.

Torres Straits, Port Jackson.

\section{[CENOBITID瓜.}

\section{Conobita, Latr.}

\section{Cœnobita rugosa, Milue-El.}

Conolita rugosa, H. Milne-Ed., Hist. Nat. Crust., ii. p. 241 (1837).

Abcl-el-Kuri.

See page 214 .

Olsserved in large numbers near the shore, and also a mile or two from the sea, and at an altitude of a couple of humdred feet.-H.O.F.].

* This memoir was communicated to the Linnean Society on March 20, 1902. On April 28, 1902, Mr. Walker receired, by the kinduess of Mons. E. Cherrenx, his paper from the Mémoires de la Société Zoolorique de Frunce, Vol. XIV., on the Amphipod Crustaceans collected by Mons. Ch. Alluaud in the Seychelles Islands. Among these, Aululla chelifera, n. sp., Chevreux, is certainly identical with a species which had been described in this paper under the name of Gammaropsis chelata, 11. sp., and we have accordingly substituted Mons. Chevreux's name. Our Elasmoms sohotro appears to be almost identical with $E$. insignis n. s1), Chevreux, but there are slight differences which will be inclicated below. Finally, Grubia microphthalma, n. s1)., Chevreux, is probably the same as we have described as Grubia lomgicornis (Kossmann). Mons. Chevreux, however, is yuite justified in making a new species of it, the lifference between it and Kossmann's description of Amphithoides longiconis being, as we had pointed out, considerable.-A. O. W., A. S. 


\section{ALPHEID开.}

Alpheus, Fabr.

2. Alpheus edwardsii, Aulouin.

Athancsus edcardsii, Andouin, Expl. planch. de Sarigny, Deseript. de l'Egyp., pl. x. fig. 1 (ISU9).

One specimen withont chelipecles.

\section{HIPPOLYTID压.}

\section{Hippolyte, Leach.}

\section{Hippolyte leptocerus, Heller.}

Virbius leptocerus, Heller, Crust. des südl. Europa, p. 289, 11. x. fig. 5, 6.

Three young specimens.

Rostrum very slemler, and bent rather downwards, not reaching beyoud the eyes, with one tooth on the upper sirle and one just beneath the point. In other respects they agree with Heller's description. Abd-el-Kuri.

\section{EDRIOPHTHALMA.}

\section{SPH屈OMID床.}

\section{ISOPODA.}

\section{Sphæroma, Latr.}

4. Sphæroma grantii, n. sp. (Plate xiv A. figs. 1-1c.)

One specimen.

Body rather ollong, widest in front, with prominent tubereles. Head as wirle as, and rather longer than, the first segment withont the epimeres; 2 prominent tnbercles towards the front, near the median line, and 2 smaller ones between these and the eyes, but rather in front ; 4 more along the hind margin, the two middle the largest. Eyes large and prominent in the posterior angle of the head. Antemnules more than half as long as the antennæ, with the basal joint not enlargerl.

Mesosome: first segment twice as long as the second ; epimeres, as seen from ahove, widlening posteriorly ; t tubereles on the hind margin, the two middle ones the largest. The next 5 segments sub-equal with 6 small tubercles on the elevated hind margin of each. Seventh segment with the hind margin smooth. All the epimeres are much deflexed. Netasome: first segment smooth, partly concealed by the last mesosome segment; second segment with a large, hlunt tooth on each side of the median line, and the hind margin at each side prodnced into a lobe with the apex sinuate. The remaining segments are coalesced with (1st) 3 large tubercles, and (2nd) 2 prominent blunt teeth on each side of a central excavation. The hinder portion is produced much beyond the uropods, with a tricuspidate senlpture on the upper side, near the end. The uropods have the rami sult-equal, rounderl-oblong, with smooth margins; a few short setie on the imer margin of the inner rami. 
Length $4 \mathrm{~mm}$.

Alol-el-Kini.

The single speeimen was not dissected, the external charaeters being in this cise of more value than the internal. The palp of the maxillipedes has narrow joints. The species is characterised by its prominent tubercles, de.

\section{IDOTEIDÆ.}

\section{Edotia, Guérin-Méneville.}

5. Edotia? hirtipes, Milue-Edw. (Plate xiv 1. figs. 2, 2a).

Idoted hirtipes, Milne-Ed., Hist. Nat. Crus., iii. p. 134 (1810).

Two young specimens.

Head as wide as, and rather larger than, the 1st segment; eyes large and prominent. Mesosome: first 4 segments longer and wider than the next :3*; 110 epimeres are visible in a dolsal view. Metasome: first segment indicated, but not separate, the rest coalesced ; the extremity roumled, and the whole fringed with short sete. Antenne : the upper reaching beyond the seeond joint of the lower; the one-jointerl flagellum as long as the last two joints of the perluncle: lower antenne reaching to the 4 th segment; the last joint of the peduncle ahmost as long as the two preceding united; flagellmm longer than the peduncle, the first joint as long as the next three together. Uropods, with the terminal portion obliquely pointed, 2 or 3 setules at the tip; the proximal part with 2 plumose setre at the onter angle and a few setules on the inner margin.

Length $+\mathrm{mm}$.

Abd-el-Kuri.

The specimens are too young for certain identification, and may, very possibly, be the above S. African species.

\section{ORCHESTIIDÆ.}

\section{AMPHIPODA.}

\section{Hyale, Rathke.}

6. Hyale nilssoni, Riuthke, var. Plate xiv 1 . figs. 3a-3e.)

Amphithoë nilssoni, Rathke, Beitrage Fanna Norweg. Verhaud. der K.

Leop. Carol. rleuts. ak. Naturf., xx., abh. i., p. 2640 (Bresl. 1s43).

Several specimens, male, female, and young.

Body morlerately compressed. Śgments of mesosome increasing slightly in length from the head. Hind margin of third metasome segment rather convex and erenate; the posterior angle subacute, and slightly up-turned. Head almost as long as the first two segments together. Lateral angle slightly produced; subacute. Eyes round-oval; the vertical diameter rather greater than that of the first joint $t$ of the

*This means, in all similar cases, longer than the next three united.-A. O. W.

t The first joint of upper or lower antenne means the first exprosed-i.e., the antepenultimate-joint. The first joint of a leg is the basipodite, not the coxopodite. 
upper antenna. Upper antenuie about twice as long as the peduncle of the lower; peduncle about half as long as the eleven-jointed flagellum, the joints of whieh increase in length distally ; lower antennæ in the male more than half the length of the body ; peduncle about one-third of the length of the flagellum ; the last joint as long as the two preceding. First gnathopods: side plates oblong, widening below, with the angles rounded; first joint as long as the next three: carpus produced behind in a semi-cirenlar lobe fringed with setie which appear to spring from sockets; proporlos as long as the two preceding joints, widest a little below the middle and contracted leelow the palm, below which is a fringe of setar. Second gnathopods: in the female, like the first gmathopods. In the male the side plates are quadrate, with rounded angles; the propodos is large, widely ovate, and almost exactly like that of $H$. nilssoni (Rathke). In the fenale the incubatory lamelle are rounded at the distal end, and fringed with long hairs. Perropods as in $H$. nilssoni, except the first joint of the last two pairs, which are rather deeply crenate, especially the lower half. Uroporls: the first extend beyond the second, and these beyond the third; rami of the first and second longer, of the third shorter, than the peduncles. Telson normal.

Length of adult $6 \mathrm{~mm}$.

Abrl-el-Kinri.

Very near H. nilssoni, but differs in the length and proportions of the antenne; form of the earpus and side plates of the gnathopods, and of the inculatory lamellie, and in the erenate first joints of the last two pair of pereopods. We cannot, however, consider it as more than a variety. Specimens of $N$. nilssoni from $\mathrm{N}$. Wales approach these very closely, especially as regards the antennæ.

\section{LYSIANASSID床。}

\section{Lysianax, Stebbing.}

\section{Lysianax urodus, * n. sp. (Plate xir A. figs. $4-4$ g.)}

Body moderately compressed; first segment of mesosome rather larger than the rest, which are suberpual; first four side plates considerably deeper than the segments; third segment of metasone with the hinder angle rounded. The head is as long as the first segment; the lateral angles romeder. Eyes large, clark, oval, reniform. Upper antemne rather longer than the lower in the female; the first joint very thiek and nearly twice as long as the next two; Hagellum seven-jointed, shorter than the peluncle; the accessory appendage three-jointed and about two-thirds the length of the flagellum: the first joint ather longer than the second, the third very small. Lower antemia: in the female the last three joints of the peduncle are as long as the fire-jointed flagellum, and are subequal in length and

\footnotetext{
* From oupá, tail, odous, tooth, in allusion to the tooth on the third uropods.
} 
breadth. First gnathoporls : the first joint as long as the next three; the front margin of the carpus abont two-thirls the length of the propodos, which is not subchelate; dictylus short, strong, and curved : side plate roumderl and expanuled forward so as partly to cover the hear. Pereopods : the last three pair increasing gradially in length posteriorly ; first joint much expanderl, with a few shallow teeth on the hind mingin. Umpods: the first extenrl heyourl the second, and these beyond the thind: the pedmele of these last is about as long as the rami, and has a conspienous tooth at the extremity of the upper margin; the rami are subequal, and densely setose in the $\delta$. The telson is entire, rounderl at the apex, with two setw on each side and two pair of setules near the midkle. It reaches to about the middle of the peduncle of the third mopods.

Length of adult male 5 mm.

Abrl-el-Kur.

This species is nearly allied to $L$. cinghalensis (Stebhing), but difiers chiefly in the form of the eyes.

\section{Parambasia, gen. nov.}

Side plates very deep. Mandihles as in Ambasia integricandu, Stebhing, but with a distinet aceessory lobe. Maxilliperles, as in Amberiu integricumele, except the dactylus of the palp which is longer. Upper antemne, with the first joint orerhanging the second, as in Ambusiu dunielsseni, Boeck; first joint of the flagellum like the succeeding joints. First gnathopod not subchelate, feeble. Second guathopod with the propodos short, truncate. Pleopods normal. Uropods slencler, with the imer rami shorter than the outer. Telson entive.

The species on which this genus is founded resembles Ambasia integricuma, Stebhing ('Challenger' Amphipoda p. 695, pl. xxvi.), in the mandibles, the first gnathopods and the telson; but difters in the swollen first joint of the upper antenne, and in having the first pair of pleoporls normal. Sars (Amphipode of Torwen, p. 46) consider's that Stebling's species is wrongly placed in Ambusiu which has in the type species, A. dunielsseni, Boeck, normal pleopods and a divided telson: the first joint of the flagellum of the upper antenux is also that of a typical Lysimassid and quite mlike our speeies and Stebhing's. From Nunnony.x, G. O. Sars, it differs in the comparatively slencler and makel first gnathopod and uropods, in the form of the propodos of the second gnathopod and of the upper antenne, and in the length of the dactyli of the perieopods.

\section{Parambasia forbesii, n. sp. (Plate, xiv A. figs. 5--5m.)}

One female with ora.

Borly compressed: first four sirle-plates more than twice as deep as the segments, the next three nearly as deep as the segments; hind 
margin of the third metasome segment slightly eoncave, posterior angle acute, minutely produced. Head as long as the first segment; lateral angle romded. Eyes large, dark, oval. Upper antenna : first joint swollen and overhanging the next, second and third subernal, and like the joints of the flagellum; flagellum, seven-jointed, the first joint like the remainder but shorter, all fumished with long seta on the lower side; accessory appendage three-jointed, reaching the end of the second joint of the flagellum. Lower antemre slender, the first joint half as long again as the second and twice as long as the third, flagellum six-jointed. Maxillipedes: ends of the inside plates rather obliquely trmeate, with a emred spine near the onter angle; fourth joint of palp rather long and irregularly formed. First gnathopod sparsely setose, not sulnchelate, the first joint as large as the next fomr: the second joint as long as the third and fourth; third very short: fourth (wrist) half as long as the hand: side-plates large : front margin expanded below, so as to cover most of the head. Second gnathoporls : the propodos wirlening distally and abruptly trumeate; the dactylus small and placed low down on the truncate face with a semi-circular row of stiff hooked setax directed forward above it. Side-plates expanded below. Pereoporls: first and second have the third joint but little enlargerl, dactylus alout half as long as the preceding joint, no spines except one at the end of the fifth joint; the third has the first joint irregularly oval, wider than deep, the third joint enlargerl, sicle-plate abont twice as large as the first joint; the fourth and fifth have the first joint very large, in the fifth larger than the fourth and expanded downwarts, daetyli about half as long as the preceding joint. Croporls: in all, the peduncles are longer than the rami, and the onter lamus than the immer. Telson semi-oral, with a minute setule on each sicle of the extremity.

Length $3 \mathrm{~mm}$.

Alid-el-Kuri.

\section{AMPELISCID床.}

\section{Ampelisca, Kröyer.}

9. Ampelisca, sp. (Plate xir A. figs. 6a, 6b.)

One specimen : length $2 \mathrm{~mm}$.

This example is too youmg for determination or description. Its prineipal character's are the romuled rectangnlar posterior angle of the third segment of metasome and the hroad oral dactylus of the last pair of perreopods.

\section{ATYLID无.}

\section{Atylopsis, Stebbing:}

\section{Atylopsis latipalpus, ${ }^{*}$ n. sp. (Plate xiv A. figs. 7-7l.)}

One female with ora.

\footnotetext{
* From the unusually wide palp of the first maxille.
} 
The sixth segment of the mesnsome is the shortest, the seventh the longest; first $t$ side-plates abont ${ }_{3}^{2} \mathrm{rds}$ of the depth of the segments; posterior margin of third segment of metasome romeled, with a slight indication of the posterior angle; segments of urosome ristinct. Head longer than the first segment. Eyes large, oval, dark. Mandihles as in Purutylus, small ; palps lost. First maxillie: outer plate erowned with rather Iong dentieulate setre; inner plate small, with three long plumose setie on the aper; palp remarkably broad, mueh wirler than the outer plate: the inner angle of the seeond joint eut off, and the sloping edge with five short teeth; the top of the joint with three setre. Second maxille normal. Maxillipedes with the third joint searcely prodneed over the base of the fourth, otherwise normal. Upper antenne $\frac{2}{3}$ rels as long as the lower: peclunele short, the joints suecessively decreasing in length and thickness : flagellim ten-jointed, the first joint the longest. Lower antenne: the first joint rery short, the second as long as, but thicker than, the third; Hagellum with about 25 joints. First gnathopods: the first joint almost as long as the next four: the second and third short; the wrist as long as the hand, the posterior angle prominent; the hand with parallel margins, the palm oblique, shorter than the posterior margin, slightly convex. Seeond gnathopods like the first, but rather larger : the first joint longer and stonter ; the posterior angle of the wrist prodnced to about $\frac{1}{3}$ rel the length of the hand. Perreopods : the first and second have the first joint as long as the next three; the third and fourth as long as the fifth : the last pair hare the first joint rather deeper than wide, the hind margin shightly serrate. All the pereopods have strong curved dactyli, and are more or less spinous. Uropods: the first and second with narrow pedmeles and rami, the former the longer: inner rami shorter than the outer; pedunces of the third less than half as long as the rami, which are lanceolate and equal, the imer rather the wider; hoth are spinous on both margins, and furnished with plumose seta on the inner. Telson divided to about half its length ; the extremities of the divisions rounded, and without spines.

Length $4 \mathrm{~mm}$.

Alud-el-Kuri.

But for the dirided telson, this genus would seem to belong rather to culliopieles than Atylinte.

\section{GAMMARID压.}

\section{Elasmopus, A. Costa.}

11. Elasmopus sokotræ, n. sp. (Plate xir r. figs. 1-1i.)

Sixteen specimens-males, females with ora and young.

The first two segments of the mesosome are the shortest, the remaining segments increase in length suceessively ; the side plates of the first four are not as deep as the segments; lower margins romded; the 
third segment of the metasome has the posterior angle acute, and slightly turned up ; the first segment of the urosome has, in the male, a prominent tooth on each sicle of the median line. The head is as long as the first two segments. Eyes oval, clark, placed elose to the edge of the rounded lateral angle. Upper antenne nearly twice as long as the lower: encl of the perluncle in the male reaching to the end of that of the lower antemme; in the female exceeding it by the last joint; first joint thiek, almost as long as the second; third joint in the male one-third, in the female two-thirds the length of the second; flagellnm rather longer than the pecluncle; accessory appentage (often wanting in the female) of three subequal joints. Lower antemne: Last joint of the pedunele rather shorter than the preceding, the two together rather longer than the flagellum. Mandibles very deep, the palp small, shorter than the upper margin, the first joint the shortest, the remaining two of eqnal length, without setre, excejt two at the tip. First gnathopods: the first joint abont as long as the next three, propodos oral, as long as the two preceding joints, palm undefined: hind margins of hand and wrist setose ; daetylus alont one-third the length of the hand. Second gnathopods : in the male the propodos is very large, oval, very sparsely setose, the palm as long as the posterior margin, and defined by a tuberele and the usual spines; a larger spinons tuberele near the base of the daetylus, and a smaller one between these two; dactylus strong; carpus short, and somewhat produced behind in a very setose lobe. In the female the propodos is mueh smaller, oval, very setose, the palm not defined; carpus about half the length of the propodos. Perropods : the first and second moderately strong, the hind margins of the fourth and fifth joints spinous, and a long spine on the side of the latter towards the distal end. Remaining legs extremely robust, spinous, and setose, the third joint as wide as the expanded first, which is finely serrate on the lower part of the hind margin. The dactylus in all five pairs has a secondary tooth, and two or three setie, and is strong and eurved. Uroporls: first and second with perluncle longer than the rami, the imner of which in both pairs terminates in a very long spine; loth pairs reach to the end of the telson ; the third pair are very short, wide, and spinous, the rami equal, rather longer than the peduncle. The telson reaches the end of the peduncle of the third uropods; it is eleft to the base with three unequal spines at the extremity of each dirision.

Length of male, $7 \mathrm{~mm}$. ; female, with ova, $5 \mathrm{~mm}$.

Abd-el-Kuri.

This species shows even more than the usual differences of the genera Elusmopus, Heteru, and their allies between the sexes, viz., in the upper antennx, the second gnathopods, the presence in the male only of teeth on the urosome, and in the size. It is very near to E. subcurinatu (Haswell), as deseribed in the 'Challenger' Amphipodu, but differs in 
having a three-jointed ancessory appendage, in the approxinate equality of the three joints of the mandibulan palp, and a few other minor particulars. As regards the mandilular palp, we prefer Prof. G. O. Sar's definition of the genus, which wisely, in om opinion, makes no mention of this part, as Boeck does. We, therefore, do not feel called upon to create a new genus (as Mr. Stebling felt eonstrained to do in Parilusmopus), becanse the thirl joint is neither "nuch langer" than the second, nor "curverl," ete. We venture to think that the introrluction of such trivial "hanater's into the refinition of a genus only leads to the munecessiry multiplication of genera. It is hardly neessiry to say that Costa, the founder of the genus, saly's nothing alout the mouth organs. As a specific character, the mandibular palp is often very useful-e.g., it woukl be almost impossilule to distinguish the female of this species from that of $L$. mpex (Costa) but for the difference between the small nakerl appendinge of the former, which cannot be seen till the mandilse is dissected out, and the powerful setose one of the latter, which projects far beyoul the montl. From E. insignis (Cherreux) it differs in the seulpture and eompanative mulity of the posterior margin of the propodos of the second gnathopor of the male, and in the absence of the teeth on the first urosone segment in the female.

\section{PHOTID压.}

\section{Audulla, Chevreux.}

Andulla, Cherreux, Mem. Soe. Zool. de Fr., xiv. p. 388 (1902).

12. Audulla chelifera, Cherrent. (Plate xir B. figs. 2a, 2b.)

Audulla chelifera, Chevreux, loc. supra cit.

Fifteen specinens, male, female, and young.

Body slender : the two first segments the shortest, the last three of the mesosome the longest : posterior angle of the third metasome segment acute and uptumed ; the first two segments of the urosome are dorsally depresserl, with a pair of upright setie near the hind margin ; side plates small and rounded. Head as $\operatorname{long}$ as the two first segments: lateral angle acute, the dark, oval eye being situated in it. Nouth organ normal. Upper antemie: first and third joints subequal in length: the second considerably longer ; the acessory appendage is fire-jointed ; the last joint minute. Lower antenne like the upper, exeept the thimer first joint. First guathopod like that of Gummaropsis erythro, hthulmus (Lillje); the side plate olstusely rhomboidal. Seeond gnathopod in the male very large; the first joint rather longer than the next three; earpus short, triangular. Propodos as long as all the precerling joints, oblong, the hinder margin produced to meet the point of the dactylus, so that the limb is truly ehelate; the upper and lower margins with rows of long setie; dactylus very short and strong, like a parrot's upper mandible, with a strong tooth 
in the middle of the imner margin. In the female the propodos is much smaller, oval, the palm oblique, more than half the length of the posterior margin; the whole densely setose; the daetylus is serlate on the distal two-thirds of its length. The pereopods resemble those of G. erythrophthalmus, exeept that in the last three pairs the first joint is considerably narrower. The first and second uropods have the pedunele abont as long as the rami, with a few spines on both; the outer rami are a little shorter than the inner; the third are the same, but stouter; the tips of the rami densely spinous. The telson is of the usual convex, semi-tubular form, but the extremity is hollowed out, so as to present a deep sinus when flattened out. It has a strong spine, terminated ly a setule, and a small setule near it at the extremity of each lobe.

Length of male $5 \mathrm{~mm}$; the female is rather shorter and stouter.

The males of this species may easily be distinguished by the chelate second gnathopod.

Abd-el-Kuri.

The above species was deseribed by us as Gammaropsis chelatu before M. Chevreux's paper was received. We still consider that the structure of the third uropods places it in the Photide, rather than the Ischyroceride, to which it is referred by Mous. Chevreux.

\section{AMPHITHOID压.}

\section{Grubia, Czerniavski.}

13. Grubia longicornis, Kossmann. (Plate xiv 13. figs. 3a-3e.)

Amphithoides longicornix, Kossman (:) Zool. Reise Roth. Meeres, 2 Hälf., 1st Lief., p. 135, pl. ii. (1880.)

One adult male and two young.

The first two segments of horly of equal length, the remainder inereasing successively; side-plates of the first five segments rather deeper than the segments; the whole body finely but not closely granulate; branchial vesicles large, broadly oral; third segment of the metasome with the lower margin convex, the posterior angle slightly upturned. The head is half as long again as the first segment, the lateral angle rounded. Eye rather small, round, red. Mouth organs as in Amphithöe (ef. Sars Amphipoda of Norway), but the mandibular palp in a young specimen is relatively smaller, and has only a few setæa at the extreme tip. Upper antenne considerably longer than the lower, the first joint thicker and rather shorter than the second, which is four times as long as the third; flagellum with $40-50$ joints; accessory appenclage one-jointed, half as long as the first joint of the flagellum. Lower antemie: first joint shorter than and about as thick as that of the upper; second and third subequal and rather longer than the seeond joint of the upper; in the adult male the lower margins of the distal third of the second, the whole of the third and the first few joints of the flagellum are densely fringed with plumose setie; 
flagellum with about thirty joints, the first few ill defined. Finst gnathoporls as in Amphithoë rulricutu (Mont.), but the sirle-plates are expanded helow towards the hear, and have a few sete at the hind corner. Seeond guathopods: anterior margin of the wrist alont two-thirds as long as the hand, which is broadly oval; palm oblique, slightly conrex and even, shorter than the posterior margin - these two joints in the adult male are densely elotherl on the front side with plumose setie : side-plates ohlong-oval, with sete at the hind eorner. Percopods: the first and second as in Amphithoe, the renaining pairs wanting in all three specimens. Uroporls : peduncle of the first rather longer, of the seeond rather shorter than the rami; outer rami the shorter; pedunele of the third more than twice as long as the short, thick rami, of which the outer is the shorter, and furnished with two hooked spines as in Aimphithö̈. Telson half as long as the peduneles of the third uropods, like Amphithoë, but rather nore rounded.

Length of adult male $11 \mathrm{~mm}$.

Abd-el-Kuri.

In spite of considerable diserepancies with Kossmann's deseription of Amphithoides longicomis, it is probable that our speeimens should be referred to that speeies. His specimens were only $4 \mathrm{~mm}$. in lengththe size of one of our young ones. These had lost all their antemie, but in the adult male the peduncle of the lower antennie is much longer relatively to the upper than in his speeies. Again, the aecessory appendage in his is two-jointed, and the outer lamus of the third uropods is said to have only one hook, while in ours these figures are reversed, but it is rery easy to make mistakes in such points. Della Valle (Gummarini del Golfo de Neupoli, p. 464) unites this species with $G$. crassicomis (Costa), but the form of the second gnathopod in the male is quite different.

\section{PHLIADID冉.}

\section{Pereionotus, Bate \& Westwood.}

14. Pereionotus testudo, Montugu. (Plate xiv B. figs. 4a, 4b.)

Icridium fuscum, Grube, Arch. für Naturgesch. (1864), Vol. i., p. 195, Taf. v.

To this species we refer-at all events, provisionally-a single specimen, which agrees with it in every respect, exeept in the second uropods having two rami instead of one. This is, no doulbt, the form mentioned by Mr. Stebbing (Trans. Linn. Soc., (2), vol. vii., p. 4] 7). Mons. Cherreux has very kindly sent us a similar specimen, and writes as follows:-"I have found the two forms (with one and two rami) in the same loealities, among algae, on the eoast of Provence, as well as of Algeria. They have alssolutely the same aspect, and only differ in the eharacter of the uropods. It may be a case of sexual dimorphism, but these animals are rare everywhere and I have not sufticient specimens to be sure upon this point." 


\section{FAMILIE INCERTE SEDIS.}

\section{Kuria, ${ }^{*}$ gen. nov.}

Burly laterally compressed. Mandibles with dentate primary and secondary cutting erlges; molar tuberele rather large; palp wanting. Maxillipedes with inmer and onter plates very small, especially the latter ; palp four-jointerl. Antennæ suberual; flagella fer jointed; no accessory appendage. Guathopods sulvequal, very long and slender: propodos in both pairs long and narrow, with a small subchelate palm. Pereopods: last three pair rery robust, with the first and third joints greatly developed. Third uropods with one lamus. Telson divided to the base, consisting of two subtriangular plates set on erlge.

Abd-el-Kuri.

A very aberiant genus. Its nearest ally seems to be the New Zealand genus Bircenuc (Chilton), which Mr. Stebling has placed in the Phliudita (Truss. Limu. Soc., 2nd ser., rol. rii., p. 421), where, however, it seems somewhat out of place with genera such as Pereionotus, Iphinotus, ete. It resembles Kurin in the characters of the antenne, gnathopords, mandible, and maxillipedes, and the unilamous third uroports, but differs in having rery shallow side plates, and an entire telson.

\section{Kuria longimanus, 11. sp. (Plate xiv 13. figs. 5-5u.)}

Two females with ova.

Borly rather plump; first and seeond segments subequal, remaining segments of the mesosome rather longer than these ; first four sicte-plates deeper than the segments, upper posterior angle of the fourth ent away ; thirk metasome segment with the hind margin almost straight, with two narrow notehes, posterior angle subacute; mosome with the three segments coaleseerl. Hear small and partly concealed by the first sirle-plate; no rostrum. Eyes rather small, oval, dark. Upper anteme rather shorter than the head, and first segment, first and second joints respectively, about twice as thick, but the same length as the following joint; flagellum four-jointed, with a rather long seta, and two or three short ones on the lower margin of each joint. Lower antenne with seren joints in all, the peduncle apparently of two joints only, of which the first is rery small. In both pairs of anteme it is difticult to distinguish the permuele from the flagellum. First gnathopods rery long and slender, reaching beyoud the end of the antenne ; first joint as long as the next three, wrist as wide amd almost as long as the hand, which is abont five times as long as wide; palm very small, oblinne, and defined by a spine; daetylus projecting beyond the palm by abont one-fourth of its length ; side-plates oblong, the anterior angle romder, the surface eovered

* Derived from Abd-el-Kuri, where the specimens were taken. 
with short setules. Second guathoports like the first. Pereoporls: first and second with the first joint narrow and about as long as the next three; third joint a little expanderl and prorlueed downwarels to a spine; fourth joint about one-fourth as long as the fifth; dactylus strong and conved: the third have the first joint semi-arenlar, with the himl margin deeply crenate, a forked setule between each of the loles, a strong spine on the anterion margin near the top, and another in a downwarl prolongation of that margin; the second joint is small with three spines on the front margin; the third has about eight spines on the front, and the hind margin is greatly produeed and dilaterl, erenate, and furnished with forked setules, as in the first joint; the fifth joint is about as long as the third and fourth, with two or three spines on the front margin: in the last pair the first joint is much wirler, and almost cirenlar, the hind margin rather finely ser'ate with simple setules in the notehes; the third joint is much less produced behind, and las four or five setie in front. The sideplates of all and the first joints of the last three pair of peraeporls are studrlerl with setules, especially towards the hind margin. Uropods: the first and second have the peduncles rather shorter than the rami, which are equal and similar; in the third the peduncle is short and thick, with a strong spine at the outer extremity. The single ramus is about as long as the peduncle, with a large and small spine at the tip. The telson is divided almost to the base, and the two sultriangular divisions turned up on elge, the lower margin being convex and the upper straight, with two or three seta near the distal end.

Length $2 \mathrm{~mm}$.

Abel-el-Kuri.

\section{COROPHIIDÆ.}

\section{Cerapus, Say.}

16. Cerapus flindersi, Stebbing. (Plate xiv B. figs. 6-6g.)

Cerapus flimdersi, Stebhing, 'Challenger' Report, Vol. xxix., p. 1163, pl. exxy. (18Ss).

One female. Length $4 \mathrm{~mm}$.

This agrees in all respects with the female descriled loy Mr. Stebling ('Challenger' Ampllipmla), from Flinders l'assage, Torres Straits. The male has been descrilued by In. C. Chilton in the liecords of the Austruliun Museum, vol. ii., 1892, from Port Jackson. 


\section{PLATE XIV A.}

Fig. I. SPH $A$ ROMA GRANTII, n.sp., p. 218.

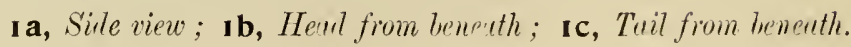

Fig. 2. EDOTIA, sp., p. 219.

$\mathbf{2 a}$ Operinlum.

Fig. 3. HYALE NILSSONI, linthike, var., p. 219.

3a, Lover untennu ; $\mathbf{3} \mathbf{b}, 1$ st gnuthoporl, of; $\mathbf{3} \mathbf{c}, 2 m$ d do., of; $\mathbf{3} \mathbf{d}, 2 \mathrm{ml}$ to., $+; \mathbf{3 e}$,

Fig. 4. LYSIANAX URODUS, n..p., p. 220.

$\mathbf{4 a}$, Ulyer antenne; $\mathbf{4} \mathbf{b}$, Lower $10 . ; \mathbf{4}$, 1st quathopol: $\mathbf{4} \mathbf{d}, 1$ st perterpod; 4e, 3rd do.; 4f, 5th to.; 49, Telson ame 3ret wropod, of.

Fig. 5. PARAMBASIA FORBESII, $n . g \% n$. et $s p$. p. 221.

$\mathbf{5 a}$, Upper antenne; $\mathbf{5} \mathbf{b}$, Lower do.; $\mathbf{5 c}, 1$ st gmuthoport; $\mathbf{5} \mathbf{d}, 2 m$ l do.; $\mathbf{5 e}$, 1st perceopul ; $\mathbf{5} \mathbf{f}, 3 \mathrm{rl}$ do. ; $\mathbf{5 g}, 5$ th do. ; $\mathbf{5} \mathbf{h}, 3 \mathrm{rd}$ segment of metusome; $\mathbf{5} \mathbf{i}, 1$ st uropod; $\mathbf{5} \mathbf{k}, 2$ mel do.; $\mathbf{5} \mathbf{l} .3 r d$ do. ; $\mathbf{5} \mathbf{m}$, Telson.

Fig. 6. AMPELISCA, sp., p. 222.

6a, Heul ; $\mathbf{6 b}, 5$ th pereopred.

Fig. 7. ATYLOPSIS LATIPALPUS, $1 . .8 \%$, p. 222.

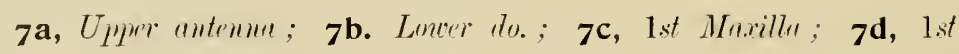
ynathopod; 7e, 2ud do.: $\mathbf{7} \mathbf{f}, 1$ st preceopod; $\mathbf{7 g}, 5$ th do.;

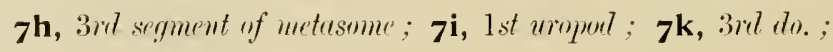
7l, Telson (mulformed). 
Liverp Nus: liep. Solertre Firped.

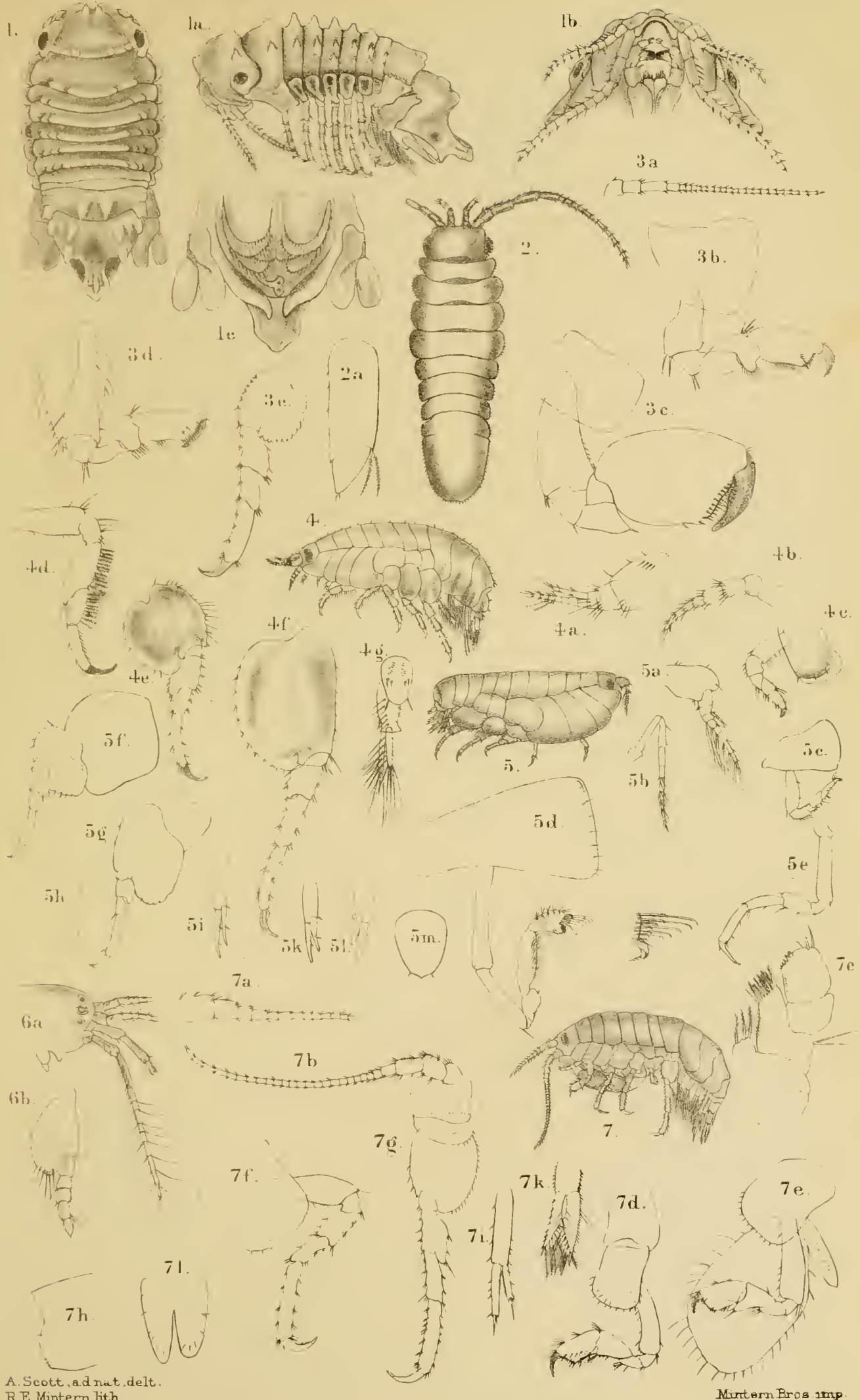






\section{PLATE XIV B.}

Fig. 1. ELASMOPUS SOKOTRAE, 11.s\%., p. 223 .

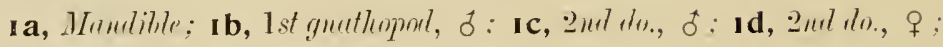

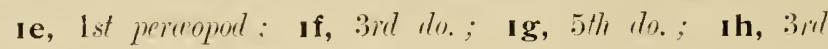
nrolored; i i, Telsun.

Fig. 2. AUDULLA CHELIFERA, Cletren, p. 225.

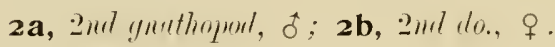

Fig. 3. GRUBIA LONGICORNIS, Kossmumn, p. 226.

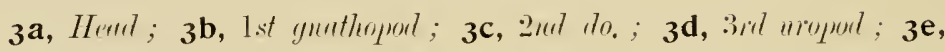
Telsont.

Fig. 4. PEREIONOTUS TESTUDO, Mont., vir, p. 227.

$\mathbf{4 a}$, Trosome from beneith: $\mathbf{4} \mathbf{b}, 3$ red peremporl.

Fig. 5. KURIA LONGIMANUS, n.gen. et sp., p. 228.

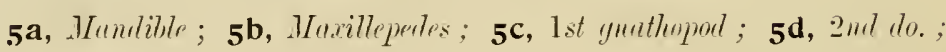

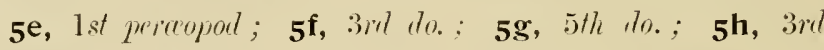

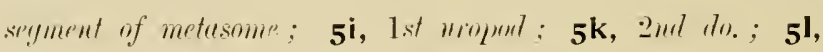

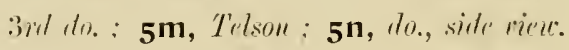

Fig. 6. CERAPUS FLINDERSI, stehtim!, $q$, p. 229.

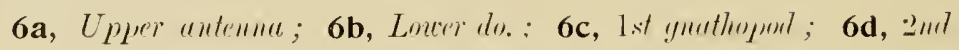

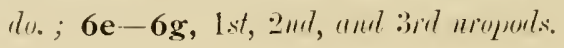




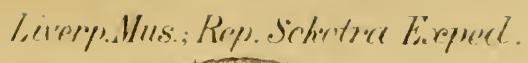

PT. ITI'B.
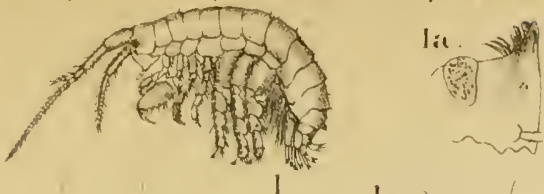

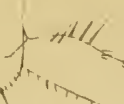

1,1
$\Rightarrow+\pi$

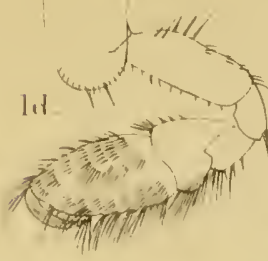

II:

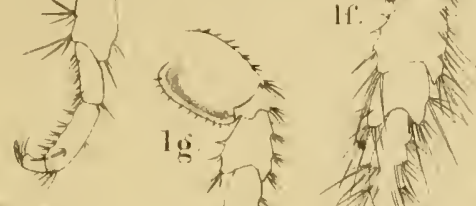

13

为散

in
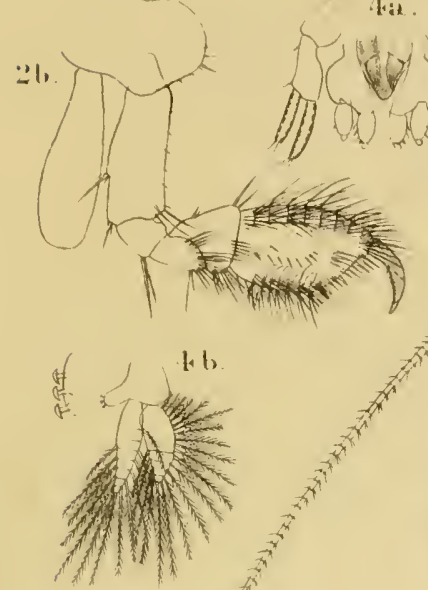

$$
\text { (n) }
$$
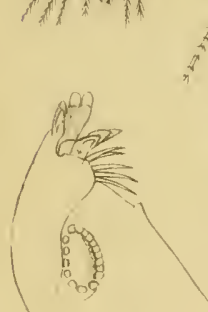

5a
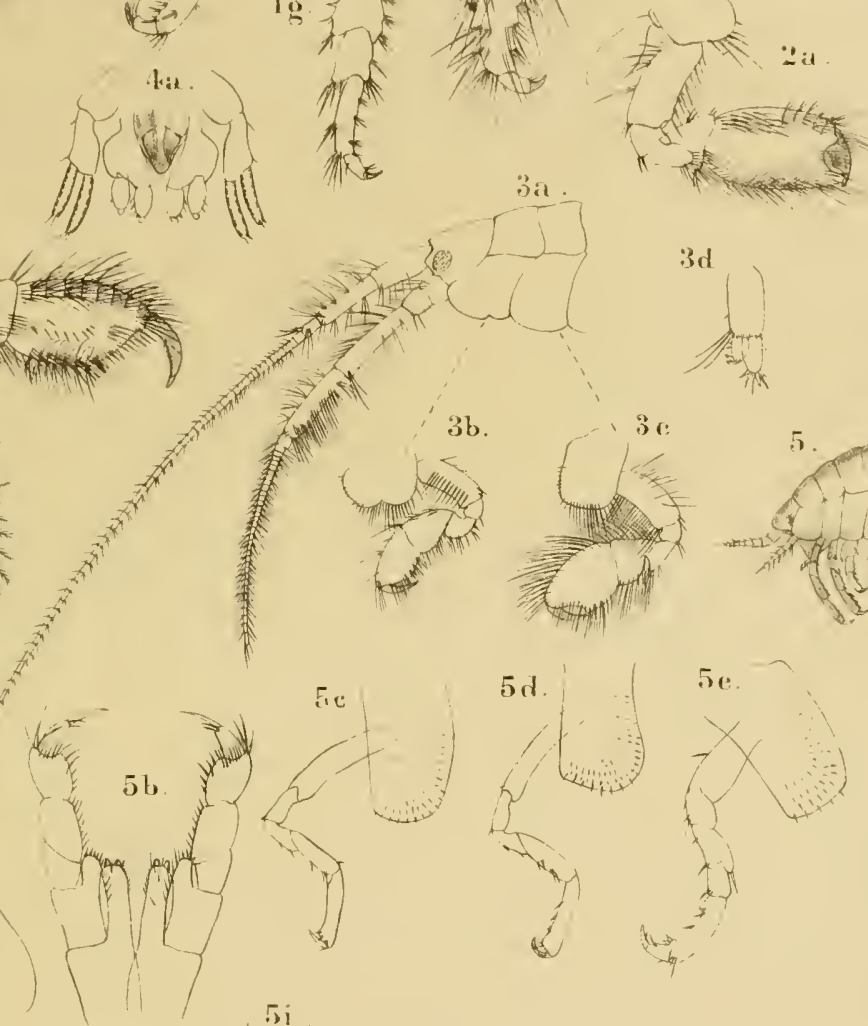



\section{ARTHROPODA.}

\section{Insecta: \\ Hymenoptera.}

By W. F. KIRBY, F.L.S. 



\section{Ichneumons, Wasps and Bees.}

As is usually the case with small insular faunce, the Hymenoptere of Sokotra appear to consist ehiefly of endemic species, the fow which have heen identified as previonsly known being almost all insects of very wide range. It is, however, quite possible that some of the species, here described as new, may ultimately prove to be identical with forms alrearly described from other localities. Without an approximately complete named collection from all the neighbouring comntries to Sokotra, this camnot always be avoided in the case of so large and difficult an order as the Hymenoptera. No special olservation respecting the faunia occurs to me, except that some of the species exhibit an unusually dark colour, as compared with allied species from other localities.

The Expedition collecter $4 t$ species of Hymenoptra in all, of which 27 have proved to be new. If we deduct 5 species, all new, from the adjacent island of Abd-el-Kuri, we have a total of 39 species from Sokotra itself, of which 24-two of which were previously described (P.Z.S. 1881, p. 649) by myself from the specimens collected by Professor Bayley Balfour, F.R.S.are believed to be peculiar to the island.

I have also noticed a species of Harpactopms, Smith (Sphergide), as occuring in Sokotra (P.Z.S. 189 , p. 386). It was eaptured by Mr. E. B. Bennett. As the probable number of species of Hymenoptera existing in Sokotra is hardly likely to be less than from 3000 to 4000 , at the lowest possible estimate, it is evident that we must wait for much larger collections before we can attempt to make any useful generalisations lespecting the fama. In the case of known species I have nsually referred to Professol Dalla Torre's Catalogne Irymenopteromm, instear of attempting to give the synouymy here in full. 


\title{
I.-The Ichneumons, Wasps and Bees of Sokotra.
}

CHALCIDID屃.

\author{
TEREBRANTIA.
}

\section{LEUCOSPIDIN $/$ E.}

\section{Leucospis, Fabricius.}

1. Leucospis insularis, Kirly. (Plate xr. fig. 1.)

Lencospix insuluris, Kirby, Bull. Liverp. Nluss, iii. p. 13 (1900).

Length of borly $122 \mathrm{~mm}$; ; length of anterior wings $9 \mathrm{~mm}$.

F'emule. Very thickly and coarsely punctured, clothed with a thin grey

pile. Head black, face more finety punctured than the rertex; antemne, including scape, and mindibles, except at the tips, red; joints 8 and 9 blackish above, and 6 and 7 more slightly. Pronotum red, with a transverse yellow line in front, interrupted in the middle; behind it atre two distinct transverse unicolorous earine, besides the terminal one. Mesonotnm black, with the siles red, and with two red central bands, broalest hehind, and not continued forward to the base. Scutellum black, the front angles markerl with red, and a yellow transverse sub-terminal line, edged hehind with red. Postseutellum yellow in the middle, and red at the sides. Merlian segment red. Tegulie and a spot below red. Mesoplenna black in front, and red behind. Legs red, middle tibix yellow abore, hind femora blackish in the midcle, and with a yellow spot at the base outside; about six moderate-sized llack teeth are risible on the outside. Abdomen red, the first and second segments with a sub-terminal thansverse yellow line, enged behind with black. Terminal segment not enlarged, oripositor hlack, red in the mirldle, recurved to a little more than the hinder third of the abdomen. Wings smoky hyaline.

Sokotra: Jenal-agahan (1200 ft., 12. I. 99); one specimen.

A species rery dissimilar to any other known to me.

\section{BRACONID压.}

\section{Iphiaulax, Forster.}

2. Iphiaulax kersteni, cierst.

Brucon liersteni, (ierst., Arch. f. Naturg. xxxvii. (1) [1. 356, n. 59 (1870) ; Von der Decken, Reisen in Ost-Afrika iii. (2) p. 361 , pl. xiv. f. 1.2 (1573).

Braron kersteni, Dalla Torre, Cat. Hymenopt. iv. p. $27+4$ (1898).

Sokotra: Monkanadia, ( = Gebel Raggit) (800 ft., 16. XI. 98); one specimen. 
Deseribed hy Gerstareker from Mombisal.

[In life the borly is much inflated, and of an orange red colour. II.li.().I..]

\section{ICHNEUMONID $Æ$.}

3. Joppa, $s p$.

\section{Joppa, Fabricius.}

Sokntra : Hallilu Plain, 15. XII. 96. ; one specimen.

[Came to light at night. - II.li.(l.(i.]

\section{CRYPTID床.}

\section{Cryptus, Fabricius.}

4. Cryptus pulcherrimus, Kirly. (Plate xvi. fig. i.)

(ryytus pulcherrimus, Kirby, Bull. Liverp. Muss, iii. p. 14 (1900).

o Length of borly $18 \mathrm{~mm}$. ; length of anterior wings $13 \mathrm{~mm}$.

q Length of horly $15-2.2 \mathrm{~mm}$. : length with ovipositor $23-32 \mathrm{2m}$.

Hearl and thorax mahogany brown, lower parts of face yellowish ; abdomen fulvous, segments after the 3rd mostly hlaekish : legs fulvous, hind tibice rellowish on the inner side in the male, ancl tipped with blackish in the female; wings yellowish subhyaline towards the base, and rich irideseent violet towards the margins, a trace of which eolour is sometimes visible on the hind coxre. Hearl and thorax thickly and regnlarly punctured: median segment rugose-punctate; scutellum, postscutellum, and abdomen nearly smooth, the latter clothed with very short hair. Clypens rery long, oblong, the sides depresserl, especially in the middle. Basal segment of the abromen very long, slightly expanderl beyond the michle, where the stigmata are placert: ?nd segment abont $\frac{1}{t}$ shorter than the first, the basal $\frac{1}{4}$ with parallel siles, the rest wirlening eonsiderably to the extrenity in the $q$, but very little in the of: the remaining joints shorter, closely connected, and with nearly parallel sides in the male, and forming a long oval in the female.

Sokotra: Groahal Gorge (16. I. 99): Jena-agahan (1200 ft., 15. I. 99); Artho I)imellus (3500 ft., \&. II. 99) : Dabamis (350 ft., ㄴ. 4. XII. 9\&) : six specinens.

Not closely allied to any species in the British Museum.

\section{OPHIONID床.}

\section{Enicospilus, Stephens.}

\section{Enicospilus, $s p$.}

Sokotra: Aclho Inimellus (3500 ft., 7. Il. 99). A single specimen, allied to E. merdurius, (tarar.

[Came to light.-II.li.().li.] 


\section{CHRYSIDID尼.}

\section{TUBULIFERA.}

\section{Stilbum, Spinola.}

6. Stilbum cyanurum, Forst.

Chryxis cyamera, Forst., Nov. Spec. Ins. p. 89 (1770).

stillum cyanurum, Dalla Torre, Cat. Hymenopt. vi. p. 37 (1892).

Sokotra: Hadibu Plain (13-15. XII. 98); Addah Valley (17-18. XII. 98);

Jeni-agahan (1200 ft., 14. I. 99); nine speeimens, all of the deep bhe variety.

[Came into tent in bright sunshine.-W.R.O.G.]

\section{ACULEATA.}

\section{SCOLIID压.}

\section{FOSSORES.}

\section{Campsomeris, St. Fargeau.}

7. Campsomeris socotrana, Kirly. (Plate xr. fig. 14.)

Campsomeris socotruna, Kirby, Bull. Liverp. Nuss., iii. p. 14 (1900).

Length of body $17 \mathrm{~mm}$. ; expanse of wings $29 \mathrm{~mm}$.

Femule. Black, face, thorax, and basal half of the segments of the abdomen rather thickly punetured; the rertex and middle of the pronotim, and of the scutellum and post-sentellum nearly smooth; faee sparingly elothed with fulvous hair, espeeially round the base of the antennie : prothorax, ridges of the pleura, and sides of metanotum clothed with fulvons hair; abdomen with hair on the base and sides of the first segment, and a band of hair at the extremity of the four following segments, of the same eolour. Legs red, clothed with very long tawny hair; femora black nearly to the extremity, with the eultrate edge beneath the four hind femora bright red. Fore-wings elouded byaline, yellowish towards the base, and iridescent riolet beyond the middle.

Sokotra: Adho Dimellus (3500 ft. 18. II. 99); two speeimens.

Allied to Colpu conescens, Lep., from Senegal, hut in that species the legs are black. I see no reason to follow Professor Dalla Torre in referring the latter species to Tiphiu colleris, Fabr.

[Rare; only met with twice, burrowing in sand; rather sluggish._ IF.R.O.G.]

\section{Tiphia, Fabricius.}

\section{Tiphia crassinervis, Kirby. (Plate xr. fig. 10.)}

Tiphia crassinerers, Kirby, Bull. Liverp. Muss, iii. p. 15 (1900).

Length of body $14 \mathrm{~mm}$. ; length of anterior wing $9 \mathrm{~mm}$.

Female. Black, shining, thickly and elosely punetured, abdomen with long, fine, ontstanding whitish pubsescence; antennie, and tibie and 
tarsi red or redllish, wings smoky hyaline, the nervmes black, very thick. Merlian segment with three longitudinal carina, expanding in front, the space between smooth; the apex is rertically trumeated. Basal segment of the abdomen romided in front, scalcely constricted behinul.

Sokotra: Arlho Dimellus (3500 ft., 4-8. II. 99); three specimens ; Homhil, E. Sokotra (1500 ft., 25. 1. 99); one specimen.

Very distinct from any other species before me, by the incrassation of the nervires.

[Similar in habits to Campsomeris socotrana.-W.R.O.G.]

\section{POMPILID压.}

\section{Salius, Fabricius.}

9. Salius extraneus, Kirly. (Plate xr. fig. 8.)

My!nimia extraner, Kirby (nec Calicagu. extraneu., Lep.) Proc. Zool. Soc. Lond. 18s1, p. 649.

Sulius extravayans, Dalla Torre, Cat. Hymenopt. viii. 1. 22:3 (1897).

The following is my deseription of the Types:-

"Expanse of wings 1 in. 1 line to 2 in. 6 lines; length of borly 1 in. to 1 in. 5 lines.

Allied to $I$. vindex, Smith, from S. Africa, and $M$. molligiosu, Gerst., from E. Africa.

Mule. Head, antenne, prothorax, and legs reddish ; a very narrow bright red line round the eyes, and the mouth also shading into bright red; meso-thorax black above, with three earina in front, and a broarl raised ridge behind; sentellum deeply ineised; meta-thorax oval, truneated behind, and elothed with long hair; pectus and abdomen clotherl with a coppery green pile; the middle of the pectus with a few long grey hairs. Wings deep purple or riolet, with blue and green reflections.

Femule. Similar, but with the red colouring less marked, especially on the hearl and pronotım."

Sokotra: Monkaradia (=Gebel Raggit) ( $800 \mathrm{ft}, 16$. XII. 98); Homhil $(2,500 \mathrm{ft} ., 19-26$. I. 00).

Five specimens were eaptmed by Mr. Grant; but the figure is taken from one of the types collected by Professor Bayley Balfour. If the genus Culicugus (which Colonel Bingham treats as a section of Pompilus) is retained, there will be no reason to employ Professor Dalla Torre's name for this species.

[Only on the hills; commonest on limestone range above Homhil ; makes a great noise flying, and sweeps romul in wirle eireles with legs stretcherl out behind._- $\|^{r}$. li.O.(i.] 


\section{SPHEGID尼}

\section{Sceliphron, Linn.}

10. Sceliphron ægyptium (Limu.).

Sphrx agyptius, Limn., Syst. Nat. (Eel. x.) i. p. 569 n. 4 (17.5s)

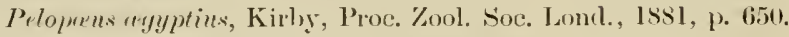

sceliphron spivifex (Limn,) var. "ry!gtherm, Dilla Torre, Cat. Hymenopt. viii. 1). 391 (1897).

Sokotıa : Hadibu Plain (11. XII. 98.) : Adkah Valley, east of Harlibu Plain

(17. XII. 9ی); and Jeniagahan (1200 ft., 17. I. 99); four specimens.

Previously olutained in Sokotra by Professor Bayley Balfoul.

[Common; makes a nest of elay inside hollow trees. One hollow bostrollin tree near Homhil contained a large colony of nests. IV.Ii.O.G.]

\section{Sceliphron violaceum (Filli:).}

Sphex riolnced, Fabr. Syst. Ent. p. 346 n. 4 (1775).

Sreliphron violacemm, Bingh. Fatun. Brit. Incl. Hym. i. p. 240, pl. 1. f. 8 $(1897)$.

Pelopern hengalensis, Dahlb. Hym. Eur., Sphex, p. 433 n. 2 (1845).

Acelizhron bengulense ot rioluceum, Dalla Torre, Cat. Hymenopt. viii. pp. $379,392(1897)$.

Sokotra: Harlibu Plain (12. XII. 98.); and one from Goahal Gorge, E. Sokotra $(1200 \mathrm{ft}$., 누. I. 99.); fifteen specinens, differing a little in size.

The types of S. violucen are said to have come from the Cape of Good Hope. The localities given by Colonel Bingham are Southern and Eastern Europe, North Africa, India, Burma, Tenasserim, Ceylon, Chini, Japan, and the Malaym and Australian sub-regions.

[Met with only on low ground: frequently seen towards evening on the bushes in chusters of hundreds. It does not attempt to sting when disturbed or caught by the hand. II.R.O.li.]

\section{Sphex, Linn.}

12. Sphex erebus, Killy. (Plate xv. fig. -2.)

Splecx evelus, Kirby, Bull. Liverp. Muss., iii. p. 15 (1900).

Length of body $20.25 \mathrm{~mm}$, ; length of anterior wings $14-17 \mathrm{~mm}$.

Deep black: face, from above the antemne to the extremity of the clypens, clothed with white hair slightly tinged with yellow ; clypeus long, with parallel sides, or, if anything, slightly narrower at the lower extremity: hair on the head alove and behind and on the thorax, petiole and coxie hlack : thorax finely and uniformly punctured, sentellum notched in the midille, post-scutellum with two smooth and shining prominences ahove, with a groove between, median segment transversely striated; legs black, the midclle and hind femora ant? tibiat more or less red, wings hyaline, black at the base, and dusky at the tips. 
Sokotra : Harlibu Plain (11-13. XI1. 9§) ; five specimens.

Allied to s. argentutus, Fabr., but clifters in the redder leg's, and the black, instead of whitish, hair on the median segment. It would doubtless he considered a mere variety hy sone Hymenopterists.

According to li. Taschenberg's deseription of s'. metullim from Khartoum, the latter has grey hair on the pro-and meso-thorax. O. Taschenberg, howerel; identifies it with a Sokotran insect, which is floubtless the same as this, and states that it also ocems in Senegal and Zanzibar.

[This insect forms colunies of nests in sindy ground, each nest being occupied by a single inclividual. liiding or walking through such a colony is at first somewhat disturbing, as the whole of the wasps carcer wildly romol the heat of the passer-ly. They are, however, apparently harmless.-II.M.O.G.]

\section{Harpactopus.}

13. Harpactopus, $s$.

Hurpuctopus, sp., Kirby, I.Z.S., 1s9s, p. 38ti.

One specimen collected by Mr. Bennett in too worn a condition for determination was mentioned by me (lor. cit.) as "allied to $H$. crulelis, smith, hut larger and with reddish mantibles ant tibie."

\section{Pseudapis, Kirby.}

Psemlapis, Kirby, Bull. Liverp. Muss., iii., p. 15 (1900).

Head as broad as the thorax. Antennæ with the 2nd joint transverse, Brd shorter than the following ones, which are about twice as long as broad till towards the extremity. Eyes converging beneath, ocelli on the vertex, the two hinder ocelli abont opposite the hinder part of the eyes, and about as wide apart as each is distant from the eye ; central ocellus placed just in front of the others. Pronotum linear ; median segment short, romtled, slightly depressed in the midclle in front. Tegule enormons, extending before and behind the bases of the wings. Legs modelately long and slender and clothed with a fine pile: fou front tibie spined at the extremity ; hind tilia encling, in the male, in a huge broad cultrate appendage : in the female, unarmerl. Tarsi long and slender; all the joints spined beneath, except, perhaps, the front tarsi in the female; first joint of tarsi as long as the succeeding ones together, terminal joint of the middle tarsi ending in a hairy parl, somewhat resembling that in some bees, such as Podlelivins acemom. Wings with one radial and three cubital cells, the radial cell broad, obtuse at the extremity, and not appendiculate ; first radial cell oblong or sub-oval, as long as the third cell in the male, but shorter than in the female; second cell nearly square, smaller in the male than in the female, third much narower above than below ; first recurrent nervure received close to the extremity of the second radial cell ; second at abont $\frac{1}{4}$ of the extremity of the third cell. 
This is a very strange inseet, which has the appearance of a Bee, although the long slender eylintrical tarsi seem to exchde it from the family. I am inelined at present to refer it to the spheginle, in whieh group it may perhaps form the type of a new sub-family.

14. Pseudapis anomala, Kirly. (Plate xr. fig. 7.)

Psemlapis anomalu, Kirby, Bull. Liverp. Muss., iii. p. 16 (1900).

Black, face below the antennæ, hinder orlbits, pectus, hind borders of scutellum, post-sentellum, and abdominal segments, base of abdomen, and legs in front, eovered with white pubescence or pile. Antenna, tegulie and legs rufo-testaceous, femora, more or less of tibire above, and terminal tuft on middle tarsi, black; antemne thiekly and finely punctured; the body thiekly punetured almost everywhere, the front of the abolominal segments less closely than the thorax, beeause the punetures are much larger; hinder part of the abdominal segments more finely punctured, or smooth.

Sokotra: Monkararlia (=(rebel Raggit) (600 ft., 15. I. 99); two speeimens of; †; Homhil (1500 ft., -26. I. 99).

\section{LARRID止.}

Astata, Latreille.

15. Astata boops, Simmli:

Sylhex loops, Schrank, Enum. Ins. Anstr. 1. 384 n. 777 (1781).

Astuta boops, Dalla Torre, Cat. Hymenopt. viii. p. 652 (1897).

Sokotra: Adho Dimellus (3000 ft., 18. II. 99); one specimen.

A widely rlistributed species in Europe and the Mediterranean region.

\section{Tachytes, Panzer.}

16. Tachytes trivittatus, Kirly. (Plate xr. fig. 3.)

Tachytes trivittatus, Kirby, Bull. Liverp. Mnss., iii. p. 16 (1900).

f Length of body $10 \mathrm{~mm}$. ; expanse of anterior wings $8 \mathrm{~mm}$.

o Length of horly $15 \mathrm{~mm}$.; expanse of anterior wings $11 \mathrm{~mm}$.

Black, sirles of fore and hinder orbits elother with silvery pile, legs black,

- femora and tibixe clothed with rery fine whitish pile, tarsi reddish, thorax elosely and finely punctured, median segment somewhat more eoarsely punctured, bordered with whitish pubescence, first three segments of aldomen with terminal band of pale blue pile. Wings purplish hyaline, darkest on the margins.

Sokotra : Homhil (1500 ft., 21. I. 99) ; and Addah Valley, East of Hadibn Plain (29. I. 99); three specimens.

In the allied species the pale bluish white bands on the abdomen are more numerous. 


\section{Notogonia, Costa.}

17. Notogonia bicolor, Kirly. (Plate xr. fig. 9.)

Notoyonin bicolor, Kirby, Bull. Liverp. Muss., iii. p. 16; (1910).

Lenerth of body $8 \mathrm{~mm}$. ; length of anterior wings $6 \mathrm{~mm}$.

Femule. Black, tegulae reddish, legs, except the black coxie and trochanters, rerl; tarsi a little brownish ahove. Median segment abont as long as the preceding part of the thorax; dull, thickly punctured, the rest of the body shining. Wings elear hyaline.

Sokotra: Adho I)imellus (:3000 ft., 18. II. 99): one specimen.

A rery distinet species.

\section{Stizus, Latreille.}

18. Stizus scutellaris, Kinlly. (Plate xr. fig. t.)

Stizus scutellaris, Kirby, Bull. Liverp. Muss, iii. p. 16 (1900).

Length of borly $19 \mathrm{~mm}$. : length of anterior wings $14 \mathrm{~mm}$.

Femule. Black, varied with yellow, and slightly with rerl. Head blaek above the antennie; back of head, and tips of mandibles also black. Vertex with the inner orbits red, and with two slightly diverging yellow marks between; hinder orbits yellow, very widely so beneath, but ending in a detached dot above, at the level of the eyes. Antennie red, scape beneath, and face yellow, the latter clotherl with a fine white pile: labrum somewhat tumid, reddish in the middle, the lower edge concave below. Thorax mostly black, pronotum red in front, and bordered with yellow behind. Mesonotum bordered with red on the sides: tegule red; mesopectus black, clothed with whitish hair, and with two yellow spots, one behind the other, and the first largest, under the base of the fore-wings. Scutellum and post-scutellum, yellow; behind is a curve, broadest in the middle, on the median segment; beneath this, on each side, is a moderately short and broad red line. Abrlomen with the first segment red above, borlered in front, and more narrowly behind, with black; a large yellow spot on each side. Segments $2-4$ with broad yellow lateral bands, bordered before and behind, and broadly interrupted in the middle, with black; and bordered on the sirles below with red; the median black space on the second segment is also marked with red on the sides and more broadly behind. Terminal segments mostly red above; fifth segment with a large oval yellow spot on each side. Tentral surface red, the segments narrowly edged behind with yellow, segments 3-5 black at the base, and segments 2 and 3 with a large yellow spot on each side. Legs reddish; tibie and tarsi yellow above. Wings of a slightly yellowish hyaline, the large nervures towards the base and costa reddish, the others black.

Sokotra: Dahamis (19. XII. 98); one specimen.

Perhaps a variety or local form of the wide-ranging and valiable $S$. refficonis, Falur. 
[This individual helonged to a nest in the gromnd. A social species, with the habits of a lespo. The species appears to be rery rare on the island, as the only individnals seen were in the inmediate neighbourhead of this particular nest.--Mr.R.O.(i.]

19. Stizus adelphus, Kirlı. (Plate xr. fig. 6.)

Stizus adelyhus, Kirby, Bull. Liver'p. Muss., iii. 1) 17 (1900).

Length of body $16 \mathrm{~mm}$. : length of anteriol wings 14 (?) $\mathrm{mm}$.

Mule. Hearl black abore and behind, the rest yellow. Space between the antentie and eyes rellow, ending in a small square semi-detached spot on each side of the frontal ocellus. Imner orbits narrowly yellow, ceasing at the level of the eyes, but comnected with each other by a row of 4 small red spots; a yellow spot near the hase of the back of the hear. Face yellow, clothed with a very fine whitish pile, tips of mandibles, and the parts behind black. Pronotum black at the base, red ahore, and bordered behind by a slender yellow line. Antenne red, four joints before the last two blackish above. Thorax black, with the sides in front of the wings yellow, as well as an adjoining spot on the plenra; tegula rerldish; seutellum broadly reddish behind, post-sentellum horlered lehind with yellow; median segment with a short eurver yellow streak marked with redlish behind towarls the base on each sile. Abrlomen yellow, first segment red, bordered behiml with black, which extends slightly to the base of the second segment ; second segment broadly bordered with black behind : third segment hordered hehind with red, preceded in the mirldle by black. Legs red, coxie and trochanter's black. Wings yellowish hyaline, with reddish nervures, the radial cell elomled.

Sokotra: Hadibu Plain (14. XII. 99); one specimen.

Resembles S. aprcalis, Simith, exeept that the yellow bands are not interrupted in the mirlde, as is the case in most of the black and yellow speeies of Sti:us. It seems to diffẹt too much fiom S's scutelluris to be the male of that speeies.

[Captured on Wild Thyme ; no other seen.--Mr.I.O.C.]

\section{Stizoides, Guérin.}

20. Stizoides fenestratus, smith.

Larra fenestratus, Smith, Cat. Hym. Ins. iv. p. 342 n. 23 (1siti). Stizus fenestratus, Handlirsch, Sitz. Akad. Wiss. Wien. ci. (1) 1). 108 n. 64 (1892).

Sokotra: West of Dahamis (1000 ft., 2.2. XII. 98); one specimen.

The types (males) are from the Congo. 1)r. Haudlirsch records specimens from Gambia, Zanzibar, and Natal. The wings and abdomen in the single female specimen from Sokotra are somewhat shorter and broader than in the male types. I can detect no other differences, and regard these as probably only sexual.

[No other seen._M.R.O.lt.] 


\section{RHOPALID压.}

\section{Rhopalum, Kirby.}

21. Rhopalum quadricolor, Kirly. (Plate xr. fig. 12.)

Rhoprulum quadricolor, Kirby, Bull. Liverp. Muss, iii. P. 17 (1900).

Length of loxly 1:2 mm.; length of anterior wings s mm.

Femule. Dnll black; liead, clypens and labrum clothed with bright silvery pile; back of head more sparingly. Scalpe of antenne yellow; mandihles red. 'Thorax with the collar, a spot below, and two nearly united spots on the scutellum, yellow; tegnle red; legs red, middile femora with a short hack stripe below, followed by a yellow one; hind femora with a black stripe below ; hind tibie with a yellow stripe behind. Four front tibia with a small yellow dash at the base. Abolomen baek, the first segment forming a short, hroad petiole at the base, and expanded at the extremity, the rest forming a regular oval; 1st and 2nd segments with short transverse blood-reel lateral stripes near the extremity of the first, and the middle of the second connected below; 3rd with longer ones near the base; th uniform black, the rest reddish, except the upper part of the 5th. Wings brownish hyaline, narrowly infuscated along the costa of the forewings.

Sokotra: I)ahamis (XII. 98); one specimen.

The blood-red markings on the abdomen of this species are peculiar.

Towads the base of the merlian segment is a eluster of 7 mites, which were probably red when alive.

\section{Cerceris, Latreille.}

22. Cerceris lobaba, Kirly. (Plate xi. fig. 13.)

C'erepris lobalue, Kirby, Bull. Liverp. Muss., iii., p. 18 (1900).

Length of body $10 \mathrm{~mm}$. ; length of anterior wings $7 \mathrm{~mm}$.

Femule. Head, thorax and abdomen eovered with large depressed punctures: heal hlack, antenne red, blackish above, mandilles red, yellow at the hase, and hack at the tips; face clothed with silvery pile: thorax black, a enred yellow line on the post-scutellum, tegnle and legs red, a black dash on the imer side of the hind femora at the tip : abdomen red, first segment subquadrate, and only half the width of the second ; incisions, lase of 1st segment, and base of 5th blackish ; 2nd segment with a yellow spot on each side before the extremity : 3rd and 5th with yellow bands, that of the former terminal, expanded on the sides, bnt interrupted in the middle above: that of the latter shorter, sub-terminal narrower, but eontimuous; pygidium black, lateral carine yellow. Wings clonded hyaline, fore-wings infusented at the tips.

Sokotıa : Homhil (1500 ft., 18. I. 99.); one specimen.

Allied to the Indian C. mestoyuster, Smith. 
VESPID曆.

\section{DIPLOPTERA.}

EUMENINAE.

\section{Eumenes, Latreille.}

23. Eumenes dimidiatipennis, Suls:

Eumenes dimiliatipemix, Sauss., Eturles Fam. Vesp. i. p. jl n. 33 (1s.2) ;

Mallit Torre, Cat. Hymenopt. ix. p. 22.2 (1894).

Sokotra: Hadibu Plain (11-13. XII. 98.); five speeimens obtainerl.

A widely-rlistributed species in Asia and Africa.

[Makes small nests attacherl to bushes, containing abont 20 to 30 individuals._- II.Ii.O.G.]

24. Eumenes granti, hïlı!. (Plate xr. fig. 5.)

Eumenes granti, Kirby, Bull. Liverp. Muss., iii. p. 18 (1900).

Length of body $20 \mathrm{~mm}$.

Femule. Head black behind, and dark brown above, as far as the antenne, which are red, brownish ahove towads the extremity. Hinder orbits narrowly yellow; space between the antenne, sinus in the inner orbits of the eyes, and face below, as far as the extremity of the clypeus, yellow; lower mouth parts reddish. Clypeus longer than broad, slightly concave at the base, and marked with a black dot below each antenna; below the eyes, the sides converge obliquely towards the extremity, which is more deeply concave than the base. Pronotum yellow, narrowly and irregnlarly erged below with reddish; a red dot in front of the base of the wings. Mesonotum dull black; tegnla black, bordered below with red; a short yellow stripe at the base of the wings, edged outside by a short black stripe on the base of the wings themselves, but not extending to the costa. Scutellum yellow, bordered with black, post-seutellum and metanotum yellow, the latter broadly black in the middle, and the suture with the post-scutellum narrowly black. Pleura yellow, the sutures very broadly black, slightly bordered with reddish. Legs, including coxa and trochanters, reddish, tibia mostly yellow on the ontside. Petiole regnlarly curved, much broader on its hinder half, with a slight central groove, red, narrowly black at the base, and with a broad black median band, bificl in front, and rather pointed at the extremity, on its hinder half ; on each side of this is a large yellow spot, before the extremity of the petiole. Below, there is a black median stripe, followed by a yellow spot before the extremity. Abdomen yellow above, with a longitudinal blackish stripe shading into reddish brown towards the extremity. At the base of the first dorsal segment it is bordered with reddish on both sides, and the middle of the first, the basal half of the second, and the greater part of the fifth dorsal segments are crossed by broud transverse black bands. At the end of the fourth segment the median stripe is interrupted, but it is continued 
beyond the diuk bise of the fifth segment. Ventral segments yellow, the first reddish nearly to the extremity, and the sutures hetween the second and fourth narrowly black. Fore-wings smoky hyaline, with an iridescence beconing purplish in the rulial cell; hind-wings cleill hyiline.

Resembles E. sichelii, Sauss, from Albania, but the latter is a more slencler inseet, with no blitek markings (except narow sutural lines) heyond the black transverse band on the middle of the first dorsal segment of the alidomen.

Sokotra : Aclho Dimellus (3000 ft., 9. II. 99).

A single specimen only ohtaned. Mr. (Arant believes that this species, or one very closely resembling it, occurs in Arabia, but l camnot find that it has been described from that comtry.

[Apparently very scalce in Sokotia, and diftient to cateh; always frequenting steep clift sides. Only three or four seen._M.li.o.r.]

\section{Rhynchium, Spinola.}

25. Rhynchium versicolor, Kirly. (Plate xr. fig. 11.)

Rhynchinm rersicolor, Kirby, Bull. Liverp. Muss., iii. p. 19 (1900).

Length of body $14 \mathrm{~mm}$. ; length of anterior wings $12 \mathrm{~mm}$.

Femule. Head and thorax with large depressed punetures, abdomen with small seattered punctures, elypeus convex, ahnost pear-shiped, pointed below, where it is deeply channelled in the middle, post-seutellum rounded behind, sides of median segment apparently rounded, abdomen with the basal segment hardly narrower, but scarcely more than half as long as the seeond. Head black above, as far as the base of the antenna; above them stands a small transverse yellow mark. Heal otherwise red, including the hinder orbits, ocular sinns, and antenne. Mesonotum and greater part of the scutellum and mesoplema blaek. Pronotmm red, with a yellow spot on each side in front. Mesoplema and mesopeetus black, with a grey pile in the middle; a lar, ye yellow spot, bordered below with red, below the tegular, and below this is another red mark. Tegule red, with a cmred yellow spot above. Scutellum blaek at base, and reddish behind, with a transverse yellow stripe before the extremity. Post-seutellum yellow, reddish in front, and the suture behind blaekish; sides of median segment yellow above, and red below. Abdomen red, the first and second segments banded behind with yellow; first segment with a broad black central mark, constricted near the base, and not extending to the yellow band; second segment with a broader continuous eentral black hand, widest at each extremity; third and fourth segments transversely blackish at the base. Ventral segments with the terminal depression of the first segment blaek, second segment with a black mark on the sides, in front of the end of the yellow band; third and 
fourth segments blackish at the base and on the sides. Legs entirely red. Wings clourled hyiline, irideseent.

Allied to K. radiule, Siusss., from S. Africa.

Sokotra: Homhil, East Sokotra (15)0 ft., 21. 1. 99); one specimen.

\section{VESPINAE.}

\section{Belenogaster, Saussure.}

\section{Belenogaster saussurei, Kirlyy. (Plate xvi. fig. -..)}

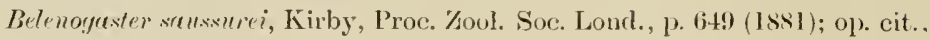
1898, p. 356.

Belenogueter suesurei, Dalla Torre, Cat. Hymenopt. ix. p. 116 (1894).

Belenogaster tricolor, Taschenberg, Keitschr. f. Natur. Wiss. lvi. p. 17t (185:3).

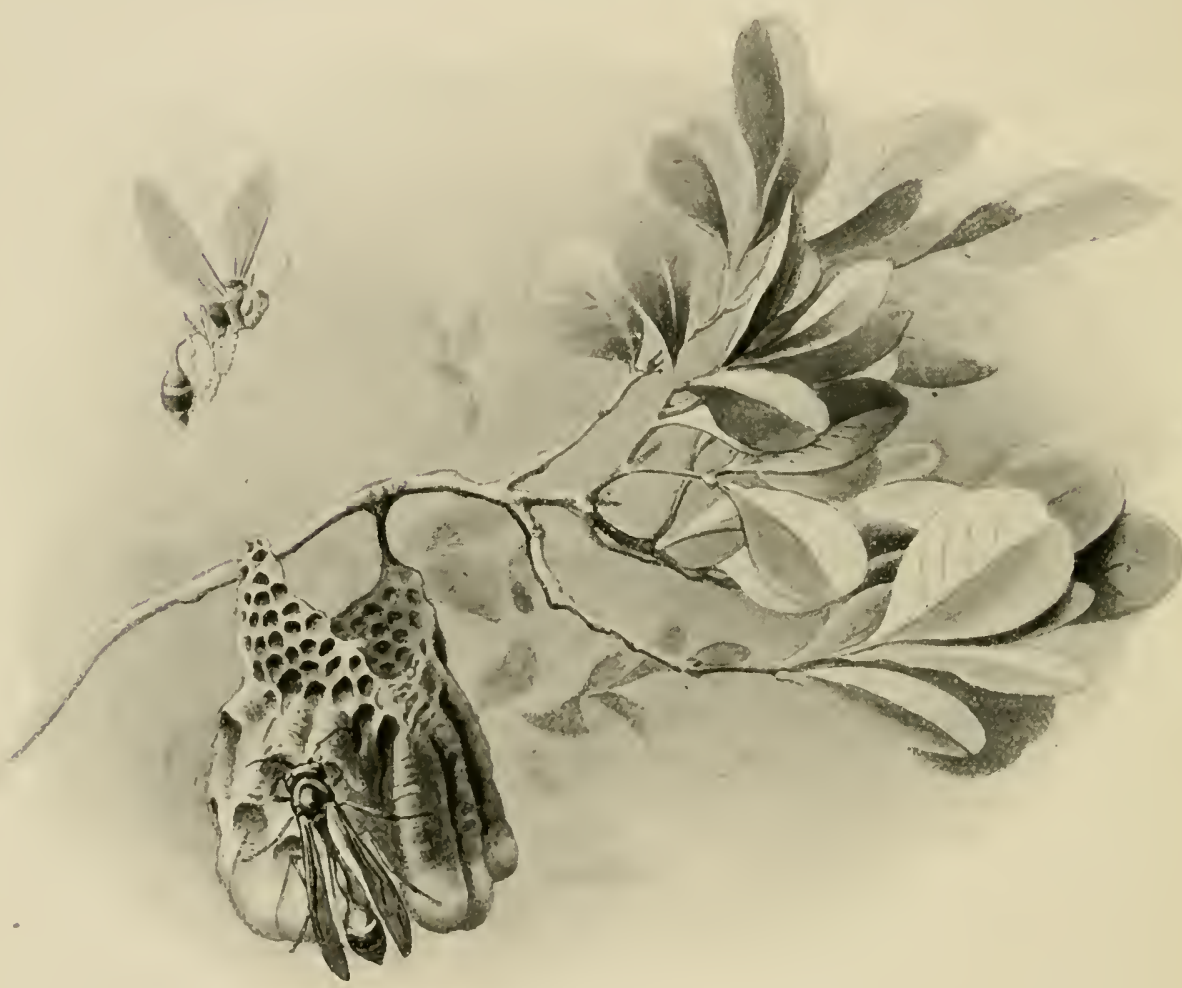

Nest of BhLENofiater saUsuret.

The following is the description I gave (lor. rit.) of the Trpe:"Expanse of wings $1 \frac{1}{3}$ in.; length of holy 11 lines.

Head, antenux, prothorax, scutellum, post-scutellum, legs and abdomen of a lively chestunt colour, meso- and metathorax, sides of pectus, and segments 2 and 3 of the abdomen, black. The prothorax is indistinctly and narrowly hordered with yellowish; and the mouth-parts are more or less yellow in the male. The first segment of the 
abdomen is distinctly bordered behind with yellow, most broadly on the upper part of the sicles. The thorax, scutellum, dee, are finely punctured, and there are three rery shallow longitulinal grooves on the mesothoras, and a more distinct groove in the midclle of the metathorax. Ilings smoky brown, with iridescent reflections; nervures bown or redelish brown: yellowish towards the hase, and along the costa and inner margin of the fore-wings."

Not closely allied to any known speeies.

Sokotra: Hadibu Plain (12-13. XII.); Dahamis (19. X1I. 98); Homhil (1500 ft., 21 d 26 . I. 99); Addah Valley, l. of Hadilun Plain, (ㅇ․ I. 99) ; eight specinems.

The figure of this wasp is taken from one of the original Types, eollecter by l'rofessor Bayley Balfour. Specimens were also collected in Sokotra by I). E. Riebeck, and Mr. E. B. Bennett.

[The habits are similar to those of Enmenes dimidiatipennis. I was fortumate in olotaining three nests of this speeies, one of which is figured above. II.li.U.(t.]

\section{Icaria, Saussure.}

27. Icaria grossepunctata, Kìly. (Plate xivi. fig. 5.)

Icaria grossepunctuta, Kirby, Bull. Liverp. Mnss, iij. p. 20 (19011).

Length of body $9 \mathrm{~mm}$. ; length of anterior wings $5 \mathrm{~mm}$

Female. Upperside evenly covered with large depressed punctures. Head black, antemne red, blackish above beyond the middle, seape yellowish beneath in one specimen. Clypeus red, elothed with silvery pile, narrow at the upper angles, broader than long at the lateral angles, and obliruely sloping below to two well-marked teeth. Prothorax wholly red, except a yellow collar in front, mesonotmin, mesopleura, front of metapleura, and middle of upper part of median segment black. Tegulie reel, with a yellow spot in front. Hinder part of scutellum yellow on the sides, and red in the mirldle; postsentellum red. Hinder part of thorax, except as alreacly specified, legs, and abdomen red. Median segment short, slightly sloping and rounded behind; petiole twice as long as broad, blackish at the hase and about one-third as broad as the following segment at the extremity. Petiole and following segment with a terminal yellow ring. Wings hyaline, with brown nervures.

Sokotra: Goahal Gorge (16 \& 26. I. 99) ; two specimens.

Not closely allied to any other species before me.

\section{ANDRENID必.}

\section{ANTHOPHILA.}

\section{Halictus, Latreille.}

28. Halictus flavovittatus, Kirlı. (Plate xri. fig. 6.)

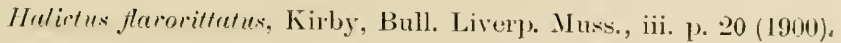

Length of body $7 \mathrm{~mm}$. ; length of anterior wings $6 \mathrm{~mm}$. 
Femule. Black, vertex and thorax above thickly and finely punctured, the depressed space at the base of the median segment rather less finely. Face rather long, sparingly elother with greyish hair, as also the pectus and plenra; hind femora beneath with woolly whitish yellow down; the short hairs of the tarsi inclining to reddish above, and bright fulvous beneath; hind tibia with tawny hairs on the inside. Abdomen black, shining, with four yellow transverse bands, one at the end of each segment. Terminal segment rufous. Wings irilescent hyaline, elothed with very fine short hairs; stigma testaceous or brown. In the male, the yellow bands of the abdomen are obsolete, and the legs are nearly black, the tarsi only being yellowish beneath.

Sokotra : Arlho Dimellus (3500 ft., 3. II. 99); three specimens.

The two females are not precisely alike, but can hardly be regarded as representing distinet speeies.

[Taken flying round St. John's Wort._Ir.li.O.G.].

\section{Halictus, $s p$.}

Homhil, E. Sokotra (1500 ft., 25. I. 99); one specimen.

A single damaged speeimen of a speeies with transverse white bands on the abdomen. The punctuation is coarser than in the last species. I do not think it worth while to describe the insect at present.

\section{APID正。}

\section{Megachile, Latreille.}

30. Megachile argentata, Fulli:

A pis argentutu, Fabr., Ent. Syst. ii. p. 336 n. 96 (1793).

Megachile aryentuta, Dalla Torre, Cat. Hymenopt. x. p. 420 (1896).

Sokotra: Jena-agahan, (1200 ft., 11. I.) ; Homhil (2500 ft., ․․․ I. 99) : two specimens.

A widely distributed species in Europe, Western Asia, and North Africa.

\section{Megachile punctatissima, Kirlı. (Plate xvi. fig. 1.)}

Hegachite punctutissima, Kirby, Bull. Liverp. Muss., iii. p. 20 (1900).

Length of body $16 \mathrm{~mm}$. ; length of anterior wings $12 \mathrm{~mm}$.

Femule. Black; head and body very thickly and finely punetured, and even the mandibles covered with large depressed punctures. Head, thorax, and first segment of abdomen clothed with white or greyishwhite hair ; clypeus and mesonotum denuded. First four segments of the abdomen with long transver'se white spots, shortening hindwards, on each side; fifth segment with a mere trace of these. Mandibles, tongue, tegulae and legs more or less rufous; fenora blackish, except at tip; pile on undersurface of abdomen yellowish brown. Wings smoky hyaline, costal half of radial cell elouded.

Sokotı"a : Homhil, E. Sokotra (2500 ft., 22. I. 99); one speeimen.

Not closely allied to any species in the British Museum. 
32. Megachile paucipunctulata, Kirly. (Plate xvi. fig. 3.)

Megachile paucipunctulata, Kirby, Bull. Liverp. Mruss, iii. p. ㄹl (1900).

Length of borly $12 \mathrm{~mm}$; length of anterior wings $9 \mathrm{~mm}$.

Femule. Head and thorax thickly punctured, but more coarsely than in 1I. punctutisime; hairy clothing similar; clypeus slightly convex beneath: lahrum set with tawny bristles. Tongue, scape of antenne beneath, tegula and legs rufous. Ablomen with the first segment concave in front, narrow, black in front, and red behind, sparingly punctured on the sides; the succeeding segments divided into three sections, most distinctly in the second and third segments ; first basal, black, very thickly punetured; second black, smooth, and sparingly punctured; and third red, smooth, sparingly punctured at base. In the following segments this is less obvions, the wilth of the thick basal punctuation being much reduced; and the terminal segment is almost wholly black, the punctuation being hidden by short bristles. There are five distinct white bands on each sicle of the first five segments: that of the first segment covers the whole width at its base. Undersurface of abdomen dark brown. Wings brownish hyaline, clearer at the base.

Sokotra: Homhil (2500 ft., 22. I. 99); one specimen.

Smaller than the last species, which it much resembles: but the punctuation of the abdomen is so different that there can he no question of any specific relationship, thongh the single specimens of cach were taken at the same time and place.

\section{Crocisa, Jurine.}

33. Crocisa forbesii, Kirby. (Plate xri. fig. 9.)

Crocisc forlesii, Kirby, Bull. Liverp. Muss, iii. p. 21 (1900).

Length of body $10-11 \mathrm{~mm}$.; length of anterior wings $9 \mathrm{~mm}$.

Female. Black, with white pubeseence on the head, thorax, and upper part of the femora and front tibia ; on the rest of the legs it is reddish. The mesonotum and scutelhm, are, however, almost demuded, and maly have been spotted. Antemme reddish brown, scape black. Head sparingly punctured, mesothorax less thickly than the scutellum, the hinder part of which has a tuft of white pulsescence, and terminates in a plate, concave on each side, and deeply bifid in the miidle. Abdomen, with each of the first four segments apparently divided in two by a deep suture; the front half is thickly punctured, and the second half smooth. On each side of the hinder smooth half of these segments is a broad irory-white stripe. The apical segments are strongly punctured, and clothed with tawny hair. Wings iridescent hyaline, clonded at the tips and in the upper pint of the radial cell ; marginal and post-costal nervures dark brown, only separated by a slender hyaline streak. 
Sokotıa: Hardibu Plain (16. XII. 96); and Homhil, E. Sokotra (1500 ft., 18-27. I. 99); three specimens.

I)iffers from the other species of the genus in having pale bands on only fonr segments of the ablomen.

34. Crocisa uniformis, Kirly. (Plate xvi. fig. 10.)

Crorise uniformis, Kirhy, Bull. Liverp. Muss, iii. p. 21 (1900).

Length of body $10 \mathrm{~mm}$. ; length of anterior wings $9 \mathrm{~mm}$.

Deep inky blick, antenna clotherl with fine greyish pile, the tegula reddish in the millle, and the trochanters, femora, and tibia of the four hind legs more or less ferruginuus, at least beneath. Wings jurplish hyaline, with some subritreous spaces just beyond and arounel the onter cubital cell of the fore-wings; hind-wings paler towards the base. Narginal area of all the wings thickly sprinkled with brown rlots. Clypeus obtusely truncated at the extremity; a strong median carina between the antemm. Head, thorax, and scutelhum thickly punctured; abdomen more finely, but still more thickly. Scutellum very broad, only slightly narrowerl at the extremity, where it ends in a point on each sirle, between which is a concavity which is rather obtusely angulated than rounded. Between the sides of this angle projects a tuft of rather strong greyish bristles.

Sokotra: Moukararlia (= (ielel-Raggit) (800 ft, 16. XII. 98); Dinehan Talley (3000 ft., 11. I.); Arho Dimelhs (3000-3500 ft., 3-5-7. II. 99); seven specimens.

A rery remarkable species, abumlantly distinct from any other.

[Apparently a solitary, gromulfrequenting species. liather sluggish in halbits, lut stings severely.--M.li.O.(i.].

\section{Podalirius, Latrelle.}

\section{Podalirius quadrifasciatus, le lillers.}

A pis quatrifusciutu, De Villers, Linn. Ent. iii. p. 319 n, 90 (1789).

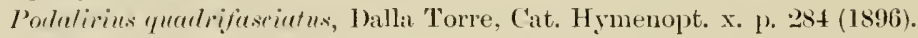

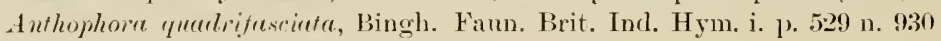
$(1 \mathrm{~s}: 17)$.

Sokotra: Moukaradia ( = Gelel haggit) $(600 \mathrm{ft}$, 15. XII. 9s); Hombil (2500 ft., 19 if 26. I.): Homhil (1500 ft., 21. I.); Dinehan Valley (3000 ft., 1. II.) : Arlho I)imelhs (3500 ft., 5 i 15. II. ; $4000 \mathrm{ft} ., 16$. II. $99)$; nime specimens.

A widle-ranging species found throughont the greater part of Europe, Asia, and Africa. These Soliotra speeimens are finer than any previously in the Natural History Museum Collection, except a pair from the C'anaries.

[By no means common in Sokotra, but most mumerons in the limestone district round Homhil, where several were taken in a marsh below our camp.-M.Ii.O.(i.] 
36. Podalirius fulvitectus, Kirlyy. (Plate xri. fig. 14.)

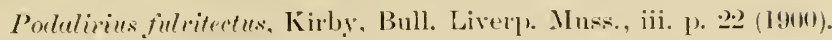

Length of body 11-1.2 mm.; length of anterior wings $7-9 \mathrm{~mm}$.

Almost the whole insect thickly elother with fulvous pubeseenee, the base of the segments of the abdomen and the terminal segment very thinly. A broad triangular spot above the elypens, the elypens, and all the lower month-parts pale yellow, clypens with a broad trapezoichal black spot on each side, not extending to the extremity, which is ent off straight, and is broader than above : base of labrum with a black dot at each angle, sometimes comnected by a hlack line. Wings almost hyaline, with brown nervures. Antemue rufons.

Sokotra: Monkaradia (=Gebel Ratggit) (22. XII. 98); West of Dahamis (500 ft., 22. XII. 98); Jena-agahan (1200 ft., 9. I. 99); Homhil (2500 ft., 2.2. I. 99); Adho Dimellus (3500-4000 ft., 16-17. II. 99); seven specimens.

Allied to the S. European P. gurmlus, hossi : hut in that species the antenne and the base of the segments of the abdomen are black.

37. Podalirius antennatus, Kirlyy. (Plate xvi. fig. 11.)

Pordalirius antennatus, Kirby, Bnll. Liverp. Mnss. iii., p. 222 (19010).

Length of body $11 \mathrm{~mm}$; length of anterior wings $7 \mathrm{~mm}$.

Female. Black. Hearl elothed with greyish white hair, inclining to tawny on the vertex, elypens black above, and broadly yellow below, with a small triangular projection upwards; labrum yellow; clypens and labrum narrowly elged below with rnfons; mandibles black. Thorax above with light tawny, and below with grey hair; legs elothed with grey hair, mixed with tawny ; hind legs almost entirely tawny; tarsi rufous. Antenne red, hack towards the base, and along the outer sile. Abrlomen thiekly punctured; first segment elothed with grey hair at the base, and terminating in a very narrow orange, yellow, and white line, the white colonr widened hehind on the sides over the bise of the seeond segment, which terminates in a narrow orange line. Third segment with a broad white band at the base, and a narrow terminal orange line. Fourth segment with white bands at the base and extremity, beneath which may be seen the terminal orange line. Fifth segment entirely tawny: sixth black in the mic d1? and tawny on the sides. Wings hyaline, with brown nervures.

Sokotra: Homhil (2500 ft., 22. 1. 99); one specimen.

A rery peenliar species: it is to be regretted that a series was not olstained.

\section{Xylocopa, Latreille.}

38. Xylocopa æstuans, Linn.

A pis tratuens, Linm., Syst. Nat. (Ed. x.) i. 1). 57 n. 37 (175s).

Iylocope restuan, Kirby, Proc. Zool. Soc. Lond., 1s81, p. (it!) : Inalla Torre, Cat. Hymenopt. i. p. it0 (1s:\%).

Sokotra: Hadihu Plain (1:2-17. XII. 9s); Goahal Gorge (500 ft., ㄴ․ I.) ; 
Adho I)imellus (3500 ft, 7. II. ; 3000 ft., 9. II. 99); twelve males and six females.

This species was previously brought from Solkotra by Professor Bayley

Balfour. It is widely distributed in North Africa, Irestern Asia, and the Indo-Malayan region generally.

\section{Apis, Linn.}

39. Apis fasciata, Luti:

Alpis fusciutu, Latr. (nec Limn., nec Fabr.) Amn. Mus. Hist. Nat. v. 1). 171 n. 5, pl. 13. f. 9 (1804).

Apis mellifica, var. lighestira, Spin., Ins. Ligur. i. p. 35 n. 15, pl. 1. f. 13 (1806).

A pis mellifera, varr. fasciate ef ligustire, Dalla Torre, Cat. Hymenopt. x. Pp. 60 s, $6099(1896)$.

Sokotra: Hadibu Plain (12-13-16. XII. 98); Adho Dimellus (3500 ft., 10. II. 99); five specimens.

This is evidently the common Hive-bee of Sokotra.

I cannot distinguish between specimens labelled $A$. fusciutu and $A$. lignstica in the Museum ; and both insects are regarder by Smith and Dalla Torre as mere rarieties of A. mellifera, Liun. A. fusciute and ligustica may be the same, but I doubt their identity with mellifera.

[Met with oceasionally in enormons eolonies. One particular colony on the lower slopes of Gebel Raggit was formed in a hollow in the rock, and must have contained a rast number of individuals. for they streamed in and out of the fissure in endless eolumms. These colonies are said to be owned by the natives.-II.I.O.d.]

\section{[FORMICID 压.}

Lient. Wellsted noted in $183+$ that "Ants are very numerous," and when eamping on the erge of the Nugget Plain he found the gronnd so "infested with Saml-Flies and Red Ants that it was almost impossible to sleep. The bite of one kind," he adds, "is searcely less painful than the sting of a Wasp.."-II.O.F.] 


\title{
II.- The Wasps and Bees of Abd $=$ el $=$ Kuri.
}

\author{
ACULEATA.
}

FOSSORES.

\section{BEMBICID无.}

\section{Bembex, Fabricius.}

1. Bembex dissimilis, Kirly. (Plate xvi. fig. 4.)

Brmbex disimilis, Kirby, Bull. Liverp. Muss., iii. p. 22 (1900).

Length of body $14-16 \mathrm{~mm}$. ; length of anterior wings $10-11 \mathrm{~mm}$.

Frmule. Head, thorax and abrlomen black above. Head clothed with whitish pubescence above, hinder orbits narrowly yellow, clypens yellow on the lower border, and more narrowly on the sides, proboscis pale yellow on the basal half, and with the apical half reddish. Antemne with the scape yellow beneath, and black above, except at the extremity ; flagellum blackish above, more or less reddish at the joints, and reddish beneath, except for a short longitudinal line at the base. Pronotum thickly and finely punctured, black, clothed with greenish grey hail, which is longer and whiter on the hinder borders. Abdomen more coarsely punctured than the thorax, the pubescence scanty, except at the base. Legs yellow or reddish, the femola above and below, the tibie and the first two joints of the hind tibia lined above with black. Front tarsi with a row of very long pale yellow bristles, tipped with black. Wings clear hyaline.

Abd-el-Kuri (22. II. 99) : six specimens.

$\Lambda$ very remarkable species, on account of the total absence of yellow markings on the abdomen; in one specimen only is there a small transverse pale yellow mark on each side of the second segment of the abclomen.

[A solitary ground-frequenting species.-II.R.O.G. $]$

\section{SPHEGID尼.}

\section{Sphex, Linn.}

2. Sphex granti, Kirly. (Plate xvi. fig. 12.) sphex granti, Kirby, Bull. Liverp. Muss., iii. p. 23 (1900).

f. Length of body $15 \mathrm{~mm}$. ; length of anterior wings $11 \mathrm{~mm}$.

․ Length of body $22-25 \mathrm{~mm}$. ; length of anterior wings $14 \mathrm{~mm}$.

Head, thorax, and petiole hack, clother with long white pubescence, which is silvery white on the clypens and hinder orbits; abdomen 
fulvous, the basal segments and incisions exhibiting a fugitive silvery pile; segments 3 to 5 with more or less extended transverse black spots over the sutures. Head broader than the thorax, clypeus mueh widened below the eyes, anterior margin transverse, hardly notched in the middle, thorax punctured, sentellum and post-sentellnm with a smooth transrerse elevation in the mildle, merlian segment elosely and regularly longitudinally striated from side to side, and with a strong conical tooth on each side a little before the middle; abdomen smooth and shining, terminal segments of female rather long. Wings hyaline, slightly darker towards the tips; nervures piceons.

Abl-el-Kmi (22. Il. 99.) : ten specimens.

This species has a superficial resemblance to the European S. fluripmus, Fabr, lint the petiole is longer. It is perhaps nearest allied to $S$. lineolu, Lep., from Java, but in the latter species the wings are dusky, and the dark markings of the ablomen are more extensive. S. grunti is abmulantly distinct from this or any other species at present in the Museum.

[A solitary gromel species, generally seen lomrowing, or rmming abont quiekly among the sand and stones.- M.li.o.(r.]

\section{VESPID床。}

\section{DIPLOPTERA.}

\section{VESPINAE.}

\section{Icaria, Saussure.}

\section{Icaria aterrima, Kirly. (Plate xi. fig. ‥)}

Icaria alerimu, Kirby, Bull. Liverp. Muss, iii. 1. 23 (1900).

Length of body $7 \mathrm{~mm}$; ; length of anterior wings. $5 \mathrm{~mm}$.

Femule. Deep) black, withont a trace of any other colouring; head and thorax thickly and closely punctured, the mesonotum more finely than the rest; aldomen more sparingly, especially behind, clypens longer than lnoad, strongly bifid at the extremity, median segment furrowed down the micllle, and terminating in two small teetl, petiole rounded in front, raised part not longer than broad. Wings deep jurple.

Abr-el-Kuri (22. II. 99); two speeimens.

Its small size and perfectly black colour will easily distinguish it from every other known species.

\section{ANDRENID胥.}

\section{ANTHOPHILA.}

\section{Colletes, Latreille.}

4. Colletes inconspicua, Kirlı. (Plate xvi. fig. 15.)

Colletes inconsprina, Kirby, Bull. Liverp. Muss., iii. p. 23 (19001). .

Length of body $8 \mathrm{~mm}$; length of anterior wings $5 \mathrm{~mm}$. 
Female. Black, thickly clotherl with yellowish grey hair, except on the upper surface of the four front femoris, a line down the tibia, and three broad and one narrow band on the abdomen. Hair on the underside of the tibire and tarsi golden or rufous ; tongue, terminal joint of antenne, and terminal joint of the tarsi rerl. Eyes long, inner orbits slightly convex above, and barlly converging below, clypens truncated at the extremity : pronotum sparingly, abdomen very finely and thickly, punctured. Tegule testaceous, wings hyaline, with brown nervures and reddish stigma.

Abd-el-Kuri (22. II. 99); two specimens.

Most resembles an unnamed species from $S$. Africa in the British Museum.

[Found Hying about bushes._W.I..O.G.].

\section{APID压.}

Podalirius, Latreille.

5. Podalirius pyramidalis, Kirly. (Plate xvi. fig. 13.)

Podalivius pyramidalis, Kirby, Bull. Liverp. Muss., iii. p. 24 (1900).

Length of body 9-10 mm. ; length of anterior wings $8-9 \mathrm{~mm}$.

Black, vertex, thorax above, and the front logs and upper and onter side of the four hind femora and tibie clothed with fulvous hair. Inner and hinder orbits and sides of clypens elothed with white hair. Clypeus arehed above and cut off straight below; black above, yellow at the extremity, with a pyramidal spot rising from it to two-thirds of its height. Labrum and lower mouth-parts yellow, labrum with a black dot at the base on each side, sontetimes connected by a black line. Antennæ dark reddish brown, almost black. Plemra clothed with greyish hair. Abdomen black, very finely punctured, with four snow-white bands at the extremities of the segments; terminal segment with greyish white hair on each side at the base. Wings hyaline, with brown nervures.

Abd-el-Kuri (22. II. 99); four specimens.

Allied to the widely-distributed $P$. qualrifusciutus, Villers, but smaller and with the face differently marked. 


\section{PLATE XV.}

Fig. I. LEUCOSPIS INSULARIS, p. 236.

Fig. 2. SPHEX EREBUS, p. 240.

Fig. 3. TACHYTES TRIVITTATUS, p. 242.

Fig. 4. STIZUS SCUTELLARIS, p. 243.

Fig. 5. EUMENES GRANTI, p. 246.

Fig. 6. STIZUS ADELPHUS, p. 244.

Fig. 7. PSEUDAPIS ANOMALA, p. 242.

Fig. 8. SALIUS EXTRANEUS, p. 239.

Fig. 9. NOTOGONIA BICOLOR, p. 243.

Fig. Io. TIPHIA CRASSINERVIS, p. 247.

Fig. II. RHYNCHIUM VERSICOLOR, p. 238.

Fig. 12. RHOPALUM QUADRICOLOR, p. 245.

Fig. 13. CERCERIS LOBABA, p. 245.

Fig. 14. CAMPSOMERIS SOCOTRANA, p. 238. 


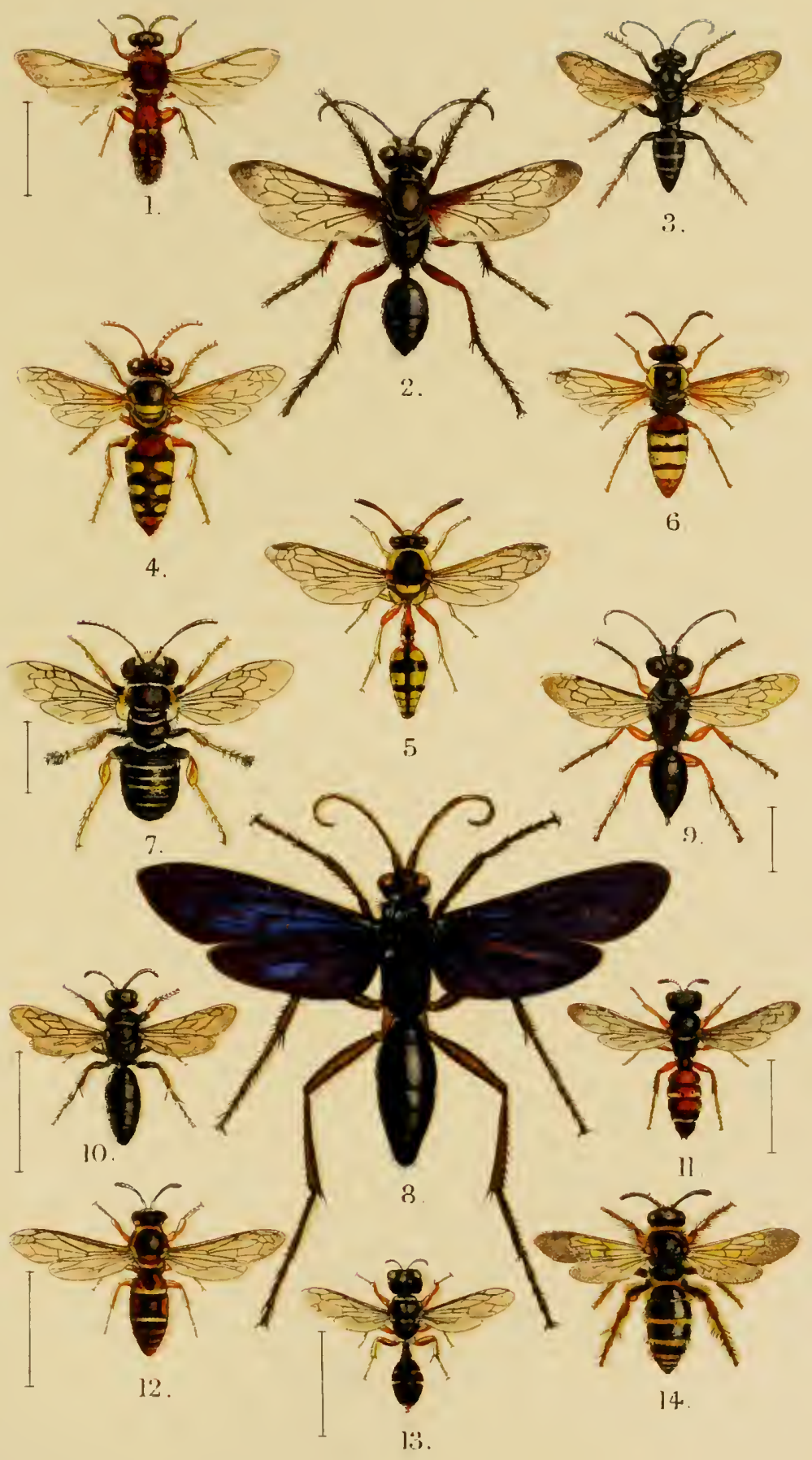




\section{PLATE XVI.}

Fig. I. MEGACHILE PUNCTATISSIMA, p. 250.

Fig. 2. BELENOGASTER SAUSSUREI, p. 248.

Fig. 3. MEGACHIIE PAUCIPUNCTULATA, p. 25 !

Fig. 4. BEMBEX DISSIMILIS, p. 255.

Fig. 5. ICARIA GROSSEPUNCTATA, p. 249.

Fig. 6. HALICTUS FLAVOVITTATU.S, p. 249.

Fig. 7. CRYPTUS PULCHERRIMUS, p. 237.

Fig. 8. ICARIA ATERRIMA, p. 256.

Fig. 9. CROCISA FORBESII, p. 25 I.

Fig. Io. CROCISA UNIFORMIS, p. 252.

Fig. II. PODALIRIUS ANTENNATUS, p. 253.

Fig. 12. SPHEX GRANTI, p. 255.

Fig. 13. PODALIRIUS PYRAMIDALIS, p. 257.

Fig. I4. PODALIRIUS FULVITECTUS, p. 253.

Fig. I5. COLLETES INCONSPICUA, p. 256. 


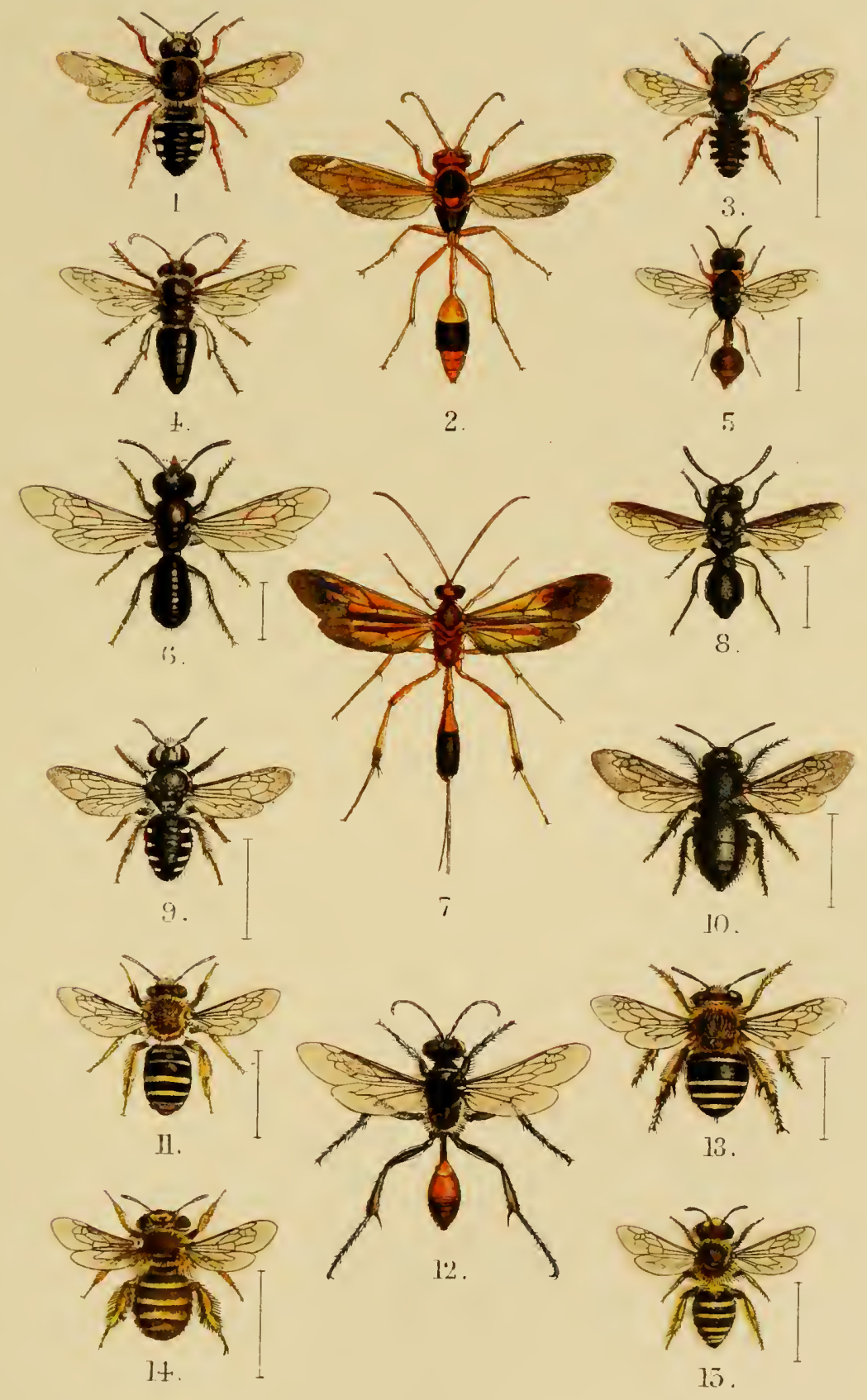





\section{ARTHROPODA.}

\section{Insecta: \\ Coleoptera.}

By C. J. GAHAN, M.A.

PLATE XVII. 



\section{Beetles.}

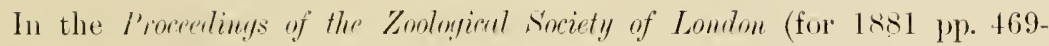
47E), Mr. C. O. Waterhouse gave an accomnt of the Coleoptem collecterl in Sokotra in the previons year by Professor Bayley Balfour. 'T'wenty-fom species were enmmeraterl, of which twolve were deseribed as being new. Two years later, Dr. Taschenberg published his beitiage zur Fanmu der

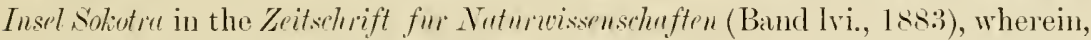
from the materials collected by Dr: Riebeck, he was enablerl to add nine species, including six new, to the list of the Coleoptra previonsly recorded by Waterhouse, thus bringing the total number of species known from the Island up to thirtr-three. With the exception of one or two isolated descriptions of species, these two are, so far as I know, the only papers dealing with the Colpopter of Soliotia which have appeared up to the present year.

In the following list of the known Coleoptere of Sokotra and Abd-el-Kuri, seventy species in all are recorder : sixty-two from Sokotra, eight from Abdel-Kuri, and one common to hoth, so that as a result of the recent expedition by Mr. W. R. Ogilvic-(riant and Dr. H. O. Forbes no less than thirty-six species have been added to those previonsly olstained in the Islands. Of these thirty-six speeies, twenty have been deseribed as new. Nine of the species, collected hy Professor Balfour in 1880, and six of those collected by Dr. Riebeck, were not ohtained during the recent expedition, the total number of species collecterl by Mr. Grant and Dr. Forbes heing fifty-four.

\section{I. - The Beetles of Sokotra.}

CARABID无.

\section{Calosoma, Weber.}

1. Calosoma rugosum, lo Geer.

Curalus ruyosu, De fieer, Insectes, vii. 1) 6:27.

Culosomu rugoxum, Dejean, Species ii. p. 20.2.

Sokotra : Jena-agahan (1.00 ft., I. 99); Homhil (1500-3000 ft., 1. 99): and Harlibu Plain (XII. 98).

This species is widely distributed in Africa, ocemring in Nulia, Ahrssinia,

Somaliland, East and South Africa. 


\section{Pheropsophus, Solier.}

2. Pheropsophus sobrinus, Dejenn.

Pheropwophus sobrims, Dejean, Species ii. p. 462.

(.) Pherop sophlns africanus, Taschenb., Zeit. f. Naturwissenschaften, lvi. p. $176(1883)$.

Sokotra: Hadibu Plain.-(Ricbeck.)

3. Calleida, sp.

\section{Calleida, Dejean.}

Sokotra : Harlibu Plain.

\section{Tetragonoderus, Dejean.}

\section{Tetragonoderus flavovittatus, /F werlh.}

Tetragonoderu.s flarovitutus, Waterh., Proc. Zool. Soc. Lond., 18si, p. 471 ; Tasehenb., Zeit. f. Naturwissenschaften, lvi. p. 176 (1ss:3).

The following is the description of the Type:

"Length $3 \frac{1}{2}$ lines. Very close to $T$. quethrm, Oliv., and of the same form and appearance. The head and thorax, however, are black (with the mandibles and the margins of the thorax slightly tinted with pitchy), very smooth, and shining. 'The eyes are protected posteriorly ly the hear partly surrounding them there. 'The thorax has the median ehanmel well marked; and in the middle of the basal margin there are some longitudinal strie. The elytra are slightly aneous, shining, with the stria well marked, the fourth and fifth strie rather distinctly puneturerl in their hasal half; the interstices are nearly flat; the yellow markings resemble those of $T$. quulrum, but consist of two patches on each elytron, the basal one occupying the fourth, fifth, and sixth interstices, the second one forming an undulating faseia, commencing on the third interstice and reaching to the eighth; that portion of it which is on the fifth interstice is more removed from the apex, and nearly joins the other patch on the fourth interstice. The legs and antennie are pale pitchy, the femora dark in the middle."-(I'cterhouse.)

Sokotra: Hadilı Plain.

\section{Chlænius, Bonelli.}

5. Chlænius conformis, Hejern!.

Chlomius conformis, Dejean, Species v., 1) 630.

Sokotra : Jena-agahan ( $1200 \mathrm{ft}$.).

This species is apparently wilely distributed thronghont Africa, having been recorded from Senegal, Nubia, Zanzibar, and Natal.

\section{Chlænius melancholicus, $s_{p} \cdot n$.}

Head, prothorax and elytra of a huish-black colour, the elytra, as a rule, being less glossy than the pronotum. Antemie black, with the first 
joint almost entirely, and the second at the apex, testaceous ; fourth and following joints pulbescent. Prothorax widest across the middle, narrowed thenee towads the apex and, to a somewhat less extent, towarls the hase; its length eyual to ahont $\frac{4}{5}$ of its wilth across the midcle; the dise somewhat thickly lunt not strongly punetured. Striae of elytra impunctate, the interstices feebly comvex, and very sparsely punctulate. Legs and molerside pitchy black, very glossy; sides of metastermum with some rather large sparsely placerl punctures; rest of mulersirle almost impunctate. Anterior femora of the male furnished moderneath near the hase with a very minute tooth, this tooth being in some speeimens ahmost or altogether obsolete.

In general form this species resembles ('. rumulis, Fisch., hut has the prothorax somewhat less narowed towarls the base. The presence in some specimens of a mimute tooth near the lasse of the anterior femora of the male suggrests also that the place for this species is in the group of C. courens and cruculis. On the other hand, the slencler last joint of the palpi, the sparser and finer puncturation of the pronotmm, the rery sparse puncturation of the elytra, and the almost entire absence of puncturation from the underside are characters which rearlily distinguish the present species from any in the group of ('. usmens.

Sokotra: Jena-agahan (1200 ft.) ; Dahamis (350-1000 ft.), and Hadibu Plain.

\section{DYTISCID压.}

\section{Hyphydrus, Illiger.}

\section{Hyphydrus guineensis, Anbe.}

Hyphyrlrus ynineensis, Anbé, Species gén. des. Coléopt., vi. p. 455 (1838). Sokotra.-( Bulfour.)

\section{Cybister, Curtis.}

\section{Cybister tripunctatus, Olic:}

Dytivens tripunctutu, Olir., Ent., iii. 40, p. 14, pl. iii. fig. 24 .

Tro!lus (Cybister) tripunctutus, Taschenb., Zeit. f. Naturwissenschaften, lvi. p. $176(1883)$.

Sokotra: Hadihu Plain.-One example.

\section{Cybister punctipennis, Tusrlent.}

Trognes punctipennis, Taschenberg, Zeit. fur Naturwissenschaften, lvi. p. $176(1883)$.

Black, with the upper side olive green, the mouth, the lateral margins of the prothorax and elytra, the antenne, and part of the anterior legs, yellowish. Elytra punctite.

Length, $24-27 \cdot 5 \mathrm{~m} . \mathrm{m}$.

Sokotra.-(I), liebeck.) 


\section{GYRINID尼.}

\section{Dineutes, MacLeay.}

10. Dineutes æreus, Kilng.

Gyrinus rene, Klng, in Ehrenberg's Symb. physs. iv. pl. xxxiv. fig. \& (1834)

Dinentes wren., Taschenb. Zeit. f. Naturwiswenschaften, lvi. p. 17 (1883).

Sokotra: Hadilm Plain. - Sereral examples.

This species is common and rather widely distriluted in East Africa.

\section{Aulonogyrus, Motsch.}

11. Aulonogyrus virescens, Réyimbuit (?).

Anlonoyyms virescens, Régimb., Ann. Soc. Ent. de France (6) iii. p. 138 (1S53).

Sokotra : Harlihu Plain.

I am not certain that this species is correctly determined, as in some minor points it does not agree sufticiently well with liégimbart's description. It probahly is the species recorded from Sokotra ly Taschenber'g as cyllinus sp.

\section{HYDROPHILID磨.}

\section{Temnopterus, Solier.}

12. Temnopterus spinipennis, Gory.

Hydrophilus spinipennix, Gory, Icon. rēgne Animal, p. T:2, pl. 20 fig. 14.

Temnopterus npinipennis, Taschenb., Zeit. f. Naturwissenschaften, lvi. p. 177 (1883).

Sokotra.- (Bulfom:)

Found also by Dr. Rieheck.

\section{HISTERID丑.}

\section{Saprinus, Erichson.}

13. Saprinus elegans, l'(y)k.

Hixter eleyans, Payk., Mlonographia Histerorum, p. .7, pl. v. fig. I.

Sokotra : Jena-agahan $(1200 \mathrm{ft}$. $)$.

14. Saprinus splendens, P(ty)k.

Hister splendene, Payk., Mon. Hist., p. 53, pl. iv. tig. 7.

Sokotra.-(Ihr. lieleck.)

\section{DERMESTID压.}

\section{Dermestes, Linn.}

15. Dermestes vulpinus, Fub.

Drrmestux milpinu, Fab., Species Insect, i. p. 64.

Sokotra: Harlibu Plain.

Found also by Balfour and Rieheck. 


\section{SCARAB庈ID压.}

\section{Scarabæus, Linn}

16. Scarabæus sacer, Limn.

Sccercherens secer, Linn., Syst. Nat., i. 2, p. 54.5.

Sokotra.--( Bialfour.)

[Seen rluring our ascent of the Dinegan Valley, among camel dung.II.O.F.]

\section{Cheironitis, Lansberge.}

\section{Cheironitis socotranus, Gulum.}

Cheironitis socolrunus, Gahan, Bull. Liverp. Muss., iii. 1900, p. 10.

This speeies somewhat closely resembles (. sombosu, Fab, in the colour of the upperside, and in the tuberculation of its elytra. The tubereles of the elytra are, however, more elongaterl, and have a tendeney to run together, forming short longitudinal carine, while there is a continuous carina running almost the whole length of each elytron on the first interstice (counting from the suture), and another on the fifth. The body miderneath, except on the sides of the metasternum, is of a dark metallic green colour; the legs are also metallic green, with the molerside of the femora pale testaceous.

In the male each of the anterior femora is armed with a rather long process, which is directed obliquely so as to form an acute angle with the terminal portion of the femur, and is somewhat hlunt at its extremity. Each of the middle coxie is armed near its posterior end with two laterally compressed spines, the hinder one being shightly longer than the one in front.

Sokotra: Dahamis (350-1000 ft., XII. 98).

18. Aphodius, $\therefore$.

\section{Aphodius, llliger.}

Sokotra: Hadilu Plain, Dahamis, and Homhil.

\section{Rhyssemus, Mulsant.}

19. Rhyssemus senegalensis, $H_{u}$ :

Sokotra: Hadibu Plain and Jena-agahan (1200 ft.).

\section{Hybosorus, MacLeay.}

20. Hybosorus illigeri, lieiche.

Hyloworus illigeri, Reiche, Ann. Soc. Ent. France, 18.53, p. 88.

Sokotra: Hadibu Plain.-One example only of this widely distributed species was obtained.

It has been recorded from South Emrope, North America, North Africa, Senegal, East Africa (inchuding Somaliland), and Arabia. 


\section{Pachydema, Castelnau.}

21. Pachydema puncticeps, I'uterh.

Pachydema puncticeps, Waterh., l'roc. \%ool. Soc., Lond. 18si, 1. 471.

'The reseription of the Type is as follows:-

"Length 10 lines. Very jolust, convex, a little flattened on the hack of the eyltia, sulparallel at the siles. The head is rather strongly and very thickly punctured, the punetures erowled near the eyes; the clypens is coneave alove, sparingly puncturerl, very slightly sinuate in the middle of the front margin, the margins reflexed. Thorax castaneous, one third Inoader than long, not rery elosely punctured, the punctuation more distinet alove than at the sides; obliquely narowed in front of the middle, subparallel hehind the middle (viewed from above), with a very slight sinnosity, finely margined and fringed with long fulvous bairs ; the posterior augles, viewer from alove, appear little greater than right angles (slightly rounded), but when riewed laterally they are completely roumled off; the lase is very slightly oblinne on each side. Sutellum sparingly punctured on each side. Elytra much paler in colour than the thorax ; at the base a very little broarler than the thorax, a little wider in the middle, olntusely romuled at the apex; finely ciliated on the margins; moderately finely and not very closely puncturer ; each elytron has four fine, nalow smooth lines (included lretween lines of close, very fine punctures), the first one very slightly raised. The pygiflium is very delicately and rather thickly punctured. The elul, of the antennie is fuscous testaceous, not very long. The tarsi are very long; the anterior have the second, third, and fourth joints moderately chlated ; the intermediate pair are only slightly so."-(I'terhouse.)

Sokotia.-(Balfour.)

Collected also by I)r. Rielreck.

\section{Oryctes, Illiger.}

22. Oryctes vicinus, Guhum.

Oryctes vicimu, (iahan, Bull. Liverpool Mnss, iii., 1900, p. 11.

The Type, $3: 2 \mathrm{~mm}$. long, 15 broar, is alout equal in size to small males of Oryctes bous, Fals, and in general form somewhat resemliles the latter species; but in structure and in sculpture it seems to be more nearly allied to O. momorers, Oliv. The clypeus is biclentate, with the enargination between the teeth lather deep, and lined with reddishtawny hairs; the ceplatic holn in size and shape resembles that of O. moneress; the prothorax is relatively wicler than in C. momoreros, and the dise somewhat more exeavate anteriorly; the elytra are shorter and hroaler in proportion, the sides more romuled, and the puncturation a little stronger and less dense, than in 0 . monoceros ; the propygirlium is very finely striate transwersely over the median area, 
the strie appearing to be more regular and continuous than in $O$. momoreros.

Sokotra: Halibu Plain (1. XII. 98).-One male example of this species was obtainerl.

\section{Homothyrea, Kolbe.}

\section{Homothyrea inornatipennis, $s \% . \prime$.}

Oxythyre helene, Waterhouse, P.Z.S., 1881, 1. 470.

This species is rery elosely allied to $I I$. heleme, Schatum, and is chiefly to be distinguished from it by the eomplete alssence of white bands or other white markings from the elytra, and ly the shortuess of the apical sutural process of the elytra. One example only was olitained at Hatilu Plain; hut a specimen agreeng with it in all respects was previonsly collected in Sokotua hy Professor Balfour, and has heen recorded hy Waterhouse (P.Z.s., 1881) as Orythyren heleme, Schaum. The genus /Iomothyren was established ly Kolbe in 1895, to inchude Leneorelis thoruticu, Schaum., and $L$. helene, Schaum.

Sokotra : Hadilu Plain.

\section{BUPRESTID床.}

\section{Julodis, Eschscholtz.}

24. Julodis clouei, Buq. (Plate xrii. fig. 6.)

Juladis clouei, Buq., Rev. Zoologique, 1843, p. 22: : Id., Ann. Soe. Ent., France, 1843 , pl. ir. fig. 1.

A large series of this speeies was ol,tained, showing a great amount of variation. Some specimens resemble the type figured by Buquet in Ann. Soc. Ent. de Frmee, 184:3, Plate iv. fig. 1, in having short tawny hands of puluescence on the elytia, but with these hands more oblique and less symmetrical. In others the tawny hands are replaced by mmerous whitish spots, and the puhescence on the thorax is also whitish instead of leeing tawny, while the elytral derm is somewhat rugosely punctured, has a steel-blue instear of a leep violaceous-blue tint, and shows a coppery tinge in eertain lights - one of these specimens is figured on Plate xvii. fig. 6. Between these extremes the rarions intermediate gradations occur.

This speeies oceurs in Ahyssinia.

Sokotra: Jena-agahan, Homhil, and Hanlibu Plain.

[This handsome Sokotran species, which was also collecterl by Prof. Balfour, is remarkalhy variahle in colour. It was commonest perhaps on the Harlibu Plain, where a considerable number were captured generally at rest on the tufts of bush-grass. The greyish bronze form was very rarely met with. During the daytime this beetle may not infrequently be seen on the wing, its handsome tawny wings rendering it a conspicuous object in flight. - II.R.O.G.] 


\section{ELATERID尼.}

\section{Alaus, Eschscholtz.}

25. Alaus sulcicollis, Guhun. (Plate xvii. fig. 1.)

Aluus sulcicollix, Gahan, Bull. Liverp. Muss, iii. p. 11 (1900).

Covered above with a dense scaly pubescence which is for the most part whitish in colomr, but on the head and the hasal declivity of the elytra is of a dingy fulvous or brownish tint interspersed with small whitish patches; the pubescence on the underside is fulvous-brown, exeept over the micklle of the metasternum where it has a whitish colour; the pronotum is sometimes marker with a few fulvons or brownish patehes, and each of the elytra presents one or two oblong fuscous spots near the midclle, and a few dark patehes along the outer margin. Prothorax with each side slightly rounded anteriorly, and rather strongly sinnate posteriorly, the dise with a median groove extending from a little before the middle almost up to the base. The latter character distinguishes this species from all others belonging to the genns; for although there is a merlian groove present on the pronotum in A. rewotus, Fib., the groove is abruptly limited behind by a triangular ridge or tubercle interposed between it and the median lobe of the hasal margin. In the present species there is no such ridge, and the median groore extends downwards behind to the slightly arched mirldle lobe of the hase.

In both sexes, the last rentral segment is hroally truncate behind. The one male specimen captured is much smaller than either of the two females, and differs further in having the elytra marked with a unmber of fuscous lines.

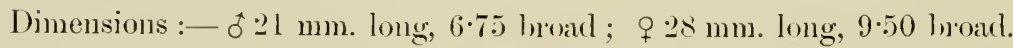

Sokotıa: Hadibu Plain (10-15. XII. 9s), ơ q: Homhil (1500-3000 ft., 17-2. 4. 1. 99), q.

[All the examples of this species were taken at light.- iV.li.O.(r.]

\section{RHIPICERID必.}

\section{Chamærrhipis, Latreille.}

26. Chamærrhipis bifoveolatus, Tuschenbery.

Chrommiphis bifoceolutur, Taschenberg, Zeit. fur Naturwissenschaften, lvi. p. 177 (1883).

Chestmut-brown, densely covered with an ashy-grey pubescence, lamella of the tarsi ferrnginous; prothorax with two small pits on the clise; elytra punctate and quarhi-costate.

Length, 13-16 mm.

Sokotra.-(Di: Rieber.)

\section{BOSTRYCHID无.}

\section{Phonapate, Lesne.}

\section{Phonapate nitidipennis, Ituterh.}

Apute nitimlipennis, Waterh., Proc. Zool. Soc., Lond., 1881, p. 4i2.

Mr. Waterhouse described the Type as under:-- 
"Length $7 \stackrel{1}{2}$ lines. Foreheat elothed with fulvous pile to rather alore the middle of the eyes: without tubereles: the rertex finely and elosely glamular, with a fine smooth merlian line, the sides of the neck elosely longitudinally rugulose. The lithrum is rery closely and extremely finely punctured. Clypens moklerately emalginate. Antemie pitehy, the elul clear fulvous. Thorax searcely narrower than the elytra, a trifle broarler than long ; the hasal half closely covered with small depressed gramules; the front is eovered with small tubercles with rather larger ones intermixed, these litter becoming more prominent and aente towarls the anterior angles: one at the anterior angles lecomes a strong leflexed, recurved tonth, close to the margin. The elytia are ${ }_{-4}^{1}$ times as long as the thorax, a rery little wider near the apex than at the hase: the surface eren and shining; the punctures are clear and clistinct (distant from each other alout twice the diameter of the larger punctures), they are fine at the base, ant gradually beeome stronger and a little larger towarls the apex, lut ther alre very fine at the sides: in the apical declivity the punctures are rery strong; on the hack there are two pairs of lines of punctures on each elytron. indicating the dorsal costie frequently seen in this gemus ; the spaces hetween them are not at all rased, exeept at the apieal declivity, where they are rery slightly intlated, lut searcely projecting ; the inelassated apical margin is closely and finely punctured. The mulersicle is olscure pitchy, chothed with fine yellowish pubescence. The legs are also pitehy : the whole of the inner sile of anterior tilbie is elothed with rery pale fulvous pile: on the onter edge are three or four very small teeth. The intermediate tilhie have on their onter edge four or five very small sharp teeth: the posterior tibic are smooth. The ahdomen is opaque, very elosely anf extremely finely punctured.

"A single example, apparently a female.

"In the Musenm collection there is a specimen from East Africa which differs from the above in having the elytra a little shorter, the punctuation on them rather stronger, with two fine dorsal costax, and with an indieation of a thire more lateral one; the tiluie have more teeth on their onter edge, and the posterior pair have also a few fine teeth; the abdomen is less elosely pmetured ; the labrum is less closely punctured : the clypens deeply emarginate, ive. I have no name for this species, and only mention it that it may not be confounded with that from Sokotra.

"Both these species appear" to he nearly allied to A. rormifroms, Bandi de Selve (Berl. Eut. Zeit., 18it, xxriii. p. 8:34); lut that speeies is described as being somewhat pulnescent, and the forehear of the female has a longitudinal channel and a forea on the vertex.

"The fine frontal line in my speeies ean searcely le described as a chamnel ; and there is no forea on the vertex."

Sokotra: Dahamis. 
The example collected by Professor. Balfour and deseribed by Waterhouse wats a male, not a female as he supposed it to he. Both sexes are ineluded among the specimens obtained by Dr. Forbes and Mr. OgilvieGiant at Dahamis.

\section{Bostrychus, Geoffroy.}

28. Bostrychus, sp.

Sokotia.

\section{Rhizopertha, Stephens.}

29. Rhizopertha pusilla, Full.

synodendron pusillum, Fab., Ent. Syst., Suppl., p. 156 (1798).

Sokotra : Jena-agahan (1:00 ft.).-One example.

\section{TENEBRIONID床.}

\section{Zophosis, Latreille.}

30. Zophosis æqualis, Iritril.

Zophosis arqualis, Waterh., Proc. Zool. Soc. Lond., 18s1, p. 473.

The Type of this speeies was deseribed as follows:-

"Length 3 lines. Oblong-ovate, not very convex; slightly tinted with ieneous. Head convex, rensely and rery finely punctured; labrum not very closely hut extremely delicately punctured. Thorax evenly conrex, deflexed at the sides, finely margined anteriorly, twice as broarl as long, arenately narowel anteriorly, very closely and extremely delieately punctined. Elytra as broad as the hase of the thorax, nearly straight at the sides, arcuately narrowed at the apex, moderately convex: the punctuation is extremely fine, but rather more distinct than on the thorax, and recirledly less close ; on the margin, near the apex, some of the punctures are longitndinally asperate ; the epipleural line is completely marginal; the epiplenron has a few short longitudinal impressed lines. The antemne are black: the second and fourth joints are nearly equal, both a trifle shorter than the third. The spurs on the tibice are rerkish. The prosternal process is elongate-ovate, moderately broad, finely margined, extremely delicately, and not very thickly punctulate.

"Some of the specimens have the epistoma separated from the forehead by a fine sinuous line, in the middle of which is a shallow forea; the epistoma is more strongly punctured; and the elytra have more asperate punctures along the whole margins. I take these to be merely varieties, as they rary somewhat among themselves.

"This speeies appears, from M. Deyrolle's Monograph, to be nearly allied to Z. elomyutu, Deyr. (Awu. Sor. Ent. Fr., 1867, vii. p. 219); but that species has evidently much more asperate punctuation on the sides of the elytra, \&c." - (Wuterhous. $)$

Sokotra: Adho Dimellus (3500 ft.), Homhil (1500 ft.), and Hadibu Plain. 


\section{Histeromorphus, Kraatz.}

\section{Histeromorphus plicatus, Krutt:}

Histeromoryhus plicutus, Kratatz, Revision Tenebrioniden, p. 12.

Sereral examples of this species were oltained. Those from Hadibu Plain alle all chanacterised by having the elyta very strongly plicate especially towards the sides, much more so judeed than in typical specimens from Alyssinia, so that at first sight they wonld seen to be specifically distinct. But as the specimens from the other localities named exhihit consideralile variation, some having the elytra almost fuite smooth, while in others they are almost as strongly plicate as in the examples from Harlibu Plain, I am foreed to consides all the eximples as belonging to one extremely variable species.

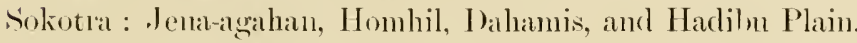

\section{Histeromorphus plicatipennis, Wher $/$.}

Histeromoryhus plicatipemix, Waterh., Proc. Zool. Soc., Lond., 18s1, p. 473, 1). xhiii. fig. 1 .

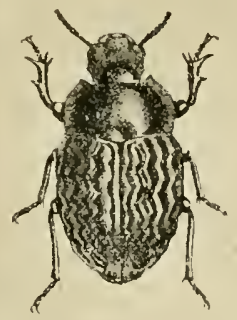

HISTEROMORPHE'S PLIGATIPENNIS.

Mr: Waterhonse describerl the Type as follows:-

"Length 4 lines. This species is much smaller than $I I$. plicutus, Kz., lut has almost precisely the same form. It is at once distinguished by the remarkable plicate elytra. Each elytron has four zigzag stria (hesides a portion of a fifth on the side) : the space between the first and second strie is only slightly convex; the three following interstices are very convex and are zigzag in the same way as the stria, impunctate; the apex of the elytra is flattened above, lut scarcely reflexed."

Sokotra.-(Belforr:)

[We did not meet with this speeies.-M.O.F.]

\section{Rhytidonota, Eschscholtz.}

33. Rhytidonota exigua, linlen!n.

Rhytidonotu rigun, Gaham, Bull. Liverpool Muss, iii. p. 8 (1900).

Hear densely punctulate, antenne scarcely reaching heyond the midclle of the pronotum, with the third joint alont half as long again as the

*All the figures in the text of this paper are from the Prockerlings of the Zooloyical Socitty of London, with the kind permission of the Council.-Editor. 
second, the fourth appreciably shorter than the second, the fifth and following joints grarlually and lut very slightly decreasing in length, and the eleventh narrower than the tenth. Prothorax densely and minutely punctulate, slightly rounded at the sides, widest a little in front of the middle, and thence narrowed to the base and apex, heing a little narower across the apex than at the hase, where the width is almost equal to the length of the pronotum along the middle. Elytra ovate, about two and a half times as long as the pronotum, finely and rather sparsely punetulate, and each impressed along the dise with five or six shillow and nearly ohsolete grooves.

Length $7 \cdot 5-8.5 \mathrm{~mm}$.; breadth (at micl. of elytra) $3 \cdot 2 \cdot 5-3 \cdot 5 \mathrm{~mm}$.

Sokotra: Homhil, East Sokotra (1500-3000 ft.).—Eight examples

\section{Rhytidonota socia, Grelerru.}

Rhytidonotre socie, Gahan, Bull. Liverpr. Mluss., iii. p. 9)(1910).

This species has the same dull black colour as the preceding species, which it closely resembles also in size and shape. It differs from it as follows:- The antemie are longer, reaching quite to the base of the pronotum, less closely punctulate, and with the second joint relatively shorter, heing less in length than the fourth joint and little more than half as long as the third; the pronotum is more parallelsiderl, and its wilth across the hase is a little greater than its length along the midrlle.

Sokotra: Adho Dimellus (3500-4500 ft.).

\section{Eusyntelia, Waterhouse.}

Euxynteli, Waterhouse, P.Z.S., 18s1, p. 473.

Mesosternum sloping, more or less concare. Eyes subreniform, not divided by a lamina, not prominent laterally. Head below with a deep transrerse impression, ahore with a rilge orer each eye. Epistoma with a somewhat acute projection in the middle of the front margin, the labrum distinctly risible from above. Antenne with the third joint scarcely twice as long as the second. Borly not very convex, not pubescent. Thorax as broad or rather broader than long, the sicles gently areuate. The elytra with distinct shoulders, ahout one third longer than the head and thorax together, margined at the hase, somewhat produced at the apex.

"The species upon which l establish this genus very mueh resembles Thulpophilu cublrexicte, Fals., in form, but is shining black or without pubescence. It has, however, the gular line transverse and not ol,lique at the sides, as in Thulpoplitu. I propose to place it before Tentyriu (following Dr. Kratz in classification), so that it may come in proximity to those genera which have the labrum exposed.

"The second species closely resembles the first, lut has the throat more approaching that of Anutulire.

"The third species somewhat resembles a species of Dichommu."-( "Iuterhouse.) 
35. Eusyntelia opacicollis, (ruhun. (Plate xvii. fig. 5.)

Enxyntelin oprecicollis, (iahan, Bull. Liverp. Muss., iii. p. 9 (1900).

Hearl and pronotum elosely and distinctly punctulate and oparye, the punctures on the head heing somewhat larger than those on the pronotum. Pronotum widest between the middle and the anterior margin, its sides there loeing distinctly arenate, while from the middle to the hase they are almost rectilinearly convergent ; its length along the miclde a little greater than its wirlth across the base. Elytra rather stromgly sulcate, with the interstices convex and somewhat closely punctulate.

Length $12 \cdot 0-15 \cdot 0 \mathrm{~mm}$. ; Treadth (at micl. of elytra) $4 \cdot 5-6 \cdot 0 \mathrm{~mm}$.

Solotra : Jena-igahan ( $1200 \mathrm{ft}$.) and Harlihu Plain.

This species is most nearly allied to $E$. pbeminu, Waterh., which it resembles in size and form, but from which it may he distinguished at first sight by the duhness of its whole upper surface, the head and pronotum especially being elosely and rery distinctly punctulate, while the same parts in E. obenimu are rery sparsely and minntely punctulate and the surface highly polisherl. In the latter species also the length of the pronotum is only ahout equal to, or scarcely appreciably greater than its width across the base, and is, therefore, relatively a trifle shorter than in opuciollis. Ensyntelin Imlfonri, Waterh., differ's from loth of these species loy its shorter antemne and its lonoarer pronotmm, the width of the latter across the hase being listinctly greater than its median length; in the figme of this species (Proc. Zool. Soc., 1881, pl. xhiii, fig. 5) the form of the pronotmm is inaecurate, and more nearly represents the shape ocenring in elemime and opurimollis.

36. Eusyntelia balfouri, II uterh.

Eusyntelin lualfouri, Waterh., Proc. Zool. Soc. Lond., 1ss1, p. 47t, pl. xliii. fig. 5 .

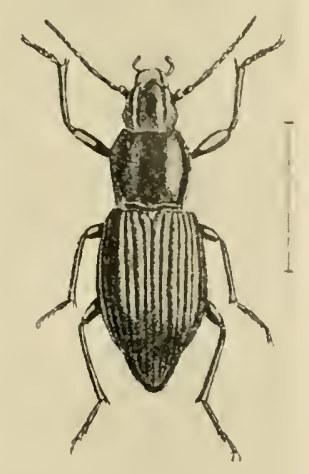

EUSYNTELIA BaLFOURI. 
The following is the original description of the Type of this species:-

"Length 6 $62_{2}^{-} 8$ ! lines. Head finely or moderately thickly punctured, with several irregular longiturlinal inpressed limes on the forehearl, deeply impressed within the ocular rirlge; the clypeus producerl in the mirlde into a point, which is slightly bent down at the apex. Eyes not much conrex, slightly reniform, the upper part the larger, not so prominent as the hearl in front of the eye, supported posteriorly by a swelling of the neck. Thorax not quite twice as hroal as the head, about one fifth broarler than long, only gently convex; finely margined all roumer, except in the micklle of the anterior margin ; areuately emarginate in front, slightly narrowed in front and hehind: the anterior angles bhunt; the sides gently arcuate; the posterior angles a little greater than right angles and blunt; the base searcely sinuate on each side, gently lober in the mirlle. Scutellum small. Elytra at their lase not inoader than the hase of the thorax, and fitting close to it, gradually and slightly widening to the middle, and then again narrowed to the apex, not rery convex, rather lepressed on the back; rather strongly and olutusely sulcate, the interstices rather conrex, extremely delicately and not very closely punctured : the apex somewhat producer and impressed ahore Antemie as long as the hear anct half the thorax. Posterior tilive closely and rather strongly punctured on their upper edge, the punctures almost asperate."

Sokotıa : Jena-igahan (1200 ft.) and Arho I limellus (3500 ft.).

\section{Eusyntelia ebenina, /iterh.}

Eusyntelie eleninu, Waterh., Proc. Zool. Soc., Lond., 1881, 11. 474.

The following is Mr. Materhonse's description of the Type:-

"Length $7 \frac{1}{2}$ lines. This species is rery close to the preceding, but is at once distinguished by the thowax being rather narrower, more convex in front, rather more narowerl hehind, and the sides, instead of heing regularly arenate, are somewhat rectilinear hehind the mirldle. 'The anteme are rather longer. The head is more delicately punctured; and there are no longitudinal inpressed lines on the forehead. The thorax is almost entirely smooth, a few excessively fine punctures being visible near the posterior angles. 'The punctures on the posterior tilice are finer, and distinctly separated from each other.

"This species so closely resembles s. lulfomi in all its general characters and appearance that it occurred to me that the differences might, perhaps, he sexual; this, however, I have, by dissection, proved not to be the case."

Sokotra.-(Bulfomi.)

\section{Eusyntelia glabra, Wuter\%.}

Eusynteliu glalma, Waterh., Proc. Zool. Soc., Lond., 1851, P. 475, pl. xliii. fig. 6.

The following is the original description of the Type:-

"Length $5 \frac{1}{2}$ lines. Elongate-ovate, moderately convex, glabrous. Anten- 
ne moderately short, shining, not very thickly hut very finely punctmerl. Hearl moderately thickly and very distinctly punctured : the ocular ridge moderately strong; the projection in the mirldle of the margin of the elypens rather small and aente. Tholax nearly twice as broak as the head, about one fifth hroader than hong, a very little more narrowed in front than behind, gently eonvex; fincly margined all round (except, perhaps, in the middle of the anterior margin); very finely and lather closely punctured, and evenly so all over ; the anterior angles moderately prominent; the sides moderately and perfeetly evenly areuate; the posterior angles are rather greater than right angles (alont $120^{\circ}$ ) : the hase is boadly and gently lobed in the

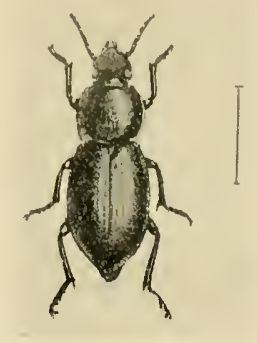

Eisyctelia filabra.

midkle. Elytra about one quarter longer than the head and thorax together, rather convex, a little flatter on the back; at the base a very little broader than the base of the thorax, gradually and evenly enlarged to the middle (where their wilth is equal to the length of the head and thorax together), then narrowed again to the apex, which is very slightly produced ; each elytron has four or five rather olscure impresserl chammels (ohsolete at the base); the second, third, and fourth interstices are very gently convex; the punetuation, althongh not sparse, is very fine and obsemre, and in parts scareely visible."

Sokotra : Dahamis (350 ft.); Jena-agahan ( $1200 \mathrm{ft}$.) ; Adlho Dimellus (3500 ft.) : Homhil (1500 ft.), and Hautibu Plain.

\section{Adelostoma, Duponchel.}

\section{Adelostoma bicarinatum, I'iterh.}

Alelostoma bicurinatum, Waterh., P.Z.S. Lond., 1881, 1. 4i.s, pl. xliii. tig. 3.

The Type was described as follows:-

"Length $2 \frac{1}{2}$ lines. A short, lnoarl sprecies. Head closely and rugosely punctured, scarcely impresserl on each side above, shightly lnoaler posteriorly than in front, nearly straight sided: the merlian carina is fine, and is continued baek to the vertex: the ocular carina is very short. Thorax very closely and rugosely punctured, at the anterior angles very slightly broader than the hearl, much broader behind the 
middle, narrowed again at the base, gently reflexed at the sides, with two strong dorsal costie ; the anterior angles, although not very acute, are decidedly prominest : the sides are strongry angular considerably behind the middle; the base is divided into three equal parts by the

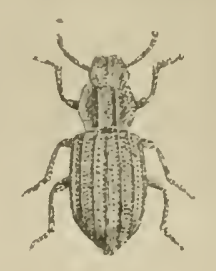

points of jumcture with the dorsal carina. Elytra one quarter longer than broat, depressed, rather suddenly deflexerl at the apex: each elytron with three well-marked costie, the second distinetly ahbreviated at the hase and apex ; the first interstice with two lines, the second and third with three lines of strong deep punctures. Legs olscure pitchy."

Sokotra.-(Bulfour.)

Ocnera, Fischer.

40. Ocnera setosa, Ménétries.

Ocnere setose, Ménétries, Cat. raisonné, p. 1922 (1832).

Sokotra.-(Bulfour.)

\section{Opatrum, Fabr.}

41. Opatrum costiferum, I/ itrih.

Opatrum costiferum, Waterh., Proc. Zool. Soc. Lond., 1ss1, p. 476, pl. xliii. fig. 2.

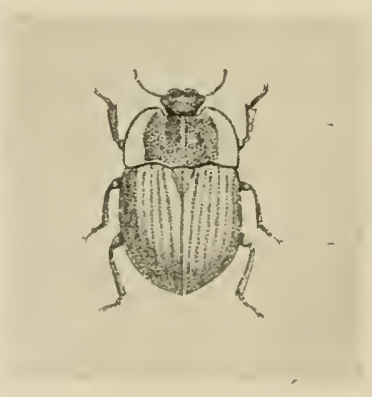

OpATRLM CONTHERTM.

The following is the original description of the Type:- 
"Length 6 lines, breadth 4 lines. Heal corered with small, round, shining, black graumles placed moderately elose together. The clypens has its frout margin straght on each sirle of the deep triangulan incision: at the sides it is sudelenly ololiquely turned hack, so as to form an olutuse angle with the antemial orlits. The third joint of the antennie is at least as long as the three following joints together: the fourth joint is a tritle longer than lororl, the fifth to eighth are nearly globnlar ; the ninth and tenth are distinetly tansverse, and a little broader than the eighth ; the eleventh is nearly globular, searcely narrower than the tenth. The thorax is twiee as hroad as its length in the mildle, deeply emarginate in front for the reception of the head, convex on the dise, impressed at the sicles, arenately narrowed in front of the mickle; the anterior angles are bhunted right angles ; the sides behind the middle are parallel; the posterior angles are hlunt, and a little greater than right angles; the lase is broally lobed in the middle, the lobe itself straight next the sentellum; all the dise rather closely covered with depressed conical black tubercles; there is a fine median impressed line. Elytra at the base seareely broader than the thorax, a trifle broader at the middle, scareely longer than broad, very convex, deseending at the apex, very gently arenate at the sides; each elytron has seren slightly raised hroad teetiform eoste, a line of small romnd obtuse tubereles being ranged along the summit of each eosta. Tarsi short and thiek."

"This speeies has somewhat the appearanee of Surums luvicollis, Oliv., and at first sight wonld seareely be taken for an Oputrum."

Sokotra : Jena-agahan (1200 ft.).-One example.

\section{Opatrum, $s p$.}

Another example of this genns was olitained. It resembles O. custiferum,

Waterh., in general form and in having costate elytra, lont it is less than half the size of that speeies.

Sokotrat : Homhil (1500 ft.).

\section{Apithesis, Waterhouse.}

Apithesis, Waterhouse, P.Z.S. Lond., 18s1, p. 476, pl. xliii. fig. ta.

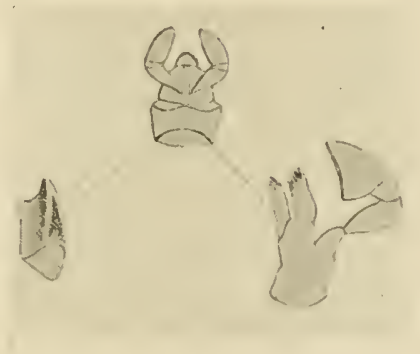

Mouti Orgaxs in Aprtiesis 
"Mentum transversely trapeziform, narrowest at the base: labial palpi short and thick, the apical joint large, thick at the base, narrowed towarls the apex. Inmer lube of the maxilla terminating in a horny hook; the palpi morlerately large, the apical joint strongly securiform. The mandilles emarginate at their apex. Labrum transverse, projecting and exposerl, entire. Head imbecled in the thorax as far as the eyes: the "pistoma separated from the forehearl on each sifle by a fine line, the front margin emarginate. Eyes moderately transverse, the canthus half diviling them: the upper and lower parts nearly equal. Antenne rather short; the second joint a little longer than hroad: the third trice as long as the second: the fourth a little longer than the second; the fifth and sixth shorter: the seventh as long as hoad, rery narrow at its base, very hroad at the apex; the eighth nearly an equilateral triangle; the ninth and tenth very transversely cup-shaped ; the eleventh nearly as hoad as the tenth joint, flat, somewhat circular in outline. Thorax as in Alphitobin., lnt more convex, and with the lateral margins slightly impressed. Elytra rely convex, very little hroarler than the thorax, very little longer than broad, elescencling at the apex, strongly striated, the epiplemal fold rather boat at the hase, gradually marowed posteriorly, terminating sudelenly a little way from the apex. Legs slightly rough and finely puhescent ; the talsi clothed leneath with close fine hair : the anterior tibia more linear than in Alphitobius. Anterior coxe slightly transverse. Prosternum arehed between the coxe, very slightly produced posteriorly. Mesosternum sloping and gently concave. Metasternum short. Borly abore not pubescent. Wings none.

"I have great difficulty in placing this genus : but, on the whole, it secms best arranged near. Alphitobius, although its broader and comvex form gives it a different appearance: the tibic are more linear than in that genus, and the whole legs more punctured and pulescent. The under flanks of the thorax are concave as in Cryptirlis quisquilius, lut it has not the longer slender legs as in that insect. It is apterous; a character which is hitherto foreign to the Clomine, lut which I do not consicler a fatal har to its being placed in that sub-family." -(It uterhonse.)

\section{Apithesis obesa, "/uterh.}

Apithexis obesa, Waterh., Proc. Zool. Soc. Lond, 1ss1, p. 47., pl. xliii. fig. 4.

The following is the description of the Type:-

"Length $3 \frac{1}{3}$ lines. Hearl closely and rather strongly punctured : clypeus very elosely and more finely punctured, oblipute at the sifles, emarginate in front, the margin pitchy. Thorax convex, twice as broad as its length in the miclelle, graclually arciately narowed from the base to the front ; morlerately, thickly, evenly, finely, but rlistinctly punctured; the siles narowly impressed above, very delicately margined; the pos- 
terior angles slightly acute; the base rather strongly simuate on each side, funcly margined; on each side, almost on the margin, is an abbreviated impressed line, partieularly visible when viewed from behiml. Elyta at the hase as hoad as the thorax, a little widel posteriorly, where they are more convex, decliroms at the apex; each

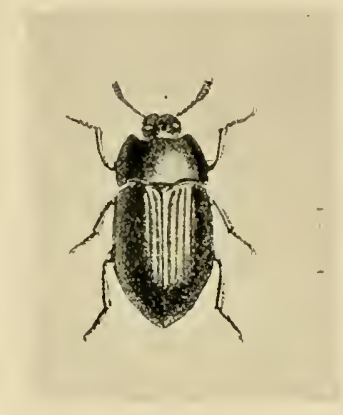

APITHESTA OBESL.

elytron has eight rather strongly impresser, finely and closely punctured strie, the fouth aud fifth much shorter than the others, and mited posteriorly ; the interstices are slightly convex, oparue, finely and rather thickly punctured." - (I/ cuterlumse.)

Sokotra. (Bulfoni.)

\section{HELOPIN/E.}

\section{Deretus, Gahan.}

Deretu., Gahan. Bull. Liverp. Muss., iii. p. 11 (1960)).

This genus seems to be most nearly allierl to Enberns, Boield., from which it differs chiefly in the shape of the pronotum. The pronotum is narrowed at the base, and at the lateral margin on each side between the base and the mirlle there is a short llumt tooth, behind which the maryin is rather deeply sinuate, while between it and the middle there is a feebler simbation. The clypens is boadly rommled in front, not trumeate nor emarginate as in Eulvers: the antenne are a little shorter and more slender than in the latter genus, and the proximal joints of the himl tarsi somewhat shorter. In other points of structure the agreement hetween the two genera is fairly complete.

44. Deretus denticollis, (́r,hun. (Plate xvii. fig. 9.)

Devetus denticollis, Gahan, Bull. Liver]. Muss., iii. 1) 10 (1901).

Dark brown and somewhat glossy. Head, and prothorax almost quite l, lack alove, both very closely and rather strongly punctured; labrum transverse, thickly pinctured, mited to the elypens by a narrow and smooth coriaceons laund: eyes transiersly ovate in form. Antenue of the female less than half as long as the looly, with the joints from the fourth to the eleventh sub-equil in length, each being ahout two- 
thirds of the length of the third joint, and the last three or four somewhat broarler than the others. Posterior margin of pronotum almost straightly transierse, the anterior margin shightly curved forwards towards the outer angles, the latter being somewhat romded. Elytra each with ten rows (including the very short juxta-sutmal row) of punctures, with the interrals between the rows slightly convex, and sparsely and feet)ly punetured. Underside and legs very closely punctured.

Sokutra : Jena-agahan (1200 ft.).

\section{CISTELID Æ}

45. Allecula, sp.

Allecula, Fabr.

Sokotra: Jena-agahan (1200 ft.).--Two examples.

\section{ANTHICID床.}

\section{Anthicus, Paykull.}

46. Anthicus floralis (Limu.).

Heloe floralix, Limn., Famm Suecica, 1. 228 (1761).

Sokotra: Artho Dimellus (3.500 ft.).-One example.

\section{MELOID曆.}

\section{Meloe, Linn.}

47. Meloe trapeziderus, sp.n.

This species is readily distingushed from others of the genus by the form of its prothorax. 'The latter is broalest in front, with its anterior angles acute; its sides are vertically deflexed, and converge strongly in straight lines from the apex to the base; the dise is almost quite Hat, strongly rugose-punctate, and without a groove or impression along the mirldle. The head and prothorax are purplish-blue coarsely punctures. The antemne reach bat little beyond the lase of the elytra: the joints from the third to the eighth are sul-equal in length and thickness, each being nearly as broad as it is long, the ninth and tenth joints are each a little longer than the eighth, and the eleventh is nearly twice as long as the ninth. The elytra blue, irregularly rugase; dorsal segments of the abromen dark hlue, each having a postero-merlian semicircular shiny spot.

Soliotra : Jena-agahan (־000 ft.).

48. Meloe, sp.

Solotra: Dahamis (350 ft.).-One example.

\section{CURCULIONID䇥.}

\section{Piazomias, Schönherr.}

49. Piazomias vermiculosus, I'atert.

Piazomiax rermiculoxux, Waterh., Proc. Zool. Soc. Lond., (18s1), p. 478.

The Type was described ly Mr. Waterhouse as under:- 
"Length 6-7! lines. This species has much the form and general appearance of Herpystimlus eremitu. Rostrum nearly parallel, flattened ahove, longitudinally rngulose, with a fine impressed merlian line reaching nearly to the vertex; and on each side there is a longitudinal impression. The eyes are molerately prominent, ratler less than a semi-eirele viewer from alove. Thorax a trifle hroaler than long, truncate in front and behind, moderately rounded at the sides, broulest rather behind the middle: slightly depressed on the disc, with a well-marked median chamnel, which does not reach the frout margin; all the surface (except the anterior borler) rermiculose, and divided into rather irvegular romd areas, which have generally one puncture ahout the mitulle: the disc is covered with pale scales, and there are some rery pale scales at the sides: the hase is margined. Sentellum rery small, shining black. Elytra at the margined base a very little wider than the base of the thorax, lut immerlately becoming wirler (without, however, making any distinet shoulders), oblong-ovate, convex, sloping down and somewhat aemminate at the apex, strongly striated, the strie strongly lut not closely puneturer?; the interstices almost flat, covered with sandy grey seales, with small dots of a paler colom at intervals on the strie: the seales on the margin of the elytra and on a spot on the himler femora are also paler. Tarsi grey."

Sokotra: .Jena-agahan (1200ft.), and Hadibu Plain.

\section{Systates, Gerstacker.}

50. Systates angusticollis, Trsilenler?.

systates cungusticollis, Taschenberg, Zeit. fur Naturwissenschaften, lvi. p. $179(1883)$.

Black, and somewhat glossy ; with a faint greyish-white pubescence. Anteme filiform, with a whitish pubescence at the apex. Prothorax sulb-erlimbical, pitted ahove. Flytra somewhat globose, pitted in rows with the interstices raised.

Length $5 \cdot \overline{5}$, lnearlth : 1 mm.

Sokotra. ( 1 ri. livelueli.)

Fonr species of 'minlimidu, in arddition to the one referred to above, were collected by the Expedition. Two $(51,52)$ of these, belonging to systates or some elosely related genus, were found in Sokotra, the remaining two having heen obtained in the island of Abd-el-Kuri.

\section{BRENTHID尼.}

\section{Ceocephalus, Schönherr.}

53. Ceocephalus picipes, olir.

Brentus picipes, Oliv, Entomologie, v. No. 84, p. 442, pl. ii. fig. 18.

Ceorephalus piripus, Taschenh. Zeit. f. Natnrwissenschaften, lvi. p. 179 (1853).

Sokotra.-(I)i. liebeck.) 


\section{CERAMBYCID曆.}

Mallodon, Serville.

54. Mallodon arabicum, lintinet.

Malloton arabicum, Buquet, liev. Zoologiqne, 1843, p. 330 ; Waterhouse, Proc. Zool. Soc. Lond., 1s\$1, p. 478, pl. xliii. fig 7.

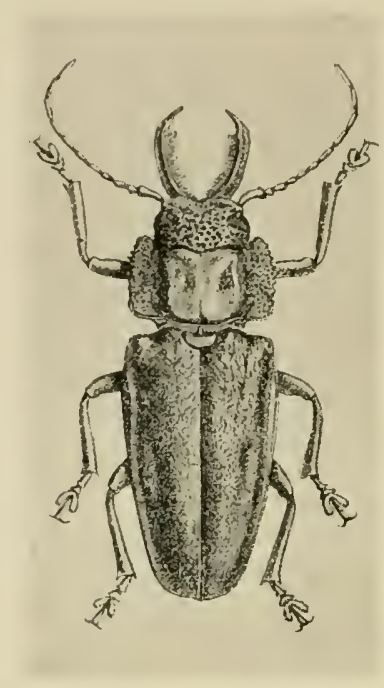

MALIODON ARABICUM.

A series of specimens, inchuling both sexes, of this species were collecter lyy Mr. Grant and Dr. Forbes. The largest male measures over $60 \mathrm{~mm}$. in length (mandibles inchuled), while the smallest is not more than $3+\mathrm{mm}$. long. The original specimens deseribed by Buquet were, he says, foumd by M. Clouce, "sur les êtes d'Arabie."

Sokotra : Dahamis (350 ft.); Homhil (1500 ft.), and Hadibu Plain.

[All the examples of this fine longicorn were foumd in holes in rotten trees. On one oceasion at Homhil I saw the head of a rery large specimen protruding from a hole, and attempted to extract it with the aid of a pair of foreeps. The beetle absolutely refused to let go its hold, and as force was gradually brought to bear its thorax telescoped to an alarming extent. After several minutes its grasp suddeuly relaxed, and I foumd on extracting the Mallodon that it was perfectly deal. I feel certain that this species was olstaned ly M. Clone in Sokotra along with Julolis rlonei, and does not ocenr in Arabia.II.R.O.(i.)

\section{(Eme, Newman.}

55. Eme fusca, Guhun. (Plate xvii. fig. 2.)

(Eme fuxc't, Gahan, Bull. Liverp). Muss., iii. 1). 12 (1914).

Dark hrown in colour, varying in parts to hrownish-testaceous, covered with a faint gleyish pubescence. Anteme of the male more than half 
as long again as the boly ; those of the female a little longer than the hody ; joints third to fifth shortly spinose underneath. Eilytai closely punctured, the disc of each maked with two aised lines.

Notwithstaneling its habitat, this species seems to be correctly placed in the gems CEme, and to be not very distantly allied to the NorthAmeriean species (E. lineniz from which it is chiefly distinguishable hy its darker colour, somewhat horker form, less leeply emarginate eyes, less strongly spinuse antenus, and shorter alolomen.

bength $13 \cdot 0-16 \cdot 0 \mathrm{~mm}$., lireath $2 \cdot 6-3 \cdot 3.5 \mathrm{~mm}$.

Sokotra : Dahamis (350-1000 ft., XII. 98).

[All the examples of this species were olotained from one or two rleal trees in the neighlourhoor of our camp at bahamis. - II.li.o.(1.]

\section{Coptops, Serville (?).}

56. Coptops hieroglyphica, Therthenlery.

Copfops hieroylyphica, Taschenberg, Zeit. fur Natuwissenschaften, lvi. ए. $179(18 \times 3)$.

Vertex of head marmed; eyes approximated; prothorax with three tubercles, and with two anterior and two posterior transverse grooves : elytra romgh, furnished with two basal teeth and deep punctmes, obliquely carinate behind; micklle tibie grooved. Borly black, covered with a grey pubescence mixed with rusty-brown and white: prothorax with a darker rhomboidal plaga in the middle, and four white specks in a row near the hase: elytan also with some darker markings.

Length 9-17 mm.

Dr. Taschenberg has referred this species with some dould to the genus Coptops: ; and one of the characters given by him - "tilia mediu sulcute" - indicates that the species certainly camnot he a true (opptops ; but the other characters mentioned do not sufficiently relate to structure to enable me to identify the gemus or even the group to which it helongs. The size and coloration of the species suggest that it may find a place in Lldutus, and may possibly be identical with the following species.

Sokotra.--(1)i: Rieberk.)

\section{Idactus, Pascoe.}

57. Idactus granti, Gulinn. (Plate xvii. fig. 10.)

Iductus yranti, Gahan, Bull. Liverp. Nuss., iii. 1) 122 (1900).

Allied to I. mernlirnmis, Gahan, and differing from it as follows:Pubescence much paler in colour; elytra longer and less convex, without tufts of hairs, and with the two tubereles near the latse of each much smaller; pygidimm of the female without the two tufts of tawny hairs which are present in the female of muculirormis.

Length $10 \cdot 0-15 \cdot 0 \mathrm{~mm}$., brearth $4.6 \mathrm{~mm}$. 
Sokotra : Dahamis (350-1000 ft.); Jena-agahan (1 200 ft.); Homhil (1500 ft.) : and Harlibu Plain.

[Mostly found in dead trees, but a good many were captured at the lanterns of an evening. H.M.O.G.]

\section{Sybrinus, Gahan.}

sybrimu, Gahan, Bull. Livelp. Muss., iii. p. 1:2 (1900).

Head slightly transrerse in front, feebly concave above between the antennal tubercles; eyes coarsely facetted, deeply emarginate with the lower lohes slightly transverse. Antenure of the male abont half as long again as the hody, those of the female alout reaching to the apex of the elytra, fomth joint enual in length to the second and third united, and scarcely longer than the first, fifth shorter than fourth, sixth to elerenth gradually diminishing in length. Prothorax unarmed, and slightly romeded at the sides, its length alout equal to its width across the base. Elytra hoader than the prothorax, nearly parallel-sider in their anterior two-thirds, and thence narrowed to the apex. Legs rather short; with the femora stont and clarate: tibire of the middle pair notched on the ontside lelow the midrle, those of the hind pair sinuate on the onter horder below the middle, and furnished with a row of short stiff sete; tibire of the anterior pair with a finely serrate ridge along the outer borter' claws of the tarsi wirlely divergent. Prosternal process slightly archerl in the middle, rather widely dilated behind the eoxit. Mlesosternal process with a small angular dilatation on each sirle near its extremity. Internediate coxal cavities almost completely elosed in extermally.

This genus belongs to the group Pteviroptirles, and seems hest placed near Sybre, Pasc., which it apploaehes in genteral form and in many of its structural characters, differing chiefly in its more widely divergent tarsal elaws, in its relatively longer scape and shorter third joint of the antenne, and in the presence of a serrate rirlge on the onter border of the anterior tibire.

\section{Sybrinus commixtus, Guhun. (Plate xrii. fig. 8.)}

Sylminus commixtux, Gahan, Bull. Jiver'1. Muss., iii. p. 12 (1900)).

Closely covered with a fulvons or fulvous-grey pubescence. Dise of prothorax with a lioad suli-glabrous fuscous land, elosely and rather strongly punctured, extending along the midclle from the lase to the apex. Elytra with small fuscons spots anteriorly and along the sides, each with a large ohlique cinereous patch, followed by a lumate blackish brown spot, placed a little in front of the apex; the elytra are punctured, with the punctures visible only where the pubescence has been rubbed away, and each shows indications also of three or four shightly raised longitudinal lines.

Length $11 \cdot 0 \mathrm{~mm}$., lireadth $3.5 \mathrm{~mm}$. 
Sokotra : Arlho-Dimellus (3500-4000 ft., II. 99).

[I helieve all the eximples of this longicorn were taken at light, mostly on onr dining tahle.-II'.R.O.li.]

59. Sybrinus, $\&$.

Very like the precerling species, of which it may prove to be a variety, the chicf difterences noticeable heing (1) the presence of an clongaterl dark brown patch on the intermediate thire of each elytron about mid-way hetween the sutne and the onter margin, and (2) the smaller extent of the cinereous pateh on the hincler part of each elytron.

Sokotra : Jena-agahan ( $1200 \mathrm{ft}$.).-_one female example.

\section{Sybrinus simonyi, $s p . \mu$.}

ln this species the pulveseence covering the elytra is of a nearly miform greyish-tawny colour, this colour heing varied only lyy some small and inconspienous cinereous speeks, arranged somewhat in longiturlinal rows. The underside and legs are covered with a pulbescence rery similar in colour to that ou the upperside, lut varied more with small brownish spots.

Length $9 \cdot 0 \mathrm{~mm}$., lirearlth $3 \cdot 0 \mathrm{~mm}$.

Sokotra : Jena-agahan.-One male example.

This speeies is derlicated to Plof. Osear Simony, a well-known naturalist and keen entomologist, a member of the Expedition of the Imperial Acarlemy of Seiences of Vienna, engaged in the exploration of Sokotra at the same time as Dr. Forles and Mr. Grant, in remembrance of their pleasant meeting there.

\section{EUMOLPID压.}

\section{Eryxia, Baly.}

61. Eryxia socotrana, sp.n.

Dark metallic green having on tho uppersicle a slight coppery tint: thinly elotherl with a short adpresserl grey puhescence. Antennat ferruginous with the last five juints, which are slightly dilaterl and compressed, more or less infuscate. Head elosely and finely punctulate : prothorax transrerse. rounled and distinctly matrinate at the sides, closely and rather strongly punctulate alrove ; elytra densely punctulate with the punctures somewhat unequal in size. Intercoxal process of the prosternum rely much lnoarler than in $E$ holdsericen, Klng (= builiii, Baly), and only slightly convex in the midrlle: the intercoxal process of the mesostermum a little narrower than that of the prosternum. Tibie without trace of emargination on the outer side.

A species from Aden, which I have determined from the description to be the Eryxiu grandis of Leferre, is elosely ablied to the present one, differing chiefly by its smaller size, and relatively shorter and broader 
elytra. This species also differs from $E$. loloserifen, Klug, the type of the genus Eryrin, in having the prostemum rery much broader between the coxie.

Length $7 \cdot 5-9 \cdot 0 \mathrm{~mm}$.

Sokotra: Haudilu Plain.

\section{COCCINELLID厯.}

\section{Epilachna.}

62. Epilachna chrysomelina, vur. reticulata, Olir.

Coccinellu reficulutu, Oliv., Encyl. Méth., vi. p. 56 (1791); Elviluchure recticulute, Mulsant, Species des Col. Trimères, p. 794.

Sokotra: Homhil (1500 ft.).-.-One example. 


\section{II.- The Beetles of $\mathrm{Abd}=\mathrm{el}=\mathrm{Kuri}$.}

\section{MELYRIDE.}

\section{Melyris.}

1. Melyris insularis, Guhtn. (Plate xvii. fig. 3.)

Melyris insuleris, Gahan, Bull. Liver'p. Muss, iii. p. 8 (1900).

This species is chiefly distinguishable by the form of the prothorax, the sides of which are almost straight, and continuously divergent from the apex to the hase, with the posterior angles slightly acute, and prominent. It is of a metallic-green colour, with the abdomen, the legs, and the last five or seven joints of the antemne, black, and the remaining joints of the antenne, except the first, testaceous.

Alid-el-Kuri.

\section{PTINID尼.}

\section{Paranobium. Gahan.}

Puranobium, Gahan, Monogr. Christmas Id., p. 104 (1900).

The genus Paranolimin was founded for the reception of a species-l'. posticum, Gahan--collected in Christmas Island, Indian Ocean, and figured and described in the "Monograph" of that island. In this genus the prosternum is not excavated for the reception of the head, and extends but a short distance in front of the anterior eoxa; the latter are rather closely approximated to one another, the intercoxal process being short and narrow. Each of these coxie fits lrehind into an excaration formed partly from the mesosternum, and in part from the mesothoracie episternum, the two excavations in the mesosternum being separated in front by a median vertical lamella. This structure of the sterna is very much the same as oceurs in the genus Hedobiu; and in certain other respects I'urnobium shows considerable atfinity with that genus, but it differs in having a relatively broader prothorax (which approximates more to the form characteristic of Probium), and in having the antenne inserted widely apart, and close up to the margin of the eyes, closer even than is the case in the genus I'riobinm. From I'riolium, I'armobium is distingmished by the strueture of the antenne and of the mesosternum, as well as by the alsence of a stridulating area from the gular surface of the head, this surface in I'dranolinm heing smooth and nitid and limited on each side hy a nearly straight sutural line, whereas in Priotium, and in Iryoplitus also, the muclersicle of the head has a transversely oval area, which is striated finely throughout nearly all its extent in * Dryoplitus, towards the silles only in I'riobium.

* I have so far examined this structure only in one species of Dryophilus-D. puxillus, fierm. 


\section{Paranobium forbesii, sp. $u$.}

Pitehy-lnown in colonr, the head and prothorax being slightly darker than the elytra; clother with a greyish pubescence, which is not sufficiently rlense to mask the colour of the rerm. Antenure testaceons; the joints from the third to the tenth somewhat triangnlar in form, and nearly equal to one another in length. Prothorax appearing somewhat globular in form when looked at from above, distinctly narrower than the elytra, its upper surface finely and closely gramulate. Elytra densely and rather strongly punctate. The fifth joint of each of the tarsi almost equal in length to the first, this joint being ahout as long as the second and third mited.

Length $8 \cdot 0$, brearlth $3 \cdot 0 \mathrm{~mm}$.

Abd-el-Kuri.-One eximple.

\section{TENEBRIONID屟.}

\section{Zophosis, Latreille.}

\section{Zophosis undulata, Guluen.}

Zophasis undulute, Gahan, Bull. Liverp. Muss., iii. p. 8 (1900).

This species is closely allied to Zophesis cequelis, Waterh., but is relatively hroader, and is easily distinguished at first sight by the slightly raised and obtuse midulate ridges ruming along the elytra. It differs also in having the upper part of the head less closely punctulate, and the pronotum distinctly lut rather sparsely punctulate.

Length $7.0 \mathrm{~mm}$., brealth $3.5 \mathrm{~mm}$.

Abd-el-Kuri.-Two examples taken (22. II. 99).

\section{Histeromorphus, Kraatz.}

\section{Histeromorphus undatus, Guhen. (Plate xvii. fig. 7.)}

Hixteromoryhus undatus, Gahan, Bull. Liverp. Muss., iii. p. 8 (1900).

In size and general form this species somewhat closely resembles $H$. plicutus, Kratz, lut may be easily distinguished from it by the following characters. The clypeus is almost straightly truncate or. Jut very feebly sinuate in front, whereas in $H$. plirutus it is arcuately emarginate; the sides of the prothorax have a broader margin, and converge more strongly in a more regular arcuate curve from the base to the apex; the elytra are more regularly plicate in wary lines rumning parallel to one another in a transverse direction.

Length $8 \cdot 5-11 \cdot 0 \mathrm{~mm}$, lirearth $6 \cdot 5-8 \cdot 0 \mathrm{~mm}$.

Abd-el-Kuri. -Ten examples captured 22. XII. 98, and 22. II. 99.

\section{Rhytidonota, Eschsch. (?).}

\section{Rhytidonota (?) tibialis, Guluen.}

Rhytirlonotu (?) tilialis, Gahan, Bull. Liverp. Muss., iii. p. 9 (1900).

This species is very distinct from $l i$. exiyue and $l i$. sociu; and, in certain of 
its characters, such as the form of the prosternal process, and the presence of a groove along the outer (or dorsal) face of each of the tilice, it differs from all other known speeies of lihytirlomotu.

Length $11 \cdot 0-1 \cdot 2 \cdot 0 \mathrm{~mm}$., breadth (at middle of elytra) $+0-4 \cdot 2 \mathrm{~mm}$.

Alol-el-Kuri.-Two examples taken (22. II. 99).

\section{Adelostoma, Duponchel.}

6. Adelostoma granti, Guluen. (Plate xvii. fig. 4.) Adelostoma granti, Gahan, Bull. Liverp. Muss., iii. p. 10 (1900).

Oblong-elliptical, depressed, black; the hearl in front areuately emarginate, aud furnished alrove with four small cariniform tubereles. Prothorax greatly and abruptly narrowed slightly in front of the base and fumished above with two longitudinal carinie. Both elytra are provided with three earina, the imner earina widely intermpted towards the middle, and the intermediate one shortened posteriorly.

Length 6 , lirealth $2 \frac{2}{3} \mathrm{~mm}$.

Alst-el-Kmi (22. XII. 98).

[I met with only one example of this species. - Ir.Ii.O.G.]

\section{CURCULIONID咂.}

\section{Piazomias, Schönherr.}

7. Piazomias, $s p$.

Ald-el-Kuri.

8. (?) Systates, $s p$.

\section{Systates Gerst. (?).}

In addition to the species of I'iuzmius, a seeond species of this family was obtained belonging to Systutes or some elosely related gemus.

Abd-el-kini.

\section{EUMOLPID床.}

\section{Eryxia, Baly.}

9. Eryxia socotrana, sp.n.

For description of this species see p. 287 .

The examples of this species taken in the island of Abr-el-Kuri differ slightly from those fomd in Sokotra, inasmuel as they show no trace of the coppery tint present on the upperside in the Iatter. 


\section{PLATE XVII.}

Fig. I. AlAUS SULCICOLlis, Gahan, p. 270.

Fig. 2. EME FUSCA, Gahun, p. 284.

Fig. 3. MELYRIS INSULARIS, Gahm, p. 289.

Fig. 4. ADELOSTOMA GRANTI, Gulun, p. 29 I.

Fig. 5. EUSYNTELIA OPACICOLLIS, Gulun, p. 275.

Fig. 6. JULOdis CLOUEI, Bir., p. 269.

Fig. 7. HISTEROMORPHUS UNDATUS, Guhu, p. 290.

Fig. 8. SYBRINUS COMMIXTUS, Gulun, p. 286.

Fig. 9. DERETUS DENTICOLlis, Gahun, p. 281.

Fig. Io. IDACTUS GRANTI, Gahm, p. 285 . 
Liverp. N/us.: Kep. Soleotra Liapued.
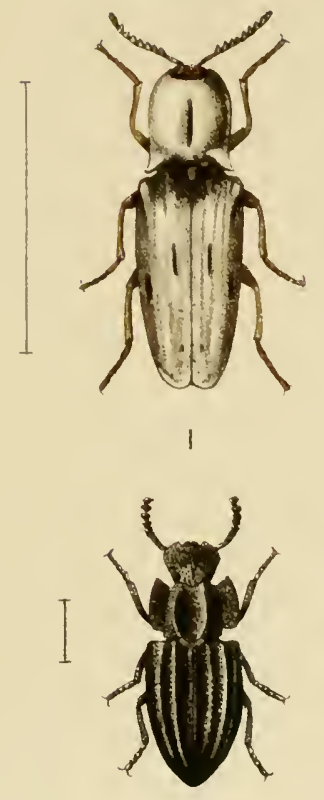

4

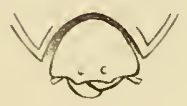

$7 a$

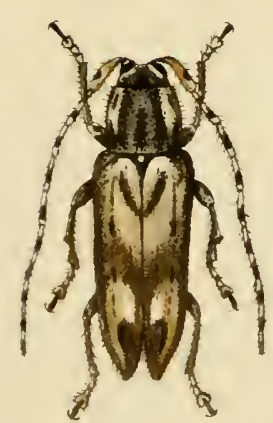

8
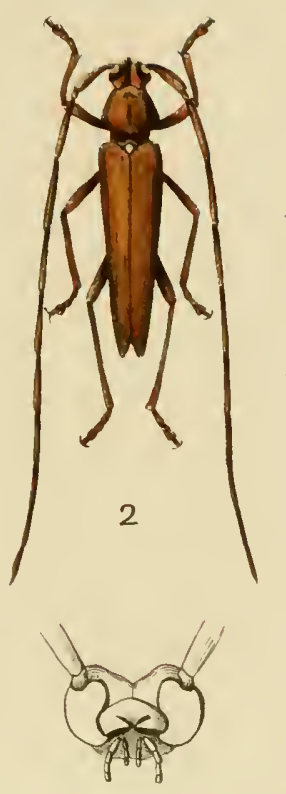

$2 a$

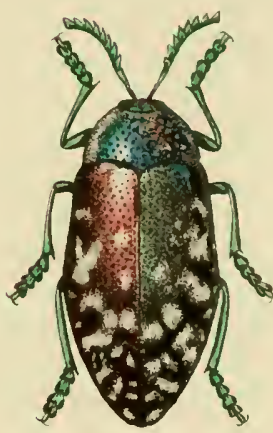

6
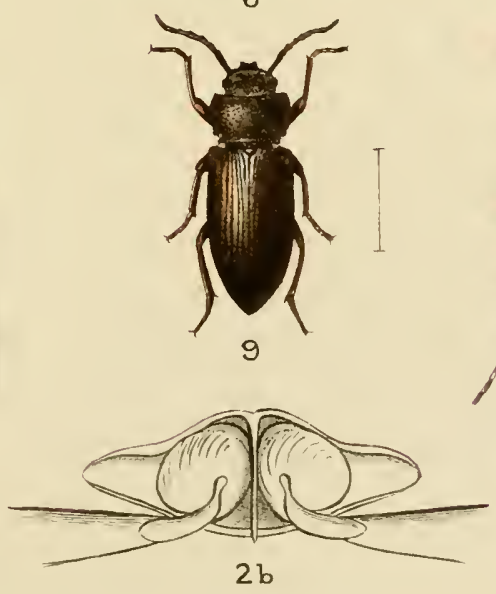

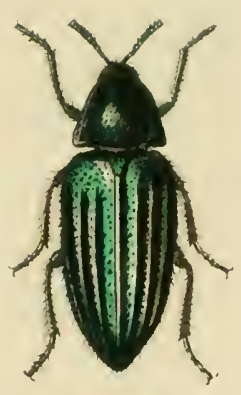

3
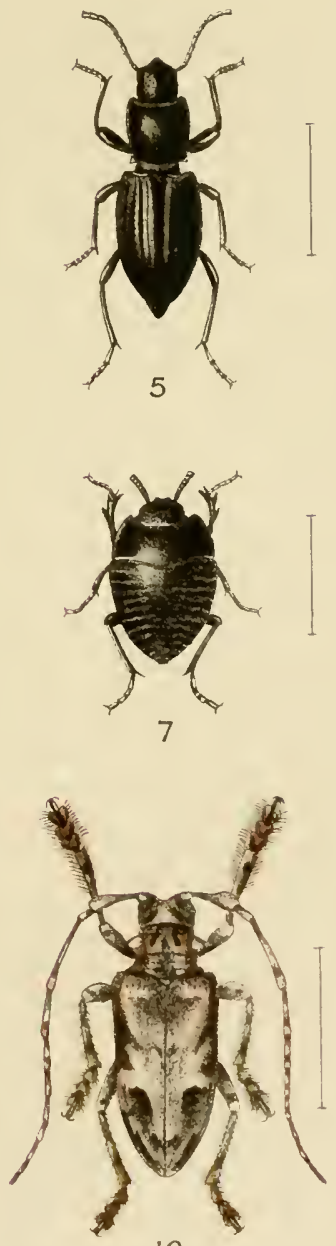

10 



\section{ARTHROPODA.}

\section{Insecta:}

Lepidoptera.--I.

Rhopalocera.

by W. R. OGILVIE=GRANT. 



\section{Butterflies.}

The collection of Butterflies made by our Experlition raises the total number of species and varieties found in Sokotia to 28 ; of these 15 had already been recorded by Dr: Butler. (P.Z.S., 1881, pp. 175-179 pl. xviii.), and Mr. Dixey (P./.s., 1898, pp. 37.-382 pl. xxx.). The present list thus adrls 13 species or varieties not previonsly recorder, and inchules three species new to science, the most remarkable being a secund speeies of Churtexes (C. velox). We also olstained the nuknown males of Churuces bulfouri and Belenois anomula.

Ten speeies and one variety are peculiar to Sokotra, the remainder are all widely distributed species, belonging for the most part to Africa and Arabia.

The oceurrence of the splendid North Indian speeies Hypolimmes jucintlue is remarkable: it has probably been accidentally imported, and is certainly one of the rarest insects on the island.

On Abd-el-Kuri Butterflies were very poorly represented, only three very common and widely-distributed species being met with.

\section{I.-The Butterflies of Sokotra.}

\section{NYMPHALID尼.}

\section{RHOPALOCERA.}

\section{LIMNAINÆE.}

\section{Limnas, Hübn.}

1. Limnas chrysippus, Limı.

Pepilio chrysippus, Linn., MLus. Ulr., p. 263 (1764).

Danais chrysimpus, Butler, P.Z.S., 1881, p. 17.5.

Limnas chrysippus, Dixey, P.Z.S., 1895, 1. 373.

On the Hadilu Plain and on the lower valleys on the north side of Sokotra we found this species fairly common but nowhere numerous. The wild Thyme covering the plain, in full flower in December, proved extremely attractive to insects of all kinds, and it was then that most of our examples were obtained. Hypolimus misimpus was also fairly 
common there, and the females of the two species might easily be mistaken for one another at a short distance. The present species was never seen on the more elerated parts of the island. Mr. Bemett remarks that it was "seen only in the hills flying strongly." This statement does not agree with my olsserrations, and it seems possible that he may have mistaken Churuxes relow for the present species.

2. Limnas chrysippus, var. klugii, Butl.

Limnas klugii, But1., P.Z.S., 188.5, p. T5s.

3. Limnas chrysippus, var. dorippus, kluy.

Euplene dorippues, Klug., Symb. Phys., pl. xlviii. figs. 1-5 (1845).

These rarieties were both obtained on the Hadibu Plain, lnt the latter for'm was only once seen, and apparently very scarce.

In describing a collection of Somaliland Lepidoptera in comparison with a series from Arlen, Dr. Butler makes (P.Z.S., 1885, p. 758) the following interesting remarks in reference to the distribution of these two varieties (or'species as he there reckons them):- "If my views of the relationship of this species [Limnes dorippus] to L. clrysippus and allies is correct, it will probably be found that typical $L$. dorimpus does not lange inland to any rery great distance from the Somali enast, but that its place is occupied by its Indo-African representative. So far the two series before me fulfil my expectations; that received from Major Yerbury [from Arlen] containing one male of each form, whereas that collected by MLr: Thrupp [in Somaliland] contains three pairs of the Indo-African form [L. litugii] and none of $L$. doriplus. Mr. E. Lort Phillips assures me, howerer, that three of the specimens were oltained within 80 miles inland from Berbera. . . . [Limnus liluyii] is clearly the prevalent Limnes in Somaliland; L. chssyippus and $L$. alcippus having, apparently, entirely disappeared, I. dorippus being scarce and in all probability confined to the eastern coast. . . ."

\section{SATYRINÆ.}

\section{Mycalesis, Hübn.}

\section{Mycalesis socotrana, Butl.}

Calysisme socotrana, Butler, P.Z.S., I8s1, p. 175, pl. xviii. fig. 7.

Calysisme anynana, Dixey (nec Butl.), P.Z.S., 1898, p. 374.

The following is Dr. Butler's description of the Types:-

"Nearest to C. cnynume from Johanna (Comoso group). Olive-brown; wings above with paler onter borker traversed by a wary submarginal brown line; a black marginal line; fringe slightly darker than the outer border: primaries erossed beyond the cell from costa to first median branch by a slightly mululated pale-bordered dusky line; two ocelli of the ordinary type, one towards apex about a quarter the size (i.e., half the diameter) of the other, which is placed on the first median interspace: secondaries with a scarcely perceptible small blind ocellus on the first median interspace. Wings below paler, trans- 
rersely striated with darker lines, the disc (particularly in the female) suffused with lilacine grey, the ocelli with pale zones, and in the male, with whitish insteal of orange irides, those of the primalies situater as on the upper surface, but the subapical one, particularly in the fentale, greatly redueed in size; the outer border with sharply defined zigzag inner edge towards apex, in the female suffused with ferruginons, the intersecting submarginal line being lark ferruginous; a broad central belt, the inner edge of which is olssolete in the male but sharply defined by a white-bordered ferruginous line in the female; the outer edge slightly undulated and angulated on all the wings, dark lrown with pale borler in the male, ferruginous with white border in the female; seeondaries with seven discal ocelli, of which the second, thirl, and seventh are very small, and the fifth the langest. Expanse of wings, of 1 ineh 6 lines, +1 inch 9 lines."

This was perhaps the eommonest butterfly in Sokotra, being almost equally numerous from sea level to an eleration of nearly 1500 feet. Wherever suitable bush eover occurs this species is plentiful. It is not met with in the more open eonntry, being always found among the open bush jungle, or aloug the erlges of the tiuy grassy glades or dry beds of streams. Its flight is feeble and irregular like that of its allies, and from its bush-frequenting habits individuals ane sometimes troublesome to net. We obtained both the 'wet' and 'dry' phases of this species, some examples having the ocelli on the under surface of the hinder wing largely dereloper, while in a few these markings were nearly olsolete. At Artho Dimellus, 3500 feet, our highest camp in the central Haghier range, it was particularly abundant, and numbers might be seen during the day time resting on the sugared posts put up for the eapture of nocturual lepidoptera. It was a constant visitor to our hreakfast table, spread in a sharly reeess overhung by bushes, often settling on the open pots of jam or tasting the chutnee. One peeulianity of this speeies is its unusual aetirity. It may be seen on the wing from early moming as soon as it is light till late in the evening after the sun has disappeared hehind the hills, and even on dull, clondy days, when other butterffies are seldom seen on the wing, it is constantly Hitting about among the bushes.

\section{NYMPHALINAE.}

\section{Charaxes, ochs.}

\section{Charaxes velox, Giunt. (Plate xviii.).}

Charares relox, (irant, Bull. Liverp. Muss., ii. 1) 10 (1899).

Wule:-Upper surfice most like that of the male of $C$. crnumi; under surface like that of the female of $($. cuntumbunlon but darker. General colour above of both wings dark chestnut. Primaries with the brownish-hlack submarginal band narower, and broken up, between the extremity of the discoidal eell and the ornamental sub-marginal 
row of chestuut spots, by two patches of chestnut relieved by brownish-black markings; the row of chestunt spots larger and with the margins much less sharply defined. Costal and median nervues pale green. Seeondaries with the hrownish-l,lack marginal horder much narrower, grarluaterl, and terminating in a point above the first median nervule. The six spots ornamenting this borler rounded and pale buff sharling into pale cream on the two nearest the anal angle. Anal angle with a well-marked green patch sharling into violet internally and ornamented by two romded hack dots, the same green eolour strongly indicated between the 1st median and discoidal nervules by three patches. A rufous buff werlge-shaped mark arising about the midrlle of the costal and extentling towards the apex of the cliscoidal cell. General colour of the moler surface altogether darker and browner than in the female of $c$. antumboulon, from which it chiefly differs in the following points :- The rlarker basal part of the band across the disc of the primary extenfts to the first disco-cellular nervule : the submarginal spots next to the posterior angle are larger and blackish enclosing a lilac spot. On the secontaries the internal horder of the spot at the anal angle, as well as of those along the hinct margin, is greyish violet. Expanse, 3.05 inches.

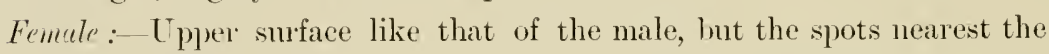
costal margin rather larger and more oblong; general eolour of the under surface much greyer than that of the male, but with similar markings. Expanse, $3 \cdot 35$ inches.

Hubitut. Sokotra, from nearly sea-level to an elevation of at least 4000 feet, where it becomes searce.

This splendid new species was our most important addition to the list of the butterflies found in Sokotra. Considering how plentiful it is, and how widely distributed, it seems strange that it should have hitherto escaped eapture, hut no doubt this is clue to its wariness, remarkably swift flight, and the diffieult nature of the ground it generally frequents. The speeies was first met with on the 15 th December, one or two examples being seen in a dry, rocky water-course on Gebel Riaggit, one of the outer spurs of the Haghier range to the south of our camp on the Hadibu Plain. I failed to seenre a specimen, but found a nearly full-grown larva (fig. 3) feeding on a sloe-like bush (Itivichletiu oborutu, Balf. fil) so common on the lower slopes of the hills. This larva prupated (fig. 4) on the 27 th of December, and a male Charaxes hatched on the Sth of January. A second larva was afterwards fomd and preserved. This butterfly was met with in suitalule localities from nearly sea-level to an elevation of at least 4500 feet, but its mmbers gradually diminished as the higher ranges were reached. It was particularly numerous in the Adda Valley to the east of the Hadilu Plain, and in the neighbourhood of onr camp at Jena-agahan, 1200 feet on the northern slopes of the Haghier range. Its farourite haunts are the steep, dry, boulder-strewn water-comrses 
overhung by bushes and trees. During the hottest part of the ray it is rery fond of sumning itself on the limb of some dead tree, or on the tip of an overhanging hanch, sailing every few minutes to some fresh point. The Hight is extraorlinarily swift and strong, very different from that of its ally C. bulfouri. The romgh nature of the ground makes it generally impossible to follow it on the wing, and though one oceasionally succeels in netting one as it lashes past, by far the hest mode of capture is to stalk them. As soon as the Chalaxes settles, follow him up, stepping quickly and quietly from rock to rock, and when within striking distance a punck sweep of the long-landled kite net is generally suecessful. A pail of boots with very thick indiarubber soles will be found invaluable for such work, for in these one can move orer the houlders without making a sound, anrl with little fear of falling, though it must be added that granite rocks soon play havoe with even the strongest soles.

On rull, cloudy days, or in the early morning and towards evening, this speeies may often be found at rest among the banches of the bush Euphosbias, and may then occasionally be boxed or taken with the finger and thumb. Many of our funest examples were secured in this way, for in the net the long swallow tails often get damaged before the butterfly ean be got into the killing bottle.

On the limestone hills round Homhil, at the east end of Sokotra, this species was only rarely met with, while $C$. bulfuri $i$ was comparatively colmmon.

6. Charaxes balfouri, Butl. (Plate xix. figs. 1, la $0^{+}$.)

Charceres balfouri, Butler, P.Z.S., 18s1, p. 176, pl. xviii. fig. 6 ( $q)$.

I). Butler's description of the Type is as follows:-

"Femule:-Allied to C. rurenes, from which it differ's as follows:--The outer" margins of all the wings dentated at the extremities of all the reins, that of the secondaries with two tails of the orlinary type, that at the end of the first median branch being rather short (3 to + millimetres), and that at the encl of the third limanch of about double the length, more slender and gradually tapering towards the point. Wings alove deep mahogany red, rather paler on the basal half; primaries with all the markings as in C. rerreses, excepting that the spots beyond the eell are not so black; secondaries with the rounded black spots only distinct towards the apex: onter border black with a marginal series of pale blue lumules fringerl with snow-white. Body laky brown, prothorax and head olivaceons. Under surface of wings very like C. vurun's, lut the general eolour greener, most like that of the darkest Natal specimeus, the black characters on the basal area better marked, the white stripe limiting the broad hasal area wider, more diffused externally, and distinctly angulated on all the wings; the ocelli on the secondaries slightly narrower, and the outer margin of these wings bordered with a series of large black and white lunules. Expanse of wings 8 inches 8 lines. 
"The allied species C' rurumes has hitherto heen referred to the genus Plitegnoma on account of its only having one peculiarly shaped tail to the secondaries; but the arrival of this form from sokotra necessitates its transfer to Churuxes, since we now possess a species with the structure of the latter genus, and the general character of the supposed I'hitornomu."

"Mrele:-Similar to the female, but smaller Expanse of wings 2 inches $\$ 10$ lines to 3 inches. One exceptionally large male taken at Arlho I)imellus, in Fehruary, (liffers conspicuonsly from all others, in wanting the onter row of pale sulmarginal spots."

It was not until we reached the limestone ranges at Homhil, at the east end of Soliotra, that we met with this splendid butterfly. There, in a small rocky valley, traversed by a clear, rushing stream, overgrown with clumps of boxwoor bushes and various other shrubs and trees, inchuling fine examples of the Iragons-bloorl, we fell in with a brood, and secured some splendid examples of hoth sexes. A large bush, bearing small brownish nuts, appened to be specially attractive, and some of these butterflies, mostly females, were generally to be found hovering round the lower lranches, and it may therefore be presumed that this is one of the food plants.

This species, unlike $C$. mlox, is comparatively easy to capture on the wing, the Hight being neither so swift nor so strong. It was afterwards met with in the Adda Valley to the east of the Harlibu Plain, and subsequently at Artho Dimelus in the Haghier range up to an elevation of at least 4000 feet, but on the granite ranges it appeared to be decidedly rare. At Homhil, where it was fairly numerous, C. velor was but rarely seen. The Charaxes, like all the large strong-flying butterfies, rery soon damage their wings, and examples in fine condition, with all four tails complete, are seldom to be caught. Many specimens of $C$ : lulforri were so clamaged that it would have been useless to kill them, and out of perhaps 50 netterl, only half a dozen or so were perfect, and perhaps twice that number worth keeping. Only the female of this fine species was previously known, a somewhat worn example having been collected by Professor Bayley Balfour, in whose honour it was named.

\section{Hypolimnas, Hübn.}

7. Hypolimnas jacintha, Imury.

Papilio jacintha, Drury, Ill. Exot. Ent., ii. pl. xxi., figs. 1, 2 (1773).

P'apilio acia, Filhr., Ent. Syst., iii. 1, 1. 111 (1793).

The occurrence of this magnificent north Indian species in Sokotra was must mexpected. How it came there no one can tell, lut it may have been acciclentally introduced. It is certainly the rarest butterfly in the island, for during our three months' stay only eight were seen, and three secured. While at I)ahamis our taxidermist, Mr. Cutmere, 
reported having seen on the 2 lst Decemher a very large dark hutterfly with white latticed markings on the hind-wings, which was doulstless a female of this species : lut though I carefully searcher the neighhoulhood, nothing more was seen of it. It was not mutil the 30th of December that I saw and eaught the first specimen-a male in perfect condition. I shall never forget the excitement of that capture, for I fully believed that it would prove to he a new species. After a long tramp up to our new camping gromel at Jena-igaham (1200 feet) on the northern slopes of the Haghier range, we were all enjoying a well-eamed rest, when suddenly I beheld a magnificent butterfly smming its wings on a granite rock close by, and a few seconds later the prize had been securely placed in the largest killing hottle. I canght two other specimens near this camp, a male and female, the former haring the wings latticed with eream colour like those of the female. I also saw two more which I was malle to eatch.

One female was seen at Homhil on 25 th Jamary by the Somali boy who accompanied me, and lastly a male was seen at Arlho Dimellus (4500 feet) on the 15th of Feluruary.

It will thus be seen that the species was thinly distriluterl over the greater part of the island risited. The flight is remarkal,y powerful, and on the wing this insect looks very large, and more like a bird than a butterty. At Jena-agahan, the only place where I personally saw the species, four ont of the five seen were met with in the houlderstrewn lred of a dry watereourse. They loved to sum themselves among the granite rocks, where it was extremely difficult to cateh then without tearing one's net to pieces.

\section{Hypolimnas misippus, Liun.}

Papilio misipums, Linn., Mus. Ulr, p. ㅇt (176t).

Ilypolimna* misippus, Dixey, P.Z.S., 1898, 1. 379.

This handsome and widely distributed species was met with on the lower gromuls of Sokotra borflering the north coast, lnt I lo not remember ever ohserving it at any of om higher camps.

It was most mumerons, thongh not common, on the Thyme-covered Plain of Hadibu in the neighlombood of om first camp on the Hanefu river, where the females were often mistaken at a short distance for Limuas shrysingus, limn., which is faily common on the same ground. All the females of this species were of the ordinary form, shewing $n$ tendency towards the var. alrippoillos, Butl.

A few examples were met with on the bush-clad Garieh Plain, below Jena-agahan, and in the I)imichiro Valley.

The flight of the male is very strong, and it is generally a troublesome butterfly to net. Mr. Bennett notes that he met with this species "chiefly in the hills," but my observations, recorled at the time, were exactly the reverse. 


\section{Pyrameis, Hübn.}

9. Pyrameis cardui, Linn.

Papilio curdui, Linn., S.N., i. pl. ii. p. 774 (1767).

Pyrameis cardui, Butler, P.Z.S., 1881, p. 177; Dixey, P.Z.S., 1898, p. 379 .

The Painted Larly was common on the low ground of Sokotra, the wild Thyme on the Hadibu Plain proving especially attractive.

\section{Precis, $H$ bn.}

10. Precis clelia, Cramer.

Papilio clelia, Cramer, Pap. Ex., i. pl. ii. E. F. (1775).

Junonire relix, Dixey, P.Z.S., 18!18, p. 379.

Mr. Bennett found this species "very common in the mountains" of Sokotra and collected six examples, two males and four females. Curiously enough, I never came across it, and it was the only butterfly previously known that was not procured.

On the other hand, we oltained twenty-three species of butterflies, seren of which were new to science or to the island, and among the latter were examples of l'recis relurue not met with by either Professor Bayley Bilfour or Mr. Bennett.

11. Precis cebrene, Trimen.

Junonir celmene, Trimen, Tr. Ent. Soc. Lond., 1870, p. 353.

This is another low ground hutterfly, and we found it decilledly scarce ; but as most of the specimens seen in the early part of December were faded and dimaged, it is quite possible that earlier in the season the species may be commoner. Almost all the examples captured were taken on the Hadibu Plain in the neighbourhood of the Hanefu river. The farourite haunt of this species was a part of the plain corered with elumps of "hush grass" and stones on which it loved to settle and display its gorgeonsly colourerl wings. It is a shy butterfly and tronblesome to net, its flight being very strong, and, if once misserl, it seldom affords a second chance.

\section{Atella, Doubl}

\section{Atella phalantha, Imiry}

Papilio phalantha, Drury, IHI. Ex. Ent., pl. xxi. fig. 1, 2 (1773).

A locally common species on the middle and higher slopes of the Haghier range from an elevation of about 1000 to 3000 feet. We first met with two examples of this handsome butterfly on Moukaradia (600 feet) hovering over some flowering bushes on the sicles of a dry tolrent bed, and subsequently foumd it fairly numerous ahove Dahamis (1600 feet), on the 21 st of December, on one of the small open platean corered with spear grass, where numbers were hovering romul a large sort of tree-iry. A few were seen ahout our camp 
at Jena-aghan, and many on a platean on the pass helow Adho Dimellus (3000 feet, 18th of Fehrnaly). The flight is mneh like that of the Fritillary, which it resembles in ontwarl appearance, and, generally speaking, it is an easy butterfly to net.

\section{Byblia, Hübn.}

\section{Byblia boydi, llixey.}

Mypmix cora, Butler (nee Feisth.), P.\%.S., 1881, p. 177, pl. xviii. fig. 4.

Byblice boydli, Dixey, P.Z.S., 1s98, p. 375, pl. xxx. figs. 1 o and 2 \%.

Mr. Dixey has described the Types as follows :-

"Distinguishahle from the 'dry season' form of B. gittius Herbst., and B. anruturl, Boiscl., ly the following particulars:-(1) The area of fulvons ground colour lying between the hack submarginal band and the olliqne median black patch on the disc of the fore-wing is in B. boyli divisible into two portions, separated by a pair of black denticulations, which almost meet one another along the conrse of the first median branch. Of these two portions, the posterior is conspicnonsly narrower than the anterior, the narrowing being cansed mainly by the encroachment ontwards of the obliqne median patch. The ontline of this latter patch in the allied forms tends rather sharply inwards letween the first median lranch and the dorsal border, but in B. boydi it is continued to the dorsal horder at such an angle as to preclude the fulvous area from expanding again posteriorly, as it does in normal B. gïtzins. (2) A chain of small black spots is more or less visible, crossing the fulvous median area of the hind-wing upperside. These spots, which correspond to a series constantly present in $B$. ilithyiu, Drury, are only rarely indicated in B. götsins. The above characters appear to be constant and distinctive. One or more of the following features may be found in specimens of $B$. yijt:ius from various localities on the mainlind, but they do not oceur all together except in B. boydi, where the combination appears to be constant:(1) The black costal bar of the fore-wing is eontinued across the wing to meet the submarginal black bant. (2) The fulvons submarginal spots of the hind-wing upperside are large, subeonical, and only slightly separated by the black-coloured reins. (3) All the black markings of the upperside are highly developed, especially the submarginal band of the hind-wing, which encroaches considerably inwards. In the presence of the chain of small median dark spots, and in the large size of the fulvons submarginal spots of the hind-wing, B. boyrti approaches b. ilithyin; in other respects it is much nearer B. gützins. The combination of characters above given renders the Sokotran form easily recognizable among its allies, and seems to justify its separation as distinct."

This is one of the commonest buttertlies in Sokotra, and universally distributed from the lower slopes of the hills to an eleration of at least 4000 feet. Though I never saw it on the wing on the Hadibn 
Plain, it must occasionally occur there, for I found the remains of one which had evidently been eaten by some bird close to our first eamp. It was perhaps most numerous on the higher ground, being especially abundant roum Adho Dimellus. There it was to be found in all the glades and openings among the bushes, and splendid freshly hatehed eximples were constantly to lre met with. It is difficult to imagine a more pleasing contrast in colour than the rich chestunt and black wings of this butterfly resting on the clnsters of pale lilae blue Howers of the Gentians (Exucum affine). We noted nothing very peculiar in its habits; the flight is not very rapid, and it is easily caught.

Ont of a rery large number of perfect specimens taken, many of which were preserved, larrlly any variety of marking was observed, all being wonderfully alike, and it may therefore he presumed that the characters of this insular species are constant.

\section{ACRÆEINÆ.}

\section{Acræa, Fabr.}

14. Acræa neobule, Iroubl.

Acrra neolule, Doubl, Hew. Gen. D. L., pl. xix. fig. 3 (1S4S).

Acrea neolnte, Butler, P.Z.S., 1S81, p. 177, pl. xviii. fig. 5 ; Dixey, P.Z.S., 1895, 1. 374 .

This lovely butterfly, first met on the lower bush-clad slopes of the Haghier range, was found in gradnally inereasing numbers up to an eleration of at least 4500 feet. It was erfually abumlant on the limestone range round Hombil at the east end of Socotra. On the higher grassy slopes round Adho Dimellus (3500 ft.) it positively swarmed in places, and was to be seen in all directions resting on the tall grass stems, slowly moving its wings in the brilliant sunshine and looking like some lovely flower. There can be little donbt that the lrilliant scarlet of the wings fades after death. Possibly this may be due to the damping process which is unavoidable when hutterflies have to be relaxed lefore they are set. Most of the specimens were in snch splendid condition that even after a good series of perfect examples had heen captured we found it difticult to refrain from taking just one more.

Though not swift the flight of this insect is rery beantiful ; after a few beats of the wings it sails gracefully along over the tops of the lushes for a considerable distance, hovering here and there or resting for a few moments on the flowering shruhs and plants. Though easily canght it is very tenacions of life, and we frequently fomd it come to life again after a sojourn in the killing bottle ealculated to kill any ordinary hutterfly. The males are apparently very mueh more numerous than the females. 


\section{LYCÆNID必.}

\section{Tarucus, Moore.}

15. Tarucus socotranus, (immt. (Plate xix. figs. 2, 2a, 2h).

Tarmcus rorotranus, Giant, Bull. Liverp. Muss., ii. p. 10 (Is99).

Mrule:-Most nearly resembles the male of $T$. plinine, var. fulchre, the upper surface heing practically alike in both, but on the under surface the pattern is quite different. The sub-marginal hands across the discal area of the primaries are continuous and rmu parallel to the margin. On the hinder wings, this peculianity is even more marked, the seeond sub-marginal hand being unusually wide and uninterrupted, while the dusky band within is ornamented in the middle by a clearly defined long oval spot of hlackish girdled with white. lixpause 1.2 inch.

Frmale:-Much like the female of T. trlicanus, lut with the general colour of the upper surface darker sooty brown and more miform, the lighter pattern above heing inconspicuous; the llack spot between the first and second median nervoles oblong and margined above and below with white bands; the moler surface like that of the male.

Hellitut. Sokotra.

We met with this handsome Blue both on the plains and on the ligher slopes of the hills. It was perhaps most numerous in the pass helow Arlho Dimellus, at an elevation of about 3000 feet. It is a hushfrequenting species, and was invariably to be seen Hying round the larger flowering shrulss or at rest on the leaves.

16. Tarucus quadratus, Girent. (Plate xix. figs. 3, 3a, 31,).

Turucus theophrastus, Dixey (nec Falr.), P.Z.S., 1898, p. 380.

Tarucus quadratus, Grant, Bull. Liver1. MIuss., ii. p. 10 (1899).

Itule:-Most nearly allied to the Sonth African form of T. Aheoplerustus, the upper surface being very similar, but the black sul-marginal markings on the secondaries are reduced to two well-defined spots, one sitnaterl at the anal angle, and the other letween the first and second median nervules. The under surface of the primaries differ's conspicuonsly in having a large sub-quadrate black patch sitnated between the costal band and the black hand crossing the middle of the wing ; the patch commences about the middle of the sub-median nervule and extends to the anterior angle of the discoidal eell. Expanse 0.9 inch.

Frmule :-Most like the female of the South Afriean form of T. theopherestus, but the row of spots along the hind margin of the secondaries is more widely edged with white; under surface like that of the male. Expanse, 0.75 inch.

Hulitut. Sokotra.

This beautiful little butterfly, which we knew as the "Zebra-blue" on account of the markings on its under surface, was first seen among the young date-palm groves on the lanks of the Hanefu river, and subsequently met with in the Arda Valley and Goahal Gorge at elevations 
not exceeling 500 feet above sea level. It was not seen at any of our higher camps, and is apparenty comfined to the low glomol. Like $T$. socotiuns it is a bush-frequenting species, and spends most of its time hovering romul the smaller trees and flowering shrulss. Though nowhere very common, it was fairly plentiful in the Goahal Valley below Homhil, and in the Adila Valley to the east of the Hadibu Plain.

\section{Cacyreus, Butl.}

7. Cacyreus lingeus, Cremer.

Papilio lingens, Cramer, Pap. Ex. iv., pl. ecclxxix. F. G. (178:2).

This species was met with on the plains and on the lower and midnle slopes of the Haghies range up to an elevation of ahout 3500 feet. The halbits are very similar to those of the two species of Tomerns previously mentioned.

\section{Chilades, Moore.}

\section{Chilades trochilus, Freyer.}

Lycena trorhilus, Freyer, Nenere Beitr., v. pl. 440 fig. 1 (1844).

This lovely little Argus Blue was only fomd in the Goahal Gorge below Homhil.

\section{Zizera, Moore.}

\section{Zizera knysna, Trimen.}

Lycrence liny:un, Trimen, Trans. Ent. Soc. Lond. (3), i. 1. 282 (1862). Zizera lysimon, Dixey, P.Z.S., 189s, 1. 380.

Very abmulant everywhere from sea-level to an elevation of at least 4000 feet. Unlike the other Blues mentioned ahove, this little butterfly is essentially a ground species, preferring the stony plains, mountain paths, and similar open spots, where it is always in eridence either smming its wings on the ground or darting about at a great pace in pursuit of its fellows.

As it is always lather a troublesome matter to obtain perfeet speeimens of Lyecenider, I shonld like to draw the attention of field eollectors to the following points. All the Blues when placed in a killing bottle lave a most perverse halit of dying with the upper surface of their wings exposerl. If attended to at once, with the aid of a fine-pointer pair of forceps, which should always be earried, the wings can he easily reversed, hut if left a minute too long, rigor mortis sets in and it is then impossible to move them. It is of eourse essential to leave all specimens in the fumes of the cyanide until they are quite dead, so, after attending to the wings, they should be replaced in the killing lottle, for, however carefully the latter may he carried, the exposed surface of the wings is sure to become more or less rubled hefore the butterfly can be safely transferred to the zine pocket hox. If placerl in paper envelopes with the upper surface of the wings ontermost 
butterflies not only get rubher, lout are very much more diffieult to pin and set when relaxed. These remarks of comse lo not refer to such specimens as may be collected to show the muder surfice.

\section{PAPILIONID必.}

\section{PIERINA.}

\section{Teracolus, Swains.}

20. Teracolus niveus, lintl.

'Terucolus nireus, Butler, 1'.Z.S., 1881, p. 177, pl. xriii. fig. 1; Dixey, P.Z.S., 1898, 13. $38 \%$.

The Types have been described hy I): Butler as follows:-

" \& Nearest to T. exuyore, demugore, and liugnr, but differing from all in the considenably smaller extent of the orange aprical patch on the primaries. Wings above, snow-white; primaries above with a narrow triangnlar, orange, apical patch from eosta to third median branch, hounded externally by five hastate black spots, and in front by an abloreviated black costal line: body hack, tholax clotherl with silvery hairs, abdomen cream-colomed at the sides. Under surface white, each wing with a small black dot at the end of the cell, primaries indistinetly showing the orange of the upper surface through their texture; secondaries with a greyish costal spot, and one or two dots of the same colour ou the dise beyond the cell, basi-ahdominal area slightly speckled with black. Expanse of wings 1 inch 5 lines.

" q Snow-white, base speckled with blackish: primaries above with a dot at the end of the cell, four spots in an oblique series, more than half-way between the eell and apex, and four or five squamose marginal spots between the apex and the third median branch, back; secondaries with four deereasing marginal black spots between the apex and the second median branch: body blackish, elothed with white hairs, but rather paler than in the male. Primaries below white, a black dot at the end of the cell: four brownish spots in an oblique series, limiting the inner edge of the apical area, which is eream-coloured and speckled with grey : secondaries cream-coloured speckled with grey ; a black dot at the end of the eell ; an angulated series of seven more or less distinet brownish spots aeross the dise: body snow-white. Expanse of wings 1 inch 4 lines."

The Larger Orange-tip was very common on the lower and midalle slopes of the Haghier range and at Hombil up to an elevation of about 2000 feet. It frequents the thin jungle and small open spaces along the sides of momtain torrents, and is constantly to be seen flitting along close to the ground, threading its way among the stems of the bushes. 'The flight, though mueh stronger than that of the smaller' form $T$. cumblidus, is decidedly slow, and there is never much difticulty in securing any partieular individual.

The large series of specimens collected shows considerable rariation both in size and markings. Some males have the orange patch at the tip 
of the fore-wing, pale in colour and much recheed in size; while in others it is large and sharlerl internally with rermilion. The black markings in the fenales vary greatly in intensity. Towalds the end of January most of the examples seen were very worn, and huring our return to the coast in the mirldle of February harlly any were met witl.

\section{Teracolus niveus, var. candidus, Butl.}

Teracolus cundidus, Butler, P.Z.S., 1881, p. 178, pl. xirii. fig. 2.

The following is the description of the Types:- -

"of Allied to the preceding, but smaller"; the primaries with an oblique subapical orange patch, five pyriform marginal black spots; secondaries with two apical marginal black lots: below much as in $T$. mireus. Expanse of wings 1 inch 2 lines."

" $q$ Chiefly differs from the preceding in its smallel size and less pronounced markings. Expanse of wings 1 inch 2 lines."

The Smaller Orange-tip, though less plentiful than the larger form, was met with in the same localities, and readily distinguished on the wing by its much smaller size and feeble flight. The very small examples which form the bulk of the specimens collected look so very different from typical $T$. niveus, whether male or female, that one is at first rlisposerl to believe they must belong to distinct species; but in the large series collecter smaller examples of the latter so closely approach larger individuals of $T$. cumlidus that it appears to be impossible to separate the two forms specifically. I think it is a mistake to suppose that $T$. nirens is the wet season and T. andidns the dry season form of the same species, for loth were plentiful on the wing in December and Jamuay, and had almost disappeared by the middle of Felnuary.

\section{Catopsilia, Hübn.}

22. Catopsilia florella, Fulr.

Prepilio florellu, Fabr., Syst. Ent., 1) 479 (1775).

C'atopsilia pyrene, Butler, P.7.S., 1881, p. $17 \mathrm{~s}$.

C'atopsilia florella, Dixey, P.Z.S., 1898, p. 381.

This species was especially common on the Hadibu Plain in December, when hundreds might be seen on the wing flying in every direction, or hovering over the sweet-scented wild Thyme then in full bloom. It is essentially a butterfly of the plains, hut was occasionally met with "1) in the Haghier range on the open grass plots.

23. Catopsilia florella, var. aleurona, buttl.

Cutopsilic aleurona, Butler, Ann. and Mag. N.H. (4), xviii. p. 489 (1876).

24. Catopsilia florella, val: pyrene, Swains.

Colias pyrene, Swains, Zool. Ill., i. pl. 1i. (1821)-21).

Besicles the typical form these two varieties were obtained on Sokotra. Both were rare, and only seen on one or two oceasions. 


\section{Belenois, Hübn.}

25. Belenois anomala, Butl. (Plate xix. fig. 4, o.)

Synnchloë anomula, Butler, P.Z.S., 1881, p. 17s, pl. xviii. fig. 3 (\&).

Belenois amomala, Dixey, P.Z.S., 1895, 1. 380.

1). Butler gives the following rleseription of the Type:-

"Femule:-Most like Syndhore protortire of North Ameriea, but larger than any speeies of the gromp. Wings alove white, specklerl with hlack seales at the base: primaries with the costal horler to the end of the cell heavily l,ack-speckled ; a large sulwuadrate black spot on the rliscoeeffulars: a very irregular black discal band formed of large ohlong spots altermating with lumules, only separaterl from a rather lnoad extermal borler hy a series of six meepual white spots: this horter is lroad at apex, and gradually tapers to the external angle; secondaries with angular sulmarginal series of five hlack spots (the first on costal border large and (puadrate), separated from a tapering hrow border by spots of the gromd colour, as in the primaries; body above blackish, elothed with silky grey hairs: prothorax clothed in front with short brown hair: palpi white, with brown edges; antemne pale brown. Under surface white, broarly lut sparsely speckled with black seales towarls the base; primaries with the diseocellular spot, thiseal hand, and rlusky hasal half of costa as above; outer border olssolete, this part of the wing heing, however, apparently greyish owing to its semi-transparency, and slightly shot with pink: secondaries with slight pink reflections; the markings of the upper surface only indistinctly visible through the texture of the wing; hody helow white. Expanse of wings 2 inches 6 lines." Some of the females we obtained measure 2 inches 9 lines.

Mule:-Most nearly resembles the female, but the general colour of the wings is white, and the black markings are fewer and reduced in size. The irregnlar black discal band on the primaries is broken, the alternating lumles leing lut faintly indieaterl or alsent. On the secondaries the sulmarginal series of llack spots is reducerl to three. The first and second are well marked and situaterl as in the female, but the thind is placed between the 2ml and 3rol nervules and indistinct. The under surface is similar to that of the female.

Expanse of wings 2 inches 8 lines.

We found this handsome white lutterfly thinly distributed from the lower granite slopes of the Haghier range up to an elevation of ahout 4000 feet, and on the limestone ranges alwont Homhil. It is one of the most diffieult of all the Sokotran hutterflies to eatch, for it rarely approaches the gromml, and generally travels along at a great pace over the tops of the bushes and trees, fifteen or twenty feet from the gromnd and sometimes much higher. It rarely seems to settle, and then only for a few moments on some inaccessible flower.

Though a fair number may be seen daily on suitalle ground, it is only now and then that an odd specimen can be seenred. Individuals may 
occasionally lie fonnd settled on a flower within easy reach, but this is prite exceptional, and, as a rule, the nature of the ground renders pursuit impossible. Being anxions to olitain a full series of this butterfly, I found it necessary to pay special attention to its habits, and by doing so erentually secured a number of perfect eximples of both sexes. By watching closely it soon hecame evident that most of the individuals seen followed much the same line of Hight across the tops of the trees, and that every now and then this track descended from the higher lonaches and passerl orel the lower bushes, where it was just prossible to net them. By taking up a suitable position in the line of flight, and waiting patiently, it was possible to secure several in a morning, and on one occasion I managed to net as many as five perfect specimens in an hour. Many of the males were in such poor condition that they were not worth keeping. and no doulst in the course of their strong restless thight the wings soon become ramagerl. On several occasions I was fortunate enough to meet with pairs, hut though the females were perfect, the males were nearly always more or less worn.

The species was first described from a very worn and ragged female specimen brought home hy Professor Bayley Balfour in 1ss1: sulsequently a second example of the same sex was collected by Mr. Bennett. The male fignrerl in the accompanying plate was not previously known.

\section{Papilio, Linn.}

26. Papilio bennetti, Irirey.

Parilio bennett, Dixey, P.Z.S., Is98, p. 381, pl, xxx. fig. 3.

Mr. Dixey describes the Types of the species as follows:-

"Two specimens, both prohahly $\delta$, hut the abdomen of one is imperfect. These resemble I'. demolens, Limn., from the African mainland, but may be distinguished by the following characters:-(1) On the upper surface all the yellow markings are much reduced in size, and the second spot from the rlorsal border of the yellow merlian chain in the fore-wing is more or less Z/-shaped, instear of being irregularly rhombic as in I'. Armolens. (2) There is a broarl black area of almost miform width letween the merlian and the sulmarginal chains of yellow spots on the fore-wing. 'The corresponding area in l'. demolens is companatively narow, and conspicuously denticulated in consequence of the relatively large size of the median yellow spots. On the muler surfice the pale submarginal spots of the hind-wing are quadrate, or eren elongated in a rlirection at right angles to the horder of the wing: whereas in I'. demolens they tend to be oblong, with the long diameter parallel to the hind horder. The same applies to the series of rudimentary eye-like marks immerliately proximal to the yellow sulmarginal row. Another feature which is probalny distinetive is the fact that in the eye-like mark within the cell on molerside 
of the hind wing the blue elging with its accompanying hufl crescent extends only alomg the posterior side of the triangular black pateh, instearl of heing continum along two sicles, the posterior and the dorsal, as in l'. demoleus. An appronch to this condition may occasionally be seen in the latter species. Many specimens of $I^{\prime}$. demoleus fiom Aden resemble Ir. bennetti in the nurrowness of the pale merlian band of the hind-wing ; they differ, howerer, in the other particulars."

The Type is in the Hope Musermm at Oxford.

It was not mitil we reached om highest camp at Arlho 1)imellus (3500 ft.) in the Haghier range, that we met with this fine butterfly. It was first discorered by Mr. Bemett, whose name it bears, neal the summit of Gelel Dryat, a huge granite peak, the highest in Sokotra, rising some miles to the east of our camp. 1)uing the first few days of om stay mone were olserved, lut on the 3rel of Felnully I saw one flying at a great pace along the bush-clad hillside near our camp, and Dr. Forles reported that he hat seen two more, so it was evident that the species had hegun to make its appearance. On the 6th of Felnuary, accompanied by .Jama, ou excellent Somali butler, I made a special expedition to the top of a high point in the neighbourhoorl, and on reaching the summit foumel two fine P'upilio on the wing. Their flight was very strong and rapid, and so far as I saw they never settled during the hours we watched them, but continued their marl carcer up and down the bare granite elifts, every now and then descenting to take a turn orer the thick bush suromoling the base. Like many other lutterHies, they seemed to have partieular lines of Hight, so after watching their manourres we posted ourselves on suitable lexlyes. But luck was against us, and during three hom's patient waiting in the lnoiling sull we never once got so much as a chance of netting one. One hates being beaten, and as a last resonce I determined to try shooting one. Taking most of the No. 12 shot out of a light cartridge for the collecting gun, I waited my chance and made a good shot at one as it crossed the hushes. The result, though apparently satisfactory, proved disastrous, for almost the whole charge had gone through the wings, and the splendid insect was utterly rumed. Subsequently, however; I was more successful, and with the airl of two of our Somalis, we gradually mate up a fair series, a good many leing in perfect condition. A large number were seen on the highest ground on the Sth of February, and harl we been alble to remain a few days longer, many would certainly have been added to the collection, hut as it was we got sufficient. It is essentially a butterfly of the granite peaks, and the few captured lower down ahout our camp at Arlho Dimellus were all males and evidently stragglers in search of a mate. This is a difficult hutterfly to follow with the eye, the flight being very rapid while the mottled yellow ant black markings of its quickly lreating wings prodnce an indefinite colour hard to distinguish from the surlounding oljects at any great distance. 


\section{HESPERIID压.}

\section{Gegenes, Hübn.}

27. Gegenes occulta, T'rimen.

Pamphilu acculta, Trimen, 1\%.\%.s., 1891, p. $11 \% 3$.

Gegenes nostradamus, Dixey, 1'./.S., 1898, p. 35'.

This small, widely distriluted skipper was far from (common in Sokotra, and most of the specimens captured were in more or less worn condition. I first met with a single example on 17 th of l)ecember in the lod of the Hanefu river elose to on eamp at Hadibu, and subsernently captured several, hoth in the (Goahal Gorge (1200 ft.) below Homhil, and at Arlho Dimellus (3500 ft.), the highest pass in the Haghier lamge. It wats also met with at one ol two other places, always singly. It appears to learl a somewhat solitary existence, fresuenting the diy rocky paths, where it may occasionally be seen bustling along at a great paee, or resting to sun its wings on the gromol. The flight, though very rapid, is selrlom long sustained, and, as it eonstantly settles, it may he easily captured if carefully approached.

\section{Rhopalocampta, Wallengr.}

28. Rhopalocampta jucunda, Butl. (Plate xix. figs. 5, 5a, 5b, 5e.)

Hesperiu jucumle, Butler, P.Z.S., 1881, p. 179, pl. xviii. fig. \&.

Rhopelocempta jurunda, Dixey, P.Z.S., 1898, 1). 38:2.

Dr. Butler's description of the 'Type is as follows:-

"Dull blackish brown: primaries shot with shining green and lnonzy" lown towards the base; edge of costal margin yellow towads the base, but white towarls the apex: fringe of outer margin snow-white : secondaries with costal border and anal angle velvety black; the hairy clothing of the basal area greenish-grey, of the abrominal fold pale testaceous; a patch of ochreons hair just above the anal angle ; fringe with an ochreous basal line, externally snow-white to the first merlian hanch, where it changes to bright reddish-orange: head and thorax rery dark green; the palpi (excepting their terminal joint and external margin, which are velvety llack), a spot at the base of each antema, and the back of the hearl bright reddish-orange; alodomen dull black, with greyish hind margins to the segments, anms surromuled by redlish-orange hairs. Wings below grepish-hown: primaries with a large diffused pupplish-hlack basal patch ; costal margin orange towards the base, lut afterwards white: an abloreviated line on the submedian vein, a second on the inner margin, and the fringe white: secondaries with the fringe as above; a triangular spot within the end of the cell, a large elongater patch enclosing a black spot on the interno-median interspace, and an interrupted syumose streak ruming upwards towards the apex from its external extrenity orange; a circular spot near the outer margin on the interno-median intersace, and a second at anal angle confluent with the fringe, recldish-orange ; 
pectus blackish ; femora and tibie streaked with pale huff and clothed with long resldish-orange hair's, venter black at the siles, with two or three small orange dots; a hoad contral lomgitudinal reddish-orange stripe. Expanse of wings of 2 inches 6 lines, $q$.2 inches 9 lines.

"The species comes nearest to II. trminis."

This handsome skipper, first discovered hy Professor Bityley Balfour, is one of the most abunclant hutterflies in Sokotra, and is met with from sea-level to an clevation of at least 1000 feet, where the bush ceases. Though a few were seen from time to time crossing the Hadihu Plain at a great pace, these were merely stragglers from the hosts that frequent the thick hish that corers the sides of the hills. Here they are constantly to be seen on the wing, moving with heary flight and quickly vibrating wings among the foliage, or hovering over the flowering shruls and looking more like great dark moths than buttertlies. So fall as 1 olserved, and I must have seen thousinds, they never settle on the ground, but always on the stems of the lushes, where they may constantly he seen resting with closed wings, showing the handsome orange yellow yattem on the under surfice. Among the bush they are very easy to catch, heing in no way shy, and one has only to wait for a favourable opportunity, which som presents itself. We fomd large numbers of the extremely handsome larva (fig. 5a) of this skipper feeding on a shruhhy species of Fïns, and a number pupater in a breeding calge. The caterpillan spins one on' two of the leares together and forms a shelter, within which the chrysalis (fig. ac) is suspenderl. The latter is at first of a heautiful pink colour, inclining to crimson in places, lut soon changes to dull yellowish white. The lanve of this skipper remains in the pupa stage for about thirty-four days, for the first which spun up ahout the :0th of Jannary dicl not hatch till the 23rd of February, the day we left Sokotra and went on hourl the 'Elphinstone.' Besides ahont fifteen pupa and some larve of this skipper, I took on board numerous chrysilicles of other species, including some large hawk moths, probably of the sharp winged species alrearly met with. These came to an untimely end, heing all destroyed by thousands of tiny red "ship ants" in a single night. Not one esenped. It was a most unfortumate encling to on otherwise successful expedition, and meant the loss of much time and trouble. 


\section{II. - The Butterflies of Abd=el=Kuri.}

NYMPHALIDÆ.

LIMNAINAE.

\section{Limnas, Hübn.}

1. Limnas chrysippus, Linn.

See page 295 .

Sereral examples of this form were captured on Abd-el-Kuri.

NYMPHALINÆ.

$$
\text { Pyrameis, Hübn. }
$$

2. Pyrameis cardui, Limn.

See page $30 \%$.

The Painted Lady was common on the northern slopes of the high mountain overlooking our anchorage at Bandar Saleh.

\section{PAPILIONID压.}

\section{PIERINAE.}

\section{Catopsilia, Hübn.}

3. Catopsilia florella, Falu.

See page 308 .

One or two specimens of this speeies were taken during our first visit to this island in the beginning of December, 1898 , and were then in poor condition. 



\section{PLATE XVIII.}

CHARAXES VELOX., Grint, p. 297.

Fig. I. Frmmle, upper sirle.

Fig. Ia. Femule, muler sille.

Fig. 2. Mule, under side.

Fig. 3. Full gronen lerve.

Fig. 4. Pим 


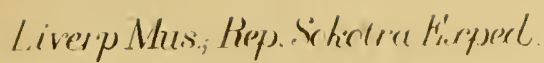
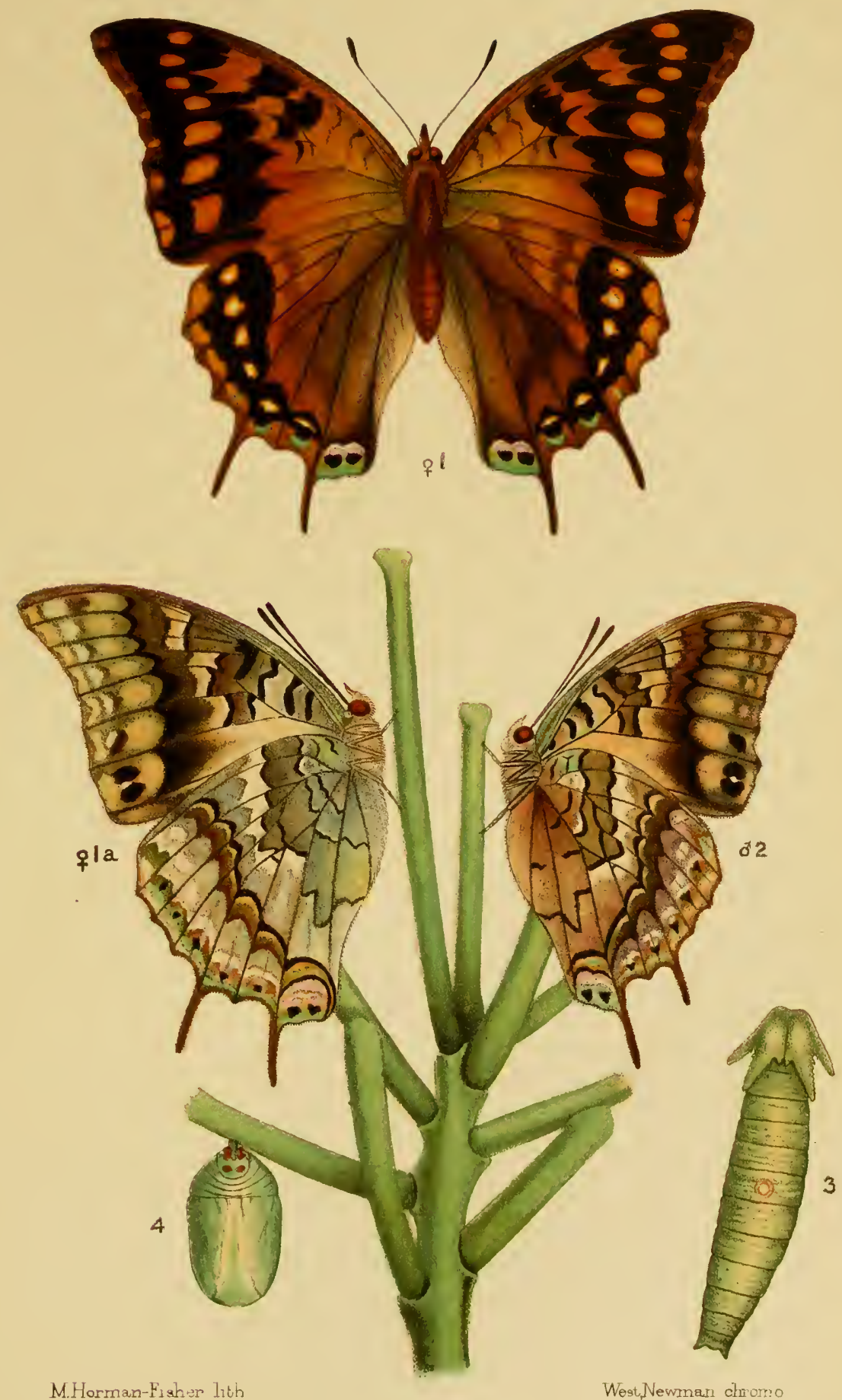


\section{PLATE XIX.}

Fig. 1. CHARAXES BALFOURI, Butl., ot, "pper sufuce, p. 299.

Fig. Ia. The stune, unter surfure.

Fig. 2. TARUCUS SOCOTRANUS, Gimut, ô, "lpmer surfure, p. 305.

Fig. 2a. The stume, mulet suffure.

Fig. 2b. The serme. o, upper suefuee.

Fig. 3. TARUCUS QUADRATUS, Girut. ơ, "lpper surfure. p. 305.

Fig. 3a. The strue, under surfine.

Fig. 3b. The sume, o, "ppwer surfuce.

Fig. 4. BELENOIS ANOMALA, lintl., o. "upre suffare, p. 309.

Fig. 5. RHOPALOCAMPTA JUCUNDA, Butl., unter surfure, p. $3 \mathbf{I z}$.

Fig. 5a. Litrin of sume.

Fig. 5b. Fiont vien of heal of larre of seme.

Fig. 5c. l'upu of setme. 

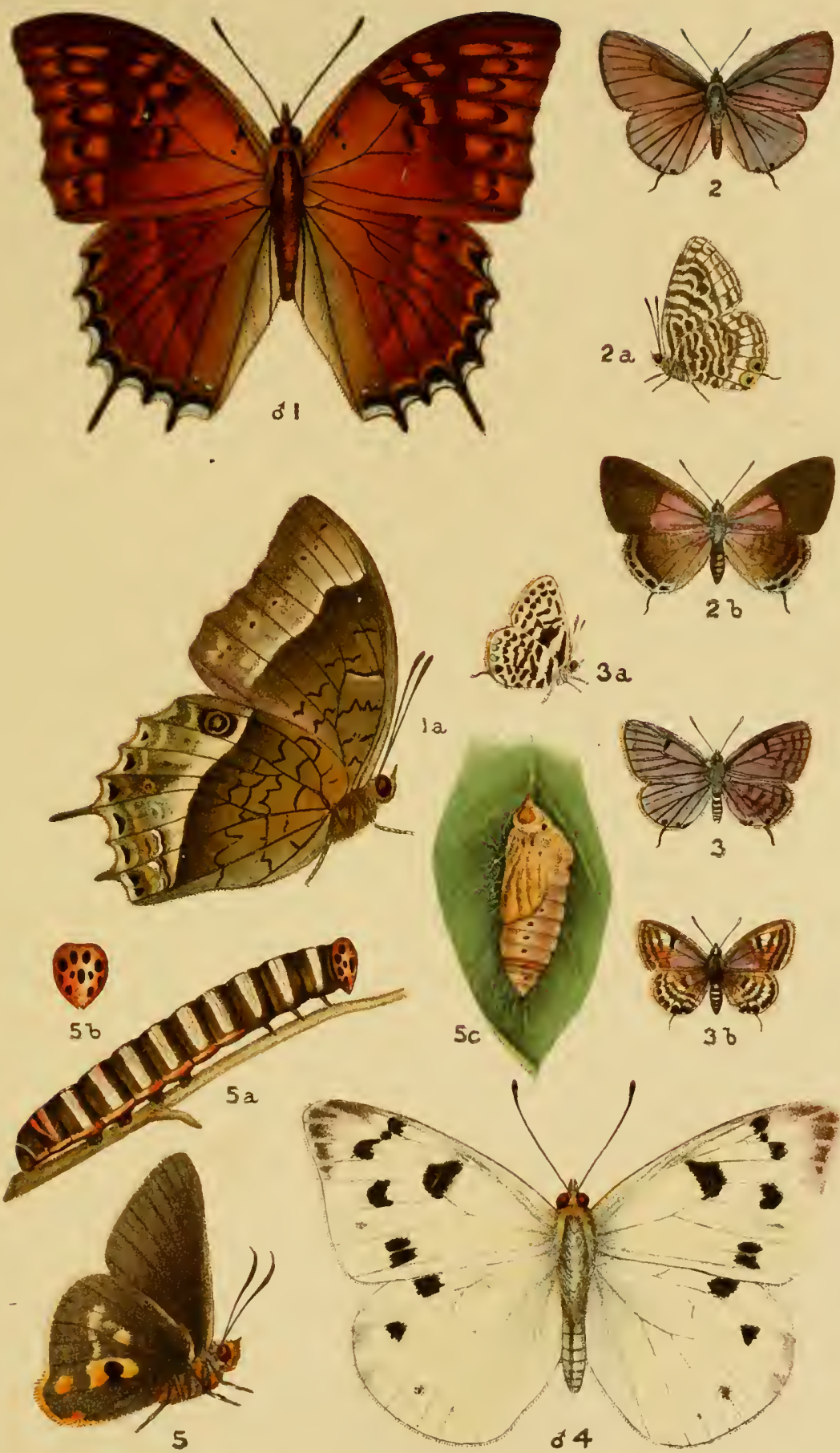

M.Homnan-Fisken lith

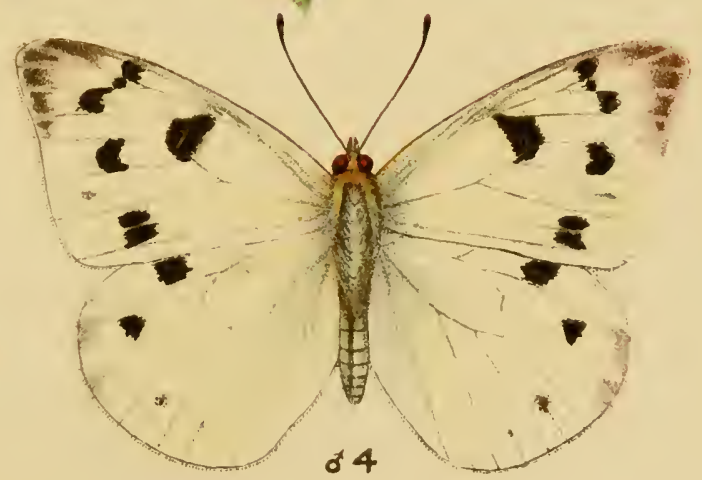

West,Newman ch. 

ARTHROPODA.

\section{Insecta:}

\section{Lepidoptera.-II.}

Phalanæ.

By Sir G. F. HAMPSON, Bart., B.A., F.E.S.

PLATE XX. 



\section{Moths.-I.}

The species of Moths taken in Sokotra and Alxl-el-Kuni by Messis. Forbes and (irant as given in the following list are all typical of the fanma of the more arid distriets of E. Africa, Somaliland, Arabia, Persia, and $W$. India, and not a single species was taken, the affinities of which are other than might he expected.

The species collected in the former island by Mr. Bennett, of which a list was published in the P.Z.S. for 1s98, p. 38:3, by Professor Dixey, were in such bad condition that only approximate irtentifications were possible, any corrections necessary will be found below.

\section{I.-The Moths of Sokotra.}

\section{LEPIDOPTERA PHAL $Æ N \notin$.}

\section{ARCTIAD无。}

NOLINÆE.

1. Celama pumila, Snell.

\section{Celama, WIk.}

Sola pumila, Tijel. v. Ent. xrii. p. 6s, pl. (i fig. 4 (157t).

Sokotra: Adho Dimellus (3500 ft.), 10 : . lena-agahan (1200 ft.), 1 f ;

Harlibu Plain, 1 q.

[Taken at light. W.li.U.G.]

\section{LITHOSIANÆE.}

\section{Ilema, Hübn.}

2. Ilema sokotrensis, $/$ m $m$ psu.

Ileme solotrenxis, Hmpen., Cat. Lep. Phal. B. M., ii. p. 166i, pl. 22.2 fig. 26.

Lithoxiu retusta, Dixey, P.Z.S., 189s, p. 38:3 (nee Wlk.).

Sokotra: Adho Dimellus (3500 ft.), $3 q$; Homhil (2.500 ft.), 1 q

[Taken at light._II.T.O.G.] 
ARCTIAN Æ.

\section{Utetheisa, Hüon.}

3. Utetheisa pulchella, Linn.

Tinen pulchella, Linı., Syst. Nat. 1, ii. 1. 884.

Deiopeie pulchella, Butler, P.Z.S., 1881, 1) 179.

Sokotra: Arlho Dimellus (3500 ft.), 1 cै, $3 q$; Jena-agahan 4 tิ, 1 ; Homhil (1500 ft.), 1 б, 1 q : Hadilsu Plain, 1 \&.

[Very common among the open patches of spear grass from sea-level to an eleration of at least 4000 feet. - IV.R.O.G.]

\section{NOCTUID床.}

\section{CARADRININÆE.}

\section{Agrotis, Ochs.}

4. Agrotis segetis, Schiff.

Noctua segetis, Schiff, Wien Verz, 1. 2.5.2.

Sokotra: Arlho Dimellus (3500 ft.), $30^{*}, .2 q$.

[Taken at sugar. - II.M.O.G.]

\section{Agrotis brachypecten, 1 mplsn. (Plate xx. fig. 1.)}

Agroti. brachypecten, Hmpsn., Bull. Liverp. Muss., ii. 22, p. 35 (1899). Agrotis dirisca, Dixey, I'.Z.S., 1898, p. 383 (nec Wlk.).

of Antenne bipectinate, the branehes rery short with fasciculate cilia; reddish brown, mixed with grey ; palpi fuseous at sirles; tegule with blackish lines; patagia with blackish streak ; abdomen paler, dorsally tinged with fuscous towards base. Fore-wing with subbasal and antemedial greyish lines defined by fuscons, the former short waved, the latter waved, produced to a rather long angle above inner margin, and with the short blackish elariform stigma on its outer edge; the orbicular greyish defined by fuscous, and either circular or rather elongate and pointed at the ends: the reniform large with fuscous centre and outline, or entirely suffused with fuscous, and with fuscous suffusion above it on costa ; the postmedial line excurved from below costa to vein 2, and produced to short black streaks on the reins: some fuscons suffusion on terminal area; a greyish subterminal line expanding into a spot at apex, then clentate inwards to vein 5 and outwards on veins 5 and 4 ; a fine lumulate terminal line. Hind-wing white, the reins and termen often tinged with fuscous.

q Fore-wing sometimes suffused with fuscous. Exp. o 32-38, q $40 \mathrm{~mm}$.

Sokotra: Adho Dimellus (3500 ft.), 1 ઈ, 18 ; Jena-agahan (1400 ft.), 1 \% ; Hadilı Plaiı, 5 ô.

Extremcly like $A$. rortireu, Schiff, but with very much shorter branches to the antemne.

[Common at sligar ; also came to light.-W.W.R.O.G.] 


\section{Hadena, Schrank.}

6. Hadena consanguis, Guen.

Hadenu ronsangu is, (inen., Noct., ii. 1). 97.

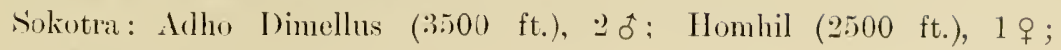
Hadibu Plain, 1 s.

['Taken at light and at sugar.-IV.li O.G.]

\section{Leucania, ochs.}

7. Leucania scirpi, $I / \mu p$.

Leuranice scirpi, Dn\}., Hist. Nat. Lep.. iii. p. 3:2.

Sokotra: A

\section{Euplexia, Steph.}

8. Euplexia conducta, $\mid I 7 /$ :

Cerertrinu eoneluctu, Wlk., x. p. 296.

Solkotra: Arluo Dimellus (3500 ft.), 3 f, s, .

\section{Spodoptera, Guen.}

9. Spodoptera mauritia, Boist.

Hatenu mauritia, Boisd., Faun. Ent. Matlag., Lep., p. 92.

Sokotra: Adho Dimellus (3500 ft.), 2 of.

\section{Caradrina, Ochs.}

10. Caradrina orbicularis, $W l k$. (Plate $x x$. fig. 26.)

Curadrince orlimblaris, Wlk., x. p. 294.

Sokotıa: Adho Dimellus (3500 ft.), 1 t.

11. Caradrina exigua, Hiilm.

Nocture exigure, Hübn., Samml. Eur. Schmett. Noct. fig. 36².

Sokotra: Hadilu Plain, 1 ㅇ.

12. Caradrina partita, $W / l$ : (Plate xx. fig. -24.)

Caradrinu partitu, W'lk., x., p. 294.

Sokotia : Atho Dimellus (3500 ft.), 3 o .

\section{Amyna, Guen.}

13. Amyna octo, Gurn.

Amyma octo, (inen., Noct. 1, p. 233 .

Sokotra : Jena-agahan (2500 ft.), 1 f ; Dahamis, 1 q.

14. Amyna selenampha, Guen.

Amyna selenemy,ha, Guen., Noct. 1, p. 406.

Sokotıa : Moukararlia (=Gebel Raggit) (600 ft.), 1 f; Hadilı Plain, 1 q. 


\section{Callopistria, Hübn.}

15. Callopistria recurvata, Morre. (Plate rx. fig. ¿.)

Callonintivia recurrata, Moore, Lep. Atk. 1) 14t.

Sokotra: Adho Dimellus (3500 ft.), 7 o , j) $q$ : . Jena-agahan (1140 ft.), 1 오.

[Taken at light, also found common on the damp sharly parts of the track

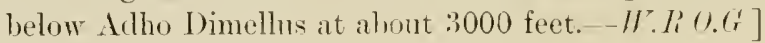

\section{ACONTIANAE.}

\section{Megalodes, Guen.}

16. Megalodes insocia, IIlli: (Plate xx. fig. 6.)

Acontic insocire, Wrlk., xii., iss.

Sokotra: Hadibn Plain, 1 of.

\section{Tarache, Hubn.}

17. Tarache hortensis, Sirinh.

Acontia hortensis, Swinh., P.Z.S., 1854, 13. .17, pl. xlvii. fig. ¡.

Sokotra: Hadibu Plain, 로.

18. Tarache melæna, Himpsn. (Plate xx. figs. 9, 10.)

Tarache metena, Hmpsn., Bull. Liver'p. Muss., ii. p. 36 (1ss9).

q Head and abdomen fuscons ; thorax black. Fore-wing slossy blackbrown ; a white antemedial band with nearly straight, almost rect edges bounderl hy black lines, the fand sometimes narower or not extending below rein 1, or in one speeimen redncerl to a grey spot on costa; a triangular postmedial white spot on easta with the minutely dentate postmedial black line arising from it, strongly incured below rein 3 : a terminal series of white points usmally present, and sometimes some slight subteminal marks towards torms. Hind-wing dark fuscons. E.r.p. $20111 \mathrm{~m}$.

Sokotıal : Hadibu Plain, 9 ․

[Taken at light.- - I'.li.O.G.]

19. Acontia malvæ, lisp.

Acontia, Ochs.

Nocture mulwe, Esp., Schmett., iv., 2, p. 6:3, pll. cxcr. fig. 4. Sokotra: Hadibu Plain, 1 f.

\section{Metachrostis, Hübn.}

20. Metachrostis terminipuncta, Hmpsu. (Plate xx. fig. 2.)

Metachost is terminipuneta, Hmpsn., Bull. Liverp. Muss., ii. p. 36 (1899).

\& Head and tholax red-brown: abdomen fuscous. Fore-wing with the basal half pale red-brown; two subbasal black points on costa with short obscure lines from them: two antemedial waved red-lorown lines arising from hlack points on costa ; a waved medial line with the area beyond it deep red-brown with some pale patehes: an ollique 
discoidal lunule with sone black on its immer edge; a hackish mark in submedian fold before the donble, minutely dentate, postmedial line which is bent out wards between reins 6 and 3 ; a sinuous subterminal line witl a prominent back spot beyond it on termen above vein 5 ; some slight terminal llack hunules. Hind-wing dark fuscous, the molerside hown, irrorated with fuscons, with dark discoidal point and waved postmedial line. Eixp. 20, $11 \mathrm{~m}$.

Sokotra: Alho I)inelhus (3500 ft.), 1 of.

21 Metachrostis badia, swiml.

Acontin beelie, Swinh., 1'.\%.S., 18sti, p. 44.5.

Sokotsa: Adho !)imellus (1500 ft.), 1 of: Hadilm Plain, 1 ơ.

22. Metachrostis pulla, swinh.

Acontice pulle, Swinh., P.Z.S., 188., p. 4.56, pl. xxvii. fig. 15.

Solotra: Acho Imellus (3500 ft.), 1 fo ; Jenlatagahan (1200ft.), 1 q.

\section{Eublemma, Hü̈n.}

23. Eublemma bifasciata, Moore.

Therlyocheres bifusciatre, Moore, P.K.S., 1881, 1. 371.

Sokotra : Jena-agahan (1200 ft.), 1 of : Hadilu Plain, ㄹ․

The ground-colonr much darker than in specimens from Arlen and India.

[Taken at light._W'Ii.O.G.]

24. Eublemma admota, Felil.

Acontie admote, Feld., Reis. Nor., pl. criii. fig. 31.

Sokotra: Harlibu Plain, 1 $q$.

\section{EUTELIAN/E.}

\section{Eutelia, Hübn.}

25. Eutelia bowkeri, Felt.

Enrhipia barkeri, Feld., Reis. Nor., pl. cx. fig. 29.

Sokotra: Adho Inimellus, 2 ơ, 2 $q$.

[Taken at sugar.-MI.T.O.G.]

\section{GONOPTERINÆE.}

Cosmophila, Boisd.

26. Cosmophila erosa, IIiilin.

Noctua enose, Hitbn., Zutr. Samml. Exot. Schmett., ii. 19, figs. 28i, $28 \mathrm{~s}$.

Sokotra: Adho I)imellus (3500 ft.), 1 f, 1 q.

\section{Earias, Hübn.}

27. Earias insulana, Boist.

Tortrix insulane, Boist., Faum. Marlag., 1) 121, pl. xvi. fig. 9.

Sokotra : Adho I Dimellus (3500 ft.), 2 ․ 
28. Earias uninotata, $I / l k$.

Digha uninotata, W'lk.. Joum. Limn. Soc., vi. p. los.

Sokotra: Jena-agahan (1300 ft.), 1 o.

\section{NOCTUINÆE.}

\section{Cerocala, Boisd.}

29. Cerocala socotrensis, $/$ mins . (Plate xx. fig. 27.)

Cerorela sorotrensis, Hmpsn., Bull. Liverp. Muss., ii. p. 36 (1899).

Cerocula ermiculose, Dixey, P.Z.S., 1898, p. 383 (nec H.S.).

Head and thorax clothed with grey, fuscons, and brown scales; palpi white, except at tips, the rertex of head and front of tegnlie hrownish-white; abdomen lorownish-white, irrolated with fuscous; pectus and ventral surface white. Fore-wing with the lase, costal area, and termen grey, irorated with fuscons and hown, the rest of wing fuscons and brown, with learlen suffusion in parts : a fine black line from subcostal nervme before middle curved to above mildle of inner margin, defined on outer side by grey, and followed by a hoad rufous hand; the orbicular small, black-edged, with brownish centre, and eleptical ; the reniform gley, black-erlged, somewhat quadrate; the postmerlial black line oblifue from below costa to vein 2 , recurved to the inner edge of reniform, then excurved and bounding the rufus land, a large barshaped brown-irrorated white pateh on its imes side beyond the cell; a subterminal brown line definerl by whitish on inner sirle, strongly angled inwards in discal fold and slightly in submedian fold, with two black marks on its inner side below the upper angle, and slight marks above and helow the lower angle; the termen suffinsed with hown; a crenulate terminal hack line; cilia intersected with whitish. Hind-wing with the base and inner area brownish white; a slight blackish streak on imner area; an olslipue blackish bar from upper angle of cell to the lnoal fuscons sulsterminal hand at vein 2 , and with a whitish patch beyoul it, beyond the cell : two deep hack subapical spots on termen; a large patch at middle extending on to cilia, with a small spot below it with white spot on its imer side: cilia white. Underside yellowish-white; fore-wing with oblique llack bar from upper angle of cell to the sintons postmedial line, the area beyond, which is brownish, with a large apical black patch : a white patch heyond the cell; hind-wing with small llack spot on discocellulars and another heyond lower angle of cell.

Sokotra: Jena-agahan (2500 ft.), 1 q: Hatibu Plain, 1:2 ơ, 221 .

Closely allief to C. vermiculata, H.s., from Sonth Africa, but differs in the ohlique discoilal band of hind-wings and black terminal spots.

[One of the commonest species of moth in Sokotra, coming freely to light. It proved a perfect nuisanee at night in the tents, constantly putting out the cancle if the lantern was left open for a moment. 
It was most common on the planis, and foumd in numbers up to an elevation of abont 2000 feet. I olstained one worn specimen at Adho Dimellus, but, unfortumately, rid not preserve it. - II. P.O.G.]

\section{Amefrontia, Hmpsn.}

\section{Type A purpurea.}

Palpi oblipue, reaching just leyoud the large frontal tuft, which has a Hattened corneous plate helow it with rounded edge: antenne bipectinate, with moderate branehes: tibia without spines. Fore-wing with areole; the costa slightly arched; the termen obliquely eurverl: the eilia non-crenulate. Hind-wing with vein s from well above angle of cell.

30. Amefrontia purpurea, $H m p s \%$. (Plate xx. fig. 11.)

Amefrontia purpurea, Hmpsn., Bull. Liverp. Muss., ii. p. 37 (1899).

of Head and thorax vinous red; antemne black-brown with white tips: legs bown, the joints ringed with white; ablomen ochreons-brown. Fore-wing vinous-red ; the dise tinged with hrown ; the orbienlar and renifor'm ochreous-white with some purplish seales at centre; an indistinct, dark, waved, antemedial line ; a crenulate, slightly eurverl postmedial line with short streak beyond it on the reins; a terminal series of ochreous points. Hind-wing white, tinged with fuscous. Exy. 2.2 $111 \mathrm{~m}$.

Sokotra: Hadilu Plain, 1 ô.

31. Amefrontia albiluna, $H m$ msn. (Plate xx. fig. 12.)

Amefrontia allilinua, Hmpsn., Bull. Liverp. Muss., ii. p. 37 (1899).

o Head and thorax ochreous brown, mixed with darker seales; fore tarsi handed with black; abdomen ochreous-white, slightly tinged with fuseous. Fore-wing ochreous-lrown, irrorated with dark brown : traces of a sinuous antemedial line with a dark shade on its inner side and some black scales on its onter'; a medial dark sharle angled at lower angle of cell; a black discoirlal lumule with a white lumule on its outer erlge; the postmedial line double, exeurved from costa to rein 3 , then incurved, some black points on its imer side, and fuscousgrey suffusion beyond it. Hind-wing whitish, the terminal half suffused with fuseous: cilia whitish. Exp. $20 \mathrm{~mm}$.

Sokotra: Hadibu Plain, 2 우.

[Both this and the previous species were taken at light. -II.li.O.G.]

\section{Catephia, Ochs.}

32. Catephia linteola, Guen.

Catephia linteola, (xuen., Noct., iii. p. 44.

Sokotra: Adho Dimellus (3500 ft.), $4.35,5 q$.

[Common at sugar. Only met with at our highest camp.-M.R.O.r.] 
33. Ophiusa serva, Fulri.

\section{Ophiusa, Ochs.}

Nocture serve, Kabr., Syst. Ent., 1. 593.

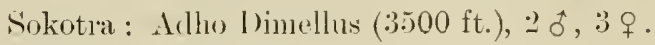

[Taken at sugal:- M'.li.U.G.]

34. Ophiusa melicerte, Iru!y.

Noctue meticerte, Drury, Ills. Exot. Ins., i. p. 46, pl, xxiii. fig. 1.

Sokotra: Hadilı Plaun, 3 ô, 1 ․

[Taken at sugat.-II.li.O.G.']

35. Ophiusa äianaris, Guen. (Plate xx. fig. 15.)

Ophiodes rlienuris, Gitien., Noct., iii. p. 2:?2.2.

Sokotra: Arlho Dimellus (3500 ft.), 30 , 2 우.

[Taken at sugar, and once olntained lluing the day.-IV.li.O.G.]

36. Ophiusa tirrhaca, Crum.

Noctur tirhece, Cram., Pap. Exot., ii., pl. clxxvi, s.

Sokotia : Arlho Dimellus (3500 ft.), :3 $q$.

[Two taken at sugar ; one specimen came to light. - II.L.O.G.]

\section{Baniana W/k.}

37. Baniana intorta, Suinh. (Plate xx. fig. 14.)

Athymu intorta, Swinh., Trans. Ent. Soc., 1s91, 1. 150.

Sokotra: Hadilu Plain, 20 ô.

[Taken at light. - II.L.O.G.]

\section{Acantholipes, Lederer.}

38. Acantholipes circumdatus, //77:

Iydrelia circumedatu, W1k., xr., 1763.

Soliotra: Arlho Dimellus (3500 ft.), 1 o ; Jena-agahan (1140 ft.), 2o of;

Moukaradia (= (rebel haggit) (600 ft.), 1 o ; Hadlibu Plain, 6 of, 6 \%.

[Taken at light._II.li.O.G.]

\section{Calpe, $T r$.}

39. Calpe emarginata, Fulln:

Noctuce emerginutu, Fabr., Ent. Syst., iii. 르, p. s.2.

Sokotıa: Arlho 1)imellus (3500 ft.), 3 q.

[Came to light.-II.li.U.G.]

\section{Plusia, Ochs.}

40. Plusia eriosoma, Imebl.

Pluxin eriowome, Doubl., Dieffenbach's New Zealand, ii. p. 288.

Sokotra: Moukaraclia (=Gebel Raggit) (600 ft.), :3 0 .

[Captured in the diylight among the grass and undergrowth on the hill side.-IV.li.(1.G. 


\section{HYPENINÆ.}

\section{Simplicia, Guen.}

41. Simplicia robustalis, Guen.

Iterminie rolustulis, Guen., Delt. \& l'yr. p. is.

Sokotra: Arlio Dimellus (:3000 ft.), 1 ․

\section{Hypena, Schrank.}

42. Hypena masurialis, G'u'n.

Hyperu mextrialix, Guen., Delt. \& Pyr., 1. 3s.

Sokotra: I)alımis (500 ft.), 1 o ; Iaulibu Plain.

43. Hypena lividalis, Huilun.

Pyjalix liridalix, Hiihu., Sitmml. Eur. Schmett, l'yr., fig. 11, 1 sti.

Sokotıa : Jena-agahan (.2500 ft.)., 1 f , 1 q ; Dahamis (1000 ft.), 1 q.

44. Hypena abyssinialis, Guen.

Hypr ure chyswinialix, (inen., Delt. \& Pyr., 1. 39.

Sukotral : Adho I)imellus (.2500 ft.), 1 q.

45. Hypena sinialis, Guen.

Hypene sinimlis, Ginen., Delt. \& Pyr., p. 31).

Sokotra : Arlho Dimellus (3500 ft.), 1 o , 1 q.

\section{Rhasena, w/k.}

46. Rhæsena transcissa, //7/:

Rhersene transcissu, Whik, xxxv. 197t.

Sokotia : Arlho Dimellus (3500 ft.), 1 ot.

\section{Galleridia, Hmpsn.}

47. Galleridia atrisigna, $/ m p s n$.

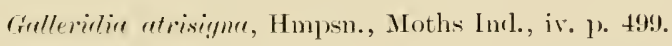

Sokotra: Jena-agahan (1॰00 ft.), 1 ơ ; Harlibu Plain, :) ơ.

\section{SPHINGID尼.}

\section{Chœrocampa, Dup.}

48. Chœrocampa celerio, Limu.

Sphime crerio, Linn., Syst. Nat., i. p. som.

Sokotra: Homhil (1500 ft.), 1 .

[Taken at light in tent. Other pupie apparently of this species were destroyed ly small ants on the royage home.-II.li.O.G.] 


\section{GEOMETRID EE.}

\section{BOARMIANFE.}

\section{Hyperythra, Guen.}

49. Hyperythra ædiphlebia, Hmpsu. (Plate xx. fig. ㄹ.)

Iyperythra whiphedir, Hmpsn., Bull. Liverp. Muss, ii. p. 37 (1899).

Hyperythre lueicolor, Dixey, P.Z.S., 1898, p. 383 (nec Butl).

of Fore-wing without fovea: hind-wing with the base of costal rein swollen. Orange-yellow : antenne with the hanches brownish; palpi at sides and legs thickly irroraterl with red-brown; abdomen slightly irrolated with hown; wings with fine red-lorown strie. Fore-wing with inclistinet antemedial hrown line bent inwarks to costa; a similar lut more prominent medial line with darker discoidal striga on it ; an oblique subterminal har from costa, with traces of a line arising from it, and dark point beyond it ahove vein 3 . Hind-wing with almost medial, slightly oblique, brown line, and curved diffused subterminal line. Exy $202 \mathrm{~mm}$.

Sokotra: Harlibu Plain, 3 o

[Beaten out of a small thormy bush on the plain.-II.R.O.G.]

\section{Boarmia, $T r$.}

50. Boarmia acaciaria, Boist.

Bourmia acaciaria, Boisd., Faun. Ent. Madag., Lep., 116, pl, xvi, fig. 4.

Sokotra : Arlho Dimellus (3500 ft.), 1 oे, 4 .

[Taken both at light and at sugar.-W II.R.O.ti.]

\section{LARENTIAN王.}

\section{Scotosia, Steph.}

51. Scotosia rubritincta, Hmps". (Plate xx. fig. 20.)

Srotosia mulritincta, Hmjsn., Bull. Liverp. Muss., ii. j). 38 (1899).

Grey and red-brown, thickly jrorated and strongly suftused with black; pectus, underside of legs, and ventral surface of aldomen, whitish ; wings with numerous indistinet waved dark lines. Fore-wing with more clistinct subbasal line angled below costa; an antemedial line exemved helow costa and angled in sulmedian interspace, the medial area somewhat darker with dark streaks on the veins and diseoirlal har; the postmedial line defined ly grey, dentate and strongly angled ontwards hetween veins 4 and 2 ; the terminal area darker, with dentate grey sul,terminal line. Hind-wing with rliscoidal point; a minutely dentate postmedial line defined hy grey and angled outwards heyond lower angle of cell : the terminal area darker, with dentate greyish subterminal line, hoth wings with terminal series of pale points and fine black striae. Undersicle yellowish white, striated with fuscous ; black discoidal spots and postmedlial line angled beyond 
the eell : the terminal area black with whitish spots on fore-wing and waved line on hind-wing. E'rp. $3: 2-40 \mathrm{~mm}$.

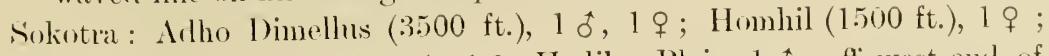

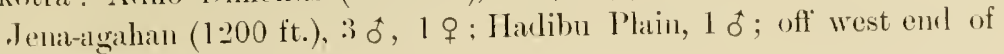
Soliotra, 1 ơ.

One $q$ of this species was oltained in British East Africa by Dr. Gregory. [Most of the examples were taken at light: the first met with eame to the aleetric light on board the Elphinstone, when we were anchorer off the west end of Soliotial. - II.Li.O.G.]

\section{Cidaria, $T r$.}

52. Cidaria holophæa, $I / m p s n$. (Plate xx. figs. 3, 르).

Cirleriu holophere, Hmpsin., Bull. Liverp. Mluss., ii. p. 3s (1s!9!).

of Dark fuseons hrown. Fore-wing with three or form minutely waved lines on basal area slightly angled below costa ; two antemedial lines with reldish-lirown hetween them, the inner line waverl, the onter slightly angled inwirds in submedian fold; a discoidal point; two postmedial lines with red-bown letween them, the inner minutely waved and angled helow costa, the outer slightly defined hy grey and strongly angled ontwards beyond lower angle of cell, then inenryed, and with indistinct waved lines beyond it ; a wared grey subterminal line with black marks in its eurves; a fine black terminal line. Hind-wing with two medial lines slightly angled at middle, with indistinet waved lines between and beyond them, an indistinet waved grey subterminal line, and punctiform black terminal line.

q Fore-wing with the medial area much darker, and usually strongty defined ly grey before and beyond it ; the subterminal line with the hack marks prominent. Er\%. $30 \mathrm{~mm}$.

Soliotra : Ailho Dimellus (3500 ft.), $1+\delta, 5 q$.

[Common on the highest part of the Haghier range, at an elevation of about 3000-4000 feet. In creeping through the thicker parts of the bush one eonstantly eame across these moths at rest on the stems, but they were very easily disturbed and diffieult to box. At night they came freely to light, and mmlers might, with the air of a lantern, be taken resting on the spear glass.-II.R.O.G.]

\section{ACIDALIAN/E.}

\section{Craspedia, Hubn.}

53. Craspedia fulvicolor, $H$ mplsu. (Plate xx. fig. T.)

Craspetlin julvicolor, Hmpan., Bull. Liverp. Muss. ii. p. 38 (1899).

Coraspertia pulceroweria, (?) Dixey, P.Z.S., 189s, p. 383 (nee W'lk.).

Oehreous thickly imorated with dark red; frons and palpi chestnut; vertex of heal whitish. Fore-wing with antemedial series of three dark points on the reins angled on merlian nervore; a dark disenirlal spot with an indistinct, oblique, slightly sinuous line just beyoud it : 
a postmedial series of dark points angled ontwads at veins 6 and $t$, and with traces of a waved line beyond it; a terminal series of points. Hind-wing with discoidal lrar-shaped spot; an indistinct cured diffinsed medial line; a postmedial series of points slightly bent ontwards below costat and excured at median nervules: traces of a wared suloteminal line; a terminal series of points. Himul tibie of male not dilated and withont spurs. E.rp. $24-30 \mathrm{~mm}$.

Sokotra: A, lho I)imellus (3500 ft.), 우 : Jena-agahan (1200 ft.), 2 q ; Kimahann (500 ft.), 1 ; Harlibn Plain, 1 ơ, 1 \%

[Taken at light.-II.I.O.l:.]

54. Craspedia remotata, fuen.

Acichliu remotute, Guen, Phal., i. 1. tis.

(irespediu lacturiu, Dixes, P.7.S., 1s98, p. 38:3 (mee W"lk.).

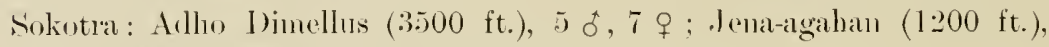

1 ơ: Momkatarliar ( = (telel Raggit) (600 ft.), 1 of.

[Taken at light. - II.R.O.(r.]

55. Craspedia actuaria, $/ / 7 \%$.

Acrelule recturerie, Wlk., xxii. Tr.2.

Craxpedia deraxata, Jixey, P.Z.S., 1s9s, 1. 34.3 (nec Wlk.).

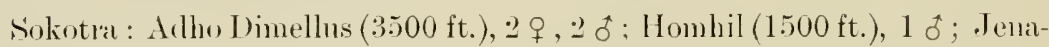

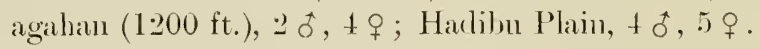

The ground colour varies from pale ochreous to bright rufous.

56. Craspedia disparata, Styr: (Plate xx. fig. 18.)

cresperlie dimpureter, Stgr., inerl.

Sokotra : Adho I bmellus (3500 ft.), 1 \%: Moukararlia (= Gebel Raggit) (600 ft.), 1 \%; Harlibı Plain, 1 है, 10 \%

Exactly agrees with a typical specimen from Mesopotamia, and one from

Jumood, N. II. India; it also occur's at Aden.

\section{Acidalia, $T r$.}

57. Acidalia testacea, Swinll.

Enpithecie testrecer, Swinh., P.Z.S., 188.), 13. S63, 1,l. lvii. fig. 1.,

Sokotıa : Jena-agaham $(1200 \mathrm{ft}), 20$; Hadibn Plain, 3 of, 1 q

\section{Timandra. Dup.}

58. Timandra mundissima, $I T l k$.

Acieleline mendisximu, Wlk, xxiii. 7!).

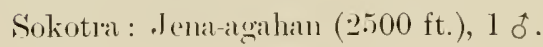


GEOMETRIN/E.

\section{Nemoria, Hübn.}

59. Nemoria directa, $/ / \|$ :

Semorie directe, Wlk., xxii. 535.

Sokotra: Arlho Dimellus (:3500 ft.), 1 q ; Jena-iggahan (1200 ft.), 1 ;

Hadilu Plain, 1 oै, + $q$.

\section{COSSID屟}

Azygophleps, Hmpsn.

60. Azygophleps inclusa, //lk: (Plite xx. fig. 13.)

Zenstra incluser, Wlk., vii. 1.534

Sokotial : Hadilon Plain, 1 ơ.

\section{Eremocossus.}

61. Eremocossus proleuca, $H m i s n$.

Liemocosets prolence, Hmpsin., 1'.\%.S., 1896, p. 276, pl. x. fig. 4.

Sokotıa: Harlibu Plain, 1 s̊.

\section{PYRALID平.}

CRAMBINÆ.

\section{Culladia, Moore.}

62. Culladia admigratella, II $7 \%$.

Arecers cedmigretellu, W'lk., xxvii. 192.

Sokotra: Hadibu Plain, ㅡㅇ.

PHYCITINÆE.

Hypogryphia, Rag.

63. Hypogryphia pulverealis, $I I m p s n$. Plate xx. fig. 16.

Hyproyrypthe pulcererlis, Hmpsn., Bull. Liverp. Muss., ii. p. 39 (1899).

Grey-white thickly irrorated with fuscons. Fore-wing with indistinct antemerlial rlark line strongly angled in submerlian fold ; a medial line strongly angled ontwards in cell and submerlial fold and inwards on median nervure and rein 1 ; a dark point at lower angle of cell : the postmedial line angled inwards at vein 6 and in submedian fold, bent ontwards and minutely dentate letween reins 5 and 2 ; a prominent terminal series of points. Aludomen and himl-wing miform pale grey, the latter with traces of a curved subterminal line; a fine terminal line, and line thomgh the cilia. E.r. ot 22,2 , $926 \mathrm{~mm}$.

sokotra: Jena-agahan, 1 o, 2 2 .

\section{Heterographis, Rag.}

64. Heterographis (Ntandingeria) suboblitella, Rug.

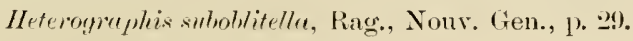

Sokotia: Hadihn Plain, 1 . 
65. Heterographis pygmæella, $H$ mpsu.

Heterographix pygmetellu, Hmpsn., Moths Ind., iv. p. 69.

Sokotra: Adho I)imellus (1500 ft.), 1 q; Hadlihu Plain, 30 , 29.

66. Heterographis flammealis, Hmpsu. (Plate xx. fig. 19.)

Heteroyraphis ftemmealis, Hmpsu., Bull. Liverp. Muss., ii. p. 39 (1899).

Head oehreous whitish; thorax and abdomen pale red-lorown, the tegule whitish in front. Fore-wing vinous red, irrorated with white and fuseous ; the basal inner area without irroration : a medial orangerellow hand with waved edges prodneed along eosta to well beyond middle, and with a red hand, not irrorated, heyond it; a black discoidal point; a pateh of rerl-hrown on terminal area. Ilind-wing pale semi-hyaline, tinged with brown, especially towards termen : a fine terminal line, and line through the eilia. Exp. $1+\mathrm{mm}$.

Sokotra : Arlho Dimellus (3500 ft.), 1 q : Hadihu Plain, 1 f, 1 o .

\section{Nephopteryx, Hübn.}

67. Nephopteryx serratella, Piey.

Iyrrea sermetlla, Rag., Rom. Mém., vii. p. 399, pl. xv. fig. 23.

Maxillary palpi of male in the form of a triangular tuft appressed against frons : anteme pectinate with miseriate branches, the sinus and tuft large.

Sokotra: Hadibu Plain, 6 of, $24 \%$.

68. Nephopteryx (Oligoehroa) terrella, liay.

Oligocherou terrellu, Rag., Nouv. Gien., 1. 20) : Rom. Ném., vii. p. 389, 11. xiii. fig. 15 .

Sokotra: Adho Dimellus (3.500 ft.), 1 of, 6 q; .Jena-igahan (1200 ft.), 1 ㅇ.

69. Nephopteryx (Thylacoptila) paurosema, IIey/:

Thylacoptila parrosemu, Meyr., Ent. Mo. Mag., xxii. p. 166 (1885).

Sokotra: Hactibı Plain, 1 ơ.

\section{Epicrocis. Zell.}

70. Epicrocis (Candiope) uberalis, Swinh.

Pyralis uheratis, Swinh., P.Z.S., 1854, p. 52:3, pl. xlviii. fig. 10.

Sokotra: Hadibu Plain, 2 q.

\section{Etiella, Zell.}

71. Etiella zinckenella, Treitshlile.

Tinea zinckenella, Treitschke, Schmett., Eur., ix. 1, p. 201.

Sokotra: Homhil (2500 ft.), 1 f: Hadihn Plain, 1 o 


\section{HYDROCAMPIN $Æ$.}

Nymphula, Schrank.

72. Nymphula affinialis, (ituen.

Puraponyx affiniulis, (inen., 1)elt. \& P'yr., 1. 20-11.

Oligoxtigme incommode, Butl., P.Z.S., 18s1, p. 180.

Sokotra: 1 q taken by Professor I. B. Balfour: hut the speeies was not seen by the present Experlition.

\section{Stenia, Guen.}

73. Stenia grisealis, $M m p s n$. (Plate xx. figs. 4,23 ).

$$
\text { Steniu grisculis, Hmpsn., Bull. Liverp. Mluss., ii. 1. 39 (1899). }
$$

(irey-brown; palpi white at base; flons erged with white; antenne with the shaft white above; legs and ventral surface of alshomen striper with white. Fore-wing with the costal edge white; a yellowish spot helow vein 2, near its hase, sometimes almost olsolete, sometimes with traces of spots in eell and above veins 2,5 , and 6 . Hind-wing paler ; the cilia white. E.r. $18 \mathrm{~mm}$.

Sokotra: Ailho Dimellus (3500-1500 ft.), 로, 29 ; Homhil (2500 ft.), 1 f : Jena-agahan (1200 ft.), 1 to; Hadilı Plain, $1: 3 q$.

\section{SCOPARIANÆE.}

\section{Scoparia, How.}

74. Scoparia murificalis, $/ 7 l k$. (Plate xx. fig. 25.)

Scoperie murificalis, Whk., xix. 8:26.

Sokotia: Artho Inimellus (1.500 ft.), 1 to.

\section{PRYAUSTIN/E.}

\section{Zinckenia, Zell.}

75. Zinckenia fascialis, Crum.

Pyralis fascialix, Cram., Pal. Exot, iv. pl. ecexcriii. o.

Sokotra: Hadtibu Plain, $3 q$.

\section{Syngamia, Guen.}

76. Syngamia abruptalis, $I / \%$.

Asopia abruptalis, Wlk., xvii. 371 .

Sokotra: Homlil ( $2500 \mathrm{ft}.),+q$.

\section{Hellula, Guen.}

77. Hellula undalis, Fuln.

Pyralis undalis, Fabr., Ent. Syst., iii. :2, p. ㄹ.26.

Sokotra: Hadibu Plain, 1. 


\section{Phlyctanodes, Guen.}

78. Phlyctænodes undalis, Hïlu.

Pyrulix undulix, Hubn., Samml. Eur. Schmett., Pyr., fig. 90. Sokotral : 1 of without exact locality.

\section{Metasia, Guen.}

79. Metasia corsicalis, $I / \eta)$.

Pyralis corsiculis, 1)up., Lép. Fr., viii. p. 3146, pl. cexxx. figs. 6, 7 . Sokutra : Jena-agahan (1200 ft.), 1 o : Hadibu Plain, 1 of.

80. Metasia prionogramma, Memr. (Plate xx. fig. 5.)

Ietasia pronoyromma, Meyr., Trans, Eut. Soc., 1ss6, p. 265.

Sokotra: Harlibu Plain, 20 . 


\section{II - The Moths of Abd=el=Kuri.}

\section{NOCTUID压。}

CARADRININ/E.

\section{Caradrina, Ochs.}

1. Caradrina exigua, $H i i l$.

Socture exignu, Hïb., Samml. Enr. Sehmett., Noct., fig. 362.

Alrl-el-Kuri, 1 ơ.

\section{SPHINGID曆.}

\section{Chærocampa, Dup.}

2. Chærocampa celerio, Limu.

Sphinx celerio, Limn, Syst. Nat. i., p. soo.

Abrl-el-Kuri, 1 o.

[One example bred from pupa._II.R.O.G.]

\section{PYRALID压.}

\section{PHYCITINÆ.}

\section{Heterographis, Rag.}

3. Heterographis (Staudingeria) innotalis, $1 \mathrm{~m} \mathrm{mpsn}$. (Plate xx. fig. 17.)

Heterographis (Staudingeria) imotalis, Hmusn., Bull. Liverp. Muss., ii. p. 39 (1s99).

\& Hearl and thorax pale red-brown; palpi below, edges of tegule and upper edge of patagia white; a slight dorsal tuft on first segment of aludomen, pectus, greater part of legs, and ventral surface of abdomen white. Fore-wing pale red-brown; a white pateh at base of imer margin; the marginal areas broarlly anrl strongly irrorated with fuscons. Hind-wing semi-hyaline white, the terminal area tinged with fuscons. The antenne with very long cilia, as in the $/$. yerburi from Aden. Exp. $24 \mathrm{~mm}$.

Alsl-el-Kuri, 1 o.

\section{PYRAUSTINÆ.}

\section{Zinckenia, Zell.}

4. Zinckenia fascialis, Crem.

Pyralis fascialis, Cram., Pap. Exot., iv. pl. cecxeviii., o.

Abr-el-Kuri, 1 t, 2 오. 


\section{Glyphodes, Guen.}

5. Glyphodes indica, Sunut.

Eudioptis indice, Saund., Trans. Ent. Soc. (2), i. 1. 1633 (18.51).

Abd-el-Kuri, 1 o .

\section{Antigastra, Led.}

6. Antigastra catalaunalis, Dup .

Pyralis catalaunalis, Dup., Lép. Fr., viii. p. 330, pl. cexxxii., fig. s. Alxl-el-Kuri, 1 ơ, 1 ․ 



\section{PLATE XX.}

Fig. 1..... AGROTIS BRACHYPECTEN, Himpsu., p. 322.

Fig. 2..... METACHROSTIS TERMINIPUNCTA, $\Pi m p s n$. p. 324 .

Figs. 3, 22. CIDARIA HOLOPH $Æ$ A, $H m p s n$., p. 33 I.

Figs. 4, 23. STENIA GRISEALIS, IImpsn., p. 335.

Fig. 5..... METASIA PRIONOGRAMMA, Meyr., p. 336.

Fig. 6...... MEGALODES INSOCIA, $W l l$., p. 324.

Fig. 7...... CRASPEDIA FUlVICOLOR, Hmpsu., p. 33 I.

Fig. 8..... CAllopistria RECURVATA, Moor $r$, p. 324 .

Figs. 9, 10. TARACHE MELAENA, Hmpsu., p. 324.

Fig. II..... AMEFRONTIA PURPUREA, Hmpsu., p. 327.

Fig. Ira. ... Antennu "f same inlurged.

Fig. 12. .... AMEFRONTIA ALBILUNA, $H m p s n .$, p. 327.

Fig. 13..... AZYGOPHLEPS INCLUSA, $\| 7 /:$, p. 333.

Fig. 14...... BANIANA INTORTA, Swiut., p. 328.

Fig. 15...... OPHIUSA DIANARIS, Guen., p. 328.

Fig. 16. ..... HYPOGRYPHIA PULVEREALIS, $H m p s n$. , p. 333.

Fig. I7..... HETEROGRAPHIS INNOTALIS, Himpusu, p. 337.

Fig. 18. ..... CRASPEDIA DISPARATA, Styr., p. 332.

Fig. 19...... HETEROGRAPHIS FLAMMEALIS, Hmpsn., p. 334.

Fig. 20...... SCOTOSIA RUBRITINCTA, $H m \mu s n .$, p. 330.

Fig. 21..... HYPERYTHRA AEDIPHLEBIA, $W l k$., p. 330.

Fig. 24...... CARADRINA PARTITA, Wll., p. 323.

Fig. 25...... SCOPARIA MURIFICALIS, II $7 k$, p. 335.

Fig. 26...... CARADRINA ORBICULARIS, II lk., p. 323.

Fig. 27..... CEROCALA SOCOTRENSIS, Hmpsn., p. 326. 
Liverp. Mus. Rep Sohcira linped
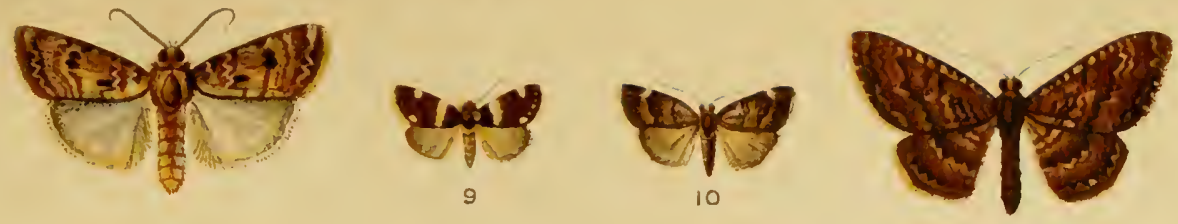

20
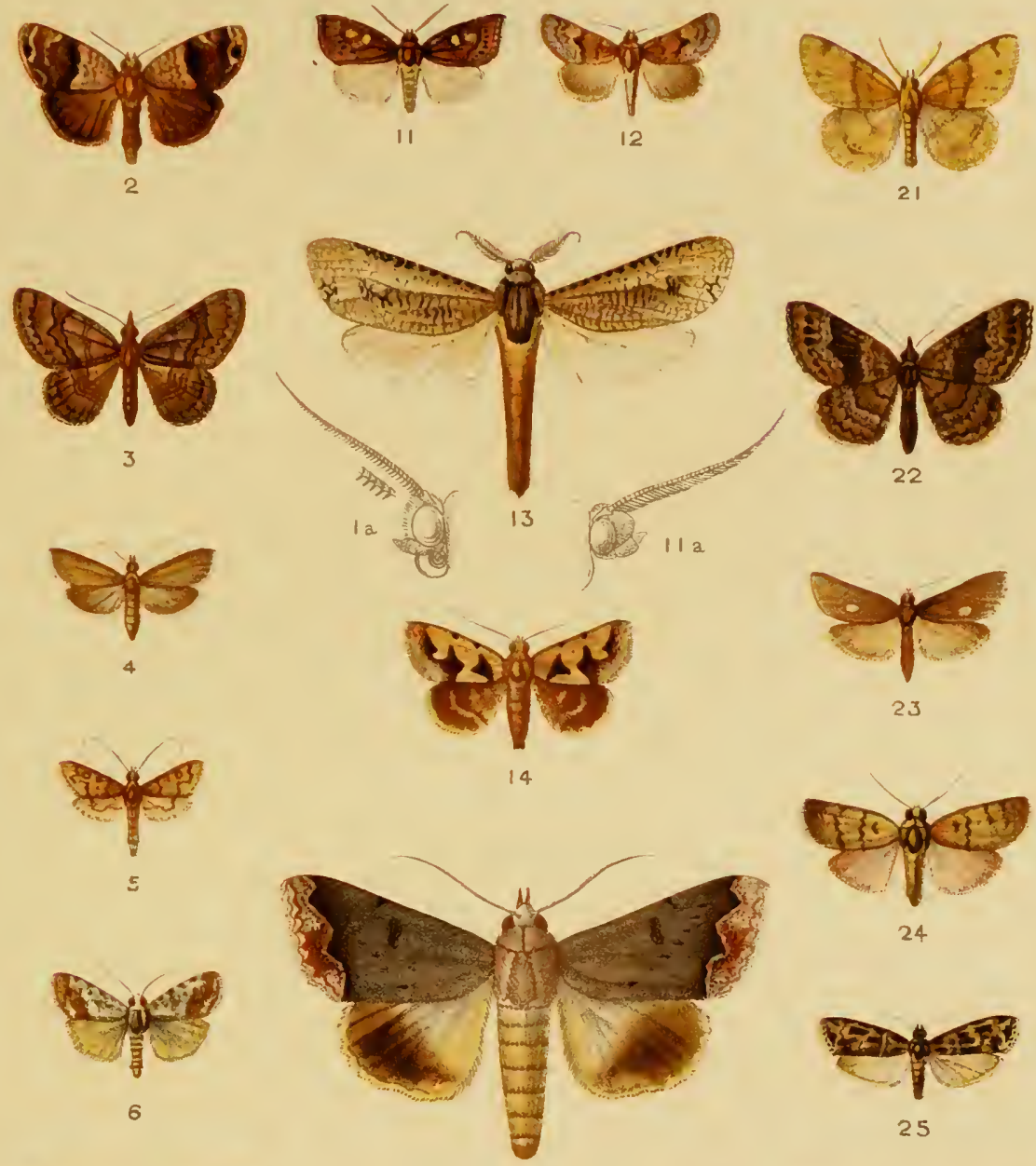

6

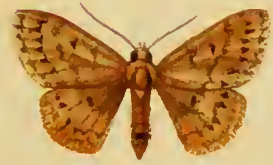

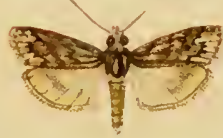

16

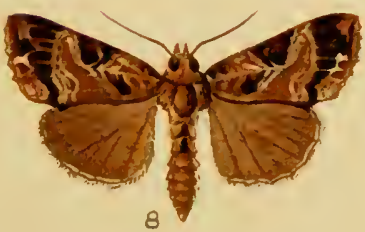

ECKnight ad nat.ith

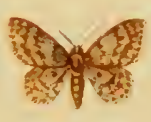

18

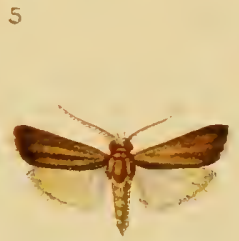

17
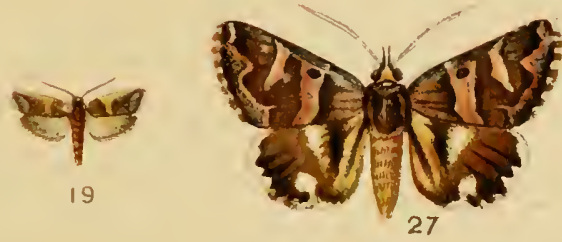

Wost,Neurnar, chromo 



\section{ARTHROPODA.}

\section{Insecta:}

\section{Lepidoptera.--III.}

Pterophoridæ and Tineina.

By The Right Hon.

LORD WALSINGHAM, M.A., LL.D., F.R.S. 



\section{Moths II.}

With so small a relection from among the numerons species which must umbonbtedly ocem in the island of Sokotra, it would be premature to express any deeided opinion as to the geographical attinities of the ishand fauna : indeed, there are no sufficient indications to warrant the chim that these insular forms are more intimately related to one of the arljaeent eontinents than to the other. With few exceptions they eonform to the ordinary Mediterranean type, although in all eases speeially distinct. One new species is interesting as oceurring also in West Africa, on the Gimbian eoast, afforting a parallel instanee to that of Laverne yumlielle, Wlsm., atrearly reeorded from the Gambia and Arlen.

Some ineonvenience oecisionally arises in describing Lepidopter, from the faet that no single term has hitherto heen used to express the angle so frequently formed on the dorsum of the fore- or hind-wings in the direction of the hase. On the hind-wing this angle is usually deseriber as the abdominal angle, and the margin between this and the base is called the abrominal margin. I shonld propose, for conrenience of description, that the word flems be applied to the abdominal angle and to its equivalent when it oeeurs on the fore-wing, that the term dorsum should lie limited to that portion of the margin which lies beyond it, except when no appreeialole angle exists, and that the term limbus should be userl for that portion of the margin lying between the flexus and the base. I have marle use of these terms in the present paper.

I must express my thanks to Mr. Wr. R. Ogilvie-Grant and Dr. H. O. Forbes for the opportunity they have afforded me of working out this small but interesting collection.

The following signs are nsed in this paper :-

* = invalid, as not containing the type of the eonception.

$\dagger=$ wrongly witten either in inception or in adoption.

[Wlsm. \& Dint., Merton Rules, p. 18 (1896).]

In cleference to the wishes of the Editor, l.c. numerals have been substituted for caps.., which I habitually employ when quoting volumes or plates. 


\section{The Micros of Sokotra.}

PYRALIDINA.

\section{PTEROPHORID压.}

\section{Trichoptilus, W/sm.}

1. Trichoptilus oxydactylus, $\| / k$.

n. synn.=harmiiensis, Btl. ; = centetes, Meyr.

Pterophomes oxymlertylus, Wki., Cat. Lp. Ins. B. M. xxx. $944(1 \& 61)^{1}$.

Aciptitia huenoiensis, Btl. Ann, and Mag. N. H. (5. s.) rii. 408 (1881) ${ }^{2}$.

Aciptitie oxydertyla, W1sm., Pr. Z. Soc. Lond., 1885, $885(1886)^{3}$.

Trichoptilus centetes, Meyr., Tr. Ent. Soe. Lond., 1886, 16-17 4 : 1887, $266^{5}$.

Pterophorus oxyductylus, Moore, Lp. Ceyl. iii. 528-9, Pl. 209, 16 (1887 $)^{6}$.

Trichoptilus havaiensis, Meyr., Tr. Ent. Soc., Lond., 1888, 239 ?.

Pterophorus orydletylus, Swinh. \& Cotes, Cat. Moths Ind. 669, No. $45+9$ $(1889)^{8}$.

Trichoptilus centetes, W'sm., Pr. Z. Soc., Lond, 1891, 494-5, 542 (1892) ${ }^{9}$.

Trichoptilus orydlectylus, Wlsm, Pr. Z. Soc., Lond., 1896, 27т 10.

Trichoptilus centetes, Wlsm, Pr. Z. Soc., Lond., 1897, 56, No. $1^{11}$ : Ent.

Mo. Mag. xxxir. 192 (1898) ${ }^{12}$.

Sokotra: Hadibu Plain, 12-15. XII. 98: Abd-el-Kmi Id. 1-3. XII. 98.-

Seven specimens.

[? United States ${ }^{(9,12)}$ ? Mexico $\left.{ }^{(9)}\right]$. West Indies ${ }^{(9,11)}$. Arabia ${ }^{(10)}$. India ${ }^{(3,8)}$.

Ceylon ${ }^{(1,6,8)}$. New Guinea ${ }^{(4)}$. Queensland ${ }^{(5)}$. Hawaiia ${ }^{(2,7)}$.

\section{TINEINA.}

GELECHIAD无.

\section{Onebala, $W k r$.}

2. Onebala simplex, $1 / 7 \mathrm{sm}$. (Plate xxi. fig. 2.)

Onehala simplex, Wlsm., Bull. Liverp. Muss., iii. 1. 2 (1900).

Antenne slightly serrate; pale fawn-ochreous, rlusted with greyish fuscous above, the basal joint dark fuscous above. Pulpi long, strongly reeurved, smooth, the median joint somewhat flattened; pale fawn, ochreous. Head greyish. Thorax pale fawn-ochreous, smeared with greyish fuscous above. Fore-wings pale fawn-ochreous, slightly sharled with greyish fuscous, especially above the fold and before the apex and termen; with three blackish spots, the first on the cell before the middle, another in the fold straight helow it, a thirrl at the end of the cell; also four or five blackish dentate spots along the termen at the base of the greyish ochreous cilia which have a paler basal line. Exip. 
al. $115 \mathrm{~mm}$. Himl-wings pale greyish, the eentral portion slightly iridesent; cilia brownish grey. Andomen fawn-ochreous, with greyish fuscous shading. Legs pale cinereous.

Type of (1:3361) Mus. Wlsm.

Sokotra: Adho Dimellus (3500 ft., 2. II. 99).--Unique.

This has the true neuration of Onebula, Wkr., 2 and 3 of the fore-wings stalked, 7 and 8 stalked, 9 separate. The Onebule of Meyrick (Tr. Ent. Soc. Lond. 1894, 15-16) = Coyfdullı, Wkr., not Onebule W $\mathrm{Wr}$.

3. Frisilia (?), sp.

\section{Frisilia, $W k r$.}

Sokotra : Arlho Dimellus (3500 ft., 12. II. 99). [Wlsm. Coll.13386.]

An utterly worn speeimen belonging to the Geledicule and allied to Frisiliu, Wkr., hut in the fore-wings 7 and 8 (coincident) are stalked with $9, \tau+8$ to costa : - and 3 (eoincident) are shortly stalked with 4 and commate witlı 5 .

\section{Hypsolophus, $F$.}

$$
=\dagger \text { Yiselophers (F.), Auct. }
$$

I use this generic name in its accepted sense, but doubt the correctness of its application.

4. Hypsolophus granti, iVlsm. (Plate xxi. fig. 3.)

Hypsolophus gremei, Wlsm., Bull. Liverp. Muss., iii. p. ㄴ(1900).

Antenme pale brownish testaceous, with some fuscous scaling near the basal joint. P'elpi with the usual triangular tuft on the median joint, dark brownish externally, with a whitish line along its upper edge; the terminal joint white, speckled with black scales. Head and Thorux pale brownish testaceous. Fore-wings pale brownish testaceous, speekled with black; some short oblinue fuscous streaks along the costa, and a few groups of similar scales about the micldle and end of the cell, on the dorsum before the tormus and abont the termen, with one erect black dorsal patch at onc-sixth from the base (this patch, which is very distinct, occurs in one specimen only ont of a series of five, but in one or two of the others it is indicated by a few dark scales in the same position; the ground-colour slightly varies either in the direction of paler brown or darker greyish testaceous, the sharing on the termen being also variable in quantity, and the speckling of dark scales more or less gronperl or tending to obliteration); cilia of the same colour as the wing-surface, slightly streaked with darker scales. E.ry. al. 15-16 mm. Himd-rings with the termen slightly bisinuate; somewhat iridescent along the mirldle, brownish grey ; cilia paler than the wing, and with a slender subochreous line along their base. Alulomen brownish grey (rarying to brownish testaceous). Legs pale brownish, with rather speckled fuscous sharling on their outer sicles. 


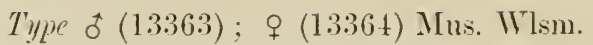

Sokotıa: Adho Dimellus (3.500 ft., 2. II. 99); Hadibu Plain (19-21. II. 99). -Five speeimens.

This species approaches the Enpatorial African IIypsolophus bresistriutus, WTlsm., but is slightly smaller, with narower wings, and less distinct makings. Teins 2 and 3 of the fore-wings are stalked.

5. Hypsolophus thoracellus, $177 \mathrm{sm}$. (Plate xxi. fig. 4.)

Hypsolophus thorecellu, Wlsm., Bull. Lirerp. Muss., iii. 1. 3 (1900).

Antenue cincreons, dusterl with blackish scales. I'ulpi with the usual projecting triangular tuft on the second joint, pale cinereons along its upper edge, rank grevish fuscous, minutely speckled with chestnutbrown alont its base, and becoming chestmut-brown to the apex along its lower half : terminal joint pale cinereons, sprinkled with blackish scales. Ilend dark greyish fuscous, face pale chestmut-bown. Throur chestmut-lnown. Fome wims dark greyish fuscous, with a broad chestnut-brown streak from the base along the costa to a little beyond one-thind: mottled along the extreme costa with fuscous, a small pale cinereous spot on the costa at its onter extremity, a larger pale cinereous spot occurring at the commencement of the costal cilia from which a faintly indicated pale band (arosses to the tormus; from the dorsum close to the hase arises an oblique streak of slightly raised scales reaching to the npper edge of the cell ; at the end of the cell is a minute blackish spot, its imner and lower edge narowly ontlined with whitish scales; cilia greyish fuscons, with numerous pale brownish einereous dentate points along their hasal third, these extending around the apex and termen. Lir. al. 16 mm. Himlwings trapezoidal ; somewhat iridescent, hownish grey, the costa and limbus tending more to brown, the central portion of the wing tending to grey with bluish iridescence : ailia pale brownish grey. Alutumm and Leys greyish brown, the latter thickly sprinkled with fuscous externally ; the underside of the abdomen whitish peppered laterally with fuscous seales.

Type $q$ (13:362) Mus. Wism.

Sokotra: Homhil (1500 ft., ert. 26. I. 1899).-Unieque.

Teins 2 and 3 of the fore-wings are stalked. This specimen was hed hy Mr. Grant, but the name of its ioorl-plant is not recorterl.

\section{Gelechia, $H b$.}

Gelechia sarcochroma, $/ / 7 \times m$. (Plate xxi. fig. 5.)

Gelechice sereochoma, Wlsm., Bull. Liverp). Ml1ss., iii. p. 3 (19001).

Anterne pale cinercous, with fuscous bars across the upper side. I'ulpi with the median joint thickened with rough scales heneath; Heshy white, with two fuscous anmulations on the terminal joint, a fuseous band on the outer side of the median joint at the base and some spots also near its apex. Hew fleshy whitish. Thoreri whitish thesh-colon, 
with slight fuscous shading. Fore-kings: whitish Hesh-colour, with slight fuscons shading: with four fuscons costal spots, the first at the base, the second at about one-sixth, the thind at ahout the micklle, the fourth at the commencenent of the costal cilia : a houl dorsal streak, arising at one-fifth from the base, terminates at the upper erlge of the cell a little beyond the second costal spot, some of the flesh-colomred scales between this and the hase are distinctly raised; there are a few fuseous seales beyond the mirlde of the cell and one or two in the fold beneath them: cilia dull greyish ochreous, faintly specklect with fuscous and tinted with flesh-colour ahout the apex. E.r o. al. $16 \mathrm{~mm}$. Hind-xings shining pale bluish grey : cilia very long, pale hrownish ochreous. Alutomen pale hrownish ochreous. Leys somewhat hairy alove: whitish ocheous, with two fuscous spots externally at the base of the hind tibiate.

Type of (13:360) Mus. Wlsm.

Sokotra: M(lho Dimellıs (3500 ft., 2. II. 1899).-Uninue.

\section{HYPONOMEUTIDÆ.}

Batrachedra, Stn.

7. Batrachedra atomosella, $\| \%$ sm. (1'late xxi. fig. 6.)

Butrachedre atomosella, Wlsm., Bull. Liverp. Muss., iii. P. 4 (1941).

Antenne with the hasal joint long, slightly thickened with appressed scales above; white, with minute blackish dots above. l'ulpi recurverl, terminal and median joints of abont equal length, the latter elothed with a rather long tuft of projecting scales; white, speckled with black; the terminal joint smooth, with three blackish anmulations, the apex blackish. Heal white, profusely speckled with black at the eme of the broal flattened seales. Therex white, specklerl with black, assmming the form of minute strigat on the tegule. Forp-riags white, speckled with black, assuming the form of minnte strigae in a short series at the base of the costa; a second series from the base along the cell to about one-sixth, thence the remainder of the wing, nearly to the apex, is more or less profusely speckled with greyish fuscons having a tendeney to run in transrerse strigule: a slight shade on the middle of the costa is succeeded by a transverse shade-hand at threefourths, beyond which the acute apex of the wing is narrowly ontlined with brownish ochreons bearing a reduplicated minute hrownish ochreous oblipue streaklet at the commencement of the costal cilia and another beyond it on the dorsum, a slender blackish line points to the apex in the intermediate space; cilia at the apex white, freely speckled with minute black scale-points, the cilia about the tormu. greyish cinereous. Exp. al. $10 \mathrm{~mm}$. Hind-rings and cilia greyish einereous; the wings lather shining. Abclomen with an ochreous tinge 
on the basal half, whitish posteriorly ; with an expansible hair-pencil

posteriorly. Legs smooth, whitish, specklerl with black externally.

Type of $(13376)$ Mus. Wlsm.

Sokotra: Hadibu Plain (21. II. 99).-Unique.

\section{Scythris, $H b$.}

8. Scythris denticolor, $/ / 7 \mathrm{sm}$. (Plate xxi. fig. 7.)

Scythris denticolor, Wlsm., Bull. Liverp. Muss., iii. p. 4 (1900).

Autenue dirty brownish white. Palpi whitish, with a slight brownish tint externally. Hew and Therex brownish white. Fore-wings whitish, with a faint brownish tinge except about the apex; a small fuscous spot lies in the fold a little before the middle of the wing and another at the end of the cell; eilia white at the apex, suftuserl with brownish ochreous towards the tormus. Exp. al. $16 \mathrm{~mm}$. Hind-uings whitish grey, with some faint brown scaling towards the apex; eilia light brownish ochreous. Abdomen whitish, shining silvery white beneath. Ley: whitish.

Type o (13377) Mus. Wlsm.

Sokotıa: Hadibu Plain (11-12. XII. 98).-Two specimens.

9. Scythris neurogramma, $I / 7 \mathrm{sm}$. (Flate xxi. fig. 8.)

Srythris neurogremme, Wlsm., Bull. Liverp. Mluss., iii. 1. 4. (1900).

Antenua greyish brown. Palpi smooth, recurver ; rirty whitish, shaded with greyish brown externally. Head and Thorax pale greyish brown, mixerl with dirty whitish. Fore-uings dirty whitish, with greyish brown shading, nsually broken into length-streaks eorresponding to the spaces between the veins, separated by lines of the white groundcolour of variable wirlth; a narrow greyish brown line along the upper erlge of the eell is recurved around the outer end of the eell, while above and heyond it is a series of very short greyish brown oblirne streaks not reaching the costa, and more distinetly separated in the direction of the costa than towards the apex and termen, where they are somewhat densely crowded; another narrow line follows the upper edge of the fold and the dorsal space below the fold is almost entirely suffused with pale greyish brown; eilia greyish brown, with a slight ochreous tinge, giving them a brighter appearance than the wing-markings. Exp). al. 1: $\mathrm{mm}$. Hind-uings brownish grey, the cilia as in the fore-wings. Abdomen greyish, anal tuft whitish einereous. Legs dirty whitish.

Type of (13379) Mus. Wlsm.

Sokotıa : Hadibu Plain (11. XII. 98); Adho Dimellus (3,500 ft., 12. II. 99). -Five specimens.

The wings of this species are somewhat narrow and very acutely pointed, and the markings assume the pattern so frequently represented in the genus Coleophoru, $\mathrm{Hb}$., especially in troglodytellu, $\mathrm{D}_{\mathrm{p}}$., and its allies. 
I lave slight varieties of what appears to be the same speeies from Bathurst (Gambia).

10. Scythris, sp.

Scythri, sp. Wlsm., Bull. Liverp. Muss, iii. p. 5 (19000).

Sokotra : Hadilnu Plain (15. XII. 98).-[Mus. IV'sm., 13375.]

A single specimen in poor condition, bnt distinct from those now described.

11. Scythris (?) pectinicornis, Wr $1 \mathrm{sm}$. (Plate xxi. fig. 9.)

Scythris (.) pectinicornis, Wlsm., Bull. Liverp. Muss., iii. 1. I (1900).

Antenne? with a strong elosely packed pecten on the hasal joint; biciliate in both sexes (o 1-1 $\frac{1}{2}$, o rather less); pale cinereons. Pulpi, of recurved to the level of the rertex, the terminal joint shorter than the median; \& more slender and less recurved: whitish cinereons. Heul and Thorex whitish cinereous. Forp-evings whitish cinereons, profusely dusted with lnownish grey scaling, evenly rlistributed throughout, except a little beyond the middle of the fold where it appears somewhat eoncentrated ; cilia whitish cinereous, becoming brownish ochreous abont the tornus. Err. al. of 12 , o $11 \mathrm{~mm}$. Kiml-wings rosy grey ; cilia pale brownish ocheous. Abumen. whitish cinereous. Leys, hind tibise pale brownish ochreous, hind tarsi whitish einereous. T'ype of (1338.3); q (13382) Mus. WTsm.

Sokotra: Harlilu Plain (15. XII. 98).-Two specimens.

This speeies, which might easily be confused with nenrogrumma, W'sm., agrees with Srythis in nemation and in all other respects, except in the ciliation of the antemne; lnt with snch insufficient material before me I shall not renture to make it the type of a new genus.

\section{Genostele, W/sm.}

Genostele, Wlsm., Bull. Liverp. Muss., iii. p. 5 (1900).

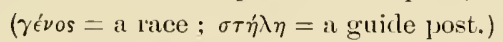

Type Genostele reniger, $/ / 7 . m$. (Plate xxi. fig. 11.)

Antenne (q) $\frac{3}{4}$, simple, tending to slight serrations before the apex. Ocelli alssent. Muxillury Prlpi well-developerl; porrect, inflected. Labiul Palpi long, recurverl, the median joint slightly roughened towarls the apex; terminal joint scarcely shorter than the median, slender acute. Hewl and face clotherl with loose scales. Thorur: smooth. Fore-vings fon times as long as loroal, elongate, eosta slightly archerl, the apex clepressed, romoled, termen oblique. Neurufion, 11 reins, ( 7 and 8 coincilent) to costa ; the other veins separate. Hind-wings not hroarler than the fore-wings, somewhat romeled at the apex, not emarginate. Nemration, 8 reins ; 3 and + almost connate, 6 and 7 separate and almost parallel, 6 about equidistant fiom 5 and 7 . Aludomen normal. Leys, hind tibia somewhat hairy above.

This genus differs from C'rostomm, L.tr., in the separation of veins 6 and 7 of the hind-wings and from Plutella, Schrk, in the remoteness of 
vein 6 from 5 ats also in the coincidence of reins 7 and 8 of the forewings, but in general appearance and structure its aftinity would be to these genera. The genus Anrylometis, Meyr., from Manritius appears to approach fienostele in some respects, particularly in the coineirlence of veins 7 and $s$ of the fore-wings, but if Meyrick is correct in describing it as haring rein $\tilde{5}$ of the hind-wings approximated to, or coincilent with $t$, it must be regarderl as sufficiently distinct.

12. Genostele reniger, $117 \mathrm{sm}$. (Plate xxi. figs. 10-11.)

Genostele reniger, Wlsm., Bull. Liverp. Mnss., iii. p. 6 (1900).

Antemuce pale stone-ochreous, ammulate with fuseons. Pulpi with the median joint thickened with appressed scales which are somewhat loosener towarls its apex beneath, pale stone-ochreous, profusely speckled with brownish fuscous; the terminal joint slender, similarly colonred. Ifeul pale stone-ochreous, with a brownish fuscons streak along its middle above, this is continned throngh the anterior half of the pale stone-ochreons Thorux on which are also two parallel lateral dark fuseous streaks. Fore-wings pale stone-ochreous, speckled with brownish fuscous, a narrow dark fuscous streak along the base of the costa, with another beneath it, parallel to the limbus, but not extending heyond the flexus; at the base of the cell is an elongate reniform patch, outlined with dark fuscous, extendert to about one-fifth and tonching at its outer extremity the transverse reniform patch, which covering the whole wilth of the eell, extends downwds across the fold nearly to the dorsum : this is separated from a third reniform patch, occupying the end of the cell and extending a little below it; these patches are all narrowly ontlined with dark fuscous (and from inrlications aflorded by a second specimen-presumably of the same species - will be foumd in some varieties to be more or less strongly filled in with rark brownish fuscons) ; above the outer pateh is a clark fuscons costal shade before the commencement of the cilia ; a gromp of dark fuscous scales also oceuring before the apex mirlway between the costa and termen, and accompanierl ly some profusion of nownish fuscous speckling which extends along the termen and is strongly repeated thronghout the pale stone-ochreons terminal and apieal cilia. Erp.ul. 19 mm. Hind-uings greyish; cilia pale bownish cinereous. Aludomen brownish ochreous. Leys pale brownish cinereous, the tarsi speckled with brownish scales.

Type o $(1336 s)$ Mus. Wlsm.

Sokotra : Arho Dimellus (3500 ft., 2-3. II. 99.)-Two specimens, both $q$.

\section{Prays, Ho.}

13. Prays (?), sp.

Prays (?), sp. Wlsm., Bull. Liver], Muss., iil. p. 6 (1900).

Sokotra: Arlho Dimellus (3500 ft., 11. II. 99).-[Mus. W'sm. 13370.] 
A single speeimen of what appears to be a species of Pruys, allied to citri, ILill., in damagerl comblition, having evirkntly been taken with the assistance of oil and tire.

\section{Mieza, Wkr.}

14. Mieza (?) inornata, // 7 sm. (Plate xxi. fig 12.)

Jieza (?) inornala, Wlsm., Bull. Liverp. Nluss, iii. p. 6 (1900).

Intenne fusco-cinerenus. Pulpi porrect, slender: hoary whitish, with some fuscons seales externally. ILead and Therex dirty whitish. Fore-rings: dull grevish white, the reins and cell narrowly marked out by lines of hownish arey, the costa and the dorsmm beneath the fold slightly suffused with the same: cilia hoary whitish, sprinkled with lownish grey atoms. E.r. "ll. 12 mm. Himl-reinys dirty whitish cinereous: cilin whitish cinereous. Ablomen buwnish grey. Leys: whitish cinereous; the tarsi slightly sharled.

Type q (1337t) Mus. W'sm.

Solotra: Haclibu Plain (11. XII. 98).-Unique.

In the hind-wings reins 3 and 4 are stalked, in which respect some divergence is shown from the typical nemation of Hies.

\section{TORTRICID压.}

\section{OLETHREUTIN/E.}

\section{Cryptophlebia, W/sm.}

Cryptophletru, Wlsm. Ind. Mus. Notes iv., 10.5 (1899).

15. Cryptophlebia (?) socotrensis, $I / 7$ su. (Plate xxi. fig. 13.)

Crytophlebia socotrensis, Wlsm., Bull. Liverp. Muss., iii. p. 6 (1900).

Antenne greyish fuscous, the hasal joint tawny reddish. Pulpi conical, extending more than the length of the head beyond it ; tawny reddish, the apex of the terminal joint slightly fuscoms. Heal and Thorar tawny redlish, the latter slightly tufted posteriorly. Fore-wings tawny reddish, with elosely packed transverse wary lines of sericeons motthing arising from the eosta and traversing the whole width of the wing, leaving a faint indication of two tawny redrlish spots at the onter angles of the cell; the extreme hase only appears to be free from these sericeous wave-lines, and the extreme elge of the costa is very narowly touched with ocheous [what remains of the cilia is tawny redlish]; the underside is tinged with ochreons thronghout, and shows a faint indication of greyish fuscous mottling, especially arouml the costa and termen. Exp. al. $22 \mathrm{~mm}$. ILiml-wings brownish fuscous, cilia slightly paler; underside with a faint indication of grevish fuscous mottling especially around the costa and termen. Aludomen brownish fuscous. Leys pale greyish ochreous, the hind tarsi transversely shaded with brownish fuscous.

Type q (13371) Muss. Wlsm. 
Sokotra: Arlho Dimellus (3500 ft., 12. II. 99).-Unique.

In the absence of the $\delta$ it is impossible to rletermine whether this species belongs to the genus Cryptophlelin or to an undescriber genus ocenring in Africa and Anstralia to which * Arotrophora ombrodelta, Lower and Froggatt, belongs. The lanva will probably be fomd to be attached to Legruminose', presumalbly to some species of Acuriu.

16. gen. ? sp.?

Sokotra: Under Alilo in the Dinehan Valley (1500 ft., 2 II. 99).-[Mus. Wlsm. 13387.]

A single $q$ in very poor condition, belonging to the group of Crocidlosema, Z., and lihopolote, Ld., cannot he generically irlentified in the alsence of the of.

\section{TORTRICINÆE.}

17. Oxygrapha, sp.

\section{Oxygrapha, $H b$.}

Teras, sp., Dixey, Pr.Z. Soc. Lond., 189s, 383.

An undetermined species was collecterl hy Mr. Bennett.

\section{Archips, $H b$.}

18. Archips (?) socotranus, $/ / 7 \mathrm{sm}$. (Plate xxi. figs. 14-15.)

Archips (?) socotranus, Wlsm., Bull. Liver]. Muss., iii. p. T (1900).

Antenna cinereous, sharlerl with lrown (or testaceons). Palpi porrect, conical, stretching twice the length of the head beyond it, thickly clothed above with appressed scales; dark lust-brown (or testaceous). Heal rust-hown (or testaceons). Thor farn-brown (or testaceons). Fore win!s fawn-hown (or brownish testaceons), with a faint indication of a darker reddish (or testaceons) ol,lique fascia from before the mirdle of the costa, and an ante-apical costal pateh, [in the darker of the two specimens (13373) there is a slight outline of a basal patch-in the of these markings may he expected to assume a more pronounced appearance]; the surface of the wing is somewhat shining, and thickly speckled with scarcely darker spots in transverse simuate lines (visible only with the light striking the wings at a suitable angle); cilia along their base chestnut hown, except around the tormus, greyish cinereous on their onter half and at the tornus ; faintly reticnlated along the costa and around the termen on the underside. Exp. al. 22-23 mm. Himl-ximys somewhat incised helow the apex and near the flexus; shining brownish grey, strongly iridescent towards the base and paler in the costal than in the dorsal region, a slight reticnlation of darker scales abont the apex and on the base of the cilia aromd it ; cilia pale shining brownish grey ; underside faintly reticulated along the costa and around the termen. Alulomen shining greyish ochreons (or pale brownish grey). Legs shining, pale brownish cinereous. 
Type $[=$ Cotypes $q$ \% $(13372-3)]$ Mus. Wlsm.

Sokotia : Adho I)imellus (3500 ft. 11-12. II. 99).-Two specimens.

Two $q$ q showing some diversity of colour, hut obviously belonging to the same species which appears to he related to lufuniyours, liag., but to rlffer in the somewhat more rounded costa towards the base and in the more sericens appearance of the wing-texture. In the alssence of the of this camnot he referred with certainty to the gemms Arrlipos.

\section{TINEID必.}

19. Acrocercops sp.

\section{Acrocercops, WIgrn.}

Sokotıa: Haggier liange (II. 99).--[MIus. Wlsm.]

I am indelsted to Dr. Relsel for a specimen of a small obscure species of this genus collected hy Professor Simony, a member of the Austrian Expedition to Sokotra under the anspices of the Imperial Academy of Sciences in Vienna, in $1 \leqslant 99$. 


\title{
Micros from Abd=el=Kuri.
}

\author{
PYRALIDINA.
}

\section{PTEROPHORID尼.}

\author{
Trichoptilus, W/sm.
}

1. Trichoptilus oxydactilus, $I \% \%$.

(See p. 344.)

A1-el-Kuri (1-3 XII. 98).

\section{Agdistis, $H b$.}

2. Agdistis minima, $\| / 7 s m$. (Plate xxi. fig. 1.)

Agdistis minima, Wlsm., Bull. Liverp. Mnss., iii. p. 1 (1900).

Antenne brownish einereous. Pulpi very short, elosely appressed to the face, the terminal joint scarcely visible at the end of the rather thickly elothed median joint; whitish einereous. Heal and Thorex whitish einereons. Fore-wings whitish cinereous, thiekly dusted with blackish scales along the costal and dorsal thirds, on the costa before the apex are three slight aggregations of the black sealing forming searcely noticeable eostal spots; the usual elongate semi-transparent triangle reaches to within one-third of the base, and is brightly iridescent; eilia whitish cinereous, speckled with black scales along their base. E.rp. wl. 12-14 mm. Hind wings with a noticeable elongate mat of black seales near the base on the undersile, terminating in a comb of separate black hair-seales along the lower margin of the cell ; brownish grey, mueh speekled with black scaling along the dorsum, slightly iridescent towards the costa; eilia whitish einereous. Abdomen whitish einereous. Legs whitish, profusely sprinkled with minute llack scale-points.

Type o (13358) Mus. W'lsm.

Abd-el-Kuri Id. (1-3. XII. 98).-Two specimens.

This is the smallest known species of Agdistis and differs very eonsiderably in its paler colouring from those European species which tend to approach it in size. 



\section{PLATE XXI.}

Fig. 1. AGDistis Minima, $/ 7$.sm. Type ô, p. 354.

Fig. 2. ONEBALA SIMPLEX, $/ 77 \mathrm{sm}$. Type ơ, p. $\mathbf{3 4 4}$.

Fig. 3. HYPSOLOPHUS GRANTI, $I / \mathrm{km}$. Type ô, p. $345 \cdot$

Fig. 4. HYPSOLOPHUS THORACELLUS, $I / 7 \mathrm{sm}$. Type $q$, p. 346.

Fig. 5. GELECHIA SARCOCHROMA, $I T / s m$. Type $\delta$, p. 346.

Fig. 6. BATRACHEDRA ATOMOSELLA, $\| l \times m$. Type ô, p. 347 .

Fig. 7. SCYTHRIS DENTICOLOR, $I T / s m$. Type + , p. 348.

Fig. 8. SCYTHRIS NEUROGRAMMA, $/ l s m$. Type ${ }^{\dagger}$, p. 348.

Fig. 9. SCYTHRIS (?) PECTINICORNIS, Wlsm. Type ô, p. 349.

Fig. 10. GENOSTELE RENIGER, $\| 7 \mathrm{sm}$. Type $\uparrow$, p. $\mathbf{3 5 0}$.

Fig. 11. GENOSTELE, $\| 7 \mathrm{sm}$. : neuration and head, p. 349.

Fig. 12. MIEZA (?) INORNATA, $W l s m$. Type $q$, p. 351.

Fig. 13. CRYPTOPHLEBIA (?) SOCOTRENSIS, $I 7 / s m$. Type $q$,

p. 351 .

Fig. 14. ARCHIPS (?) SOCOTRANUS, IV lsm. Co-type $\left(\frac{1}{2}\right) q$, p. $35^{2}$.

Fig. 15. ARCHIPS (?) SOCOTRANUS, $I 7 l s m$. Co-type $\left(\frac{2}{2}\right) q$, p. 352. 

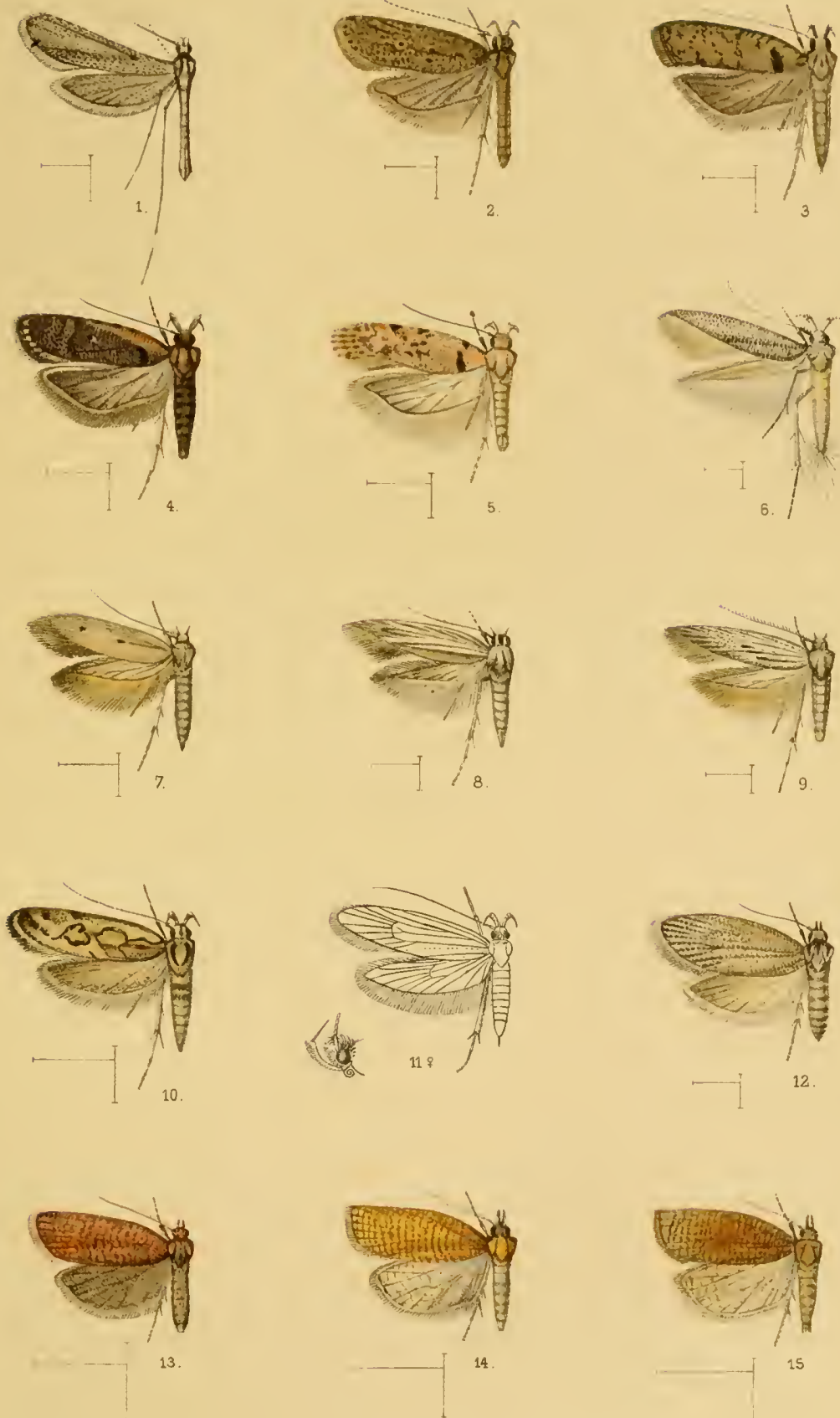

13. 



\section{ARTHROPODA.}

\section{Insecta: \\ Diptera.}

by GERTRUDE RICARDO.

('ulicide By F. V. THEOBALD, M.A.

PLATE XXII. 



\section{Flies.}

In this small collection of Diptere from Sokotra and Abd-el-Kuri, nine speeies appear to be new to science, and of those identified with eertainty, two are illentical with European species, three with Sonth African, one with a ITest African, and six with speeies whieh have heen met with in the neighbourhood of Arlen and the Red Sea.

I am much indelted to Colonel Yerbury for his kind assistance and suggestions in the identification of many of the speeies, and without his help this list would have heen eren more ineomplete than it is. I regret it has not been possible to work out the Muscile more thoroughly; this family requires an expert's knowledge.-G. li.

\section{I.- The Flies of Sokotra.}

\section{TIPULID $Æ$.}

1. Tipula, $s p$.

\section{Tipula, Linn.}

Sokotra : 1 of, 2. $q$, Adho Dimellus (3500 ft., 10. II. 99).-A pair taken in coitu; and 1 q.

\section{Limnobia, $s p$.}

\section{Limnobia, Meig.}

Sokotra : 1 f , Adtho Dimellus (3500 ft., 15. II. 99).

[Crane-flies appear to be extremely rare in Sokotra. The specimens taken were almost the only ones seen._II.R.O.G.]

\section{MYCETOPHILID尼.}

3. Sciara, sp.

\section{Sciara, Meig.}

Sokotra : Arlho Dimellus (3500 ft., 3. II. 99). - One specimen.

\section{CULICID膺}

\section{Stegomyia, Theob.}

Female palpi short, male palpi long, as in Culex. Venation as in c'ulex. 
Head clothed entirely with flat hroad scales and upright forked ones; 110 traee of narrow curved seales; the head thus resembling that of Megurhime; meso-thorax with narrow enred or spindle-shaped scales; the seutellum with broad flat scales like the head; meta-notum unde.

This genus contains a number of closely related species, which were formerly ineluded in the genus Culer, but from which they differ in regard to the seale structure of the head and scutellum; the greater part of the hearl of Culer: is covered with narrow eurved scales, as also is the scutellum, whilst in this genus these two parts are eompletely eovered by flat seales, giving them a very marked appearance. The Type of the genus is Culex tuenutus, Wied. The larvae apparently have a short thick respiratory siphon.

4. Stegomyia granti, Theol. (Plate xxii. fig. 6.)

Stegomyia grantii, Theob., Mon. Culicidie, B.M., 1" 306, pl. xiv. fig. n.s (1901).

Thorax chestunt-brown; meso-thorax with a narrow median line of white scales forked in front of the scutellum, then a fine curved lateral pair, and another pure white line helow on each side. Abdomen black with well-defined narrow hasal white bands, which bend oblignely and form a straight oblique white line on each side of the segments. Venter white scaled. Legs black with fine pure-white lines and white basal bands to the hind tarsi ; lases of some of the fore- and mid-tarsi pale.

q Head black with two median lines of white scales meeting in a point in front, expanding baekwards, border of the eyes white-scalerl and a line of pure white scales between the eyes; eyes silvery; antenue brown with pale bands, basal joint black with a border of pure white seales, base of second joint reddish-brown; palpi eovererl with black and white scales, the tip being white scalerl. Thorax bright chestnutbrown, eoverect with very fine scales, almost like little hairs; a thin but very distinct median line of white scales which forks round a bare space just in front of the sentellum, a fine curved line on each side, starting from the side of the meso-thorax near the head, and abont the middle bending in and ruming down the dorsum of the mesothorax to the scutellum, there is also another lateral white line helow on each side; seutellum chestmut-hrown horlered with white seales and black bristles; metanotum chestnut-brown; plem:e chestnut-lorown with white scales.

Abdomen covered with dusky brown seales, showing a dull purplish tinge, and a few traces of ochraceous eoloration in some lights, each segment with a narrow hut very distinct basal band of white scales, which turns off' at an ohtuse angle on each side forming a straight lateral oblique line on each side of the segments; on the last two segments the white scales of the venter come up as a narrow line and join the oblique lateral stripes; posterior borders of the segments erlged with pale golden hairs. Legs black with white lines and hands as follows:-

Fore-femora and tibixe with three white lines of seales rumning the whole length, one ventral, the other two lateral ; lase of fore-metatasus white, 
also with white lines; tarsi black, slightly pale at the base owing to the absence of scales; mid-legs rery similar, but the bases of the first two tarsal joints bather more distinctly pale; hind-legs with the lase of the femora quite pale, and the hases of the first and second tarsi hoully banderl with white: last two talsid joints lost. Ungues of the fore and mid legs small, eynal, and simple. Wings with rather long narlow brown seales on the veins; first submarginal cell very little narower or longer thim the second posterior eell, the stem of the latter only about half the length of the cell ; posterior cross-vein alout $1 ? 2$ times its own length distint from the mid eross-rein.

l.ength 5 mm. (not including proboseis).

Soliotra. - Time of ripture, December.

Ohserations.-Described from a single o specinen brought back from Sokotra, where Mr. (Grant tells me it is very troublesome. It resembles in a most striking manner C. sputhipulpis." Tond., the thorax and head being similarly marked, but the peculiar alodominal banting, the perfect white lines on the black legs, the posterior crossvein being close to the mid cross-vein and smaller, and the entire alssence of wing spots separate it at sight: moreover, owing to the head and scutellar scales being flat, it is clearly separated from C. sputhipulpis, and comes into my new genus stegomyin.

[In addition to the alove there were at least two other species of mosquito that attacked us in Sokotia. I was, unfortmately, mmare at the time of the interest attaching to these flies, and, being much occupied with other branches of zoology, dicl not preserve a series, which I greatly regret.-II.R.O.G.]

\section{THEREVID曆.}

\section{Psilocephala, Zett.}

5. Psilocephala albohirta, ". s\%. (Plate xxii. figs. 5, 5a.)

Type of. Black with white pulbescenee. Face naked. Fourth posterior cell of wing closed.

Face with white tomentum, forehead dull black with a little tomentum in the centre of the lower half. Antennat with the first joint shortly eylindrical, black, clothed with black hairs, the second short and roumd, bright red, with a few black hairs at the sides, the third long, as wide as the second at the base, gradually tapering to a point, loright red, back at apex. Palpi black, with long white hairs. Beard white. Eyes eontiguous. Hind-part of the head with short liack pubescence. Thorax dull black, with seattered fulvous pubescence on the dorsm and sides. Breast elothed with white hairs. Seutellum with a fringe of white hairs on its outer. margin. Aldomen with white hairs on the posterior margins of all the segments, and on the whole width of the segments at the sides; genital organs red, the underside of ahdomen with a few scattered 
white hairs. Legs black, the coxie, the apex of the femora, the hasal half of the tibie and of the tarsi reddish-brown, the femora with white pulnescence, longest on the anterior pair, the pulrescence on the tibia and taws black. Wings clear, grey, reins hown, the eross veins with very slight shating, the fourth posterior and anal cell closed.

Length $9 \frac{1}{2} \mathrm{~mm}$.

Sokotra: Homhil (2500 ft., 26. I. 99).--Two specimens.

[Both were olitained on a dry stony path near the top of the limestone range at Homliil. The species appeared to be both local and rare.II.Ti.O.T.]

\section{ASILID虑.}

\section{Hoplistomera, Macq.}

6. Hoplistomera nigrescens, $4 . s /$. (Plate xxii. figs. 11, 11a.)

Type $q$. Blackish. The hind femora with no spines on the underside, lut some weak yellow hristles. The last segment of abdomen red, the antenme and legs black.

Face shining black, the moustache consists of long white hairs extending to the antenne: palpi black, with hack hains. Antenne with white hairs on the first two joints, ancl some long black bristlelike hairs on their undersides. Hind part of head with white hairs, and some black lristles in the centre. Thorax with spare fulvous tomentum, and some white hain's chiefly on the sides and posteriol part. Breast sides with greyish tomentum and scanty white pubeseence. Abdomen almost blue-hlack, with the extreme posterior margins of segments fawn coloured, the last segment almost wholly red; the pubescence black, white at the sides and on the posterior margins. Legs black, with yellow bristles, some black ones on the hind tarsi; pubescence white, the tibice and tarsi sometimes redrlish hrown. Wings elear, reins redclish brown, the small cross vein below the middle of the discal cell.

Length $10 \mathrm{~mm}$.

Sokotra: Harlihu Plain (11. XII. 98).-Two specimens.

\section{Promachus, Loew.}

7. Promachus sokotræ, $n . s p$. (Plate xxii. figs. 7, Ta, ô, figs. 9, 9a, q.)

Type of, Adho Dimellus; Type $q$, Actho Dimellus. Allied to P. rectangularis and I'. reppelli, Loew (Neur Britr. ii. p. 5), from Massowah, but easily distinguished from both by the dark colour of the legsfrom the former by the black hristles on the scutellum, and from the latter by the quite clear wings. Grey, with black bands on the ablomen, black legs and clear wings.

Face grey with white tomentum, the moustache composed of long white hairs helow and large yellow hristles alove, with six or more stout black luristles above these, in two of the of specimens these last bristles 
are reduced to one or two ; long white hatrs are continued up cach side to the antemie. Beard white. Palpi black, with long white hair's on the lasal half and stout black bristles on the apex. Antenne brown with short black bristles on the sicles of the first two joints. Forehead brown, with white pubeseence and black bristles. Hind-part of the head with white hairs and llack bristles. Thorax brown, the central stripe black, the side ones less distinct and hrownish, with black pubescence, fulvous tomentum and black bristles ; there are a few white hairs on the posterior sides. Scutellum greyish, with white hairs, and black bristles on the margin. The hreast sides are brown with fulvous tomentum and white pubescence. Alylomen with broad hack bands on the second to the seventh segments, which only leave the grouml colour free on the posterior horders and sides, and have romuled hind-conners; the eighth segment is wholly black, with a prolongation beneath bealing a tuft of black and white hairs: the genital organs are long and stout with a tuft of white hairs alove at their base, encling in long black hairs at their tips, ancl with black pubescence; the puldescence and bristles on the abdomen are black on the dorsum and yellow on the sides and underneath. Legs black, the pubescence is white on the immer side of the femola, the hiul tilia and metatarsus, on the upper side of the anterior and mirlle tibie, and on the four last joints of the fore-tarsi, where it is long and very distinct ; on the inner side of the fore-tibia there is short dense fulvous pubescence; elsewhere black, with all bristles hlack. Wings clear, veins reddish-hrown.

Length $2+1 \mathrm{~mm}$.

The $q$ is identical, lut the white hain's on the fore-tarsi are not so distinct and thick; the eighth segment of the abdomen is black and shining.

Sokotra : Arlho Dimellus, $4 \delta, 5 q$ (3500 ft., 4.-12. II. 99) ; Goahal Gorge, $3 q$ (200 ft., 16.-27. I. 99).

[This large predacions fly was fairly common on the middle and higher ranges, especially among the granite peaks of the Haghier range in the neighbourhood of Adho Dimellus. It frequents the neighhourhood of the rough hill paths, settling on the stones. As a rule, it is extremely alert and not very easy to net, lut while engaged in derouring its prey may sometimes be boxed. There is a rery large male in the collection, taken in the act of killing a cicarl. It was so much engaged in this pleasant oceupation that it allowed me to place the muzzle of a +10 gun on its back ancl gently squeeze it to death. II.R.O.G.]

\section{Machimus, sp?.}

\section{Machimus, Loew.}

Sokotra: Jena-agahlan, ơ (4. I. 99); Adho I)imellus, of (3500 ft., 15. II.99).

9. Machimus, s\%.

Sukotra: Homhil, 1 f (2500 ft., 22. I. 99). 
10. Itamus, sp.

Itamus, Loew.

Sokotra: Harlibu Plain, of $q$ (12. XII. 98); Homhil, + \& (1500-2500 ft., 19-25. I. 99).

\section{BOMBYLID无.}

\section{Exoprosopa, Macq.}

\section{Exoprosopa punctipennis, 1. sp. (Plate xxii. figs. 1, 1a, ô.)}

This and the following species are similar to Erroprosonu schmidti, Karseh (Berlin Ent. Zsit., xxxi. p. 372), in having the lranch vein the reverse way to that of the species described ly Loew in Dir. II. (Iript. siudufrili, p. 2+1), viz., lunning into the discoirlal cell instead of into the thirel posterior cell.

Type ô, Arlho Inimellus; Type $q$, Harlilu Plain. Black, with white lands on the sides of the thorax and on the aldomen: scutellum rlull red.

Face brown, with lalack pubeseence and glittering white pile. Antemne brown, the first joint bright red, the first two joints with black hairs, the bristle redklish, stout, and shorter than the third joint. Proloscis longer than the head. Hind-part of hearl with white pile hordering the eyes. Collar composed of yellow hairs above, and black below ; the pubescence at sicles of thorax and on breast liack. Thorax with a well-marked stripe of white hairs on each side, extending to hase of sentellum, pubescence on dorsum black with scattered white pile. Scutellum lull red, llack at the base, the pubescence hack with white pile on margin. Abromen wholly hlack, pubescence black, on the anterior lyorders of seconrl, third, fifth, sixth, and seventh segments a fringe of whitish-yellow pile, hoadest at the sides; on the fifth segment the band is of the same width throughout and quite white; the hairs on the sides of abdomen are white on the first segment and on the anterior border of the second segment, black on the others; the underside is black, reddish in the eentre, with rather thiek black pulsescence. legs black, with black pubescence and bristles. Wings brown on the fore-loorder, clear on the posterior part, with the cross reins shaded; the dark shading on the fore-border extends at the extreme lase to the posterior border of wing, from there it reaches half-way up the second hasal cell, wholly throngh the first hasal cell just into the first posterior cell, and half-way up the second sub-marginal cell; from there it is bonnderl by the second longitudinal vein as far as the cross vein, from whenee it runs to the junction of the first longiturlinal vein in the border, leaving the apex of the marginal eell nearly wholly elear, but joining the second longitudinal vein again when it reaches the border; the spots on the eross veins are as follows: One each at the base of the first and second sulh-marginal cells, one on the upper part of the cliscoidal cell extending as far as the angle, and one each 
at the base of the third and fourth posterior cells; the branch emitted into the cliscoidal cell is just below the cross vein ; the first posterior. cell is only slightly namowed, the second slightly wider than the third, and the fomth wice as hoard as the second.

Length $1+\frac{1}{2}$ mim.

Sokotra: Ilomhil (2500 ft., 19-22. I. 99); Aclho l)imellus (3000 ft., 7.-9. II. 99) : Hadibu Plain (14. X11.98).—3 ơ, 5 q olotained.

[This handsonne speeies was common on the middle and higher ranges of hoth the granite and limestone langes. Like the rest of its kind, it was generally met with on the dry, stony paths. It was espeeially common in the neighlomhood of Hombil at an eleration of about

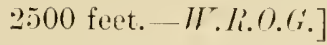

12. Exoprosopa insularis, n. sp. (Plate xxii. figs. 3, 3iı.)

Type of. Black, with bands of yellow and white pubescence on the abdomen.

Face black, yellow romd the mouth, with black pubeseence and white and yellow pile. Antenua hrown, the first joint red, the first two joints with hack hairs, the lnistle stout, not half as long as the third joint. Hind-part of hearl with yellow pubescence. The collar is eomposed of yellow hairs. Sirles of thorax with yellow puluescence, below the halteres with orange hairs, and yellow and black hairs on the breast. Thorax and seutellmm clothed with black pubescence and yellow and white pile. Aldomen with a fringe of yellow hairs extending across the middle of the first segment and reaching the sides, on the anterior borders of second and third segments a fringe of white pile, broadest on the third, on the anterior horders of the three last segments a fringe of yellow pile ; on the sides of first, second, and anterior horder of third segment are yellow hairs, on the suceeding ones a thick fringe of black hairs; molerside of ablomen black, with scattered yellow hairs and yellow pile. Legs hlack, with black pubescence, thickest on the anterior femora, bristles black. Wings dark brown, in the arrangement of the shading very similar to those of Eroprusope renus, Wied. (see Loew, Dipt. Siudufirit, tab. II. fig. 11); the cells on the posterior border are elear, but all the longiturlinal veins have dark shading, hesides the cross veins; there is a clear spot in the apex of the second basal cell, and in the centre of the discoidal cell, and the second posterior cell is elear; the hranch emitted into the discoidal cell just below the cross rein is rery short; the first posterior cell is narrowed, the other posterior cells about equal in width.

Length $11 \frac{1}{2} \mathrm{~mm}$.

Allied to E. disrupte, Walker, Ent., v. p. 255, 1871, from Hor Tamanil, near to Snakim on Red Shea, but easily distinguished from it hy its black legs and seutellum, and by the lower branch of the thirel longiturlinal rein being sharler like the rest, not elear as in Walker's type in the British Museum collection. 
Sokotra: Jena-agahan, 1 ơ (1200 ft., 7. I. 99).

[This extremely handsome species was met with in the middle granite hills of the Haghier range. I tried hard to procure more examples, but never came across a second specimen._II.R.o.Gr.]

\section{Argyromœba, Schiner.}

\section{Argyromœba fuscipennis, $n . s \%$. (Plate xxii. figs. 2, 2a.)}

Type $q$, Adho Dimellus. Black, with lands of white pile on the alidomen.

Face clothed with black hairs and some whitish pile. Antemnit with the third joint grey on the upper part, the first and second both with black pubescence, the third broarler than the second with a rim-like base, the upper part narrower, sulconical, with a two-jointed bristle as long as the second and third joints together, its second joint shorter than the first, with hristles at the tip. Collar composed of black hairs. The sides of the thorax and the hreast with black pubescence, the dorsum of the thorax with the same and some scanty white pile. Abdomen with a bunch of white hairs on the sirles of the first segment, black hairs on the remaining ones; on the anterior borders of the second and following segments are narrow bands of white pile, most distinct on the second, hecoming narrower as they reach the centre; the pubescence consists of long black hairs, thickest on the apex of abdomen, the unclerside clothed with black pubescence. legs with l.lack hairs and Juristles and white pubescence on the femora and tilice. Wings with dark brown shading at the base and on the fore-border, at the base it does not quite reach the posterior border, extends across the basal half of the anal cell and the base of the discal cell to the fore-border, reaching the junction of the first longiturtinal rein in the horder; opposite the junction of the second longitudinal with the third it extends across as a narrow hand, encireling the small cross vein, and just reaehing into the discal cell, the rest of its length along the fore-border is hounder by the first longitudinal vein; there is a large clear spot in the apex of the second basal cell; appendix present on the base of the second longitudinal and on the branch of the thind longitudinal vein, the angle on the above branch being rather acute, veius lrown.

Length $10 \mathrm{~mm}$.

Sokotra: 3 q, Adho Dimellus (3000 ft., 17.-1R. II. 99); Hadibu Plain (30. I. 99).

[Apparently a lare species. I first ohtained a single example on the east of the Harlibu Plain at almost sea-level on the 30th January, and subsequently eaught two more at Arlho I)imelhus at an elevation of 3500 feet on the 17 th and 18 th Fehruary. - II.I.O.G.] 


\section{Anthrax, Scop.}

14. Anthrax sokotræ, ".sp. (Plate xxii. figs. 4, ta.)

This species might almost be included in the genus Apheluntus formed by Loew for a North American species (see Centur., x. No. 39, 1872, and Osten Sacken, Bioloy. Centr. Am., i. p. 143), lut the eyes of these males are not contiguons as in those of Aplueluntus, so that for the present it must remain under. Inthrur in Div. I.A of Loew (I)ipt. Südufirili). The wing is very similar to that of Anthrer fulvipes, Loew (Iript. Siidufriti, tab. ii. fig. 14).

Type of, Arlho Dimellus. Black, with yellow hairs, and the sides of the abdomen red.

Face black, yellowish round the month, with long black hairs on the upper part extending just below the antenne, and bright red hains romd and ahove the oval aperture: some grey tomentum on the face. Antenne with the first two joints short, the third onion-shaped, with a long styliform prolongation ending in a short joint with a bristle, the first two joints with long black hairs. Eyes separated in male. Hindpart of head with some short fulrous pubescence in the centre, and long black hairs at the sides. Collar composerl entirely of light yellow hairs. The pubeseence at the sirles of the thorax and on the ireast of the same colour : there are three or fon black bristles on the upper side ahove the yellow hairs in the centre. Thorax and scutellum covered with yellow tomentum, the bristles black. Abdomen with a central black dorsal stripe, the sides leing bright red, the first segment is covered with bright yellow hairs, the hairs on the sides of the other segments are black, and the pubescence on the dorsum is black, with yellow tomentum; the undersicle is red with yellow pubescence and tomentmm. Legs red, with black hristles and pubeseence, pulvilli distinet. Wings hyaline, with a faint yellow tinge on the fore-border extending into the second hasal cell and above the junction of the second and thind longitudinal veins; there is a grey spot in the apex of the second hasal cell; the bifurcation of the second and third longiturinal rein is some distance below the cross vein; the branch of the third rein has the rudiment of an appendix, not always present; posterior and anal cells open, veins brown.

Length $12 \mathrm{~mm}$.

Type $q$, Homhil, is identical, lut the red on the abrlomen is not so prominent, and on the underside there is a narrow black dorsal stripe.

Sokotra: 3 ơ, Adho Dimellus (3000 ft., 9. II. 99); Hadibu Plain (30. I.99) ; Ardah Valley, east of Harlilu Plain (29. I. 99); $\uparrow$, Homhil (1500 ft., 21. I. 99).

['This species was occasionally met with in the months of January and February from sea-level to an elevation of at least 3500 feet. It clid not appear to be common._II.R.O.G.] 
15. Anthrax hottentotta, (Limu.).

Mnscu hottentottu, Linn., Faun. Suec., 1) 441 (1761).

Nemotelus hottentottuk, Degeer, Insect, vi. p. 190, Tab. 11, fig. 7 (1776).

Anthrax cingulata. Ahrens, Fauna Eur., iii. fig. 19 (1817).

Anthrax circumlata, Meig. Syst. Beschr., ii. p. 143 (18:20).

Authrox hottentottr, Schiner, Fauna Austr., i. p. jol (1863).

Sokotra : of, 9 $q$, Homhil (1500-2500 ft., 25. I. 99); Goahal Gorge (S00 ft., 16. I. 99): Addah Valley, E. of Hadilu Plain (30. I. 99); Adtho Dimellıs (3000-3500 ft., 1.- . II. 99).

These seem identical with the European specimens, the only apparent difference leing in the hairs of the face, which are scantier and bluck, not yellow, and have scantier golden pile.

[Common on dry paths. I am surprised that this species should prove to be $A$. hottentotte, with which I am well acquainted._II.R.O.(r.]

\section{Anthrax, sp.}

Sokotra: 4 q, Hombil (2500 ft., 22. I. 99); Alıl-el-Kuri (9. XII. 98: 22. II. 99).

A black species with clear wings, of which I have not heen able to find any description, so that it may possibly be unclescribed.

17. Bombylius, sp.

\section{Bombylius, Linn.}

Sokotra: 1 ơ, Adho Jimellus (3500 ft., 9. II. 99).

[Apparently rare; the only example seen during our stay in Sokotra is unfortmately in worn condition, and cannot he irlentified. It was hovering over a stream at the bottom of the deep ralley to the south of our camp at Arlbo Dimellus.-W Ir.R.o.G.]

18. Phthiria, sp.

\section{Phthiria, Meig.}

Sokotra: 2 of, Harlibu Plain (12. XII. 98); Homhil (2000 ft., 19. I. 99).

\section{SYRPHID冉.}

\section{Paragus, Latr.}

19. Paragus serratus, Fubr.

Puragits serratus, Fabr., Syst. Antl., J. 186 (1805); W'ied., Auss. Zweifl. Ins., ii. p. $88(1830)$; Verrall, Traus. Ent. Soc. Lond, 1898, 1. 413.

These differ from the Inclian species in the colouring of the thorax, which is bright metallic-blne, not black; the grey lines on the thorax in the ot are only present on the anterior part; in the $q$ they are altogether. wanting.

Sokotra: 1 đ, Harlilu Plain (13. XII. 98); 1 q, Jena-agahan (2500 ft., 13. I. 99).

[Apparently scarce.-Mr.R.(.)(t.] 


\section{Asarcina, Macq.}

20. Asarcina ericetorum, ( $F^{\prime}(t)$. $)$.

syprohs erieform, Fabr., Sprec. Ins., ii. 1. +25 (1781).

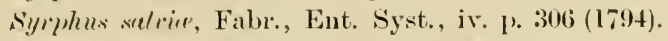

Sireere sal riee, Fabro, Syst. Antl., p. 2050 (180.5).

Asereine selvice, Loew, l)ipt. Sïlafrik., 1).311 (18611); Verrall, Trans. Ent.

Soe. Lond., 1898, p. 414.

Sokotrat: 20 of, (Gebel Raggit (600 ft., 15. XII. 98) : 1 q, Adho Dimellus (3800 ft., 5. II. 99).

[Fairly common all over the island._Ir.li.O.G.]

\section{Syrphus, Fabr.}

21. Syrphus ægyptius, thiel.

Syrphne ryyptins, Wied., Auss. Zweifl. Ins., ii. p. 133 (1830); Verrall,

Trans. Ent. Soe. Lontl., Js98, p. 4 l4.

? Screere scutellurix, Fabr., Syst. Antl., 1. 2052 (180.5).

? Syrphus splenden., Dolesch., Nat. Tijol. Ned. lnd., x. p. 410, pl. i. fig. 3 (1856).

S.yrghus jurann:, Wierl., l.c. p. 131.

Sokotra: 2 o , Homhil (22. I. 99); Harlibu Plain (12. XII. 98).

[Common.-H.R.o.G.]

\section{Melanostoma, Schiner.}

\section{Melanostoma gymnocera, Bigot.}

? Melenoxtoma yymmocere, Bigot, Ann. Soc. Ent. Fr., 1891, p. 37.5.

Sokotra: 3 of, Jena-agahan (1200 ft., 12. I. 99) ; Arlho Dimellus (3500 ft., 10. II. 99); Homhil (2500 ft., 19. I. 99).

This may perhaps be the of of the o deseribed by Bigot from Aloyssinia, agreeing with his deseription of $1 /$. yymuoren except as regarls the alxlomen; in these speemens the spots on the second segment are oblong, not attaining the sides, nor meeting in the centre, the thind segment is wholly yellow with the exception of a narrow band of black on the posterior margin, and the heginning of a hlack central line on the anterior margin, the fourth segment is yellow with only the posterior black band.

23. ? Melanostoma, sp.

Sokotra: $q$, Homlil (26. I. 99).

\section{Eristalis, Latr.}

24. Eristalis tæniops, Iriel.

Eristalis trmiops, Wied., Zool. Mag., ii. 1. 42 (18I8); Loew, 1)ipt. Sirdafrik, 1. 3224 (IS60) ; Verrall, Tr. Ent. Soc. Lond., 1898, 1) 4l.5.

Eristalis torridus, Walker, List 1)ipt. B.M., iii. p. 612. (1849).

Eristulis regyptin., Walker, 1.c. p. 621 .

Sokotra: 2 q, Dahamis (2000 ft., -21. XII. 98); and Jena-agahan (1200 ft., 5. I. 99). 
[Appeared to be common in the midlle range of the Haghier, but not

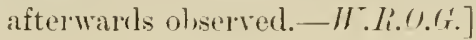

\section{Eumerus, Meig.}

25. Eumerus obliquus $\left(F_{u}(t)\right.$. $)$.

Milesice oblique, Fabr.. Syst. Antl., 1, 194 (1801.5).

Eumerus obliqun:, Wied., Auss. Zweifl. Ins., ii. 1). 112 (1830); Verrall, Tr. Ent. Soc. Lond., 1s!s, 1\%. 422.

Eumerus cilitaris, Loew, Stett. Ent. Zeit., ix. p. 120 (184s).

This specimen agrees with Loew's description of the of, with the exception of the legs, which are lighter coloured, the anterior tibise and tarsi being almost wholly yellowish-hrown and the posterior ones partly so: the forehead is coarsely punctated, and its pubescence entirely white.

Sokotıa : 1 q , Homhil (2500 ft., ㄴ6. I. 99).

\section{MIUSCID}

\section{Sarcophaga, Meig.}

26. Sarcophaga africa, ITied.

Sarcophaga africe, Wied., Auss. Zweifl. Ins., ii. p. 3.56 (1s30).

Sokotıa : 3 q, Hadibu Plain (13. XII. 98) ; Jeni-agahan (1200 ft., 9.1.99); and Flomhil (1500 ft., 18. I. 99).

The Type came fiom the Cape.

27. Sarcophaga, s\%.

Sokotra : 1 ơ, 1 o , Hadihu Plain (1‥-14. XII. 9§) : 1 ㅇ, Homhil (2500 ft., 26. I. 99).

28. Sarcophaga hirtipes, IIied.

Surcophagre hirtipes, Wied., Auss. Zwcifl. Ins., ii. p. 361 (1830): Taschenb., Zeitsch. f. Naturw. Halle (4), ii. 1) 182 (1883).

Sokotıa: Wady Kischen.-( Rielseck).

29. Ocyptera, $s p$.

\section{Ocyptera, Latr.}

Sokotra : 2q, Jena-agahan (1200 ft., 4.-9. I. 99).

Allied to O. ctrete, Fahn., which was found hy Col. Yerbury at Aden.

30. Gonia ? nigra, Itecq.

\section{Gonia, Meig.}

Gonia fraxciuta, Wierl. (nec Meigen), Auss. Zweifl. Ins., ii. p. 344 (1830).

Gonie nigra, Nac(., Dipt. exot., ii. p. 49 (I840) ; Snppl. iv. p. 177 (1850).

Sokotra: 2q, Artho Dimellus (1000 ft., 16. II. 99); Dinehan Valley (3000 ft., 1. II. 99).

May perhaps helong to this speeies, the type of which eame from the Cape.

[Only seen on the higher ground.-Mr.R.O.Gr.] 
31. Melanophora, $: \%$.

\section{Melanophora, Meig.}

Allied to .H. utru, Macel., and H. romelis, Limu.

Sokotra: Arlho I)imellus (3500 ft., 15. II. 99).-Five specimens.

[These were all eaptured dhuing rery heary lain at Adho Dimellus; numbers wonld settle on the sheltered sides of the tent, and were easily boxed.-W.I..U.G.]

32. ? Phorocera, $\%$.

\section{Phorocera, Rob. Desv.}

Sokotra : Arlela Valley, E. of Hadihu Plain (28. I. 99).-Two specimens.

[These two specimens are particularly interesting, as they ale eviclently parasitic in the nests of the wasp (brlenoyaster sansurei). Both specimens were hatehed from a nest of this species - II.L.O.G.]

33. ? Genus (Tethiminer).

Sokotra: Hadibu Plain (12. XII. 98).-One specimen.

34. ? Genus (Tachininu).

Sokotra: Dahamis (350 ft., 19. XII. 98); Adho Dimellus (3500 ft., 2. I. 99).

\section{Rhinia, Rob. Desv.}

35. Rhinia testacea, liob. 1)ese.

Rhinice testacer, Rob. Dess., Myodaires, p. 423 (1530); Mace. Suites à Buff., ii. p. 246 (1835) ; Schiner, Reise der Novara, p. 310 (1866) ; Corti, Ann. Mus. Civ. Gen., xxxv. p. 138 (1895).

Sokotra : 1 f, Dahamis (3500 ft., 19. XII. 9s) ; 3 q, Homhil (1500 ft., 19.-21.I.99); and Harlibn Plain (11. XII. 98).

Corti remarks that this species has a wide geographical range. Rob. Desvoidy gives Mauritius as the locality of the Type.

[This species was extremely fond of risiting our tents. It would buzz yuietly along elose to the ground investigating one's boots or any thing that happened to be lying about the floor._II.li.O.G.]

\section{Idia, Meig.}

36. Idia simulatrix, Loew.

Illu simulatrix, Loew, Berlin K. Acad. Wiss., 18.52, p. 660; Peter"s Reise nach Mossambique, 1). 25 (1562) ; 'Taschenb., Zeitsch. f. Naturw. Halle (4), ii. ए. 182 (1583).

Sokotra: Wady Kischen.-(liebeck).

\section{Musca, Linn.}

37. Musca domestica, Linn.

Musca domestica, Linn., Fauna Suec., p. 453 (1761).

5 of, 2 o , Adho Dimellus (3500 ft., 14.II.99); Homhil (1500 ft., 19. I. 99); and Hadibu Plain (11. XII. 98).

[The House-Hy proverl a great torment at times in the tents._Mr.M.O.C.] 
38. Musca (?) spectanda, ITicd.

Musce (.) sprecturtu, Wied., Aus.. Zweifl. Ins., ii. p. 419 (1s:30).

1 q, Hadilu Plain (11. X1L. 98).

The Type cante from sierra leone.

39. Musca, sp.

Sokotra : Below Artho Dimellus (3000 ft., 17. II. 99).-One specimen.

Calliphora, Rob. Desv.

40. Calliphora marginalis, (ITiet.)

Musce marginalis, Wierl., Auss. Zweitl. Ins, ii. p. 395 (1830).

Lncilin maryinalis, Nac(1., 1)ipt. Exot. ii. p. 143 (1840) ; Karseh., Ent.

Nach., xii. p. 257 (1886); id., Berlin Ent. Zeit, xxxi. p. 337 (1887).

Calliphora marginalix, Brauer, Denkschr. Akad. Wien., Wiii. p. 420 (1s91).

Sokotra: + + , Hadibu Plain (12. XII. 9s); (rehel liaggit (600 ft.,

15. XII. 98) ; Jena-igahan (1200 ft., 15. I. 99); and I)ahamis (350 ft.,

19. XII. 98$)$.

The Type came from the Cape.

[This handsome species was only met with on the plains and lower slopes of the Haghier up to alout an elevation of 1500 feet. It was always to be seen in numbers where there was any earrion or filth._II.R.O.G.]

Lucilia, Rob. Desv.

41. Lucilia cyanea, (Futrir).

Musce cyuneu, Fabr., Spec. Ins., ii. p. 439 (1781) ; Il. Ent. Syst., iv. p. 319 (1794); Id. Syst. Antl., p. 292 (1805); Wied., Auss. Zweitl. Ins., ii. p. 397 ( 1830$)$.

Lucilie cyanen, Macq., Dipt. exot., ii. p. 14., pl. xwiii. fig. 4 (1840); Braner, Derkschr. Akad. Weiss., lviii. 1) 420 (1891).

Sokotıa: 1 f , Dahamis (350 ft., 19. XII. 98) : 4 q , Gehel Raggit (600 ft., 15. XII. 98) ; Dinehan Valley (3000 ft., 1. II. 99).

The Type came from the Cape.

[Takes the place of $C$. murginulis on the higher ground; its habits are similar.-IT.R.o.G.]

42. Lucilia, ? sp. $"$.

'The palpi are yellow at the hase and black at the tip.

Sokotıa: 1 f , 1 q , Hadilı Plain (11.-13. XII. 98).

43. Cyrtoneura, sp.

\section{Cyrtoneura, Macq.}

Sokotra: Aclho Dimellus (3500 ft., 3. II. 99. and 18. II. 99); Dahamis (350 ft., 19. 12.98).-Four specimens.

44. Stomoxys, sp.

\section{Stomoxys, Geoffr.}

Sokotra: 1 f, 2 , Harlilu Plain (11.-12. XI. 98); Dahamis (350 ft., 19. XII. 98). 
45. Hæmatobia, sp).

\section{Hæmatobia, Rob. Desv.}

Sokotral : 2 of, Dimichiro Valley.

[These little flies swimed all orer the eimels._IV.I.O.G.]

46. Hyetodesia, s\%.

\section{Hyetodesia, Rond.}

Sokotra: 20 ô, Mrlho Dimellus (3500 ft., 3. II. 99, and 14. II. 99).

Allierl to $/$. Inrorum, Fallen, a European species.

\section{Hyetodesia, sp.}

Sokotral: 1 ơ, Adho Dimellus (3500 ft., 5. II. 99).

\section{Anthomyia, Meig.}

48. Anthomyia bifasciata, ".s\%. (Plate xxii. figs. \&, sa.)

Tyle ơ, Dinchin Valley. Allied to A. tomitmi, Wierl., Ans. Zuveifl. Ins., ii. p. 4.99 (1\&30). Black, thorax with two grey bands, abdomen yellow with black central stripe and black baurls.

Face with silvery-grey tomentum. Antenna and palpi black. Forehead with a row of black bristles in the centre not quite reaching the vertex. Eyes sub-contignous. Thorax with the first grey band on the anterior part, the second one on the posterior margin. Breast sirles grey. Scutellum black, grey at its apex. Alulomen with the first and fomth segments black, and a black central stripe and black bands on the posterior margins of second and third; some faint white tomentum on the yellow part; pubescence black. Leegs hlack, the knees lighter. Wings clear.

Length $5 \mathrm{~mm}$.

Sokotra: 4 ot, Adho Dimellus (3500 ft., 4. II. 99); Dinehan Valley (2500 ft. 1. II. 99).

[This handsome speeies was eommon, and might constantly he seen in companies "dancing" mucler the sharle of the trees.-W.L.O.G.]

49. Lispe, ? sp. $n$.

$$
\text { Lispe, Latr. }
$$

Sokotra: Ailho Dimellus (3500 ft., 12. 11. 99).-Two specimens.

50. Atherigona, $s \%$.

\section{Atherigona, Rond.}

Sokotra : 1 ô, Adho Dimellus (3000 ft., 9. 1I. 99).

\section{EPHYDRINÆE.}

51. Ochthera mantis, Deg.

\section{Ochthera, Latreille.}

Ochthere manti., Deg., Ins., vi. 143 (1766); Schiner, Fauna Austr., ii. p. 256 (1863).

Sokotra: 1 o , Aclho Dimellus (3500 ft., 12. I1. 92).

Identified by Col. Yerbury ; a European species. 


\section{CHLOROPINÆE.}

52. Oscinis, $s p$.

\section{Oscinis, Latreille.}

Sokotra: Elhe, E. of Hadihu Plain (30. I. 99).-One speeimen.

\section{AGROMYZINÆ.}

\section{Agromyza, Fall.}

53. Agromyza, sp.

Sokotra: Arlho Dimellus (3500 ft., 10. II. 99).-Three specimeus.

\section{OPOMYZINÆ.}

\section{4. ? Genus.}

Sokotra: Hadibu Plain (14. XII.98).--One specimen.

\section{PHORID尼.}

55. Phora, sp.

\section{Phora, Latr.}

Sokotra: Artho Dimellus.-Fourteen specimens.

[Hatched out of grass and soil lifted with pupa of Hawk Moth._II.I.O.(r.] 


\section{II. - The Flies of $\mathrm{Abd}=\mathrm{el}=$ Kuri.}

\section{TABANID床.}

1. Tabanus, sp.

\section{Tabanus, Linn.}

Abd-el-Kuri, 1 \& (5. XII. 9s).

[The only horse-fly I recollect seeing either here or in Sokotra during the three months spent on these islands. - W. R.U.G.]

\section{ASILID床.}

\section{Ommatius, Illiger.}

2. Ommatius tibialis, n. sp. (Plate xxii. figs. 10, 10a.)

Type . Black, tibia yellow, wings clear.

Face grey, moustache of white hairs, and long black hristles on the upper part, nearly reaching the anteme, which are brown, the ocellar tulerche blaek, with black bristles. Thorax shining lolack, with grey tomentum, some white hairs and black bristles on the posterior part. Scutellum gley, with white pubescence. Alxlomen with black pul,escence, white at the sirles. Legs back, tilize yellow, black at their extreme apex; the anterior and middle tarsi dull red, the underside of the femora with long white pubescence, which is also present on the upper side of the hind-femora; there are some long weak yellow bristles on the outer side of the fore and middle tibie, and elsewhere the pubescence and bristles are black. Wings with the small cross vein beyond the middle of the discal cell.

Length $9 \mathrm{~mm}$.

Abd-el-Kuri, q (22. II. 99).

\section{BOMBYLID压.}

\section{Argyromœba, Schiner.}

\section{Argyromœba massauensis, Jeteniirke.}

Armyromnta muxantenxix, Jaennicke, Abh. Senck. Giesell., vi. p. 336 (186s).

These agree with the description of the $q$ given ly Jaennicke, lut the one of (?) which is so imperfect that it is impossible to ascertain the sex with certainty, has white, not liack, hairs on the lower part of the face extending half-way up the sicles of the eyes.

Abcl-el-Kururi, 1 ơ, 1 ơ (?) (2.2. II. 99).

4. Anthrax, sp.

\section{Anthrax.}

Alul-el-Kuri, ’ ㅇ (9. XII. 9s; 22. II. 99).

See page 368 . 


\section{SYRPHID平。}

\section{Syrphus, Fabr.}

5. Syrphus ægyptius, Wicl.

Abd-el-Kuri, 1 q (22. II. 99).

Sce page 369.

\section{MUSCID死.}

6. IMusca, sp.

Musca, Linn.

Abd-el-Kuri (22. II. 99).

\section{HIPPOBOSCID Æ⿸厂}

\section{Olfersia, Meig.}

7. Olfersia (?) spinifera (Leuch).

Feronia spinifera, Leach, Mem. Werner Nat. Hist. Soc., ii. p. 557, tab. xxvi. figs. 1, 3 (181s).

Olferia spinifera, Wied., Anss. Zweifl. Ins., ii. 1). 607 (1830) ; Schiner, Reise Novara, p. 373 (1866) ; Wulp, Tijd. v. Ent., xxiii. 1) 193 (1880).

Abl-el-Kuri (23. I1. 99).--Two specimens captured oft a specimen of the Booloy (Sulle sulit).

These may probably lelong to this species, specimens of which Wiedemann believes to have come from the Cape. Schiner gives Batavia as the habitat of his speeimens, and Van der Wulp, Java, for his. These agree fairly with Leach's plate, with the exception of the wing, which is clear, not shaded, as in the plate.

[Two Boobies (Sulu sulu) had no sooner been shot and lifted into the launch than two of these curious parasitie flies were seen to leare their hodies, rum with great speed along the seat, and fly orerboard. Their movements were so rapid that one had searcely time to realise what they were, hefore they had ilisappeared. Two more were, however, eaptured as deseribed above (see Ates, p. 62). It is extraordinary that these flies shonld be able to survive the constant immersions in salt water to which they are subjected._II.li.O.G.] 



\section{PLATE XXII.}

Fig. I. EXOPROSOPA PUNCTIPENNIS, n. sp., ơ, p. 364.

Fig. 1a. The stme.

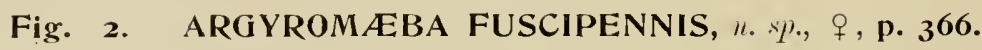

Fig. 2a. The sume.

Fig. 3. EXOPROSOPA INSULARIS, $n . s p$., ơ, p. 365 .

Fig. 3a. The stme.

Fig. 4. ANTHRAX SOKOTRAE, n. sp., p. 367.

Fig. 4a. The sume.

Fig. 5. PSILOCEPHALA ALBOHIRTA, n. $\%$. p. 361.

Fig. 5a. The seme.

Fig. 6. STEGOMYIA GRANTI, Theol., $q$, p. 360.

Fig. 7. PROMACHUS SOKOTRA, ".. . ', ô, p. 362.

Fig. 7a. The sume.

Fig. 8. ANTHOMYIA BIFASciATA, $и . s p$. , 。, p. 373.

Fig. 8a. The sume.

Fig. 9. PROMACHUS SOKOTRA, n. sp., $q$, p. 362.

Fig. 9a. The steme.

Fig. Iо. OMMATIUS TIBIALIS, $u . s p ., q$, p. 375.

Fig. roa. The strme.

Fig. 11. HOPLISTOMERA NIGRESCENS, $n . s p \cdot q, q .362$. Fig. I Ia. The seme. 


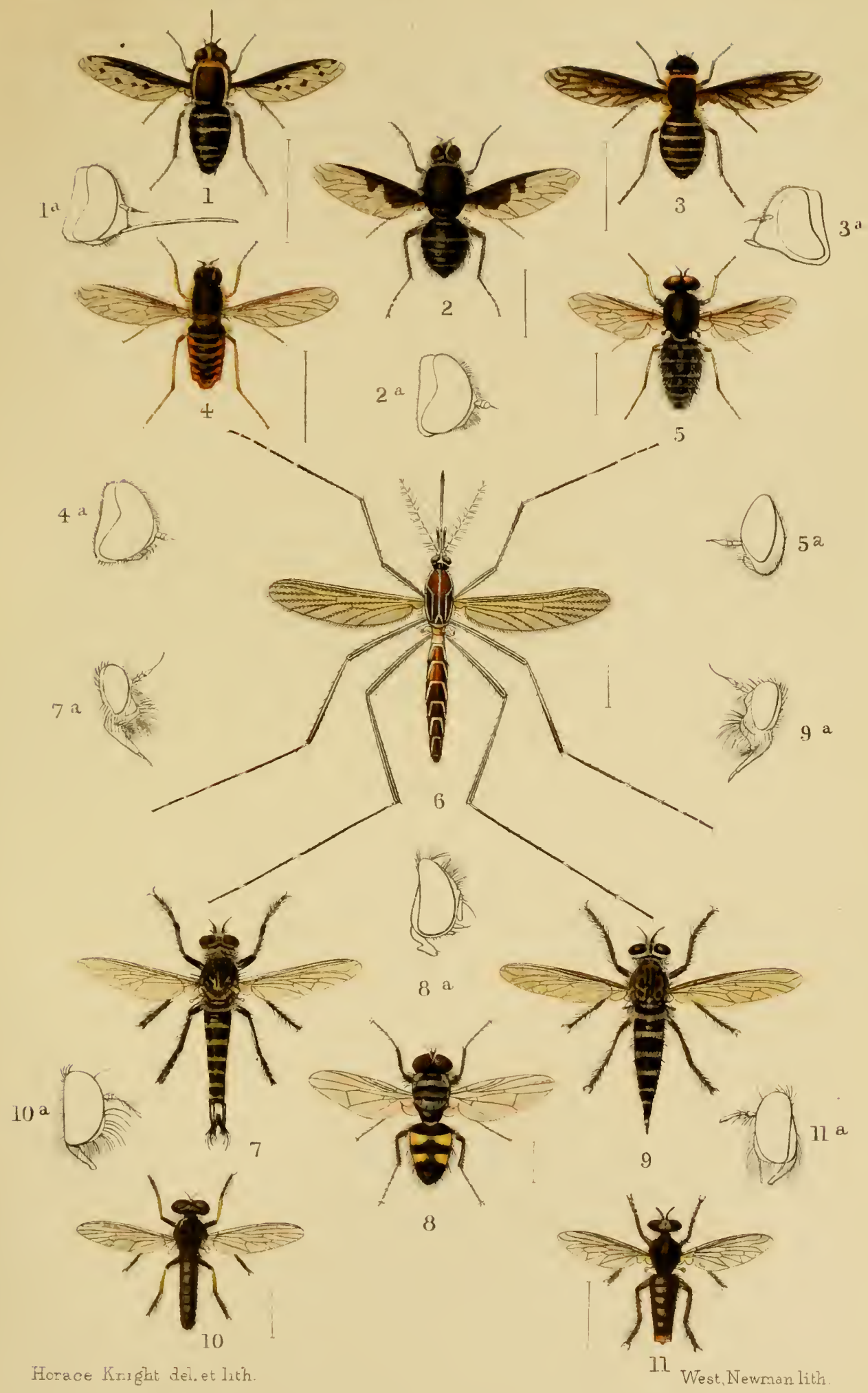



ARTHROPODA.

\section{Insecta: \\ Hemiptera.}

By G. W. KIRKALDY. 



\section{Cicads and Bugs.}

'The Hemiptera colleeted hy Mr. IV. R. Ogilvie-(trant and Dr. H. O. Forhes in Solkotra and Abd-el-Kuri inspire one with a lively lesire to acquire a more extensive knowlerge of the Homopterons and Heteropterous fauna of these islands. Unfortmately the other lranches of Zoology were so alsorling that little attention could he paid to this group, and no special search was marle for them, only 43 specimens (35) imagines and 8 nymphs) being ohtainerl, embracing 13 species, viz. :-2 Homoptera and 1 I Heteroptera. Of special interest is the new species of Klinophitos [Cimer or Actuthin (olim)]. I would ask naturalists alnoarl to make a point of eapturing and sending to me, in formalin or aleohol, the 'Bed-bugs' of the localities which they visit or in which they reside, as many new and interesting speeies are undoubterlyy orerlookerl, or passed by as the 'Common Bug.'

I have to thank Mr. Ogilvie-Grant for providing munerous interesting biological details, which are distinguished hy the addition of his initials.

\section{I. - The Cicads and Bugs of Sokotra.}

CICADID压.

\section{HOMOPTERA.}

\section{Cicadetta, Kolenati.}

1. Cicadetta omar (Kirl). (Plate xxiii. figs. 1, 1a, 1b.) Melumpsalte omar, * Kirk., Bull. Liverp. Nuss., ii. p. 4.5 (1899).

Covered thickly and alnost entirely-less so on the abdomen-with short yellowish pulnescence, and with long seattered hairs. Face closely striated transversely $(\dagger)$; rostrum reaching to intermediate coxie. Anterior femora greatly incrassate, armerl beneath with three stout sharp teeth; tibia slightly longer than femora, alsont $\frac{1}{3}$ longer than tarsi : third tarsal segment $3 \frac{2}{3}$ longer than first, second $\frac{2}{3}$ longer than first. Intermediate and posterior femora, anterior and intermediate tibia, marmed ; posterior tilize with three long, acute spines

* The immortal Persian Poet.

+ This character is not obvious owing to the pilosity. 
on each sicle of the apical half. Intermediate tibie twice as long as tarsi, third tarsal segment ahont three times as long as first, which is slightly shorter than the second: posterior tilice nearly twice as long as tarsi, third tarsal segment alout three times as long as first, seconrl ahout one-half longer than the first. Tegmina immaculate, except that the apical margin of the exterior ulnar area is infuscate. Wings immaculate.

Length of body $12 \frac{1}{2} \mathrm{~mm}$., expanse of tegmina $32 \mathrm{~mm}$.

Sokotra: Arlho Dimellus (3500 ft., 3. and 15. II. 99), and Homhil (2500 ft., 19, and 26. I. 99).

I thiuk that too much reliance has lieen placed in the past upon colour and pattern for specific purposes; the 6 specimens hefore me seem all to be referable to me species, practically identical in structure, although varying in colour and pattern sufficiently to form at least three species according to some recent descriptions. I therefore now describe them in cletail.

(a) 3 oै.

Dull black, ocelli flarous or 1ufo-flarous; the apical three segments of antenne flavescent; anterior margin of head (as seen from above) partly, posterior margin of pronotum very narrowly, posterior margin of the three middle abdominal segments more or less, sanguneoflavous; lateral margins of clypens narrowly sanguineous: posterior margin of mesonotum somewhat flavescent. Opercula sorrlid pale flavous or whitish apjically, black laterally and hasally. Venter sordid flavous, black centrally longitudinally. Anterior coxa and femora longitudinally fasciate, tilice biannulate, intermediate femora narrowly apically, basal half of third posterior tarsal segment, and posterior spines wholly - sanguineous or sanguineo-flarons. Posterior tibice sanguineous; l,ack narrowly at apex, lroadly at base. Costa, dc., flavons; nervures flavous or sanguineo-flavous.

(в) 1 .

Black; a large lnoarl $Y$, the anterior and posterior margins and a number of spots on the head; the lase of the $Y$ continued along the pronotum, the hase, lateral margins, \&c., of the pronotum ; lateral margins and two central lateral stripes on mesonotum ; apical margins of abdominal segments more or less widely-flavous or Inteons. Nervures same colour. Legs as in (a), except that the sangumeous is replaced by luteons. Clypeus spotted aud broadly margined laterally with fuscous. Whole rentral surface pale luteous, except oripositor and a central spot on each abdominal segment, ice.

(r) $2 q$.

A little smaller and much paler; luteous. Head and pronotum with three black blotches on head, two olblique inverted V's on pronotmm. Venter immaculate; legs immaculate except very narrowly at base ancl apex of each segment; spines of anterior femora hlack.

["The Cicarlas were mostly captured at night, attracter by the light of the 
lantern in one's tent. A fer were foumd at rest under stones during the day."--MT.R.o.(1..]

I inarvertently used the name "Melumpsestu" in the preliminary deserip-

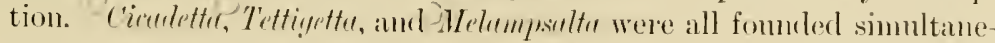
ously by Kolenati (1857, Bull. Sor. Musrom), but as they are now considered co-extensive, I have employed the first of the three. Ciruerefte appears to be a most misatisfactory genus from a speeific

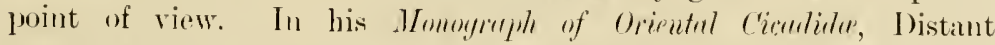
mentions scarcely a single structural character, while Karsch (1890 ber. Ent. Zritshe, xxxv. 12:3-6) divides the African speeies primarily ly eolobation, one species - ('. musim (Germ.) - being distinguished by its much narrower tegmina. Aceorling to the learned Doetor, in musim the tegmina are three times $(23 \div 8)$, while in the other species the tegmina are only $2 !-2 !$ times, as long as wirle in the midclle. One of the males herein deseribed, howerer; has the tegmina fully three times, while the others have them only ?2! times, as long as wide.

\section{FULGORID蚱.}

\section{Elasmoscelis, Spinola.}

2. Elasmoscelis iram, Kirk. (Plate xxiii. fig. 2, 2a.)

Ela:moxcelis iram, Kirk., Bull. Liverp. Muss, ii. p. 45 (1899).

Dark lrown. fo, frons long; marginal carine distinetly diverging outwards towards the apieal margin (that is to say pmsteriorly); central carina alsent, exeept olsoletely towards the apical margin. Second intemal segment rohust, sulprotumlate. Pronotum distinctly longiturlinally earinate, with a tulrercule on each side of the earina. Sentellum distinctly tricarinate Iongitndinally. Anterior femora and tilia folinecous, lather more elongate than in $k$. rimirvides. (Germ.). Blackish-hrown; frons vermilion ; lateral carine altogether, and gene externally-green. Antemne testaeeons. Elytra with a large white spot on the lateral margins of the corimm, albout the middle : a smaller whitish spot hetween the latter and the apical margin : apical margin whitish. Femora and anterior tihice blackishlnown with whitish spots, intermerliate and posterior tiliw and all the tarsi fuseo-testaceons. Closely allied to E. trimuculutus, Walk.

Length (inclurling tegmina) $6 \mathrm{~mm}$.

Sokotra: Hadilu Plain (11. XII. 98).

["Captureel on a bath towel, on which the light of a lantern had been thrown to attract moths." - Ir.P.O.G.]

\section{ANTHOCORID压.}

\section{HETEROPTERA.}

Cimicidle (in part) anctt.

\section{Klinophilos, Kirkcaldy.}

\section{Klinophilos horrifer, kitk. (Plate xxiii. fig. 3.)}

klinophilos horrifer, Kirk., Bull. Liverp. Nuss., ii. 1) 45 (1899).

Closely punctured on tholax and almoment, covered with short hairs, 
thicker and longer on the hearl and at lateral margins of pronotnm and elytra, and at apex of aldomen. Rostrum not reaching anterior coxie. Third segment of antenne ${ }_{4}^{1}$ longer than second, which is three times as long as the first, and slightly longer than the fourth ; first segment not quite attaining to apex of hearl. Pronotum convex, lateral margins not reflexerl, antero-lateral angles prominently produced in front. Thirr tarsal segment twice as long as second, which is slightly longer than the first. Ahlomen subrotundate posteriorly, first five ventral segments longitulinally liearinate. Castaneous, micolorons, exeept the blackish eyes and the flavous antenne and pubescence.

Length of body $+\mathrm{mm}$.

Halritut. Sokotra: Arlho Dimellus (3500 ft., 16. II. 99.).--Very common ; only one specinen in the collection.

Belongs to Stall's section "a a" (Cimex in K. Se. Alud. Hamll., 187:, Band xi. No. 2, p. 104), and (liffers from Acunthiu rotnmlate, signoret (185.2, Ann. Sor. Ent. France (2), x. p. 540, plate xvi. fig. 2), lig the rounderl apical parts of the alodomen, and the much more prominent antero-lateral pronotal angles.

The usual generic names for the 'Berl-hugs' are rejecterl (see Entomolorist, 1899, p. 219) ; Cimex birlens, Linm., being the Type of (imex, Limn., and cimer littondis, Limn., the Trpe of Acunthiu, Falor.

["The example here reeorderl was found walking inside my mosquito curtain, and at first mistaken for a small heetle. A volume of "Vanity Fair" offering the most convenient means of eaptme, it was earefully syuasher lietween the pages, when the urlour at once proclaimed the objectionable nature of my visitor. Unfortumately, I rlir not attach any importance to this acyuisition, ancl though other examples were seen and killed, none were preserved. So far as onr experience went, this lug dirl not lite white men, and was, no doubt, a somvenir of the Arab eamel-men who transporterl our haggage, or of the Sokotri natives who raily visited our camp." - IT.L.O.G.]

\section{REDUVIID正。}

\section{Reduvius, Fabricius.}

\section{Reduvius azrael, Kirl: (Plate xxiii. fig. 4.)}

Reflurius asreel, Kirk., Bull. Liverp. Nluss., ii. 1) 46 (1899).

Antemie very pilose. Second segment $\frac{5}{7}$ longer than first, not rlilated near the apex, seeond $\frac{3}{5}$ longer than the third; rostrum searcely reaching to middle of the eentral part of the prosternum. Longitudinal carinse not nearly reaching the base of pronotmm. Sirles of corimm and of aldomen glahrons. All the tarsi trisegmentate; posterior tibie rery pilose. Tenter sparsely pilose, hasal four segments carinate.

Blackish ; antemne stramineous, apex of first and second segments black. Humeral angles of pronotnm and extreme base ('apex' of most 
authors :) yellowish, a few of the elytral nervures yellowish, memlnane fuscous. Legs (except coxa) flaro-stramineous, femora and tibie marked with black at hase and apex. Commexirum whitish (w orange-yellow) spotted.

Length $15 \mathrm{~mm}$.

Sokotra: Adho 1)imellus (3500 ft., 3. II. 99 ; 9. II. 99).

Symmphs in (?) penultimute stuyp. (Plate xxiii. fig. 4a.)

Hearl much as in the imago, antenne t-segmentate onlyr; second, third, and fourth segments together longer than the whole looly: first as in arlult, second not so thiek as the first, but thicker than third or fourth: second about $: 3$ longer than first, second and fourth expal, together equal to third. Rostrum not reaching anterior eoxie. Tarsi all lid-segmentate (the second represents the second and third in the imigo). Sterna and first three abdominal segments elevated in the eentre longitudinally. Abdomen rounded laterally ; nine dorsil, eight or nine rentral, segments visible.

Brownish, lighter on abdomen and legs, darker on head ; eoxe, tibia, tarsi and apex of femora, sterna, hasal rentral segments, and antemiepallicl. Abrlomen dorsally with two darker large spots near the centre of each segment and two on each eommexival segment.

Length $9 \frac{1}{2} \mathrm{~mm}$., brearlth near apex of alklomen $5 \frac{1}{2} \mathrm{~mm}$.

Sokotra : Homlil (1500 ft., 18. I. 99), and .Jena-agahan (1.200-2500 ft., 5. I. 99).-I.R.O.Cr.

["The adult form was foumd among stones whilst we were searching for lizards. The emions larval forms were sometimes observed on the Hoors of the tents, their singular appearance and mode of progression at onee attracting attention. When first eaptured the hody was entirely concealed with grits of sand, empty bodies of ants, and other particles, hut in travelling from place to place many of these became detached. When walking they move sicleways, like a crah, and seem for all the world like animated "casting" of some small insectfeerling bird." - II.I..(1.G.]

\section{Aspilocoryphus, Stail.}

\section{GEOCORIDÆ.}

Lygeriler, anett.

\section{Aspilocoryphus forbesii, Kirl. (Plate xxiii. fig. 6.)}

Aspilocoryphu, forlexii, Kirk., Bull. Liverp. Muss, ii. p. 46.

Pronotum, scutellum, and elytra densely punctured. Antennx, fourth segment $\frac{1}{5}$ larger than the third and searcely longer than the seeond, the latter twiee as long as the first, which is stonter and furnished with short bristly hairs as in Euthetus grenti.

Black; second and third segments of antenua at hase, coxie, tarsi more or less beneath testaceons; basil third of fourth antemnal segment, 
antero-lateral margins of pronotum, femora at hase-whitish; a number of olscure minute testaceons spots on pronotum and a narrow ochreous longitudinal line (represented in one specimen by four spots, and alsent in two specimens) on the apical half of hasal lobe of pronotum; scutellum, with two small ochreous spots, the lateral margins and lase (apex uurt.) testaceous. Exoeorium and claval sutuue narrowly testaceous, the formel with a llackish spot towarls the apex. Tilia brownish, apieally black. Allied to A. fusciutiontris (Stial).

Length $10 \frac{1}{2}-12 \frac{1}{2} \mathrm{~mm}$.

Sokotra: Hadihu Plain (XII. 98); Jena-agahau (1200 ft., 29. I. 99); Adho Dimellus (3500 ft., 3. II. 99).

Aspilocoryphrs does not appear to me to afford sufficient generic characters for separation from Lyyerosmu, Spin. I have great pleasure in dedicating this species to I)r. H. O. Forbes.

[" Met with in dry, sandy spots, where they may be seen moving rather slowly about among the stones, occasionally making short flights of a few inches."-M.li.o.(t.]

\section{Geocoris, Fallén.}

6. Geocoris sokotranus, Kirl. (Plate xxiii. fig. 5.)

Geocoris solotrunus, Kirk., Bull. Liverp. Muss., ii. p. 46 (Is99).

Head not punctured, furnished with short hairs, and a fovea on each side at the base; sccond and fourti segments of antema subequal, each $2 \frac{1}{3}$ longer than the first, $\frac{1}{3}$ longer than the third. Pronotum rlensely punctured all orer, except on the lateral parts of the central smooth transverse callosity; distinetly narowed at the rounder antero-lateral margins. Scutellum closely punctured exeept on the central longitudinal carina. Clavus with one row of punctures along the corial margin ; corium with two well-separated, slightly diverging rows of punctures along the claval nargin, two rather more inegular rows on the pale exterior lateral margin. Membrane well developed. First tarsal segment (of each leg) equal to second and third together, thirel slightly longer than second.

Shining black; eyes sulicastaneous, antenue flavescent, second segment paler, first darker. Seutellum pale at extreme base ("apex" uurtt.) and very narrowly paie laterally. Hearl beneath, anterior margin of prostermun, exocorium, ancl membrame, sordid flavescent.

Length, $+\frac{i}{4}$ mm.

Sokotia : Elhé, Hadibu Plain (30. I. 98).

This species does not seem to fit well into any of the divisions proposed hy Fieber or stal hut perhaps loest into Stal's "h" -Eunm. Hemipt.

["Caught among the stones on the dry sandy ground near our camp at Elhé."-II.R.O G.] 


\section{LYGÆIDÆ.}

('m)illue, auctt.

\section{Leptocoris, Hahn.}

7. Leptocoris bahram, Kirk. (Plate xxiii. ふ..)

Leptocoris bahrem, Kirk., Bull. Liverl. Muss., ii. p. 46 (1899).

Hear and pronotum furnished with sparse, short; somewhat stiff, black hairs, not readily perceptible on the dise of the pronotum, but thicker and eloser on the lateral margins thereof. Juga distinctly more elevated towards, and at, their apices than that of the tylus, and adranced a little in front of it ; dorsum of hear romolly raised, rery narrowly suleulate from the base of the tylus to the space between the ocelli; a sulb-olnitue forea on each side of the hearl alongside of and close to the eves, its posterior extremity almost touching the nearer ocellus. Rostrum reaching to middle of first aldominal segment. Fonrth segment of antemne slightly longer than the thirl, which is slightly longer than the second, which is a little more than three times as long as the first; the latter extends beyond the apex of the hear for alwont one-lialf its (the segment's) total length. Collar narrow, somewhat feebly punctured; anterior margin sulitruncate, posterior margin lisinuate, slightly produced in the middle basally: posterior part of pronotmm transversely subrugose, coarsely punctureel, lateral margins slightly sinuate, the latter and the posteriol margin narrowly reflexed; distinctly carinated longitudinally down the centre ; an impunctuate callosity on each sirle of the earina, reaching laterally as far as the reflexerl margin, posterior to the collar. Anteriol and lateral margins of schtellum strongly elevated, extreme hase acute. Metasternum sulcate. Clavns and corium punctured. First segment of posterior tarsi a little longer than the other's together, third one-half longer than the second.

of First genital segment posteriorly sulutruncate, posterior angles not prodnced.

Heal collar, callosity, sentellnm, de., reddish-orange ; rest of pronotnm, elytra (except membrane), dorsm of ahdomen, and whole rentral surface (except rostrum) yellowish-orange, deepening on the coxie, vental smface of head, elytral nervmes, lateral margins of pronotmm, die., eyes dark crimson-rerl, ocelli a little paler ; antemie and legs (except coxie) black; memlnane and wings lurid (black in repose).

Length, $15 \mathrm{~mm}$.

Sokotra: Hadilur Plain (XII. 98); Homhil (1200 ft., 17. 1.99): Arlho Dimellus (3000 ft., 5., 6., anrl 9. II. 99).

The gems Leptororis, Hahn., antedates Seriuethu, Spinola, ly six yean's ; it must not be confoumded with another lygaril genus of very similar nane, viz., Lepturorise, Latr. (=Leptormisu anctt.). The present species belongs to Stal's section "a a" (K. Str. Alud. Hamdl., 1873, Band xi. 
No. 2, p. 100), and is clistingnished from every other species known to me, except frutrous, Westw., (from which it is at once separated ly" the pale scutellum and elytra) ly the apically elevated jugil.

["The adult was generally met with among stones when searching for Lizards and Arachnida, fe. The orange-colomed nymph is rery common on dry stony gromel, and is extremely active, ruming with amazing rapidity."-II.L.O.G.]

Nymples in ultimute sturge. (Plate xxiii. fig. Ba.)

Covered sparsely with short, stiff, lack hairs, more sparingly on alolomen. Head very similar to that of adult, except that the ocelli are alssent (indicated hy two white-ringed eye-like spots?). Rostrum 3-segmentate, first segment reaching lase of hearl, second reaching hase of mesosternum, third reaching mickle of first aldominal segment. Pronotum transverse, collared in front, posterior margin notal,ly sinuate. Scutelhum sub-cuadrate, base searcely angular. Elytra and wings semicollaceous. All the tarsi li-segmentate. Ten abdominal segments visilhe dorsally, posterior margins of the first three straight, fourth scarcely sinuate, fifth medianly emarginate; the glandular openings of the fourth and fifth segments are very small, that of the fourth on the posterior margin, that of the fifth nearer the mirldle. Nine segments (1-7 and 9-10) risible rentrally (the eighth slightly visible ventro-laterally).

Pale luteons; head and eyes sanguneons. Antemue and legs reddishpiceous, coxie and segmental articulations paler. Elytra and wings basally and laterally hrownish-black. Ctandular openings pale sanguineous.

Length $10 ! 2 \mathrm{~mm}$.

Sokotra : Homhil (1500-2500 ft.).

\section{Euthetus, Dallas.}

8. Euthetus granti, Kirl: (Plate xxiii. figs. 7 , 7a.)

Euthetus yruti, Kirk., Bull. Liverp. Muss., ii. p. 4 (1) (1s99).

of Strongly rugosely-punctured on pronotum, sentellum, and elytra. Furnished with short silvery hairs. First three segments of antemux sparsely furnished with short bristly hairs, mueh longer than the usmal antemal elothing ; first segment reaching apex of head, second slightly compressed towarls the middle, slemlerer than either the first or third ; fomth $\frac{3}{5}$ longer than the third, which is three times as long as the second, first $\frac{3}{5}$ longer than the second. Pusterior angles of pronotum acute, very shightly prominent. Posterior femora very slightly incrassate, slightly incurved, a little nurrower towards the apex. Sixth ablominal segment apically trumeate (seventh segment not visille from above), not laterally produced into spines; secondfourth segments ventrally carinate. 
Black ; clypens and rostrum at the hase greenish-yellow ; first and second segments of antenne at the base, anterior margin of prostermm (except in the miclle), lateral margins of the froms, apjeal margins of plenra-testaceous: third and formth antembal segments, tilice and tarsi-fusco-testaceous, cach of the talsal scegnents black aprically; femora sordicl fuscons, uni-ammlate with black anm with white; alylomen searlet dorsally, more or less the same colour ventrally. Corium (triangular patch rear the junction of the clavus and menhrane excepterl) and exocorim fusco-testaceous. *

o Similar to the male. Sixth alulominal segment somewhat deeply and widely rommly emarginate: apieal segment visible from alose (fig. Tia).

Black: spots and lines on head and pronotum rery narrow or almost ohsolete. Abdomen searlet ilorsally, margins black -sixth-minth segments black, except whitish median stripe; rentrally block, except a noticealile latero-appical whitish line on the third segment.

Lengeth $10 \mathrm{~mm}$.

Soliotra : Eilhé, Hadibu Plain (30. I. 99).

I have great pleasme in derlicating this species to Mr. IV. R. OgilvieGrant.

[ Very common on the sandy plain near our camp at Elhe. Their movements are mueh like those of certain Hymenontern, especially the ichneumons, as they run swiftly among the stones and roots with their antemie constantly viluating, and every few seconds make a short swift flight, which looks almost like a jump._II.I.(I.G.]

\section{CIMICID无.}

\section{Aspongopus, Laporte.}

9. Aspongopus assar, $\uparrow$ Kirk. (Plate xxiii. fig. 10.)

Aspongopus us:ar, Kirk, Bull. Liverp. Muss., ii. 11. 4 (1899).

Scutellum and basil part of pronotum tianssersely rugose and irregularly elosely punctured ; clavus and corium somewhat superficially, dorsum of abdomen closely and finely, punctured. Second and fourth segments of antenne depressed, slightly wider than fifth; fifth segment one-fourth longer than fouth, which is $\frac{3}{10}$ longer than thind : second and third sul-equal, each $\frac{1}{3}$ longer than first. Lateral margins of pronotum narowly reflexed, hase of sentellum rounded. Hearl, antenne, anterior part of pronotum (except laterally), legs, dorsum of alxlomen, and entire rentral surface (except lateral margins of prosternum) black, with a slight redelish tinge in parts. Membrane sordid bronze, nervures with a riolet tinge. Rest castaneons (in one

* One specimen, $\delta$, differs as follows:-Apical half, a narrow central longitudinal band and 2 lateral spots near base of head; anterior margin of pronotum narrowly, lateral margins wirlely-testaceous.

†"Assirir," a Persian poet ; literally "an oil-presser." 
specimen, yellowish-hrown), clarker on disc of scutellum and on apical margin of corium.

Tarsal pilosity castaneous ; ocelli rubricl.

Length $15 \mathrm{~mm}$.

Sokotra : Jena-iggahan (1200 ft., 29. I. 99).

Apparently very closely related to 4 . idumtus (Fabro), but the apieal margin of the corium is sinuate, and the dorsm of the alulomen dull black (cyaneous in vilmotns): moreorer, the second segment of the antemne is somewhat longer than the third in ridnutus, subecplal to it in assur. Apparently also allierl to nigentiolurens, Pal., hut at once separated by the colour of the clorsum of the abelomen (reddish in the latter).

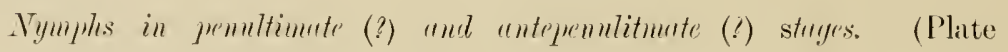
xxiii. fig. 10a.)

Trmucate-orate. Antenne short and stout, quadri-segmentate, fourth about twice as long as third, which is a little shorter than the second, which is 21 times as long as the first. Rostrum reaches apex of intermerliate coxie. Pronotmo widely reflexed laterally. Meso- and metastermum sulcate. Tarsi li-segmentate. Stigmata : thoracic (three on each sirle plainly visible) elongate; aludominal round (eight visible on the aldomen-not on the connexivm-near the apical margin of each segment). The three abdominal glands are rery large (second and thind larger than the first)-(lecreasing in eomparative size as the nymph becomes older-transverse, ahout one-third of whole lreadth of alxlomen, situaterl dorsally in the centre of third, fouth, and fifth segments, which are deeply convexly emarginate. The thoracic oritices of the stink glands become visible in the penultimate stage. Nine or ten abdominal segments visible dorsally, each one (from the second to the ninth) transversely sulcate (there thus apparently being 18 abdominal segments). These segments are also, but more superficially, transversely suleate ventrally.

Sokotra: Dahamis (350-1000 ft., 17. and 22. XII. 9\&).

Castaneous; hearl, antenne, legs, dc., black. Eyes sangmineous. Sterna sordid pale castaneous; alıdomen ventrally greyish castaneous, stigmata black.

["The imagines were pieker up among some stones when searching for lizards and spiders. The nymphs were oltained in a cluster on a shruh near our camp at Jena-agahan, but I never observed them anywhere else."-W..li.O.G.]

\section{Geotomus, Mulsant \& Rey.}

10. Geotomus attar, * sp. nor. (Plate xxiii. figrs. 9, 9a.)

Head very transwerse, rugosely punctured, reflexed anteriorly with six or 
seven hairs on each side; central lolse failly wide and subparallel, rather obsolete posteriorly, narrowed anteriorly. Ocelli nearer to the eyes than to the central line of the hearl. Rostrum reaching to the intermediate coxie. Antenme: secoml and third segments suberfual ; fouth and fifth suherual, each slightly longer than second or third. Pronotum subghabrous, punctured literally and anteriorly ; scutellum and corim more or less densely pumctured, the former rounded at the base ('alpex' signmet); lateral margins of pronotum ancl corimm piligerous. Membrate sub-hyaline.

of Sixth ablominal segment romolly excavated apically.

Redelish-pitchy, lighter on sentelhm and corimm, antemue and tassi still paler. Eyes rubicl, ocelli clear luteo-stramineons.

length $6 \frac{1}{2} \mathrm{~mm}$., lorealth $+\frac{1}{2} \mathrm{~mm}$.

Sokotra.

Appears to difler from the previonsly described species of the grems by the form of the ostiolary regions. (Plate xxiii. fig. 9a.)

11. Nezara, $s \%$.

\section{Nezara, Amyot \& Serville.}

I have not enmmeraterl two species (embracing fom specimens) of ("imicidee, one of which is a Neruru, and, although apparently new, has not been described here as it appears to be immature in colouring. 


\section{II. - Bugs from Abd=el=Kuri. \\ Chroantha, stäl.}

Chroantha ornatula, silietf:

Chroantha (?) heteshie, Kirk., Bull. Liverp. 11 uss., ii. p. 47.

Abd-el-Kuri (5. XII. 98).

This specimen was describerl in the Bulletin of the Liverpool IInserms (loc. rit), as a cloulutfully new species, lut after a re-examination, it appear's to me that, despite some minor differences, it is not sufficiently distinct to rank as a separate species from $C$. ornutula. 



\section{PLATE XXIII.}

Fig. 1. CICADETTA OMAR, Kirk, ơ, p. 381 .

Fig. Ia. Abrlomen of sume (ventrul).

Fig. 1b. Froms, die, of sume.

Fig. 2. ELASMOSCELIS IRAM, Kirk, p. 383 .

Fig. 2a. Anterion leg of sume.

Fig. 3. KLINOPHILOS HORRIFER, Firk, p. 383.

Fig. 4. REDUVIUS AZRAEL, Kirk., p. 384.

Fig. 4a. Nymmle of sume.

Fig. 5. GEOCORIS SOKOTRANUS, Kitk, p. 386.

Fig. 6. ASIPILOCORYPHUS FORBESII, Kirk, p. 385 .

Fig. 7. EUTHETUS GRANTI, Kirk., p. 388.

Fig. 7a. Apical segments of $q$.

Fig. 8. LEPTOCORIS BAHRAM, Kirk, p. 387.

Fig. 8a. Nymph of same.

Fig. 9. GEOTOMUS ATTAR, Kirk, p. 390.

Fig. 9a. Sterme, de., of sume.

Fig. 10. ASPONGOPUS ASSAR, Kirk, p. 389.

Fig. Ioa. Nymull of setms. 

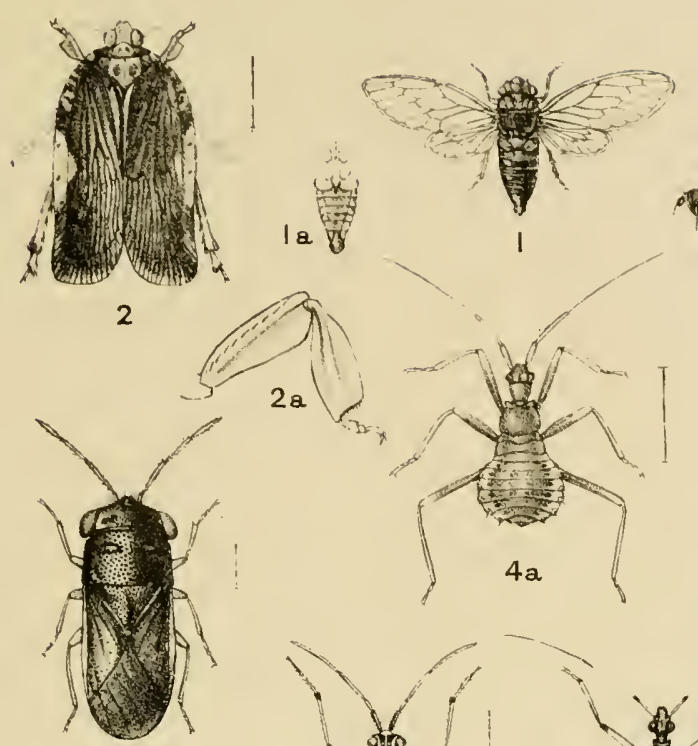

5

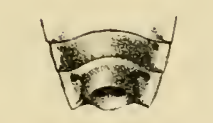

$7 a$

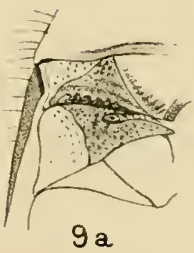

$9 a$

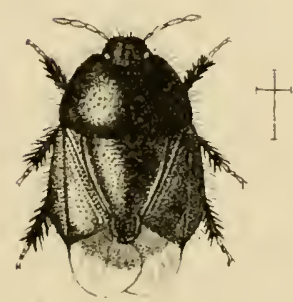

9
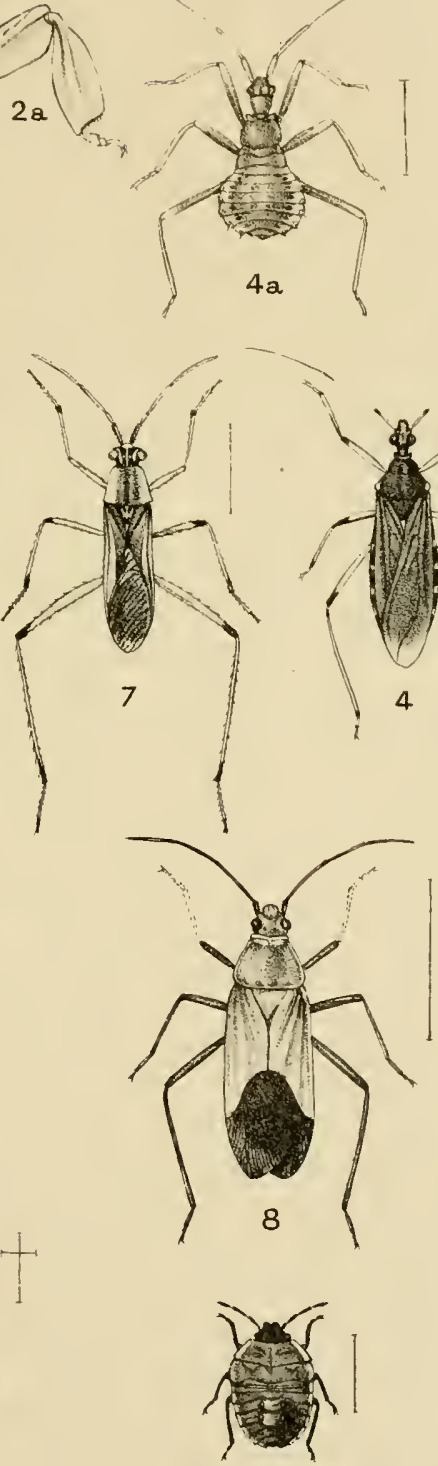

102

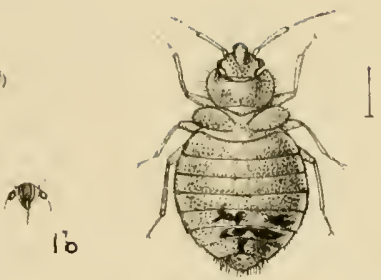

3
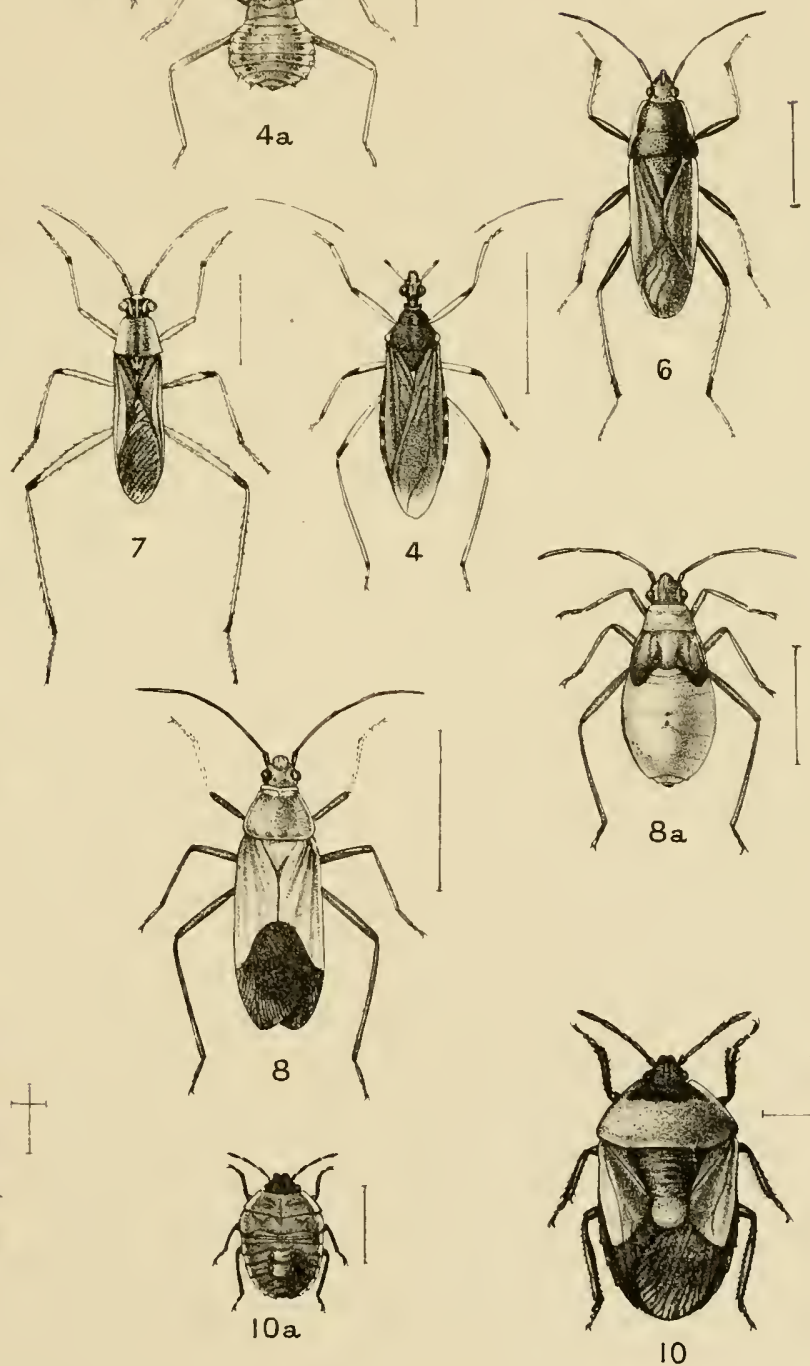

Horace Knight del et lith.

Mintern Bros imp 



\section{ARTHROPODA.}

\section{Insecta:}

\section{Neuroptera.}

Pseudo=neuropter .

Wite ly HENRY O. FORBES, LL.D.

Amphibiotica.

liy R. MCLACHLAN, F.R.S.

Planipennia.

byy W. F. KIRBY, F.L.S.

PLATES NXIY, NXIVA. 



\section{White Ants, Dragon= Flies, and Ant=Lions.}

\section{The White Ants of Sokotra.}

\section{PSEUDO-NEUROPTERA.}

There are two speeies at least of Termites in Sokntra. The one erects a termitarimm on the surface of the gromel to a height of some 1.2 to 18 inches, of a red elay mixed with bueeal or excrementitious matter which gives the clay so rery tenacions a character that after being kneaded in the hands and dried it acquires a hardness almost equal to stone. These termitaria occur, as a rule, on hare, treeless spaces. It is a different species from that which, in Afriea, makes the surprisingly large nests, 122 to 20 feet high, whieh have heen described by traveller's as looking from a distance like a eluster of native huts. None of the termitaria observed by us exceeded ls inehes in height.

The second speeies was found only among the serub. Their colonies live in the hollows of clead hanches, which they have eaten out and lined with woody, probably excrementitions, matter, and whose external shell they have also eovered over with the same deposit. This deposit, instead of being of a tenacious character, is very frialole, the nest generally falling to pieces on being touched.

Both species occurred up as high as our eamp at Adho Dimellus ; lut I have no recorl of them alove that eleration.

In Abd-el-Kuri I ohseryed no Termite nests. 


\section{The Dragon=Flies of Sokotra.}

As very little was known of the Odonate fanna of Sokotra, the thirteen species foind by Mr. Ogilvie-(xrant form an item of importance, and it is very seldom I have har the pleasure of examining materials in this group preserved in better order.

The general aspeet of the species is rery distinetly Afriean, or, to be more preeise, I might say, Tropical African. An Indian element probably exists in the case of Thumen lurmeisteri and Macroliplur rittatu. The palaaretic element may exist in the ease of the mmamed Orthetrmm, which belongs to a paliearctic "alliance," which, when tropical, is usually associated with consiclerable altiturle.

I do not imagine these thirteen species represent the entire Orlonate fama of Sokotra. Haring regard to the position of the island, and the known migratory powers of these insects, it is possible that the number of speeies that oceur will remain very much an unknown quantity. The really endemic species could only be ascertained by residential observations extending over a series of years. But the practically certain immigrant (or "sporadie") element deriverl mostly from the west, hut also partially from the east, is the unknown quantity.

\section{ODONATA.}

\section{AMPHIBIOTICA.}

\section{LIBELLULIN}

\section{Pantala, Hagen.}

1. Pantala flavescens (Ful.).

Libellula Anerexcen.s, Fabr., Ent. Syst. Suppl., p. $2 \times 5$ (1798).

Sokotra: Harlibu Plain (12. XII. 98).--1 $q$.

[Sides of ahdomen ochre, pale greenish-grey (m each sirle, the black marking down the midclle.-II.L.O.G.]

\section{Tramea, Hagen.}

2. Tramea burmeisteri, Kirly. (Plate xxir. fig. 4).

Tremea lnemeisteri, Kirby, Trans. Zool. Soc., xii. p. 316 (1889).

Sokotra: Hadilı Plain (13. XH. 98).-20 0 .

[Thorax (in life) yellowish-brown, ahdomen dark crimson (or earmine) marked with black.-IV.R.O.G.]

This is searcely more than the Indian raee of T. busiluris, Beanv., which is mostly IVest African in chistribution. 'The Sokotran examples agree 
better with the Indian in the slight points of difference, the most marked of which is that the irregular hrown crescentic marking at the bise of the hind-wings invales the triangle in betsiluris, and does not ordinarily rto so in lnermeisteri.

It is to be remarkerl that Mr. Kirby's name, hurmeisteri, was professedly bestowed upon T. chinensis, Burm., which Mr. Kirly did not consider. to represent De (iecr's species of that name, and there is something in Burmeister's rleseription that wonkl seem to warlant such an irlea. But 1)r. Calvert, in his reriew of Bumeister's types (Truns. Amer. Ent. S(r., xxr.), passes " hiurnsis" without comment.

\section{Rhyothemis, Hagen.}

3. Rhyothemis semihyalina, Irsjurdius, race separata, selys (?). (Plate xirir A. fig. 3.)

Libellule separata, Selys, Lucas Expl. Alg., iii. p. 11:), pl. I. fig. 1 (1S49).

Sokotra: Hadibu Plain (12.-16. XII. 98).-4 to.

[Colom in life-Thorax and abdomen bluish-hlack.-Ir.li.O.G.]

These examples are of somewhat large size (alxlomen $20-21$ mm., posterior wing 29-31 $\mathrm{mm}$.), the hyaline portion of the wings tinged with olivaceous, the opaque hasal portion of the posterior not reaching the nodus, the pterostigma rather long (-2.5 mm.), the nodus in the anterior placed midway from the base to the end of the pterostigma.

The Type form of semilyulinu (or hemihyulimu, as it is often termed) was from the island of Mauritius, and is smaller, with a shorter pterostigma, the oparue portion of the posterior wings often extending to the nodus, ire. The form described by De Selys from Algeria as sepurutu would also seem to have been smaller, and to have had the outer edge of the opayue portion of the posterior wings more regular according to the figme in Lucas' Explorution d'Alyério. I have never seen the Algerian insect.

A form very similar to that from Sokotra, but from Central Africa, has been deseriber by Mr. Kirloy as Rih. duectis.

\section{Macrodiplax, Brauer.}

4. Macrodiplax vittata, Kirly. (Plate xxiv A. figs. 4, fa.)

Urothemis vittatu, Kirby, Journ. Linn. Soc., Zool., xxiv., p. 5.2., pl. xlii. fig. 2 (1894).

Sokotra: Harlibu Plain (12. XII. 98). -1 ㅇ.

On comparing this with Kirby's Types (Uruthemis vittutu, Kirby) from Intia and Ceylon, the only point of difference appears to be that in the Sokotran inseet the face is purer white. I do not feel inclined to bestow a name on this single example.

In fact, it may be that $M$. lyeoris, Selys (united by I)e Selys to nigriledris, Selys), and $1 \%$. vittutu are only laces one of the other. 1 . vittutu is smaller, the labrum less distinetly hack, the merlian lobe of the labium searcely blackish, and the side lohes not margined with 
blackish (some minute points of neural detail can scarcely be settled from scanty material). The vulvar seale is distinctly but shallowly bilohed in both lyentis (nigritulnis) and ittutu. I)e Sely's (Anu. Sor. Eut. Brly., xli. p. T4) speaks of the vulvar scale in lycoris as "sul)arrondie," lout in his original deseription of lycoris (lier. of May. Zool., Mai, 1872) he alludes to it as "paraissant échancrée."

Another point is here involved. Lib. lycoris, De Selys, was originally described hy him as from Mauritius or Madagascar. But in 1897 (Aun. Sor. Eut. Brly.) he was inducer to consider this doubtful locality distinctly emoneous, and he united the oriental niquilduris with the hitherto supposed African lycoris as one and the same species. Now that an African (albeit insular) example of the genus has been discorered, it is perhaps desirable that the whole subject be reconsidered.

\section{Trithemis, Brauer.}

5. Trithemis arteriosa, Burn., race distincta (liamb.). (Plate xxir. figs. 1 t, 2 우.)

Libellula distimetr, Ramb., Ins. Név1., 1). 85 (1542).

Sokotra: Hadibu Plain (11.-13. XII. 98), 6 t, 7 ; and Goahal Gorge (200 ft., 27. I. 99), 1 t.

In varying degrees of maturity. The colours of the living males are variously given by Mr. Grant as "hronze-carmine, and hack," "crimson-earmine, and black," "dull bronze-madder, and black," and of the female it is said "greenish-ochre with hlack marks."

These examples are referred to the race distinctu mainly on the deseription and especially the figme given by De Selys in Lucas' Enplonation "'Alqérie. It is there given as conjunctu, Ramb., but it was subsequently discovered ( $f f$. Amn. Soc. Ent. Bely., xiv. p. 12) that the true conjunctu is American. The principal reason for so doing is the large extension of yellow coloration at the base of the wings, much simulating Sympetrum flaveulum. The female has the borly strongly marked with black. Accouling to D1: Calvert, the Type of arteriose, Burm., has the yellow at the lase of the wings very much less extended, as in a form widespread over Africa.

It must he remembered that Rambur's distiucter was from the Cape, and De Selys' from Algeria. A thorongh revision of the African species or races of Trithemis is necessary, based on very exact loeal data. It is a genus in which the genitalia of the second segment, nsually of such great importance, seem to afford little help, being much the same in ohviously distinet speeies, sneh as certeriust and rulurinervis.

\section{Crocothemis, Brauer.}

\section{Crocothemis erythræa, Brullé.}

Libellula erythrieu, Brullé, Expéd. de Horée, iii. (1) p. 102, pl. xxxii. fig. 4 (1832).

Sokotıa: Hadibu Plain (16. XII. 98). 
6 of of this widesprearl species.

[Colom in life-Entirely carmine. Two specimens have the general colour ochre. - Ir.li.O.G.]

\section{Diplacodes, Kirby.}

\section{Diplacodes flavistyla, Ruml.}

Libellulu, flatixtyla, Riamb., Ins. Névr., p. 117 (1842).

Sokotra: Harlibu Plain (11.-15. XII. 98).--5 $0,3 \%$, all matme.

[Of the living of the hody colom is blue-black, and of the of blue-blackishgrey.-II.R.O.G.]

8. Orthetrum, $11.8 p \cdot(?)$

\section{Orthetrum, Newman.}

Closely allied to O. chrysostigma, Burm.

Sokotra: Homhil (1500 ft., 24. I. 99)., 1 oै, 1 \% ; Adho Dimelhs (3500 ft., 15. II. 99), 1 ธे, 1 \%.

It may be that this is really 0 . chrysostiyma, or a local race thereof, and I am not disposed to risk the creation of additional synonymy ly bestowing a name, and I now donlut very much the supposed identity of chrysostigmu, Bum., with barbun, Selys, from Spain, Algeria, de.

\section{ÆESCHNINAE.}

\section{Anax, Leach.}

9. Anax mauricianus, lictmb.

Anax mauricianus, Ramb., Ins. Nérr., p. 184 (1842).

Sokotra: Addah Valley (30. XII. 99), $10^{\star}$.

[Colour in life-Dull grey blue.-W.R.O.G.]

What I now mnderstand by muriciuns consists of all those examples very closely allied to imperator (formosus), found in tropical and Sonthern Africa, Madagascar, and the smaller South African islands. In Northem Africa it is imperctor that occur's, and I now feel sure that the example, presumably from Madeira, to which I formerly (Neuropterce of Hadeiru and Cunuries) applied the name manticianus, was only imperator.

These tropical and sonthern African specimens are always more slender than the more northern imperalor, and there appears to be a decided difference in the superior appendages of the ot, which in muriciamus are more deeply excised on the imer edge before the apex. Rambur calls attention to these charaeters, and adds others as regards colour, which are problematical, and with regard to the length of the pterostigma, which is variable. I have never yet seen an example of mauriciunes in which the abdomen was not discoloured, and it is very desirable to prepare some when fresh, so that the markings can be compared. 


\section{Hemianax, Selys.}

10. Hemianax ephippiger, Burm. (Plate xxiv. fig. 3.)

Eschne ephippigerce, Burm., Handb. Ent., ii. p. 840 (1839).

Sokotra: Hadibu Plain (16. XII. 98), 2 む.

[Colour in life-Creenish-yellow, first segment of alylomen cobalt-blue, markings black.-W'.li.O.G.]

\section{AGRIONINÆ.}

\section{Ischnura, Charpentier.}

11. Ischnura (?) granti, sp. n. (Plate xxiv A. figs. 1, 1a, 1b of, 2, ㄹa q.)

of Head black ahove; frons transversely bluish ; rhinarium blaek; labrum and moler parts yellowish-white: post-oenlar spots very elongatepyriform, blue, comeeted by a fine blue line.

Prothorax black, its posterior edge raised and nearly semicireular, very slightly produeed and bluish in the middle: on the middle of the clise are two elosely placed mimute bluish elongate points.

Thorax deep hlack, the dorsal crest and an ante-humeral line pale bluish, the sides pale bluish enelosing two narrow black lines, one on the first lateral suture, the other metepimeral, abbreviated and slightly eonverging anteriorly. Pectus whitish.

Legs whitish with hlack spines; the onter side of the femora, and of the tilice at hase, black; tarsal joints blaek at the tips; tibial spines moderately long, five-six on the intermediate and posterior.

Aldomen long and slender, bronzy-hlack ahove with a bluish ring anteriorly on segments three to seven, segments nine and ten wholly deep blue; the sides of segments one to five bluish-white, with an extension of the dorsal black immediately hefore the lase of three to five.

The margin of the tenth dorsal segment slightly elevated, truncated, excised in a broadly triangular mamner if riewed from above : viewed in front, there is an open tulbe immediately below the margin, helow which are the whitish, not prominent, superior appendages in the form of two swollen lobes, but each with a lower and more elongate black oltuse branch (which may possibly pertain to the inferior appendages); inferior appendages black, distinct at the base, the upper edge exeised and the apex slightly ineurved, not prominent.

Wings hyaline, nemation black; pterostigma rhomboidal, blackish with narrowly paler margins, eovering rather more than one cellule in the anterior, rather less in the posterior; post-costa eommeneing shightly liefore the first post-eostal nervule ; upper edge of quadrilateral about one-third as long as the onter in the anterior, and one-half the length in the posterior ; thirteen to fourteen post-nodals in the anterior, twelve in the posterior. 
o Head and thorax as in the of, but the pale bluisl colour of the markings is replaced hy dingy yellowish, the sicles of the prothorax broadly of that colour.

Leegs as in the of, but the blate is redueed.

Ablomen coloured much as in the of, lut above it is apparently only the tenth segment that is blue; the sides and heneatl whitish for nearly the whole length, with black segmental divisions and an extension of the libek dorsil colom near each end of most of the segments. A strong, shanp, triangular, apical tonth on the eighth ventral segment. Appenlages short, lnoal, stout, and eonical, rery olotuse black. Valvules white with blaek filiform appendages.

Wings apparently not essentially liffering from those of the o.

Length of ablomen, of, o , 33-34 mm.; posterior wings, ot, o , 23-24 mm.

[Colour of $q$ in life-Ahore deep bottle-green; lower half of eyes and hand across head pale blue; longitudinal bauds on thorax pale straw, lower half of abdomen pale greenish-grey ; nine pale bhe hands (the segmental divisions) (lown lack.-Wr.li.U.(i.]

Sokotıa: Dahamis (19. XII.98), 1 o ; .Jena-agahan (1200 ft., 11.-12. I.99), $2 q$.

This insect is difticult to locate generically, and one wavers between Emullenme and Ischunru. I have decided on the latter principally on account of the colours and the slight elevation of the tenth dorsal segment in the of, lut the protlorax and size would be more in favour of Encellugmue.

12. Ischnura (?), n. sp.?

A small species, not a true Iselmuru, but deeptively resembling one.

Sokotıa: Harlibu Plain (1 2.-16. XlI. 98), 2 ơ.

[Colour in life-Colnalt-h,lue with black markings.-M.li.O.G.]

\section{Ceriagrion, Selys.}

13. Ceriagrion glabrum, Burm.

Agrion glabrum, Burm., Handb. Ent., ii. p. \$21 (1839).

Sokotral : Hadiln Plain (16. XII. 98), 1 o.

[Colour in life-Eyes green, abdomen redlish-orange.-IT.R.O.G.]

[In Abd-el-Kuri.-No Dragon-Flies were olserved.] 


\title{
The Ant=Lions of Sokotra.
}

\author{
PLANIPENNIA.
}

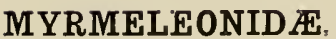

\section{Acanthaclisis, Rambur.}

\section{Acanthaclisis lineata, sp. $n$.}

Long. cor'p. 23.30 mm. ; long. al. ant., $32 \mathrm{~mm}$. ; long. al. post., $30 \mathrm{~mm}$.

Antentre rather long, gradually thickening towards the obtusely rounded extremity, reddish, browner towards the extremity, and anmulater with white. The greater part of the inseet elothed with long pale grey hair. Face white, rertex blackish, but horrlered hehind with grey. A rather narrow black stripe, lisected by a white line, extencls from the lack of the vertex over the prothorax, mesothorax, and scutellum, hut most rlistinetly on the prothorax. Prothorax with two rather widely separated lateral lines, the imner one turning obliquely outwards and hindwards, parallel with an oblique line running backwards from the midrle of the double central stripe. Mesothorax with two parallel lateral lines; scutellum with one lateral line only. Abdomen carinated in the mirldle, and marginer on the sides, blackish, slightly tinged with reddish, clothed ahove with short hair, and with some slight reddish markings towards the extremity of the last two segments on the median line; a red mark is also visilble beneath the white hair on each side of the extremity of the postseutellum. Undersurface blackish, densely hairy : legs redrlish, the tips of the tibie and the tarsi hlackish. Apical half of spurs slender, hent at a right angle. Cerci of male reddish, alont twice as long as broarl, obtusely rounded at the extremity, and set with stiff cliverging hairs as long as the cerci. Wings hyaline, the neuration brown, alternating with tawny and white. Nervures of the costal area only lifureating a little before the extremity of the cell in the fore-wings, and not till beyond it in the hind-wings; nervires of the apical area with nmmerons bifureations; marginal nervures regularly bifureaterl.

Sokotra: Harlilu Plain (15. XII. 98).--Five specimens.

This species belongs to the group of $A$. distincta, Rambur, which differs from typical Acunthaclisis in not possessing a double row of costal cells from the base, and should form a separate genus; but it is not worth while making new genera of Myrmeleonide without thoroughly revising the family. The insect is closely allier to, if not identical with, an insect described by Walker, from Natal, as Myrmeleon distinctus, var. (?) [List Neur. Ins. B.1H., ii. p. 360 11. 30 (1853)]. It is 
also allied to $M$. molestus, Walk., but this is a redeler insect, with smaller and darker black markings on the wings.

\section{Creagris, Hagen.}

2. Creagris mortifer, $\|^{\prime}, l l k$.

yyrmeteon I-nigrum, Walker (nec Ramb.), List Neu. Ins. B. M., ii. p. 3.51 n. 84 (1853).

.Vyrmeleon morlifer, Walk., I.c. p. 3.53 n. ss (1853).

syrmeleon perrigil, Walk., l.c. p. $35+\mathrm{n}$ n. 89 (1853).

Solotral : Dilhamis (1000 ft., 2.2. XII. 98).-A single specimen, which appear's to he elosely allied to, if not identical witl, this well-known species from Natal.

[In Abd-el-Kuri.--No Ant-lions were collected or ohserved.] 


\section{PLATE XXIV.}

Fig. I. TRITHERNIS ARTERIOSA, $B m$. , race DISTINCTA,

Fig. 2. The stme, ㅇ. licumb., \&, p. 400 .

Fig. 3. HEMIANAX EPHIPPIGER, Burm., p. 402.

Fig. 4. TRAMEA BURMEISTERI, Kirly, p. 398. 


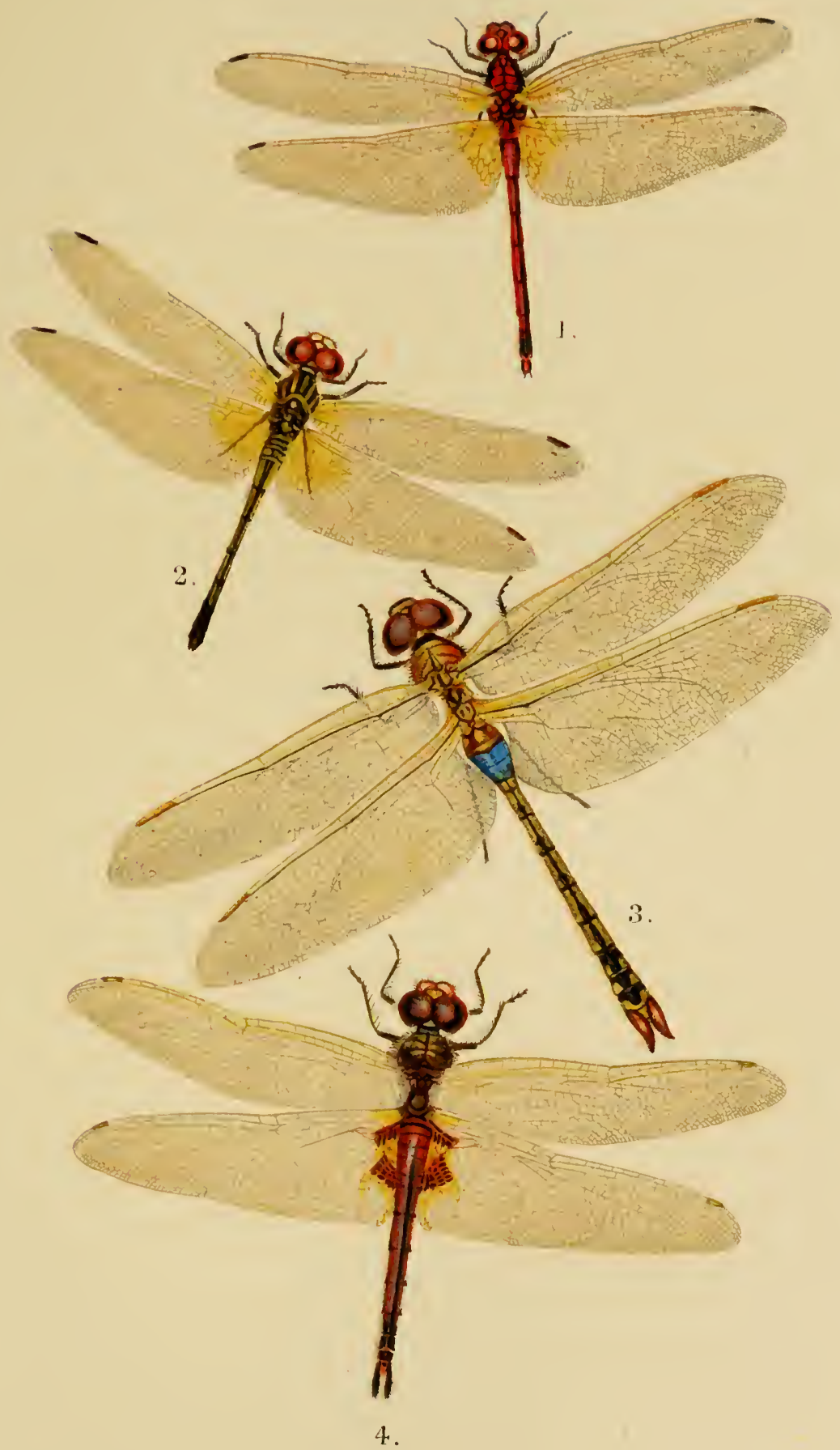




\section{PLATE XXIV A.}

Figs. I, 1a, Ib. ISCHNURA (?) GRANTI, sp. n., of, p. 402. Figs. 2, 2a...... The setme, $q$.

Fig. 3. ....... RHYOTHEMIS SEMIHYALINA, Le.j., race SEPARATA, Selys (?), p. 399.

Figs. 4, 4a...... MACRODIPLAX VITTATA, Kirby, p. 399. 


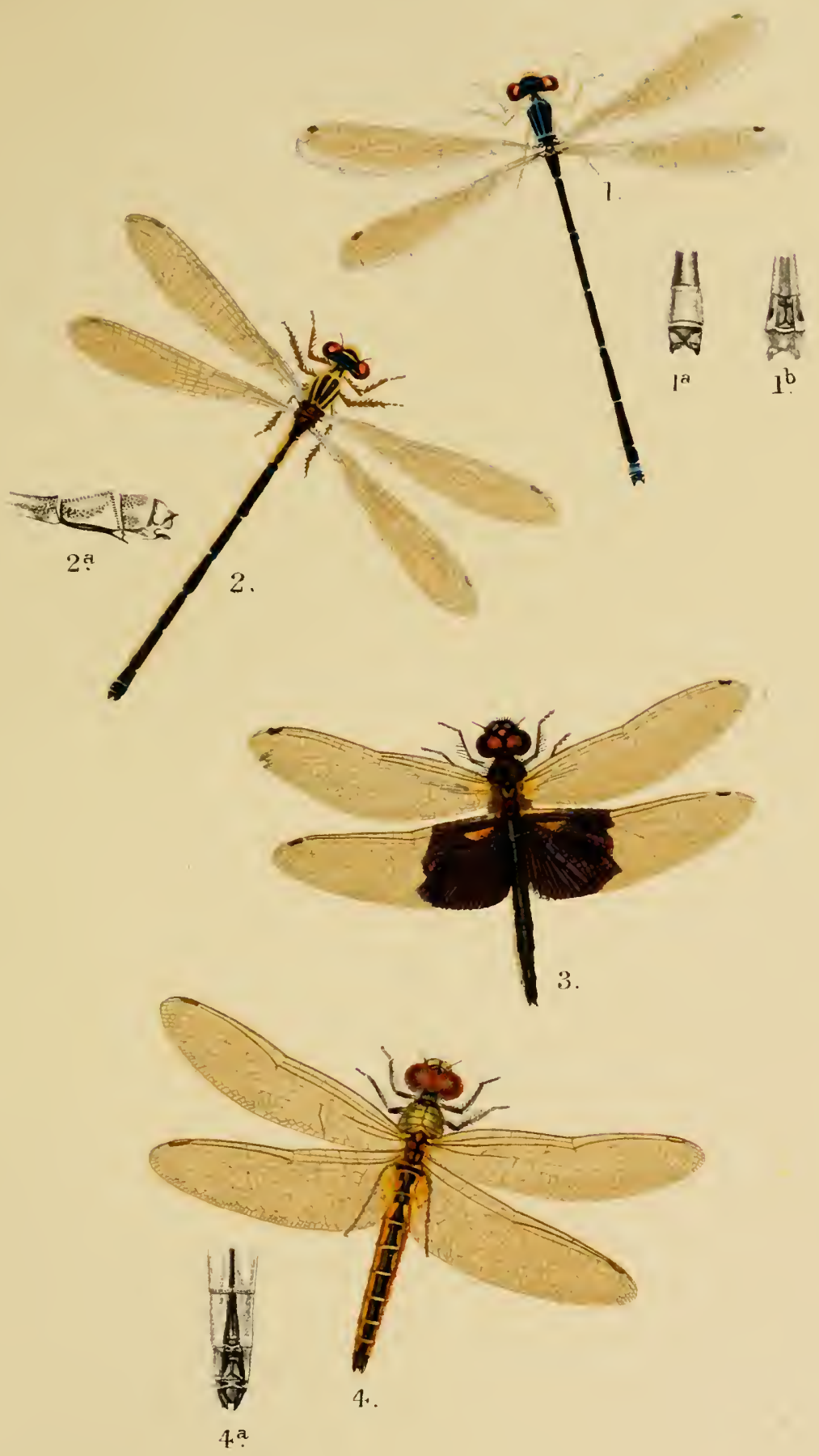





\section{ARTHROPODA.}

\section{Insecta:}

\section{Orthoptera.}

By MALCOLM BURR, F.L.S., F.Z.S., F.E.S.

PLATE XXV. 



\section{Earwigs, Crickets, and Grasshoppers.}

For our knowledge of the Orthoptera Fanna of Sokotra we are indehted to three sources.

First, the species mentioned by Taschenberg, sixteen years ago, when he rlescribed the peculiar Mecopodu whlnevinte, a most interesting form.

Second, six species lonought from the island by Mr. E. N. Bennett, in $1 \$ 96$, determined hy me, among which was a new P'oecilocens.

Third, the materials collected hy Mr. Ogilvie-Grant and Dr. H. O. Forbes, which are worked out in the following pages.

1 know of 110 other recorts of Orthoptera from the island of Sokotra; and none from Abl-el-Kmi hesides those marle by the present Expedition.

Out of the thirty-three species collected, six are new to science, and there are two new genera. The mumbers of species of each family are as follows :-

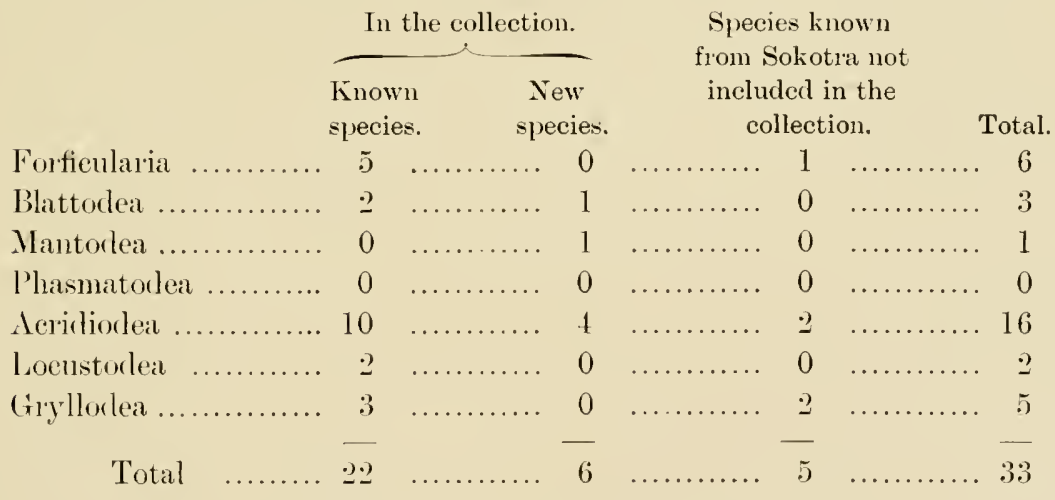

\section{Forficularia.}

\section{LIST OF SPECIES.}

1. Labidura riparia (Pall.). .

2. Forficula smyrnensis, Serr.

3. Forficula lucasi, Dohro.

4. Anechuna fedtchenkoi (Siluss.)

5. Anisolalnis stali (Dohru) .

6. A. martima, bon.
Cosmopolitan.

Palcarctic.

Cosmopolitan.

Paliearctic.

Oriental (? Cosmopolitan).

Cosmopolitan. 
Blattodea.

. Phyllodromia unicolor, Brumner

8. Loboptera peculiaris, Burr

9. Periplaneta americana (Linn.)

Mantodea.

10. 'Terdia dioscoris, Burr

\section{Acridiodea.}

11. Truxalis nasuta (Limn.) .

12. T. ensis, Burr .

13. Epaeromia thalassina (Fam:)

14. Plagiotriptus insularis, Burr

15. Phaulotypus granti, Burv

16. Edalens senegalensis ( $\mathrm{Kr}$.)

17. Dissosteira forlesii, Bur .

18. Acrotylus longipes (Charp.)

19. Sphingonotus eitrulans (Alul-el-Kmi)

20. S. savignyi Sianss. (Abrl-el-Kuri)

21. Pyrgomorpha cognata (Kíauss). (Abrl-el-Kuri)

2.2. Poccilocerus sokotranus, Bur.

23. Oxya vicina, Brumer

24. Cataloipus oherthuri, Bol.

25. Caloptenus italiens (Limu.)

26. Acridium tataricum (Linn.)

27. Acriclium, sp.
Oriental.

Endemic.

Cosmopolitan.

Endemic (Palæaretic).

Palregrean.

Endemic (mainly Ethiop.).

Palaarctic.

Endemic (Ethiop.).

Endemic (Orient.).

Cosmopolitan.

Endemic (Nearctic).

Ethiop. Paliearc. Cosmp.

(Linn.).

Paliearctic.

Ethiopian.

Ethiopian.

Endemic (Ethiop.).

Oriental.

Ethiopian.

Palæaretic.

Ethiopian.

\section{Locustodea.}

28. Phaneroptera nana, Charp. . . Ethiop. (Paliarctic).

29. Phaneroptera, sp.

30. Pachysmopoda ibbreviata (Tasch.) . Endlemic.

\section{Gryllodea.}

31. Liogryllus bimaculatus (de Geer) . Cosmopolitan.

32. Gryllus lepidus, Walk. (?). . . Orient. (Ethiop.).

33. Cophogryllus, sp. . . . . Ethiop.

34. Landreva, sp. . . . . . Ethiop.

35. (Ecanthus pellncens (Scop.) . . Palianctic.

\begin{tabular}{|c|c|c|c|c|c|c|c|}
\hline & Forf. & Blatt. & Mant. & Acrid. & Loc. & Gryll. & Total. \\
\hline Endemic............ & 0 & 1 & 1 & $\overline{5}$ & 1 & 0 & 8 \\
\hline Oriental ............. & 1 & 1 & 0 & 1 & 0 & 1 & 4 \\
\hline Ethiopian .......... & 0 & 0 & 0 & $\tilde{5}$ & 1 & 2 & 8 \\
\hline Palæarctic ........ & 2 & 0 & 0 & 5 & 0 & 1 & 8 \\
\hline Cosmopolitan ...... & 3 & 1 & 0 & $\ddot{2}$ & 0 & 1 & 7 \\
\hline Total & 6 & -3 & $\overline{1}$ & $\overline{18}$ & 2 & $\overline{\tilde{y}}$ & $\overline{35}$ \\
\hline
\end{tabular}


In the ahove I have not inclurled the three meertain species of fryllorlea, and l hare regaried as cosmopolitan such forms as are common to tiw regions, as icrotylus longipes (Chapp), which ocems in the Palanactic and Ethopian regions. The aftuities of the endenic species are given in parentheses.

From the Orthoptera alone it wili he seen, that the Fanna of Soliotra bas very strong Ethiopian attinities, lut ahmost equally close relations with the Palatenctic region. Of the novelties, Lobopteru peculiuris 11 . helongs to a genus with wirle distribution; one species is essentially South European, while others are Australian and Indian. Tedelie n. g. falls into a group of genera oecurring in North Africa and Western Asia, while Truralis ensis n. represents a genus which is found throughout the Old World. Plagiotriptus (sp. 1 . insuleris) is an Afriean gems, with Oriental aftinities, and Phunlotypus g. n., as far as we know yet, is restrieted to Sokotra, lout its nearest allies are Oriental. Disosteiru forlusii sp. In. is interesting, for, with one exception, the genus is charaeteristically Amorican; the exception, /). suncin, oecurs in Sonth Africa.

A noteworthy point is that, as yet, not a single species of Phusmutorled is known from Sokotra, and only one of Mentoded, and that is peculiar to the island: Lomistoden also appear lane, for I only know of two species hitherto recortert from Sokotra.

\title{
I.--Earwigs, Grasshoppers, and Crickets of Sokotra.
}

\section{FORFICULID床.}

\section{FORFICULARIA.}

1. Labidura riparia (l'ull.).

\section{Labidura, Leach.}

\author{
Forficulu ripurire, Pallas, 1773, Reisen ii. Anhang 1) 30
}

This speeies would natmally he expecter to ocem in the island, owing to its universal distribution.

Sokotra.-( Burr.)

\section{Forficula, Linn.}

2. Forficula smyrnensis, Sert. (Plate xxv. fig 5.)

Forficula smyrnensis, Serville, 1839, Orth., p. 38.

This pretty earwig has been taken at Constantinople and Athens, as well as from Asia Minor, and Brumer records it as far west as Corsica.

Sokotra: J)ahamis.-1 0 .

\section{Forficula lucasi, Dohrn.}

Forficula hueresi, H. Dohrn, Stett. ent. Zeit., xxvi, p. 98 (1865).

It is interesting to find this earwig in the island, for its distribution appears to be wide, though the insect is searecly common. Dohrn 
first described specimens from Syria (Mus. Paris), aud it is known from Egypt. It was then taken loy Fea in Burma, at Teinzo, and recorded hy de Bormans. A still more remarkible locality, if it is a domesticated species, as it appears, is the road of Beni Mzal, on the road from Ghardaia to Gmervara in the Oned En-Nsa, and also in a house at Oned lu-Nsa, in the Algerian Sahara, where it was taken ly my friend l)r. Kinauss.

Sokotra : Hombil (1500-2500 ft.).-1 0 .

\section{Anechura, Scudd.}

4. Anechura fedtchenkoi (sinus.s.).

Forficulu fedtchenkoi, Siuss., 1s94, in Fedtchenko, Turkestan, Orth., p. 6. This is the most interesting of the earrigs taken in Sokotra, for it is unexpecterl. The species was originally described by de Samssure from specimens taken ly Fedtchenko in Turkestan, and since then has apparently not been eapturerl again. The Sokotran specimens I have submitted to my friend M. de Bormans, who informs me that they are of a variety which was taken with the type form in Turkestan. 'The wings are entirely hidden by the elytra and the foreeps are flattened. The species seems to he incipable of flight, and it is most striking that so far it shonk have been found in Turkestan and Sokotral only : doulutless it will some day le eaptured in intermediate localities.

Sokotra.-1 ô, 1 ㅇ.

\section{Anisolabis, Fieb.}

5. Anisolabis stäli (Ltele'n.).

Forcinella stâli, H. Dohrn, 1864, Stett. ent. Zeit. xxv., p. 2866.

Deseriber ly Dohrn from Javanese specimens.

Sokotra: Hadilı (XII. 98), 1 §ో.

6. Anisolabis maritima, $B \mathrm{i} m$.

Anisolalsis maritima, Bon. in MS., 1852, Géné. Mon. Forf., p. 9.

These indiriduals seem to be a variety of $A$. muritime, and in dould I have sulmitted them to M. le Bormans. They are "eharaterised by nothing : antenne with 23 segments, micolomons, no ruliments of elytra, forceps orrlinary, medimm sized, feet micolorons."

Sokotra.-:3 우

Six specimens received.

It is emions to note that the common Forficulle auriculurin does not seem to ocenr in the island.

PHYLLODROMIID尼.

\section{BLATTODEA.}

\section{Phyllodromia, Serv.}

7. Phyllodromia unicolor, $\mathrm{Br}$ :

Phyllodromia unicolor, Brunner, 1893, Rev. Orth., p. 18.

Phyllodromiu sp., Burr, 1.7.s., 1s98, p. 384.

This species was described first by Brumner from Mandalay. I refer the 
lava from the same locality to this species, but it might well he that of Ph. germunierl L.

This species was olitained also by Mr: Benuett.

Sokotra: Hadilur Plain (21. II. 99). 루. (XII. 98). - I larra.

\section{Loboptera, Brunner.}

8. Loboptera peculiaris, limr. (Plate xxv. fig. \&.)

Lohoptere peculinvi, Burr, Bull. Liverp. Muss., ii. p. 42 (1899).

of Testaecous shining. Antenna setaceons. Pronotum rounded in front, truneated posteriorly, narower anteriorly than posteriorly. Mesoand netanotum transverse. Elytra lobiform, lateral, hardly surpassing the hinder margin of the mesonotmm. Wings alsent. Head testaceons, with a transverse black hand letween the eyes; face with two black longitudinal bands. Aludomen dilated, castaneous, the margins paler, with a black spot on each side of the segments. Feet pale; femoral very spiny ; tarsi armed with a minute pulvillus between the cliws, the first segment longer than the three following taken together. Cerci short. Suhgenital lamina of the of triangular, transversely obtusely roumderl.

Length of hody, of 11-1.2 mm., of pronotum $4-4.25 \mathrm{~mm}$. : Breacth of pronotum 5 $\mathrm{mmm}$.

This species differs from all its congeners by its light shining testaceous colour. The pad between the tarsal claws is also somewhat larger than in the other described species. The genus is essentially sonth European and Asiatic in distrilution.

Sokotia.- - 30 .

\section{PERIPLANETID床.}

\section{Periplanata, Burm.}

9. Periplanata americana (Limn.).

Blatfu americana, Linn., Syst. Nat., ii. 687 (1766).

This species is quite cosmopolitan.

Soliotral : Homhil (1500 ft., 22. I. 99).--1 ơ.

Periplanata americana (Liuu.), var. brunnea, Klu!).

Periplanate bremere, Klng., M.S. in Burm. Hand., ii. p. 503 (1839).

Sokotra : Harlibu Plain (16. XII. 98).-1 9 . (‥ XII. 98).-1 larva.

\section{MANTID压.}

\section{MANTODEA.}

\section{Teddia, Burr.}

Teddia, Burr, Bull. Liverp. Muss, vi. p. 42 (1899).

o. Body slender, elongate. Eyes round, not tuberculate. Antemue rery slender. Pronotum elongated, making a small dilatation over the coxie; the edges are dentienlated, and the dise entirely gramulated. Prosternum flattened, smooth, slightly gramulated posteriorly. Elytra 
and wings ablneviated; the latter dark testaceous, shaded with purple, the anal part with a large dark spot; the former short, testaceous, romided at the apex. Feet slender ; anterior coxie long; anterior femora slender, straight, with five spines on the onter margin beneath, of which the last is the largest; there are six larger spines on the imner margin, alternated with six smaller; there are four discoilal spines, of which the first is the smallest, the third the largest; the first hasal spiue is not remote from the others. Anterior tilice with ten small spines on each side; intermediate and posterior tihise with three spinules at the apex; posterior tibie very finely denticulated or marmed. Supra-anal plate large, lilated, narrow at the apex, elongate, eompresserl.

This new genus is probably pecnliar to the island, owing to the abbreviation of the organs of flight. It is much more slender than its allies (Fischeriu); the unarmed posterior tarsi distinguish it from Ischnomuntis, Fischeriu and sipheulule; the romuled supraanal plate of, from Deiphobe and Eremopleru; the long posterior femora from Solygia; and the general facies of the insect and its slenderness forluid its confusion with Bolivuriu.

10. Teddia dioscoris, Buri: (Plate xxv. figs. 3, 3a, 3h.)

Teddia dioscoris, Burr, Bull. Liverp. Muss, ii. p. 42 (1899).

3. Of medium stature, slender ; colour fuscons, elytra testaceous ; wings testaceons, shaded with purple. There is a variety with feet paler, shaded and banded with darker.

Length of hody, of $40-46 \mathrm{~mm}$., of pronotum $12-13.5 \mathrm{~mm}$., ditto, anterior part, 4-5 mm., ditto, posterior part, $8-8.5 \mathrm{~mm}$, of elytra $5.25 \mathrm{~mm}$. , of anterior coxa $7-8 \mathrm{~mm}$., of anterior femora $8.5-9 \mathrm{~mm}$., of anterior tilise $4-4.5 \mathrm{~mm}$., of posterior femora $11.5-13.5 \mathrm{~mm}$., of posterior tibix 13-15 mm., of posterior tarsi $5 \mathrm{~mm}$.

Sokotra : Dahamis (500-1000 ft., 21. XII. 28), 20 0 .

TRUXALID压.

\section{ACRIDIODEA.}

\section{Truxalis, Fabr.}

\section{Truxalis nasuta (Limr.).}

Gryllus (Acrida) nesuta, Linn., Mus. Lud. Ulr., 1) 118 (1764).

Truxalis mexuta, Burr, P.Z.S., 1898, 184.

The solitary larva which I recorled as this species, may very likely be the immatme of the following.

12. Truxalis ensis, Burr, (Plate xxr. figs. 4, ta.)

Truaulis ensis, Burr, Bull. Liver|'. Muss, ii. p. 43 (1899).

q. Green. Body extremely elongated, eylindrical. Hearl not sharply, ascending; antemne long, Hattened, the apical segments smaller, the antenure longer than head and pronotum combined. Pronotum small, 
eylindrical, neither constrieted nor clilated posteriorly; the lateral eariux slightly undulating, slightly direrging posteriorly ; the typieal sulcus sitnated well behind the middle, sinnate; lateral lobes of the pronotum obtuse-ingled in front, not romeded, its carina almost parallel with the dorso-lateral carine. Sternum strongly carinate in the midlle. Elytua very long and narow, sharply pointed at the extremity, green, the seapular area with olligue transrerse reins somewhat remote from each other, and with a spurions vein. Wings brightly coloured, long and narrow, considerably shorter than the elytra, golden-yellow, tesselated with black, yellowish-hyaline at the extremity. Alxlomen typical. Feet rery long and slender ; claws of the tarsi long, the pulvillus large.

Length of body, $q 53-6.3 \mathrm{~mm}$, of antemme $2-4 \mathrm{~mm}$., of head (from above) $14.5 \mathrm{~mm}$., of pronotum $8-8.25 \mathrm{~mm}$., of elytra $52-57 \mathrm{~mm}$., of wings $46 \mathrm{~mm}$., of posterior femora $37 \mathrm{~mm}$., of posterior tilize $36-75 \mathrm{~mm}$. This very fine species is even more slender and elongated than the other members of this extraordinary gems. Characteristie points are the length of the antenn:e which exceed the combined length of the head and pronotum, the golden-orange colom of the wings, with black tesselations, the narrow, almost eylindrical head and pronotum, and the great length of the elytra. It falls into Bolivar's sulggenus Trumlis sensu strictn, into the group of crocen, Bol., with brilliantly coloured wings and carinated stermm.

Sokotra: Jentaggahan (1200 ft., 11. I. 99); Gebel liaggit (800 ft., 16. XII. 98$),-2$ 웅.

\section{Epacromia, Fisch.}

\section{Epacromia thalassina (Fubr.).}

Gryllus thalewsinus, Fabr., knt. Syst., ii. 57 (1793).

This is a sonth Enopean speeies, hut oceurs in Africa at least as far south as Somaliland.

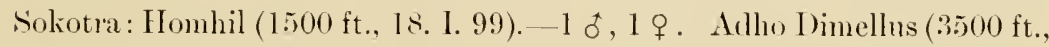
11. II. 99), 1 \%.

\section{EUMASTACID无.}

\section{Plagiotriptus, Karsch.}

14. Plagiotriptus insularis, liurr. (Plate xxr. fig. 6.)

Plapiotriftus insuleris, Burr, Bull. Liverp. Mnss., ii. p. 44 (1899); id. An. Soc. Es[añ. N.H., 1899, p. 302.

q. Small, testaceous. Pronotmm higher than long, slightly prodnced in front: lateral lobes with hinder margin straght, the anterior margin simate; meso- and meta-nota visible. Anterior feet and midelle tibie and tarsi clark : posterior tibice not loher.

Length of hody $13 \mathrm{~mm}$. ( $q$ ), of pronotum (max.) $6 \mathrm{~mm}$., of pronotum (min.), :3 mm.; height of pronotum $7 \mathrm{~mm}$; length of femora postica $8 \mathrm{~mm}$. 
This speeies is very eonsiclerably smaller than I'. hiprisens. In the shape of the pronotim it approaches rather to P. rotumlifions, Burr, hut is much smaller and less dark in colour.

Sokotı: : Jena-agahan (-2500 ft., 3. I. 99).

\section{Phaulotypus, Burr.}

Phaulotypus, Burr, Bull. Liver. Muss, ii. p. 44 (1899).

Pronotum covering the hear, compressed, elevated, acuminate hefore and hehind, strongly proflneed posteriorly, the upper margin of the erest equally rounded, with no veins, granulated. Elytra and wings alsent. Hearl formed as in Choratypi. Anterior and middle femora compressed but not dilated: posterior femora strongly compressed and dilated, the upper erest denticulate, and genieular loles aeuminate. Posterior tihice curved, not lobed, the terminal spurs on the onter margin rery small, the inner spur large; the first tarsal segment very finely cremulate Face granulaterl. Male muknown.

This new genus can he easily rlistinguished from the other genera of the group Chorutyni. The shape of the pronotum, the alssence of lohes on the posterior tibiz, and the alosence of organs of flight distinguish it at once.

15. Phaulotypus granti, Burr. (Plate xxr. fig. T.)

Pheculotypus yrcenti, Burr, Bull. Liverp. Muss., ii. 1) 44 (1899); id. An. Soc. Españ. N.H., 1899, p. 303.

१. Small, castaneous, unicolorous.

Length of body, $q 1+\mathrm{mm}$., of pronotim $9 \mathrm{~mm}$.; height of pronotum $5.5 \mathrm{~mm}$. ; length of posterior femolal $8.5 \mathrm{~mm}$.

I have great pleasure in dedicating this curious little novelty to $\mathrm{Mr}$. Ogilvie-Grant, who collected Orthoptem so assidnously in Sokotra.

\section{OEDIPODID后.}

\section{Edaleus, Fieb.}

16. Edaleus senegalensis $(K \%)$.

Pachytylus seneyalenxis, Kr., Orth. Seneg., p. 28 (1877).

This speeies is wirlely distributed through the Ethiopian and Oriental regions. Senegal, Ternate, and New Holland are given by de Sanssure as loealities. The three specimens from Sokotra are the type form, as originally described from Senegal by Ir. Kranss.

Sokotra: Elhe, Hadibu Plain (30. I. 99).-웅, 1 ㅇ.

\section{Dissosteira, Scudd.}

17. Dissosteira forbesii, Burr. (Plate xxr. fig. 1.)

Dissosteira forbesii, Burr, Bull. Liverp. Muss., ii. p. 44 (1899).

of + . Colour testaceous; head olstuse ; vertex depressed between the eyes, not carinate; fastigium of the rertex seareely divided from the fastigium of the face; face strongly convex, earinate; eyes large, romd ; 
antemin fusco-testacens, longer than the head and pronotmm taken together; pronotum keeled, slightly constricted in the midrlle, the anterior horder obtusely angled, the rentral keel sulsimute, not ent ly the sulci ; hinder borler rectangular ; lateral keels not very prominent ; erest of the pronotum not deeply intersected in the midrle by the typieal sulcus ; lateral lobes narrow. Elytra long, obliquely subtruncate at the apex, fusco-testaceous, with three clark bauds, coriaceous, closely and irregularly reticulated, hyaline only in the apical third, where the reticulation is open and regular, markerl with a few dark spots ; vena intercalata nearly straight, near to the ralial rein. Wings shorter than the elytra, narow, deep purplish-Jlack, the apical part excepted, hyaline, the apex itself smoky ; this hyaline and smoky part inchuding the two apical lobes. Ablomen black; valves of the oripositor short. Feet testaceous or fuscons. Posterior femora very stont, fusco-testaceous outside, purple inside, with two pale spots ahove, and a pale ring at the apex; the upper crest slightly denticulate; knees spotted with hack on the inside. Posterior tilix hack at the base, linged with testaceous, then sanguineous, the spines dark at the apex, lieing 10 on each sicle, of which 1-3 are the smallest.

Length of body, of $23.5 \mathrm{~mm}$., $q 30 \mathrm{~mm}$; of pronotum, $\delta 5.5 \mathrm{~mm}$., q $6.5-6.75$ : of elytra, $\delta .24 \mathrm{~mm}$., $q 3.3 \mathrm{~mm}$.; of femora postica, of $14.75 \mathrm{~mm}$., o $16.75 \mathrm{~mm}$.

This species may le recognised at once by the inky black wings, with only a small clear hand just before the apex, which is smoky. Its attinities are American, lut one species of the genus (its arrangement in this genus is, however, provisional), I). succie, oceurs in Southern Africi.

Sokotra : Homhil (2500 ft., 2.2. 1. 99).-1 $\delta, 1 q$. Goahal Gorge (16. I.

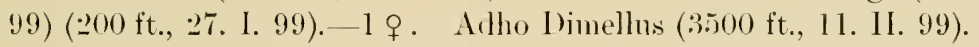

\section{Acrotylus, Feib.}

\section{Acrotylus longipes (Churp.).}

Eddipordu longipes, Charp., Orth. deser. et dep., tab. 5t (1845) (?).

Sokotra. (Benuett.)

This is the for'm with the red wings.

\section{PYRGOMORPHID厯.}

\section{Poecilocerus, Serv.}

22. Poecilocerus sokotranus, Burr.

Poecilocerns solotranus, Burr, I.Z.S , 1898, p. 384.

This species appears to he common in the island, and is apparently restricted to Sokotra. The peculiar dorsal tubercles to which I have referred (P.Z.S, 1898, p. 385) are present on all the specimens, and seem to be organic, and not a foreign body, as previously suggesterl. They have since been diseussed by Krauss (Zool. Anzeiger 
xxiii. No. 610, March, 1900). The genus contains five other species, foumel in Tranquelar, Somaliland, and Egypt.

Sokotia : Kamaham (500 ft., 30. XII. 98). -1 ot, 2 q. Homhil (1500 ft., 18. I. 99). 1 of. Adrla Valley, east of Hadibu Plain (29. I. 99).--

1 ㅇ. Dahamis (1000 ft., 2:3. XII. 9s). -1 o .

$\mathrm{Mr}$. Bemett also ohtainerl this species.

\section{ACRIDIID平.}

\section{Oxya, Serv.}

23. Oxya vicina, $\operatorname{li}$.

Oxya vicinu, Brumner, Rev. Orth., p. 152 (1893).

This species is very widely distributed, but only hitherto recorded, so far as I am aware, from the Oriental region. Brumer mentions China, Hainan, Iapan, and the Himalayas as localities from which he possesses exampless.

Sokotra: Harlilı Plain (2.2. XI. 99).-1 $q$. Homhil (1500 ft., 18. I. 99). 1 ㅇ.

\section{Cataloipus, Bol.}

24. Cataloipus oberthuri, Bol. (Plate xxr. figs. 2, 2a.)

Euprepocnemis (Cataloipus) olvethmi, Bol., An. Soc. Espann., N.H., xix p, 321 (18:90).

This fine grasshopper is rare, and only known elsewhere from Taloma, in Uyanyembe. The genus is characteristically African. C. whethmi is very close to cymbifer", Kr., but may be clistinguished by the form of the sulggenital lamina of the male, which is rouncled, with a slight rounder emargination in rymliffor, lut strongly exeised with triangnlar loles in ollerthriri.

Sokotra : Hadihu Plain (20. II. 99). -1 f , 1 \%. Hombil (1500 ft., 18. I. 99). -1 to, 2 \% ; and (2500 ft., 22. I. 99). -1 .

\section{Caloptenus, Burm.}

\section{Caloptenus italicus (linn.).}

Gryllus italicus, Linn., Syst. Nat., ii. p. T01 (1766).

This specimen differs from the ordinary forms of $C$. itulicus in the colour of the posterior femola. These are dink and bright purple on the imer sirle; the inferior sulcus is light pupple, the outer inferior suleus is pale; the posterior tibie and tarsi are yellowish: the pronotum, too, is produced further posteriorly than in the typical forms. Another point is that the lower margin of the lateral lobes of the pronotum are slightly convex, in the type, but in this specimen they are straight. C. itulicus is an extrenely variable species, and I therefore hesitate to deseribe this as new. It is essentially a European form, but oecurs also in Syria, and has heen taken at Khartomm.

Sokotıa: Elhé, Hadibı Plain (30. I. 99). 


\title{
Acridium, Geoff.
}

26. Acridium tataricum (Limm.).

Gryllu. (Locustu) theturicus, Linn., Syst. Nat. (ed. x.), i. p. 432 (1758).

Sokotlal: (roahal Gorge ( $200 \mathrm{ft}, 27$. I. 99).-1 $q$.

27. Acridium tataricum, Limn. vall. mœstum, sern.

A'ridium luturicum var. imestum, Serv., Orth., p. 6i5t (18:39).

Sokotra: One specimen-(Taschenbery).

28. Acridium, sp.

Sokotra : Jena-igahan (1200 ft., 1. I. 99); Homhil (1500 ft., Ls. I. 99).

'These specimens ane all in the larval stage, and it is impossible to determine the species with precision.

Mr. Bentuett also collected this species.

\section{LOCUSTODEA.}

\section{PHANEROPTERIDÆ.}

\section{Phaneroptera, Serv.}

\section{Phaneroptera nana, C'herip.}

\author{
Phaneropterce nana, Charp., Fieb., Syn., p. 49 (18503).
}

It is impossihle to determine with any degree of satisfaction the speeies of this genus without examining the male, lut these specimens are extremely probahly $I / h$. nemu, an insect which has a wide distribution in Africa and Southern Europe.

Soliotıa : Hadilın Plain (11. XII. 98), 1 q : Jena-agallan (1:200 ft., ‥ I. 99), 1 ㅇ․

\section{Phaneroptera, sp?}

Sokotra.-Three examples (Trsehenbery). Probably to be referred to the ahove.

\section{MECOPODIDÆ.}

\section{Pachysmopoda, Karsch.}

31. Pachysmopoda abbreviata (Tusch.).

I/cropode abbreriata, Tasch., 1883, Zeitschi, für. Naturw., lvi. 1. 184.

Mecoporte (Prechysmopode) ublineriate, Karseh., 1886, Berl. Ent. Zeit., p. 114. Taf. iv. fig. $2, q$.

Puchysmopodu abluteriutu, Kirby, W.F. 1892, Trans. Ent. Soc. Lond. p. 409 ; Karsch, 1892, Berl. Ent. Zeit., p. 342.

Pachysmoporta abbrevictu, Redt., Mon. Uebersicht. Mecop., 1892, p. 216. Pachysmopoda abbreviuta, Burr, 1898, I.Z.S., p. 384-note.

Green or testaceous. Antemna pale ringed. Head stont, strongly punctate. Pronotum with the dise and lateral carine dark. Elytra with anterior and intermedial area, black and white spotterl. Posterior knees dark. 


\begin{tabular}{|c|c|c|c|}
\hline & & ț & $q$ \\
\hline Length of & pronotum. & 10 millim. & 12 millim. \\
\hline " & elytia.......... & $27 \quad 11$ & $33 \quad 11$ \\
\hline$"$ & posterior femora.. & 28 & $3+\quad 11$ \\
\hline "1 & ovipositor........... & - & $25 \cdot 5 \quad 11$ \\
\hline
\end{tabular}

This is a very fine species. So far, the only speeimens known to be in existence in collections, appear to be the types of, $q$, of Taschenbergr, which ane in the Berlin Musem. Karsch has redescrilued it, and given a fignre of the fomale. In the dried specimens, the muder sirle of the posterior femora is dull, testaceous, or fuscons, but in one example in spirits, the inferior suleus is lyight purple: the antennes scarcely show any traees of the pale rings, hut the colour of the living animal is rery rlfferent from that of the dried specimen. According to the deseriptions and Karsch's figure, the elytra exactly reach the apex of the abdomen, but in the examples which I have been able to examine they are invariably considerably longer : this is probably due to the contraction of the borly.

The Mecoporlider ane a small family characteristic of the Ethopian and Oriental Regions.

Sokotra: Jena-agahan (1. I. 99), 1 f , $2 \%$; Dahamis (350 ft., 22. XII. 98),

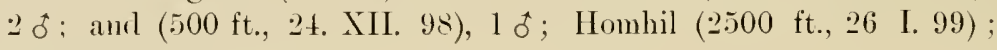
and $(1500-2500 \mathrm{ft}$.)

\section{GRYLLID君.}

\section{GRYLLODEA.}

\section{Liogryllus, Sauss.}

32. Liogryllus bimaculatus (de Geer.).

Gryllus bimaculatus, de Geer, Mem., p. 521 (1773).

This speeies is distriluted throughout Afriea, Sonthern Enrope, Central Asia, India, and the Malay Aichipelago.

Sokotra : Jena-agahan (1־00 ft., 1. I. 99), 1 §, 1 \% ; Elhé, Haulibu Plain (30. I. 99), 1 nymph.

\section{Gryllus, Linn.}

33. Gryllus lepidus, Willi:?

Cryllus lepiclus, Walk., Cat. Derm. Salt., 1) 46 (1869).

I am not certain as to the illentity of this species, having only females to examine.

Sokotıa: Homhil (1500 ft., 18. I. 99), ำ (0, I. 99), 1 ㅇ.

\section{Cophogryllus, Sauss.}

34. Cophogryllus, sp.?

Sokotra.-One example (Tuschenlerg). 


\section{Landreva, Walk.}

35. Landreva, sp). "1.?

Sokotia (burr).

\section{CEANTHID尼.}

\section{CEanthus, Serv.}

36. Ecanthus pellucens (Scop.).

Gryllus pellucens, Scop., Ent. Carn., 1. 32 (1763).

'This delicate little cricket is extremely common in Southern Europe, lut is represented in the Oriental Region hy O. mufesens, Serv. O). pellueens is rlistinctly a Paliearctic species.

Jinehan Valley (3000 ft., 1. II. 99), 1 q. 


\section{II. -Grasshoppers from Abd=el=Kuri.}

\section{ACRIDIODEA.}

CEDIPODID无.

\section{Sphingonotus, Fieb.}

Sphingonotus cærulans (Limn.), var.

Gryllus (Locesta) cremlens, Linn., Syst. Nat., i., part ii. p. 701 (1766).

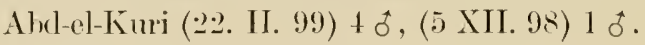

Sphingonotus savignyi, Sinuss.

sphingonotus savignyi, Sauss., Prod. (Ed., 1). 208 (188s).

Alrd-el-Kuri (5. XII. 98).

\section{PYRGOMORPHID君.}

\section{Pyrgomorpha, Serv.}

Pyrgomorpha cognata, Kronss.

P'yryomorphre cogmutu, linuss, Orth. Seneg., p. 30 (1877).

This species is essentially African, having been noticed bitherto from Senegal and Dagana. The genus is widesprearl, there being two Paliearctic species, two American, several Ethiopian, and one or two Indian and Asiatic representatives.

Abd-el-Kuri (5. XII. 98).

[Our stay in Abd-el-Kmi was so short that we obtained, I have no doubt, but a few of the species of Orthopteru that the island contains.-H.O.F.]

\section{List of Works Quoted.}

Tuschember:y 0. - Beiträge zur Fanma der Insel Sokotra, vorzigglich nach dem von Herrn 1): Emil Riebeck aus Halle a. S. gesammelten Materiale zusammengestellt ron . . . (Zeitsehr. fiir. Natuwiss., 1883, p. 184.)

Sirrsch, F. Orthopterologische Beiträge. I. Die Mrkoporliden des Berliner Zoologischen Museums. (Berl. ent. Zeitschr., 1886, XXX. p. 114.)

Kursch, F.-Uehersicht der ron Herrn Dr. Piul Preuss anf der BarombiStation in Kamerun gesammelten Lowstorlen. Anhang: Ueber die Meliopordirlen. (Berl. ent. Zeitsch., 1891, XXXV1. p. 342.)

Kirby, $H^{r}$. F.-Notes on the Orthopterous family Mecopolide. (Trans. Eut. soe. London, 1891, p. 405.) 
EARWITS, GRASSHOPPERS, AN1) (RRIKETS OF SOHOTRA.

lientenburher, J.-Monographische Uehersicht der Merromethiden. (Verh. k.k. zool-bot. Ges. Wien. XLII. 189.2, pl) 18:3-2.24, 'Taf. III.)

Burr, . H. On a collection of Insects and Arachuids made by Mr. E. N. Bemrett in Sokotra, with descriptions of new species. II. Orthopteru, by M. Bur (I'Z.S., 189\&, pp. 3\&4-5). 


\section{PLATE XXV.}

Fig. I...... DISSOSTEIRA FORBESII, liurt, $q$, p. 418.

Fig. 2...... CATALOIPUS OBERTHURI, Bel., ơ, p. 420.

Fig. 2a.... The seme, sulugenitul leminu, of.

Fig. 3..... TEDdIA DIOSCORIS, Burr, of, p. 416.

Fig. 3a.... Anterion foot, internal surfure.

Fig. 3b.... Anterior foot, edermal surface.

Figs. 4, 4a. TRUXALIS ENSIS, burr, p. 416.

Fig. 5..... FORFICULA SMYRNENSIS, Sert., f.p. 413.

Fig. $6 \ldots . .$. PLAGIOTRIPTUS INSULARIS, $B w r$,, p. 417.

Fig. 7..... PHAULOTYPUS GRANTI, Burr, $q$, p. 4 I8.

Fig. 8..... LOBOPTERA PECULIARIS, Burr, p. 415. 


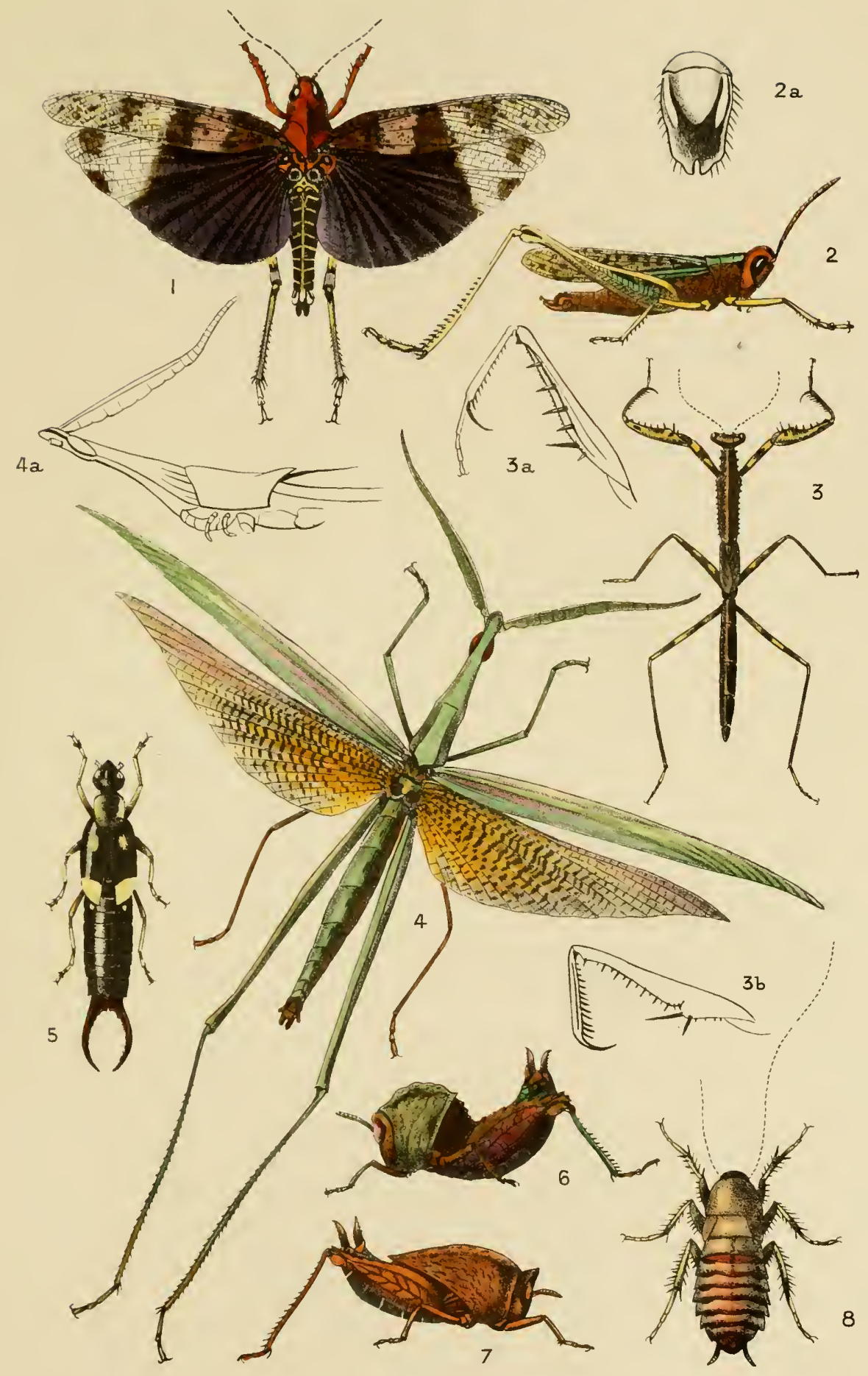





\section{ARTHROPODA.}

\section{Myriapoda.}

By R. I. POCOCK.

PLATE XXYI. 



\section{Centipedes and Millepedes.}

So far as individuals are eoncernerl, Centiperles are alumdant in the island of Sokotra. The speeies, however, are few in number, six only being known up to the present time. With the exception of the Cryptops, which was met with but once, all the species seem to be listributed everywhere throughont the island, ocenring both in the Hadibu Plain and at all altitudes up to to00 feet, scolopember mlide heing the dominant form.

The relationship of the famma to that of the surrounding areas presents some interesting anomalies. In the first place, it is not a little singular that the genus lihombocephulus* is altogether ahsent, although it is represented by sereral indigenons species in the Mediterranean and Oriental Regions. Similarly the geuus Lithohins, a typical Palearctic and North Ameriean genus, is alsent: and no trace was foumd of sentigere, which is universally distributed south of the 45th parallel of $\mathrm{N}$. latitude.

The two species of seoloperuldu, namely culirle and bulfouri, belong to a genus which is now restricted in its range to the Mediterranean, Neotropical, and Sonoran Regions. The clistribution and names of the species in the Mediterranean Region are as follows:-S. vulide, Canary Islands and Sokotra; S. belforit, Sokotra and Abd-el-Kuri ; S. deserticole, S. Arabia and Somaliland; S. persicu, Persian Gulf. The genus Asumulu has, in addition to the Sokotran species, a form helonging to the Himalayan and Burmese fauma.

* This term is here used for the first time in a sense that requires explanation. The genus Scolopendra, as hitherto recognised by the majority of writers, is divisible into two sections dependent upon the presence or absence of a transverse groove on the first tergal plate. Newport, who was the first to dismember Scolopemlra, as limited hy Leach, gave the name Rhomboceplalus to a species of the section in which the groove is absent, namely, to the young of S. ringulata, Latreille (see Pocock, Am. Mug. Nut. IIist. (6), vii., p. 53, 1891). Although hased on a fortuitous and valueless character, the name must stand for the section named Calcurin by lorat, of which cingulatu is a representative, if the section be accorded generic or sub-generic rank. The term Scolopendia can thus be retained by elimination for the section, named Colluria by

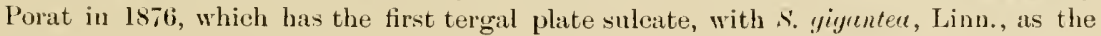
Tyle.

+ Pocock, Journ. Linn. Soc., Zool., xxw. p. 297 (1896). 
Riflysidu is distrilnted in Algeria, Somaliland, the Oriental Region, and Central America. C'ryptops is cosmopolitan, and Meristorepluelus is a northern type which, althongh abunlant in the tropies, does not for the most part penetrate far into the southern Hemisphere.

The most singular fact eomected with the Millepede fauma (Diplopoda) of Sokotra is the entire alsence, or, at all events, the great scarcity, of all forms belonging to the Iuloidea. It is possible, of course, that some ohscure species of the group were orerlooked: but it is certain that none occur in any abundance.

Three species only were obtained, all belonging to the Polyrtesmoidea. Although one of these species differs from the others, and indeed from all preriously described species, in a character namely, the absence of pores from the seventh somite - which must he considered of generic value, there is no doubt that the three are closely relater, as is attested in particular by the structure of the copulatory organs of the male. The two species which have a normal pore formula also constitute a peculiar genus, which in one particular resembles Fonturiu - a genns characteristic of the Sonoran region of North America. This resemblance, howerer, is probably due to convergence rather than to actual relationship.

It cannot be said that these species throw any light upon the origin of the fauna of Sokotra since they present no particular resemblance to the genera known from any of the adjoining areas.

That none of the species recordert in the following pages have been artificially introduced into Sokotra is shown by the absence from the istand of all the species of Arachnida and Myriaporta, such as lihemboreplutus morsiturs,

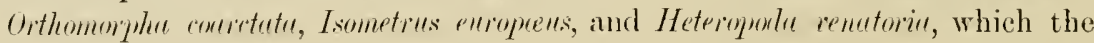
development of commerce has now spreal all orer the tropics. This fact, conpled with the peculiarity of most of the species, enforces the conclusion that Sokotra gained its present Myriopod population at a remote periori when the island formed part of the continent of Arabia or Somaliland.

\section{I.- The Centipedes of Sokotra.}

CHILOPODA. SCOLOPENDROMORPHA.

\section{SCOLOPENDRID尼.}

The genera of the family represented in Sokotra may he tabulated as follows :-

(a) Seventh somite with a pair of stigmata

Rileysidu.

(i) Seventh somite without stigmata.

$\left(a^{1}\right)$ Anal somite large, with exposed porous pleura and spiny legs, 1st tergite transversely sulcate 
(lis) Anal somite smatl, with plemra largely concealed and poreless; anal legs minjined: lst tergite not transversely suleate

Astemerte.

\section{Scolopendra, Linn.}

One species of this genus figures in 'Tissehenherg's list muler the name Collevio morsituns, with Scolopemdre crmelelis and romplunde ats synonyms. There is no reason to doulht that Riebeek's specimens thus identified and symonmised hy Karseh are specifically inlentical with either one or both, probably both, of the species recorded below. It is certain also that they are not referable to the same species as the types of S'. complumutu and (roulelis, which belong to the older species s. altermuns, Leach-a common West Indjan form. The same may be said of the Sokotran specintens in the Bremen Musemm, referred by Karsch to Collerin morsitens (Alh. Nat. Ver. Bremen, ix. p. 67, 1884).

1. Scolopendra balfouri, I'or. (Plate xxvi. fig. 5.) See p. 20^.

Collaria morxitans, Karsch, Abh. Nat. Ver., Bıemen, ix. p. 67 (1884).

Scolopendre ralida, subsp. lulfouri, Pocock, Jouru. Linn. Soc. Zool., xxv. p. $297(1896)$.

The specimens of Seolopendra collected in Sokotra hy Professor Balfont were sent to the British Musemm in 1\&81, and were examined and described by me as conspecific with a species known at that time only from the Camary Islands - namely, Srolopendra culide, of lucas (see A un. Mug. Lrt. Hist. (6), i. p. 335, 18ร8). Subsequent examination of the same material convincerl me that, at all events, the larger specimens found in Sokotra are distinguishable both by size and coloming from Canary Island specimens, althongh the smaller Sokotran specimens, which I took to be the young of the larger, appeared to be inseparable from them. Hence I proposed the name bulfouri as a sulspecific term for the Sokotran form (Jomr. Limn. Son. Zool., xxr. pp. $297-298,1896$ ). The mass of material hrought back hy Messis. Grant and Forbes has developed on knowledge of the subject still further, and has convinced me that it was an error to regard the small specimens of Srolopendir taken by Balfour as the young of the larger, and that, as a matter of fact, two elosely allied species of this gems inhabit the island, the linger of the two being $S$. luelfomi and the smaller S. culidu, there leing practically no constant character by which the latter can be distinguished from the Canary Island species.

'The young of $S$. bulfonri are entirely pale, lunt in ahlu specimens, which may reach a length of $190 \mathrm{~mm}$., the head, antenue, and all the legs are green, or even hlack, and althongh the posterior half of the trumk is paler, the anterior half is distinctly olivaceous or olivaceo-castaneus. Sokotra : Hombil (1500-2500 ft.); I)ahamis (350-1000 ft.) ; Monkararlia (=Eeliel laggit ( $800 \mathrm{ft}$.) ; Jena-agahan (1200-2500 ft.) ; Hadihu Plain. 
Professor Balfour and Dr. Rieheck hoth obtainer this speeies, but no locality leyoud "Sokotia" is giren.

2. Scolopendra valida, Lucus.

Scolopendra valida, Lucas, in Webb and Berthelot, Hist. Nat. des. Iles. Canaries, ii., Entoml., p. 49, pl. vii. fig. 14(1836-1844); Newport, Tr. Jimn. Soc., xix. p. 402 (1545); Pocock, Ann. Mag. Nat. Hist. (6), i. pp. 335-338 (1858) (in part, specimens from Canary Islands); II., Journ. Linn. Soc. Zool., xxr. 1. 297 (1896).

Sokotra: Homhil (1500-2500 ft.); Dahamis (350-1000 ft.) ; Jena-agahau ( $1200-2500 \mathrm{ft}$.) ; Adtho Dimellus (3500-4000 ft.) ; and Hadiln Plain.

Both Professor Balfour and Dr. Riebeck eollected this species in "Sokotra" without further locality.

The characters of the two alove-mentioned species may be tabulated as follows :--

(a) Total length up to about $180 \mathrm{~mm}$. (9 inches); legs and antemie riolet-green in adult; the whole borly a clarker olive-lnown, increasing in intensity at the anterior and posterior extremities ; anal legs long and slender, the segments more than twiee as long as broal ; antennie long, about four times as long as the hearl

balfouri.

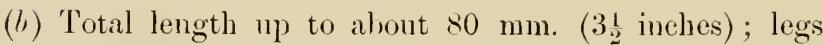
yellowish or pale green: head, antennæ, and anal legs yellowish or yellowish-brown; anal legs short and thick, the segments less than twice as long as hroad; antenne short, only about three times as long as the head

\section{Rhysida, Wood.}

3. Rhysida longicornis, $P^{\prime} m o r k$.

Rhyxida longicormis, Pocock, Ann. Mag. Nat. Hist. (6), vii. p. 60, pl. iv. fig. 5 (1891).

Colour olive lown with metallic lustre: antennæ yellowish, rlarker at lase; legs yellowish or hluish-green, the posterior pair turcluoise-l, lue. Hrud sparsely puncturerl ; antemie, composer of $20-202$ segments, long, reaching (when extendert laterally) past the sth tergite, the basal three segments naked, the rest covered with yellowish pulsescence. Preenul plutes of maxilliperles armed with four hack conical teeth ; process on femur triclentate. Teryul plutes smooth, from the ath lisulcate, from the 9th-1 Ith marginate. Stermel plutes furnished with only two very short sulei in front. Anul tergite without merlian suleus; plenre with process armed with 3 apical, 1 lateral anrl sometimes 2 small superior spines ; legs very long and slenrler, not much less than half the length of the body, femm armed in its lasal half with $8-13$ spines, 3 of which form a row beneath, the rest less regularly arranged above 
and below on the imer sicle; protarsal segment unspined. Protarsi of remaining leys spured loneath, those at the anterior half of the borly spurred in front as well.

Length up) to about 5.) $\mathrm{mm}$.

Sokotra : Jena-agahan (120-1500 ft.) ; Dahamis (350-1000 ft.) ; Moukarandia ( = Gebel haggit (600 ft.) ; A(tho I)imellus (3000-4000 ft.) ; and Homhil.

Professor Balfour also collected this speeies.

\section{Asanada, Meinert.}

Asanarle, Nleinert, Trans. Amer. Phil. Soc, xxiii. 1). 189 (1886) ; Pocock, Ann. Mag. Nat. Hist. (6), vii. p. 22:9 (1891).

4. Asanada socotrana, Pocock.

Axanade socotranu, Pocock, Bull. Liverpool Muss., ii. p. 9 (1890).

Colone a tolerably uniform yellowish-green, with the hearl plate and maxilliperles tinted with reddish-lnown. IIend and muxillipedes smooth, the latter strong, the coxal plates armerl with three sharp teeth; antemie short, composed of 17 segments, reaching to the end of the first tergite. The 1st terifte not suleate, - $n$ nd at most obsoletely, 3rd weakly sulcate, the rest strongly bisulcate, laterally punctate or sul-rugulose, margins not raised. Sterme smooth, bisuleate. Anal somite with small tergum, rery small plenra, and large wile stermm, the latter wirler than long, wider than the sternm of the preceding somite, and with its posterior margin very lightly convex. Legs; anal very thick, patella sulcate above in its clistal half; protarsal and tilial segments of legs withont spm's.

Sokotra : Homhil (1500-2500 ft.) ; Dahamis (350-1000 ft.) ; Jena-agahan (120-2500 ft.), Hadibu Plain.

Only one other species of the genus Asunula has hitherto been discovered. This is A. lrevirmis of Meinert, which forms part of the Himalayan and Burmese famma of British India. The existence of the genus in Sokotia also is a most interesting riscovery.

The Sokotra species differs from the Indian in having the anal stermum transversely oblong instear of semicircularly rounded, the antenne longer and much more attemated, the apical segment being much longer than widle.

\section{CRYPTOPID必.}

\section{Cryptops, Leach.}

\section{Cryptops socotrensis, sp.n.}

Colour uniformly pale yellow. Antennce composerl of 17 segments, those in the distal half moniliform. Head with a pair of ablureviated sulci behind, its posterior horeler transversely trincate, overlapping the lst tergite. Finst teryite with a rleep, lightly procurved transverse suleus in front and a pair of longitudinal sulci; 2nd tergite also with pair of 
sulci; the rest and the sternites normally sulcate. Logrs armed with strong spiniform setix. Imul somite with a few similar setie; anal legs strongly armed below and internally, except in the distal segments, with stiff spiniform seter, the distal segments fumished with finer setie; femur armed above on the immer side at apex with a strong cuver spur, a similar but smaller spm on the apex of the upper side of the patella externally, and two larger and stronger upon the posterior end of the tilia, the posterior end of the protarsns angled lut not spmred apically alove ; tilia armed below with a series (6) of short spiniform teeth, the protarsus with a pair of stronger teeth, the proximal of which is the larger.

Length about $16 \mathrm{~mm}$.

Sokotra : Arlho Dimellus (3000-1000 ft.).

This species may he recognised hy the spine-armatme of the anal legs.

Only one specimen was oltained.

\section{GEOPHILOMORPHA.}

\section{DICELLOPHILID曆.}

\section{Mecistocephalus, Newport.}

\section{Mecistocephalus punctifrons, Nerport.}

Mecistocepledus punctifions, Newport, Proc. Zool. Soc., p. 179 (1842) ; id. Tr. Linn. Soc., xix. p. 429 (184.5), and of subserpuent authors.

Sokotra: Hadibn Plain; Lahamis (350-1000 ft.) ; Jena-agahan (1200$2500 \mathrm{ft}$ ) : Homhil (1500-2500 ft.) ; ancl Arlho Dimellus (3000-4000 ft.).

This species, which is common in the Oriental region and has also heen recorted from Somaliland, was the only representative of the long rermiform centiperles that was met with in Sokotra.

\section{POLYDESMID必.}

\section{DIPLOPODA.}

By their generic and specific featmes the males of the three Sokotran species of this family may he rliagnosed as follows:-

(11) Keels of serenth somite without pores; trochinters of legs with searcely a trace of spiniform process, merely angular at their distal extremity ; first tergite with its anterior border lightly emarginate laterally : tergites scarcely gramular; keels of anterior somites not laterally emarginate, as in $F$. forlosio; copulatory orgall more like that of $F$. sucotrensis.

(b) Keels of seventh somite with pores; troehanters Aneptopumus gronti. distinctly spined : first tergite with anterior horder evenly eonvex from sicle to side.

$\left({ }^{1}\right)$ Colour redder ; lateral border of keels of 
second to fifth somites lightly emarginate; keels larger, and with thicker margins; tergites with row of glamules or small tubereles along posterior borrer ; extermal curled branch of copulatory organ very stout ; the two processes of the sulmembanous inner banch subermal in length

$\left(b^{1}\right)$ Colom browner; lateral lorrler of keels not

Fontrizopsis suretrensis. emarginate; keels smaller and with thieker erlges: no tubercles on tergites : external hauch of eopulatory or gan small and slender; two plocesses of memhranous piece very unequal . . .

Fouturiopsis forlesii.

\section{Fontariopsis, gen. nov.}

Antenure about as long as wiflth of body in $q$, exceerling it hy as mueh as one-fomrth of the wilth in of, not visibly incrassate, the segments from 2-6 suberual in length, grarlually thiekenerl distally. Hern smooth, with frontal sulcus. First teryite as wide as the seeond, with laminate expansion. Remaining trigites smooth, or sparsely gramular laterally and posteriorly, convex, not suleate; the groove defining the cylindrical portion not sculptured. Cinulul frocess trapezoidal, narrowed posteriorly, truncate along the posterior margin hetween the two tulsercles; a lateral tubercle on each side. Keels of moderate size, rising above the middle of the side, horizontal, with posterior angle acntely profluced, anterior angle widely obtuse and rounded, lateral margin thickened, posterior margin toothed or tuberenlar. Lateral smiface of segments granular. Sterne broad, unarmed : the last narrowed between the legs of the last pair, the interval being equal to alout the length of the coxil and trochanter of one of the legs. Logs with trochanters longer than coxie, and armed with a spike, as in the Central American genus Fonturiu. Anul strmite twice as hoat as long, semieircularly triangular, its sides lightly eonvex, apex obtusely angular; a low tubercle on each side hetween the apex and the hase.

ocromlutor!y oryusu, when at rest, projecting, straight forwarel, parallel, complicated, consisting of two main portions, an afmerlian whieh is distally membranous and divides into an outer and an inner branch, and an external or a median which is composed of two branehes, an external, simple and sinnous, einving round the hase of the internal, which is apically lificl. stermum of sixth somite lightly hollowed lehind for the reception of the apices of the copulatory organs. No process on sixth or fifth sterna.

'Type F. socotrensis.

This genus resembles Fonturim only in the presence of a spike on the lower sicle of the distal end of the troehanter of the legs. It differ's in the form of the keels, of the copulatory organs, dic. 


\section{Fontariopsis socotrensis, sp. $n$.}

o Colour blool-red, very like that of Anephopurus gronti, described below, hut with the legs, sterna, and anteme paler yellow. Allied in general characters to 4 . yrunti, but the anterior horder of the first teryite is eventy convex from angle to angle, the keels are larger, and those of somites -2 to 5 lightly emarginate; and the median and posterior terga, especially the latter, furnished along the posterior borler with a distinct row of small granuliform tubereles. Cundul proress broarler across the mirldle and more abruptly narrowed than in $A$. yrunti. A unl strinite, not so distinetly triangular.

I) Iffering from the of of $A$. fromti in the same general features as roes the $f$. Copulatory organs very similar to those of A. grunti, but the external luanch much stouter, thick and rounderl throughout, with the apex not abuptly expanderl.

o Total length $29 \mathrm{~mm}$., wirlth $4.8 \mathrm{~mm}$.

Sokotia : Gebel Raggit (600 ft.).

The specimens of this species ocenred at Gebel Raggit with those of A. grunti taken at the same place. So similar in general form and colouring are the two that on the first enrsory examination to whieh they were submitted they were all ascribed to the same species and and described as Odomtopeltis grumti.

8. Fontariopsis forbesii, Prock.

Odontopeltis forbesii, Pocock, Bull. Liver'p. Muss., ii. 1. 9 (1898).

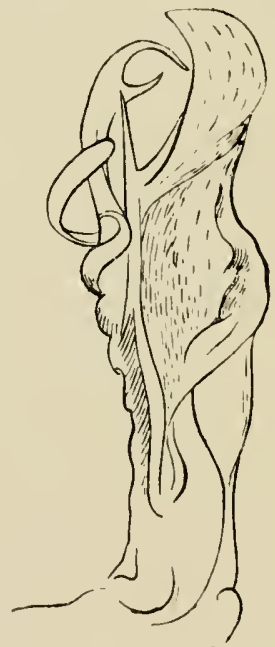

Fin: a.-Loweir View of Rigit Copvlatory Organ of Fonteriopsis fortesii.

of Larger and darker in colour than $F$. socotrensis, the prevailing tint heing hrownish and not pinkish-red. Keels of somites 2 to 4 not emarginate along the lateral horder; terga without granules; keels thicker on the margin, more depresserl, the anterior angle less prominent. 
Copulutory oryun (fig. a) very different, the external buanch small and slemler, and the principal branch of the membanoms selerite much longer than the smaller pointed branch.

Total length $31 \mathrm{~mm}$., width $5.5 \mathrm{~mm}$.

Sokotra : Arlho Dimellus (3500-4800 ft.). -1 single male eximple.

\section{Aneptoporus, gen. nov.}

Closely allied to the preceding grenus Fontropiopis, as indicated by the form of the keels and of the copulatory organs, but distinguishable by the almost complete alsence of the spike on the trochanters, and ahove all hy the alsence of pores from the serenth somite a feature in which it differs from all the hitherto describer genera, the pore formula being $5,9,10,12,13,15,19$.

'Type A. grenti, Pocock.

\section{Aneptoporus granti, Pocock.}

Odontopeltis yrunti, l'ocock, Bull. Liverp. Muss., ii. 1). 9 (18!\$).

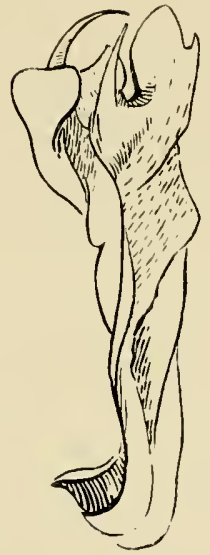

Fir. b. Lower Viliw of Right Copllatury Orias of Aneplopome granti.

q Colour blood-red, with darker lout indistinct median dorsal line; legs genesally paler yellow, sometimes as dark as the dorsal surface; stema pale. First teryite with anterior horder lightly lut distinctly emarginate at the sides, the posterior horder similarly but less distinctly emarginate, hence the lateral expansion is elearly definexl. Second and third teryites with margin of keel strongly thickened in its posterior half, posterior angle slightly acnte, the anterior and posterior edges scarcely dentate. The rest of the lieels strongly produced and spiniform posteriorly, those in the middle of the body the largest : the anterior portion of those at the posterior end much reduced : the posterior horler of the keels from the fourth, sixth, seventeenth or eighteenth denticulate or tulserenlar: the anterior, horder from the fifth to the twelfth or thirteenth also denticulate, hut 
more weakly so. No tubercles on the tergal, or, at most, a few at the posterior end of the body. Cuntul prorss triangular and truncate, its sides evenly converging. Amel stermite nearly rectangular and pointed. Coxie and trochanters of leqs funished with a long bristle : a row of longish hairs along the posterior horler of the sterna. of Smaller than female. Legs thicker: Copulutory orym as in fig. 1,: the external branch with apex expanded, the two processes of the memloranous pieee not rery unequal in length.

ㅇ Total length $:-7 \mathrm{~mm}$., width $4 \cdot 3 \mathrm{~mm}$.

Sokotra: Dahamis (350-1000 ft.); Gebel Kaggit (600 ft.); Hombil (1500-2500 ft.) ; Jena-agahan (1200-2500 ft.). 


\section{II. - The Centipedes of Abd=el=Kuri.}

\section{SCOLOPENDRIDE}

Scolopendra balfouri, $l ' u$.

Scolopendra, Linn.

Scolopentre valilu, sub sp. batfouri, Pocock, Journ. Linn. Soc. Zool, xxv. p.97 (1596).

(Sice p 4:31.) 

ANNULATA.

\section{Hirudinea: \\ Chætopoda.}

Note by HENRY O. FORBES, LL.D. 



\section{Leeches and Worms.}

Only two species belonging to the Annulute were collected during our experlition, and hoth only in Sokotra. The first helonged to the order Hirudinea. During the skimming of a batch of Sokotran Gros-beaks (lihnmhostruthus solutrams) by our taxidermist Cutmore, my attention was drawn hy him to a small species of leech which he found occupying the nasal chambers of many of these birds. From an ocular examination of them in life, they appeared to me from their form, attitudes, and mode of movement, to belong to a specially smill species of Homadipsa; at all events, from the alsence of any sign of proboseis, they would seem certainly to be Gnathobetellicls. It was impossible to determine whether they were present in the nostrils of these hirds accidentally and temporarily (the bird heing able to remove them at will), or whether they have become, as their presence in so many individuals wonld suggest, a sort of internal parasite in the way that the Horse-leech Hemopsis may infest the pharyngeal passages of eattle, and Hirudo sanguisugu has been occasionally known to attack the human subjeet. No Hemalipse were observed by us on the regetation or elsewhere in any part of the island we risited. I do not rememher, also, ever to have met with leeches in the nostrils, or even on the bodies, of hirds taken in the Malayan forests, where Hremudipse oceurred frequently enough in thousants.

The second Anmulate we encomtered was an Oligochæte living in the humil, sandy earth of the morassy bank of the Hanefu river, a short clistance sonth of Harlibu village, and not entively beyond tirlal influence. It was $1 \frac{1}{2}$ inches in length, slender, pale red in colour, lut with a prominent and very lright red clitellum. As I had then no other receptacle with me exeept a cyanicle insect-killing hottle, I lropped the specimen into it among some Coleoptera already there. On reaching camp, I found to my chagrin that the creature harl become shrivelled and contracted into an mrecognisahle pellet. Although I searched afterwards most diligently, both in the plains and in the hills, I was never fortmate enough to find another specimen. Worms were manifestly extremely rare. The determination of a species from this ancient land smface would have been of special interest, consiclering the importance of the Oligoehreta from the point of view of geographical distribution. 



\section{Botany}

$$
\text { of }
$$

Sokotra

and

$A \mathbf{b d}=\mathrm{el}=\mathrm{Kuri}$ 



\section{PLANTE PHANEROGAME.}

\section{Angiospermæ.}

By Prof. I. B. BALFOUR, F.R.S.

PLATES XXVI A., XXVIB. 



\section{Flowering Plants.}

The botanieal colleetions lowght hy l)r. Forbes and Mr: Ogilvie-Grant

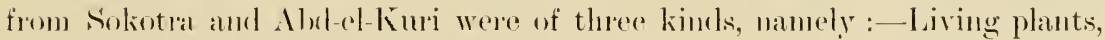
tubers and bulhs, seerts and dried specimens.

The Living Plouks, which were lononght over in Wartian cases, arrived at

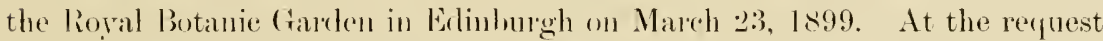
of 1). Forbes I hal furnished the expedition with a couple of Warlian cases, and it was with mixed feelings that I received, at the end of March, 1899, chring a spell of harrl frost, an intimation from him that the cases with plants from Sokotra were about to he despatehed from London to the Royal Botanic ciarlen. The cases chuly arrived, and thanks to the care with which Messrs. Stahlschmirlt if Co., of Great Tower Street, arrangerl for their transport, and to the attention which the officials of the london and NorthWestern Railway gave to the cases, the extrene frost of the night churing which they travelled dirl not, I think, seriously affect the plants in the cases.

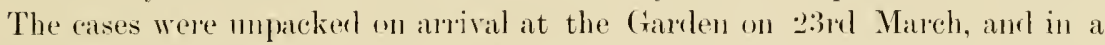
few days I was ahle to send to J)r. Forles a report regarding the seremal plants they containel. The terms of this and a note of the fate of each to the date of present writing (.Tanuary, 190-2) is given unler the respective species.

Along with the Warlian cases there arrived also a large crate containing a splendid specimen of the new fleshy Euphorbia from Abr-el-Kuri, described helow, of which a figure, taken shortly after its arrival, appears in the text.

On the evening of the same ding two more boxes, filled with living surenlent

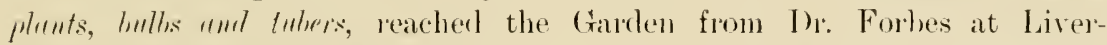
pool. I wish to gut on recorl that in all my experience of shipments of speeimens of a similar kind I have never seen a finer lot unpacked. Knowing as I do the contitions under which I)r. Forbes must have workerl on the island, and the diftienties of collerting, hush bunding, packing and transporting, the state in which his specimens arrivel speaks in emphatic tems of his (alpacity, skill anul industry in the work of exploration. Notes on the contents of these boxes are given under the species to which they belong, ancl I have adkled a note of the result of our cultivation of them. I must, howerer, point out that the naming of some of the hulls is only tentative, as they have not all flowered. 
The collection of serests was extensive, and we have suceresled in raising a number of interesting plants. In the following pages I refer muler the spectes to lexults we have olitainet. Many of the seedlings cammot yet be irlentified with certainty, aml a few years must of necessity elapse lefore we can say what will he the immerliate benefit to horticulture frem the progeny we may raise, lunt I hope that this will not he insignitieant.

The driod syrimes form an interesting collection. The total mumber of Howering plants and fens which have been islentified bronght by the

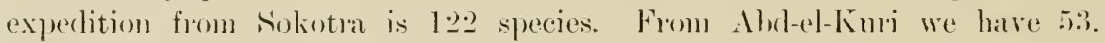
Whon all the seerllings now growing have been illentitied there will be some arlitions to the list. Many species were, however, observed and identified ly 1). Forlues in the tiekl, which it was fomm impossible to collect. An asterisk prefixed to the name of a species in the following list indicates that it has leen so irlentified.

Of the Sokotran pints fom are novelties, namely, Erlithrolen smrlide, $\mathrm{N}$. E. Brown, helonging to a small asclepiatacens gems established by Mr.

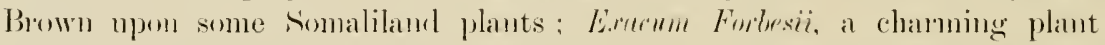

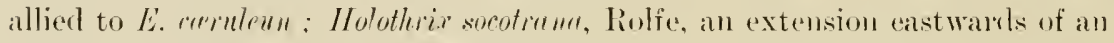
African genns of orchirls: and flow Forlesil, a small species distinct from the well-known sokotran Aloe: whilst six have mot been previonsly reeorded from the island, namely: Abutitom grareoleus, Wight amI Arn., a tropical cosmopolitan form ; In!frernm dires, Rolfe, an epiphytic orchicl of Kilimanjaro and Momblasa: Remusetin rivipurn, Schott, a species with an Easter'n Asiatic rlistribution ; Srille indire, Baker, a plant of Hindustan and Alyssinia ;

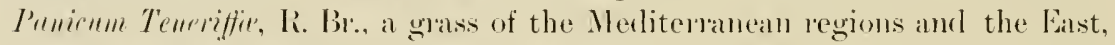
ancl Prenuisetwm orientule, lich., a guass which is spreat from North Africa to Inclia.

It will be seen, then, that the new evirlenee bronght ly the experlition hearing 11 on the character and relationships of the Sokotran flora hears ont the conchusions that have been based mpon the plants previomsly lomght from the island. The African especially Alyssinian and Somaliand-. comnection is supported, the lomels with the opposite Asiatic majuland are strengthened, and most interestingly the remarkable East ludian relationship receives a further illustration.

Of the Alulel-Kmi plauts all hut six were previonsly known to occur in Sokotrat. Of these six, three are new to seience, namely:- Commlinlus circunti, Balf. f., a distinet little species of the section which inchules forms vecurring in arjacent eontinental areas; Sulsulu cycloptern, Stapf., looking to the distribution of the gems, the occurrence of this species need not smprise us ;

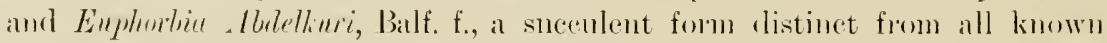
ones, and, perhaps, the most remarkahle lotanical discovery of the experlition: the other three species are Linuriu Elutime, limm, a wirlely-spreat

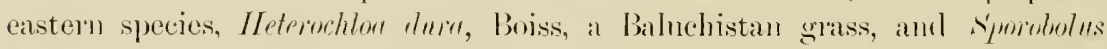
minutues, Link, a grass of Abyssinial.

It is satisfaetory that we now bave some acpuaintance with the natme of the regetation of Abd-el-Kmi. I think it is probalule that, when the Hom of 


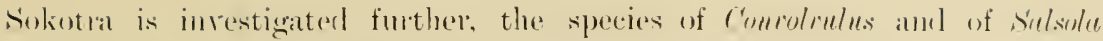

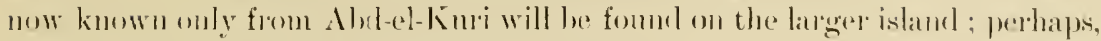
too, the Eanphorlin may be fomml, althomgh of this l am less confirlent,

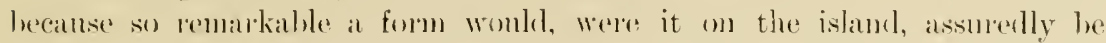
kuown to the people of soliotra, and some one of the exploring experlitions shonld have heard of it and olstained specinens. I an inclined, therefore.

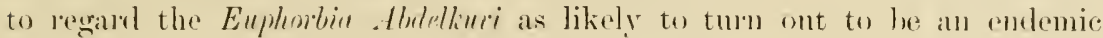
species. I take it to Ire, like the Heshy elphorlias of Soliotia, the Demlensirmes, Dorstenie gigns, and others, a relic of the old African Hora.

It is mofortmate that, as lor. Fortes has explained, the expedition was prevented form leaching the gromel to the south-west of the Island. Of the regetation of this alrea we, als yet, know nothing, and the aspect of the valleys into which one call look from the higher central platean gives promise of much movelty. The gromel over which I)r. Forbes was able to botantise wis very much that which earlier expeditions had covered, and this probithly aceomits for the alsence of more new species in his collections. Nevertheless, what he has homght home is of hortieultmal merit, and will also, when its results are fully secured, ardd to our botanical kmowledge. Notwithstanding all that hats heen done, $l$ am of opinion that a rich lontanical harvest still awaits further exploration of sokotra.

Is it is clesired to publish in this volume-containing the results of the expedition-al complete list of the names and halbitats of the plants mow known from Sokotra, with the names of the collectors or reeorlers, Dr. Forlies has extracted the necessary information fuom the 'Botany of Sokotra,' and has incorporated it here: and hy the farom of the loirector of Kew I am enabled to inchule a record of the collections marle in $1897 \mathrm{hy}$ Mr. and Mrs. Theodore Bent.

I wish also to say that I am greatly indeloted to I)r. Stilpf, Mr. N. E. Brown, and Mr. R. A. Rolfe, of the liew Herbarimm, for molertaking the examination and description of plants helonging to gomps to which they have given special attention.

The lutanical collectors indicaterl in this list, and the dates of their collecting or recorrling ane :-

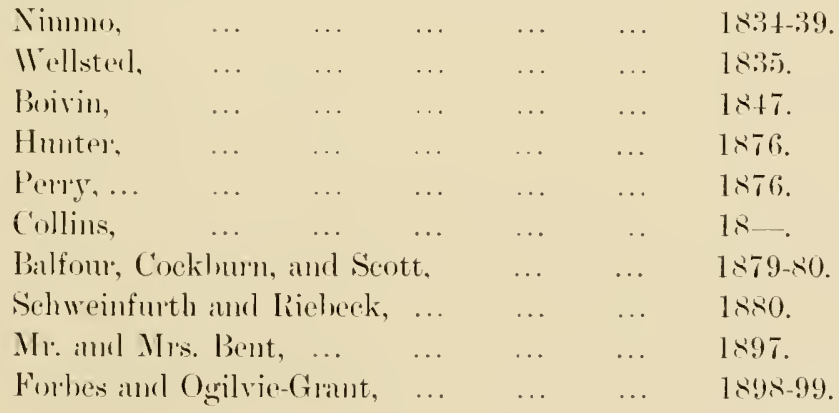




\section{I.-The Flowering Plants of Sokotra.}

* Is prefixed to those species observed or collected as Herbarium speeimens, living llants, seeds or bulbs.

+ Prefixed to a speeies or genus indicates that it is endemie.

\section{DICOTYLEDONES.}

\section{POLYPETALAE.}

\section{MENISPERIMACE无.}

1. Cocculus Leæba, $I x$ :

\section{Cocculus, $D C$.}

Hill slopes.-B.C.s., simurinf.

2. * $†$ Cocculus Balfourii, Sherinf. Balfom fil., Trans. R. S. Ehinh., xxxi., Bot. of Seliotin, Til). I.

Observed growing abumlantly in dense, wieked, and impenetrable thickets on the Haghier hills far and near romul our eamp at Arlho Dimellus. Found no fruit, thomgh alomdantly in flower.- II.O.F.

Haghier slopes (over $2000 \mathrm{ft}$.). - B.t's., sherevinf., Bent.

\section{PAPAVERACE 瓜.}

\section{Argemone, Linn.}

3. * Argemone mexicana, Limu.

Elhe, Harlihu Plain (3. I. 99).--H.O.F.

Vicinity of Harlibu.- B.C.s., Bent.

\section{CRUCIFER蚱.}

\section{Diceratella, Boiss.}

4. † Diceratella incana, Balf. fil., Op. cit. Tah. II. Sandy spots of the plains alout Galonsir.-B.C.S.

\section{Farsetia, Desv.}

5. Farsetia longisiliqua, Dcue.

Common on the limestone plains._B.C.S., Shluevinf.

6. Farsetia prostrata, Brilf. fil.

On plains about Galonsir.-B.C.S.

7. † Farsetia sp.

Near Galonsir.-M.1'S. 


\section{Sisymbrium, Linn.}

8. Sisymbrium erysimoides, Des.

An occasional weerl. B.t.s., shluerinf.

\section{Brassica, Linn.}

9. Brassica rostrata, linlf. fil.

Almulant on the libll slopes up to a galeat elcration; on sheltered spots murler cliffis or loulders._- b.C.s.

10. † Brassica rostrata, litlf. fil. val. hirsuta, linlf. fil.-li.t.s.

\section{Lachnocapsa, Balf. fil.}

11. † Lachnocapsa spathulata, linff. fil., Op. cit. T'ah. III.

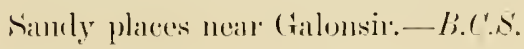

\section{CAPPARIDE正.}

12. Cleome papillosa, steml.

Near Hadlilu._Silurcinf.

13. $\dagger^{*}$ Cleome socotrana, biclf. fil.

On (rantieh Plain.-H.1).F.

Not uncommon. - B.C.S., Sicherinf.

14. Cleome tenella, Linu. fil.

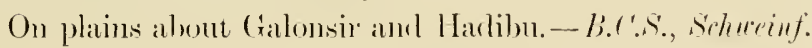

15. Cleome brachycarpa, twhl.

Sandy parts of the limestone plains.-B.C.S., Schureinf., Bent.

16. Cleome brachycarpa, $V_{t h l}$. var. filicaulis, schueinf.

Near Hartilus.--Shluceinf., lirent.

17. Cleome viscosa, Limn.

About villages.-B.c.s., sidureinf., bent.

\section{Gynandropsis, DC.}

18. Gynandropsis pentaphylla, $M$ :

Alrout halitations.-B.t's., sthweinf.

\section{Mærua, Forsk.}

19. * Mærua angolensis, $I C$.

Seen growing in the crevices of the limestone rocks on the slopes of Gel)el-Raggit alowe Hartibu village.-H.O.F.

On hills and plains; Keregnigiti : near Hadiln Plain: at (ialonsir:-

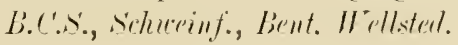


Cadaba, Forsk.

20. Cadaba rotundifolia, F, $\%$ :

Hill slopes near (kalonsir:-D.C.s.

21. Cadaba longifolia, $D C$ :

Not common on the plains. B.C'.s'.

\section{Capparis, Linn.}

22. Capparis aphyila, limth.

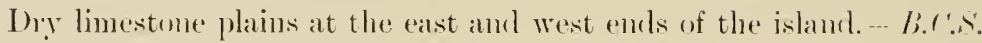

23. Capparis spinosa, Limn.

On the plains, common.-B.C's., siluceinf.

\section{RESEDACE压.}

Caylusea, St. Hil.

24. Caylusea canescens, N. Hil.

Bent.

\section{Reseda, Linn.}

25. $\dagger^{*}$ Reseda viridis, birlf. fil.

Olsserved on hills ahove Homhil; and on Hadilu Plain.-II.().F'.

Seed collected on slopes of hills near Galonsir at $1500 \mathrm{ft}$. The plants raised from this have flowered freely in the Royal Botanic Garden. B.C..., bent.

\section{Ochradenus, Del.}

26. Ochradenus baccatus, Del.

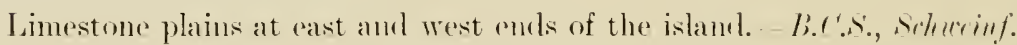

\section{VIOLARIEÆ.}

Viola, Linn.

27. $\uparrow *$ Viola cinerea, boiss.

Homhil (-2.). I. 99); olserved and seed collectel.-II.).F.

Near (ialonsir.-li.es'.

Ionidium, vent.

28. Ionidium suffruticosum, liin!.

Common. - B.c.s., seluceinf.

Alsodeia, Thouars.

29. † Alsodeia socotrana, liclf. fil.

Near Harlibu. - L.C.S. 


\section{BIXINE床.}

Aberia, Hochst.

30. Aberia abyssinica, 1 'tus.

Common._lices., stherinf.

\section{POLYGALEÆ.}

\section{Polygala, Linn.}

31. Polygala abyssinica, Fres.

Common.-li.t's:

32. Polygala erioptera, $I M$ :

On the planis. - licr.s., stherinf.

33. Poiygala chinensis, Limn.

On limestone hills, sparingly. - b.e.s.

\section{CARYOPHYLLE尼.}

\section{Gypsophila, Linn.}

34. Gypsophila montana, billf. fil.

Haghier Hills (over 2500 ft.). - li.c.s.

35. Gypsophila montana, var: viscida, Irilf. fil.

Rarer than the Trye.-B.c.s., sidneinf.

\section{Silene, Linn.}

36. * Silene apetala, $\|$ illl. Homlil (No. 167). - H.O.F.

Common on hills at all elevations._B.C.S., shtherinf.

\section{Arenaria, Linn.}

37. Arenaria serpyllifolia, Limu.

Abunlant in many places.. - li.r.s.

\section{Polycarpæa, Lamk.}

38. Polycarpæa corymbosa, lmiki.

Plain near Khathp.- B.C.S.

39. * Polycarpæa spicata, . $/ \mathrm{r}$.

Slopes of Arlunia (600 ft., ㄹ1. XII. 98, No. 1.88).- H.o.F.

Haghier Ilills near Harlilus.--B.C..s.

40. $\dagger$ Polycarpæa spicata, Air., var. capillaris, linlit fil.

Near (Balonsir: anl elsewhere-B.Cs., sherrinf.

41. $\dagger^{*}$ Polycarpæa divaricata, litlf. fil.

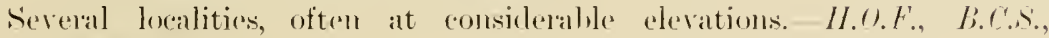
schereinf. 
42. * Polycarpæa, cæspitosa, ljulf. jil.

Homhil (1:00 ft., 1. 99, No. 1\&6). II.().F.

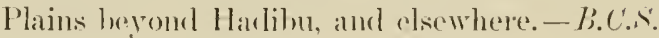

\section{PORTULACE曆.}

\section{Portulaca, Linn.}

43. * Portulaca oleracea, limn.

Aluudant.-B.C.S., H.I)F.

44. Portulaca quadrifida, Limn.

Abundant.--Hunt., B.t's., shluevint.

Talinum, Adans.

45. * Talinum cuneifolium, $\|$ ill .

I ahamis, seeds collecterl (20. XIl. 98): Ilomhil (1000 ft., I. 99). - II.1).F.

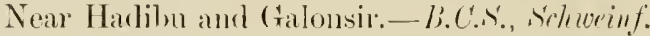

46. Talinum crassifolium, $\|$ ill,.

bient.

\section{TAMARISCINE E.}

\section{Tamarix, Linn.}

47. * Tamarix gallica, lim!.

Near Khor Garieh.--H.O.F.

Shore at Garieh.-B.C.S., Schueinf.

\section{HYPERICINEÆ.}

Hypericum, Linn.

48. Hypericum (Androsemmm) mysorense, Hetyne.

Especially ahundant round our camp at Adho Dimellus (No. 27:3). - H.O.F.

Two plants lnought over in a Wardian ease mofortunately died, but we

have raised a mumber of plants from seeds brought home by the expedition. The shoots and foliage are elegant in themselves, lut the large Howers which helong to the species, and which will, I hope, be produced ere long on our plants, make this plant a most welcome addition to our stock of flowering plants for green-honse cultiration.

Rocky places at an elevation of orer $1500 \mathrm{ft}$. lient, Nimmu, b.t.s.', sitherinf.

49. * Hypericum (Amlws:mum) lanceolatum, Lamk.

Ailho Dimellus.-H.1.F.

On the higher rocky parts of the hills.... B.I's.

50. $\dagger^{*}$ Hypericum (Arthophylia) scopulorum, linlf. fil., Op. cit. Tall. IV, A. Seeds of this have given us several nice seedling plants, which, as small woody shruls with a profusion of small yellow flowers, will not be 
without attraction in our green-houses. Of eight plants hought home in a IVarlian calse alive, in valions stages, all unfortumately died.

Not nucommon amongst the lonlien's on the Sokotan hills at altitudes wer $1000 \mathrm{ft}$ - D.e.s., simerinf.

Arlla, Dinellis ( $4000 \mathrm{ft} ., 2$. II. 99).--M.O.F.

51. $\dagger^{*}$ Hypericum (Arthrophylla) tortuosum, lirlf. fil., Op. cit. 'Tal. IV, B. Aillu) Dimellus ( $1000 \mathrm{ft}$.). - H.O.F.

IIth the foregoing speedes on the Haghier range at a high elevation.-

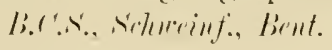

\section{MALVACE巴.}

\section{Malva, Linn.}

52. Malva parviflora, Limn.

On the linestone plains near villagess-- b.t...

53. Sida cordifolia, Linu.

\section{Sida, Linn.}

In the valley Kischen.- Sthereinf.

54. Sida rhombifolia, Linu.

Common.-B.C.s., shlurinf.

55. * Sida humilis, $\|$ ill .

Aduma slopes (21. XII. 98, No. 123).-H.U.F.

By the Wadi Digal.- Sthereinf.

56. Sida grewioides, finill. et l'err.

Common on the linestone plains. - b.t.s.

\section{Abutilon, Gertn.}

57. Abutilon fruticosum, Guill. et Perr.

Common.-li.C.s., sillereinf.

58. Abutilon muticum, $\left(i . D_{m} \prime \prime\right.$.

sparingly on the hills. -- B.C.'s'.

59. *Abutilon graveolens.

Haclibu Plain (No. 100).-H.O.F.

A very hary form of this species, which is an arldition to the plants previonsly known from sukutra.

\section{Pavonia, Cav.}

60. Pavonia odorata, I'illi.

Brint.

\section{Senra, Cav.}

61. Senra incana, Cuv.

Common round Galonsir and other villages.-B.C.s., sthereinf. 


\section{Hibiscus, Linn.}

62. Hibiscus (Bombicella) intermedius, $t c h$.

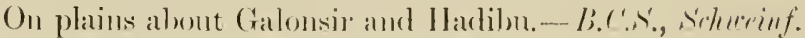

63. Hibiscus (Bombicolli) micranthus, Lim. fil.

Not uncommon._-13.C.S., schurinf.

64. Hibiscus (Lalgmatal) Solandra, Lillir.

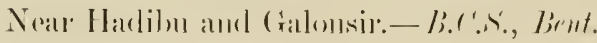

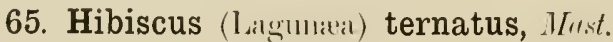

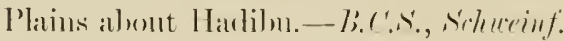

66. *Hibiscus (Ketmia) vitifolius, Limm.

(No. 17t.)-M.().F.

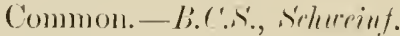

67. $\dagger *$ Hibiscus (Ketmia) Scotti, liwlf. fil., ()p. cit. Tal. V, A.

Alove (amp) at Homhil (2000 ft.) ; at Arlho Dimcllus (4000 ft.). (Nos. $206,215).-11.1 \%$. 5 .

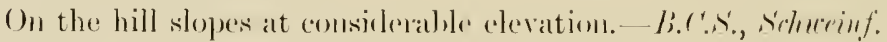

Sereral plants have come up from seeds of this species, and its large brilliant yellow Howers should give it a distinct place in horticulture. Unfortumately, its hains are stiff and ansily retacherl, and therefore apt to canse some irritation in the skin of any one hanclling the plant, and this may militate against its snceess as a horticultural acquisition.

68. $\dagger^{*}$ Hibiscus (Ketmia) stenanthus, Bulf. fil.

Matagoti, above camp at Homhil (1500 ft., 19. I. 99). M.O.F.

On limestone plateaux (over $1000 \mathrm{ft}$.).-B.C.s., Munter.

69. † Hibiscus (Ketmia) malocophyllus, lielf. fil.

Nour Arlho limellus; not ahundaut. - b.C.s., silurenf, lient.

70. Hibiscus, sp.

Almulaut on liill slopes.--li.t's.

\section{Gossypium, Linn.}

71. * Gossypium barbadense, Limn.

Beluw . lenialagahan; on the (iarieh Plain : cultivated (No. 147).-H ().F. Neal halbitations. - B.C.S.

\section{STERCULIACE压.}

\section{Sterculia, Linn.}

\section{2. * Sterculia Triphaca, li. lir.}

Hombil (2000 ft., 19. I. 99). In Dinelanu Valley learling from Harlihu Pain to Arlbo Dinellus. - H.1).F'.

Common on the hills.-li.C.s., streneinf. 


\section{Mellania, Forsk.}

73. $\uparrow$ Melhania muricata, Pilf. fil., Op. cit. 'Tal. VI, $\Lambda$.

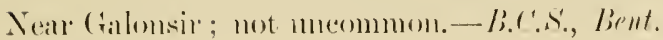

\section{TILIACE圧.}

\section{Grewia, Linn.}

74. Grewia populifolia, lill.

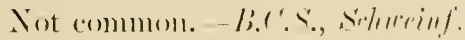

75. Grewia orbiculata, liottl.

Hill slopes. - b.' '.s'.

76. Grewia salvifolia, //eyue.

Hill slopes: not freguent.-B.t.s.

77. $\dagger^{*}$ Grewia turbinata, birlf. fil.

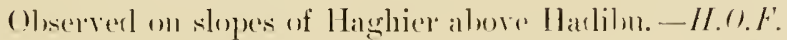

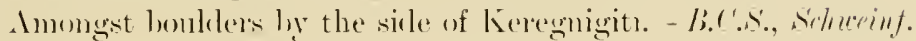

78. † Grewia bilocularis, Bilf fil.

Near Arluma (over $3000 \mathrm{ft}$.). M.'.S.

\section{Corchorus, Linn.}

79. Corchorus acutangulus, limli.

On plains; not uncommon.-ls.C.s., s'therinf.

80. Corchorus Antichorus, linusilel.

On dry plitins; commom.-. li.t's., shlureinf.

81. $\dagger^{*}$ Corchorus erodioides, Inelf. fil., Op. (eit. Tal, ITI, B.

Hadilu Plain (X11. 9s, No. 106i). Olserved also on (Barieh Plain: and om Kamaham slope and elsewhere-II.O.F.

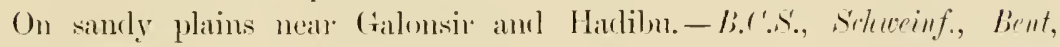
bivinin.

\section{Elæocarpus, Linn.}

82. † Elæocarpus transultus, bielf. fil.

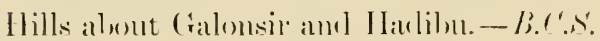

\section{LINE曆.}

\section{Linum, Linn.}

83. Linum gallicum, Linı.

Hill slopes (over $1000 \mathrm{ft}$ ). - li.1'.S. 


\section{MALPIGHIACE无.}

Acridocarpus, Guill. et Perr.

84. ${ }^{*}$ Acridocarpus orientalis, .ll. Juss.

In the valley of the Ininehan en. route to Arlho I)imellus, in seed and

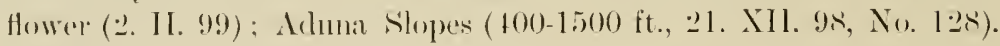
$-I I .0 \%$. $F$

On Haghier Hills: abmulaut. - li.C.S., sidnerinf., lient, Nimmo.

\section{ZYGOPHYLLEÆE.}

\section{Tribulus, Linn.}

85. Tribulus terrestris, lim!.

On plains: commono-bir's., silnecinf., brent.

\section{Zygophyllum, Linn.}

86. Zygophyllum simplex, Limn.

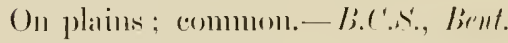

87. * Zygophyllum album, Limu.

Collected, but with locality lost.--II.().F.

Siandy spots near the shore at (ialonsil and elsewhere.-B.C.S.

\section{Fagonia, Linn.}

88. Fagonia cretica, Limn. vill arabica, T. . Imtrrs.

On plains; ; common.-li.C.s., Nimmm.

89. †* Fagonia cretica, Linn. vill socotrana, bult. fil.

On Hadiln Plain, at Elhe ; and on Garieh Plain, near Kinnahann camp.II. ().F.

Alumlant.- R.e.s'.

\section{GERANIACE尼.}

\section{Geranium, Linn.}

90. * Geranium mascatense, livis:.

Homhil (No. 166, 172). On Matagoti, alwe Homhil campl (ahont 1900$2000 \mathrm{ft}$.). At $4000 \mathrm{ft}$. this heautiful Geranium had a more erect tham procumbent halit. - II.1).F.

Seerls of this have germinated: hut the plant is not of horticultural interest. - b.t.s., lient.

\section{Dirachma, Schweinf.}

91. †irachma socotrana, Schueinf. Balfon fil., Op. eit. Tab. VIH.

On slopes of Thaghice; not uncommon.-B.C.S., Shluerinf. 


\section{Oxalis, Linn.}

92. * Oxalis corniculata, limu.

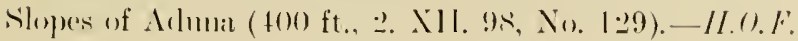

Common.-li.e.'.

\section{RUTACE压.}

\section{Ruta, Linn.}

93. Ruta graveolens, Limn. vill: angustifolia, Homk, fil.

Near Harlilur. - B.C.S.

\section{Thamnosma, Torr. et Frem.}

94. $\dagger^{*}$ Thamnosma socotrana, liclf. fit.

'Two plants were lnomglit over in al Warlian case, hut, heing far gone on alrival, unfortmuately died.

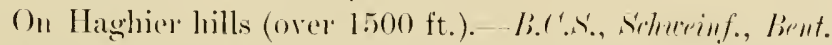

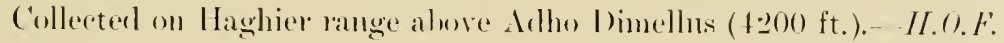

\section{Citrus, Linn.}

95. * Citrus aurantium, /rilll.

Oliservert on the Tahisheh plateau, above the Ininehan Talley, near Arlho Dimellus camp (1000 ft.). Probahly introrluced from Portugal and deteriolated, ats the fruit is quite as litter as aloes.--H.O.F.

()u hills at Arlho Imellus, and also near Feregeh.-licts.

\section{BURSERACEÆ.}

\section{Boswellia, Roxb.}

96. $\dagger *$ Boswellia Ameero, Bulf. fil., Op. cit. Tal. IX.

I)inehan Valley. Native name "Ameiro" (No. 200). - II.O.F.

On slopes of the Ilaghier Ilills alwut Harblu; also alont Homhil.-

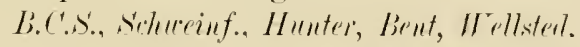

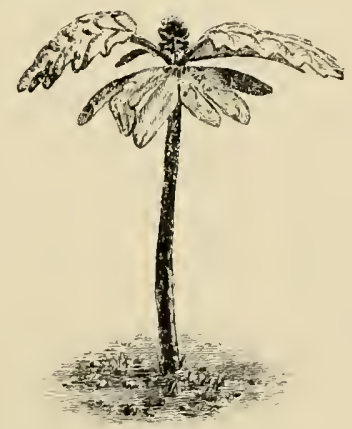




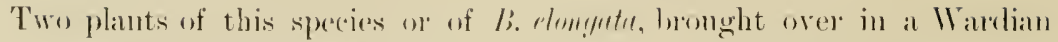
case, are growing well (1)ecember, 1900). The acempanying figme shows a yommg seedling which we have raised. It is interesting to mote that its atylexlons are quite these of a Titiv. I am not able to deter-

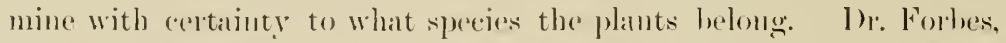
howerer, assures me the species is li. Amerin, collecterl below Arbo Dimelhs in the I) mehan Valley (3800 ft.), Jamnary 18 , 1899 , the trees then (onning into flower; the fruits gathered were those of the previous year, which haul not fallen from their capsules.

Mr. E. M. Holnes, of the Pharmatentical Society's Musemu in Lomrlon, sends the following note to Dr. Forles on a specimen of gim collected on the 2301 . 1amary, 1898 , and sent to him for examination.

"The sticky oleo-gmm resin mixed with hark received from 1)r. Forlues muder the name of Ameen is evirlently a variety of frankincense derived from lioswellin . Imeren, Balf. f., an account of which is

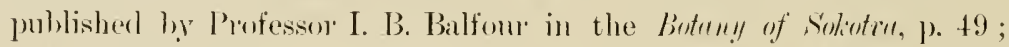
of. also Introduction, p. xxxviii., and Appendix, p. $+41-4+2$, where an analysis hy In. Dobhie is given. Fren when dried in the form of small teals, in which form it was presented to the Mnsemm of the Ploaramacentical Society some years ago hy Professor Balfonl, it wouk not fincl a market in this comutry, since frankincense from Arabia and somaliland can be olstained of much better quality at at cheaper rate (10kl. per 11 . wholesale)."

97. $\dagger *$ Boswellia elongata, liulf. fit., Op. (it. Tal, X.

seen at Ilombil at $1500 \mathrm{ft}$.

On the hill slopes.-B.c's', Bent.

\section{Boswellia sp.}

On the litls south-west of (Aalonsir.-B.'.S'.

99. $\dagger *$ Boswellia socotrana, Bulf. fil., Op. eit. 'Talı. Xl.

seen at Homhil, and in the Dinehan valley on our way from Hadiln Plain to A(hos) Inelhus; lut not in flower. (II. 99.)

()1 the Haghier hills: not meommon.-B.('s., sthuerinf.

\section{Boswellia sp.}

()n the limestome plains.-B.r'Ss.

\section{Balsamodendron, Kunth.}

\section{Balsamodendron Mukul, Hook:}

()n the Khathip I'lain.- li.t.s'.

102. $† *$ Balsamodendron socotranum, Brilf. fil., Op. cit. Tal,. XII.

Ohserverl almudantly at Hombil, and in the valleys both morth and sonth of the Allo bimellus water-parting. Called wy the natives "lagghan" and "Semahänu." Some of the gum-resin, "laban" 


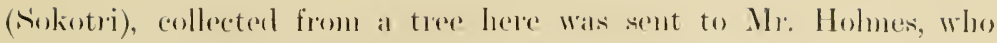
semels the following mote:

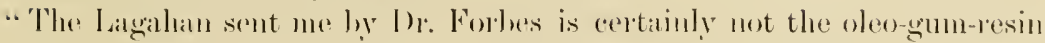

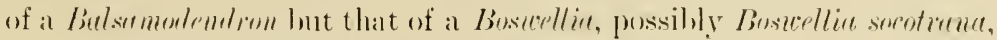
Ibalf. f. There is polably some mistake alout the name. It is not so fagrant as orelinaly framkincense of Somaliand and Arabia, amel rould not possilly eompete with it in English commerce."

In faee of the above statement, I harelly like to assert that I feel con

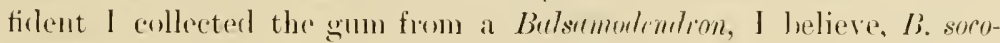
trenum, and hoxed it on the spot.-H.1).F.]

Alumdant.-B.('S., Stherinf.

103. † Balsamodendron parvifolium, Billf. fil.

On the plains.-B.r's'.

104. $\dagger^{*}$ Balsamodendron planifrons, schurint. Balfour fil., (Op. eit. Tal. XIII.

Sieen in the Dinchan valley leading from Hadilun to Adho l)imellus, and in the valleys learling south from our camp at that place.-H.1).F.

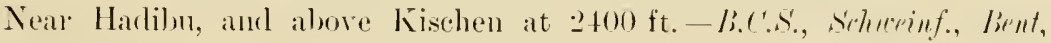
IInuter.

105. Balsamodendron sp?

li.c.s', Biret.

106. Balsamodendron sp?

li.t's., lisent.

\section{RHAMNE尼.}

\section{Zizyphus, Juss.}

107. *Zizyphus jujuba, lımk.

(No. ).-W. H.F.

Plants have heen raised from seeds bronght ly the experlition.

('ommom. - - B.C.C'.

108. * Zizyphus spina-christi, I'illd.

The finit is largely eaten by the natives: mmerons limels also feed on it

the Amythi and the ('nckoo: and the leaves are eagerly devoned

ly camels. Sicen everywlere up to $2000 \mathrm{ft}$. H.o.F.

Common.-li.C.s., Irollstrl.

\section{AMPELIDE $Æ$.}

Vitis, Linn.

109. Vitis quadrangularis, $\left\|{ }^{\prime}\right\| l$.

() platean S. W. from (xalonsir (over l500 ft.). - li.t'st. 
110. $\dagger^{*}$ Vitis subaphylla, linlf.,fil.

(Nos. 26a, 40, 41, s1e, 150i.) Kamaham (ㅊ․ XII. 9s). Fadehen (:i. 1. 95). - II.0.F.

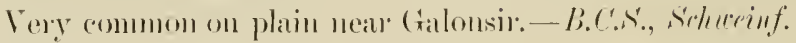

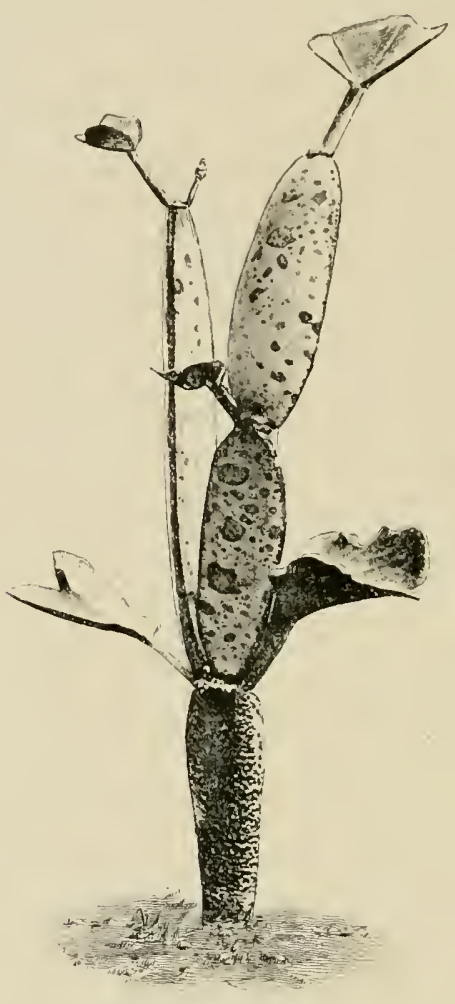

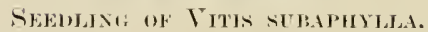

The have raised several seedlings of this plant. The hypoestyl rises about a comple of incles ahove gromel hearing a pair of slightly palmately lohed cotyledons. The rarlial orthotropons axis of the lypocotyl is terete at the base and gladually becomes furdrangulan with nearly equal sirles. (Tpun the top of the hypocotyl at the hase of each cotylestom is a pair of corshon-glands, one on each sisle of its petiole. The plumular shoot forms a lomg internote with ome leaf at its apex at right angles to the median of the cotyledons, and this leaf has a pair of enshom-glands at its lase. Sureedlug similar internodes are developerl, and the leaves are distichous. It is interesting to note, however, that the finst intermole of the phumular axis is mot like the hypocotyl quadbangulas with equal siles. It is distinctly compessed, aud has two broal surfaces aud two narrow erlges. Of the lorod surface, that upon the sirle upon which the leaf springs is eoncare, the opposite side is convex, the narrower edges are flat. In the second 
intermede the same type of flattened axis is dereloperl, but the dires-

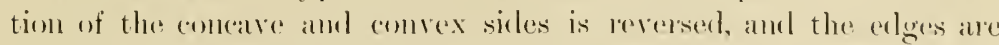
commenly reduced so as to be mere sharle margins without any surfice. In this plumulat axis, then, we have the interesting feature of the development of a dorsirentala axis as an orthotropous shext on the top of a ratial orthotropous hypoentyl, the change being lownght alout ly the flattening of the internodes in one direction.

These points will lo realily molerstoorl from the aceompanying figure.

111. $\uparrow$ Vitis paniculata, lirlf. fil.

Common, climbing among small trees on the hill slopes. - b.r.s., stheeinf.

\section{SAPINDACE $Æ$.}

Allophylus, Linn.

112. *Allophylus (Álmiclelia) rhoidiphyllus, Bialf. fil.

Ohservel at Homhil (19. 1. 99). Gathered seeds on Matagoti in the clefts of the rock above the camp (2500 ft.), which hal apparently been passed by hirds, mobably Amydri, in large quantities. Achua shopes (400-1500 ft., 2) 1. XII. 98, No. IIJ).-H.0.F.

IVe bave some seedlings which probally are this plant.

Very common.-li.C's., stheinf.

113. Allophylus, $x p$. ?

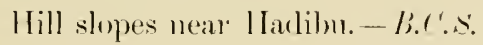

\section{Dodonæa, Linn.}

\section{4. *Dodonæa viscosa, limn.}

Arlho I)imellus (3500 ft., I. 99, No. +7).-II.O.F.

seeds of this common plant have germinaterl.

Haghier hills.-li.t's:

\section{ANACARDIACE 2 .}

\section{Rhus, Linn.}

115. Rhus glaucescens, th. likh.

llill shopes.- li.r's.

116. $\dagger^{*}$ Rhus thyrsiflora, licelf. fil.

Armua slopes (400-1500 ft., 21. XII. 9s. Nos. 11t-1:31). Adho l)imellus, (4000 ft.. No. 20 s').-.-M.1).F.

Common on hill slopes and in the valleys.-P.t'S., Srhueinf., bent, Vimmon.

\section{Odina, Roxb.}

117. $\dagger^{*}$ Odina ornifolia, lielf. fil.

Jena-agahan (1500-2000 ft., :3. 1. 99, N11. 151).-H.1).F.

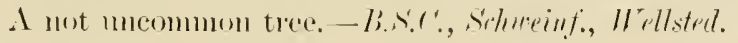


118. $\dagger^{*}$ Odina asplenifolia, limlf. fil.

Arlma (ำ1. XII. 98., 400-1800 ft., No. 1:39). - M.0.F.

One plant which apparently belonged to this species was luonght home in a Warlian case, lout it hamlly survived its arrival.

On hill slopes, of ten at high elevation.--li.li.e'.. lient.

\section{LEGUMINOS $巴$}

\section{Crotalaria, Linn.}

119. Crotalaria spinosa, Horllst.

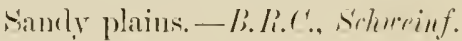

120. Crotalaria retusa, Linn.

['lains near Galonsir:--li.t's., sillmeinf, lirnt.

121. $\dagger^{*}$ Crotalaria strigulosa, linlf fil.

Achuna slopes (201. XII. 9s, No. 1:32).--M.1).F.

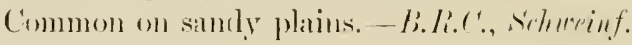

122. * Crotalaria leptocarpa, limlf. fil., Op. cit. 'Tal, XIV, A.

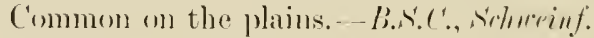

123. † Crotalaria pteropoda, liulf. fil., Op. cit. 'Tab. XIV, B.

Hills sonth-west of (xalonsir. - B.C.S.

\section{Priotropis, Wight \& Arn.}

124. $\dagger^{*}$ Priotropis socotrana, liulf. fil.

In the Ininehan valler learling to Arho I bimellns (2000 ft., 1. Il. 99. Nos. 201-2:32).-11.1).F.

Iigher levels of the Haghier hills.-B.C.S., strmeinf.

\section{Trigonella, Linn.}

125. † Trigonella falcata, linlf. fil.

samly places. - li.t's.

\section{Medicago, Linn.}

126. Medicago denticulata, Willl.

On the plains : common. - li.t's.

127. Medicago minima, L $\|_{m} m$.

Common. - B.t.s.

128. Medicago laciniata, All.

Sandy plains. - li.er.s. 


\section{Melilotus, Juss.}

129. Melilotus parviflora, Lesf.

('omm11111. - li. '. s'.

\section{Lotus, Linn.}

130. Lotus (Ononilinun) arabicus, Linn. var. trigonelloides, $\|$ r hl of Bifflr. Silurly plains.-li.t's.

131. $\dagger *$ Lotus (Hunidimm) ononopsis, linlf. yil., Op. cit. Tah, XVI.

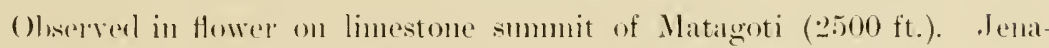
agahlan, on glanite (I500-2000 ft., :3. I. 99, No. 1 199).-II.0.F.

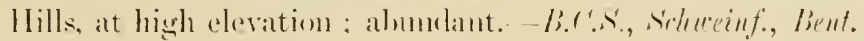

132. $\nmid *$ Lotus (Oumidium) mollis, linlf fil.. Op. cit. Tal. XVII, A.

Observed in Hower on limestone smmit of Matagoti (.500 ft., I. (99).II.1).F.

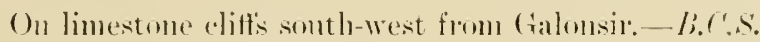

\section{Psoralea, Linn.}

133. Psoralea corylifolia, Litun.

Alont dwellings._- li. '.S.

\section{Indigofera, Linn.}

134. $\dagger^{*}$ Indigofera nephrocarpa, Bielf, fil.. Op. cit. Tall. XVIII, A.
On the summit of Hamadern, alove 1 Iombil camp, at $2700 \mathrm{ft}$. (No. 16.2.)
(Observed also on Hadilun Plain. -II.().F.
(immon plant of the platin.s.-b.t's., Srluceinf.

135. Indigofera cordifolia, Roth.

Cormmon.-B.C.S., Silnceinf.

136. Indigofera paucifolia, telite.

(ralonsir am elsewhere.-li.e.s.

137. * Indigofera intricata, limis..

()herved un Harlibu Plain.-M.1).F.

Very almurlant in the plains, especially on Hadibn Plain.-B.c.s., sillewint.

138. Indigofera leptocarpa, Hochst. et Stent.

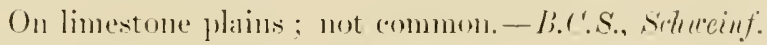

139. Indigofera viscosa, Ltm

Common on limestone plains.-B.C.s., shlueinf.

140. †Indigofera marmorata, limlf. fil., Op. cit. Till. XVIII, B.

Hill shepes (over $1000 \mathrm{ft}$.).-B.r's... Siturerinf. 
141. * Indigofera Gerardiana, chull.

Atho I)imellus. (Nos. $207-2.21$.$) H.11.F.$

Higher regions of hills (orer $2000 \mathrm{ft}$.) : almulant on Haghier, sonth of

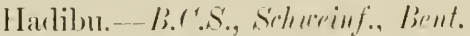

142. * Indigofera tinctoria, Liun.

()hserved erergwhere--B.C.S., Schuriuf., lirut.

Utsed hy the natives to dye cloth.--M.1.l.

143. * Indigofera argentea, Limu.

Oliserved near Hadihu.--II.(I.F.

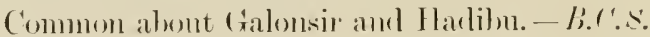

\section{Tephrosia, Pers.}

144. $\dagger^{*}$ Tephrosia (Brissonia) odorata, Bulf. fil.

Homhil (1700 ft., Nos. 17 -179.)-H.O.F.

On the eliffs sonth-west from (Galonsir (ores $1500 \mathrm{ft}$.). - li.C.S.

145. Tephrosia (Reineria) subtriflora, IIochst.

On the plinins.-B.C.S.

146. Tephrosia (Reincria) anthylloides, Iloclest.

On the plains.--b.t's.

147. * Tephrosia (linincia) vicioides, Ich. lich.

On the plains.- li.t's., Sthereinf.

148. Tephrosia (lieinelia) purpurea, Pers.

On the plains.-B.r.s.

149. Tephrosia (Reineria) Apollinea, $I J$ '

On the plains:--li.t.s. / Inuter.

Taverniera, $D C$.

150. † Taverniera sericophylla, Bulf. fil., (op). cit. 'Tal. XIX.

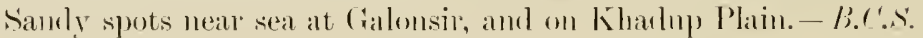

Ormocarpum, Beauv.

151. † Ormocarpum cæruleum, Bielf. fil., Op). (it. Tall. XX.

Plains and hill slopes at low altitudes.-B.ts., siducenf., Bent.

\section{Arthrocarpum, Balf. fil.}

152. † Arthrocarpum gracile, Bulf. fil., Op. cit. 'Tah. XXI.

Hills near Hadiln and elsewhere.-l.c.s., shueinf. 


\section{Zornia, Gmel.}

153. Zornia diphylla, l'e's.

Hatghier hills near Harlibu I'lain. -lit's.'.

\section{Desmodium, Desv.}

154. Desmodium triflorum, $D$ :

Not uncommonom. li.r.

\section{Alysicarpus, Neck.}

155. * Alysicarpus vaginalis, $I C$ :

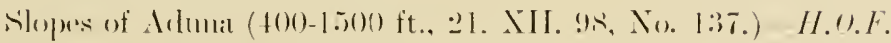

Oecasional werd. b.t's., selneriut.

\section{Teramnus, Swartz.}

156. * Teramnus labialis, smene. var. mollis, Bulier.

Nilopes of Achuma (100-1500 ft., 21. XII. 9s, No. 124.) -II.O.F.

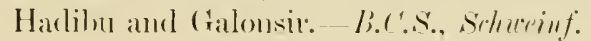

\section{Erythrina, Linn.}

157. Erythrina, $\approx \%$

Hills south of Hadilon. Bi.c.s.

\section{Canavalia, Adans.}

158. Canavalia ensiformis, $I X$.

Hill slopes.-B.C.s.

\section{Vigna, Savi.}

159. *Vigna luteola, Beuth.

slopes of Aduna (400-1500 ft., 2)1. XII. 9s, No. 136).-H.(1.F.

Common.-B.C.s., sihneinf., bent.

\section{Cylista, Ait.}

160. * Cylista scariosa, tit.

Homhil (No. 199.)--H.".F.

\section{Rhynchosia, Lour.}

161. Rhynchosia minima, IM:

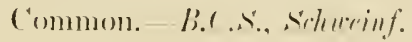

162. Rhynchosia Memnonia, $M$ :

Hill slopes. b.c.s., silmerinf. 


\section{Cassia, Linn.}

163. * Cassia Sophora, Linu.

Olserved aluurlantly.- II.().F.

Common abont villages on the plain.-B.C.S., Sitherinf., lient.

164. Cassia Tora, Linn.

Near villages. B.t'S., lirut.

165. Cassia obovata, c'olletl.

Near Hadilu. Sthwerint.

166. Cassia holosericea, Firsen.

On plains near villages. - li.t'.S., Shlueriuf.

167. Cassia Absus, Linn.

Near hahitations. li.t's.

\section{Tamarindus, Linn.}

168. * Tamarindus indica, Lim.

Ohserved on the slopes of Admia and elsewhere. II.1).F.

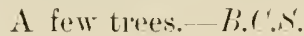

169. † Entada, $s p$.

Entada, Adans.

slopes of Haghier.-B.r.s.

\section{Dichrostachys, $D C$.}

170. † Dichrostachys dehiscens, liulf. fil., Op. vit. Tal). XXII.

Kharlup and Hadihu Plains.-B.C.S., sthweinf.

\section{Acacia, willd.}

171. †* Acacia socotrana, bulf. til., Op. cit. Tal. XXIII.

Ohserved on Haclihu P'lains. II.().F.

On the plains near sea on morth sible of island, espectally in vicinity of Delishi. - b.t's., stheriuf.

172. ${ }^{*}$ Acacia pennivenia, Schrriff. Balfon fil., Op. cit. 'Tal, XXIV.

Ohserverl on slopes of Arlunit. H.o.k.

Hill slopes of Haghier:- B.t.s., Schuriuf., Hunter.

173. $\uparrow$ Acacia, sp.

Plains near (xalonsir:- li.t's.

\section{CRASSULACE无.}

\section{Tillæa, Linn.}

174. Tillæa pentandra, limyle.

Common on hills. - b.c.s., sillurinf. 


\section{Kalanchoe, Adans.}

175. "Kalanchoe rotundifolia, Itew.

Three plants of this species, lumght home in a Wardian case, ale now

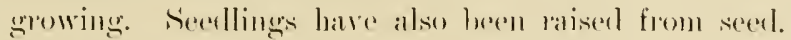

Collereted on the limestome hills aromed Hombil ; also on glanite hills

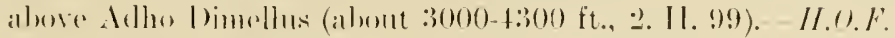

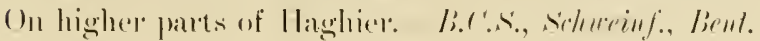

176. $\dagger$ Kalanchoe farinacea, Bulf. fil., Bot. Nag. tib. 7769.

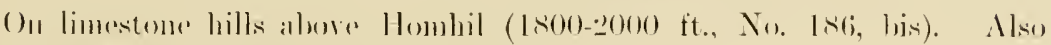

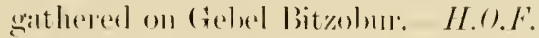

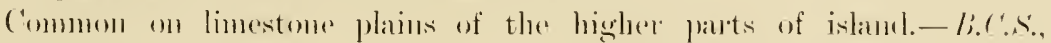
simuriuf., Iluntre.

Twelve plants of this specier, honght in a Miarlian casse, alle now growing.

177. $\dagger^{*}$ Kalanchoe robusta, Bulf. fil.

Homhil.-H.O.F.

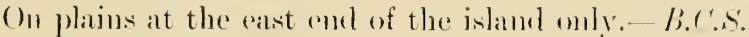

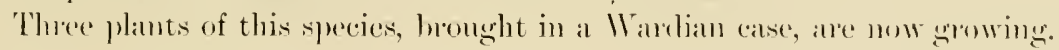

178. † Kalanchoe abrupta, Bulf. fil.

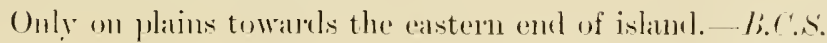

\section{LYTHRARIEÆ.}

\section{Ammannia, Linn.}

179. Ammannia baccifera, Livu.

Galonsir: Hadilu, and elsewhere--li.r.S., sechreinf.

180. Ammannia multiflora, $R o r \%$.

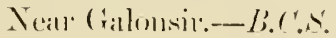

\section{Lythrum, Linn.}

181. Lythrum hyssopifolium, Linn.

(1) the plinin.

\section{Punica, Linn,}

182. $\uparrow *$ Punica protopunica, linlf. fil., (Op. cit. Tah. XXV.

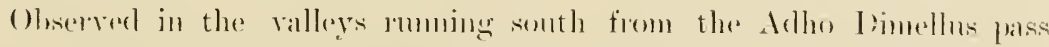

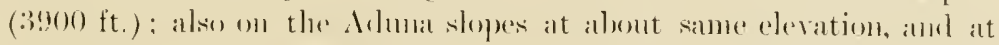

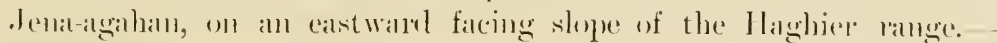
II. (1.F. 


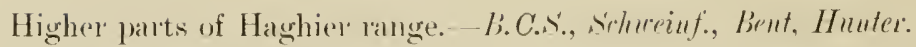

We have raiserl a comple of yomug plants from seerls of this species hrought ly the experlition.

\section{ONAGRARIE尼.}

Ludwigia, Limn.

183. Ludwigia palustris, Ell.

Common.-Bs.s'., sicheriuf.

\section{CUCURBITACE床.}

\section{Eureiandra, Hook. fil.}

184. † Eureiandra Balfourii, Cognianr. Balfour fil., Op. cit. 'íal. XVII, B. spread over the island. li.c.s., seluceinf.

\section{Momordica.}

185. * Momordica Balsamina, Limn.

Olsserver in IFadilun Plain. - H.O.F.

Near Hadilu. - B.e.s.

186. Momordica Charantia, Limu, var. abbreviata, Sel.

Near Galonsil: - B., 's.

\section{Cucumis, Linn.}

187. Cucumis ficifolius, Ach. Rich, var. echinophorus, Neter.

Not uncommon.-B.C.S., schuceinf., Bent.

188. * Cucumis prophetarum, Linn.

Olserverl several places.-H.O.F.

Not micommon. - B.T's.

189. Cucumis dipsaceus, Eltrenl.

Hadibn. Sidneriuf.

\section{Citrullus, Schrad.}

190. * Citrullus Colocynthis, Siretr.

Fruits collecterl on (rehel Farlehen (3. 1. 99).--II.).F.

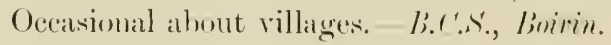

\section{Melothria, Linn.}

191. Melothria punctata ?, cingn.

Near Harlibu. - B.C.s. 


\section{Dendrosicyos, Balf. fil.}

192. $\dagger^{*}$ Dendrosicyos sozotrana, liall. fil., () r. cit. Tial. XXYl.

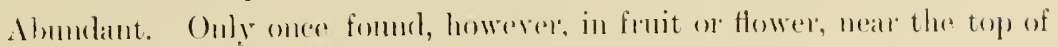

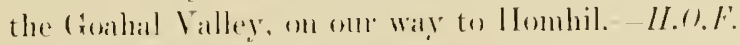

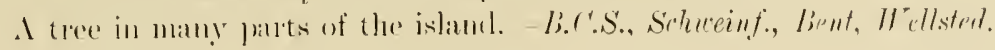

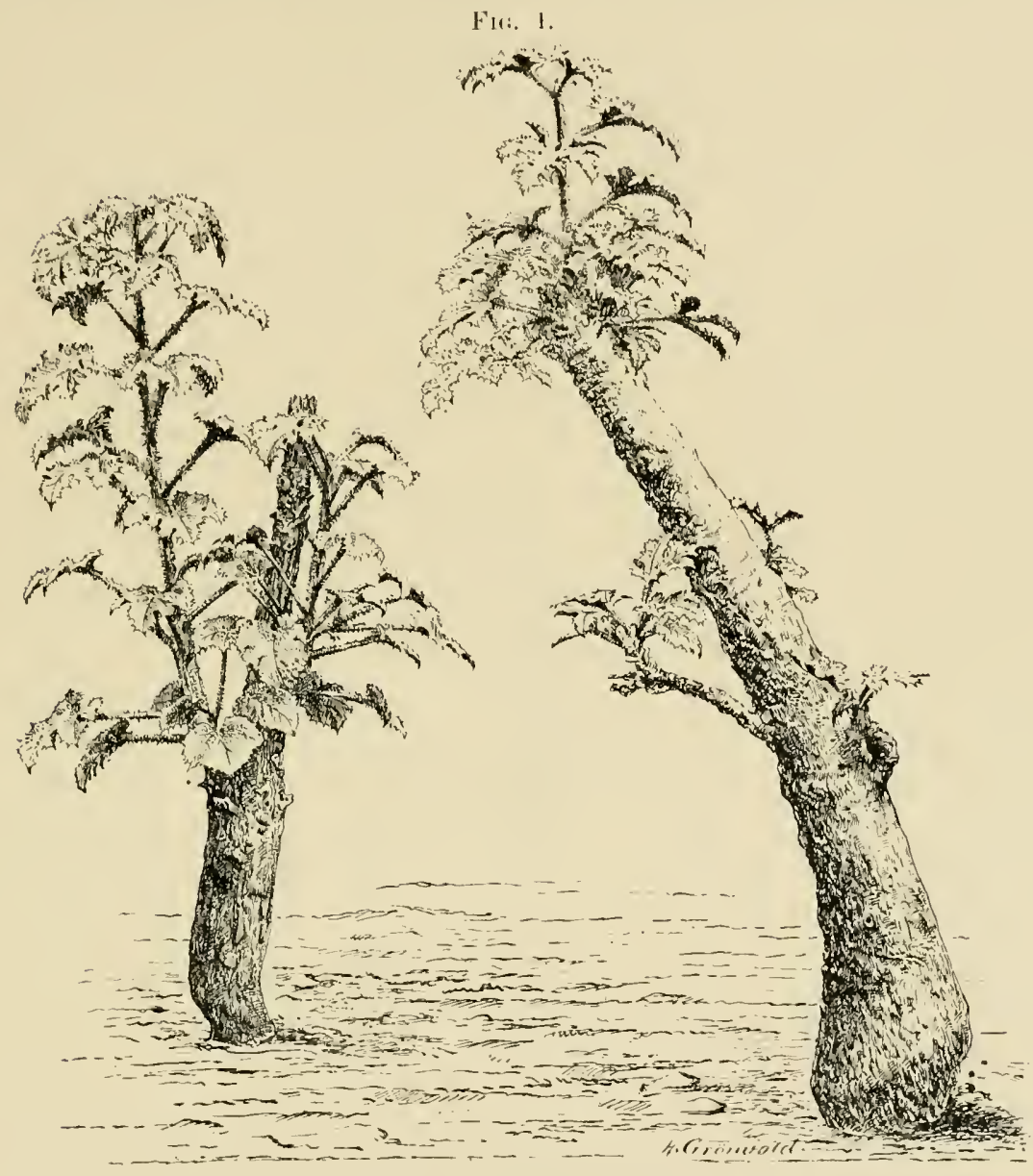

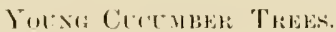

(Grown in Royal botanic Garlens, Elinluresh.)

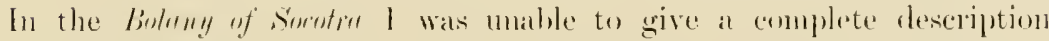
of the plant as mueh of our material haul leen lost. The plants we have growiog and the material which I) Forlose loromght heme in spirit will allathe us eventually to make ont an accomit of the structure of this interesting plant. The late Mr. Theorlore Bent

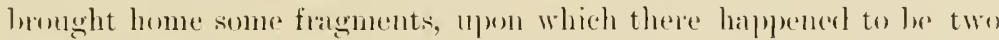
female Howers, and amongst the specinens lor. Forbes collected are two female Hower's and al yommg front in spirit. I am alre, therefore, 
now, from the arditional material at my disposal, to supplement the description aldardy publisher ly the rescription of the female Hower. and to give figmes of it :-

$$
\text { FIr: :2. }
$$

Fl1: 3.
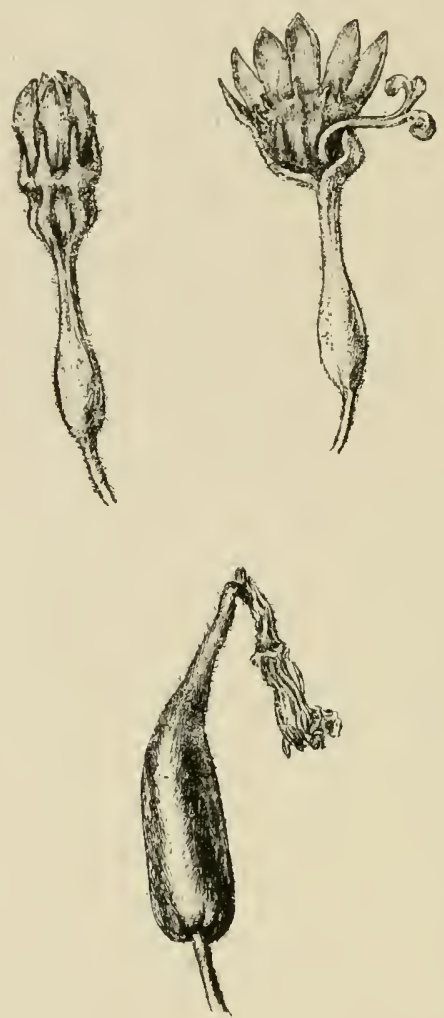

Flli. 4.

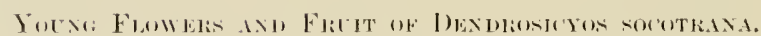

(Fïg. 2. In lucl. Fig. 3. "1,en Huwer. Fig. 4. Yomg fruil.)

Flores $q$ in falsciculos axillares perhunculatos aggregati, finciconli lhachis

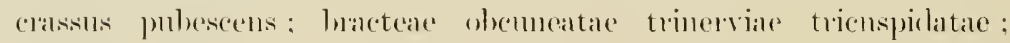

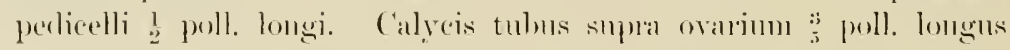

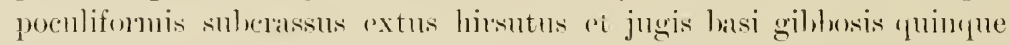
sepalis respondentilus vallecula quacpure medio costata motatus, intus

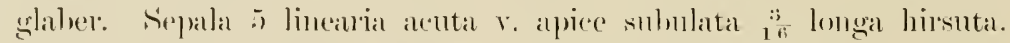
Petala is libera integras oblonga $\frac{3}{8}$ poll. Jongal fanci calycis inserta

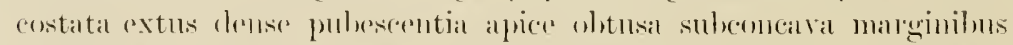

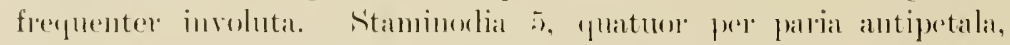

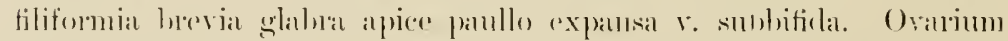

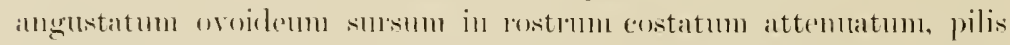
hrevilus plus mintsve restitum, triloculare. Stylus elougatus lamis tribus stigmatiferis corollate aeduilongus: stigmata expansa cristata. 
Discus o. Orular plurimal horizontalia lateribus placentalum orarii parieti proximis insertal.

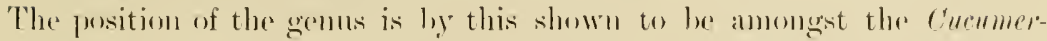

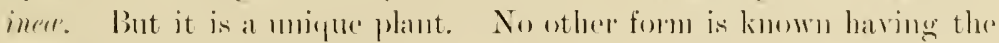

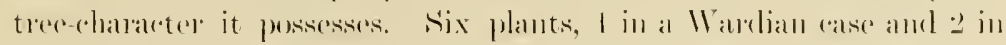
a der comblition, were bought over. Those in the lladelian case were in excellent health, rooting in the soil anel semeling out fratres. A

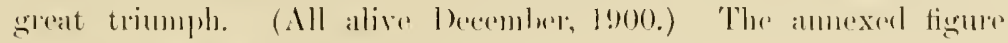
(tig. 1) shows two of these plituts.

\section{BEGONIACEA.}

\section{Begonia, Linn.}

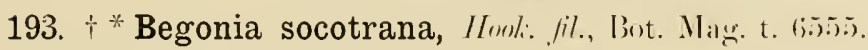

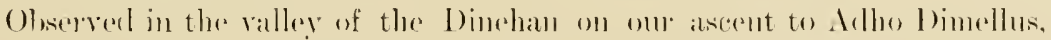
growing in fine frialle soil, but nowhere below 1500 feret : seen also slowing abmotantly in the erevices of the exposed falces of glanite

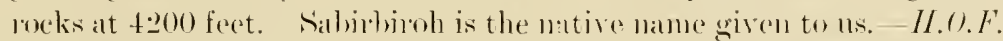

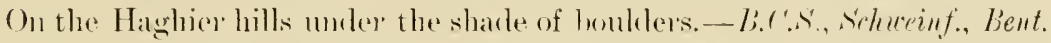
This plant, introduced in lisso from the istanul has beren the porgeniton of an entirely new race of Begonias. I think that in some of the othes. plants we now have in cultivation from the seeds and bulls bought home by the experlition these ane possibilities which will remder them acruisitions in a like waly. Some of these ane certalnly of themselves horticulturally valuahle.

\section{FICOIDE正.}

Tetragonia, Linn.

194. † Tetragonia pentandra, Bulf. fil.

Near Galonsir.-B.C.S.

195. Aizoon canariense, Linn.

Aizoon, Linn.

Common on the planis.-B.C's., sidnerinf.

\section{Trianthema, Linn.}

196. Trianthema pentandra, Limm.

Neall llarlibu.--li.e.S., shlueinf.

\section{Orygia, Forsk.}

\section{7. * Orygia decumbens, Forki:}

Hadilu Pain (XII. !s, No. 105).-H.O.F.

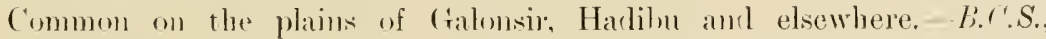
Sillereinf.

fereral secellings of this, from seed homght hy the expedition, we have now in cultivation. 


\section{Mollugo, Linn.}

198. Mollugo hirta, Thmul.

Near Galonsil:- - li, r's.

\section{UMBELLIFERE.}

Hydrocotyle, Linn.

199. "Hydrocotyle asiatica, Linn.

On the swampy hank of a stleam neall Homhil.-M.1).F.

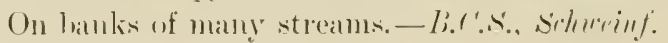

Nirarathamnos, Balf, fil.

200. $\dagger^{*}$ Nirarathamnos asarifolius, linlf. fil. () . cit. Tirl. VII, A.

The flowers were orees: and the froits were fully formed, but not ripe in

Fehruary. The native name given to no wass "I Dosif." Artho Dimellus (4:300 ft., No. 2:36).-M.1).F.

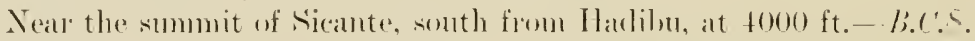

Plants of this species herenght home in a liardian calse clid not survire, and the secel of it was not ripe, so that this remalkalde plant is not yet in cultivation.

\section{Carum, Linn.}

201. Carum (Thachyspermum) pimpinelloides, birlf. fit.

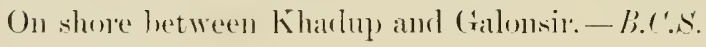

202. † Carum (Tracly'spermum) calcicolum, Bulf fil.

Common on limestone plains near the seal. - b.e C.S.

\section{Fæniculum, Adans.}

203. Fœniculum vulgare, Giirtn.

Cultivaterl at ('alomisir.-B.r.s.

\section{Peucedanum, Linn.}

204. $\dagger^{*}$ Peucedanum cordatum, Bulf. fil.

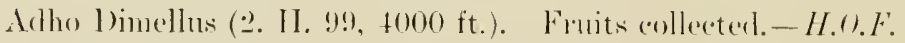

Common on the hills.- li.t's., siluerinj.. lient.

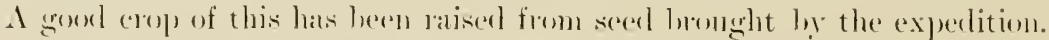

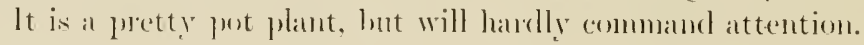

\section{RUBIACE正.}

\section{GAMOPETALÆ.}

\section{Dirichletia, Klotzsch.}

205. * Dirichletia glaucescens, Mirin.

Olserverl at the hase of (iehel liaggit, south-west of llarlibll.-H.1).F.

On Haghior hills, soutle of Hadihu.-M.c.s., Scherent. 
206. ${ }^{*}$ Dirichletia venulosa, Bulf. fil., Op. cit. Tal,. XXY11, (!.

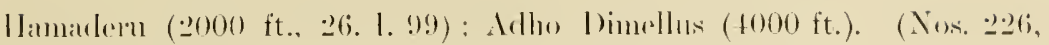
$23(1)-1 / .1 \% .1 \%$

Only wh the highes parts of Maghier.-B.t'S., Sidneinf., lient.

207. $† *$ Dirichletia lanceolata, Bsulf, fit.

Allho Dimellus (3.500 ft., II. 99, No. 2.2:3). - - I. ().F.

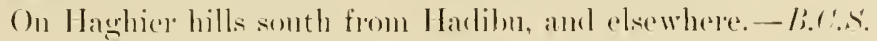

208. $+*$ Dirichletia obovata, Bult. fil., Op. cit. Till. XXVII, A.

(Barich Plain (Nos. 1!).2, 19) 1). - Il.1).F.

Common everywhere on the hills. - B.t.s., lirut.

(One seedling has come up form our sowing of this plant hromght hy the experlition.

209. †Dirichletia obovata, var. albescens, Bulf. fil., Op. (it. Tal. XXiII, B.

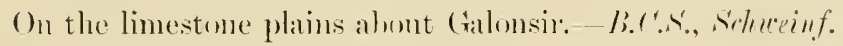

\section{Placopoda, Balf. fil.}

210. † Placopoda virgata, Bult. fil., Op. cit. Tah. XXVIII.

Abundant on the plains.-B.C.S., Schueinf., lient.

211. Placopoda virgata, var. nana, $B, l f$ fit.

()n the plaius. - li.t's.

\section{Hedyotis, Linn.}

212. † Hedyotis pulvinata, Bulf. fil.

Very common on the plains alunt Galonsir.-B.C.S., Sthweinf., Brut.

213. † Hedyotis bicornuta, lialf. fil.

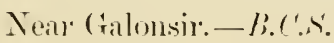

214. † Hedyotis stellarioides, Bulf. fil.

(ommum on hill slopes.

Near Kischent.-li.t's., lirnt.

\section{Oldenlandia, Linn.}

215. Oldenlandia Schimperi, T. Anters.

()n the platins.-li.t.s., silureinf.

216. Oldenlandia corymbosa, Limn.

Common. li.cs.., siluminf.

\section{Oldenlandia Heynei, olir.}

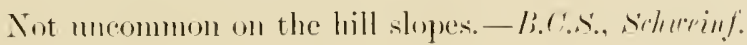




\section{Mussanda, Linn.}

218. $\dagger^{*}$ Mussænda capsulifera, Brilf. fil., Op. cit. Tah. XXIX.

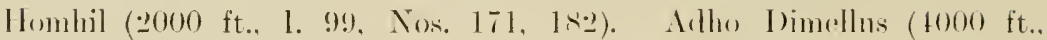
I. 99, No. 21(i). - H.11.f.

() the hills. - li.t's., sidneinf., lirut.

We have seedlings of this plant miserl fiom seerl homght hy the axperlition. Plants grown at Kew from seeds lnomght home from sokotia hy Ma: and Mrs. Theodore Bent have floweresl, and the plant is figned by sir Joseph Hooker in the Botanical Magazine, t. 7671.

\section{Gaillonia, Ach. Rich.}

219. † Gaillonia (Microstephns) tinctoria, liali. fil.

In tufts on rocks near Galonsir:- B.C.Ss.

220. Gaillonia (Microstephus) puberula, Balf. fil.

Not nucommon.-B.C.S., sithereinf.

221. * Gaillonia (Microstephus) thymoides, Brelf. til.

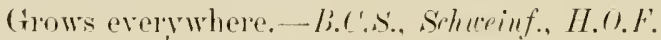

\section{Spermacoce, Linn.}

222. Spermacoce hispida, Lim.

Harlihus.- li.r's., sthurinf.

\section{Vaillantia, $D C$.}

223. Vaillantia hispida, Lim!

Hill slopes.--li.C'.S.

\section{Galium, Linn.}

224. * Galium Aparine, Limn.

Alho I)imellus (4000 ft.). - II.O.F.

On the bigher parts of Haghier:-- li.e.,.s., Sthereinf.

\section{VALERIANEÆ.}

\section{Valerianella, Mönch.}

225. † Valerianella affinis, Balf. fil.

liy hill slopes near (Galonsir.-B.C.S.

\section{COMPOSITAE}

\section{Vernonia, Schreb.}

226. $\dagger^{*}$ Vernonia (Lepirlellis) Cockburniana, Balf. fil., Op. cit. Tal, XXX.

Arlho [)imellus.-H.O.F.

Not uncommon luth on the linestone and the granitic regions. - B.C.S., Schureinf. 
This is sue of the few enmpesites that have grown in the Royal botanic (Bardens, Eslinlmogh, from seed hrought by the experlition.

227. Vernonia ('l'pphrorle's) spathulata, Hochst.

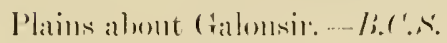

228. Vernonia ('Tephroles) cinerea, Less.

('ommon. - li.c.s.s., sitheinf.

Ageratum, Linn.

229. *Ageratum conyzoides, lim.

(ramich Plain. H.1).L.

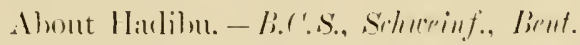

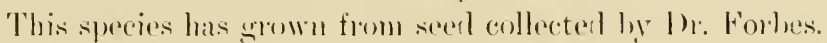

\section{Dichrocephala, $D C$.}

230. Dichrocephala chrysanthemifolia, $M$.

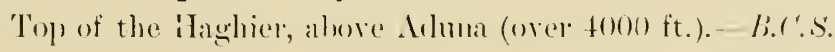

Conyza, Less.

231. Conyza Hochstetteri, Sclint: :

Not commmm.-li.c's.s., Srherinf.

\section{Psiadia, Jacq.}

232. † Psiadia Schweinfurthii, Balf. fil., Op. cit. 'Til. XXXI.

Kischen, in Haghier range (at 1800 ft.).-Secheinf.

\section{Pluchea, Cass.}

233. $\dagger *$ Pluchea glutinosa, Balt. fil.

Arluma slopes (2800 ft.). - H.O.F.

On Haghier lange above Harlibu and Kischen; nean Galonsir.-B.C.s., sheriuf.

234. $\dagger^{*}$ Pluchea aromatica, Bulf.fil., Op. cit. Tal, XXXII.

. Jena-agahan (1500-2000 ft., :3. I. 99, No. 1 H's).-M.(1).F.

On Hagher lange sonth of Hadilm and above Kischen. - B.t's., Sihnerinf.

235. $\dagger^{*}$ Pluchea obovata, Balf. fil., Op. cit. Tah. XXXIII.

Observed on Arluna slopes.-- H.().F.

(Only on the clifls on higher parts of Haghier, especially ahout Kischen

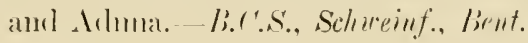

\section{Achyrocline, Less.}

236. * Achyrocline luzuloides, l'ullie.

. Jella-agahan (1500-2000 ft., :3. I. 99, No. 155).-II.0.F.

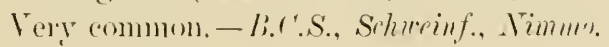


237. Achyrocline Schimperi, Sehult:-

(O) the hills.-li.e.s., selhecinf., bient.

\section{Helichrysum, Gärt.}

238. $\dagger^{*}$ Helichrysum rosulatum, Oliv. \& Hieln., Balf., Op. cit. Tal. XXXIV, 1 .

Observed high up (toog ft.), on the slope of Gebel loyat, or Felah, als it is also callerl (the highest peak of the Haghier range), alwre om (amp) at Arlho l)imellus (3. I1. 99).-II.().F.

On the highest points of the Haghier range (orer fooo ft.). - li.t.s.. selleceinf., lient, vimumo.

239. $† *$ Helichrysum sphærocephalum, Bali. fil.

Arlho Dinellus (4000 ft., No. 214 ).-H.().F.

()n higher Haghier hills. - B.('.s., Schueiuf., lient.

The two plants of this species, in which on arval life was Hickering, did not survive.

240. $\uparrow$ Helichrysum sphærocephalum, val. sarmentosum, Bu!f fil.

In dry hoalities. - li.c'.s.

241. $\dagger *$ Helichrysum arachnoides, Balf. til.

Homhil (2700 ft., No. 1s5.) - II.O.F.

On hills sonth-west fiom Galonsir.-B.C.S.

242. $\dagger^{*}$ Helichrysum aciculare, Balf. fil., Op. cit. Tal, XXXIT. B.

Hombil ; frolits collected by the experlition.-II.(1).F.

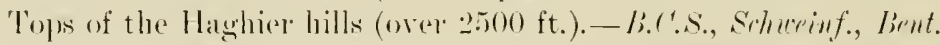

243. $\dagger^{*}$ Helichrysum Nimmoanum, Mlie. \& Mirrn., Balf., Op. cit. 'Till. XXXY.

High up in the Nesharir valler, moler Arhuna, and alove omr camp at Dilhamis (almolt $3000 \mathrm{ft}$.). - II.1).F.

(On the higher slopes of Haghier.-B.s.e., sicherinf., lient, Nimmo.

244. $\dagger^{*}$ Helichrysum suffruticosum, Brelf. fil., Op. cit. 'Tal. XXXVI.

Froits of this species were collecterl ly the experlition.-M.1).F.

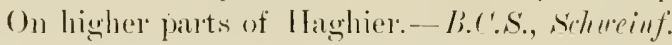

245. $\dagger *$ Helichrysum gracilipes, Oliv. of Hierm., Balf., ()p. rit. 'Tah. XXXYiI.

Slopes of Arhua (201. XIl. 9s, Nos. 11:3, 1:33). Hamarlern smmmit, alwe Homhil camp (2000 ft., No. l6i). Arlho Dimellus $(4000 \mathrm{ft}$. , No. $2(1) !)$. - H.(1). $F$.

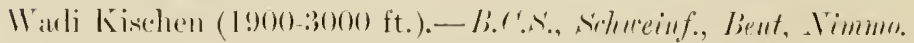

246. † Helichrysum gracilipes, var. lanatum, Balf. $f i l$.

shore near Hadilu. - Schueinf.

247. † Helichrysum gracilipes, vill profusum, $3 a l f ., t i l$.

Near Kerangiti._s shurint. 
248. † Helichrysum gracilipes, val. stoloniferum, lial\% fil.

Hills south-west of (Balonsir._-li.('.S., Nimmo.

\section{Pulicaria, Gärtn.}

249. $\dagger^{*}$ Pulicaria diversifolia, limlt. til.

Jena-agahan (1500-1s00 ft., I. 99, Nos. 156, 15s).-W.1).F.

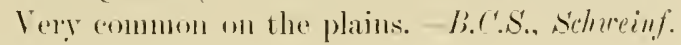

250. † Pulicaria stephanocarpa, Bulf. fil., Op. cit. 'Tal. XXXVII.

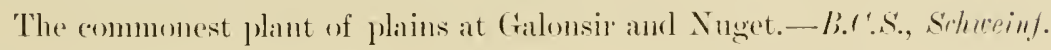

251. † Pulicaria vieræoides, Balf. fil., Op. cit. Tal, XXXIX.

On Haghire lange south of Hadibu (orer 2000 ft.). - B.S'S.

\section{Siegesbeckia, Linn.}

252. Siegesbeckia orientalis, Lim.

On hills near liay village and clsewhere. Lli.t's., Stheeinf.

\section{Eclipta, Linn.}

253. Eclipta alba, IIassl:

Near Hadibu._Is.C.s., Srhueinf.

\section{Blainvillea, Cass.}

254. * Blainvillea rhomboidea, Cuss.

Slopes of Alumi (400-1500 ft., 21. XII. 98, No. 14:3).-M.(1.F.

Not uncommon.-B.C.S., Srlueciuf.

\section{Bidens, Linn.}

255. * Bidens pilosa, Linu.

Arllı Dimellus ( $1000 \mathrm{ft} .$, No. 2.25).-H.().F.

Hadiln.-B.C.S., sidurent.

\section{Senecio, Linn.}

256. † Senecio (Kleinia) Scotti, Balf. fil., Op. cit. Tal. XI.

Haghier range alove Hadihn (over $2500 \mathrm{ft}$.). Rare.-B.r's., sehceinf.?

\section{Euryops, Cass.}

257. $\dagger *$ Euryops socotranus, Balf. fil., Op. cit. Tal,. XI.I.

Slopes of Arluma (1500-2000 ft., No. 120 $)$. Never collected below $1500 \mathrm{ft}$. Begomiu, Hyperienm and Euryoms appear sudrlenly at about this elevation. - II.O.F. 
We have thirteen plants of this, which came home alive in a Wardian ase : and we have also a large chop of seedlings. It will he a useful decorative plant for the green-honse.

On higher regions of Haghier.--B.C.S., Sthweinf., Bent, Hunter.

\section{Tripteris, Less.}

258. Tripteris Lordii, Oliv. \& Hiem., val. racemosa, Balf. fil.

Near Galonsir and Hadibu. -li.C.s., Seluceinf.

\section{Volutarella, Cass.}

259. Volutarella Lippii, Cass.

Near Harlibu.--li.C.S.

\section{Dicoma, Cass.}

260. Dicoma tomentosa, Cass.

Haghier range near Hadilı.-B.C.S., Schweinf.

261. † Dicoma cana, Balf. fil., Op. cit. Talb. XliII.

Cliffs overhanging the shore on south-west of (xalonsir (over $1500 \mathrm{ft}$.).

On limestone.-B.C.S., Bent, Hunter.

\section{Lactuca, Linn.}

262. † Lactuca rhynchocarpa, Balf. fil.

On the plains.-B.er.s., Schweinf.

263. † Lactuca crassifolia, Balf. fil.

On the plains. - li.e.s.

\section{Heterachæna, Fresen.}

264. Heterachæna massaviensis, Frese».

Common.-li.c's', schueinf.

\section{Prenanthes, Linn.}

265. $\dagger^{*}$ Prenanthes amabilis, Bulf. fil., Op. eit. Tah. XLIII.

Observed below the Artho Dimellus Pass. - II.O.F.

On rockis sonth-west of Galonsir (over 1500 ft.).-B.C.S.

\section{Reichardia, Roth.}

266. Reichardia tingitana, Roth.

Gahonsil:-B.C.S., Srhucinf.

\section{Sonchus, [inn.}

267. * Sonchus oleraceus, Limn.

Observed in many places. - H.O.F.

Common near hal,itations.-D.C.S. 


\section{Launæa, Cass.}

268. † Launæa crepoides, Balf. fil.

Not uneommon on the hills. - B.t.s., Schweinf.

\section{CAMPANULACE E.}

\section{Wahlenbergia, schrad.}

269. * Wahlenbergia riparia, $A l p l$. $D C$.

Olserved in the Dinehan valley learling from Harblun Plain to Arlho Dimellus.-H.O.F.

On hills about Galonsin:-B.r.s.

\section{Campanula, Linn.}

270. Campanula dichotoma, Lim.

Hill slopes.-B.C.s.

\section{PLUMBAGINE尼.}

\section{Statice, Linn.}

271. * Statice axillaris, Forsli

Homhil (I. 99, No. 181). Adho I imellus (4000 ft., II. 99, No. 224).H.O.F.

Not meommon.-B.C:S., Nimmo.

272. * Statice cylindrifolia, Forsli.

In the swampy gromuch near Khor Garieh.-H.O.F.

In the clay margins of Khor Garieh and on Nuget Plain.--B.C.S., Bent.

Vogelia, Lamk.

273. Vogelia indica, Gibs., var. socotrana, Bulf. fil.

Slopes of Haghier:-B.C.S., schereinf., Bent.

274. †* Vogelia pendula, Bulj., fil., Op. cit. Tal. XlıIT.

Arlho Dimellus (3500 ft., II. 99, No. 212).-11.0.F.

slopes of Haghier, sonth from Hadilu. - B.C.S., sichereinf.

\section{PRIMULACE}

\section{Anagallis, Linn.}

275. * Anagallis arvensis, Lim., var. cærulea, Luml.

Hadilu Plain (XII. 98, No. 107). Slopes of Arluna (400-1500 ft., 21. XII. 98, No. $11: 2)-M .(1 . F$.

Abundant. - B.C.S.

\section{MYRSINE床.}

Myrsine, Linn.

276. *Myrsine africana, Limn.

Collected, locality doulutul. - H.O.F.

Shrut of the higher Haghier.-- I.C.S. 


\section{SAPOTACE压.}

\section{Sideroxylon, Linn.}

277. † Sideroxylon fimbriatum, Balf. fil.

In valley oprening "pon kharlup Plain. Not alundant. B.C.S.

\section{EBENACE尼.}

\section{Euclea, Linn.}

278. $\dagger *$ Euclea laurina, Hier'

"Adho Dinellus (4000 ft.. If. 99, No. 2200). The young stems are chewed loy the matives, and the chewed ont end is used as a tooth In'msh. muder the name of 'Kelle,' lut this is not the plant of the same native name, given to Dr. Sichweinfurth, nsed for the same purpose, which is Burus Hitlebrutiti."-H.O.F.

We have reared seedlings of what is apparenty this plant.

On llaghier and neal Galonsir. - B.C.S.

279. † Euclea Balfourii, Hiern.

On Haghier hills. - B.O.S., stheceinf.

280. Euclea Kellau ?, Hochst.

Abundaut.-B.C.S'

281. Euclea, sp.?

On Haghier. - B.C.S.

282. Euclea, sp.?

On Haghier..-B.r.s.

\section{OLEACE正.}

\section{Jasminum, Linn.}

283. $\dagger^{*}$ Jasminum rotundifolium, Butf fil., Op. cit. Tall. XLI.

Olserved in the valley runuing sonth from Adho Dimellus (3500 ft.). - H.O.F.

Abunlant on the eastern platean of the island, but it occurs also on the Haghier.-B.C.s.. sichureinf., bent.

\section{SALVADORACE E.}

\section{Salvadora, Linn.}

284. * Salvadora persica, Limu.

Vear Harlibu. - Il.o.F., li.c.s.

\section{APOCYNACE床.}

\section{Carissa, Linn.}

285. Carissa Schimperi, $A / p h . \nu C$.

Not uncommunu. - li.C.S., schweinf. 
Socotora, Balf. fil.

286. Socotora aphylla, Balti. fil., Op. e.it. Till. XlN1.

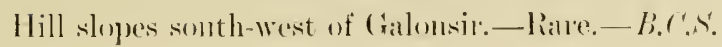

\section{Adenium, Roem. et Schult.}

287. * Adenium multiflorum, Kiotzse'll.

Arluma slopes (400-1500 ft., 21. XII. 9s, No. 116). Hombil (1500 ft., No, 160), - 11.0.l.

A number of plants, some in a IVurdian cise, lout the majonity packerl cly, arrived in exerellent endelition, and ane all alive (I. 1902) in the

lioyal Botanic Garden, Eslinlumegh.

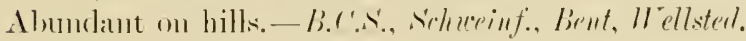

\section{ASCLEPIADEÆ.}

\section{Ectadiopsis, Benth.}

288. † Ectadiopsis volubilis, Balł. til., Oן. cit. Tal. XLI'II.

Common on linestone and granitoid regions of the island.-B.C.s., sichuerinf.

289. † Ectadiopsis brevifolia, Balf. fil.

On limestone plateau south-west from Galonsir (over $1500 \mathrm{ft}$.).- B.C.S.

290. Ectadiopsis, $* t$. !

Near Khatup.- li.es.

\section{Mitolepis, Balf. fil.}

291. † Mitolepis intricata, Bulf. fil., Op. cit. Tah. XLVIII.

Hills near Kharlu] and Kischen.-B.C.s., Schueinf.

\section{Cochlanthus, Balf. fil.}

292. $\dagger^{*}$ Cochlanthus socotranus, Bulf. fil.

Ohserved in valley ruming south from the Artho I)inellus Pass.-H.O.F.

On Haghier hills (over :3000 ft.).-B.C.C.

\section{Secamone, $R$. Br.}

293. † Secamone socotrana, Bult. fil., Op. cit. 'Tal. I.

Haghier range. Near Dimux, eastern platean of ishanl. - b.C.S., Sidneeinf., bent.

\section{Glossonema, Done.}

294. * Glossonema Revoili, Franch.

Hadilu Plain (No. 102).-H.().F.

Galonsir Plain and elsewhere.-Jic.s., sidneeinf., Bent. 


\section{5. * Glossonema Boveanum, Dcne.}

Observerl near our camp at Homhil (1500 ft.), the irlentical species I had seen in the rleselt in S. Arabia, between Lahej and Sheikh Othminl.-H.O.F.

This extends its distrilnution to the Asiatic Continent.

\section{Edithcolea, N. E. Br.}

296. Edithcolea sordida, N. E. Brown, sp. nov.

Pedicelli $\frac{1}{22}$ poll. Iongi, crassi, glabri. Sepala $2 \frac{1}{2}-3$ lin. longa, $1 \frac{1}{2}-1 \frac{3}{4}$ lin. lata, ovata, aenminata, apice recurva, glabra. Corolla magna, exsiccata :3! poll. diam., extra glabra, levis, intra tuberculato-rugosa, atropurpurea, secundum margines et prope apicem lohorum et prarterca secundum lineas ja centro ad sinus radiantes pilis claratis purpureis ornata ; tulus parvols, circiter $1 \frac{1}{2}$ lin. altus, 3 lin. diam. : limbus maximus ultra medium j-lolns disco rel parte iucliviso lato probahiliter patelliformi, lobis exsiceatis $1 \frac{1}{4}$ poll. longis, $7-8$ lin. latis, olbongo-laneeolatis, acutis, apice recurvis. Coronae exterioris lobi vix ${ }_{2}^{1}$ lin. longi, acute bificli, sacenti, intra hirti. Coronae interioris lohi $\frac{3}{4}$ lin. longi, basi lineares erecti, apice triangulari-rlilati, antheris incumbentes, tubereulati.

This differs from the only other species of Erditheolen at present known ( $E$. grumis, X. E. Brown), by the different colonr and more oblong lobes of the eorolla, which is densely tuberenlate-rugose, instead of having concentric raised rirlges as in E. grandis. - N. E. Brr.

Mi: N. E. Brown, of Kew, has kindly examined and described this plant. [This species (No. 145) grew in considerable abmutance on the low granite hills in the Garjeh Plain ; and also round our camp at Jena-agahan. On Somali hoys said they knew it well in the hills of their own country, where they chewed the leaves. These of the soliotran plant were, howerer, they said, more bitter than their own plant. The Sokotri name is Mushharmohum.-H.O.F.]

Calotropis, R. $B r$.

297. Calotropis procera, li. Br

Near Galonsir and elsewhere.-B.C.St.

\section{Vincetoxicum, Mönch.}

298. † Vincetoxicum linifolium, Bulf. fil., Op. cit. Tah. I.I.

Not nucommon.-B.C.S.

\section{Sarcostemma, $R . B r$.}

\section{Sarcostemma Daltoni, Jene.}

On the plains. Speeially abundant near Debeni.-B.C.S., Bent.

\section{Sarcostemma, $s p$.}

On the plains. - B.C'S'. 
301. Sarcostemma, sp.

On the plains. - B.C.S.

\section{Dæmia, $R . B r$.}

302. Dæmia angolensis, Hene.

Common.-B.C.s., shlueinf., bent.

\section{Marsdenia, $R . B r$.}

303. $\dagger^{*}$ Marsdenia robusta, linlf. fil., Op. cit. Talı. LII.

On Girrich Plinil.--II.O.F.

Near Galonsir and Khardup._L.C.S., scheinf., bent.

\section{Echidnopsis, Hook. fil.}

304. Echidnopsis cereiformis, Howk, fil.

limestone hills, north-west from (ialonsir.--b.e.s., lient (?)

\section{Boucerosia, Wight et Arn.}

305. † Boucerosia socotrana, bulf. fil.

Limestone plains. Hill slopes at low altitudes.--B.C.S., Schueinf., Bent.

306. Boucerosia, sp.

Limestone hills west from Hadibn. Near Galonsir.-B.C.S., Shrecinf.

307. Boucerosia, sp)

On platins.--B.C.S.

\section{GENTIANEÆ.}

\section{Exacum, Linn.}

308. $\dagger^{*}$ Exacum cæruleum, Bulf. fil., Op. cit. Tab. IIII.

Adho Imellus (4000 ft., II. 99, No. 222). Growing with its roots tightly jammerl in the seams of the granite rocks. Rich deep blue in colom, and with a sweet perfme. On the summits of both Hamaderu and Matagoti, above our Homhil camp, in the limestone crevices, white rarieties oecmred.-H.O.F.

On higher parts of Haghier hills (at $2500 \mathrm{ft}$.).-B.C.S., sidreinf., Bent. Plants of this brought in a Wardian case all failed.

309. Exacum Forbesii, Birlf. fil., sp. now. (Plate xxvi. A).

Peremis $\frac{1}{2}$ pedalis glaber erectus ramosus, caule tetragono, ramis elongatis 4-angulatis. Folia sessilia nitida $\stackrel{1}{2}$ poll. longa ovata r. elliptica aenta coriacea margine subcartilagineo trinervia ad basin quinquenervia. Flores pedicillati nutantes mediocri pentameri in dichasia terminalia ¿-ramosa aggregati, pedieelli virides r. purpurei 1 poll. longi. Calycis lohi anguste elliptici acuminati. Corolle segmental elliptica subacuta 


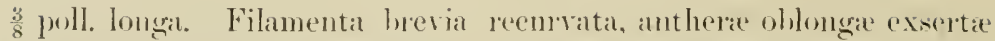
al, alpioe ar merlium dehiscentes. Stylus decurvatus ovario duplolongior, stigma spongiosi.

Sokotial.

A species nearly allied to Errucum ratrilenem. Balf. fil., but differing conspicuonsly in the colour of the flower and the size of its parts. From seeds gathered ly J)r. Forhes a number of plants have heen maised in the Royal Botanic Garken, Edimburgh, and they have flowered freely.

It is a chaming andition to our winter-flowering plants of the intermediate honse, and it is interesting to find a second species of the genus frem Sokotra of horticultural value. Firermm reffine is a Sokotanu plant now not uncommon in cultination, lut it is a poor plant comparreel with Erarmm Forbesii. The latter has the advantage of being pereminal, with a foliage of fine glossy green. It bears free cutting back, ant can le readily trimmerl into a neat companet form. Its sweet-scenterl fowers staud up nicely in small trusses above the foliage, and it las the further merit of coming into flower in late antmmu, like beymuiu sorotrome, and contimuing in bloom for many weeks. Of itself a decorative plant, it will, I heliere, prove nseful for crossing with other species.

310. $\dagger^{*}$ Exacum affine, billf. fil.

"Homhil (2000 ft., No. 176). In the valley's north aur south of the Alho Dinellus Pass, growing on the damp swampy margins of the stream. Not seen in the Haghier valleys below $2000 \mathrm{ft}$. No perfume olserved in this species as in E. cornlenm. White raricties were olsserved."--II.().F.

Whe have raised a good crop of this popmlar liemuial fiem seed brought home ly the expedition.

Not at all uncommon besifle the streams.-B.C.S., Schweinf., Bent.

311. † Exacum gracilipes, linlf. fil.

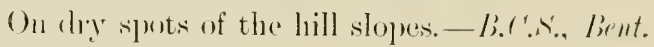

\section{Erythræa, L. C. Rich.}

312. Erythræa Centaurium, I'ris.

On hill slopes. Alumulant.-IB.t's'.

BORAGINEÆ.

\section{Cordia, Limn}

313. $\dagger *$ Cordia obovata, Bulf. fil.

H.U.F.

Common.-B.C.S., Strlneinf.

314. † Cordia obtusa, lielf. fil.

Hills near (xalonsil:--li.C.s. 
315. Cordia Rothii, linlf, fil.

() Haghier lange.-liocst.

\section{Ehretia, Linn.}

316. Ehretia obtusifolia, /hwlist.

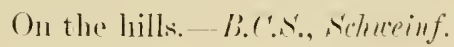

317. Ehretia, sp.

() 11 the lills. -li.e.

\section{Heliotropium, Linn.}

318. Heliotropium ('atinls) zeylanicum, Lımli.

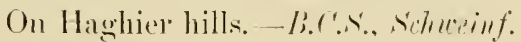

319. † Heliotropium (Monimanthal) dentatum, linlf. fil.

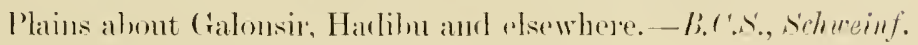

320. * Heliotropium undulatum, V ${ }^{\prime} h l$.

Kamahamu Hill in (xarieh Plain (800 ft., 1. 99, No. 145).-M.O.F.

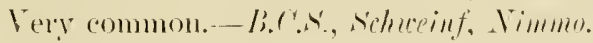

321. Heliotropium rariflorum, storlis.

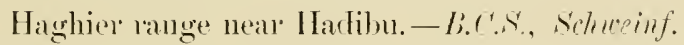

322. Heliotropium (Heliophytum) pterocarpum, Howhst. df Steml.

On slopes of Haghier. - B.t.s.

323. $\uparrow *$ Heliotropium (Heliophytum) odorum, Bulf. fil.

In valley leading south from camp at Atho Dimellus.-H.O.F.

On Haghier hills.-B.Cs.s, schereinf., lient.

324. Heliotropium (Orthostatlys) ovalifolium, Fursk.

On the plains.-B.C.s.

325. * Heliotropium (Orthostachys) strigosum, Hilld.

Homhil (No. 159).- - H.(1).F.

On the plains.-linc.s., Seluecinf.

326. Heliotropium strigosum, Hill, var. scabrum, liet:.

On the plains. - B.r.s., schuceinf.

327. Heliotropium strigosum, $\|$ illl., var. marifolium, liet...

On the plains.-B.r.

328. † Heliotropium (Orthostachys) nigricans, birlf. fil., Op. cit. Tal. LIV, B.

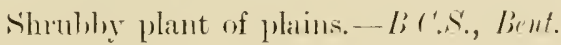




\section{Trichodesma, R. Br.}

329. $\dagger *$ Trichodesma Scotti, limlf. fil., Op. cit. Tah. LV.

Tops of Matagoti ancl Hamadern, above our Hombil camp (2200 ft., Nos. 169, 175.) Arlho Dimellus, growing at $4000 \mathrm{ft}$. in broad masses, both in the sum and under the deep shade.-H.O.F.

Five plants were hrought over in a Wandian case and are alive and healthy (I. 1902). A number of seedlings have also been raiserl in the Rioyal Botanie Garlen, of which one has Howered.

Higher parts of Halghier hills (over $2500 \mathrm{ft}$.)._ls. C.s., Seflueinf., lient.

330. $\dagger^{*}$ Trichodesma microcalyx, Bulf. fil.

Adho Dimellus (4000 ft., No. 196). Homhil. Arlma slopes.-H.O.F.

On Haghier range near Arhuna.-B.C's., Srhweinf., bent, Nimmo.

331. †* Trichodesma laxiflorum, liklf. fil.

Adho Dimellus (4000 ft., No. 18s). Growing luxuriantly under the shade. Flowers occasionally white--H.O.F.

Plants of this pretty hlue-flowered species have lieen raised from seed bonght lome by the experlition, and bave flowered in the Royal Botanic Garden, Edinhmegh.

Common._B.C.s., sirlueinf., Bent.

\section{Cystistemon, Balf. fil.}

332. $\dagger^{*}$ Cystistemon socotranus, Bulf. fil., Op). cit. Tał. LVI.

Homhil (1700 ft.), on Matagoti (No. 157). Homhil (2000 ft.), on

Hamaderı, with white flowers (No. 18t). Arlho I limellus (4000

ft.), white flowers also observed. (General colour deep blue.-M.O.F.

On limestone cliffs (over $1500 \mathrm{ft}$.).-B.C.S., Schueinf., Bent.

A seedling of this interesting plant was raised in the Royal Botanic Garden, Edinburgh, but, as is the way with many horaginaceous plants in enltivation, it suddenly died off.

\section{CONVOLVULACEE.}

\section{Ipomœa, Linn.}

333. * Ipomœa obscura, $K e r$.

Slopes of Aduma (400-1500 ft., 21. XII. 98, No. 140).-H.O.F.

Not uneommon.-B.C.S., Schueinf., lient.

334. * Ipomœa biloba, Forsk.

On the shores.-B.C.S., Schueinf., II.O.F.

335. †े Ipomœa (Quamoclit) laciniata, Bulf. fil.

Plains near Galonsir:- B.C.S.

336. Ipomœa (Pharbitis) scabra, Forst.

On the hills.-B.C.S, bent. 
337. * Ipomœa (Aniscia) cardiosepala, Morhst.

Harlibu Plain (XII. 98, No. 104). Slopes of Armua (400-1500 ft., 21. XI1. 98, No. 125). ?'Tuhers eaten ly the natives.--M.O.F.

Plants of this from seed bonght by the Expedition lave flowered in the Royal Botane (ianden, Edinbmigh.-D.C.s., schweinf.

\section{Convolvulus, Linn.}

338. $\dagger^{*}$ Convolvulus filipes, Bulf. fil.

On all the plains. - B.C.S., Schuceinf., H.O.F.

339. † Convolvulus sarmentosus, Birlf. fil.

Limestone platean overlooking Galonsir on the west (over 1500 ft.).B.C.S.

340. Convolvulus glomeratus, Choisy.

Plainss and hill slopes.-B.C.S., Schreinf., Bent.

341. Convolvulus siculus, Limn.

Near Galonsir._B.C.S., Schueinf.

\section{Evolvulus, Linn.}

342. * Evolvulus alsinoides, Linn.

Common.-B.C.S., Bent, II.O.F.

\section{Porana, Burm.}

343. * Porana obtusa, linlf. fil.

West end of Khadup Plain.-B.C.S., H.O.F.

\section{Breweria, R. Br.}

344. Breweria (Sedderia) latifolia, licuth.

On the plaius. - B.C.S., Schweinf.

345. † Breweria (Seddera) pedunculata, Bulf. fil.

On the plains. - B.C.S.

346. † Breweria (Seddera) glomerata, Bulf. fil.

On the plains.-B.C.S., Srluceinf., Bent.

347. $\dagger$ Breweria (Secldera) fastigiata, Bulf. fil., Op. cit. Tab. LVIII

On the plains. -B.C.S., Selueeinf., Bent.

\section{Dichondra, Forst.}

348. * Dichondra repens, First.

Not uncommon._-B.('s., Schueinf., H.O.F.

349. Cressa cretica, Limn.

\section{Cressa, Linn.}

Sanrly plains.-B.C.S. 


\section{Cuscuta, Linn.}

350. * Cuscuta planiflora, Teume, var. globulosa, linlf. fit.

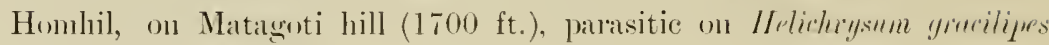
(No. 1:0). - H.O.F.

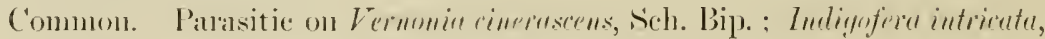

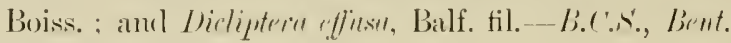

351. Cuscuta chinensis, Ltrmk:

Common on many plants. - b.t.s., schereinf., lient.

\section{SOLANACE压.}

\section{Solanum, Limn.}

352. * Solanum nigrum, linn.

Fruits collecterl on (iebel Matagoti (19. I. 99, 2000 ft.) : Kamahaum (2x. XII. 9s) : Arlho I)imellus (3800 ft.). - II.O.F.

Plants of this species, raiser from solotian seed, lave flowered in the

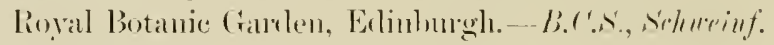

353. * Solanum indicum, leres wh. Esent.

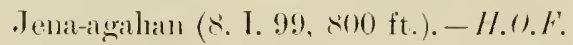

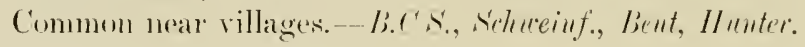

354. * Solanum gracilipes, Ir⿲m.

Haghier slopes south of Harlibu. M.O.F.

Foot of limestone hills west of Harilun.-Sichereinf.

\section{Physalis, Linn.}

355. Physalis minima, Linn.

Near Harlihn._Schucinf., licut.

\section{Withania, Pauq.}

356. Withania somnifera, Dumul.

Near Harlilu.- Schereinf., Inuter.

$\dagger^{*}$ Withania Riebeckii, Sthrinf., Op. cit. Tal). LגX.

slopes of Arluma (400-1500 ft., 21. XIl. 98, No. 119). Slopes of limestone hills west of Haulibu.-H.(1)F.

We have plants of this species in the Royal Botanie Garlen, Bimburgh, from seeds lormglat ly the expedition, and they lave flowered.

On plains near villages. - B.C.S. Sthereinf.

\section{Lycium, Linn.}

357. Lycium europæum, linn.

Galonsir ancl elsewhere.-B,CS., sthueinf., birut. 


\section{Datura, Linn.}

358. *Datura fastuosa, Limn., vall. alba, Clurlie.

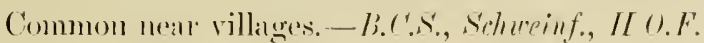

\section{SCROPHULARINE 压.}

\section{Anticharis, Endl.}

359. Anticharis arabica, Eimll.

simdy plains, - li.t's.

\section{Linaria, Juss.}

360. Linaria (Elatimuiles) hastata, R. Br.

On the plains. - B.t's', schueinf.

\section{Schweinfurthia, A, Braun.}

361. Schweinfurthia pedicellata, lientl. of Homli.

On the plains. - B.C.s.

\section{Antirrhinum, Linn.}

362. Antirrhinum Orontium, Limn.

On Khadup Plain._b.C.s.

\section{Scrophularia, Linn.}

363. Scrophularia arguta, Ait.

Hill slopes...-li.ts., Scheinf.

\section{Lindenbergia, Lehm.}

364. Lindenbergia sinaica, lientl.

On the plains. - b.c.s., schue inf.

\section{Herpestis, Gärtn.}

365. Herpestis Monnieria, H. K. K.

Common in marshy places. - B.t.s., schueinf.

Camptoloma, Benth.

366. †Camptoloma villosa, birlf. fil.

Cliffs of Haghier range (over $3000 \mathrm{ft}$.). - b.C.St.

\section{Campylanthus, Roth.}

367. † Campylanthus spinosus, Birlf. fil.

Plains near Galonsir and elsewhere-B.t.s., Shweinf., Bent, Hunter. 


\section{Striga, Lour.}

368. Striga orobanchoides, lienth.

On the plains. Parasitic on Vitis-b.C.S., Schueinf., lient.

369. Striga hirsuta, Benth.

Plains aloout Galonsir.-li.t.S.

\section{Graderia, Benth.}

370. $† *$ Graderia fruticosa, Bulf. fil., Op. cit. Tal. LXII.

Adho Dimellus (4200 ft., Nos. 229, 2:3s).-H.O.F.

We have seerllings of this species in the lioyal Botanic Garden, Eilinlmugh, from seed lnought by the experlition.

Rare. On the slopes of the Haghier hills (at about $3000 \mathrm{ft}$.). Top of Sieante Peaks, behind Hadilu. Kischen._B.C.S., Stheinf., Jent.

\section{Xylocalyx, Balf. fil.}

371. † Xylocalyx asper, Bulf. fil., Op. cit. Tal. I.XIII.

Limestone plains near Galonsir and elsewhere.--B.C.S., Bent.

\section{OROBANCHACE床.}

\section{Cistanche, Hoffm}

372. $\uparrow$ Cistanche lutea, Hoffin. ef Link.

Slopes of Aduma (4000 ft., 21. XII. 9s, No. 121). Growing in the black soil in the deep shade under the slope of a limestone rock, with no plant near it, so that the roots of its host, which were very deep, must have come from some very eonsiclerahle distance.-H.O.F.

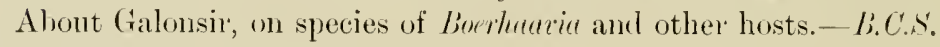

373. Cistanche tubulosa, /right.

Near Galonsir:-B.C.S.

\section{Orobanche, Linn.}

374. Orobanche (Osproleon) abyssinica, Acl. likh.

On Haghier.-B.C.S., Sihucinf., Bent.

375. * Orobanche (Osproleon) cernua, Lijfl.

Alumclant on nany posts. - B.C.S.'.

376. * Orobanche (Trionychon) ramosa, Lim.

Ohserved on hills near. Hombil anct on Arluna slopes.

Near Galonsir on Lertuce.- Bi.C's. 


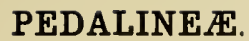

\section{Pedalium, Linn.}

377. * Pedalium Murex, limn.

Slopes of Adunia (1000 ft., 21. XlI. 98, No. 117). Jena-agahan (10. I. 99). Sieeds collecterl.-H.O.F.

Seeds of this which were collecterl by the expeclition were barely ripe, and have not germinated.

Plains ahout Galonsir, Hadilon, and elsewhere.-B.t.s'., schweinf,, Bent.

\section{ACANTHACE无.}

378. Ruellia patula, Jucy.

\section{Ruellia, Linn.}

Plains near Galonsir and elsewhere.-B.C.s., Sthweinf., Bent(?), Vimmo.

379. † Ruellia patula, Jurl., var'. pubescens, Bulf. fil.

I.C.S., Schueinf.

380. † Ruellia patula, Juc\%., var. minor, binlf. fil.

B.C.S.

381. $\dagger{ }^{*}$ Ruellia insignis, Bulf. fil., Op. eit. Tah. LXIV.

In the Dinehan valley learling from Hadibu Plain to Artho Dimellus Pass. It was not olserved below about $2500 \mathrm{ft}$., and not ahove $3600 \mathrm{ft}$. Grows in extensive thickets.-H.O.F.

I $\mathrm{am}$ glad to be alle to say that seeds of this beantiful flowered plant have germinated in the Royal Botanie Cranden, Edinhmrgh, and the thriving young plants will, I hope, flower ere long, and enalle ns to add a charming species to cultivation.

Common on Haghier. - B.C.S., Stheeeinf., Bent.

382. † Ruellia carnea, Bulf fil.

Thongh eager search was made for $R$. curnen, it was not encomtered in the Haghier mountains or the east end of the island. - II.O.F.

Plains near Galonsir._B.C.S., Sclueinf., Bent.

\section{Blepharis, Juss.}

383. Blepharis boerhaaviæfolia, Juss.

On the plains.-B.C.S., Sclueeinf.

384. $\dagger^{*}$ Blepharis spiculifolia, Bulf. fil.

Garieh Plain, at eamp under Kamahann.-II.O.F.

On the plains near Harlibn.-B.C.S., Srhweinf.

\section{Barleria, Linn.}

385. † Barleria aculeata, Bulf. fil., Op. cit. Tal,. IXVII.

Common on north slopes of the Haghier range.-B.C.S., Schueinf., bent. 
386. $\dot{\circ}$ Barleria tetracantha, Bilf. fil.. Op, cit. Tal, LXVIII.

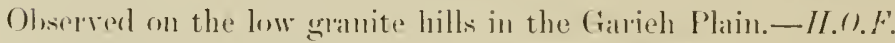

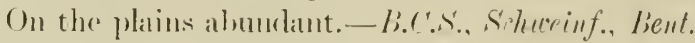

387. † Barleria argentea, linlf. fil.

Kharlup, Plain.-li.r's.

388. Barleria $\%$ " fl\% B. Lawii, T'. Amter.

Collecterl by bent.

Of this plant onity a fragmentary specimen exists in the Bent collection, and the atfinity has heen detemined as alwe ly Mr. C. B. Clarke.

Neuracanthus, Nees ab. Esenb.

389. † Neuracanthus aculeatus, linlf. fil., (Op. cit. Tihl. LXIX, A.

On the plains.-lices.

390. † Neuracanthus capitatus, linlf. fil., Op. ('it. Till. LAIX, B.

Iny limestone regioms. Kharlup Plain.-B.ts.

Asystasia, Blume.

391. * Asystasia coromandeliana, lees (t). Lisent). II.O.F.

Common._B.C.S., Sechereinf.

\section{Ballochia, Balf. fil.}

392. † Ballochia amœna, Birlf. fil., Op. cit. Tal, LXX.

Near Kharlup. Near Haulilu, on plains and hill slopes.-lics. Scheceinf., Brout, Ilunter.

393. † Ballochia rotundifolia, Bulf. fil., Op. cit. Tal, LXXI, A.

Haghier hills; limestone platean sonth-west from (ralonsir (over $1500 \mathrm{ft}$.). - b.C.S., Simurinf.

394. † Ballochia atro-virgata, Birlf. fil., Op. cit. Tal. LXXI, B. Hill slopes.-B.C'S'. Bent.

\section{Justicia, Linn.}

395. Justicia (1 Hanieria) heterocarpa, T. Amler:s.

Near Hadilur. - B.C.s., Selnceinf.

396. Justicia (Genlarussa) rigida, Bulf, fil., Op. cit. Tab. LXXII.

On the plains.-B.C'S.

\section{Trichocalyx, Balf. fil.}

397. † Trichocalyx obovatus, Belf. fil., Op. cit. Tah. LXXIII, A.

On the hills.-.-lices., Schureinf., IInuter. 
398. Trichocalyx orbiculatus, Bulf. fil., Op. cit. Tal. IXXIII, B.

Hills sontl-west of (talonsir.-- B.C.S., lient.

\section{Anisotes, Nees ab. Esenb.}

399. ${ }^{*}$ Anisotes diversifolius, Bulf. fil., Op. cit. TaI, I.XXIV.

. Tentalagahan (1500-2000 ft., :3. I. 99, No. 2:31). In valleys south of Arlho Dimellus Palss (3500 ft., II., 99, No 2:3:3). - H.11.F.

On hills near Galonsir and Keregnigiti, vicinity of Haddulu- R.C's., sirhueinf., Bent.

A pretty flowered acanth, of which we have raised a few seellings in the Royal Botanic Garden Edinlmigh.

400. † Anisotes diversifolius, vil. brevicalyx, linlf. fil.

On Haghier:- B.C.:.

\section{Rhinacanthus, Nees ab Esenb.}

401. $\dagger *$ Rhinacanthus scoparius, lirlf. fil., Op. cit. Tal. IXXV.

Near Hadilu and elsewhere.-B.C.S., Shreme.

\section{Ancalanthus, Balf. fil.}

402. † Ancalanthus paucifolius, Bulf. fil., Op. cit. Tab. LXXY'.

Entrance of valley Ireh opening on Nuget Plain._-R.C.s's.

\section{Ecbolium, Kurz.}

403. $\dagger *$ Ecbolium striatum, Bulf. fil., Op. cit. Tals. LXXVII, A.

Haghier mountains helow Arlho Dimellus (No. 20:3).-H.O.F.

On Haghier hills (over $2000 \mathrm{ft}$.). - B.C.S., Shreeinf., Bent.

404. † Ecbolium striatum, var. minor, Bulf. fil.. Op. cit. Tah. LXXYII, B. Common.- B. B.

\section{Dicliptera, Juss.}

405. † Dicliptera effusa, Bulf. fil.

Common.-B.C.S., Schuceinf.

406. † Dicliptera ovata, Bulf. fil.

Near Hadibu, on hill slopes.- B.C.S.

Peristrophe, Nees ab Esenb.

407. Peristrophe bicalyculata, Vees al, Lisent.

Widely distributerl._B.C.s., sichueinf. 
Hypoestes, R. Br.

408. ${ }^{*}$ Hypoestes verticillaris, li. lir., var. mollis, Bulf. fil.

s'lopes of Adluna ( $800 \mathrm{ft}$, , 21. XII. 98, Nus. 1:20, 1:38).-H.O.F.

Very common.-B.C.S., Scheceinf., Bent.

409. Hypoestes verticillaris, $R$. Bir, var. denudata, Teps.

410. † Hypoestes pubescens, Bulf. fil.

Haghier hills at consilerable elevation.-B.CS., Schreinf.

\section{SELAGINEÆ.}

\section{Cockburnia, Balf. fil.}

411. † Cockburnia socotrana, Bulf. fil., Op. cit. Tals. LXXVIII. Hills ahove $1000 \mathrm{ft}$ - - li.es.s., Seluevinf.

\section{VERBENACE压.}

\section{Lippia, Linn}

412. * Lippia nodiflora, Michr.

Slopes of Aduna (400-1500 ft., ㄴ. XII. 98, No. 115).--H.O.F.

In marshes - B.C..., Bent.

\section{Priva, Adans.}

413. Priva leptostachya, $J_{11 s:}$

On hill slopes. - B.C.'s'

\section{Cœlocarpus, Balf. fil.}

414. †* Cœlocarpus socotranus, Belff. fil., Op. cit. Tah. LX XIX.

Adho I)imellus (Nos. 191, 2.28).-H.O.F.

On slopes of hills (over $1000 \mathrm{ft}$.).-B.C.S., bent.

I have been disappointed in that seeds of this interesting plant have not germinaterl.

\section{Clerodendron, Linn.}

415. † Clerodendron galeatum, Bulf. fil., Op. cit. Tah. LXXX.

On Haghier hills behind Harlihu. - B.C.S.

416. $†$ Clerodendron leucophlœum, Bulf. fil.

A common tree.-B.C.S.s.

\section{Avicennia, Linn.}

417. * Avicennia officinalis, Linn.

No. 559.- H.O.F.

Khor Hadjin and elsewhere.-B.C.S. 


\section{LABIAT㾁.}

\section{Ocimum, Linn.}

418. Ocimum canum, sims.

Everywhere.-B.C.S., Schovinf.

\section{Orthosiphon, Benth.}

419. Orthosiphon tenuiflorus, Bentll.

Abundant.-B.C.s., Schueinf.

420. * Orthosiphon pallidus, lioyle.

Top of Hamadern, ahove our Hombil camp (No. 163).-H.O.F.

Common.-B.C.S.'

421. Orthosiphon ferrugineus, linlf. fil.

On Haghier hills.-B.C.S., Schreinf., Bent.

\section{Plectranthus, L'Her.}

422. *Plectranthus, sp.

Limestone plateanx (over $1500 \mathrm{ft}$.).-B.C.S., Schweinf.

Some fragments of this were in one of the Wardian cases from Sokotra, lnt alid not survive.

\section{Lavandula, Linn.}

423. † Lavandula Nimmoi, Benth.

On plains and hills._B.C.S., Schweinf., Hunter, Nimmo.

\section{Micromeria, Benth.}

424. Micromeria microphylla, Benth.

Abundant. - B.C.S., Schureinf.

425. Micromeria microphylla, Benthe, var. remota, Bellf. fil.

$$
\text { B.C.S., Schuceinf. }
$$

426. Micromeria microphylla, Bentl.. var. imbricata, Bielf. fil.

\section{Leucas, $R . B r$.}

427. Leucas (Hemistoma) urticæfolia, li. $\mathrm{Br}$.

Near Galonsir, Hadibn, and elsewhere.-B C.s., schweinf.

428. Leucas (Loxostoma) Neuflizeana, Courl.

Harlihu. Cocheeinf.

429. Leucas (Ortholeucas) lanata, Benth.

Haghier hills. --B.C.S, Schueinf., Bent. 
430. $\dagger^{*}$ Leucas (Ortholeneas) virgata, Binlf. fil.

Everywhere.-B.C.S., Schreiuf., H.O.F.

\section{Lasiocarys, Benth.}

431. † Lasiocarys spiculifolia, Bulf. fil., Op. cit. Tah. LXXXI, A.

On the plains,-li.t.s., lient.

432. † Lasiocarys flagellifera, Brelf. fil., Op. cit. Till. L.XXXI, B.

limestone eliffs south-west of Galonsir:- B.C.S.

\section{Teucrium, Linn.}

433. $\dagger$ Teucrium (Polium) prostratum, linlf. fil.

Base of limestone cliff's near Galonsir: near Hadibu. - B.C.s., Hunter.

434. $\dagger^{*}$ Teucrium (Polinum) petiolare, Bulf. fil.

Adho I)imellus (No. 211).-- H.O.F.

Hills south of Galonsir and on Haghier-_B.C.S., Stheeinf.

435. † Teucrium (Polimm) petiolare, rar. pubescens, bulf. fil.

Haghier hills (3000 ft.).-Schurpinf.

\section{PLANTAGINE床.}

\section{Plantago, Linn.}

436. * Plantago amplexicaulis, Cur.

('arieh plains.-H.O.F.

Ahundant on the plains. - B.C.S.

\section{Genus Anomalum.}

Wellstedia, Balf. fil.

437. $\dagger$ Wellstedia socotrana, Bulf. fil., Op. cit. Tal, LXXXII, A. B.C.S., Hunter.

\section{NYCTAGINE压.}

\section{MONOCHLAMYDEÆ.}

\section{Boerhaavia, $\operatorname{Linn}$.}

438. Boerhaavia repens, Linn.

(n plains.-B.C.S.'.

439. Boerhaavia diffusa, Limn.

Hill slopes.-B.C.S., Schuceinf.

440. * Boerhaavia scandens, Limn.

Seeds probahly of this species collected.-H.O.F.

Common.-B.C.S., bent. 


\section{ILLECEBRACE压.}

Haya, Balf. fil.

441. $\dagger^{*}$ Haya obovata, Bilf. fil., Op. cit. Tah. LXXXIII.

Adho I)imellus (No 19:3).-H.O.F.

Hill slopes.-B.C.S., schureinf.

\section{Lochia, Balf. fil.}

442. † Lochia bracteata, Bulf. fil., Op. cit. Tah. LXXXIY.

slopes of Haghier:-B.C.S.

\section{AMARANTACE $Æ$.}

\section{Digera, Forsk.}

443. Digera arvensis, For $s$.

Hadibu.--Schuceinf., Bent.

\section{Amarantus, Linn.}

444. *Amarantus (Euxolus) Blitum, Limu.

Commoll.-B.C.S.

445. Amarantus (Euxolus) polygamus, Limu.

Oceasional.-B.C.S., Scheceiuf.

\section{Pupalia, Juss.}

446. Pupalia lappacea, $J_{H s s}$.

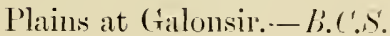

\section{Psilostachys, Hochst.}

447. Psilostachys sericea, Beuth.

Near Galonsir and Haulibu.-B.C..., Schuecinf.

\section{Arua, Forsk.}

448. * Ærua javanica, Jl1s:

Hadilu Plain (No. 98).-H.O.F.

Common._B.C.S.'

449. † ÆErua microphylla, $1 / \mathrm{w}$. Balf. fil., Op. cit. Tab. LXXXV.

Plains about Galonsir. - b.C.s., schereinf., Bent, Nimme.

450. ÆFrua lanata, Juss.

Near (talonsir and elsewhere._B.' '.s., schureinf., Itunter.

451. Erua lanata, Juts, var. robusta, Bitlf. fil.

Plains near Galonsir.-- B.C.S.', schuceinf. 
452. $\dagger^{*}$ Erua revoluta, linlf. fil.

Jena-agahan (1500-2000 ft., :3. I. 99, No. 150)- H.0.F.

On the Haghier range at considerable elevation. - B.C.S... Silucrint., Brut.

\section{Achyranthes, Linn.}

453. Achyranthes aspera, Linn.

Common.-B.C.S., bent.

454. Achyranthes aspera, Linn, var. sicula, Limn.

On plains. - B.C.s., Bent.

\section{CHENOPODIACEE.}

\section{Chenopodium, Linn.}

455. Chenopodium murale, Linn.

Near Galonsir:-B.t's'.

Atriplex, Linn.

456. Atriplex Stocksii, Boiss.

Near Khor Hadjiı, Khadup Plain. - B.C.S.

Suæda, Forsk.

457. Suæda monoica, Forsl:

Commonl. - B.C.S

\section{POLYGONACE无.}

Polygonum, Linn.

458. * Polygonum (Persicaria) glabrum, Willt. H.(1.F., B.C.S.

459. Polygonum (Persicaria) barbatum, Limn.

B.C.S.

\section{ARISTOLOCHIACE}

460. * Aristolochia, sp.

\section{Aristolochia, Linn.}

Fonncl in flower (3. II. 99), on granite slopes in a rock-crevice above onr camp at Adho J)imellus. The roots, which are narrow, watery, and white in colour, are eaten liy the hill people. The roots were brought to us also while at Homhil, lut without fower or foliage. The herlarium specimen appears to have unfortunately been lost.-W.U.F.

On cliff's sonth-west of Galonsir, _ B.C.S.

\section{PIPERACE床.}

Peperomia, Ruiz et Pav.

461. Peperomia arabica, Dent.

Haghier hills._B.C.S., stheinf. 
462. Peperomia reflexa, A. Dirti, var. parvifolia, (t.. $I)$ :

Occasional._B.es, schureinf.

463. Peperomia Goudotii, ILi $\%$.

Haghier range.- l b.C.A., stlureinf.

\section{THYMEL床ACE床.}

Lasiosiphon, Fresen.

464. $\dagger^{*}$ Lasiosiphon socotranus, Bulf. fil., Op. cit. Tab. LXXXVI.

Adho I)imellus (Nos. 17 $7,189,216)$. - H.O.F.

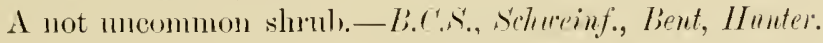

$\Lambda$ charming plant, seeds of which have, however, not yet germinated.

\section{LORANTHACEÆ.}

\section{Loranthus, Linn.}

465. Loranthus, sp.

Near Galonsir.-B.C.S.

\section{SANTALACE无.}

Osyris, Linn.

466. Osyris arborea, II ill.

On Haghier range (over $1500 \mathrm{ft}$.).-B.C.S., Schueinf.

467. $\dagger *$ Osyris pendula, Belf. fil., Op. cit. Tab. LXXXVIl.

Seen growing, out of reach, on top of a high eliff on the limestone hills to the south-west of Hadlibu.-H.O.F.

On the Haghier hills. - B.C.S.

468. Thesidium, sp.?

\section{Thesidium, sond.}

Khadup plaiı._B.C's.'.

\section{EUPHORBIACE压.}

Seeds of several Euphorbiacere plants have germinated in the Royal Botanic Garden, but it is too soon yet to identify the species in all cases with certainty.

\section{Euphorbia, Linn.}

469. * Euphorbia (Anisophyllum) indica, Lemk.

Hadibu Plain.-H.O.F.

Near Galonsir and Hadibu. - B.C.S., steweinf.

470. * Euphorbia (Anisophyllum) Chamæsyce, Linn.

Adho Dimellus. Plast gathered (‥ II. 98). - H.O.F.

Many places.-B.C.S., sirhweinf., Bent. 
471. † Euphorbia (Anismphyllum) leptoclada, Binlf. fil.

Ahove Kischen (orer $2700 \mathrm{ft}$.). Whitureinf.

472. $\dagger *$ Euphorbia (kemoplyton) socotrana, birlf. fil., Op. cit. 'Tall. LXXXVIII.

On Hamaderu, a limestone hill alwere our camp) at Homlil (at 2500 ft., No. $1 \times \cdot 3)$. - H. (1). F

On shopes of hills on looth sides of island.-B.C.S., Sthecinf., Innter:

473. † Euphorbia (Tirucalli) obcordata, Bulf. fit.

kocky places near (Galonsil:-b.c.s'

474. † Euphorbia (Timcalli) Schweinfurthii, linlf. fil.

Alsove Kischen (orer $2500 \mathrm{ft}$.).-. S'chuceinf., lient.

475. † Euphorbia ('Tirucalli) oblanceolata, Bulf. yil.

Haghier hills south from Hadibu.--B.C.s.

476. * Euphorbia ('Tirucalli) Schimperi, l'resl.

On the slopes of Aduna (500-1500 ft., ․․ Xll. 9s, No. 1:34).-W.O.F.

Common about Galonsir, Harlibu and elsewhere.-B.1's., Sthweinf., Hunter.

477. †* Euphorbia (Tirucalli) arbuscula, birlf. fil., Op. cit. Tal. LXXXIX.

Collected near Homhil.- H. () F.

Abundant.-B.C.S., schereinf., Bent.

A plant of this species came home safely in a ITandian case and is now growing in the lioyal Botanie Garden, Edinburgh.

478. † Euphorbia arbuscula, var. montana, Bilf. fit.

On the hills.--li.c.s'., s'chuevinf.

479. $\dagger^{*}$ Euphorbia (I)iaciuthium) spiralis, Bulf. fil.

Collected on Gelel Bitzobur (14. I. 99) : and at Hombil (2.2. I. 99).H.I.F.

On the plains : not inferpuent.-B.C.S.

We have a couple of plants of this species alive in the Roval Botanie Garrlen, Elinlurgh. They came home in a Wardian case.

\section{Buxus, Linn.}

$480 *$ Buxus Hildebrandtii, litill.

This species grew in great abundince at Homhil, forming large shrulheries; towarls the summit of Dimimi it was also alundant, and here ripe seed was gathered (8. 1.98) in cllautity (No 204).--II.0.F.

Many seedlings of this are in the Roval Botanic Giarlen.

Abuudant.-B.C.s., Sthereinf., Hunter.

\section{Phyllanthus, Linn.}

481. Phyllanthus (Paumphylliunthus) maderaspatensis, Liun.

Neatr Galonsir. - B.C.S., Sichuceinf. 
482. Phyllanthus rotundifolius, //illl., var. leucocalyx, Mill. Aly

Near Galonsir:- B.C.s'

483. † Phyllanthus (Kiphỵllanthus) filipes, linlf. fil.

On the plains. - b.c.s., Siluecinf.

\section{Securinega.}

484. † Securinega Schweinfurthii, Bulf. fil.

Alove IVarly l)igal (ovel $1500 \mathrm{ft}$.). - Schereinf.

\section{Fliiggea, Willd.}

485. Fluggea microcarpa, Blume.

Common. - D.'.'s., Schweinf., lient?

486. Flüggea Leucopyrus, Iilll.

Near Galonsir.- I.A.s.

\section{Jatropha, Linn.}

487. $\dagger^{*}$ Jatropha (Adenoropinm) unicostata, linlf. fil., Op. cit. Talb. XC.

Growing abundantly on Hadibu Plain, but only at the base of the limestone lills. It was alsent from the granite-sand covered parts of the plain. Seeds were colleeted and lrought home.-H.O.F.

There are several healthy young plants of this in the Royal Botanic Garden, Edinhurgh.

Alnurlant - B.C.S., Sihweinf., Bent, Perry, Hunter.

\section{Croton, Linn.}

488. † Croton (Eluteria) sarocarpus, Balf. fil., Op). cit. Tab. XCI.

Many places on hill slopes.-B.C.S., Schweinf.

489. † Croton (Elıteria) sulcifructus, Bulf. fil., Op. cit. Tal. XCII.

On Haghier hills._B.C.S., schueinf., II unter.

490. † Croton (Eluteria) elæagnoides, liulf. fil.

On Haghier hills.--li.c.s.

491. $\dagger^{*}$ Croton (Elnteria) socotranus, liulf. fil., Op. cit. Tal. XCIII.

Garieh Plain.-II.O.F.

Plains and lower slopes of hills._li.C.S., Srhweinf., Bent.

\section{Chrozophora, Neck.}

492. Chrozophora tinctoria, Ad. Jllss.

Near Galonsir.-B.C.S.

493. Chrozophora obliqua, All. J/1ss.

Near Galonsir, and Hadibu.-Di.C.S. 
494. Chrozophora obliqua, / . .uss, var, frutescens, sillueinf.

Near Hadihu.--Sthueinf.

Cephalocroton, Hochst.

495. $\dagger^{*}$ Cephalocroton socotranus, bulf. jil., Op. cit. Tal, XCIV.

Top of Hamader'n, a limestone hill alove our camp at Homhil (No. 16t). -H.O.F.

Many places, both on great altitudes and on the shore plains.-B.C.S., schueinf., birut.

Acalypha, Linn.

496. *Acalypha indica, Linn.

Near villagess. - b.c.S., schueinf., H.O.F.

\section{Ricinus.}

497. ${ }^{*}$ Ricinus communis, liun.

Near villages in Garich Plain.-II.O.F.

Near Galonsis.-B.C.S.

Tragia, Linn.

498. $\dagger *$ Tragia (Tagira) dioica, Bulf. fil.

Adho Dimellus (No. 227). Kamahanu, Gelel Bitzolur, and elsewhere; very almulant.-H.O.F.

Common on slopes of Haghier.-L.C.S., Schueinf., Bent.

\section{URTICACE环.}

\section{Dorstenia, Linn.}

499. $† *$ Dorstenia gigas, Schurinf.

On the limestone hills above our camp at Hombil, growing in erevices of the rocks and assuming extraordinary forms ; on the top of Gebel Homhil (3500 ft.). - H.O.F.

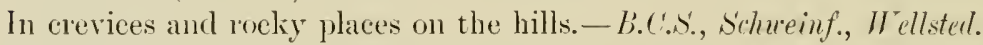

Several plants of this, brought home in a Wardian case, are now alive in the Royal Botanie Garden, Elinlurgh.

\section{Ficus, Linn.}

500. $\dagger^{*}$ Ficus (Urostigma) socotrana, Bulf. fil.

On the slopes of Achuna (400-1500 ft., 21. XII. 9s, No. 109). On the Hombil platean. Native name Taiek.-H.O.F.

Abundant.-B.C.S., Schueinf.

501. * Ficus (Urostigma) salicifolia, Tuhl.

Hadibu Plain (Nos. 99, 187). Largely fecl upon by the Starlings (Amyilus blythi).-H.O.F.

spread orer the island.-B.C'S., schueinf.

502. Ficus, $8 \%$.

b.C.S. 
Pouzolzia, Gaud.

503. Pouzolzia auriculata, Wiight.

On the hills._B.C.s., Schercinf.

Forskohlea, Linn.

504. Forskohlea viridis, l) $f$.

Common._B.C.S', Schureinf.

Australina, Gaud.

505. Australina capensis, ITedel.

On hill slopes._L.C.S.

\section{MONOCOTYLEDONES.}

\section{HYDROCHARIDE压.}

\section{Largarosiphon, Harv.}

506. Largarosiphon Roxburghii, Beuth.

In river pools.-Boivin.

\section{ORCHIDEE.}

\section{Habenaria, Willd.}

507. $\dagger^{*}$ Habenaria socotrana, Bulf. fil., Op. cit. Talb. LXXXII, B.

On the slopes of Aduna.-H.O.F.

Hills near Galonsir.-B.C.S., Nimmo.

Tubers of this small flowered species have flowered in the Royal Botanic Garden, Eslinburgh.

\section{Angræcum.}

508. Angræcum dives, liolfe?

An epiphytie speeies, found hoth by Mr. Ogilvie-Grant and Dr. Forbes to the soutl of Adho l)imellus, was brought home alive, and has Howered in the Royal Botanic Garlen. Mr. Rolfe thinks it is possibly this species, but the leaves are only one-fourth as large as those of the type which is a plant of Kilimanjaro and Mombasa.

\section{Holothrix, L. C. Rich.}

509. $\dagger^{*}$ Holothrix socotrana, Rolfe, sp. nor.

Adho Dimellus (No. 210).-H.O.F.

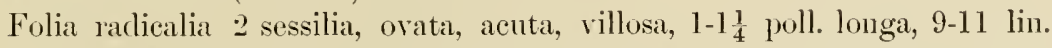
lata. Scapus erectus, dense pilosus; spica lorevis, multiflora. Bracteac lanceolatae, acuminatae, pilosae. Śepala ovato-oblonga, subobtusa. 
Petala lineari-ohlonga, subohtusi, integra. Labellum profunde trifidum, lohis lineari-ohlongis, subol,tusis ; calcare conico hrevi. Columna brevis.

Allied to the Abrssinian $/ 1$. limbrelii, Rolfe. This specimen is rather imperfect, ant the Hower's still in the hul state, hit the extension of this essentially African genus into Sokotra is so interesting that I have rentured to describe it, omitting, howerer, the dimensions of the flower, which might have been misleading. In the specimen the sepals are a line long. Li. L. Rinlfe.

I an indehtert to Mr. Rolfe, of Kew, for the description of this species.

\section{IRIDEÆ.}

\section{Romulea, Maratti.}

510. $\dagger^{*}$ Romulea purpurascens, Tenore, var. edulis, Brtker.

On the slopes of Aduma (21. XI1. 9s, $2000 \mathrm{ft}$., No. 130). Homhil (3000 ft,, No. 168). The tuhers were gathered largely here for

food. This species ocems also in Abd-el-Kuri.-H.O.F.

Haghier hills (over $3000 \mathrm{ft}$.). - Schereinf., Nimmo, Bent, llollsterl.

Plants of this species are now glowing well in the Royal Botanic Garlen, Edinburgh.

\section{Babiana, Ker.}

511. $\dagger^{*}$ Babiana socotrana, Momk: fil. Bot. Mag. Tal. 6585.

On limestone slopes alove our. Hombil camp (at about 1700 ft.). Also in the sparse soil on lerlges of the granite rocks in the Haghier hills (at $3000 \mathrm{ft}$.), in association with Exucum ceruleum, E. Forbesii, Begoniu socotictue, de.-II.O.F.

On the hill slopes south-west from (xalousir._B.C.S.

Tubers of this interesting plant have flowered in the Royal Botanic Gaurlen, Exlinburgh.

\section{AMARYLLIDE巴E.}

\section{Crinum, Linn.}

512. $\dagger *$ Crinum Balfourii, Bulier. Bot. Mag. 'Talb. 6570.

On the limestone slopes of Hamarleru above our camp at Hombil (1700 ft.), the bulbs growing sometimes in enormons clumps weighing over a humdredweight. Native name "Difataha."-H.().F"

On the high plains (at an elevation orer $1500 \mathrm{ft}$.), south-west from Galonsir:-B.C.S.'.

A splentid series of bulbs of this beantiful sweet-seented plant (collected hy Forbes) were brought home, and some of them flowered within a month of their arival in the Royal Botanie Garden, Edinburgh. It is a species which, as has been before now pointed ont, should be of value in lonticultme, not only for its indivichal merits, but for erossing for its perfume. 


\section{Hæmanthus, Linn.}

513. $\dagger^{*}$ Hæmanthus grandifolius, linlf. fil.

On the linestone slopes to the sonth-west of Hadiln ; on the slopes below

Arluma (2000 ft.) : also on the higher parts (1800-2000 ft.) of looth

Hamader'n and Matagoti, alove our camp at Hombil, this spreies was abmolant. A mumber of tubers, of what is believed to be this plant, were brought home. The plant was not seen in flower, lut its two (and oeeasionally three) large broad leaves render it conspicuons and ummistakeable. - II.O.F.

The stream banks of the slopes of Haghier, south from Hadibu. - B.C.S.

These tubers are still alive, lut they have not yet thrown up any leaves or Hower stalks (VIII. 02).

\section{DIOSCOREACE无.}

\section{Dioscorea, Linn.}

\section{4. $\dagger *$ Dioscorea lanata, Bulf. fil.}

On the hills above our eamp at Homhil. They were being constantly hunted for by the natives for food.-H.O.F.

Has flowered in the Royal Botanie Garden, Eclinburgh.

On Haghier.-B.C.S., Schueinf., Nimmo.

\section{LILIACE $Æ$.}

\section{Asparagus, Linn.}

515. $\dagger^{*}$ Asparagus africanus, Ltmk, var. microcarpus, Bulf. fil.

On the plains.-B.C.S., Schweinf., H.O.F.

\section{Aloe, Linn.}

516. $\dagger^{*}$ Aloe Perryi, Buket. Bot. Mag. Tab. 6596.

Adho Dimellus (4000 ft., II. 99, Nos. 198, 219).-H.O.F.

Various parts of the island.-B.C.S., Schweinf., Bent, Perry, Collins, Irellsted.

Several plants of this speeies were brought home by the expedition in a

IVardian ease, and are now growing well in the Royal Botanic Garden, Edinlurgh.

[Mr. Holmes sends me the following report upon speeimens of aloes brought by the expedition and submitted to him :

"Three speeimens of Soeotrine aloes were reeeived, viz. :

1. Solid, in an earthenware ressel.

๑. Liquid, in a large bottle.*

3. Liquid, in a small bottle.

* The liquid aloes in bottles Nos. 2 and 3 belongs to the same collection. That in the small bottle had stood for some time, and had thus, by evauoration, becone slightly more concentrated.-H.O.F. 
No. 1 represents aloes such as would be comsirlered in English commeree of second-elass quality, being hlackish and giving a dull bown powder and oparne splinter when hroken.

No. 2, when eraporated, gave a brownish transparent aloes, vielding a brownish yellow powder of a pleasant odom, and wonld be elassed in commerce ats first-class Sokotrine aloes.

No. 3 presents the same appeanance, and gives a similar powder to No. 2. The specimens have heen examined chemically at my request hy my friend, IV. A. H. Naylor, F.I.C., in the labolatory of Messis. Hearon Squire it Francis, with the following results:-

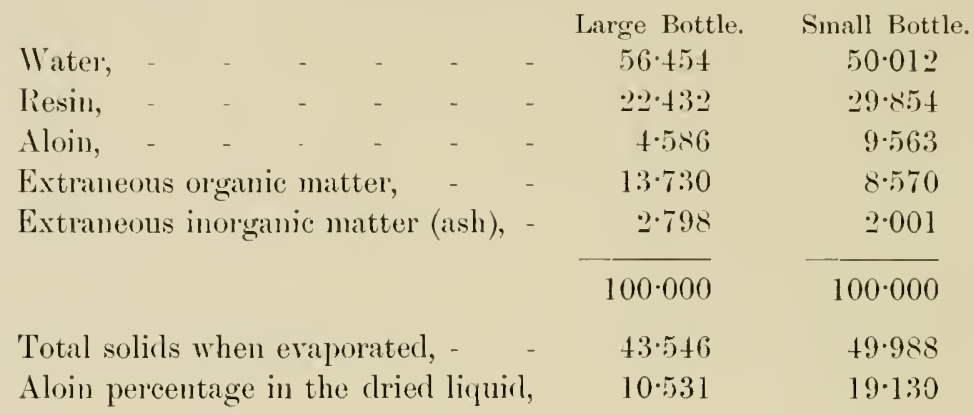

It may here be mentioned that the aloes producerl from the leaves of Aloe l'ermi, Baker, is the only kind known which does not give a crimson coloration with strong nitric acirl when the latter is chopped upon the powdered alves.

The fact that No. 3 contains a larger percentage of aloin is probaloly due to the fact that the bottle No. 2 contained the upper stratum of liquirl aloes, that bottle being first filled, whilst No. 3 was filled with the lower stratmo of the same liquicl. When aloes juice is allowed to settle a eonsiderable portion separates and falls to the bottom of the ressel, forming a yellowish deposit at the bottom of a dark brown liquid.

Socotrine aloes is usually imported into this comntry in kegs. The aloes is of a treacly or pasty consistence, and varies in colour and odour, according to the care exereised in its preparation and conservation. The parcels imported of late years have been very inferior in ruality, and a really good Sokotrine aloes has long heen a desideratmm in the market. The hest Sokotrine aloes, now rarely seen in commerce, has a garnet colomr, transheent fragments, and a somewhat fragrant odour. The wholesale price for the hest Sokotrine aloes olutainable in eommerce is at present alout 4 s. (id. per llb. But it must he remembered that $1 \mathrm{ll}$ ). of aloes juice as imported will only yield alont $\frac{3}{4} \mathrm{lb}$. of dried aloes, so that the price obtained liy the exporter at drug anctions is considerably less, varying from ahout 80s. to 90s. per cwt. Another variety presenting the characters of Sokotrine aloes in odour and ehemical test (i.c., giving a reddish brown, bnt not crimson, colour 
when a little of the powrlesed drug is touched with strong nitric acid) is sold under the mame of Zinziluar aloes. This is usnally solicl, opaque, hownish, and is packed in goats' skins. A spurions kind importer in tins, or tir-lined cases, is also sold as Sokotrine aloes. This has a different odour, and gives a crimson colour when the powder is tested with nitric acirl. It will be understoor therefore that there is a demand for gemuine Sokotrine aloes of good quality, i.e., curefully prepared as it would be done ly Europeans. Such a drug wonld prohably feteh $95 \mathrm{~s}$. to $100 \mathrm{~s}$. per ewt, aceording to the quantity in the market at the time or the scarcity of the drug. An aceount of the preparation of aloes in Sokotra is given in the Boteny of Socotre, Introduetory Chapter, p. xxxriii., by Professer [ B. Balfour."-H.O.F.]

517. $\dagger *$ Aloe squarrosa, Beker.

I'hat I helieve to be this species, the leaves being distinctly white, was olsenved on Gebel Bitzolur, a limestone hill in the Garieh Plain (about $800 \mathrm{ft}$.) ; and on the slopes of Ferah, or Gehel Dryat as it is also called, the highest peak of the Haghier (at ahont $+200 \mathrm{ft}$.), one of which I attempted to bring home alive in a Wadian case. - II.O.F.

Base of the limestone eliffs, sonth-west of Galonsir, - B.C.S.

518. +* Aloe Forbesii, Bulf. fil., sp. non. (Plate xxvi в.) H.O.F.

Camlis lnevis sulsarmentosus internorliis $\frac{1}{8}-\frac{1}{4}$ poll. longis. Folia $5-6$ patula late amplexicaulia linearia acmminata +-6 poll. longa, $\frac{1}{2}$ poll. lata, medio $\frac{1}{4}$ poll. erassa, glaucoviridia immaenlata hand lineata, facie a basi canaliculata ad apicem teretia, dentibus marginalilus plus minusve evolutis interdum in plantis junioribus mullis deltoirleis minutis $3 ?_{2}^{1}$ poll. longis rectis allidis cartilagineis. Inflorescentia simplex 8-9 poll. Jonga, pedunculo commmi deorsum applanato glanco bracteas $4-5$ steriles gerente. Racemus cylindricus laxiflorus pauciflorus 2 poll. longus, pedicellis $\frac{1}{2}$ poll. longis rulnris, bracteis deltoideo-acuminatis minutis $\frac{3}{16}$ poll. longis pedicellis hevioribus membranaceis pulvino hasali instructis. Perianthium trigono-cylindricum rulıro-lutem $\frac{3}{4}$ poll. longum, tulo supra orarimm leviter constrictum, limbi lobis oblongis $\frac{1}{4}$ poll. longis linea media virichla tinctis. Petala sepalis dorsaliter ammexa laterilmsque intra perianthii tubum liberis. Stamina antisepala loreviora inclusa filamentis applanatis, antipetala longiora loreviterque exserta filamentis teretibus. Stylus staminilus longioribus requilongus.

Sokotra.

Along with the living specimens of Alop Perryi bronght home by the expedition were youmg plants of two other species. One of these has now flowered in the Royal Botanic Garden, Edimburgh, and this hitherto molescribed species I here name. It is easily distingnisherl from Aloe Perryi and Aloe sqmurima, the other Sokotran species; from the former by its thin not erect stem, narrow leaves, and simple 
inthorescence with smaller flowers: from the latter ly its unspotted narrow leares. The plant is a neat one resembling, when young, in which condition the leaves ane often spineless, some of the Mesemhryanthemums. The inflorescence is a small one with too few and small flowers to be striking as a horticultural plant.

\section{Dracæna, Vandel.}

519. $\dagger^{*}$ Dracæna Cinnabari, Bulf. fil., Op. cit. Tabl. XCV1, XCVII.

Fomm this species in flower and fruit, on 26. 1. 99, on Hamaderu (at $2500 \mathrm{ft}$.), alowe onr eamp at Homhil. This was the ouly tree seen in Hower during our stay - lecember "98 to Felumary 99. (No. 165.) Native name given to us by the Alho Dimellus natives, "Arhiel,." -H.(I.F.

Several plants of this species came home alive in a Wardian case, and we have an almulant supply of seedlings, from fruit collected by the experlition, in the Royal Botanic Garden, Elimhmgh.

Common. - B.C.S., Schereinf., P'riry, II ellsted.

\section{Asphodelus, Linn.}

520. *Asphodelus fistulosus, Limn., var. tenuifolius, Buler, Bot. Mag. t. 984 .

On the hill slopes near Galonsir.-B.('.t.

J ena-agahan (1500-2000 ft., 3. I. 99, No. 151).-- II.(1.F.

521. * Scilla indica, Bukior.

\section{Scilla, Linn.}

II.O.F.

Amongst the bulhs lrought home are some which, on flowering in the Royal Botanic Garden, have tmmed ont to belong to this species. This is an interesting ardition to the Sokotran Flora. The plant is one of the Decean Peninsula and Central India, and is known also from Abyssinia. The Sokotran habitat thus connects these extremes.

Anthericum, Linn.

522. $\dagger$ Anthericum (Phalangimm) graptophyllum, Butker.

Hills in several places. - B.C.S., Schueinf.

\section{Dipcadi, Medicus.}

523. $\dagger *$ Dipcadi ('Tricharis) Balfourii, lukler.

some of these tubers have flowererl in the Royal Botanie Garlen, Edinhuigh.

A few tubers of this species were collected on the limestone slopes above our camp at Homhil.--M.O.F.

B.C.S. 


\section{Urginea, Steinh.}

524. † Urginea porphyrostachys, Butier.

Near Kischen (over 3000 ft.).-Schweinf.

\section{AROIDE巴.}

\section{Remusatia, schott.}

525. *Remusatia vivipara, Schott.

An abmolant supply of tubers of this species was brought home, and are now growing well in the Royal Botanic Garden. One or two Howered shortly after their arrival, and we were thus able to determine the species.

This adds another to the list of Sokotran speeies with an otherwise only Eastern Asiatie distribution. Several aroids are nseful economic plants, but I cannot find that this species has any such value, and it is not therefore likely to have heen purposely introduced into Sokotra ; but the spiny shoots might, as Sir George King suggests, facilitate its accidental introduction in the considerable intercourse between India and the island in the early portion of this century.

Arlho Dimellus. In swampy places in the valleys north and south of our camp (No. 202).-H.O.F.

\section{COMMELINACEE.}

\section{Commelina, Linn.}

\section{6. * Commelina benghalensis, Limu.}

Many localities._B.C.S., Schweinf.

Ohserver on the hills above Harlibu ; also on Hamarleru above our camp at Homhil, on the limestone. Also on the slopes of Arluma.-H.O.F.

527. Commelina (Heterocarpus) Forskalæi, Vahl.

Ahout Galonsir and Hadilu, and other places._B.C.S., Schueinf.

528. Commelina (Heteropyxis) albescens, Hassk.

Near Galonsir and Hadihu.-B.C'S., Schueinf.

\section{Cyanotis, Don.}

529. * Cyanotis cristata, licun. if Schult.

Near Hadilus.-B.C.s'.

On Hadibu Plain; slopes of Aduna, near our camp at Dahamis (21. XII. 98).-H.O.F.

\section{JUNCACE尼.}

\section{Juncus, Linn.}

\section{0. * Juncus maritimus, Lamk.}

Ahout Galonsir and elsewhere.-B.C.S., Schweinf.

Near Khor Garieh.-H.O.F. 


\section{PALM咂.}

\section{Phœnix, Linn.}

531. * Phœnix dactylifera, Limn.

On hanks of streams in Harlihu Plain, and in the ravines of the Guahal (rorge, and generally.-B.C.S., Schreinf., II.O.F.

\section{Borassus, Linn.}

532. * Borassus flabelliformis, Linn.

Oceasionial. - B.C.S.

Seen in the Date-palm groves in Harlibu and Garieh Plains.-H.O.F.

\section{NAIADACE压.}

\section{Potamogeton, Linn.}

533. Potamogeton natans, timi., subsp. plantagineus, $D u$ Croz. B.C.S.

534. Potamogeton fluitans, Fioth.

B.C.S.

535. Potamogeton pectinatus, Linn.

In streams.- I.C.S.

\section{Ruppia, Linn.}

536. Ruppia maritima, Linn.

Streams near Galonsir.-B.C.S.

\section{Naias, Linn.}

537. Naias major, All.

Streams near Galonsir.-B.C.S., Schweinf.

538. * Naias (Caulinia) graminea, Delile.

In streams near Garieh. - B.C.S.

In the Nesharhir river, under Gebel Bitzobur- - H.O.F.

\section{CYPERACE平.}

\section{Cyperus, Linn.}

539. Cyperus (Pyerens) pumilus, Linn., var. patens, Benth.

On Haghier hills. Not common.-B.C.S., Schweinf.

540. Cyperus (.Juncellus) lævigatus, Limn.

About Galonsir, abundant.--B.C.S., Schweinf.

541. * Cyperus amabilis, $V a h l$.

Near Aduni, on the Haghier hills (at a high altitude).-B.C.S.

On the slopes of Arluna, ahove our camp at Dathamis.-H.O.F. 
542. * Cyperus aristatus, lintth.

Near Harlihu.-- B.C.S.

.Jena-agahan (1800 ft., I. 99, No. 146). H.(1.F.

543. Cyperus rubicundus, lithl.

Near Galonsir.-B.C.S.

544. Cyperus compressus, Linn.

On Haghier hills south from Hadilm. - B.C.S.

545. Cyperus proteinolepis, Bkli.

Near Galonsir.-B.C.S.

546. Cyperus proteinolepis, var. major, Bulf. fil.

Nimmo.

547. † Cyperus conglomeratus, Ristll, var. socotranus, Brelf. fil.

Near Galonsir.-B.C.S.

548. Cyperus difformis, Lim.

Near Hadibu, - B.C.S.

549. Cyperus (Papyrus) Tegetum, Rork.

Near Galonsir.-B.C.S.

550. Cyperus (Papyrus) tenuiflorus, Rietth.

On the banks of the stream at Katheng,- Schreinf.

551. Cyperus (Papyrus) rotundus, Limn.

Near (Galonsir:-B.C.S., Schweinf.

552. Cyperus (Marisens) umbellatus, Benth., var. cyperinus, Bulf. fil.

Near Hadibu. - B.C.S.

553. * Cyperus Teneriffæ, Poir.

Not previously recorded from Sokotra.

.Jena-agahan (1800 ft., I. 99, No. 15:).-H.O.F.

\section{Kyllinga, Rottb.}

554. Kyllinga brevifolia, Rotth.

Common.-B.C.S., Schueeinf.

\section{Heleocharis, $R, B r$.}

555. Heleocharis (Heleogenus) albovaginata, Bckli., rar. humilis, beckl.

Near Hadibu. - B.C.S.

556. * Heleocharis (Heleogemis) capitata, R. Bi.

Almmlant on sancly banks of streams.-B.C.s., schuecint.

By the stream ruming into Khor Garieh. - II.O F. 


\section{Fimbristylis, vahl.}

557. Fimbristylis (1)ichelostylis) diphylla, $I_{11} l$ l.

Haghier hills at various altitudes.-D.C.S., Schueinf.

558. Fimbristylis (1)ichelostylis) ferruginea, $T$ whl.

Common. - B.C.S.s., stheinf.

559. Fimbristylis ('Trichelostylis) hispidula, Kinth.

At Galonsir and Harlibu.- B.C.s.

560. Fimbristylis (Trichelostylis) autumnalis, lir'm. et Srhult.

Haghier hills. - Ii.C.s.

561. Fimbristylis (Trichelostylis) glomerata, Nees ul, Esserelt. Abundant.-B.c.s., schueinf.

Fuirena, Roltb.

562. Fuirena glomerata, Lamk.

On Haghier.-B.C.s:

Cladium, $P, B r$

563. Cladium mariscus, $I^{\prime} . \mathrm{Br}$.

Near Hadilu. - B.C.S., schweinf.

GRAMINEE.

Paspalum, Linn.

564. Paspalum scrobiculatum, Liun.

Near Galonsir. - B.C.S.

565. Paspalum distichum, Limu.

Galonsir.-B.C.S., Schweinf.

Eriochloa, H. B. \& $K$.

566. † Eriochloa vestita, Bulf. fil.

Limestone plains south-west of Galonsir (at over $1500 \mathrm{ft}$.). - B.C.S.

\section{Panicum, Linn.}

567. * Panicum (I)igitaria) sanguinale, Linn.

Common.-B.C.S.

Adura slopes (400-1500 ft., No. 108, 21. N1I. 98),-H.O.F.

568. * Panicum Teneriffæ, li. Br.

This is an aldition to the Sokotran flora.

Aduna slopes (400-1500 ft., No. 108, 21. XII. 98).-H.O.F.

569. Panicum (Brachiaria) paspaloides, Pers.

Near Galonsir and elsewhere.-B.C.S., s'chueinf. 
570. Panicum (Brachiaria) eruciforme, Silth.

Near Hadibn,-B.C.S.

571. Panicum (Echinochloil) colonum, Liun.

Abundant.-B.C's'.

572. Panicum turgidum, Forsl:

Abundant near Galonsir.-lis.s., sichueinf.

573. Panicum Petiveri, Trin.

Very common. - L.C.s., Srlhweinf.

574. Panicum nudiglume, Hochst.

Wadi Digal; Kischen.--Schweinf.

575. Panicum nudiglume, Hoclst, varr. major, Hochst.

Near Galonsir. - B.C.S.

576. Panicum atrosanguineum, Hwehst.

Haghier hills.-B.C.S., schereiuf.

577. † Panicum ridigum, lialf. fil.

Galonsir, Hadibn and elsewhere. - B.C.S., schuoeinf.

\section{Oplismenus, Beauv.}

578. Oplismenus Burmanni, Betur.

Common.-B.c.s., Seluceinf.

579. Oplismenus compositus, limur.

Wadi Digal. _- śchweinf.

\section{Setaria, Beauv.}

580. Setaria glauca, Bicule.

Abundant.-B.r.s.

581. Setaria viridis, Beenr.

Not uncommon.-B.C.S.

582. * Setaria verticellata, berm!r.

Near Galonsir. - B.C's.

Aduna slopes (400-1500 ft., No. 144, 21. XII. 98).-H.O.F.

Cenchrus, Linn.

583. Cenchrus Schimperi, Itorlst. et Strut.

Abundant.-B.C.S.

\section{Pennisetum, Pers.}

584. Pennisetum dichotomum, Islil'.

Common._B.C.S., Schureinf. 
585. * Pennisetum cenchroides, l'ris.

Very common, - b.C.s., schucinf.

586. * Pennisetum orientalis, liirle.

This is an addition to the flora of Sokotra.

Acluna slopes (400-1500 ft., No. 141, 21. XII. 98).--H.O.F.

\section{Rhynchelytrum, Hochst.}

587. † Rhynchelytrum microstachyum, Belf. fil., Op. cit. Tial. XC'VIII, ג.

Galonsir: Halibu.-li.t.s.

588. $\uparrow$ Rhynchelytrum microstachyum, val, albicomum, Bialf. fil

Galonsir ; Harlihn.-D.C.S., Scherinf.

\section{Tragus, Haller.}

589. Tragus racemosus, Desf.

Common.-B.C.S.

Imperata, cyr.

590. * Imperata arundinacea, cyr.

Occasional. - IB.C.S.

Near Khor Garieh.-H.O.F.

\section{Arthraxon, Beauv.}

591. Arthraxon molle, Benth. et Hook.

Common.-B.C.s., Schueinf.

\section{Heteropogon, Pers.}

592. Heteropogon hirtus, lee's.

Common on hill slopes._B.C.S., Schueinf.

\section{Andropogon, Linn.}

593. Andropogon (Cymbopogon) hirtus, Limu.

Abundant.-B.C.S., Schereinf.

594. Andropogon (Cymbopogon) laniger, Des.j.

Hills near Galonsir and Hadibu. - B.t.S., Schueinf.

595. Andropogon (Gymuandropogon) pertusus, Willl.

Haghier hills._L.C's', s'chueiuf.

\section{Chrysopogon, Trin.}

596. Chrysopogon Gryllus, Trin.

Plains about Galonsir.-B.C.S. 
Anthistiria, Linn.

597. Anthistiria ciliata, Limn.

Common on the hills..-B.C.S., Schweinf.

\section{Apluda, Linn.}

598. * Apluda aristata, Limn.

Common.-B.C.S., Schneinf.

Aduna slopes (400-1500 ft., No. 142, 21. XII. 98).-H.O.F.

\section{Aristida, Linn.}

599. Aristida (Chreturia) adscensionis, Linn.

Very common.-B.r.S., Schweinf.

600. Aristida (Arthratherum) murina, Cnn.

Near Galonsir.--B.C.S.

Sporobolus, $R . B r$.

601. Sporobolus spicatus, Kinth.

Not uncommon.-B.C.S.

\section{Cynodon, Rich.}

602. Cynodon (Fibichia) dactylon, lich.

Near Galonsir.-B.C.S.

\section{Chloris, Swartz.}

603. Chloris barbata, sucutz.

Common,-B.C.S.

Melanocenchris, Nees.

604. Melanocenchris Royleana, Nees.

Very common.-B.C.S., Schureinf.

\section{Eleusine, Gärtn.}

605. * Eleusine ægyptiaca, Pers.

In many plices. - B.C.S.'.

Hadibu Plain (No. 101). - H.O.F.

606. * Eleusine indica, Giritu.

Common and cultivated.--B.C.S., Scluceinf.

607. Eleusine verticillata, linxt.

Haghier hills. - B.C.S. 


\section{Pappophorum, Schreb.}

608. Pappophorum (Emeapogon) Aucheri, Jutb. de Spuch.

Galonsir:-li.c's:

609. Pappophorum elegans, Nees.

Near Galonsir:- B.C.'s.

\section{Eragrostis, Beauv.}

610. Eragrostis plumosa, Link:

Common.-B.C.S., sichweinf.

611. Eragrostis orientalis, T'in.

Not uncommon.--- B.C.S.

612. Eragrostis (Leptostachya) pilosa, Beun.

Near Galonsir.-B.C.S.

613. Eragrostis (Cataclastos) ciliaris, Link.

Common.-B.C.S., Schweinf.

614. Eragrostis (Megastachya) cynosuroides, lixm. et Sichult.

Near Hadibu, - B.C.S.

\section{Aluropus, Trin.}

615. * ÆEluropus repens, Ptrl.

Shores at Galonsir and Hadibu.-B.C.S., Schweinf.

Near foot of Gebel Bitzobur.--H.O.F.

\section{Lolium, Linn.}

616. * Lolium temulentum, Limn.

Near Aduna.B.C.S., H.O.F.

Lepturus, $R . B r$.

617. $\dagger$ Lepturus tenuis, Bulf. fil.

Plains at the eastern end of island.-B.C.S.

\section{Ischnurus, Balf. fil.}

618. $\dagger$ * Ischnurus pulchellus, Balf. fil., Op. cit. Tilb. XCVIII, B.

Neal Galonsir- B.C.S.

Seen on Homhil platean._LILO.F. 


\section{II.-The Flowering Plants of Abd=el= Kuri.}

DICOTYLEDONES.

\section{POLYPETALAE.}

CAPPARIDE床.

Cleome, Linn.

1. Cleome brachycarpa, likll.

On plain facing our anchorage in Bander Saleh (Nos. 5, 29, 49; 4. XII. 98).-H.O.F.

Several forms of this varial,le species.

\section{RESEDACE庄.}

\section{Reseda, Linn.}

2. Reseda viridis, limlf. fil.

Very ahumbant on slopes of Gehel Saleh (Nos. 24, 58, 72, 77, 78: XII. 98).-H.O.F.

We have raised a number of plants of this speeies in the Royal Botanic Garlen, and they have flowered. It has not itself much value as a horticultural plant, but might be useful throngh its perennial eharacter in crossing for perennial races.

POLYGALE正.

Polygala, Linn.

3. Polygala erioptera, $D C$.

(No. \&; 4. XII. 98)-H.O.F.

\section{CARYOPHYLLEE.}

4. Polycarpæa spicata, Aim.

Polycarpæa, Lamk.

(No. 18).-H.O.F.

5. Polycarpæa cæspitosa, Bulf. fil.

(No. 39).-H.O.F.

\section{PORTULACE正。}

\section{Portulaca, Linn.}

6. Portulaca oleracea, Limn.

On the plain north of Bander Saleh.-II.U.F. 


\section{ZYGOPHYLLEÆ.}

\section{Zygophyllum, Limn.}

7. Zygophyllum simplex, Lim».

(Nos. 7:, \&6).-H.O.F.

\section{GERANIACE正.}

\section{Geranium, Linn.}

8. Geranium muscatense, Boisis.

H.O.F.

\section{LEGUMINOS $\circledast$.}

\section{Crotalaria, Linn.}

9. Crotalaria leptocarpa, Bulf. fil., Op. cit. Tal. XIV, A. Plain in front of anchorage (No. 14; 3. XII. 98).-HI.O.F.

\section{Lotus, Linn.}

10. Lotus arabicus, Lim. var. trigonelloides, II the ant benth. (Nos. 7, 9, -21, 69).-H.O.F.

\section{Indigofera, Linn.}

11. Indigofera leptocarpa, Horhst. and stemt. (Nos. 20, 2:3).--H.O.F.

\section{Tephrosia, Pers.}

12. Tephrosia (Reineria) Apollinea, $D C$ :

(Nos. 44, 70 ; 4. XII. 98).-W.O.F.

Acacia, Willd.

13. Acacia eburnea, Willi. (Nos. 63, 79; 4. NII. 98).-H.O.F.

\section{CRASSULACE正.}

Kalanchoe, Adans.

14. Kalanchoe rotundifolia, Hux:

On limestone rocks of Gehel Saleh.--H.O.F.

Seeds of this species wcre collecterl.

\section{CUCURBITACE正.}

\section{Cucumis, Linn.}

15. Cucumis prophetarum, Linn.

(No. 38; 4. XII. 98).-H.O.F. 


\section{FICOIDE压.}

$$
\text { Aizoon, Linn. }
$$

16. Aizoon canariense, Limn.

(No. s0). II.O.F.

$$
\text { Orygia, Försk. }
$$

17. Orygia decumbens, Firsk:

Seeds of this species were collected.

\section{UMBELLIFER}

$$
\text { Carum, Linn. }
$$

18. Carum (Trachyspermum) pimpinelloides, Bulf. jil. (No. 93).-II.O.F.

A seedling. probably of this species, is in the collection under No. 16.

\section{RUBIACE尼.}

\section{GAMOPETALÆE.}

Hedyotis, Linn.

19. Hedyotis pulvinata, Bulf. fil.

(Nos. 60, 66).-H.O.F.

\section{COMPOSIT无.}

Pulicaria, Gärtn.

20. Pulicaria stephanocarpa, Bulf. fil.

(Nos. 51, 55, 56).-H.O.F.

\section{Lactuca, Linn.}

21. Lactuca rhynchocarpa, Bulf. fil.

(No. 30).-H.O.F.

\section{Heterachæna, Fresen.}

22. Heterachæna massaviensis, Fresen.

(No. 70 bis). - H.O.F.

\section{PLUMBAGINE无.}

\section{Statice, Linn.}

23. Statice cylindrifolia, Firsk.

(Nos. 6, 81 ; 3. XII. 98).-H.O.F.

\section{ASCLEPIADE尼.}

Glossonema, Done.

24. Glossonema Revoili, Fruteh.

(Nos. 4.) 4:3, 5:3). -II.O.F. 


\section{Cochlanthus, Balf. fil.}

25. Cochlanthus socotranus, linlf. fil., Op. cit. Tab. XIIX.

(Nos. 7 t, $76,8: 3,85: 4$. XII. 9s). A small tree with leantiful foliage growing ont the slope of (iebel Saleh in abundance.-H.O.F.

We have seedlings of this in the Roval Botanic Garden. The dried material is not sufficient for identifieation, there being no flowers.

BORAGINE王。

Heliotropium, Linn.

26. Heliotropium undulatum, trihl.

(Nos. 3, 4, 17, 31, \&2, 97 ; 3. XII. 98).-H.O.F.

Trichodesma, $R . B r$.

27. Trichodesma laxiflorum, Billf. fil.

(Nos. 2, 27, 64; 3. XII. 98).-H.1).F.

\section{CONVOLVULACEE.}

\section{Convolvulus, Linn.}

28. † Convolvulus Granti, Bul. fil., sp. nor.

Herha rhizomate lignoso rerticali, canlilus phumis radiatim postratis

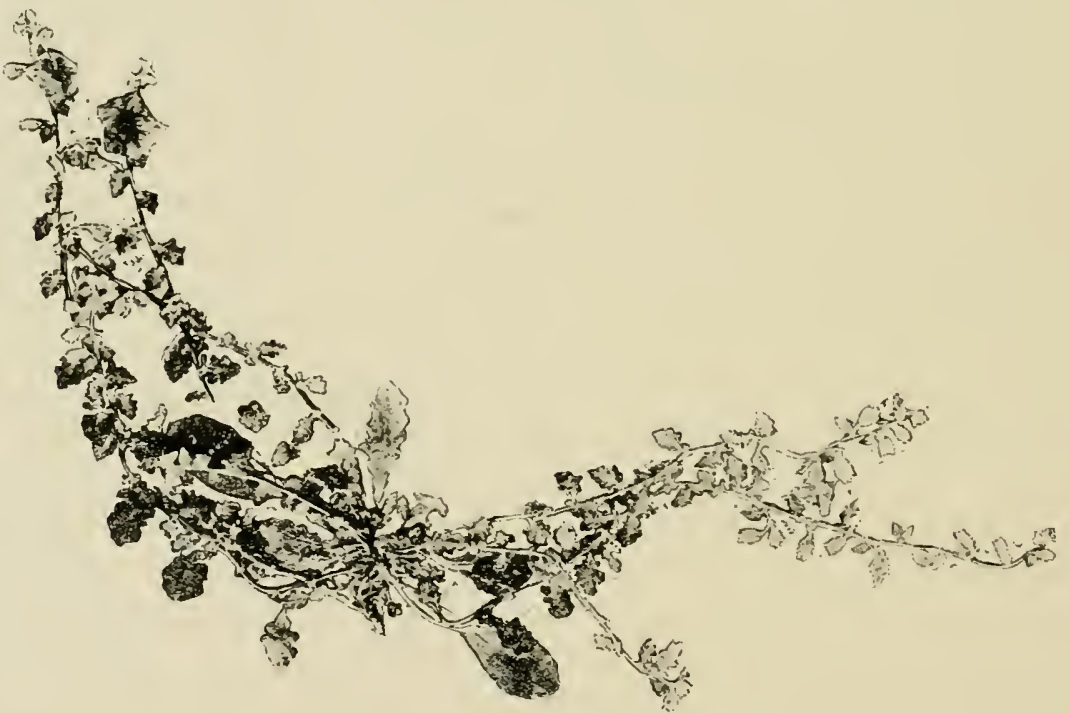

CoNVGLULet GRANT.

temuiter virgatis simplicilus elongatis fere ad 6 poll. cano-rillosis. Folia rhizomatis infima rosulata elongato-spathulata longe petiolata subsinnata apice subacuta $1 \frac{3}{4}$ poll. longa, $\frac{1}{2}$ poll. lata, superiora gradatim ollaneeolata crenato-dentata v. subcrenato runcinatil v. 
pimnatifida lohis pancis rotundatis, pulsescentia, canlina lanceolata r. sublyrata $r$. orata $v$. subhomboidea hreviter petiolata $v$ subsessilia grosse pancimque erenata $r$ lolis paucis rotumdatis lateralibus, lobo terminali triangulari, coriacea, dense cano-villosa, $\frac{1}{4}-\frac{3}{4}$ poll. longa, $\frac{1}{8}-\frac{1}{4}$ poll. lata. Flores solitarii rarissime hini, in axillis hractearmm foliacearum ad apicen ramulosum racemose positi, perlicellis ${ }_{4}^{1}-\frac{1}{8}$ poll. longis ad medium libracteolatis vilosis bracteis longioribus. Sepala $\frac{3}{16}$ poll. longa extus villosa, intus glahra, lanceolata acuta interiora lato margine membranacea. Corolla $\frac{1}{2}$ poll. longa alla extus al angulos hirsuta. Ovarium glabrum. Semina immatura glahra.

(Nos. 13, 45, 46, 50; 3-4. X11. 98.) Abumlint on the plain north of Bander Saleh.-H.O.F.

A pretty prostrate herb, and readily distinguished from all described forms. I give here a photograph of one of the dhied specimens.

\section{Breweria, $R, B r$.}

29. Breweria (Seclera) fastigiata, Bulf. fil., Op. cit. Tal. L VIII. (No. 9:2).-H.O.F.

\section{Cuscuta, Linn.}

30. Cuscuta planiflora, Ten. var. globulosa, Bulf. fil. (No. 3:3 on Gilmssmemu: No. ts on a Composite ; t. XIl. 98).--M.().F.

\section{SOLANACEE.}

Lycium, Linn.

31. Lycium europæum, Lim.

(Nos. 3:2, 96).-H.O.F.

\section{SCROPHULARINE环.}

\section{Anticharis, Endl.}

32. Anticharis arabica, Eull.

(No. 19).-H.O.F.

\section{Linaria, Juss.}

33. Linaria Elatine, Linu.

(No. 94).-H.O.F.

A widespread Eastern plant, not known from Sokotra.

\section{Campylanthus, Roth.}

34. Campylanthus spinosus, Bulf. fil., Op. cit. Tal. IXI. (No. 61).-H.O.F.

\section{OROBANCHACE压.}

\section{Orobanche, Linn.}

35. Orobanche (Osproleon) abyssinica, Ach. Kich. (No. 90). Near summit of Gebel Saleh.-II.U.F. 


\section{ACANTHACE正.}

Ruellia, Linin.

36. Ruellia patula, Jin'

(Nos. $4 \bar{\imath}, 81)$. - H.1.l.

\section{Blepharis, Juss.}

37. Blepharis edulis, Pers.

(No. 91).-H.(1).F.

A plant of Aralia, Persia, and North-West India: not known from Sokotra.

NYCTAGINEÆ.

\section{MONOCHLAMYDEA.}

Boerhaavia, Linn.

38. Boerhaavia scandens, Linn.

(Nos. 10, 95). - H.O.F.

Seeds of this speeies were collecterl.

\section{ILLECEBRACE磨.}

Lochia, Balf. fil.

39. Lochia bracteata, Bulf. fil., Op. eit. Tal,. LXXXIV.

(Nos. $41,54,84$; 4. XII. 98).-H.O.F.

We have young plants raised in the Botanic Garden.

\section{AMARANTACE巴.}

\section{Arua, Forsk.}

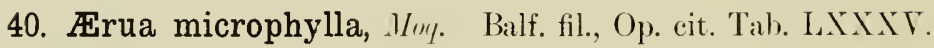
(No. 12).-H.O.F.

\section{CHENOPODIACE无.}

41. Suæda monoica, Forsk:

\section{Suæda, Forsk.}

(No. \&i).-H.O.F.

\section{Salsola, Linn.}

42. † Salsola cycloptera, O. Stupf., sp. now.

Futiculus ramosissimus glaherrimus: rami ramulique pallidi vel allicli.

Folia alterna saepe in ramulis al,hreriatis patulis approximata, emm basi persistente calloso-inerassata articulatil, cylindriea rel clavato-cylinchica, oltusissima, glauca, carnosa, 3-3 lin. longa. Flores ad foliorum axillas solitarii, distantes vel rersus ramulorum apices dense congesti (tume folia floralia saepe lnerissima, bracteiformia), hilıactenlata: luacteolae plus minusve naviculares rel coehleares marginibus hyalinis exceptis carnosae, cireiter $\frac{3}{4}$ lin. longae. Perianthinm sul, anthesi vix 11 lin. longins, ad fere medium 5-lobum, tuho cupulari, lolis connirentilus apice salpe inflexis margine hyalinis lasi carnosulis gilbrosis, 
giluh mox in alas coalescentes dilatatis. Stamina 5) filamenta hasi com holulis minutis altermantia et cum iis in anmulum tennem lorevissimmon combati, plermmere temula, e perianthio exserta, in floribus serotinis Juerissina latiuscula et emm antheris inclusa ; antherae (florm serotinormon tantum notae) $\frac{1}{3}$ lin. longace, comectivo paululo producto olbtuso. Ovarium ellipsoides-ohlongum; stylus hevis; stigmata 2. vel 3, recurval vel revoluta, tantum in latere ventrali papillosi. Fructu perianthimu anpliatmm, tuho e basi (lilatato spongioso exearato eylindrico ad fere 1 lin. longo, segmentis apice inflexis arcte comiventibus, alarmu (liseo :3 lin. dimetiente, albo, crenulato vel lobulato vel plusminusve 5-lolnato lobis saepe inaequalibus. Frnctus prater verticem convexum perianthii tubo arete inchsus, pericupio vertice spongioso excepto temui. Semen exalhmminosm ; testa tenuissima; embryo plerumque horizontalis vel olliøuus, ranius erectus, planospiralis virirlis.

A cacteris generis specielus periantheo fructifero ultra medium tuhuloso, ore ala dorsali scariosa horizontli ammulari cremulata, rarius plusal minusve 5-lolsata instıucto distineta.

(No. 37). On the plain fronting our anchorage in Bander Saleh.-H.O.F. The rather long tube of the mature perianth and the usually complete fusion of the originally distinct wing primordia into a single ringshaped wing distinguish this species from all the other speeies of Sulsolu which I know. There were only few flowers anong the very numerous fruits in the specimens which I examined, and they seemer to belong to a late series and somewhat different form, a condition not uncommon in Chrnomutiurer. Whilst the filaments of the mature periauths with fully developed wings were long and exserted from the perianth, those of the late series were short and enclosed in the perianth, together with the anther's. This was also the case in a flower where the embryo had ahearly formed, although only one anther was open and the wings were still quite small. The flowers, of this late series at least, are protogynous, and the case just mentioned points to a tendency in the late Howers, towards beeming misexual. -O. Stepif.

Dr. O. Stapf, of the Herharimm, Royal Gardens, Kew, has been so good as to examine and describe this plant.

This genus is not represented in sokotra.

\section{EUPHORBIACE \&.}

\section{Euphorbia, Linn.}

43. Euphorbia (Anisophyllum) Chamæsyce, Linn. (No. 59).--H.O.F.

44. Euphorbia ('Tirucalli) Schimperi, Prest. (No. 40 ; 4. XII. 98).-II.O.F.

45. Euphorbia (Tirncalli) oblanceolata, Bulf. fit. (No. 89).-H.().F. 


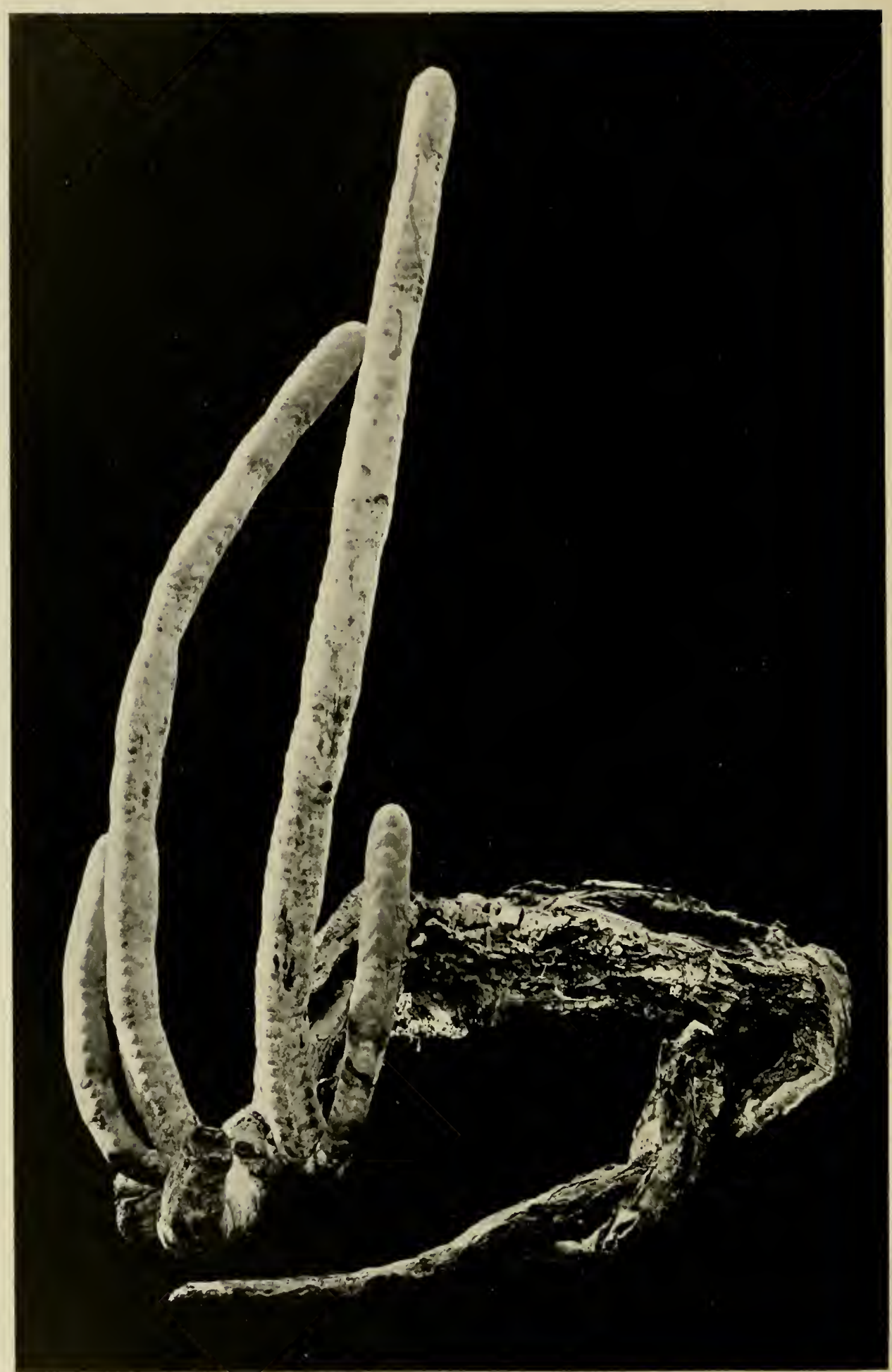


46. Euphorbia Abdelkuri, Bulf. fil., s\%. nun.

Planta aromea non aculeata truncis lignosis contortis cortice corrugato inter superfuc seopulos et lapirles jacentihus. Rami camosi intus spongiosi latice sulphumen in speciminibus nostris :3-perlales et 2- poll. lati, subeylindriei hîc illìc constrictione forsin linitatione turionis solemis circumligati, obseure 5-costati aphylli sed costis tuberculis seriatim segregatim ornatis ihique cicatricibus parvis foliorm jurenilium et ramulor'um floralium (?) axillarium notatis.

The figure (on page jos) is taken from the langest specimen, which was brought home in a large crate, and was in excellent conclition on arrival, and, although it has not ret rooted, it is as fresh as on the day upon which it ariverl.

This is a most interesting diseovery. The plant does not oceur in Sokotra, and, so far as I (aul discovel-and I am indehterl to Mr. I. H. Bunkhill, of Kew, for assistance in my search - it cliffers from all known sueculent forms of Enplumlin. Unfortunately we have not complete material of the species. Upon one sten I foum some withererl remains of flowers, but they were of mo service heyoml furnishing evilence confinmatory of the inlentifieation of the plant as a Enphorlin. As we have the plant now alive in the Royal Botanie Garden, we may hope to be alle to complete the deseription of it at no distant date.

The stem presents some curious featmes. The fresh shouts have an outer shell alout a fluater of an inch thick surromoling a lonse spongy central portion. The eprirlermis is thickly studrled with stomata, each girt by subsicliary cells. The surface walls of the epiclermal cells are entirely cuticularised, and layer after layer of euticle is laid down upon them so that ulimately a grey euticular erust which scales off covers the older part of the shoot. It is an exceptional character which I do not think has been olserver in any other plant that this cuticular layer shows distinctly its origin from indivilual cells-that is to say, the enticular scale is marle up of a series of prisms, each of which exhihits a stratification and represents the cuticle that has been formed hy a particular cell of the epirlermis. De Biry (Comp. Anat. Engl. El., p. 80 ) refer's to an isolated exception of sucl a separation into "angular piees, each corresponding to an individual eell," having been brought about ly ehemical and mechanieal means in the enticle of Cerens permitums. In omr Euphorbia the separation is normal, and the limits of the several eells are readily olserved in the cuticle by examination with even a pocket-lens. A further interesting point is that the stomatic guard-cells retain a cellulosic character in their walls, as clo also the inner subsidiary cells, conseruently they are sumk in pits of the cuticle, and the contrast hetwear them and the surromuling cuticle is rearlily marle evident by suitable reagents. A careful anatonical investigation of the whole structure of this plant 
will, I hope, he prossible when the plants we now have alive have started into growth.

[This Euphortia grows all up the sirle of Gehel Saleh, from about the upper two-thirrls (500-1500 ft.), semling up its leafless stems like a forest of green candles. The root stock seemed to be contimous, if not thronghont the entire colony on the momintain side, for at least rery great distances. It must, I think, resemble some S'omaliland species, as om Somali butler recugnised it as being a plant familiar to him and spoke of it ly a somali name, which I have recoreled as Ergin. He it was who also recogniserl the Eitithroled smrtidu as a Somaliland plant, where, indeerl, a nearly related speeies does veeur, as Mr. X. E. Brown informs me.-H.O.F.]

\section{ORCHIDE尼.}

\section{MONOCOTYLEDONES.}

\section{Habenaria, Wild.}

47. Habenaria socotrana, Bulf. fil., Op. cit. Tal). LXXXII, B.

Near top of (rebel Saleh. - H.O.F.

\section{IRIDEE.}

\section{Romulea, Maratti.}

48. Romulea purpurascens, Tenore, var. edulis, linlier.

Near summit of Gehel saleh._-H.(I.F.

\section{LILIACE无.}

\section{Asparagus, Linn.}

49. Asparagus africanus, Litmli, var. microcarpus, limlf. fil. (No. 34).-II.O.F.

\section{Asphodelus, Linn.}

50. Asphodelus fistulosus, Linn., var. tenuifolius, Bulier.

On Geliel Sirlel.,-H.O.F.

\section{Dipcadi, Medicus.}

51. Dipcadi ('Tricharis) Balfouri, Buler. (No. 5:2).-H.O.F.

\section{COMMELINACEE.}

\section{Commelina, Linn.}

52. Commelina benghalensis, Linu.

$$
\text { H.O.F. }
$$

\section{Cyanotis, Don.}

53. Cyanotis cristata, likem. "mul Schult.

On sancly plain.-II.O.F. 
CYPERACE压.

Cyperus, Linn.

54. Cyperus conglomeratus, hothl, var. effusus, liois.. (No. 56). H.().F.

\section{GRAMINE 世.}

Setaria, Beauv.

55. Setaria verticillata, bermi: (No. 6i). H.O.F.

\section{Pennisetum, Pers.}

56. Pennisetum cenchroides, Pers. (No. .56). - II.O.F.

\section{Heterochloa, Desv.}

57. Heterochloa dura, Bimis. (No. 1, 4. XII. 98).-H.O.F'. A Baluchistan plant not known from Sokotra.

\section{Anthistiria, Linn.}

58. Anthistiria ciliata, Limm. H.O.F.

Seeds of this species were collecterl.

Sporobolus, $R . B r$.

59. Sporobolus minutus, Link. (No. 36, 3. XII. 98).-H.O.F.

An Abyssinian species not known from Sokotra.

\section{Eleusine, Gartn.}

60. Eleusine ægyptiaca, Pers. (No. 25, 3. XII. 98).-H.O.F.

\section{Eragrostis, Beauv.}

61. Eragrostis minor, Host.

(Nos. $2.2,26)$. - H.O.F.

This species is not known from Sokotra.

In conchuling this Report, I desire to express my ollligation to the Director of Kew and to the members of the staff of the Kew Herbarium, and to Mr. C. B. Clarke for the willing help I have received from them in completing the foregoing list. It contains evidence in the description of new species, of the active share of some of them in the working out of the collections, lunt not of much other aid I gratefully acknowlerlge. 


\section{PLATE XXVIA.}

\section{EXACUM FORBESII, linlf. fil., p. 487.}

Fig. 1. Limuch in flonert, meturnl sisp.

Fig. 2. Collyr.

Fig. 3. C'moll" laid "ym"n.

Fig. 4. Strmen.

Fig. 4a. " ill firmt imes.

Fig. 4b. " in lutk rien.

Fig. 4c. " in silte viex.

Fig. 5. Gynecium.

Fing. 2.5 are all enlaryed.

Drawn by Mrs. I. B. BatFork, from a plant grown in the Royal Botanir fiarden, Edinburgh. 


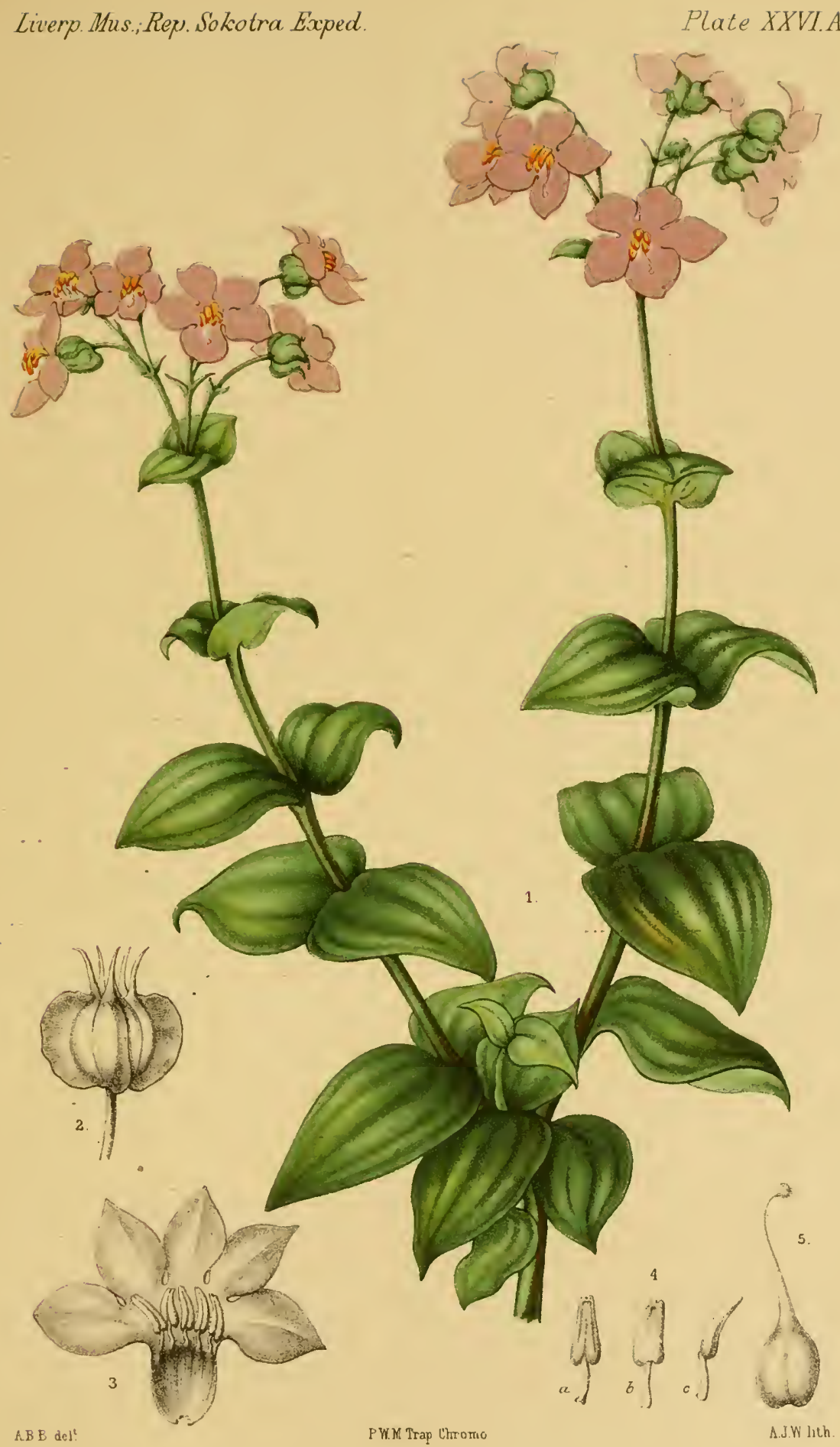

EXACUM FORBESII 


\section{PLATE XXVI B.}

ALOE FORBESII, Brlf. fil., p. 511.

Figs. 1, 2. I'lent of netural size, showing habit and inflorstene.

Fig. 3.... Bract of rueme.

Fig. 4.... I'rianth and peetirel.

Fig. 5.... P'etals removed from perianth.

Fig. 6.... a, Autisepulous strmen; b, untipetulous strmen.

Fig. 7 .... Gynurium.

Fings. 3-7 magnified.

Drawn by Mrs. 1. B. B.Lfovi, from a plaut grown in the Royal Botanic (tarden, Erlinburgh. 


$$
*
$$





\section{PLANTAE CRYPTOGAME.}

\section{Pteridophyta.}

biy Professor I. B. BALFOUR, F.R.S. 



\section{Flowerless Plants.--I.}

With the exception of a few ferms and lichens, tugether with a single Chara in Sokota and a few lichens and hamlful of sea weeds from AlukelKurj the species of which hare been identified hy Professor Balfour, I)r. Darhishire, and Mr. llolmes - no Cryptogamous plants were collected hy the experlition. For in regared to Botany our main oloject, with the limiter time at our disposal, was rather to secure as many living plants, bulls and seerls for propagation at home as possible, than to form a herbirium. The few specinens collecterl by us in the larger islanct have, therefore, been indicated in this list extracted from l'rofessor Balfour's Botuny of Solvotir... H.O.F.

\section{I. - The Ferns, Mosses, and Liver= worts of Sokotra.}

\section{FILICIN Æ.}

\section{MARSILEACE $Æ$.}

Marsilea, Linn.

1. Marsilea coromandelina, Irill.

In many of the streams in the middle of the istand.-B.r.s., sidurinf.

\section{POLYPODIACE压.}

\section{Adiantum, Linn.}

2. Adiantum Capillus-Veneris, Linn.

Not frequent. - B.C.s., siducrinf.

3. Adiantum æthiopicum, Linn.

Haghier hills sonth of Hadibu._B.C.S. 
4. $\dagger^{*}$ Adiantum Balfourii, Buliti. Balf. fil., Op. cit. Tal. XCIX, A.

Aduma slopes (1000 ft., No. 1:35, XII. 9ミ). Hombil. This speciess ocems also (1) Alul-el-Kini. - H.(1.F.

Species of this have given us a crop of youmg plants in the Royal Botanje (riarlen, and it will be an interesting aldition to horticulture.

Almulant on the hills at the eastem and centre parts of the islind.li.t..., silnewinf.

\section{Cheilanthes, Swartz.}

5. * Cheilanthes (Mleuritopteris) farinosa, kimlf. Bot. Mag. t. 4765.

(iebel Bitzohul (rising from the Garieh l'laiu) at $900 \mathrm{ft}$.

Hills south-west of Galonsir.-li.t's.

\section{Onychium, Kaulf.}

6. Onychium melanolepis, K:e. Hooker Icon. Pl. t. 90:2.

Hills sonth-west of Galonsir.-- B.C.S.

\section{Pellæa, Link.}

7. Pellæa (Cheiloplectron) concolor, Bulier. Hooli. It. Pl. t. 915. Haghier hills (over $3000 \mathrm{ft}$.). - sihnerinf.

8. Pellæa (Platyloma) viridis, Buker. Hook. Fil. Exot. t. 50.

Kischen (in Haghier Messif), over 1800 ft. Shlueinf.

\section{Pteris, Linn.}

9. * Pteris longifolia, Limu.

1)ahamis (1500 ft.).-H.(1.F.

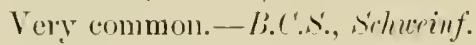

10. Pteris quadriaurita, lirt:. Hook. Sp. Fil. ii. 179, t. $13+$ B.

Haghier lange.-B.c.s., showinf.

\section{Ceratopteris, Brong,}

11. Ceratopteris thalictroides, Birony. Bedel. Ferns Sonth. Ind. t. 75. Streams near Hadibu.-Sichucinf.

Asplenium, Linn.

12. *Asplenium Trichomanes, Linu.

(Gebel Raggit, limestone outlier of Haghier, south-west of Hadibu ( $800 \mathrm{ft}$.). - H.O F.

Haghier hills south of Hadibu.-B.r's. 
13. $\dagger^{*}$ Asplenium Schweinfurthii, Buler. Balfour fil., Op. cit. Tab. C. Slopes of Admua (20110 ft.).-H.().F.

Haghier hills south of Hadilun. - B.C..., sidnerinf.

14. Asplenium præmorsum, Srent: Berld. Ferns Sonth. Ind. t. 114. Haghier hills above Hadibu.-B.C.N.

\section{Actinopteris, Link.}

15. * Actinopteris dichotoma, Berld., Ferns South. Inıl. 43, t. 124.

Arhunat slopes (400-1500 ft., No. 126, 21. XII. 98). Adtho Dimelhns $(3500 \mathrm{ft}) ..-H .0 . \mathrm{F}$.

Common.-B.e.s., schueinit.

Nephrodium, Rich.

16. * Nephrodium (Lastrea) crenatum, Bulker. Berld. Ferus Sonth Indl. t. 95.

Arluna slopes.-H.O.F.

Hatghier hills alove Hardibu_- lis.'s.

17. Nephrodium molle, Itesr. Bect. Ferus Sonth. Ind. t. 84.

On the hills.-B.C.s., sthereinf.

Nephrolepis, schott.

18. Nephrolepis cordifolia, Presl. Bedd. Ferns Sonth. Ind. t. 92. Haghier hills near Aduna.-B.C.S.

\section{Gymnogramme, Desv.}

19. Gymnogramme cordata, Schlecht. Hook. N Grev. Ic. Fil. t. 156. Above Kischen._-Shreiuf.

\section{MUSCI.}

\section{MUSCINE $\nexists$.}

\section{Campylopus, Brid.}

1. Campylopus introflexus, lirie.

Haghier hills.- b.c.s.

\section{Symblepharis, Montagu.}

2. † Symblepharis socotrana, Mitt. Balfoul fil., Op. eit. Tab. XCIX, B.

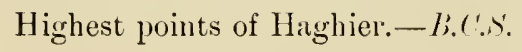

\section{Weisia, Hedw.}

3. † Weisia (Hymenostylium) socotrana, Mitt.

Near Galonsir and Hadlibu, and elsewhere common._B.C.S. 
4. $\uparrow$ Weisia (Hyophila) punctulata, Mitt.

Haghier hills._B.C.S.

Tortula, Hedw.

5. Tortula cæspitosa, Schureyr:

Haghier hills, at considerable elevation.-B.C.S.'

Anictangium, Hedw.

6. Anictangium Balfourii, llitt.

Sicante Peak of Haghier (over $3000 \mathrm{ft}$.).-li.t's.

\section{Schlotheimia, Brid.}

7. Schlotheimia Balfourii, litt.

Higher parts of Haghier.-li.('S., ? Nimmm.

\section{Philonotis, Brid.}

8. Philonotis pungens, Mitt.

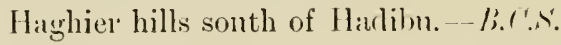

\section{Brachymenium, Hook.}

9. Brachymenium, $\%$.

li.t's'.

\section{Bryum, Linn.}

10. ? Bryum dichotomum, Herle.

On slope of Haghier behind Hadibu-B.C.S.

Fabronia, Ruddi.

11. † Fabronia socotrana, llett.

Highest peaks of Haghier, near Arluna.-b.r.S.

HEPATIC蚱.

Lejeunia, Libert.

12. Lejeunia serpyllifolia, Libert.

li. $(')^{\prime}$.

\section{Frullania, Ruddi.}

13. † Frullania socotrana, Mitt. Balf. fil., Op. cit. Tal. XCIX, C. On bark.-B.C.S.

14. Frullania squarrosa, Nees all. Es'sull.

On small stems.-L.C.'.s'. 


\section{Otiona, Corda.}

15. Otiona Aitonia, Forsk:

On the rocks. Common.-P.C.S.

\section{Fimbriaria, Nees ab. Esenb.}

16. † Fimbriaria pusilla, Mitt.

On rocks in many places.-B.C.S. 


\title{
II. - The Ferns of Abd=el=Kuri.
}

\section{POLYPODIACE压.}

\section{FILICIN Æ.}

\author{
Adiantum, Linn.
}

1. Adiantum Balfourii, lither:

Near the summit of (relrel Saleh (1200 ft.). - II.1).F.

Asplenium, Linn.

2. Asplenium Schweinfurthii, lithire:

On slope of (iehel Sileh (1000 ft.).-II. I).F. 


\section{PLANTE CRYPTOGAMEE.}

\section{Thallophyta.}

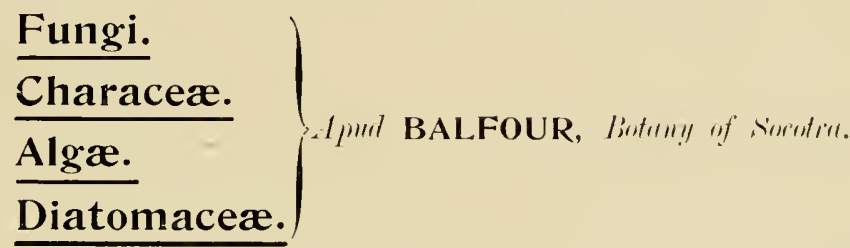

Lichenes.

biy OTTO V. DARBISHIRE, Ph.D.

Alga ex Abd=el=Kuri.

Bi!y E. M. HOLMES, F.L.S. 



\title{
Flowerless Plants.--II.
}

\section{I.--The Fungi, Lichens, Charas, Sea= Weeds and Diatoms of Sokotra.}

\author{
FUNGI. \\ ASCOMYCETES. \\ Pyrenomycetes.*
}

SPH/ERIACEI.

Sphæria, Haller.

1. † Sphæria (Rosellinia) opaca, Coolie.

On rotten wood.-B.C.S.

2. † Sphæria (Immersa) hyalodidyma, Cunke. Immersed in wood.-B.C.S.

3. † Sphæria (Kahmusia) rubronigra, Conke.

On maked woorl.-B.C.S.

4. † Sphæria (Thyridimm) colliculus, C'unle.

On naked wood.-B.C.S.

\section{Lophiostoma, Fries.}

5. † Lophiostoma (Lophiotrema) Socotræ, Conke.

On naked wood.-B.C.s.

6. Eutypa Acharii, Tul.

\section{Eutypa, Tul.}

On dry rotten wood. Galonsir Plain.-B.C.S.

7. Eutypa aspera (Nits), var. lignicola, Croke. li. '.S.'.

\section{Valsa, Adans.}

8. Valsa stellulata, Fries.

Tree stump, Galonsir Plain._B.C.S. 


\section{Ostropa, Fries.}

9. Ostropa cinerea, Fivies.

On wood, hill slopes, near Galonsir. -li.c.s.

Dothidia, Fries.

10. $\dagger$ Dothidia (Dothilella) Salvadoræ, Cotelie. On leaves of sifmelum pursion - B.C.S.'.

\section{Discomycetes.}

\section{Ailopaplum, Lib.}

11. † Ailopaplum lirelliforme. Cuoke.

On dry wood.- li.C.s'?

Asterina, Lev.

12. † Asterina dichænoides, Cmlie.

On living bark.-B.C.S.

\section{Sphinctrina, De Not.}

13. Sphinctrina microcephala, $N^{\top} y l$.

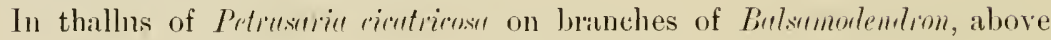
Wadi Digal (900 ft.).

\section{Lichenes.*}

'The lichens of Sokotra are not yet very fully known, but the colleetions made by Drs. Balfour and Schweinfurth some twenty years ago, and by the Sokotra Experlition (ehiefly eollecter by D1. H. O. Forlues) in $1898-99$ make up a grand total of 47 genera and 135 species.

'Those bonght over by Balfour and schweinfurth were determined by the late .J. Mieller-Argor., and they mumbered in all 47 genera and $1: 30$ species, of which $3: 3$ genera and $7: 3$ species were new to seience.t The genus Silhinetrinu, l)e. Not., of Miiller's List (Botun! of Somotru, p. 347) heing a fungns, is not mentioned here. On the other hand, the genus Firrinlum, 'Turm., has lreen introrlnced, althongh the only species helonging to it is not new to Sokotra.

* By Dr. O. V. Darbishire.

† Br. J. Müller, Diugnoses Lichenum Socotrensium nororum a participilsus expectitionum Prof. Bayley Balfour et Jr. Schweinfuth lectorum.-Proceedings of the Royal Society of Exlinburgh, vol. xi. p. 4.7-472 (1882). This paper contains the new genera and new speeies by Ililler-Argor. only. His complete list is to be found in Balfour's Botrumy of Sorotirt, pp. 343 to 390 . 
The Lichens collecterl ly the Forles-Gant lixpedition on the Islands of Sokotra and Alrl-el-Kuri nmber 10 genera with 17 species, not inchuling two sterile specimens which I am malble to name. Eight species turned out to be new for Sokotra, ant these were all known to science previously.

The most interesting additions ane the larger specimens of U'suru floridu, Ach., and $L^{r}$. articulutu, Hotfin.

The following list is mate up of the Lichens collected by Balfour and Schweinfurth, with the arlditions made ly I)r. H. O. Forbes. Nearly all those, the speeific names of which are che to Muller-Argor., have been describer only from Sokotri. 'The nimes of Lr. Forhes' plants are marked with an asterisk.

Throngh the kindness of Mr. Willian Barlocy, the owner of the Herlier Boissier. in which is incorporated the splendicl herbarimn of .J. MiillerArgov, and with the assistance of Mr. Eugine Autran, I was able to compare several of the Sokotra Jichens of the present experlition with the original specimens of Miiller-Argor: I wish to thank both these gentlemen for thus materially helping me in the rletermination of some of the species mentioned in the following list.- O.I.I.

\section{CONIOCARPI.}

CALICIACEI.

\section{Calicium, De Not.}

1. † Calicium leucinum, Miill. Ar\%.

Lignicolons. - P.C.S.

\section{DISCOCARPI.}

GRAPHIDACEI.

Dirina, El. Fries.

2. Dirina Ceratoniæ (.tch.) de lot.

Corticolons.- B.C'.S.

3. † Dirina cinerea, Irïl. Ai\%.

Calcareous rocks. - B.C.S.

4. †Dirina cinerea, Mtiill. Ary., f. sorediosa, Miell. Arg.

Caleareous rocks.-B.C.S.

5. † Dirina immersa, Müll. Arg.

Calcaleous rocks. H.C.S.

6. † Dirina immersa, Mill. Aig., f. sorediata, Mïll. Arg.

Cilcareous rocks.-B.C.S.

7. Dirina repanda, Fries.

On calcareous rocks. - B.'.S. 


\section{Opegrapha, Ach.}

8. Opegrapha (Lecinactis) chloroconia, Müll. Aiy.

On small branches, bark of lirge branches, and decorticated trunks - B.C'.S.

9. $\dagger$ Opegrapha (Lecanactis) vestita, Müll. Aig.

On decorticated wood.-B.C.s.

10. † Opegrapha (Lecanactis) elegans, Mill. Aiy.

On decorticated wood.-B.C.s.

11. † Opegrapha (Lecanactis) subcalcarea, Miill. Ai\%.

On calcareons rocks.-B.C.S.

12. † Opegrapha (Lecanactis) cretacea, Mïll. Li\%.

On calcareous rocks.-B.C.S.

13. † Opegrapha Bonplandi, Fíe.

On decorticated wood.--B.C.s.

14. † Opegrapha Dracænarum, Niill. Arq.

On branches of Diucenu, with Craplina rarims, above Wadi Kischen (2100 ft.).--Sillueinft.

15. † Opegrapha microspora, Mïll. Arg.

Corticolons.--B.C.S.

16. † Opegrapha sororiella, Mïll. Ai\%.

On bark of branches.-B.C.S.

17. Opegrapha melanospila, Mïll. Ary.

Parasitic in thallus of Purnelia priforctu, Ach., and of I'. mecolute, Eschw. above Wadi Kischen (2000 ft.). Sirherinf.

\section{Melaspilea, $\mathrm{Nyl}$.}

18. Melaspilea stigmatea, Miill. Ar!\%.

In thallus of Dirinu iepandu, Filies.-b.C.s.

\section{Graphis, Ach.}

19. † Graphis brachycarpa, Miill. Ai\%.

On branches, near Wadi Kischen (2100 ft.)...S Shucrinf.

20. Graphis comma, $\Gamma y l$.

Above Wadi Kischen, on small branches (2100 ft.). - Srluceinf.

21. Graphis tenella, $1 \mathrm{ch}$.

Above Warli Kischen, on small branches (2100 ft.).—Srhueinf. 
THE IUNG, LICHLNS, SEA-WEEH ANI HHTOMS OF SOKOTRA. 549

\section{Phæographis, Müll. Arg.}

22. † Phæographis inusta, Ach., var. radians, Miill. Aig. Corticolous.-B.C.S.

23. Phæographis inusta, M/ill. Ary., vill. simpliciuscula, M/ll. . Iry. Corticolous.-li.c's.

\section{Phaographina, Müll. Arg.}

24. † Phæographina Balfourii, Mïll. Ary.

On tree trunks. - B.C.'s.'.

\section{Graphina, Müll. Arg.}

25. † Graphina varians, Miill. Air.

On smaller branches of Jracem near Wauli Kischen (2100 ft.).-B.C.S. Schuceinf.

26. † Graphina socotrana, Miill. Ar\%.

On bark of trees.-B.C.S.

\section{Arthonia, Ach.}

27. Arthonia cinnabarina, Fée, var. adspersa, $N y$.

On tree trunks. - B.(C.S.

28. Arthonia stictaria, $N y$ l.

On Stictu aurutu, above Wadi Kisehen (3000 ft.). - Sclureinf.

29. Arthonia polymorpha, $t /$.

Bark of smaller branches. - B.C.s.

30. † Arthonia calospora, Miill. A:\%

Bark of larger branches.-li.e.s.

31. † Arthonia complanatula, Miill. Ai\%.

On bark of trunk on larger branches of trees.-B.C.S.

\section{Arthothelium, Mass.}

32. $\dagger$ Arthothelium leucocarpum, Mill. Ai\%.

On bark of thick branches.--li.c.s'.

33. † Arthothelium emersum, Miill. Aig.

On tree trunks. - B.C.'.S.

\section{Enterographa, Fé.}

34. † Enterographa affinis, Miill. Aig.

On hark, among other lichens._B.C.S. 
35. † Enterographa lactea, Miill. Ai\%.

On bark of thicker branches. - B.C.S.

36. † Enterographa fraterculans, Miill. Ary.

Corticolons. - li.C.S.

\section{Minksia, Müll. Arg.}

37. † Minksia cæsiella, Mirll. A $\%$ !

Corticoluns on the larger branches. - b.1'.S'.

38. $\dagger$ Minksia candida, Miill. Ai!\%

Colticolous.... li.t's.

\section{Chiodecton, Ach.}

39. $\uparrow *$ Chiodecton nanum, IIill. Ai\%.

The thallus of the specimen growing on the bark of a tree is rery thick and of a white colour. The apotheeia are well developed. I was able to compare it with original specimens of $(\because$ nenum, Miill Arg., C. rircumscrssum, Miill. Arg., and C. socotrenum, Miill. Arg.

On woor. Matagoti, E. Sokotra.-H.O.F.

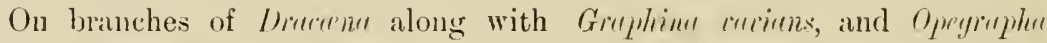

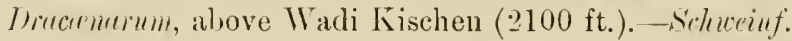

40. $\uparrow$ Chiodecton circumscissum, Miill. Ary.

Corticolous on smaller branches.-B.C's'.

41. † Chiodecton socotranum, Miill. Ary.

On calcareous rocks, - B.C.s.

42. Chiodecton farinaceum, Fie.

At Wadi Kischen, on small branches.-Firherinf.

\section{Roccella, $D O$}

43. Roccella tinctoria, $I)$ :

On granite above Wadi Kischen (3000 ft.). - Shweinf.

44. Roccella Montagnei, Biluny.

Corticolons on hranches of Mrucenu on Wadi Kischen (2100 ft.), atul on

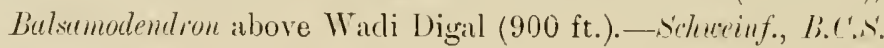

45. * Roccella Balfourii, Miill. Ai\%. (Plate xxvii. tigs. 1, -.)

Homhil ; E. Sokotra.-II.O.F.

The specimens were larger than any I have hitherto seen, ${ }^{*}$ attaining a height of $7-8 \mathrm{em}$, and bearing numerous apothecia and spermogonia. The section through an apothecium is shown $(\times 55)$ in fig. 1. The

* Darbishire, O. V., Monoyraphice liorcelleorum, 1. 43, Stuttgart, is!s. 
strongly developed epithecium, which gives the white colour to the whole fruit, is very apparent. The thallus shows the very characteristic white colour.

On rocks by the sea.-B.C.S.

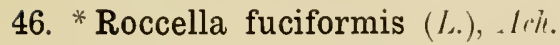

Not previously recorded from Sukotra.

E. Sokotra. On rocks.-H.().F.

LECIDEACEI.

Blastenia, Mass.

47. Blastenia poliotera, Mill. Ary.

On norther'n ascent of Mlt. Bagne (1500 ft.). - Siducinf.

48. † Blastenia albido-cœrulescens, Mrill. di\%.

On cluartz rocks.-B.C's'.

49. † Blastenia cretacea, 1 Hill. Ar\%.

On calcureous rocks.-b.C.s.

50. † Blastenia variabilis, Mrull. A\%

On quartz rocks, above Wadi Kischen (1800-1950 ft.). - B.C.S., Scheceinf.

Lecidea, Ach.

51. † Lecidea (Biatora) contractula, Irill. . Ir\%.

On quartz rocks above Wiuli Kischen (1800 ft.). - Silureinf.

52. † Lecidea (Biatora) plumbeella, Mill. Ar\%.

On quartz rocks above Wadi Kischen (1950 ft.). - Sehweinf.

\section{Patellaria, Müll. Arg.}

53. †Patellaria (Biatorina) obfuscata, Milll. Arg.

On quartz rocks.-B.C.S.

54. † Patellaria (Catillaria) sigmoidea, Mïll. Ar\%.

On ynartz rocks. - B.C.S.

55. † Patellaria (Bacidia) socotrana, Mrill. Ary.

On dead wood.-B.C.S.

56. †Patellaria (Raphiospora) decussata, Mull. Arg.

On calcareous rocks.-li.c.s.

\section{CLADONIACEI.}

Cladonia, Hoffm.

57. Cladonia verticillata, Flirilie.

Terricolons.-B.C's'. 


\section{PERTUSARIACEI.}

Pertusaria, $D C$.

58. † Pertusaria schizostoma, Miill. Ar\%.

On small branches.-li.'.s.'.

59. † Pertusaria cicatricosa, .1/ill. Ary.

On branches of Bulstmolentron, above Wadi Digal (600 ft.).--B.(.S., schueinf.

60. $\dagger *$ Pertusaria socotrana, Miill. Ai\%

Arlho Dimellus (4000 ft.), on stone.-II.().F.

On caleareous and quartzose rocks. - b.e.s., sihurinf.

Miiller's specimens showed four spores in each ascus, whereas I found eight. The number of the spores in each ascus, however, varies very much in the Pestusurue. I saw original specimens of this species, and of $I^{\prime}$. suliflurens.

61. Pertusaria flavens, $N y$.

B.C'S:

62. $\uparrow *$ Pertusaria subflavens, Miill. Ai\%.

The spores meisured as much as $48-58 \times 160 \mu$, Mill. Aig. putting their size down as $55 \times 110-130 \mu$.

E. Sokotra, on branches.-II.O.F.

On small branches of Hypericum, above Wadi Kischen (3000 ft.). - Schueinf.

63. Pertusaria lutescens, hrplh.

On branches and branchlets of Bulsumoulendron, along with $l^{\prime}$. rimtricose, Miill. Arg., above Wadi Digal (900 ft.).-Schueinf.

\section{Variolaria, Turn}

64. † Variolaria xantholeuca (1/iill. Ary), Lurbistl.

On quartz rocks above Wadi Kischen (1800 ft.)., - Schueinf.

\section{URCEOLARIACEI.}

\section{Urceolaria, Ach.}

65. Urceolaria actinostoma, l'e's.

On quartz rocks, above Wirli Digal (1650 ft.). - Sihureinf.

\section{PARMELIACEI.}

\section{Callopisma, De Not.}

66. Callopisma aurantiacum, rar. salicinum, Tus:

Ahove Warli Digal on bark of Bulsumulemlion (900 ft.).-B.C.s., Silmerinf.

67. Callopisma aurantiacum, var. isidiosellum, Mill. Ai\%.

On branches of Bulsetmodendron, above Wadi 1)igal (990 ft.).-B.C.s'. 
68. Callopisma citrinum, Muss.

On birk of trees, with preceding species.-B.C.St.

69. Callopisma steropeum, Kiirl.

On quartz rocks, above Warli Kischen (2100 ft.).-- B.6.s., Sitherinf.

70. Callopisma pyraceum, 1Liull. diry.

On branches. - Schureinf.

\section{Lecanora, Ach.}

71. Lecanora atra, tich.

Corticolous and saxicolons.-li.t's'.

72. † Lecanora notha, Miill. Ai\%.

Saxicolous, on northern sides of Mt. Bexgal (1500 ft.). - Sichurinf.

73. Lecanora subfusca, $A \%$., var. chlarona, $A c h$.

Above Wadi Digal, on decorticated wood of Balsimmentron (900 ft.) b.C.S., sthweint.

74. Lecanora angulosa, Ach.

Ramicolous.-Schueinf.

75. † Lecanora socotrana, Miill. Ai\%.

On quartz rocks; common and characteristic._B.C.S.

At Wadi Kischen (1800-1950 ft.).--Schuecinf.

76. † Lecanora socotrana, Ifiill. Ai\%, f. livido-nigricans, Mill. Ary. b.C.S.

\section{Amphiloma, Körb.}

77. † Amphiloma deplanatum, 14iill. Ar\%.

On calcareous rocks.-.li.C.S.

78. † Amphiloma Balfourii, Mill. Arg.

On calcareous rocks.-B.C.S.

79. † Amphiloma granuliferum, Miill. Ar\%.

On quartz rocks near Wadi Kischen, at northern foot of Haghier mountains.—Siheciut:

80. † Amphiloma granuliferum, Miill. Aig., var. subvitellinum, Müll. Ar!\%. Growing with true species.-micherinf.

\section{Parmelia, De Not.}

81. Parmelia latissima, F́e, f. isidiosa, Miill. . li $\%$.

On branches.-bict.s.

On granite rocks above Wadi Kischen (1800-3000 ft.). - Schucinf. 
82. Parmelia latissima, F'́, f. sorediata, Iyl.

On granite rocks above Kischen (2700 ft.). - Silucrinf.

83. Parmelia urceolata, Mill. Li\%, var. nuda, Miill. Li\%. Trunks of trees aloove Kisehen (2400-3000 ft.).—Sihueriuf.

84. Parmelia Soyauxii, Miill. Lry.

Saxicolous, alove Wadi Kischen (1800 ft).-milluevint.

85. † Parmelia Schweinfurthii, Miill. Ary.

On smaller lranches of fruiting Ruturer, above Kischen (3000 ft.). simuerint.

86. Parmelia perforata, ./ch., var. cetrata, Ny/.

On granite rocks, above $1 \mathrm{~T}$ adi Kischen (3000 ft.). - virhereinf.

87. Parmelia tiliacea, Ach., vil. rimulosa, Miill. . Iry.

Corticolous.-.-li.c.s.

88. Parmelia conspersa, $d \%$., vir. hypoclysta, $L / h$.

On granite rocks above Kischen (1950 ft.). - S'hucinf.

89. Parmelia convexula, Mill. Aig.

On ruartz rocks. - li.c.s.

90. * Parmelia nilgherrensis, $\mid$ Fy.

Not previously recorderl from Sokotra.

On bark of trees, Adho Ilimellus (4000 ft.).-H.O.F.

91. * Parmelia perlata, Mont.

Not hitherto recorded from Sokotr:ı.

E. Sokotra [?above Homhil], probably on trees. - H.(I.F.

92. * Usnea florida, . $1 \%$.

\section{Usnea, Ach.}

Not previonsly recorded from Sokotril.

Adho Dimellus, on trees (4000 ft.).-H.O.F.

93. * Usnea articulata, $I$ off $m$.

Not previously recorded from Sokotra.

Adho Dimellus, on trees (4000 ft.).-II.O.F.

94. Usnea straminea, Mill. Iiry.

Above Wadi Kischen (2100 ft.), and on Gebel Haghier (3000 ft.).—L.C.s., sichevinf.

\section{Ramalina, Ach.}

95. † Ramalina debilis, Miill. Ary.

Eifyling.

96. * Ramalina dendriscoides, Till., val. minor, IHill. . lrg.

Atho Dimellus, on brinches (4000 ft.). - H.O.F.

On smaller branches of Hyperinum above Wacli Kischen (3000 ft.), and similarly on lihois.-B.C'S., sthwerinf. 
97. † Ramalina dendriscoides, $N y /$., viu. nodulosa, Miill. A I $\%$.

Sixicolous. - li.t's.

98. * Ramalina fastigiata (Pers.), I $/$ \%

Matigoti, above camp at Hombil (E. Sokotra). On branches.-H.O.F.

New to flora of Sokotra.

99. * Ramalina farinacea (Limu.), tih.

Matagoti, above Hombil camp' (E. Sokotra). On branches.-II.().F.

Above Wadi Kischen (1800-1950 ft.).-li. 's.., sthurinf.

100. Ramalina dasypoga, T'uck.

Above Wirli Kischen (3000 ft.) -li.t'st., sillurinf:

101. * Ramalina Curnowii, crombir.

Matagoti, above cimp at Homhil (E. Sokotra). On rocks. II.O.F.

Not before recorded from soliotri.

\section{PHYSCIACEI.}

\section{Buellia, De Not.}

102. Buellia parasema, kiirl.

On smaller lianches of bulsumolention above Wadi I)igal (900 ft.). B.C.s., Schucinf.

103. Buellia parasema, Kürl., var. rugulosa, Kö̀r.

On bark of various trees.-. B.C.C'.

104. † Buellia parasema, Kirl., var. subæruginascens, Mill. . try.

On smaller branches of Bulstmolemlion above Wadi Digal. - Schueinf.

105. † Buellia parasema, Kïrb, var: contorta, ILill. Aig.

Corticolous.-B.C.'S.

106. † Buellia parasema, Kirl., val. oblongata, 1/ill. Al\%.

On dry and decorticated smaller branches of trees, above Wadi Kischen (1800 ft.). - Silucrint.

107. † Buellia brachyspora, Miill. . Ir\%.

In the thallus of lincllin innute, Mill. Ares., on Wadi Kischen (1800 ft.).sirluevint.

108. Buellia stellulata, Ti!nl., val. protothallina, Miill. . Li!.

On quartz roeks.-B.(s).

109. † Buellia albinea, Miill. Atrg.

On quartz rocks.-ls.c's'.

110. † Buellia leucina, Miill. L I\%

On quartz rocks. - B.C.s. 
111. † Buellia substigmatea, Mrill. Arg.

On porphyry rocks. - B.C.S.

112. $\dagger$ Buellia substigmatea, vil: obfuscata, Miill. di

On porphyry rocks. - B.C.S.

113. † Buellia innata, Miill. A try.

Saxicolous, above Wiadi Kischen (1800 ft.). - Trhueeinf.

114. Buellia recepta, Iirll. Ary.

On (1)artz rocks. - IB.C.S.

115. Buellia africana, Miill. Ary.

On rluartz rocks._-B.C.S.

\section{Rinodina, Ach.}

116. Rinodina teichophila, val: corticola, . Irmolel.

On branches of shrubs above Wadi Kischen (3000 ft.). - Sithueinf.

117. $\nmid$ Rinodina substellulata, Miill. Ai\%.

On quartz rocks above Wadi Kischen (1950 ft.).-s'chuciuf.

118. Rinodina minutula, Miill. Ar\%.

Rare-LB.C.S.

119. † Rinodina granularis, Miill. Ar $\%$.

On calcareous rocks. - B.C.S.

\section{Physcia, Schreb.}

120. Physcia leucomelas, Itichx.

On smaller branches of lihois, above Kischen (3000 ft.). - Sichucinf.

121. Physcia speciosa, Nyl., f. sorediifera, $\lambda^{r} y l$.

On granite rocks above Wadi Kischen.-Srkuceinf.

122. Physcia crispa, $N y$.

On granite rocks, on Wadi Kischen (1900 ft.).-Wrhweinf.

123. Physcia obsessa, Nyl.

On twigs, above Wadi Kischen (1800 ft.). - Sichucinf.

124. † Physcia obscurella, Miill. Arg.

On quartz rocks, on Wadi Kischen (1950 ft.). - Srluceinf.

125. † Physcia obscurella, var. fusca, Miill. Aig.

On quartz rocks.--Schueinf.

126. † Physcia endopyxinea, Mill. . Ary.

On twigs partly with Pyxize concexn, Mïll. Arg. -B.C.S. 
127. Physcia picta, Nyl.

Corticolons, on Prulsumodrulim, above Wadi Digal (900 ft.).-li.C.S.

128. Physcia picta, val: rupicola, buyl

On quartz rocks.-B.C.S.

129. Physcia picta, var. sorediata, Miill. Ari\%.

Ahove Wadi Kischen (1800 ft.)._B.('s., sthweinf.

\section{Pyxine, El, Fries.}

130. Pyxine Meissneri, Turl., var. endoleuca, Müll. Ai\%.

On aloe stems. - B.t'.s.

131. * Pyxine coccoes, Iyl. (Plate xxvii. fig. 3.)

Mạtagoti, above camp at Homhil, E. Sokotia. On branches.-M.O.F.

Not heretofore recorded from Sokotra.

The amphithecium (see fig. 3) in this plant cloes not apparently keep pace with the growth of the medullary tissue underneath the hypothecium. As a result the parathecium soon outgrows its former thalline covering, and from leing lecanorine finally beeomes lecideinc.

132. † Pyxine convexa, Miill. tiq.

On the snaller branches of tufts of Romella Montumnei, $\mathrm{N}_{y}$ l.-B.C.S.

\section{THELOSCHISTACEI.}

Placodium, $D C$.

133. † Placodium bullatum, Miill. Aig.

On quartz rocks. - B.C.S.S.

134. Placodium lanuginosum, Miill. Ar\%.

On stones, under shrubs, shightly covered with earth, near Wadi Kischen (1980 ft.). - Schurinf.

\section{Theloschistes, Norm.}

135. * Theloschistes flavicans, $N m m$.

Atho Dimellus (4000 ft.), and in E Sokotra (? at Homhil). - H.O.F.

On branches, above Warli Kischen (3000 ft.). - li.C's., schweinf.

136. Theloschistes flavicans, Torm., var. intermedius, Mill. Arg.

On branches above Kisehen (2400 ft.).-b.C.S., sthurinf.

\section{STICTACEI.}

137. * Sticta aurata, Sim.

\section{Sticta, Schreb.}

On branches, Adho Dimellus (4000 ft.).-II.O.F.

On small branches, above Widi Kischen (3000 ft.). - Schureinf. 


\section{Stictina, Ny/.}

138. Stictina Mougeotiana, $1 y l$.

On smaller branches, above Windi Kisehen, and on Scheheli Peak, alove Halibu (3750 ft.).- trmereinf.

COLLEMACEI.

\section{Collema, Ach.}

139. Collema multipartitum, IIr $m$ '.

C'alcicolous. - B.C.S'.

140. * Collema flaccidum, Ach.

On branches, Adho Dimellus (4000 ft.).-II.O.F.

141. † Collema flaccidum, Ath, var. subnigrescens, Mtill. Ai\%.

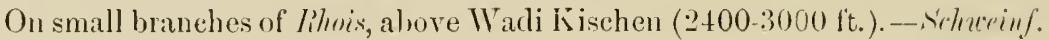

142. Collema flaccidum, Leh., var. levis, Miill. Aity.

On small branches of lihnis, above Widli Kischen (2400-3000 ft.). - Sthurrinf.

143. † Collema flaccidum, Ach., var. subfurvus, Miill. Ary.

On smaller branehes of likois, above Wadi Kisehen (2400-3000 ft.); on

Mt. Scheheli above Hadibu.-B.C.S., Schereinf.

The last three varieties Miiller Arg. emumerates in his first list as Stynecholilustus. flucrillus, Körb.

\section{Leptogium, Ach.}

144. Leptogium diaphanum, I!yl.

On Scheheli (3750 ft.). S. Shceinf.

145. Leptogium Menziesii, MLonty.

On Mt. Scheheli (3750 ft.). Sichurinf.

OMPHALARIACEI.

Anema, Nyl.

146. $\uparrow$ Anema exiguum, Miill. Ar\%.

Calcicolons. - B.C.S'.

\section{Synalissa, Nyl.}

147. $\uparrow$ Synalissa nitidula, Miill. Ary.

Calcicolons.--B.C.S.

\section{PYRENOCARPI.}

VERRUCARIACEI.

Normandina, $\mathrm{Ny} /$.

148. Normandina Jungermanniæ, Ny.

Among lobes of thalli of Purmeliur, on branches, above Wadi Kischen (3000 ft.). - Sthereinf. 


\section{Pyrenula, Ach}

149. † Pyrenula obscurata, Miill. Aig.

On bark on liranches. - li.('s'.

\section{Verrucaria, Web.}

150. †Verrucaria rupestris, Shrml., vilr. alocizoides, Miill. Ai\%.

On calcureous rocks. - B.t's'.

151. † Verrucaria prominens, Miill. Ary.

On quartz rocks.-- R.('s'.

Microglæna, Körb.

152. † Microglæna saxicola, Miill. Ar $\%$.

On (puartz rocks abnve Warli Kischen (1950 ft.).- Sthuceinf.

Microthelia, Körb.

153. Microthelia micula, Kïib.

Corticolons. On small branches.-B.C.S.

\section{Anthracothecium, Mass.}

154. Anthracothecium libricolum, Miill. Ai\%.

On branches.-. Sthuriuf.

\section{Polyblastia, Th. Fries.}

155. † Polyblastia tropica, Miill. Liq.

Corticolons.-B.t's'

\section{Bathelium, Ach.}

156. † Bathelium pauperrimum, Hiill. Ar\%.

On small branches, above Wadi Kischen (2100 ft.). - B.t's., Schueinf.

157. † Bathelium velatum, Miill. Ai\%.

Corticolons, on the larger branches.-B.C.S.

\section{PHYCOMYCETES.* Sporidesmium, Link.}

1. Sporidesmium maculans, Beitr. \& Curt.

On naked wood.--li.t.s.

\section{BASIDIOMYCETES.}

\section{GASTEROMYCETES.}

Batarrea, Pers.

1. Batarrea Stevenii, Fries.

Near Galonsir. - B.C.S.

\footnotetext{
"The remainder of this list is taken from Balfour's Botany of Socotra.
} 


\section{Podaxon, Fries.}

2. Podaxon pistillare, Frie:

Galonsir Plain.-B.C.S.

\section{HYMENOMYCETES.}

AGARICINI.

\section{Agaricus, Tournef.}

3. Agaricus (Pleurotıs) applicatus, Butser.

On bark.-B.C.s.

\section{Lentinus, Fries.}

4. Lentinus cochleatus, Fries.

On trunks near Harlibu._B.C.S.

POLYPOREI.

Polyporus, Micheli.

5. Polyporus igniarius, Fries.

Near Galonsir.-B.C.S.

\section{Trametes, Fries.}

6. † Trametes socotrana, Cke.

Logs on slopes of Haghier south from Hadibu-_B.t.S.

7. Trametes rigida, Berk \& Mtomt., var. glabra, Clie.

Wood near (xalonsir.-B.C.S.

HYDNEI.

Kneiffia, Fries.

8. Kneiffia setigera, Fries.

On bare wood.--B.C.S.

\section{AURICULARINI.}

\section{Stereum, Pers.}

9. Stereum versiforme, B. \& Curt. Rotten logs near Galonsir:--B.C.S.

10. Stereum retirugum, Clie.

On wood near Galonsir.-B.C.S.

\section{Corticium, Pers.}

11. Corticium arachnoideum, $B$. \& $B$ ? Rotten woorl, Galonsir Plain.-li.C's. 


\section{TREMELLINE $\approx$.}

Hirneola, Fries.

12. Hirneola polytricha, MLimty.

Logs and stumps.-- B.C.S.

Dacrymyces, Nees.

13. Dacrymyces stellatus, Nies.

Rotten wood, Galonsir Plain.--li.C.S.

\section{UREDINE Æ⿸尸.}

\section{Uromyces, Link.}

14. Uromyces Commelinæ, Cle.

Leaves of speeies of commelinn.-li.c.s'.

\section{CHARACE无.}

\section{ALG $Æ$.}

\section{Chara, Linn.}

1. $\dagger^{*}$ Chara socotrensis, Torelst.

In rivers in Garieh Plain.-H.O.F.

Near Hadibr. Near Katheng.-B.C.S., Schucinf.

2. Chara gymnopitys, A. Bir

$$
\text { li.c'.'. }
$$

3. Chara gymnopus, $A$. lir., var. angolensis, $t . t i$.

$$
\text { I. ':.s. }
$$

\section{RHODOPHYCE压.}

\section{CERAMIACE $/$.}

\section{Ceramium, Adans.}

4. Ceramium tenuissimum, $L, ! m ! l$.

$$
\text { li. C...'. }
$$

5. Ceramium subtile, $J .(r . A g$.

$$
\text { B.C.'s'. }
$$

\section{LAURENCIACEAE.}

Champia, Desv.

6. Champia compressa, Hurv.

$$
\text { b.C... }
$$

\section{GELIDIACEÆE.}

$$
\text { Hypnea, Lamourx. }
$$

7. Hypnea hamulosa, Mlonty.

$$
\text { li.C.'s'. }
$$


CORALLINEÆ.

Jania, Lamourx.

8. Jania rubens, Litum!ni:

Ii.C.S.'.

PHÆOPHYCEÆ.

FUCACEÆ.

Sargassum, $A g$.

9. Sargassum crispum, $A \%$.

B.C.S.

10. Sargassum asperifolium, IIfr. $c t$. Iturt.

B.C.S.

DICTYOTEÆ.

Padina, Adans.

11. Padina pavonia, Atluts.

li. C..

Dictyota, Lamourx.

12. Dictyota dichotoma, Letumirl.

li.C...

13. Dictyota dichotoma, Letumere, var. intricata, fire.

li. 's.'.

14. Dictyota acuminata, $k t *$.

li.C...

Asperococcus, Lamourx.

15. Asperococcus sinuosus, Bor $\%$. li. '..S.

16. Asperococcus intricatus, $J . G$. $A \%$.

li. C.s.

Hydroclathrus, Bory.

17. Hydroclathrus cancellatus, Bim $\%$ li. '. S'.

CHLOROPHYCE $Æ$.

ZYGNEMACE/E.

Spirogyra, Link.

18. Spirogyra turpis, kt:.

li.C.S. 
19. Spirogyra condensata, Kt*.

$$
\text { li.c.s. }
$$

20. Spirogyra decimina, Link.

$$
\text { B.C.s. }
$$

21. Spirogyra dubia, $k t . .$, var. longiarticulata, $k t *$. li. '.S.

\section{Zygnema, $A g$}

22. Zygnema Vaucherii, .ty., var. tenue, lithenh.

li.C.S.

\section{CONFERVOIDEAE.}

\section{Chætomorpha, $K t z$.}

23. Chætomorpha tortuosa, $K t z$.

$$
\text { B.C.S. }
$$

24. Chætomorpha chlorotica, Kt:

B.C.S.

ULVACEÆ.

25. Ulva latissima, Linn.

$$
\text { Ulva, Linn. }
$$

CHÆTOPHORACEÆ.

Microthamnion, $\mathrm{Nag}$.

26. † Microthamnion breviarticulatum, Gi. Dickie.

\section{SCHIZOPHYCE尼.}

NOSTOCACEÆ.

$$
\text { Nostoc, Vauch. }
$$

27. Nostoc aureum, $k t \approx$.

$$
\text { B.C.S. }
$$

28. Nostoc verrucosum, licuch.

l.C.S.S.

$$
\text { RIVULARIEAE. }
$$

$$
\text { Schizosiphon, } K t z \text {. }
$$

29. Schizosiphon aponinus, Heneyh.

$$
\text { B.C.S. }
$$


OSCILLARIEÆE.

Lyngbya, $A g$.

30. Lyngbya obscura, $k t:$.

B.C. '...

31. Lyngbya curvata, Limbenh.

li.'.S.

32. Lyngbya majuscula, Hwre. B.C.S.

33. † Lyngbya scabrosa, 1i. Iillie.

li.c.s.

Oscillaria, Bory.

34. Oscillaria Frölichii, $k t$.

li.C.S.

35. Oscillaria anguina, biry.

b.C.S.

SCHIZOMYCETES.

Hypheothrix, $k t z$.

36. Hypheothrix vulpina, lit:

B.C.S.

Beggiatoa, Trev.

37. Beggiatoa alba, Tire.

B.C.S.

\section{RAPHIDIEÆ.}

\section{DIATOMACE E.}

CYMBELL/E.

Amphora, Ehr.

1. Amphora ovalis, Ehri.

B.t.5.

\section{Cymbella, Agh.}

2. Cymbella lanceolatum, Ehr.

$$
\text { li.C.S. }
$$

3. Cymbella bengalensis, (irumul.

$$
\text { b.C.s. }
$$

4. Cymbella cistula, lihr.

$$
\text { li.c.s. }
$$

5. Cymbella cymbiformis, Ek

b.C.S. 


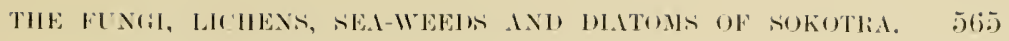

NAVICULEA.

Navicula, Bory.

6. Navicula sphærophora, $k t$...

li.'.'s'.

7. Navicula elliptica, $k$ \%

li.' 's'.

8. Navicula mutica, kt., var. Cohnii, llitse.

li.C..

Mastogloia, Thwaites.

9. Mastogloia Dansei, Thuruites.

li.1'.s:

10. Mastogloia lanceolata, Thuruites.

li. 's:

11. Mastogloia elliptica, . $1, y / 1$.

li.t's.

\section{Stauroneis, Ehr.}

12. Stauroneis anceps, Elr., val: amphicephala, I tun Heurck.

l.C.'.

GOMPHONEMEÆE.

Gomphonema, Agh.

13. Gomphonema intricatum, kt..

B.C.S.

14. Gomphonema affine, $1 \%$.

li.t'.S'.

15. Gomphonema acuminatum, Ekr'. valr. coronatum, l'in Heurk. B.I.

16. Gomphonema Turris, Eili:

li.t.s.

17. Gomphonema constrictum, Elli., var. subcapitata, litu Ileurck.

li.C's'.

ACHNANTHE/E.

Achnanthes, Bory.

18. Achnanthes linearis ( $I^{\prime} m$. S'mith).

li. 'C. 
COCCONEIDE/E.

$$
\text { Cocconeis, Ehr. }
$$

19. Cocconeis pediculus, lihr.

li. '...'.

\section{PSEUDORAPHIDEE.}

\section{FRAGILARIEÆE.}

Epithemia, De Brebisson.

20. Epithemia gibberula, Eikr., var. producta, I'n Itenick. li.'.S.

\section{Eunotia, Ehr.}

21. Eunotia pectinalis, E'h:

li. ('.S'.

Fragilaria, Lyngbye.

22. Fragilaria Ungeriana, Grunou:

I.C.C.

CRYPTORAPHIDEÆ.

BIDDULPHIEÆ.

$$
\text { Terpsinoë, Ehr. }
$$

23. Terpsinoë musica, Ehr.

b.r.s.

\section{Cerataulus, Ehr.}

24. Cerataulus socotrensis, Kitton.

I).C.S.

COSCINODISCE/E.

Cyclotella, Kütz.

25. Cyclotella Meneghiniana, Kut:., var. rectangulata, Brétisistu. B.C.S. 


\section{II. - The Lichens and Sea=Weeds of $\mathrm{Abd}=\mathrm{el}=\mathrm{Kuri}$.}

\section{DISCOCARPI.}

\section{LICHENES.**}

GRAPHIDACEI.

Roccella, Ach.

1. Roccella Balfourii, Mriill. .tig.

On rocks on Gel,el Sialel.-W.I.F.

2. Roccella fuciformis $(L),. A c h$.

On rocks on (ielrel Saleh.- II.O.F.

Some small fragments bearing young smillir.

\section{ALG $\nRightarrow$.}

The only sea- Ifeeds collected were a few 1 obtained at low ticle on the rocks near our anchorage in Bander Saleh, which were preserved in formal. They were sent to Mr. E. M. Holmes, F.L.S., who kindly examined them, and sends me the list below with the following note:- "I have carefully examinerl your hottle of Alye, and, as far as it is possible to identify them from the fragmentary, unfruiterl, and decolorized material, I find the following species."-H.O.F.

\section{RHODOPHYCE压.}

\section{GELIDIACE/E.}

\section{Gelidium, Lamourx.}

1. Gelidium rigidum, $J$. li. . Ily.

\section{SPHÆROCEACEÆE.}

\section{Gracilaria, Grev.}

2. Gracilaria corticata, $J$. . . $\%$.

3. Gracilaria Müllardetii, $J$. .t!.

The structure of these two plants is that of Crmiluriu; ; lnt neither are in fructification. I have not hitherto seen Girusiluria Minluretetii from anywhere north of the Mascarene Islands. It is plentiful at Mauritilis.

\section{Jania, Lamourx.}

4. Jania rubens, Lumouri: 
RHODYMENIAGEÆ.

$$
\text { Desmia, J.Ag. }
$$

5. Desmia ambigua, $/$ Ir $t$.

RHODOMELACEAE.

Laurencia, Lamourx.

6. Laurencia papillosa, cirr.

\section{PH压OPHYCE尼.}

FUCACE $Æ$.

$$
\text { Sargassum, } A g \text {, }
$$

7. Sargassum flavicans, $J$. .l!

8. Sargassum cargophyllum, $J$. . $t$ !)

9. Sargassum virgatum, $J . A \%$.

\section{Turbinaria, Lamourx.}

10. Turbinaria ornata, $J$. . I\%.

\section{CHLOROPHYCE压.}

CAULERPACEÆ.

Caulerpa, Lamourx.

11. Caulerpa selago, ' '. I/y.

This identification is doulteful as only two flagments of conlerpu were fouml, which are rather more slender than usial in this species. There is, however, no other species that the fragments resemble more closely.

CODIACE/E.

Chlorodesmis, Harv.

12. Chlorodesmis carnosa, IImx.

Codium, Ag.

13. Codium tomentosum, wturkit. 



\section{PLATE XXVII.}

Fig. 1. ROCCELLA BALFOURII, J. Wiill. .lig. ITrtiml sirtim

$$
\text { of Ifutherium. } \quad \text { x 5.5, p. } \mathbf{5 5 0} .
$$

Fig. 2. ROCCELl.A BALFOURII, J. Miill. Ai\%. A simple sidetled spore. $\times 1075$, p. $\mathbf{5 5 0}$.

Fig. 3. PYXINE COCCOES, Nyl. Irestical sertion of Ipotherium,

p. 557 . 

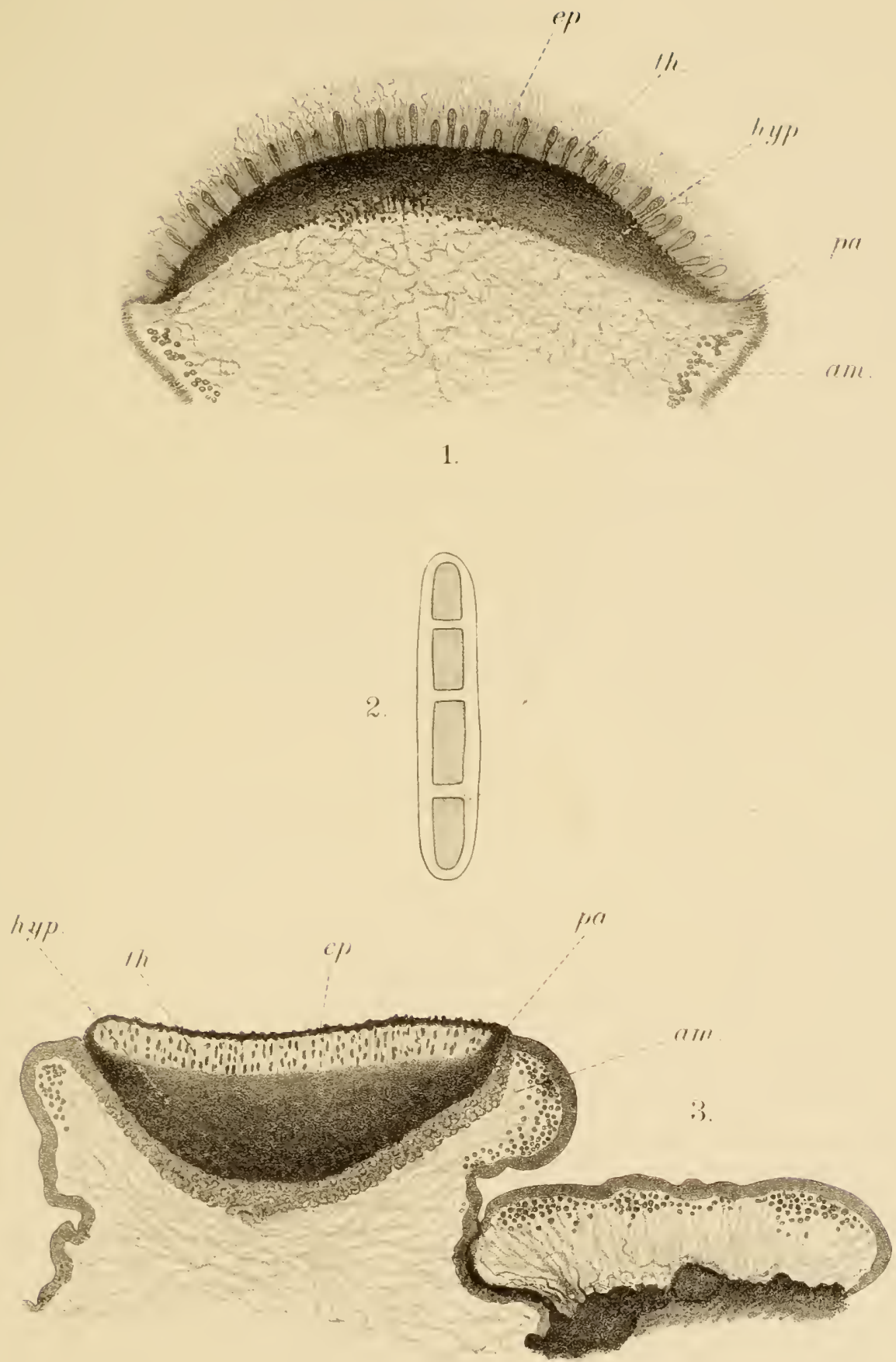

Geology

of

\section{Sokotra}

and

$\mathrm{Abd}=\mathrm{el}=\mathrm{Kuri}$ 



\section{$\underline{\text { Geology. }}$}

Note on the Geology of Sokotra and $\mathrm{Abd}=\mathrm{el}=\mathrm{Kuri}$.

By Prof. J. W. GREGory, D.sc., F.R.S.

[Ertructed from the GEoLogical MarizINE,

Decarle IV., Vol. VI., No. 426, p. 529, Iec., 1s99.] 



\section{Geology.}

The first account of the geology of Sokotra we owe to Lientenant J. R. Wellsted, * who eompiled the Admiralty chart and map, and in 18.35 described the island in a detailed memoir, in which he showerl that it consists of a mass of granite capped hy limestones. Nothing material was added to this description until 1883, when Professor Bonney published his aceount $\dagger$ of the extensive rock collection made by Professor I. B. Balfour during a six weeks' visit to the island in Fehruary and Mareh, 1879. Professor Bonney's study of the rock specimens enables him to prove that Sokotra eonsists of a block of Archean rocks covered in places by massive limestones, which, on the evidence of their foraminifera, Professor T. R. .lones suggested were probably of Miocene age. It was further shown that both the Arebean series and the Cainozoic limestones are ent throngh ly dykes of trachyte and basalt, associated with a series of rhyolitic lavas. Professor Balfour's expedition not only proved that the foundations of Sokotra are built of old materials, but that the island is of considerable antipuity, as is indicated by its rich endemie flora. +

In 1880 Sokotra was visited by Emil Riebeck, who colleeted some rock specimens containing the mineral which was described in 1888 hy Saner under the name of Riebeckite. Further details regarting the Arehean and voleanie rocks were given in the same year in a paper by Miss Raisin.

During the winter of $1 \times 9 x_{-9}$ Sokotra and the neighbouring istand of Abdel-Kuri were visited by Dr. H. O. Forhes and Mr. Ogilvie Grant, who made at

*J. R. Wellsted, "Memoir on the Island of Socotra": Jomrn. Roy. Geogr. Soc., vol. v. (1835), pp. 129-229, and map.

†T. G. Bonney, "On a Collection of Rock Specimens from the Island of Socotra": Phil. Trans., vol. $17+(1883)$, pl). $273-294$, pls. vi. and vii. Some preliminary remarks on the geology of the island were included in Professor Balfour's report, "On the Island of Socotra": Rep. Brit. Assoc., 1981, p. 486.

+According to Balfour ("Botany of Socotra": Trans. Roy. Soc. Eilinb., vol. xxxi., 1S8s, p. lxxv.), the island has been a land area since the Permo-Carboniferous. and "an island certainly from Tertary times."

\$Sauer, "Ueber Riebeckit, ein neues Glied der Hornblendegruppe" : Zeit. deut. geol. Ges., vol. xl. (1888), pp. 138-146).

(C. A. Raisin, "Rock Specimens from Socotra": ( ieol. Mag.. 1)ec. III., vol. v. (18S8), pp. $504-507$. 
collection of rocks, upon which I have heen askerl to report. Dr. Forbes has given me an aceomnt of the mode of ocemrence and distribution of the principal rocks. At about the sime time both islands were visited lyy the Austrian Sonth Arabian Experlition in the fruftfirim and a note on their geology has been published by I)r. F. Kossmat, in which he remarks the occurence of Cenomanian and Eocene limestones.*

The present colleetion does not necessitate any modification in the geological history of Sokotra, as deciphered by Professor Bonney from the materials available in 1883 . But the collection adrls to the knowlerge of the distribution of the different roeks in the island.

[Professor Bomney's conclusions on the geology of the island, hased on his examination of the rock specimens bronght home ly Professor Balfour, are:- $\uparrow$ "It woull appear that in Sokotra we have, as the foundationstones and 'core' of the island, if the phrase he permissible for the ronvenience of the reader, a mass of rock of rery great antiquity. There is clear evidence of the presence of gneissic rocks which, in their lithological characters, resemble closely those which exist in the north-west of Scotland, the Malvern Hills, and one or two other localities in our own island, in Northern America, and in many other parts of the globe. By whaterer name these may be called, and howerer they may be co-related one with another, it is evident that their antiquity is enormonsly great, and that they had attaned their present mineral condition before the earliest palreozoic rocks were deposited. Associated with these are granites, which, thongh of later date, are, probably, also of great antiquity. In the Sinai peninsula, we have also gneiss, schists, and varions granitic rocks. Of the latter, I possess a small collection, given to me hy Professor E. H. Palmer, $\stackrel{+}{\ddagger}$ and the resemblance of some of the specimens to those of Sokotra is rery remarkable. In the geological notes arded by the Rer. F. II. Holland to the Report of the Ordnance Survey (ch. viii.), we find it stated, indeed, that the prevailing rock, in the Sinai region, is syenite (by which term, probably, hornblendic granite is meant), so that ont of several hmuled specimens he only possessed two or three of true granite. This may be, but my specimens from the summits of Serbal, of Jebel Musa, and Um Shomer closely resemble some of the Sokotra rocks, especially the first and second, which are coarse reddish granites, eomposed almost wholly of quartz and felspar (pegmatites). From the summit of Serlal also comes a finer-grained granite, and I have an ordinary granite from Wady Sigillia. Other speeimens, exactly as in the Sokotra collection, might be either true igneous or highly metamorphic rock. In the Sinai region the old gneiss appears only to have been recognised in the northern part, where it forms an irregular trough to the north of Jebel Sertal, the higher peaks (like the Haggier range in Sokotra) being granite. I miss, however, from the Sokotra district, or find but fechly represented-for there is one

* F. Kossmat: Sitz. math. nat. Cl. k. Akad. Wiss. Wien, 1899, No. ix., pl. 73-82.

t This quotation from Professor Bonney's report in the P'hilosophiral Transactions (loe. cit.) is inserted here hy the editor.

\pm He was a member of the Sinai Survey Fxpedition in 1868-9. 
specimen which may belong to it-the frialle varialbly-colomed sandstones which form so marked a feature in some parts of the Sinaitic peninsula (e. $\%$, Wialy Mokatteh).*

"These, after having been assigned to more than one geological epoch, were referred by Mr. Holland, on the evidence of fossils, to the carboniferous. In Sinai, as in Sokotra, we have huge masses of limestone, which in like way form great plateanx-as, for example, the Tih-and were deposited in an ocean, in which the well-known peaks of Sinai probably formed rocky islands, but deposition there commenced at an earlier perion than we can venture with the evidence at present hefore us to claim for Sokotla, for the limestones of Sinai are assigned to part of the cretaceons and to the eocene age; the Nummulitic limestone, for example, being finely developed as in Warly Dhaghadeh. Coraliferous beds of miocene age are, however, found in that region. $\dagger$ 'The rocks of Sinai are cut by dykes of 'basalt, greenstone, and porphyrite,' the first of which, as in Sokotra, are probably comparatively modern, but we do not find there, so far as I can learn, representatives of the great group of the quartz-felsites and rhyolites which seem so enormously developed in Sokotra, and were certainly connected with active volcanoes. The geological age of these cannot be determined. They are undoubtedly older than the limestone group : so that, if no part of this is earlier than the middle tertiary, they might belong to any geological period between that and the latest Precambrian, to the volcanic rocks of which they have, indeed, considerable resemblance. I am not aware that the 'argillite' of Sokotraof which I can only say that it is older than the limestone-is represented in Sinai. As here, so also in Sokotra, there are basalts of comparatively late geologic age-post miocene - and in the latter some compact trachytic rocks, which, however, differ from the older rhyolites, and are generally paler in colour.

"We have, then, in Sokotra, as it seems to me, evidence of rocks of an immense, and a land surface of a very great, antiquity. Fxcepting this argillite of uncertain age and limited extent, and perhaps some sandstone (also local), there is no eridence in the specimens hefore me to show that this island was submerged during any part of the palæozoic or mesozoic period. $\ddagger$ During the Kainozoic it undoubterly shared in the downward movement which affecterl so large a portion of the globe in and almout the North African

* This absence of the sandstones is probably an accident (the rock being very friable), for Professor Balfonr mentions "purple sandstones" (see p. 275).

† Bauerman, Quart. Jour. Cieol. Soc., vol. xxv., p. 37.

+ "Africa south of the Sahara was probably a stable area during many of the alterations of the relative levels of land and sea of the north and of Europe." - Professor P. M. Duncin, Presidential Address to Geol. Soc., 1877, Journal, vol. xxxiii., p. 86 (Proceedings). West of the Sinai l'eninsula old schists and granite crop out in Egypt, and east of it on the opposite side of the Gulf of Akabah, flanked in both cases by "Nubian sindatone." See the map attached to the Presidential Address to the Geologists' Association (delivered November 3, 1882), by Mr. IV. H. Hudleston (Proceedings, vol. viii., p. 1), in which is given an admirable summary of the Geology of Palestine and the neighbouring districts. 
and mid-Asiatic districts: but I should infer that the invasion of the sea commencer much earlier in the Sinaitic peninsula, and think it possible that the topmost peaks of the Haggier Momntains were at no time wholly sulmerged. As it again rose from the waves-perhaps being for a while connecterl with the African continent the meteoric forces resumed their work of sculpture and the wares logan their work of insulation. Since then the fanna and Hora have mulergone their own modifications, but in the Haggier Hills we have probably a fragment of a continental area of great antiquity, and of a land surface which may have been ain "ark of refuge" to at terrestrial fam and flora from one of the very earliest periods of this wordd's history."]

\section{I.--Geology of Sokotra.}

The rock collection from Sokotra contains representatives of three groups of rocks-a basal Archean series, some massive limestones, anrl some com paratively recent volcanic rocks.

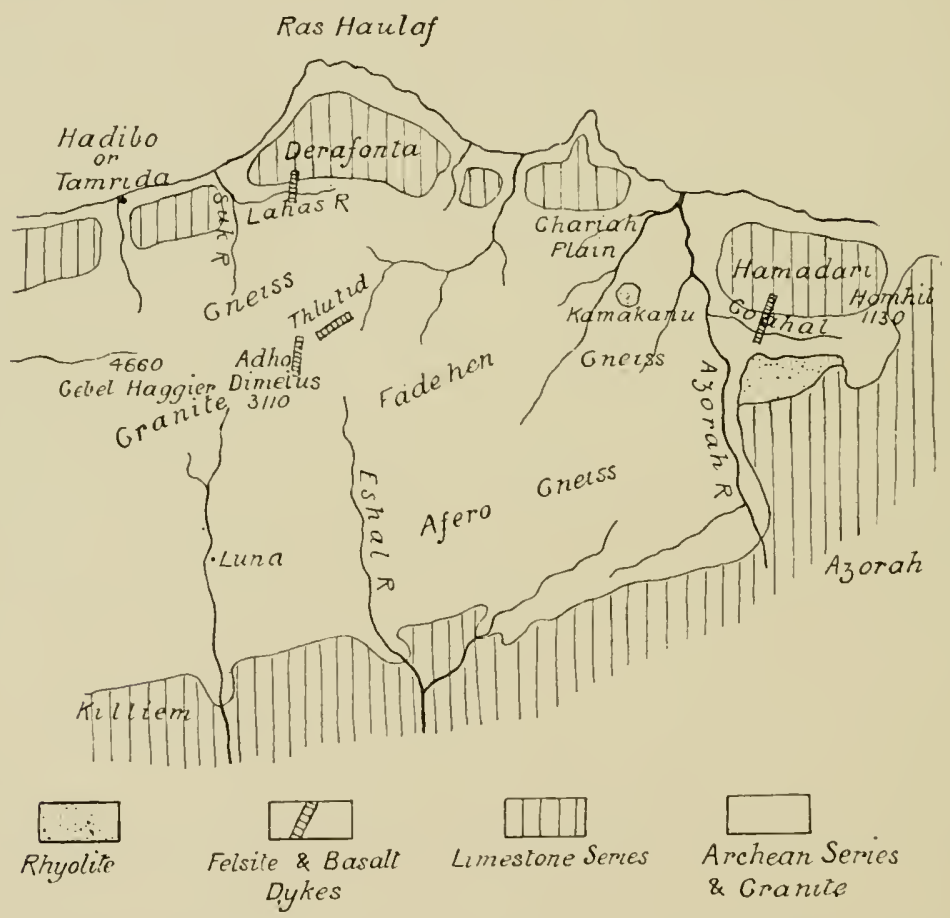

The largest part of the collection consists of Archean rocks and some associated granites. As a rule, the gneiss is more granitoid than the rock which forms the main mass of the East African Archean platean: but a specimen from Thlntid [Jena-agahan], at the height of 900 feet, corresponds 
with the typical gneiss of the mainland. With the granitoid gneiss there is a coarse pink granite which forms the summit of the llaghier, Gehel Dryat, the highest peak in Sokotra; it occurs also at Acllo I)imellus, and at the height of 1500 feet at Farlehen.

The second group of the Archean series consists of dark-green amphibolite schists, of the type that forms such a conspicuous feature in the East African gneiss series. This rock was eollected ly br. Forbes in the Harlibu Plain near 'Tamatriliı.

The Archean rocks of Sokotra therefore resemble those of the Fast African Nyika series, and the island is simply an outlier of the Last African platean.

Overlying the gneisses is a compact, massive limestone which has been sometimes renclered coarsely crystalline, probalby by contact metamorphism. This limestone forms the extensive platean at the eastern end of the island, and, accorling to I)r. Forbes, sections ent ly the Goahal river show that the limestone there rests directly on the Arehean series. South of the Goahal river the limestone forms a platean, the southern end of which is continued westward round the southern flanks of the central highlands. From the Hamadari [rmel Hamadern.-H.O.F.] plateau a helt of limestone extenrls westwarl to heyond Tamarida; the rivers have cut through it, showing that it rests on the Arehean series.

The collection gives no evidence as to the age of the limestones, but fortunately Herr Kossmat has ohtained from it a number of mollusea and echinids, which enablerl him to determine it as Eocene. Kossmat also records an underlying Cenomanian sandstone with Janim quinquecostutu.

The last group of rocks representer in the collection is a series of recent volcanic rocks, of types already described from Sokotra by Professor Bomney and Miss Raisin.

The volcanic rocks include rhyolites, quartz-felsites, and basalt. Most of the specimens are dyke rocks, lut one lava is included in the collection. It is a rhyolite with well-marked fluxion structure, and containing many angular flagments : it was collecterl on the edge of the platean, south of the Goahal river. A similar rock has heen deseribed and figurerl by Professor Bonney * from Azorah, and, aceorling to Dr. Forbes, the ronded hill in the Garieh Plain near Kamahanu eonsists of the same rhyolite. $\dagger$ †

Quartz-felsites were collecterl from dykes intrusive in the Archean series at Homhil and Adho Ilimelhss. The felsites at both localities are intensely altererl by decomposition; the abundant iron-ores have heen altered to lencoxene, and the matrix is stained bright red. The only maltered minerals are the large phenocrysts of quartz; and they are deeply corroded, as illustrated by Velain, $\dagger$ from the quartz-trachytes of Arlen, and by Miss Raisin, ${ }_{*}^{+}$ in a quartz-felsite from Sokotra. In one ease the quartz shows a zonal

* Bonney : op. cit., p. 287, pl. vii. fig. 5.

†Ch. Velain : “Descript. géol. presqu’île d’ Aden," 1878, p. 18, fig. 2.

† Raisin : op. cit., ए. 505, fig. 1 .

†† Prof. Gregory must have misunderstood me here, for Kamaham hill is entirely of granite, $-I I . O . F$. 
arangement of the inclusions, a feature umusual in volcanic quartz crystals: lut the identification of the mineral was confinmed hy the mse of convergent polarised light. The felsite from Adho Dimellus has mumerous, somewhat ill-rlefined spherulites; in that from Homhil some of the smaller patehes of secomlary puartz are travelsed by faint lines like cleavages, suggesting that the quarty has been formed hy the alteration of tridymite aggregates.

The last member of the rhyolite-felsite series is an altererl, fine-grained trachyte from the Garieh Plain. It is similar in character to the trachyte figured ly Professor Bonney * from the Azorah district.

A dyke of a failly fresh lasalt was found hy Dr. Forbes at Thluticl (Jena-agahan) on the nortlo-east $\uparrow$ slope of the granite mass of the Haghier +

The most interesting feature in the trachyte and felsite is that the rocks resemble those of the Aden volcanic series rather than those of the liast African rolcanic group. For opportunities of examining some of the Arlen rocks I an indehted to Mr. (x. T. Prior:

Hence Sokotra appears to he an ontlier of the somali platean, which hats been involved in the movements which formed the (tulf of Aden, and has heen the scene of the ermption of volcanic rocks of the Arlen series.

* Bonney : op. cit., p. 28T, pl. vii. fig. 6.

+ Professor (tregory had in his original paper inadvertently written " north-west" for "north-east" ; and the "granite mass of Adho Dimellus" for "of the Haghier." Adho I)imellus lies to the west of Thlutid (Jena-agahan), and quite in the heart of the Haghier massif. I have, therefore, ventured to correct the passage. - H.O.F. 


\section{II. - Geology of Abd=el=Kuri.}

II est of Sokotra is the small island of Abd-el-Kuri, where a larger rock colleetion was marle by Messrs. Forloes and trant. It was also risited by Dr. Kossmat, who has described it as composed of amphibolites, penetrated hy a network of granites and camptonite dykes, and capjed by a limestone which he suggests to be of Turonian age. The only previons geological accomut of the island known to me is hy H. . Carter, tho in his memoir on the greology of the sonth-east coast of Arabia described Alnd-el-Kuri as composerl of a mass of granite and rliorite, capperl hy a limestone which reaches to the summit at the level of 1600 feet ahove the sea.

The colleetion from Alul-el-Kuri is composed mainly of rocks belonging to the Archean series. They inclucle a series of amphilolite schists, a syenitic: gneiss, some specimens of which have a consideral,le development of epidote, and a white gneiss with hom mhende aggregations: the last rock is strikingly like one which is eommon in the Uln Mountains of Ukambani in British East Africa. This series of foliated rocks is cut through ly pegmatite dykes, which are almost as coarse in grain as those of Somaliaund: in one speemen collected the museovite occurs in crystals from two to three inches in dianeter.

The Arehean rocks are eovered by limestones whieh occur at different levels from 40 feet above the sea to the summits of Gehel Saleh and Gehel Somali, the highest peaks in the islind. The limestones appear to be very fossiliferons, and one specimen is crowted with shell fragments; but the only specimen generically determinable is a Verinu in a block of limestone colleeted by Dr. Forbes at the height of 700 feet. The limestone at that point is, therefore, no doul, Cretaceous.

On the lower parts of the island a reef limestone occms up to a height of to feet above sea-level. As it contains well-preserved specimens of Gomiustiven retiformix, it is no doubt of Pleistocene age.

+ "Geol. Papers on Western Indial," 18.57, p. 620. On p. 621 of the same work Carter describes "The Brothers," the islets between Sokotra and Abd-el-Kuri, as also formed of granite and rliorite capper by limestone. 



\section{N D E X.}

P.Iit.

Ahd-el-Kuri, Alge of, 567 ; beetles, 289; binds, 58 ; botany, 445 ; bugs, 392 ; huttertlies, :314; centiperles, 4:39; crustaceans, 216 ; D'Alluquerfue on domestic animals of, xxx; living for pearls, method of, xxvii: dress of natives, xxvii : fel'ns of, 5):2 ; fishing by natives, $\mathrm{xxy}$; Fissurella on hill-sides, xxvii; Hies, 375 ; Howering plants, 521 ; Gelel Sileh, highest peak, xxviii ; geoglaphical position, xvii ; gum found on, xxix ; geology, 581 ; grasshoppers, 4.24; hamlet, rlescription of, xxrii; inhabitants, xxir ; landshells, 152; lichens and sea-weeds, 567 : literature relating to Arachnida of, 204; mosquitos, xxx ; mammals, 16 : micro-lepirloptera, 354 ; moths, 337,354; native barter, xxr: neuroptera, 39i, 403, 405 : species of Otopoma doubtful in, 155 ; pearl-shelling, xxvii : plants with conspieuous flowers, xxr : Pterophoridx, 354; reptiles, 94 ; roek-faults, xxxi; scorpions and spirlers, 202 ; sea-weeds, 567 ; Expedition's second visit to, $x \mathrm{r}$; sickness among natives, xxix; species of Sokotran Hora alssent from, xlvii : stay at, $\mathrm{xx}$ : turtles, chief food of people, $x \times x$; turtle shell, xxvii ; wasps and bees of, 255.

Aberia,

Abutilon, - - - - 457

Acucia, - - - 470,522

Acalypha, -

Acantlaclisis,

PAliE,

Acanthorlactylus hoskianus, $\quad 75$

Acantholipes, - - $\quad 328$

Acarita, - - - 201

Achnanthes, - - $\quad 565$

Achyianthes - - - 502

Achyrocline - - $\quad$ - 479

Acidalia, - _ _ _ 332

Acontia, - _ _ $32 t$

Acriea, - - - $\quad 304$

Acridium, - - _ _ 4.21

Acrirlocarpus, - $\quad$ - $\quad$ - 460

Acrocercops, - $\quad$ - $\quad$ - 353

Acrotylus, $\quad$ - $\quad$ - $\quad$ - $\quad 419$

Actinopteris, - $\quad$ - 539

Adelostoma, - - $27 \tau, 291$

Adenium, t85 : figme of, xli.

Adbo-I)imellıs, (amp at, xlii ; Pass, riew from, xliv: climate at, xly possible sanatorium for Aden troops at, xly.

Adiantum, - - 53\%, 542

Evialitis, - - $\quad 53,60$

Eluropus, - - - 520

Errla, - - - 501, 526

Agaricus, - - - $\quad 560$

Agdistis, - _ _ _ $\quad 354$

Agrelena, - - _ $\quad 193$

Ageratum, - $\quad$ - 479

Agromyzil, - _ - 374

Agrotis, - _ _ _ 32.2

Ailopaplum, - - - 546

Aizoon, - - - 475, 523

Alaus, - - - - 270

Algae of Sokotra, 561 ; of Abd-elKuri, 567 : Algie, by Prof. Balfour, F.R.S., E. M. Holmes, F.L.S., 543. 
Allecula, - $\quad 232$

Allophylus, - - - 46.5

Aloe,

Aloe export,

Alphens,

Alsodeia,

Alysicarpus,

Amarantus,

Amlergris,

Amber-like gum in Alxl-el-

Kmi,

Amefrontia,

Ammannia,

Ampelisca,

Amphiloma,

Amphora, -

Amr ancl Ali, gutides in Sokotra, xxxii : olstruction lハ, xxxvi.

Amydrus, 22, 5s; A. creaghi, xlvi.

Amyna,

323

Anagallis, -

$+8.3$

Anis,

51

Anax,

$+01$

Ancalanthus,

497

Andropogon,

518

Anechura,

$41+$

Anema,

55

Aneptoporus,

437

Angiosperme, by Professol. Balfour, F.R.s.

Anglaecum,

507

Anictangium,

540

Anisolabis,

Anisotes, -

Anous,

Anthericum,

512

Anthicus,

Anthistiria,

Anthomyia,

519,531

Anthracothecium,

373

5.59

Anthrax

367,375

Anthraxon,

Anthrocarpum,

5)

468

Anthus,

34,60

Anticharis,
Antigastra,

1'Al:k.

Antirrhinum,

:3is

Ant-lious of Sokotia, - - 104

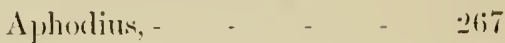

Apis, - - - - 251

Apithesis, - - - 는

Apludie, - - - - 51!)

Arachuiclat, ly R. I. Poencek, 175

Arachnicla of Soketrat andel

Alxl-el-Kuri, hiterature of,

Araneus, - - - 190, 2014

Archips, - - - 35

Arrlea, - - n 53

Alenallia, - $\quad$ - $53,45.5$

Argemone, - - 15 -

Argyope, 1кк, 203: A. clardii, хxт, xxix.

Arigyrodes,

1.5.

Argyromolat, - - 366,375

Aristidal, - - - 5l!

Aristolochial, - $\quad$ - 50.2

Arthonia, - - 54!

Arthothelimn, - _ - 5

Arthrocarpum, - $\quad$ - $46 \mathrm{~s}$

Asanadia, - - $\quad$ - 433

Asarcina, - - - - 36!

Asparagus, - $\quad$ - 509,530

Asperococcus, - _ $\quad 562$

Asphodehs, - - 512,530

Aspiloceryphus, - - 385

Asplenim, - - 538,542

Aspongepus, - - $\quad 3 \times 9$

Ass, Wili, of Sokotra, xxxviii, 9 : probalsle origin, xxxviii.

Astata,

Asterini,

546

Asystasia, -

496

Atella,

302

Atherigonla, - $37: 3$

Atriplex, - _ _ 50 -

Atrophothele, - $\quad 18: 3$

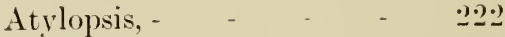

Aurlulla, - - - $\quad 225$

Aulonogyrus, - - - 266

Amicula, - - _ - 150 
PARE.

Australina,

507

Austrian Expedition, Kinduess of. towarls oll sick, $x$; visit flom at Arlho Hinellus, slv.

Ares, ly II. R. Ogilvie-

(ivant: H. O. Follues,

1.1.1).

Avicemular.

Avifamua of Sokotran Arelui pelitero,

Azyguphleps,

Billiallat, 50s

Balfour, F.li.s., Prof. I. B., Angiospelmat, lis, 417 ; Iteridophyta, hу, 535: Thallophyta, lм, 54:3 ; exploration of Solotıa, hs, xviii

Ballochia,

$+96$

Balsamodendı̀u,

462

Baniana,

328

Barleria,

Barter and currency in Sokutial, - xxxviii

Bissuluiodes,

$19 s$

Basidiomycetes, _ _ $\quad 559$

Batallea, _ $\quad$ - $\quad$ - $\quad 5.59$

Bathelimm, _ $\quad$ - $\quad$ - 559

Batrachia, Note on, by Henry O. Forbes, I.L.I)., - - 105

Bitrachedra, - $\quad$ - $\quad 347$

Bees of Sokotial. 235, 236 : of Alulel-Kin, 205.

Betetles of Sokotra, 26:3; of Alrk-elKin, உ8่9.

Begrgiatoa, 564

Begronia, 475

Belenois, 309

Belenogaster, 24

Bemlex, 25

Bemmett, Mr. E. N., Exploma tion of Sokotia, ly,

Bent, Mr. and Mrs. T., Exploration of Sokotra, by,

Biantes,

$.200,204$

Biclens,
PAIE.

Bircls of Sokotial, $2-2$; of Abrl-nKin:i, 5s.

Blainville:i,

Blastruia,

Blepharis, -

Boalninia,

$3: 30$

Buerhalavia,

$5(0), 526$

Bombylius,

:36i

Bumery, F'. li.s., l'rof. 'T. (:. on greologr of Soliotra, 575 et sere.

Bol*asils, 514

Bus, 12

Bestrychus,

$27: 2$

Buswellia, $+61$

Butanieal collectors whohave visitod Śokotri,

Botany of Soliotra and Alulel-Kuri,

Buncerosia, 487

Bunlenger, F. K.S., Mr. (*. A., Reptilia ly,

Brachymenimm,

Brassicil,

Bleweria,

Brothers, Island group of the,

xvii

Brown, Mr. N. F., on Edith colea,

Bryum, - - $\quad$ - $\quad 540$

Buelliı, - $\quad$ - $\quad$ - $\quad$ - 555

Buttalues, - $\quad$ - $\quad$ - $\quad$ - $\quad 12$

Bugs of Nokutla, 3śl ; from Ahrlelkuri, 392

Buliminus, 112-130, 15:, 170 : Species of, roultfulin Sokotra, 130 . Burr, F.L.S., Mr. Malcoln, Orthoptera, by $\quad$ - $\quad 109$

Bury, Mr., - $\quad$ - _

Buteo, - $\quad$ - $\quad 48$

Buthus, - - _ - 178

Butheolus, - - _ 1

Butterflies of Sokotıa, 295 ; of Abdel-Kini, 314.

Buxus, - $\quad$ - $\quad$ - 504

Bytilia, - $\quad$ - $\quad$ - $\quad 30: 3$ 


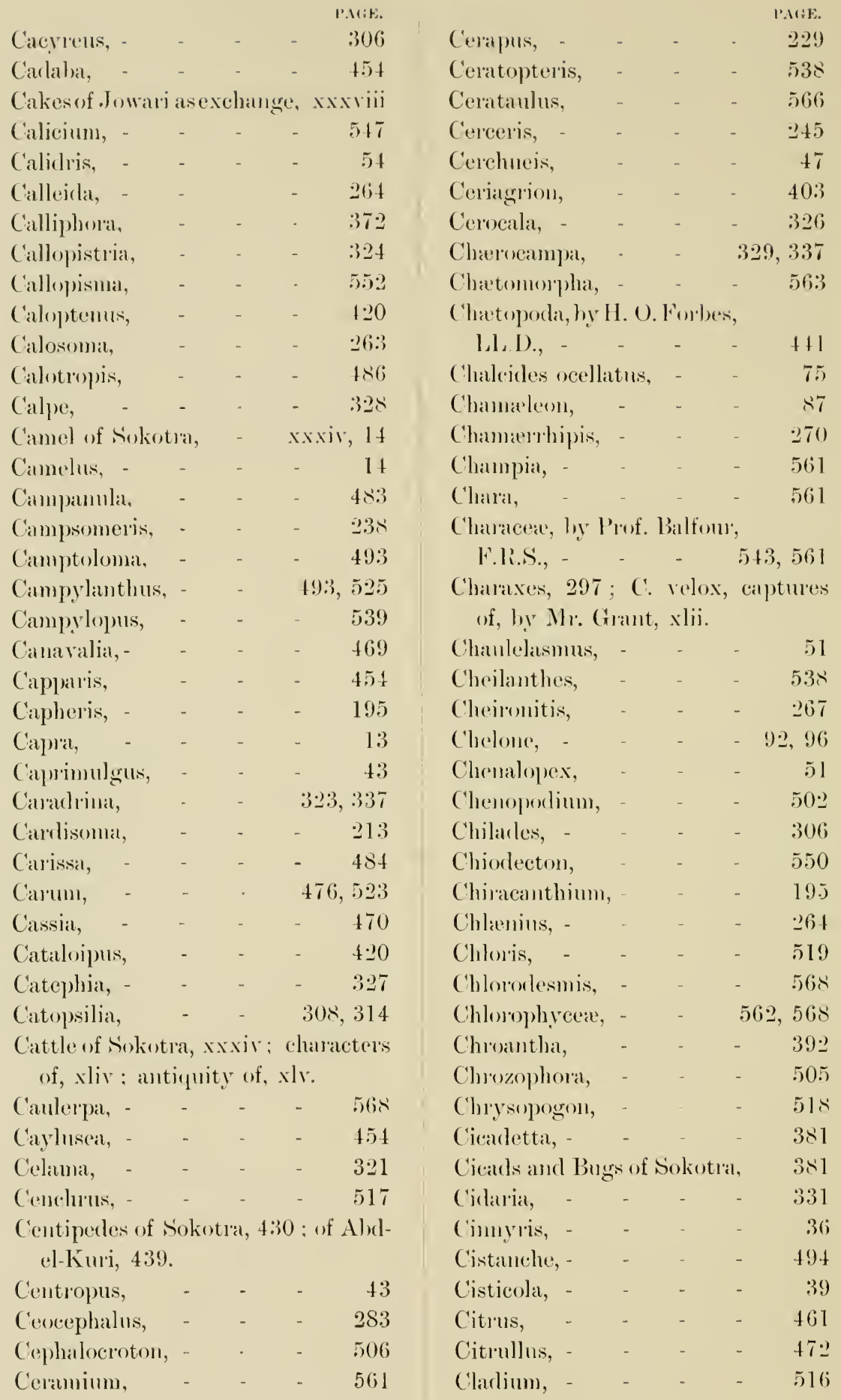


Cladonia,

Pirit.

Cleome,

Clerodendron,

Cocconeis, -

566

Coceulus, 452; C. Balfourii, xliv.

Cochlautluss, 485, 524; C. soeo tratlus, xxix.

Coeklumnia,

Corlinum, 568

Cixlocalpus,

Cienolita, 211,217

Coleoptera, hy C. J. ( Galam,

$$
\text { M.A , }
$$

Collema, 558

Colletes, 256

Commelina, 513,530

Coniocal'pi,

Conrolvulus, 491,524

Conyzal, 479

Cophongryllus,

Coptopss,

285

Coracias,

Corchorus

459

Cortlia, tis

Corticium,

Corvus, 560

Cosmophila,

Coturnix, -

Cotyle,

Craspedia, 331

Creagh, General, V.C., Resillent at Arlen, Kindness of and assistance given hy, xix : guard given ly, to Lahej, xxi : to Soliotra, xxiii.

Creagris,

Cressia, 491

Crickets of Sokotril, 413

Crinum, 508

Crocisa, 251

Crocorlilus, 93

Crocothenis, 400

Crotolaria, 466,522

Croton, 505

Crustacea, hy I. I. Pocock, A. O. Walker, A. S'eott, -
Crustaceans from Sokotra, 209) : Decaporl and S'essile-eyed, fiom Abl-el-Kuri, 216.

Cryptophlehia,

Cryptops,

Cryptoraphider,

Cryptus,

Cucumis,

Culicirlie,

Culladlia,

Cursorius, -

53

Ciscutil,

492,525

C'utmore, Mr. W., taxider-

mist to Experlition, - xx.

Cranotis,

513,530

Cylister,

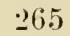

Cyelostomiclie and Helicirlie, Morphological observations on,

Cyelotella, 566

Cycolotopsis, - - - 145

Cylista, $\quad$ - $\quad$ - $\quad$ - $\quad$ - 469

Crmbella, - $\quad$ - $\quad$ - 564

Crumblon, - $\quad$ - $\quad$ - $\quad 519$

Cyperus, - - _ 514, 531

Cypselus, - $\quad$ - $\quad$ - $\quad$ - 43

Cyrtonena, - $\quad$ - 372

Cyrtophora, _ $\quad$ - $\quad 191$

Cystistemon, - $\quad$ - $\quad 490$

Dacrimyces, - _ _ 561

Demia, - - - - 48T

Dalamis, Camp at, - - xxxvi

D'Albuquerque on domestic animals of Alyd-el-Kuri, - $\quad \mathrm{xxx}$

In mishire, Dr. Otto V., Lichenes of Sokotra by, 543,546 ; of Abd-elKuri, by, 56 \%.

I)atiua,

Decaporls of Sokotra, 2212: from Alxl-el-Kinri, 216.

Dendrosicyos, 473 ; figure of, xli.

Deretus,

Dermestes,

266

Jesmiil,

56 \& 
Desmodium

De Winton, F.L.i., Mr. Wr.

E., Mammalia by - - ;

Djatomalceat, - $\quad 543,564$

Diceratelli, _ _ $\quad+52$

I)ichondra, - $\$ 91$

Dichrocephala, - $\quad$ - $\quad 479$

l)icliptera, $\quad 497$

l)icomi, - _ $\quad 482$

I)icrostachys, - - $\quad 470$

Dictrotil, - - _ 562

Digel"a, - $\quad$ - 501

Dimichiro, Bivoutac in Warly, xxxix

Dimizonops, $\quad$ - $\quad$ - $\quad$ - $\quad 199$

I)inehan, Ascent of valley of, xlii

Dinentes, - - $\quad$ - $\quad 266$

Dioscoreal, _ $\quad$ - $\quad 509$

Dipcadi, - $\quad$ - 512,530

1)iplacodes, - - $\quad$ fol

Diptera, by Miss G. Ricardo and Mr. F. V. Theobald, 357

Dirachmil, - $\quad$ - $\quad 460$

Dirichletia, - - xxxir, 476

Dirina, - - $\quad-547$

Iniscocarpi, - - 547,567

Discomycetes, - - $\quad 546$

Lissosteira, - - - 418

Ditypophis, - $\quad 90$

Dodoniea, - .. _ . 465

Ilogs, House- and sheep-, - 7

Dorstenia, - - xli, xliii, 506

Dothirlial, - $\quad$ - $\quad 5+6$

Draciena, - - - - 512

1)rigon's-blood trees, xli : figme of, $x l$

Dragon Flies of Sokntra, by Mr. R. M·lathlim, F.R.S., 398

Drumas, - - $\quad$ - 55

Dromerlary, gonel qualities of Sokotrall, - - $\quad$ xlir

Earias,

Earwigs, crickets and grasshoppers of Soliotra,

Echolinm,
Eehis,

PATiE.

Echirluopsis, - - - 487

Ecliptil, - - - $t 81$

Ectadiopsis, - - 485

Eilitheolea, - _ - $4 \times 6$

Escotia, - $\quad$ - $\quad$ - $\quad-\quad 219$

Eslrioplathalma, from Alul-

ellur, - - - 21心

Ehretia, - - - - 489

Elievcarpus, - $\quad$ - 459

Elasmopus, - - - 223

Elasmoscelis, - _ - 383

Eleusine, - - - 519, 531

Elhe, ('antp at, - - - xlii

Elphinstome of Inelian Marine lent to Expeedition, - - vii, xix

Emirlosimulia, - _ _ 93

Enicospilus, - $\quad 237$

Enilea, - - _ 111

Eutadal, - $\quad 470$

Euterographa, - $\quad$ - $\quad$ - $\quad 549$

Ejatcromia, - 417

Epicrocis, - - 334

Epilachma, - - 2 288

Epithemia, $\quad-\quad 566$

Eipuls, - $\quad$ -

Eifuus cablallus - $\quad$ - 12

Eraglostis, - - 520,531

Eremias, - - - 84

Eremocossus, . - $\quad 333$

Eriochloa, - 516

Liristalis, - $\quad 369$

Eiythrea, - - - 488

Erythinit, - $\quad$ - 469

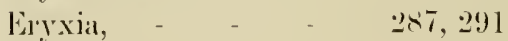

Litiella, - - 334

Eublemmia, - _ . $3: 5$

Encleal, - _ trit

Eumastacidie, - 417

Eimmenes, - - $\quad 246$

Eumerus, - - - $\quad 370$

Elunotia, - - 566

Euphorbia, 503, 527: E. Abdelkuri, xxix.

Emplexia, - - - - 323 


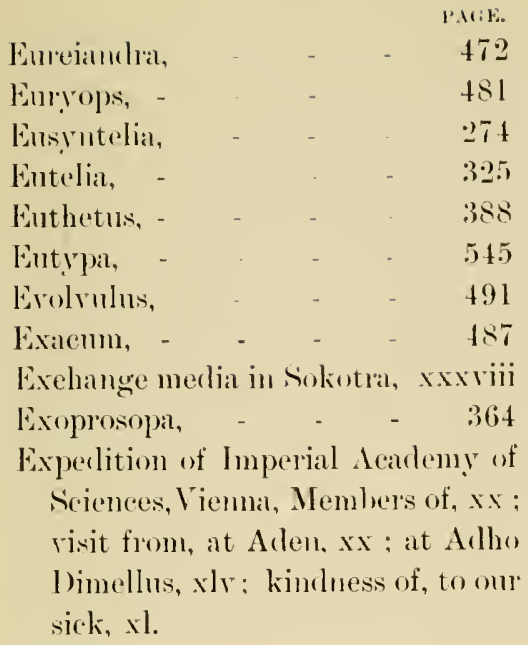

Falmonia,

Fagonia,

Falco,

Firsetia,

Felis,

Ferns of Alid-el-Kuri, 542; of Sokotra, 537.

Fever, Severity of, in Sokotra, xxxii

Ficus,

506

Filicine, 537

Fimbriaria, $5+1$

Fimluristylis, 516

Fishes, Sea and fresh-water, of Sokotra, and AbrlelKuri, Note on, 105,107

Fissurella, on hill sirles at Abrl-el Kuri, - - - xxvii Flies of Sokotra, 359 ; of AbrlelKmi, 375.

Flowering Plants of Sokotra, 452: of Alrd-el-Kuri, 521.

Fliiggea,

Fronieulum, 476

Fontariopsis,

Forlues, LL.D., Hemry O., Narrative of Ionrney,xr: on Acarida, 20 I A Aves, 19; Batrachia, 105; Chxtopoda, 141 ; Hirudinea, 441 ; Mammalia, 3; Pseudo-Neuroptera, 395, 397.
Forficulat,

P.ACE.

Formiciclar,

413

Forskohlea,

254

507

Fragilaria,

566

Fringillania,

Frisilia, -

Frogs,

Finllania, -

Fuicena,

516

Fuliearia,

Fuligula,

Fimgi, by Prot. Balfomr, F.R.S.,

Gahan, C..J., M.A., Coleoptera, ly, 261

(aillonia, 478

(ralium, 478

Gallerilia, 329

Gallinago,

Gallimula, 56

Garieh Plain, Wild Ass fomm on, xxxviii, 9, 10: view of Haghier Range from, xxxix.

Gasteracantha, - - $\quad 192$

Giasteromycetes, - - 559

Gastroporla, hy E. A. Smith, F.Z.S., - - - - 109

Gehel Dryat, highestsmmmit in Sokotra, - - xlir, 579

Gebel Saleh (Abrl-el-Kuri), Ascent of, xxriii : vegetation of, xxix ; invertebuates of, xxix: plants on, xxix.

Giegenes, - - - $\quad 312$

Geleehia, - - . $\quad 346$

Gelirlium, - - - 567

Geoeoris, - - - 386

(reology of Sokotrat and Abrl-el-kuri, - $\quad 581$

Geology of Sokotra and Alulel-Kuri, wy Prof. Gregory, F.R.S.,

Geotomils, 
Gemistele,

(ieranimm,

349

(thi, chief export from sokotri, xxxiy : Exchange for, xxxviii.

Gishin and Solotra, Sultan of,

(rlatuconiat,

(t)lossonemal, $\mathrm{xi}$

(')luviopsis,

$4+5,5 \cdot 2 \cdot 3$

(ilyphodes,

181

$33 \pi$

Grobal gorge,

Goit, Wild, of Sokotra,

xxxy

Godwin-Ansten, F.R.S., L.t.-

Col. H. H., Morphological

olservatious on Mollusca,

lier,

15.)

(xomp) honema,

565

('onlia,

Goniastrata retiformis, - xxiii

Gossypim, - - - 458

Gracilariat, - $\quad$ - $\quad 567$

Graleria,

494

(trant, IV. R. Ogilvie-, on Ares, 19 ;

Lepicloptera Rhopaloeesa, 293 ;

Mammalia, 3.

(ilaphina, -

Giaphis,

$5+8$

(tiapsins,

$21: 3$

Guasshoppers of Sokotra, +11, +13; from Abrl-el-Kini, t24.

Gregory, F.R.S., Prof.J. IV., on (ieology of Sokotra and Abr-el-Kuri,

Grewi:

(irubla,

Giryllus,

12.2

(xuillainia,

$16 \alpha^{\prime \prime}$

(ximi formel ont Abl-elKuri,

('y)mogramme,

xxix

539

Gymandropsis, -

453

(iypsophila,

Hahenallia,

507,530

Hadlena,

323

Harlibu, Camp in Plain of, xxxiii: lescription of Plain, xxxiii : of town, xxxiv: of lamblets on Plain, xxxiy : people of Plain, xxxiv : leave, in Elylinstome, xlvii.

Hamalipà,

$4+3$

Hemanthus, - $\quad 509$

Hiematolia, - _ - 373

Haghier Momntains, View of, from Tamaricla Bay, sxxii : from (aaljeh Plain, xxxix.

Halictus, - - - -

Hampson, Bart., F.E.S., Sir (x. F., Lepirloptela I'haliena, l心,

Harpactopus, - $\quad$ - $\quad$ - $2+1$

Haulaf, Laund at, _ _ xxxii

Haya, - - - 501

Hearman and hnterpreter

((xulairl Elmi), - - $\quad$ xxi

Ilerlyotis, - - $\quad 477,52: ?$

Heleocharis, - - - 515

Helichrystm, - - - 480

Heliotropium, - - $\quad 4 \times 9,524$

Hellula, - - _ $\quad 335$

Hemianax, - - $\quad 402$

Hemiclactylus, - - xxr, s0, 94

Hemiptera, ly Mr. (*. II.

Kirkealily,

379

Hemiscorpius, - - _ 181

Hepaticie, - $\quad$ - $\quad 540$

Herpestis, - $\quad$ - $\quad$ - 493

Heterachina, _ _ $\quad 48.2,523$

Heterochloa, - _ _ 531

Heterographis, - $\quad$ - $3: 33,337$

Heteronelw, - $\quad \mathrm{xxr}, 20^{\circ}$

Heteropogon, - - - 518

Hihiscus, - - _ - 458

Hippolyte, - . - 218

Hirneola, - - $\quad$ - 561

Hirudinea, by H. O. Forbes,

H.L.I). - - - - 441

Histeromorphus, - $\quad 273, \geq 90$

Holmes, E. M., Algae of

Abl-el-Kmi, by, $\quad 5+3,567$ 
Holothrix,

Homhil, Camp at, xxxiy : Plain of. xl; Climate alt, xlii.

Homothyrea,

Hoplistomera, 362

Humter, Major, formerly Political Assistant at Arlen, - - - xix, xxii, 45l

Hyale, 219

IIylosorus, 267

Hrdroclathrus.

56.2

Hydrocotyle,

Hyetodesia, 373

Hymenomycetes, 560

Hymenoptera, loy $\mathrm{IT}$. F. Kirby 233

Hypenal, - $\quad$ - $\quad$ - 329

Hypericum, 456 ; H. mysorense, and H. seopulon'um, xliv.

Hyperythra, 330

Hyphantornis, 3.3

Hypheothix, 564

Hyphyrdius, 265

Hyprea, $56 \mathrm{I}$

Hypoestes, $+98$

Hypogryphia, 333

Hypolimmas, 300

Hypsolophus, 345

Iearia, 249,256

Ichnemmons, Wasps and Bees of Sokotra, 236 ldactuss, 285

Iclia, 371

Ilema, $: 321$

Imperata, 5) 18

Incligofera, Ionidium, 467,522

Iphianlax,

454

Ipomata, $231 j$

Ischmmla, 490

Ischumurus,

40.

$5 \div 0$

Itamus

364 sistant at Mlen, vii, xix; Mrs. Jacol, vii, xix.

Iafticr, Mohammerl, Letter from, to Sultan of Sokotra, - - - - xxiii

Janial, - - $\quad 562,567$

Janima quimpureostatil, - 579

Jasminmm, - - $\quad$ - 484

Jatropha, - - - - 505

Jella-agahan, Camp at, xxxrii ; View from, xxxrii.

Joppa, - - $\quad$ - $\quad 237$

Julorlis, - $\quad$ - $\quad$ - $\quad$ - $\quad 269$

Juncus, - - _ $\quad 513$

Justicia, - - $\quad$ - $\quad 496$

Kalanchoe - $\quad+\quad 471,522$

Kamahanu, Cimp at, xxxvii ; siekness at, xxxiii.

Kirly, Mr. W. F., Hymenoptera, hy, ․3:3 : Nemoptera Planpenuia, by, 395.

Kirkaldy, Mr: G. II., IIemiptera, by, - $\quad$ - 379

Klimophilos, - $\quad$ - $\quad 383$

Kineittia, - - _ 560

Kossmat, I)r, F., $\quad-\mathrm{xx}, \mathrm{xly}, 576$

Kunhlia t:enima, - - 108

Kuria, - - - 2 228

Kyllinga, - . _ _ 515

Labirlu1'a, - $\quad$ - $\quad$ - 413

Lalcertilial, - - - 75

Lachnocapsa, - _ $\quad 453$

Lactuca, - - - 482,523

Lahej, Sultan of, xxi ; invites Expedition to, xxi: (Gnest-honse at, xxii ; Small pox at, xxii.

Land Shells of Siokotra, 111 ; Almel-Kini, 15:.

Lanchera,

Lanius, 


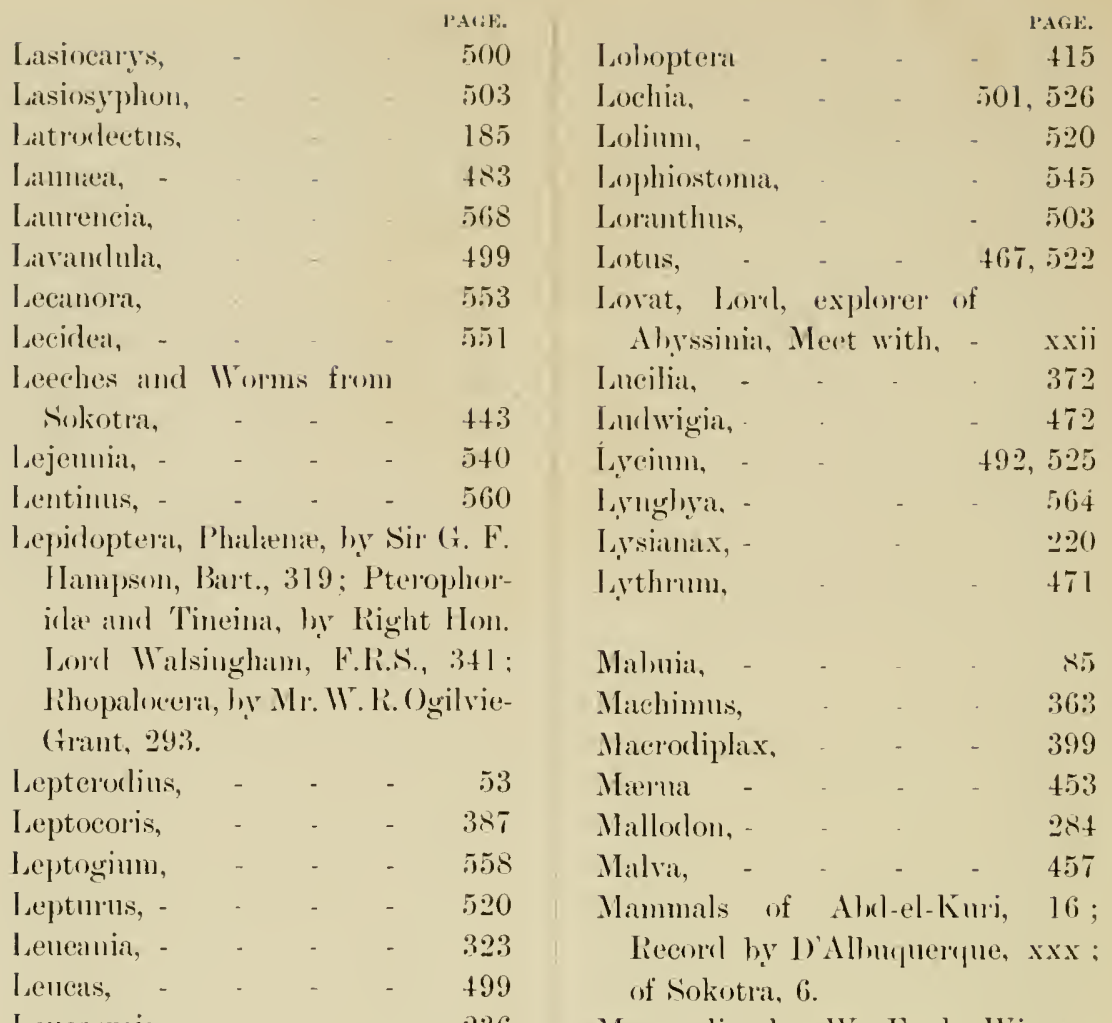

Lencospsis, - - $\quad 236$

Ijchens and Seal IVeeds of Abr-elKuri, 567; of Sokotra, 545.

lichenes, ly Otto V. Darbishire, Ph. P., - - 543,546

Lichenes, - - $\quad-543,546,567$

Limmas, - - - $\quad 295,314$

Limmobia, - _ _ $\quad 359$

Linaria, - - - $493,5.25$

Lindenbergia, - - $\quad 493$

lineat, - - $\quad$ - +59

Lintm, - - - - +459

Liogryllus, _ _ _ 422

lippia, - - $\quad$ - $\quad 49 k$

lispe, - - _ - 373

literature of Sirkotian

Orthoptera, - - - 424

lithidion, Species of, domlitful in Sokotra, - - - $14 \mathrm{~s}$

Lithidion, - - $\quad-147,154,162$

liverworts of sukntra, - 537

Mammalia, by Wr. E. de Winton, F.ZS., Hemy O. Fombes, LI.I., IV. li. Ogilvie-(irant, - : :

Marecil, - - _ - 52

Marsdenia, - - - 487

Marsilea, - - $\quad$ - 537

Mistogloia, - $\quad$ - $\quad$ - 565

M'Iachlan, F.R.S., Mı: R.,

Nemoptera Amphibiotica,

lig,

395,39 א

Meeistocephalus, - - 434

Mecopodiclit, - - - +21

Merlieatgo, - $\quad$ - $\quad 466$

Megachile, - - - $\quad 250$

Megalodes, - - $\quad 324$

Melania, - $\quad$ - $\quad 149$

Nelanocenchris, - - 51!

Meliuophora, . 371

Melanostoma, - - $\quad 369$

Melaspilea, - - $\quad 548$

Melharia, - - 459 


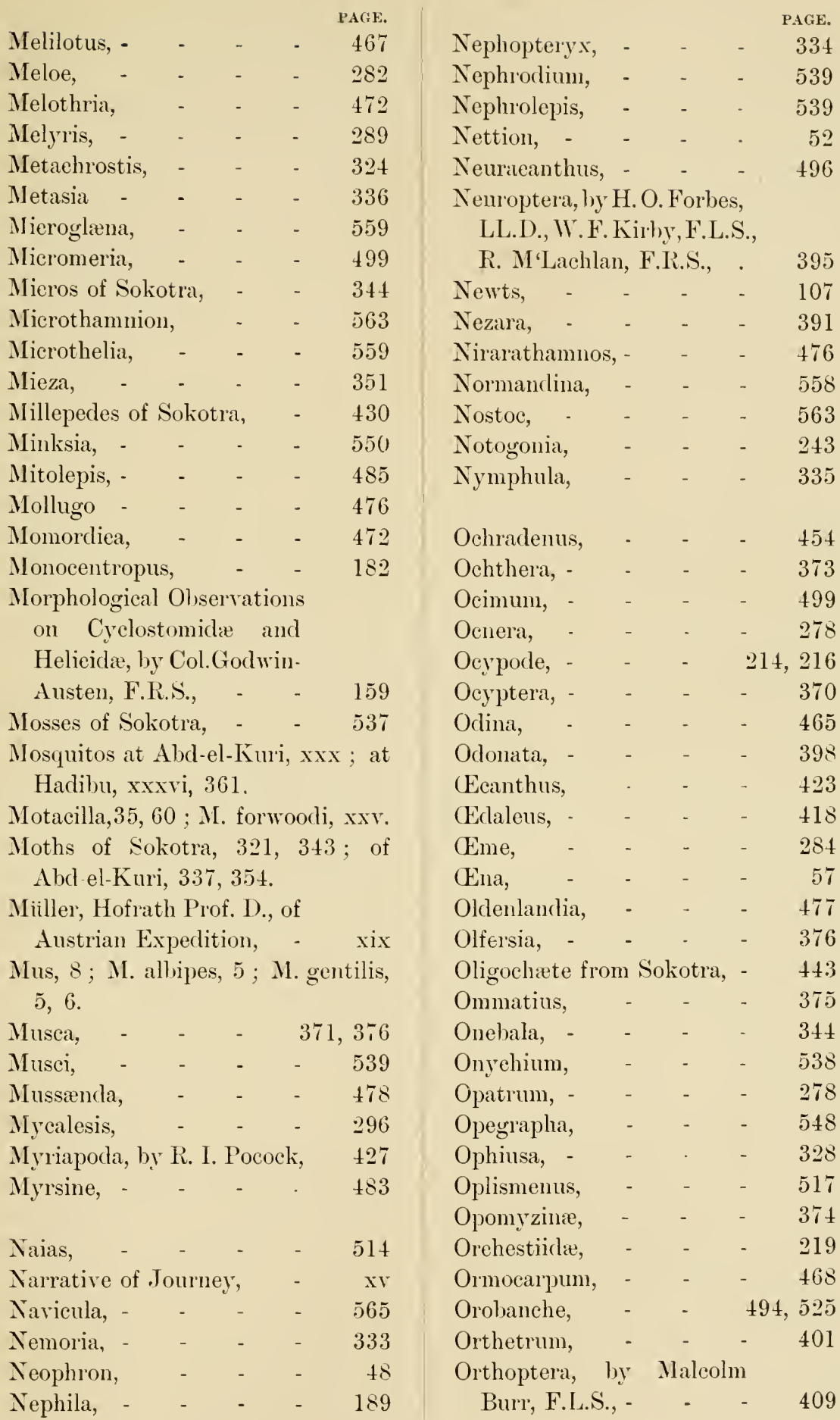


INDEX.

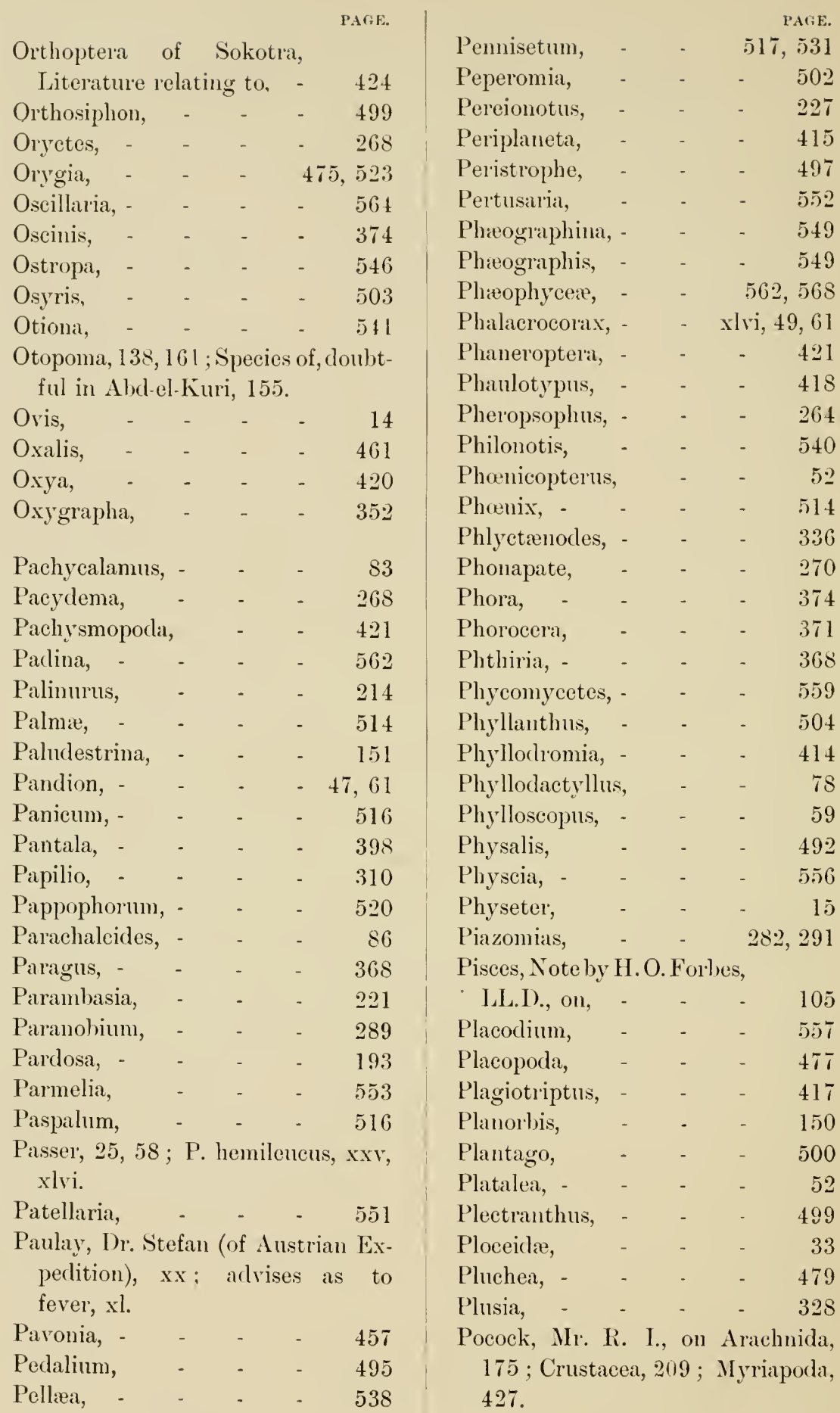


PACiE.

Podalirius,

252,257

Pyrenula, -

559

Podlaxon,

560

Pyrgomorpha, -

424

Pueilocelus, - $\quad$ - $\quad$ - 419

Polyblastia, - $\quad$ - $\quad$ - 559

Pyrrhulaurka, - - $\quad-33,60$

Polycarpiea, - - $\quad 455,521$

Polygali, - - _ 455, 521

Polygontm, - - - 502

Polyportus, - . $\quad$ - 560

Polanli, - $\quad$ - $\quad$ - $\quad$ - 491

Portulaca,

456,521

Porzana, - - $\quad$ - $\quad 56$

Potamon, - $\quad$ - $\quad 212$

Potamogeton, - - $\quad 514$

Pottery of Sokotra, Manufacture, olnamentation, and uses of, xxxiv ; as barter, xxxviii.

Pouzolzia,

Prays,

Precis, - - - $\quad 302$

Prenanthes, - - $\quad$ - 482

Priotropis, - - - 466

Pristurus, 75, 94; P. crucifer, 75;

P. Havipunctatus, 75.

Priva,

Promachus, - $\quad$ - $\quad$ - 362

Pseudapis, - $\quad$ - $\quad$ - 241

Pseudoraphideæ, - $\quad$ - $\quad 566$

Psiadia, - $\quad$ - $\quad$ - 479

Psilostachys, - - $\quad 501$

Psilocephala, - $\quad$ - $\quad$ - 361

Psolalea, - $\quad$ - $\quad$ - $\quad$ - 467

Pteridophyta, by Professor

Balfour, F.R.S., $\quad$ - $\quad$ - $\quad 535$

Pteris, - $\quad$ - $\quad$ - $\quad$ - 538

Pterocles, - - $\quad$ - 57

Pterophoridie, - _ $\quad 344,354$

Pterophorida and Tineina, by Lord Walsingham, F.R.S., -

Pucedanum, - - $\quad$ - 476

Puniea, - - $\quad$ - $\quad 471$

Pupalia, - - $\quad$ - 501

Pyrameis, - - $\quad$ - 302, 314

Pyrenocarpi, - $\quad$ - $\quad$ - 558

Pyrenomycetes, - - $\quad$ - 545

Pyxine, - - . $\quad 557$

Ramalina, - $\quad$ - $\quad$ - $\quad$ - $\quad 554$

Raphidier, - - $\quad$ - 564

Redurius, - $\quad$ - $\quad$ - $\quad$ - 384

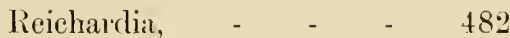

Remusatia, - _ $\quad 513$

Reptilia, by G.A. Bonlenger,

$$
\text { F.R.S., - - - - } 73
$$

Reptiles of Sokotra, 75; of Abdel-Kuri, 94.

Reseda, - - - 454,521

Resin found on Abd-cl-Kuri, xxix

Rhresena, - $\quad$ - $\quad$ - $\quad 329$

Rhinacanthus, - $\quad$ - $\quad$ - 497

Rhinia, - - - $\quad$ - 371

Rhinodina, - $\quad$ - $\quad$ - 556

Rhinopoma, - - $\quad$ - 6

Rhizopertha, - $\quad$ - $\quad 272$

Rhodophyce:e, - - 561,567

Rhopalum, - $\quad$ - $\quad$ - 245

Rhopalocampta, _ $\quad$ - 312

Rhus, - - . - 465

Rhynchelytrum, - $\quad$ - 518

Rhynchium, - $\quad$ - $\quad$ - 247

Rhynehosia, - $\quad$ - $\quad$ - 469

Rhynchostruthus, 26 ; R. louisie, 29.

Rhyothemis, $\quad$ - $\quad$ - $\quad$ - 399

Rhysida, - - $\quad$ - $\quad 432$

Rhyssemus, - - - 267

Rhytidonota, - - $\quad 273,290$

Ricardo, Miss G., Diptera, by, 357

Ricinus, - $\quad$ - $\quad$ - $\quad$ - 506

Rieheck, Dr., Exploration of Sokotra, hy, - $\quad$ - xviii

Roccella, - - - 550, 567

Rolfe, Mr. R. A., _ $\quad$ - 451

Romulea, - - - 508, 530

Ruellia, - - - 495,526

Ruppia, - - $\quad$ - 514

Ruta, - - $\quad$ - $\quad 461$ 


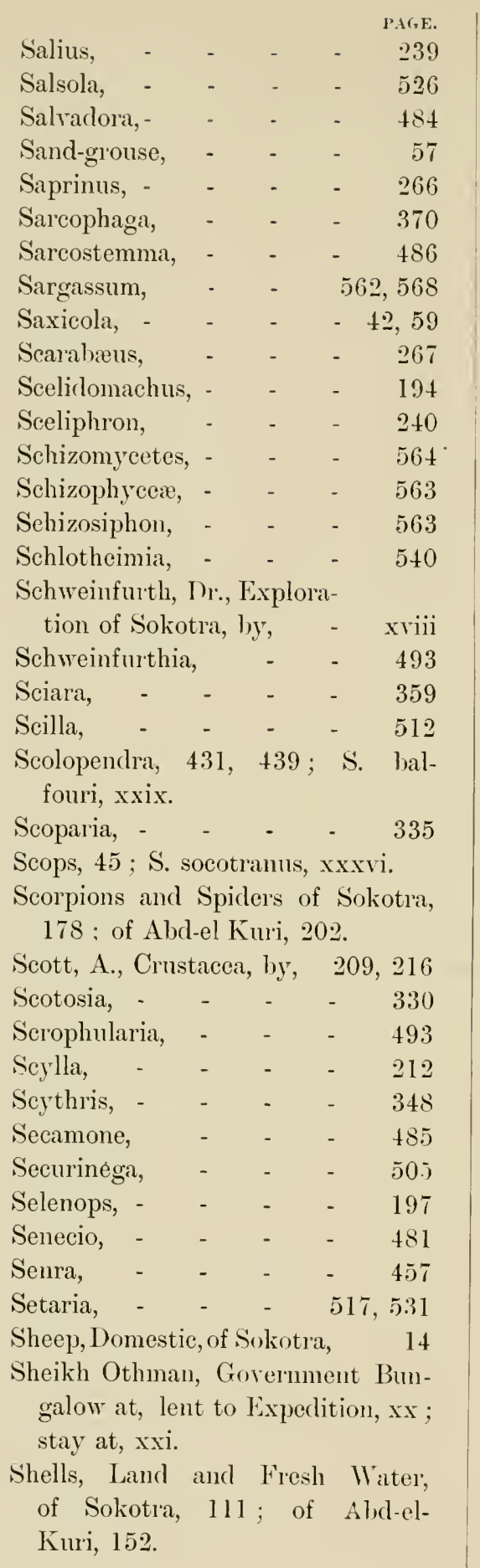

Sida,

PACE.

Sideroxylou, - - - $\quad 484$

Siegesbeckia, - $\quad$ - $\quad$ - 481

Silene, - $\quad$ - $\quad$ - $\quad$ - 455

Simony, Prof. - - $\quad$ - $\quad \mathrm{xx}$

Simplicia, - $\quad$ - $\quad$ - $\quad 329$

Sisymbrium, - - $\quad$ - 453

Smith, Eigar A., Gastropoda,

by,

Suipe, Painted, - _ - 55

Socotora, - - - - 485

Sokotra and Abd-el-Kuri zoology, 1 ; botany, 445; geology, 571.

Sokotra, algee, 543 ; ant lions, 404 ; barter and exchange, xxxviii ; bees, 236 ; beetles, 263 ; lirds, 2.2; botanical collectors who have visited, 451; butterflies, 295 ; camel, xxxiv ; cattle, xxxir, $\mathrm{xly}, 12$; centipedes and millepedes, 430 ; characex, 543 ; cicarls and luugs, 381 ; decapods, 212 ; dragon-flies, 398 ; earwigs, crickets, and grasshoppers, 411 , 413; exploration of, by Balfour, Schweinfurth, Riebeck, Bent, Bennett, Hunter, xviii ; fishes, 107 ; flies, 359 ; flowering plants, 449,452 ; frogs, 107 ; fungi, 543 ; Gebel Dryat, lighest summit, xliv ; geographical position, xvii ; geological antiınity, xvii ; geo$\log y, 573,578$; ichneumons, 236 ; leeches and worms, 443 ; lichens, 543 ; mammalia, 3 ; micros, 344 ; media of exchange, xxxviii ; moths of, 321,343 ; newts, 107 ; pottery, xxxiy ; pterophoridie and tineina, 341; reptiles, 75 ; scorpions and spiders, 178 ; shells, land and fresh-water, 111 ; Sultan, xxxii : interview with, xxxii ; toads, 107 ; wasps, 235, 236 ; white ants, 397 . 
PAGE.

PAGE.

Sokotran Arehipelago, Avifamma of,

Symblepharis, - _ $\quad$ - 539

63 ; species of flora, alsent from Abd-el-Kmi, xlvii.

Sokotri, the, Manners, eustoms, games, and industries of, xli

Solantum, - - - $\quad$ - 192

Sonchus, - - $\quad$ - $\quad 482$

Sparassus - - $\quad$ - $\quad$ - 196

Syruium, -

46

Syngamia,

335

Syrphus, - - - $\quad 369,376$

Systates, - - - 283, 291

Sperm whale, - - xxy., 15

Spermacoce, - - $\quad$ - 478

Spheria, - - $\quad$ - 545

Sphrroma, - - - 218

Sphex, - - - 2.40, 255

Sphinctrina, - $\quad$ - $\quad$ - 546

Sphingonotus, - - - $\quad 424$

Spiders of Sokotra, 178 ; of Abd-elKuri, 20\%.

Spirogyra,

562

Spodoptera,

Sporobolus,

519,531

Sporodesmium,

559

Stapf, Dr.,

451

Statice,

Stauroneis,

Stegomyia,

Stenia,

Stenogyra,

Stereulia, -

Stereum, -

Sterna,

Sticta,

Stietina,

Stillum,

Stizoides,

Stizus,

Stomoxys,

Striga,

Sureda

Succinea, -

Sula,

Sim, scorching effect of, on skin,

Sybrinus,

Sylvia,

Synalissa, xlii.

$483,5 \div 3$

565

359

335

131

458

560

55,62

557

558

238

244

243

372

494

502,526

112

50,62

59

558

Tabanus, -

375

Tachytes, - - - - 242

Talinum, - $\quad$ - $\quad$ - $\quad$ - 456

Tamarindus, - - $\quad$ - 470

Tamarix, - _ $\quad$ - 456

Tarache, - - $\quad$ - $\quad$ - 324

Taruens, - $\quad$ - $\quad$ - 305

'Taverniera, $\quad$ - $\quad$ - $\quad$ - 468

Teddia, - $\quad$ - $\quad$ - $\quad$ - 415

Temnopterus, - $\quad$ - $\quad$ - $\quad 266$

Tenebrionidx, - _ - 272

Tephrosia, - $\quad$ - 468, 522

Teracolus, - $\quad$ - $\quad$ - 307

Teramnus, $\quad$ - $\quad$ - $\quad$ - 469

Terpsinoë, $\quad$ - $\quad$ - $\quad 566$

Testudinidie, - $\quad$ - $\quad$ - $\quad 92$

Tetragnatha, - $\quad$ - $\quad 185$

Tetragonia, - $\quad$ - $\quad 475$

Tetragonoderus, _ _ $\quad 264$

Teuerium, - - $\quad 500$

Thalassochelys, - $\quad$ - $\quad$ - 96

Thalophyta, by Prof. Balfour, F.R.S.; Dr. O.

Darbishire; Mr. E. M.

Holmes, F.L.S., - $\quad$ - 543

Thamnosma, - $\quad$ - $\quad$ - 461

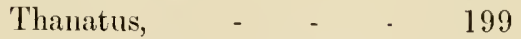

Theloschistes, - - $\quad$ - 557

Theobald, F. V., Culieidie of

Sokotra, by, - - $\quad$ - 357

Thesidium, - $\quad$ - $\quad 503$

Thlutid, see Jena-agahan.

Thomisus, - $\quad$ - $\quad$ - $\quad$ - 198

Tibellus, - $\quad$ - $\quad$ - $\quad$ - 199

Tihamah, Life on Arabian, xxi

Tilliea, - - - - 470

Timandra, - $\quad$ - $\quad$ - 332

Tineina, hy Lord Walsing-

ham, F.R.S., . - - 
INDEX.

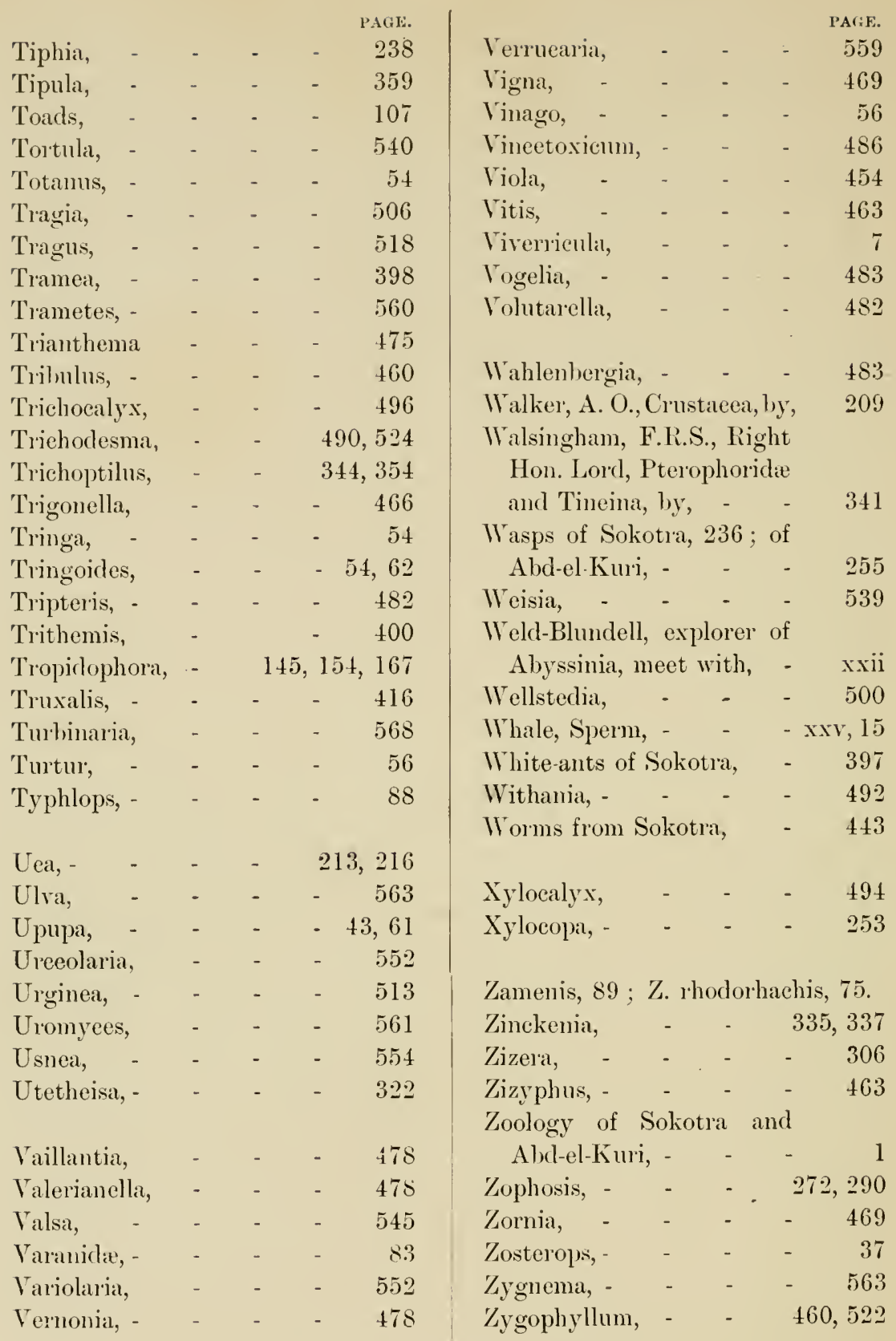






2. P. METCALF 
